\title{
figtoria mediebal
}

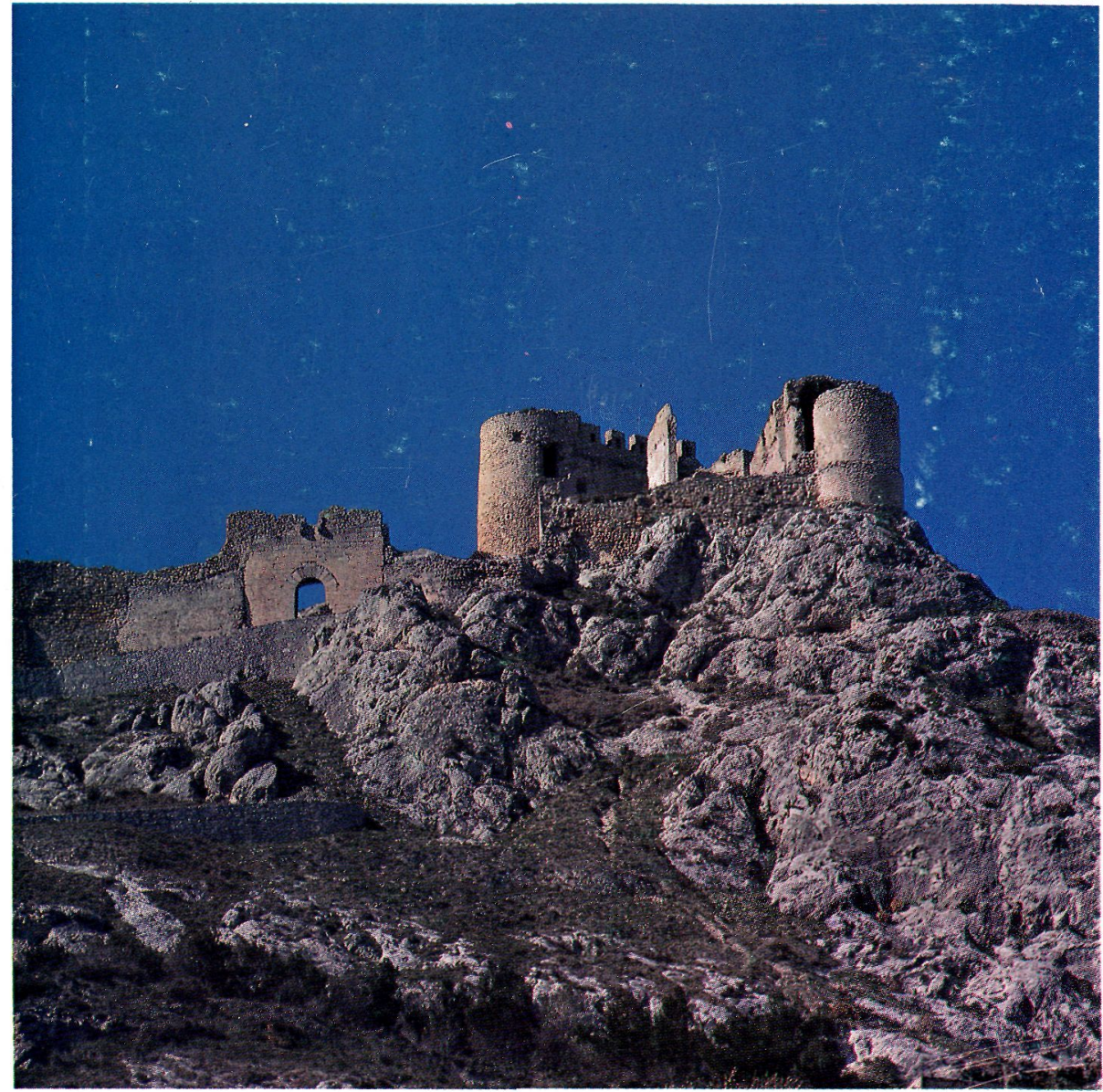

\section{anales}

\section{de la unibersidad}

de alicante 


bistoria mediebal 


\section{Anales de la Universidad de Alicante Historia Medieval}

Director: José HINOJOSA MONTALVO

Secretario: Juan Manuel DEL ESTAL

Comité de Redacción:

M. ${ }^{a}$ Desamparados CABANES PECOURT

M. ${ }^{a}$ Luisa CABANES CATALA

Odilo ENGELS

Pierre GUICHARD

Paulino IRADIEL

Margarita LA CHICA GARRIDO

Miguel Angel LADERO QUESADA

José Luis MARTIN

Alvaro SANTAMARIA ARANDEZ

José TRENCHS ODENA

SECRETARIADO DE PUBLICACIONES

UNIVERSIDAD DE ALICANTE

Depósito Legal: A-467-1984

Imprimie: Imprenta de la Universidad de Alicante 


\section{anales}

de la unibersidad

de alicante

bistoria mediebal

ALICANTE, 1988 



\section{ÍNDICE}

Sophia MENACHE

Una personificación del ideal caballeresco en el Medioevo tardío. Don Alonso de Aragón

A. M. POVEDA NAVARRO

Aproximación a la demografia bajomedieval de la comarca del Medio Vinalopó (Alicante)

J. A. GARCÍA DE CORTÁZAR

Espacio y hombre en la España norteña en la Edad Media

F. M. MARTINNEZ FRONCE

La dinámica estratégica hacia Uclés y sus puntos de encuentro

75

A. LINAGE CONDE

Trasplante de la civilización fronteriza de la España medieval al Nuevo Mundo: notas al Fuero de Sepúlveda.

C. BATLLE

Las relaciones comerciales de Barcelona con la España musulmana a fines del siglo XII e inicio del XIII

M. GONZÁLEZ JIMÉNEZ

Alcalá de Guadaira en el siglo XIII

J. HINOJOSA MONTALVO

La economía agropecuaria alicantina en tiempos de Alfonso $X$ : aproximación a su estudio

J. NAVARRO REIG

Los mudéjares contestanos en el siglo XIII.

R. BAÑÓ ARMIÑANA

Registros reales de los siglos XIII-XIV en el Archivo Municipal de Alcoy J. M. DEL ESTAL

Anexión del Camp d'Alacant al reino de Valencia por Jaime II de Aragón (1308) 
M. ${ }^{a}$ T. FERRER MALLOL

La Batlia General de la part del regne de València dellà Xixona.....

M. a DE LOS LLANOS MARTÍNEZ CARRILLO

Una economía tentacular. La relación económica Murcia-Orihuela en los finales del siglo XIV

F. DE MOXÓ Y MONTOLIU

Notas sobre la economía fronteriza castellano-aragonesa en la Baja Edad Media.

$M^{\text {a }}{ }^{\text {J. P. FERRO TAVARES }}$

Judeus e conversos casteihanos en Portugal

M. GALLENT MARCO

Documentación notarial e historia de la sanidad

369

GRUPO ILICITANO DE ESTUDIOS ARQUEOLÓGICOS

Cerámica azul y de reflejo metálico en Elche: conjunto de San José.

387

R. CÓRDOBA DE LA LLAVE

Filigranas del Archivo Municipal de Córdoba (1450-1550).

J. M. ${ }^{a}$ BERNARDO PANIAGUA

Otro discurso histórico: la Novela 


\title{
UNA PERSONIFICACIÓN DEL IDEAL CABALLERESCO EN EL MEDIEVO TARDÍO: DON ALONSO DE ARAGÓN
}

\author{
SOPHIA MENACHE
}

Universidad de Haifa

La Reconquista Española enriqueció el ideal caballeresco medieval, cuando la epopeya del Mío Cid consolidó la aureola mítica de Rolando, creando los componentes básicos del estereotipo del caballero medieval. La lucha contra los infieles, raison d'être de ambos, llegó a su cúspide con el movimiento cruzado. La llamada de Urbano II desde el concilio de Clermont, aparejada con la añoranza ancestral hacia la Tierra Santa, crearon un desafío y una meta para los caballeros medievales, quienes durante dos centurias se vieron involucrados en los altibajos de los Reinos Cruzados del Levante (1). La dedicación a la Guerra Santa fue sólo una faceta del ideal caballeresco medieval, si bien la más fomentada por el estamento eclesiástico. La cultura popular, profundamente enraizada en la tradición germánica, continuó manteniendo vivos los ideales de intrepidez en el campo de batalla, a pesar de las continuas sanciones eclesiásticas (2), el culto del bello sexo y por sobre todo, la fidelidad indestructible y absoluta del caballero hacia su señor feudal.

La esencia normativa de la sociedad medieval mantuvo indemne el ideal caballeresco en el plano teórico (3). No así en el plano práctico, donde los caballeros se vieron afectados por la evolución política y social del medievo tardio, que relegó a la Guerra Santa a una posición marginal. Dicha evolución, general a la sociedad europea, tuvo amplias consecuencias en el ámbito peninsular. El caballero español del siglo XV se vio paulatinamente liberado de la lucha contra los Infieles y sus servicios fueron en más requeridos por corrientes políticas divergentes, entre las cuales la lucha continua entre Castilla y Aragón y el conflicto agudo entre parcialidades políticas, ocuparon 
un lugar de preferencia (4). Éstas fueron las circunstancias históricas en las cuales actuó nuestro biografiado, Don Alonso de Aragón (1421?-1485). Hijo natural del Infante Don Juan, futuro rey de Navarra y de Aragón, sobrino del rey Juan II de Castilla, de Alfonso V de Aragón y Duarte de Portugal, hermanastro de Fernando el Católico, Don Alonso fue llevado por su alta cuna al epicentro de la efervescencia política y militar de la península. No obstante, la historia de Don Alonso se ha mantenido hasta el presente en una nebulosa historiográfica. La investigación moderna, amén del estudio pionero de José Navarro Latorre (5), no ha hecho suficiente uso de los datos inconexos que nos presentan las crónicas medievales.

El objetivo del presente estudio es articular la biografía de don Alonso de Aragón desde el prisma analítico del ideal caballeresco medieval (6). Las fuentes contemporáneas justifican ampliamente dicha premisa. El Memorial de Diversas Hazañas, por ejemplo, describe a Don Alonso como «muy valiente y esforçado cavallero" y destaca sus continuos servicios para con su padre, Juan de Navarra. Dicho juicio fue aceptado por Andrés Bernáldez, quien añadió a su vez: «e de muy gran consejo para la guerra», mientras $A$. de Palencia lo describe como «bravo guerrero, muy digno de tal padre» (7). En este punto es menester avanzar una aclaración metodológica. El relativamente largo periodo de tiempo cubierto por la biografía de Don Alonso de Aragón así como la efervescencia política y militar de su época, justifican una visión selectiva del proceso histórico. De alli que hemos tratado de mantener el foco de nuestra investigación en nuestro biografiado, dirigiendo al lector interesado a la amplia investigación histórica del período.

Don Alonso de Aragón fue fruto de los amores entre el Infante Don Juan, a la sazón Duque de Peñafiel, y Doña Leonor de Escobar, hija de noble familia del cortejo de la reina madre, quien se recogió posteriormente en el Monasterio de Santa Maria de Dueñas de Medina del Campo (8). La fecha del nacimiento de Don Alonso es incierta. Su biógrafo le adjudica la edad de 22 años en 1443, cuando fue electo Maestre de Calatrava (9). Por otra parte, la dispensación papal otorgada en dicha ocasión por Eugenio IV, no hace mención de su edad (10). En un documento posterior (1455) el papa Calixto III le adjuđicó a Don Alonso la edad de 14 años cuando tomó posesión del Maestrazgo de Calatrava (11). De allí que el nacimiento de Don Alonso se sitúa entre los años 1421 y 1429 . Bajo la tutela de su tío, Juan ll de Castilla, fue enviado a temprana edad a la corte del rey Duarte de Portugal, donde recibió los primeros cimientos de su educación de caballero. Llamado de regreso a la corte castellana, fue ordenado caballero por el rey, de quien recibió su escudo de armas «partido en tres cuarteles; en los dos de la mano derecha un 
castillo de oro en campo colorado y en la otra parte más abaxo un león coronado medio morado y medio roxo en campo blanco y en el otro medio escudo las armas reales de Aragón con sus colores naturales que son las cinco barras doradas en campo colorado. Después desto añadió al escudo por encima de las armas una cruz larga entre el escudo y corona quando fue electo Maestre de Calatrava» (12).

La vida de Don Alonso en estos años se pierde en el torbellino político que afectaba a Castilla. Su biografía nos lo describe peleando "como un león» en las distintas escaramuzas que se presentaron al lado de los Infantes de Aragón, «siendo tan contínuos los encuentros con cuyo exercicio salió consumado soldado y el más experimentado capitán y de mayores azañas que igualó con ellas a sus pasados y les excedió, como el Rey su padre y todos los españoles y franceses de común consentimiento solían decir. A esto se acompañó las partes personales que le hicieron lucir mucho porque fue de muy buen rostro y lindos ojos, pelo castaño, de gentil estatura. Más grande que pequeño, robusto, gran brazero, buen hombre de acaballo de entrambas sillas y gran hombre de armas, siendo temido por el encuentro de su lanza. Con todo esto mereció los grandes favores que el Rey su tío le hiço y el los alcanzó por sus servicios particulares» (13).

Los favores reales aludidos en la cita precedente se refieren, primordialmente, a la intervención de Juan II para asegurar el Maestrazgo de Calatrava en la persona de su sobrino, a pesar de la oposición de los dignatarios de la orden. Superados los impedimentos de edad, nacimiento y profesión (14), las gestiones del rey de Castilla sumadas a la presión militar de los Infantes de Aragón, dieron fruto el 18 de agosto de 1443, cuando Don Alonso fue electo oficialmente en maestre de la importante orden militar castellana (15). La elección de Don Alonso de Aragón en Maestre de Calatrava, refleja nítidamente la constelación política imperante. La derrota del rey castellano Juan II y su favorito, el condestable Álvaro de Luna en Medina del Campo (28 de junio de 1441) había llevado a los líderes de la Liga Castellana, los Infantes de Aragón, al epicentro del poder en Castilla, desde donde contaban con la cooperación incondicional de su real primo. Más aún, el levantamiento de Rámaga que había llevado al virtual emprisionamiento del rey de Castilla (19 de julio de 1443), había convertido a los Infantes de Aragón en los gobernantes efectivos del reino (16).

No obstante, el maestrazgo de Don Alonso, condicionado desde sus comienzos al provisorio poderío de sus allegados, resultó una etapa pasajera en las lides políticas de Castilla. Ya en 1444, la alianza entre el condestable Álvaro de Luna y el heredero al trono, Enrique Príncipe de Asturias, despertó 
los primeros cargos en contra de la validez de la nominación. Los dignatarios de Calatrava elevaron sus quejas frente a Don Gutierre, Arzobispo de Toledo. Dichos cargos fueron formalmente confirmados por Juan II, quien, una vez recuperada su libertad personal y vencedor en la batalla de Olmedo (19 de mayo de 1445), incentivó la formal destitución de Don Alonso por el capítulo de la orden. Paralelamente, el rey castellano patrocinó la elección de $\mathrm{Pe}$ dro Girón, quien fue electo maestre el 19 de septiembre de 1445 (17). A pesar que Don Alonso de Aragón gozó menos de un año de la posesión efectiva del Maestrazo de Calatrava, el oficio pasajero dejó huellas profundas en su vida. Formalmente continuó usando el título de maestre durante los próximos treinta años, cuando a la vez que era agraciado con el título ducal de Villahermosa (1475), contrajo enlace matrimonial, que lo descartó por completo de la alta dignidad eclesiástica (18). Más aún, la experiencia del maestrazgo no sólo fructificó las aptitudes militares de Don Alonso sino que también le brindó una nueva conciencia del poder, a través de su liderazgo de la poderosa orden castellana (19).

Al respecto de su destitución del maestrazgo de Calatrava, cabe citar la interpretación que nos brinda la biografía de Don Alonso de Aragón: «...pero habiéndole menester el Rey Don Juan su padre para la guerra que contra el Príncipe Don Carlos su hijo y hermano del maestre tenía, no obstante que el Rey Don Juan de Castilla faborecía al Príncipe Don Carlos, a quien él como Maestre debía asistir por los beneficios recividos y tenerle prestado juramento al Rey de obediencia por Maestre de Calatrava, reconociendo también los intentos de Don Pedro Téllez Jirón salido del Rey en la pretensión del Maestrazgo y que lo abenturaba si acudía al llamamiento de su padre, antepusso a todas estas razones la obediencia que le debia, conociendo muy bien que no podía hallar recompensa del Maestrazgo. Y parece que en aquel tiempo no estaba tan válida la razón de Estado como oy se ve pues pudiera haberse conservado el Maestre con su padre y su tío guardando neutralidad, pues los beneficios que tenía recividos del Rey Don Juan de Castilla su tío pudieran ser suficiente razón para suspender el yr al llamamiento de su padre, sabiendo era forçoso el pelear contra las armas de Castilla y incurrir en desobediencia de aquel Rey a quien tanto debía, perdiendo por esto el gozo del Maestrazgo como sucediós (20).

Si bien la biografía antepone el conflicto con el príncipe de Viana en seis años, esclarece fielmente el conflicto de intereses que llevó a la destitución de Don Alonso de Aragón. La abierta identificación del maestre con el partido representado por los Infantes de Aragón crearon una incompatibilidad política con su señor y rey, Juan II de Castilla. El apologético tono que acompa- 
ña el tenor de la biografía respecto a la actuación de Don Alonso, parecería destinado a justificar la incuria de nuestro héroe hacia su soberano, el rey castellano, al cual había prestado juramento y homenaje. Desde la perspectiva de nuestro anónimo autor, la apatía de Don Alonso a sus propios intereses aparejada por su abnegada dedicación filial a Juan de Navarra, aparecen como fuerzas de peso que balancean la traición incurrida al código caballeresco ancestral: fidelidad al señor feudal.

Por otra parte, la destitución del maestrazgo puede ser considerada como vaticinio del futuro político de Don Alonso de Aragón. Si bien Juan de Navarra aseguró en la práctica el gobierno de su hijo natural en las encomiendas de Alcañiz (19), a partir de 1445 hasta su muerte acaecida en 1485, Don Alonso se brindó incondicionalmente a las lides de su familia, de su progenitor y señor, Don Juan de Navarra y posteriormente de su hermanastro, Fernando el Católico. De allí que la renunciación forzada al Maestrazgo de Calatrava no involucró un revés en la carrera militar de Don Alonso; éste siguió contando con el apoyo de los caballeros aragoneses, amén del sostén de su beligerante padre. Más aún, las dotes militares de Don Alonso y su fidelidad hacia la causa aragonesa fueron prontamente reconocidas por Alfonso $\mathrm{V}$, quien desde sus lejanos reinos italianos aconsejaba al irascible Juan de Navarra que encomendase a Don Alonso toda empresa militar futura en el reino de Castilla (21). Los consejos del rey aragonés fueron llevados a la práctica a comienzos de 1449, cuando se brindó a Don Alonso la dirección de la ofensiva Juanista contra Cuenca, destinada a preparar el ataque contra Murcia. El ejército que se encomendó a Don Alonso contaba con 6.000 gente de armas, jinetes, ballesteros y lanceros. Al lado de Don Alonso participaron veteranos capitanes aragoneses y castellanos como Juan de Hijar, Pedro de Urrea, Juan de Lanuza, Ferrer de Bardaxí, Martín de Ansa, Juan Fernández de Heredia, Gómez Manrique, Rodrigo Rebolledo, Hernando de Rojas y Diego Gómez de Sandoval (22). No obstante, el bajo nivel combativo de los reclutados, en su mayor parte labradores valencianos y mudéjares, llevó al primer revés militar en la brillante carrera de Don Alonso (23).

El revés de las huestes Juanistas frente a la valerosa defensa de Lope de Barrientos y la población conquense, frustró los planes de un inmediato golpe de Estado en Castilla. Dicha situación indujo a Don Juan a fortalecer su posición en Navarra como posible plataforma ofensiva en el futuro. Mas, el regreso de Juan de Navarra a su reino a comienzos de 1450, sumado a las intrigas del condestable castellano Álvaro de Luna, dificultaron las ya tensas relaciones entre el rey y su primogénito, Carlos Príncipe de Viana, quien había gozado del virtual gobierno de Navarra desde la muerte de su madre, 
doña Blanca, acaecida en 1441 (24). Más aún, la supuesta entente castellanonavarrense (Estella, septiembre de 1451) fue interpretada por Juan de Navarra como casus belli. Convencido de la traición del príncipe de Viana y sus manejos con Castilla, Juan de Navarra promovió la alternativa bélica, que daría lugar a la batalla de Aybar (23 de octubre de 1451).

La superioridad numérica del ejército Vianista en Aybar era evidente. A los contingentes beamonteses y lusitanos, se les sumaron cuatrocientos hombres de armas y seiscientos jinetes castellanos enviados por Juan Il y el Príncipe de Asturias. No obstante, el valor de los capitanes del ejército Juanista, Rodrigo de Rebolledo y Don Alonso de Aragón, permitió conseguir la importante victoria, que se vería coronada con el emprisionamiento del príncipe de Viana (25). En su reseña histórica de la lucha fratricida, Zurita trae dos versiones respecto a la actuación de Don Alonso de Aragón y su participación en el emprisionamiento del príncipe de Viana. Si bien en ambas versiones Don Alonso aparece como héroe indiscutido en el campo de batalla, se vislumbran pequeñas diferencias respecto a la actitud de Don Carlos hacia su hermanastro. La primera versión refiere la valentía y arrojo de Don Alonso, quien logró cambiar el curso de la batalla con sólo treinta hombres de armas, criados suyos. A pesar de la inferioridad numérica de sus fuerzas, Don Alonso desbarató las formaciones del príncipe de Viana, que se tenía por vencedor. Si bien Don Carlos logró huir a la fortaleza local, se redujo posteriormente a merced de las fuerzas de su padre. La segunda versión afirma que el príncipe de Viana no se quiso rendir sino a «Don Alonso de Aragón Maestre de Calatrava su hermano, y que a él dió estoque y una manopla; y el maestre se apeó del caballo y besó la rodilla al príncipe» (26). La biografía de Don Alonso confirma la última versión, subrayando que la actitud de Don Alonso hacia su hermanastro fue «con rendimiento más de vencido que de vencedor... fiando en la gran benignidad del Rey mi señor que le tratará como a hixo». De allí que Don Alonso, sin faltar a su obediencia filial, se brindaría a endulzar la prisión de su hermanastro y consolarle en su congoja (27). La actuación de Don Alonso en la batalla de Aybar permite vislumbrar nuevas facetas de su actitud caballeresca, cuando a su valentía sin par en el campo de batalla se sumó su gentil cortesía hacia su hermanastro, al cual trató «con rendimiento más de vencido que de vencedor».

La importante contribución de Don Alonso al triunfo Juanista en Aybar le valió la concesión real de la villa pirenaica de Cortes con su castillo y jurisdicción. En la merced real concedida a su hijo natural, Juan de Navarra expresó su gratitud en términos calurosos, justificando su donación «en remuneración de los muy notables y señalados servicios que con pura voluntad 
y entera lealtad y con assaz derramamiento de sangre y gasto y pérdida de la hacienda por nuestro servicio y conservación de nuestros Reynoss le había conferido hasta el presente Don Alonso de Aragón (28). A la sazón, el otrora Maestre de Calatrava justificaba los razonamientos de su padre en las zonas fronterizas, impidiendo las incursiones de Luis de la Cerda, conde de Medinaceli, y haciendo correrías en derredor de Cuenca (1452) (29).

El acuerdo de paz con Castilla en Agreda y Almazán (septiembre-octubre 1454) llevaría a una paz provisoria en la frontera castellano-aragonesa. Por otra parte, Alfonso $V$ sacrificaba los intereses personales de su sobrino en aras de la renaciente paz. El acuerdo sustentado por el soberano aragonés hacía mención de la renuncia formal de Don Alonso al maestrazgo de Calatrava, que ya había sido adjudicado al protegido del Príncipe de Asturias, Pedro Girón (30). La muerte del rey de Aragón, acaecida el 27 de junio de 1458, convirtió a Juan de Navarra en soberano rey de Aragón, Valencia y Cataluña, mas no cambió el giro de los acontecimientos en Castilla (31). El 15 de mayo de 1460, la familia real unida hacía su entrada en Barcelona, cuando Juan de Navarra acompañado de su real consorte, Juana Enríquez, era escoltado por sus hijos, Carlos príncipe de Viana, recientemente pacificado con su padre, y el infante Fernando. A ellos les seguían los esforzados hijos naturales del monarca, Don Alonso de Aragón y Don Juan (32).

No obstante, la feliz concordia concertada entre Juan de Navarra y el príncipe de Viana sería del mismo corto alcance como lo fueron los acuerdos anteriores firmados entre padre e hijo. Los recelos mutuos y la intervención incisiva de la reina Juana (33) llevaron nuevamente al encarcelamiento del príncipe. La muerte prematura de Don Carlos el 23 de septiembre de 1461 y los odios apasionados despertados por la política de su padre, llevaron al proceso vertiginoso de la renovación de la guerra civil en Navarra y la revuelta Catalana (34). La participación de Don Alonso de Aragón en ambos casos fue decisiva y justificó la aureola heroica con la que sería galardonado en las crónicas contemporáneas.

A comienzos de 1461 Don Alonso fue puesto al mando de las fuerzas agramontesas para poner fin a la rebelión beamontesa en Navarra, incentivada por el apoyo militar prometido por Enrique IV y el encarcelamiento arbitrario del Príncipe de Viana (35). Si bien Don Alonso tuvo ganancias territoriales limitadas, logró una importante victoria sobre Gracián de Lussa, señor de Samper y otros capitanes de la parcialidad del príncipe de Viana. La victoria alcanzada por Don Alonso en el campo de batalla indujo al condestable de Navarra, Luis de Beamonte, a suplicar el reforzamiento de la ayuda castellana en el reino pirenaico, donde el campo beamontés se veía francamente ame- 
nazado (36). A pesar del éxito que coronó la gestión del condestable, la parcialidad del príncipe de Viana sufrió un nuevo revés en la batalla de Abarzuza. Con los refuerzos enviados por su cuñado, Gastón IV conde de Fox, Don Alonso se sobrepuso al ejército castellano que contaba con doscientos hombres de armas y unos cuatrocientos jinetes, de los cuales, de acuerdo al testimonio de la documentación real, ninguno pudo escapar (37). Los reveses en el campo de batalla sumados a la nueva iniciativa diplomática de Juan II, llevaron a Enrique IV a firmar un nuevo acuerdo general entre Aragón y Castilla (26 de agosto de 1461), que daba un plazo de cuatro meses a concertar el pleito navarro. Mas la muerte del príncipe de Viana antepuso las posibles decisiones de la junta nombrada a tal efecto. Posteriormente, también Juan de Beamonte juró fidelidad a Juan de Navarra, concretándose el pacto entre Agramonteses y Beamonteses (22 de noviembre de 1462). A la sazón, Juan II, libre ya de la crisis Vianesa, tendría que sobreponer la igualmente grave y prolongada afrenta que le presentaba el principado de Cataluña (38).

A comienzos de 1462 la situación de Juan de Navarra en Cataluña era francamente desesperada. El fracaso de la reina Juana Enríquez en Barcelona y su partida forzada con el príncipe Fernando, sumados al cerco hermético con que los rebeldes los tenían sometidos en Gerona, invistieron de crucial importancia las acciones militares de Don Alonso en el principado. En este sentido, la toma de Castelldásens y el triunfo en Rubinat ( 23 de julio de 1462) fueron importantes etapas en la contra-ofensiva de las fuerzas Juanistas. Destacando el rol de Don Alonso en Castelldásens, Zurita establece que «emprendió la mayor fuerza y peligro dél», así también en Rubinat, donde su coraje y acometida ayudaron a coronar con éxito el tercer y crucial ataque de las fuerzas reales (39). También en las cercanías de Barcelona fue «muy señalado el esfuerzo y valentía de Don Alonso de Aragón en las ordinarias escaramuzas que tuvo con los de la ciudad en aquella parte donde tenía sus estancias, a la puerta de Junqueras; y alli se acometian por su persona contínuos hechos de armas, peleando en las cavas y barreras con los enemigos» (40).

De esta época data también la primera relación amorosa duradera que tuvo Don Alonso (41). Estando invernando el ejército real en la zona del Ampurdán en pos de la liberación de la reina del cerco de Gerona, Don Alonso se enamoró pérdidamente de Doña María lunques, hija de los nobles en cuya hacienda se hospedaba. Dado que la doncella no retribuyó sus atenciones, Don Alonso la raptó de la casa de sus padres, ufaltando a las leyes de hospedaxe». Si bien sus aspiraciones al maestrazgo de Calatrava le impidieron contraer matrimonio con Doña María, Don Alonso tuvo de ella dos hijos, 
Don Juan de Aragón, duque de Luna, quien le sucedió en el estado de Ribagorza y Doña Leonor de Aragón, a quien casó posteriormente con Don Jaime del Milá, primer conde de Albayda (42). Cabe destacar que Doña María lunques contó con el apoyo espiritual y económico del rey de Navarra y Aragón, quien consideró a sus hijos como verdaderos nietos suyos y hasta su lecho de muerte se preocupó del futuro de Don Juan de Aragón (43). Por otra parte, las dotes personales de Doña María, su organizada administración y abnegada defensa del condado de Ribargorza, la hicieron merecedora de las gracias reales, siendo galardeada por Juan II con el título de «magnifica» (44).

Mientras tanto, la revuelta catalana alcanzaba otro de sus extremos cuando en pos de la alianza de Juan II con Luix XI de Francia (45), la Generalidad de Cataluña ofrecía la corona de Aragón primeramente a Enrique IV de Castilla (11 de agosto de 1462) (46) y en pos de la traición de su lugarteniente Juan de Beamonte, al condestable Don Pedro de Portugal (27 de octubre de 1463): Don Pedro de Portugal, nieto del conde de Urgel, otrora pretendiente al trono aragonés en la elección de Caspe, «vino a Cataluña a gozar su reyno que tan mal le salió el año de 1464 y hallóla tan llena de guerras por todas partes que pudo desde luego anteber el mal fin de aquella promesa» (47). Desde la perspectiva de Juan II, la afrenta del condestable lusitano parecía ser menos apremiante que la previa acometida castellana. Más aún, liberada de la amenaza castellana, la contra-ofensiva Juanista se volcó en 1464 sobre los puntos claves de Cataluña oriental: Lérida y Cervera, que habrian de tener un rol crucial en el balance de fuerzas contra el aspirante lusitano a la corona. El ataque Juanista concentrado en Cervera llevó a los barceloneses a estrechar sus esfuerzos en la zona, acaudillados por Don Pedro. Mas en los alrededores de Villafranca las fuerzas rebeldes sufrieron varios reveses militares por las fuerzas reales al mando de Don Alonso de Aragón, el castellán de Amposta Huc de Rocabertí y Rodrigo de Rebolledo (febrero de 1464) (48). No obstante, la tenaz defensa de Cervera encomendada a Juan de Armendáriz, llevó al ejército real a concentrarse en un segundo objetivo, Lérida, «que se juzgaba el puesto más principal después de Barcelona». Debilitada por los efectos del hambre y la falta de ayuda efectiva de Barcelona, la ciudad claudicó a Juan II el 6 de julio de 1464, mientras Don Alonso de Aragón recibía la fuerza de Garden «que está en un colado al occidente fuera de la ciudad que señorea el campo y las entradas del río y de la ciudad» (49).

Entre 1465-1466 encontramos nuevamente a nuestro biografiado en los puestos claves que posibilitaron la conquista de Igualada, Cervera y el castillo de Amposta, uno de los más importantes baluartes conquistados por las fuerzas Juanistas en la guerra civil. Comentando la toma de Igualada (17 de 
julio de 1465) las fuentes contemporáneas hacen mención de un curioso episodio: el capitán local, Pere Mateu, decidió rendir las torres a las fuerzas reales y requirió su entrada para reducir a sus contrarios; más las huestes de Don Alonso temían escalar la plaza por temor a una emboscada. Visto lo cual, Don Alonso «no se contentando de hacer el oficio de muy valeroso capitán sino adelantarse como muy valiente soldado, fue el primero que apeándose del caballo llegó a la cava y tomando por sus manos una escala, animando a los suyos, socorrieron a los que habian alzado las banderas por el rey que peleaban con los de dentro» (50). El mismo día se rindió a Don Alonso el castillo de Monfalcón, mientras Cervera capitulaba el 14 de agosto de 1465, después de ocho meses de enconada resistencia (51). La Garoffa fue conquistada por Don Alonso a comienzos de 1566 (52). Hacia fines de 1466 se desmoronaba la resistencia anti-Juanista en el mediodía de Cataluña. La toma del castillo de Amposta (21 de junio de 1466), era seguida por las capitulaciones de Tortosa, "ojo derecho del cuerpo místico de Cataluña», Flix y Miravet (53). A su vez, la muerte de Pedro IV en Granollers, el 29 de junio de 1466, parecía auspiciar el broche de la enconada contienda.

La incertidumbre que rodeaba el futuro de Cataluña no privó a Don Alonso de la gratitud de su real padre. Desde el cerco del castillo de Amposta, el 17 de noviembre de 1465, Juan II le hizo merced de la baronía de Arenós, vuelta a la corona por la rebelión de Don Jaime de Aragón, hijo de Don Alonso de Aragón, duque de Gandía (54). El documento real refleja fielmente la gratitud del militante y ya anciano rey para su hijo natural: «Por quanto vos, el muy ilustre y amado hijo nuestro Don Alonso de Aragón havéis hecho bien el oficio real exercitando todo lo que ha sido menester bastantemente en estos tiempos desta rebelión y conspiración nefassdíssima entre los Catalanes contra nos y contra nuestro estado, haciendo en el de echo militar y en las demás nescissidades de nuestra casa como varonil hijo nuestro, preciándose y obstentando su ánimo como el lugar y ocassión lo pedían. Por tanto os do, mas no suficiente ni digno a buestros merecimientos según los estimamos, pero queriendo os dar alguna cosa por lo que por nos y por nuestro serbicio habéys hecho con las armas sin cessar ni haver intermición contra los soberbios y rebeldes nuestros a quien tantas veces havéis impugnado y hechóles guerra. Por estos serbicios, peligros y trabaxos y gastos sustentados y hechos por vos, deviéndose os hazer merced, os damos la presente carta nuestra para todos los tiempos valedera, de nuestra cierta ciencia deliberada consulta, assí por nos como por todos los nuestros para vos y buestros herederos donde o quales quiera, os damos y entregamos y concedimos en perpetua donación, pura, simple y irrevocable que se dize entre vivos, para vos el illustre nuestro hijo, y para quien vos quisiereys, la varonía 
de Arenozo con sus villas, campos y lugares' (55). Así mismo, el $1 .{ }^{\circ}$ de enero de 1468, Don Alonso recibió la importante suma de 50.000 florines que habría de recaudar de las villas de Igualada y Vilafranca para «sustentar la gente de armas que con vos en nuestro servicio tubísteis, particularmente en la expugnación del condado de Pallas» (56). Por último, el 27 de noviembre de 1469, Juan II hizo entrega a Don Alonso del importante condado de Ribagorza en nombre de su hijo Fernando, Rey de Sicilia, actual conde de Ribagorza, «cuyos confines nuestro Reyno de Aragón y principado de Cataluña alcansan y se axa ser llave aquellos mismos reinos y entrada y salida de los dichos Reinos de Francia y partes de Gascuña... para la deffención y utilidad de la corona del dicho Reyno de Aragón y principado de Cataluña y por el bien pacífico quieto y tranquilo estado del mismo condado de Ribagorza» (57).

No obstante, las campañas militares de Don Alonso en el principado de Cataluña no habian alcanzado aún su cenit. El 30 de julio de 1466 la Generalidad hizo un vuelco político completo y ofreció la corona aragonesa a Renato de Anjou, quien gozaba del respaldo político y militar de su escurridizo sobrino, Luis XI, rey de Francia (58). A mediados de abril de 1467, el primogénito Juan de Anjou, duque de Lorena, hacía su feliz entrada en el principado, habiendo elegido como primer meta a Gerona, importante bastión Juanista que centralizaba la embestida real en el Bajo Ampurdán. Especialmente requerido por la población local, fue alli enviado Don Alonso de Aragón, quien logró mantener la defensa de la importante plaza (59). Mas el revés del ejército real en las cercanías de Vilademat (21 de noviembre de 1467) involucró la inminente pérdida del Ampurdán. Por ese entonces, Don Alonso daba un giro positivo a los acontecimientos, cuando el 23 de mayo de 1468 vencía la hueste del conde de Vaudemont, que avanzaba hacia Sant Joan de les Abadesses (60). No obstante, la contienda estaba aún lejos del desenlace final. Los refuerzos que trajera el duque de Lorena llevaron a la capitulación de Gerona $\left(1{ }^{\circ}\right.$ de junio de 1469), posiblemente en pos de las intrigas secretas manejadas por el clan de los Margarit (61).

La muerte del duque de Lorena acaecida en Barcelona el16 de diciembre de 1470, permitiría un nuevo vuelco de fortuna a las fuerzas leales a Juan II, donde se luciría nuevamente Don Alonso de Aragón. Secundado por el conde de Prades, Don Alonso conseguía importantes éxitos en el frente del Vallés donde se le rindieron Sant Cugat, Sabadell y Granollers (noviembre de 1471) (62). Así mismo, "corría el Maestre desde San Cugat toda aquella comarca tiniéndolos en contínuas armas asta las puertas de Barcelona” (63). El 26 de noviembre, Don Alonso consiguió un importante éxito en Santa Coloma de Gramanet, en pos del cual selló el destino del Bajo Ampurdán. Cerca 
del río Besós, las tropas reales consiguieron una significativa victoria frente a las tropas barcelonesas acaudilladas por Dionisio de Portugal, Menaut de Guerri y Jacobo Galiotto, que resultó en 4.000 muertos del bando rebelde y numerosos prisioneros, entre los cuales figuraban los capitanes de las fuerzas barcelonesas. Refiriéndose a la participación de Don Alonso en la importante contienda, Zurita establece que «él, como gran capitán y guerrero animando a los suyos, hirió a los enemigos» (64). También la biografía de Don Alonso no escamotea en alabanzas respecto a la participación de nuestro biografiado en Santa Coloma de Gramanet: «Obró el maestre peleando y animando los soldados como acostumbrava. Siendo conocido se devió esta victoria a su valor a cuyo exemplo obraron todos los cabos de su exército y en particular Martín de Lanuza que con grave valor ganó el estandarte de Jacomo Galeoto matando a su alférez» (65).

Los comienzos de 1472 auspiciaron la conquista real de la zona norte del Ampurdán, que habría de despejar el camino a Barcelona. En un período de tres meses, Figueras, Peralada, Torroella, Castello y Rosas, se redujeron a la obediencia de Juan II (66). En ese entonces Juan II sufrió un completo revés frente a Peralada, después de haber sido sorprendido por las fuezas conjuntas del capitán de las fuerzas francesas, Antoine de Lau, y de los capitanes Angevinos, el conde de Campobasso y Bofillo de Giudice (4 de abril de 1472): «con quinientas lanças francezas y algunas compañias de lacayos... acometieron al amanecer al exército del rey tan de repente, que rota la guardia y desbaratada, si no acudiera el Maestre Don Alonso, corriera gran riesgo la persona del Rey, que desarmado y casi desnudo se recogió a Figueras» (67). De allí que la fidelidad filial de Don Alonso se vería coronada por el rescate de Juan II y su liberación de un peligroso cautiverio en las cercanías de Peralada, un nuevo galardón en la epopeya caballeresca de nuestro biografiado.

La reducción del Ampurdán, facilitada por la política benevolente de Juan II, y la inminente toma de Barcelona, posibilitaron la capitulación de Pedralbes (16 de octubre de 1472), que selló los 10 años de lucha intermitente en el principado (68). Mas las preocupaciones militares de Juan II no habían desaparecido aún. La ocupación francesa del Rosellón y Cerdeña presentaba para el rey de Navarra y Aragón un nuevo desafío, al cual el ya anciano monarca dedicaría sus postreros años (69).

A fines de enero de 1473 el ejército real franqueó los Pirineos al mando de Juan II y sus fieles capitanes, Don Alonso de Aragón, Joan Ramon Folc III de Cardona conde de Prades, Don Bernaldo Hugo de Rocabertí castellán de Amposta y Fernando de Rebolledo. El ejécito real hizo su entrada triunfal en Elna, Canet, Argelés, El Voló y finalmente, Perpiñán quienes abrieron re- 
gocijadamente sus puertas al soberano (70). La lucha contra los franceses pondría nuevamente a prueba el desinterés de Don Alonso y su compieta abnegación a los intereses reales, aun a costa de los suyos propios. En septiembre del mismo año, contingentes franceses marcharon hacia el condado de Ribagorza con el propósito de dividir los esfuerzos de las huestes aragonesas. Si bien Don Alonso proveyó satisfactoriamente la defensa de su condado, antepuso su obediencia filial a su interés personal y no abandonó a su padre en Perpiñán. En vista de tal decisión concluye su biografía: «...pero el Maestre, que siempre atendió más al servicio del rey su padre que a sus combeniencias, no obstante que conocía el riesgo en que estava su estado, no se apartó de la occassión, que en Rossellón avía conocido lo que importava en ella su persona» (71). Todos estos esfuerzos serían en vano. Las fuerzas aragonesas no pudieron refrenar la completa superioridad numérica francesa y a pesar de la fidelidad de la población local, la empresa del Rosillón terminaba en un fracaso rotundo con la caída de Perpiñán el 10 de marzo de 1475. A la sazón comenzaba una nueva etapa en la vida de nuestro valeroso caballero. Enviado a llamar a Castilla «a grand priessa» por el rey Fernando, su hermanastro, empeñado en la lucha contra las pretensiones lusitanas al trono en pos de la muerte de Enrique IV (72), Don Alonso habría de dedicar los últimos diez años de su vida al servicio de los Reyes Católicos.

El regreso de Don Alonso de Aragón a Castilla estaba también relacionado con sus añejas pretensiones al maestrazgo de Calatrava. El apoyo del nuevo maestre, Rodrigo Téllez Girón a la parcialidad de Doña Juana, sumado a la popularidad de Don Alonso entre los comendadores de la orden, presentaban buenas perspectivas para su restitución al deseado maestrazgo (73). No obstante, una vez más las aspiraciones personales del antiguo maestre eran sacrificadas en aras de intereses políticos. La posibilidad de devolver a Rodrigo Téllez Girón y su primo, el poderoso marqués de Villena, a la fidelidad de los Reyes Católicos, inclinaron la balanza real en desfavor de su allegado, a pesar de los importantes servicios que le debian (74). Por otra parte, Fernando e Isabel encomendaban a Don Alonso la capitanía de la Santa Hermandad, aquella importante fuerza militar que habría de tener un rol crucial en la pacificación del reino, así como en la lucha contra los portugueses hasta 1479 (Tratado de Alcaçovas) y posteriormente, contra los últimos baluartes moros en la península (75).

Al mando de las fuerzas de la Hermandad, Don Alonso habría de cumplir un rol destacado en la lucha contra la parcialidad de Doña Juana (76). A fines de noviembre de 1475, lo encontramos estrechando el cerco de Burgos, «homenaje y cabeza del reino de Castilla». La llegada de Don Alonso 
con 50 hombres de armas y 100 jinetes, permitió la partida de Don Fernando a Zamora. Resume la biografía: «Quedó el Maestre Don Alonso sobre la fortaleza de Burgos que como cabesa de Castilla la vieja hera la más importante plaça y de mayor estimación y assí lo hazía el Rey de Portugal de tenella, y el Rey Don Fernando en desealla, que corriendo su expugnación por manos de su hermano, el maestre, le asegurava el buen suscesso. Los de dentro sentian tan grande enemigo, porque su nombre era formidable por sus haçañas y en este sitio peleó por su persona como lo solía hacer en todas las ocasiones en que se allava» (77). A pesar de la valerosa resistencia de sus defensores, la falta de refuerzos prometidos de Portugal y de Francia, llevaron a la rendición del importante baluarte en manos de la Reina Católica, el 31 de enero de 1476 (78). La toma de Burgos permitió a Don Alonso concentrar sus esfuerzos en las zonas fronterizas, donde lo encontramos con cuatrocientos jinetes estorbando las rutas de los lusitanos desde Medina del Campo, Tordesillas y Madrigal (79). El 19 de marzo Don Alonso tenía un rol clave en la toma de Zamora. De acuerdo a Zurita, «aprovechó en gran manera para que se rindiese haber llegado algunos días antes Don Alonso de Aragón con cuya presencia se entendió que no se podía defender mucho tiempo por ser muy diestro en todo género de combate y haberlo dispuesto en tan pocos días, de suerte que desconfiaron del todo de la defensa" (80). La rendición de Doña María Sarmiento y del alcázar de Toro en manos de la reina, coronó finalmente las hazañas de Don Alonso en el transcurso del año (81).

A la sazón, distinguido por su padre con el título ducal de Villahermosa (82), nuestro biografiado abandonaba sus añejas pretensiones al maestrazgo de Calatrava, para contraer matrimonio con Doña Leonor de Soto, dama del cortejo de la reina Isabel (83). Los vástagos de dicho matrimonio fueron Don Alonso de Aragón, quien sucedió a su padre en el ducado de Villahermosa y Doña María de Aragón quien contrajo enlace posteriormente con Roberto de San Severino, príncipe de Salerno. La reacción de Juan II al enlace de su hijo natural refleja un aspecto recóndito en la personalidad del monarca aragonés en las postrimerías de su vida. En una enérgica carta que dirigió a Don Alonso (marzo de 1477) el anciano rey lamentaba que ninguna otra noticia podía haberle causado mayor pesadumbre, que el ver a su hijo abandonar su profesión y obligación a la Orden de Calatrava, en pos de una dama a quien doblaba en edad. La pesadumbre del monarca estaba aparejada de aspectos prácticos, no mienos amenazantes. Juan II se oponía a la concesión de la villa de Cortes, otorgada por Don Alonso a su joven esposa en dote nupcial y así mismo proyectaba la transmisión del ducado de Villahermosa y Arenós a Juan de Aragón, hijo natural de Don Alonso y Doña María lunques (84). ¿Serían éstos, sinceros remordimientos de conciencia del rey ara- 
gonés al umbral de su muerte? La respuesta es difícil de discernir. Amén de su simpatía hacia Doña María lunques, la reacción de Juan II refleja, quizás, la frustración que le acometió ante la decisión independiente de Don Alonso, que involucraba su permanencia constante en Castilla. Por otra parte, la reacción del monarca aragonés contirma la importancia que adjudicaba al maestrazgo de Calatrava, actitud que fuera compartida por Don Alonso durante los últimos treinta años.

A pesar de las reservaciones de Juan II, el destino del duque de Villahermosa continuó estrechamente ligado al de su hermanastro, Don Fernando, al cual continuó secundando hasta las postrimetrías de la lucha contra Alfonso V. En 1477, Don Alonso sobresalia nuevamente en la toma de Cantalapiedra y Siete Iglesias, posteriormente en Escalona (1479), logros que apresuraron el completo desbande del partido lusitano en Castilla (85). Fernando del Pulgar, quien a lo largo de su crónica se refirió a nuestro biografiado como «el bastardo hermano del rey», establece, no obstante, que Don Alonso "puso así mismo gran diligencia en el sitio que tenía puesto sobre aquella fortaleza de Siete Iglesias que tenía en cargo, e en espacio de dos meses la guerreó» (86). A la vez, Don Alonso comenzaba a tomar responsabilidades gubernamentales. En pos del viaje de los Reyes Católicos a Andalucía, fue nombrado gobernador de Castilla y León, junto al condestable, Don Pedro Hernández de Velasco (87). En 1481, Don Alonso acompañó a los Reyes Católicos a las Cortes de Barcelona, donde fuera jurado Don Juan como príncipe heredero. En dicha ocasión, Don Alonso fue elegido miembro del estamento nobiliario representado en las Cortes. También en 1484 tomó parte de las Cortes de Tarragona junto a los Reyes Católicos (88).

La última etapa en la vida de Don Alonso que irónicamente no logró concluir, estuvo ligada a la lucha contra los moros del reino de Granada. En 1482 Don Alonso tomó parte del cerco de Loja, «que sabiendo que se alló en esta guerra, esta provado quan valerossamente obró en ella quando sus muchos años le estorvassen al pelear por sus manos como solía» (89). Refiriéndose a la participación de Don Alonso en el funesto sitio, Alonso de Palencia nos refiere en colores vívidos la decadencia biológica de nuestro héroe: «Esta insensatez (uso de bombardas mayores para abrir una brecha en las murallas de Loja) encontró severo censor en el duque Don Alfonso de Aragón, guerrero experimentado, y a quien acompañó frecuentemente la victoria mientras mandó los ejércitos. Un padecimiento de la vista y la obesidad, disminuyendo su aptitud para la guerra, dieron pretexto a los bisoños, y por tanto, malos jueces en asuntos militares, para conceder menos autoridad a la opinión del ilustre guerrero. El cual pronosticaba que el sitio elegido para el campamento 
sería funesto a los nuestros...» (90). Demasiado anciano para tomar parte activa en la lucha, Don Alonso fue, no obstante, el arquitecto de la estrategia militar seguida por los Reyes Católicos en la guerra de Granada, cuyo desenlace no alcanzaría a festejar. Don Alonso de Aragón falleció en Linares, en la campaña que siguió a la toma de Zalea, cuando escoltaba a sus Reyes a Alcalá de Henares (1485) (91).

Los calurosos elogios fúnebres que recibió Don Alonso de la pluma de sus contemporáneos, lo acercan, indudablemente, al ideal caballeresco medieval, donde junto al mítico Mío Cid o al no menos legendario Rolando, Don Alonso de Aragón merece un lugar de preferencia. Citaremos el epitafio de Alonso de Palencia: «Fue Don Alonso afortunado en los combates con los enemigos; salvó a su padre y a su hermano de trances muy difíciles y supo triunfar de muchos peligros. Fue tenido por guerrero esforzado. Le abatió mucho la desenvoltura y loca fatuidad de su mujer, ya anciano. Ejemplo elocuente para que los ilustres capitanes cuiden de conservar su buena fama hasta el último día de su vida, porque sus hechos han de andar de boca de todos" (92), Si bien Juan II, no pudo ver el desenlace matrimonial que confería sus previsiones, los últimos días de Don Alonso de Aragón aparecen rodeados de los sinsabores que le produjeron una consorte joven y una senilidad prematura, que rodeaba de sombras un pasado glorioso.

La ingratitud de sus contemporáneos o la fatuidad de su consorte rodearon de sinsabores los últimos días de Don Alonso, mas no borraron la aureola caballeresca que rodeó al aragonés durante toda su vida. Aunque no murió en la lucha contra los moros y su muerte no pudo ser congraciada con el martirio, la biografía de Don Alonso de Aragón personaliza el ideal caballeresco del medievo tardío, ya sea por su completa abnegación a su padre y señor, Juan de Navarra o hacia los Reyes Católicos (93), su valentía en el campo de batalla o su culto del bello sexo. Teniendo en cuenta las luchas apasionadas que afectaron al reino de Castilla en sus días, entre Juan II y su hijo el Príncipe de Asturias, futuro Enrique IV, al reino de Francia, entre el rey Carlos y su hijo el delfín, futuro Luis XI y al reino de Navarra, entre su propio padre, Juan de Navarra y el príncipe de Viana, Don Alonso de Aragón aparece como una figura excepcional, símbolo de fidelidad filial, valentía y amor, a quien sus dotes personales elevaron a la cúspide del ideal caballeresco medieval. Tal como concluye Jerónimo Zurita, los dones de Don Alonso de Aragón lo hacen acreedor de una «muy particular historia». 
NOTAS

(1) J. PRAWER, The Crusaders' Kingdom: European Colonialism in the Middle Ages, Nueva York 1972, págs. 6 y sig.

(2) A. GRABOIS, «De la trêve de Dieu à la paix du roi - Etude sur les transformations du mouvement de la paix au XII siècle», Mélanges René Crozet, éds. P. Gallais et Y. Riou, Poitiers 1966, I, págs. 585-95.

(3) J. HUIZINGA, El Otoño de la Edad Media, tr. José Gaos, Madrid 1981, págs. 133 y sig. M. ESPADAS BURGOS, «El sentido de la vida en el caballero medieval», La Orden de Calatrava. VIII Centenario, Publicaciones del Instituto de Estudios Manchegos, Ciudad Real 1959, págs. 68-71.

(4) La bibliografía sobre el período es extensa. Como estudio panorámico, cabe citar la monumental obra editada por R. MENÉNDEZ PIDAL, Historia de España, vol. XV, Los Trastámaras de Castilla y Aragón en el siglo XV, por LUIS SUÁREZ FERNÁNDEZ, ÁNGEL CANELLAS LOPEZ y JAIME VICENS VIVES, Madrid 1964.

(5) JOSÉ NAVARRO LATORRE, Don Alonso de Aragón, la «espada» o lanza de Juan 11. Barcelona 1983.

(6) La principal fuente a nuestra disposición es la biografía inedita, Historia del Invicto Don Alonso de Aragón Maestre de la Orden de Calatrava y Conde de Ribagorza, hijo natural del inclito Rey Don Juan el segundo de Aragón y de Navarra. Real Academia de la Historia, Colección Luis de Salazar I-35, Sign. 9-609, n. ${ }^{\circ}$ 36203, (de aqui en adelante citado como Historia). Ver la descripción del manuscrito en el Índice de la Colección de Don Luis de Salazar y Castro, ed. Baltasar Cuartero y Huerta \& Antonio de Vargas Zúniga y Montero de Espinosa, Madrid 1959. XXIII, 173. Si bien la biografía es anónima, tanto la redacción como el estilo de la misma esbozan la posibilidad que fuera escrita a comienzos del siglo XVII por un admirador del rey Don Juan II de Aragón.

(7) MOSÉN DIEGo DE VALERA, Crónica de Enrique $N$, ed. Juan de Mata Carriazo Madrid 1941, págs. $65,205,255,289$. ANDRÉS BERNÁLDEZ, Memorias del Reinado de los Reyes Católicos, ed. Manuel Gómez Moreno y Juan de Mata Carriazo, Madrid 1962, c. XVIII, p. 51. ALONSO DE PALENCIA, Crónica de Enrique $N$, tr. D. A. Paz y Meliá, Madrid 1904, 5 vols., I. p. 100.

(8) Historia, fol. 3 r. JERÓNIMO ZURITA, Anales de la Corona de Aragón, Zaragoza 1579, ed. Ángel Canellas López, Zaragoza 1975, XV-29, p. 313. LUCIO SíCULO MARINEO, Crónica d'Aragón, 1523, repr. Barcelona 1974, fol. $66 \mathrm{v}$.

(9) Historia, fol. $4 \mathrm{v}$.

(10) Religionis zelus rite, 3/9/1443, Archivo Histórico Nacional, Documentos eclesiásticos de Calatrava, n. ${ }^{\circ} 126$. 
(11) Bullarium Ordinis Militiae de Calatrava, opus D. Ignatii Josephi de Ortega et al., Aranjuez 1747-1761, p. 254.

(12) Historia, $3 v$.

(13) Historia, 4 v. $-5 \mathrm{r}$.

(14) Consultar nota $\mathrm{n} .{ }^{\circ} 10$.

(15) A.H.N., Documentos eclesiásticos de Calatrava, n. ${ }^{\circ} 128$, fols. 4-7. En otro artículo, «A Chapter in the Juridical History of the Order of Calatrava - The Election of Don Alonso de Aragón» hemos discutido en detalle los distintos aspectos de esta discutida elección (en prensa).

(16) PEDRO CARRILLO DE HUETE, Crónica del Halconero de Juan I/, ed. Juan de Mata Carriazo, p. 357 y sig., págs. 417-39. Ver así mismo, J. VICENS VIVES, Juan II de Aragón Monarquía y revolución en la España del sigio XV. Barcelona 1953, págs. 96-123.

(17) ALONSO DE PALENCIA, Crónica, I, p. 74. Consultar así mismo, J. O'CALLAGHAN, «Don Pedro Girón, Master of the Order of Calatrava, 1445-1466", Hispania, 21 (1961), págs. 346 y sig.

(18) ZURITA, XIX-61, p. 245. Algunos cronistas contemporáneos se identificaron con las reivindicaciones de Don Alonso. Alonso de Palencia, por ejemplo, lo designa como «legítimo maestre de Calatrava», actitud común también a Mosén Diego de Valera, ver Alonso de Palencia, Crónica, III. p. 154, IV, p. 19. MOSÉN DIEGO DE VALERA, Crónica de los Reyes Católicos, ed. Juan de Mata Carriazo, Madrid 1927, p. 40.

(19) JAIME CARUANA GÓMEZ DE BARREDA, "La Orden de Calatrava en Alcañiz", Teruel, 8 (1952), págs. 132-33.

(20) Historia, fols. 5 r. -5 v.

(21) ZURITA, XV-39, p. 352.

(22) Crónica de Don Álvaro de Luna Condestable de Castilla, ed. Juan de Mata Carriazo, Madrid 1940, págs. 224-29.

(23) A. de Palencia, Crónica, I, págs. 99-100.

(24) ZURITA, XV-63, 64, págs. 438-44. Sobre la situación en el reino de Navarra consultar, V. VIVES, p. 139 y sig. FERNANDO RUANO PRIETO, Don Juan // de Aragón y el Príncipe de Viana, Bilbao 1897. GEORGES DESDEVISES DU DEZERT, Don Carlos d'Aragón, Prince de Viane, París 1889, págs. 123-313. JOSÉ RAMÓN CASTRO, Carlos III el Noble, Rey de Navarra, Pamplona 1967, págs. 11 y sig.

(25) Sobre la batalla de Aybar y su desarrollo, consultar, MANUEL IRIBARREN, EI Príncipe de Viana, Barcelona 1947, págs. 88-97.

(26) ZURITA, XV-65, p. 446.

(27) Historia, fols. 8 v. -9 r.

(28) Historia, fol. $10 \mathrm{r}$.

(29) ZURITA, XVI-1, p. 11. Historia, fol. 8 r.

(30) A. de Palencia, Crónica, I, págs. 273-74. FRANCISCO R. DE UHAGÓN Órdenes Militares - Discursos leídos ante la Real Academia de la Historia, Madrid 1898, págs. 75-6. Historia, fol. $12 \mathrm{~V}$.

(31) Ver la confirmación de los acuerdos de Agreda y Almazán, firmada en Alfaro, el 20 de mayo, 1457, Real Academia de la Historia, Memorias de Don Enrique IV de Castilla - Colección diplomática, Madrid 1835-1913, vol. II, págs. 149-51. Cabe destacar que la preocupación de Juan de Navarra por recuperar el maestrazgo era genuina. Ya en 1450, había tratado de volver a Don Alonso a la dirección de Calatrava a través de los tratados de paz con Castilla; si bien dicha propuesta resultó ser un ardid del condestable para desviar la atención del rey de Navarra a sus planes, Don Alonso entró en Pastrana y tomó la posesión de la villa, pero fue derrotado por el Maestre Pedro Girón en Almagro, ver Crónica de Don Álvaro de Luna, p. 251. ZURITA, $X V-63$, págs. 439-40.

(32) VICENS VIVES, Juan II, p. 218.

(33) Sobre la personalidad de la reina y su influencia sobre Juan II ver el detallado estudio de Carmen Muñoz Roca-Tallada, Doña Juana Enríquez, Madrid 1945. 
(34) MANUEL IRIBARREN, El Príncipe, págs. 159-202. G. DESDEVISES DU DEZERT, Don Carlos, págs. 308-52.

(35) A. de Palencia, Crónica, I, p. 340.

(36) ZURITA, XVII-23, p. 353. Historia, 12 r.

(37) ZURITA, XVII-26, págs. 359-60. A. de Palencia, Crónica, I, p. 350

(38) Real Academia de la Historia, Memorias, págs. 304-311. Sobre la voluminosa literatura histórica de la revuelta catalana, consultar especialmente, SANTIAGO SOBREQUES, "Los orígenes de la revolución catalana del siglo XV: las cortes de Barcelona de 1454-1458", Estudios de Historia Moderna, 2 (1952), 1-96. CARMEN BATTLE, «La ideologia de la busca: La crisis municipal de Barcelona en el siglo XV», Estudios de historia moderna, 5 (1955), 165-196, asi como la edificante reseña de la situación del principado por C. BATTLE GALLART, La crisis social y económica de Barcelona a mediados del siglo XV. 2 vols. Barcelona 1973

(39) ZURITA, XVII-40, p. 415, 418.

(40) ZURITA, XVII-44, p. 428.

(41) Si bien desconocemos los nombres de los otros amores de Don Alonso, los cronistas contemporáneos nos brindan los nombres de sus otros hijos naturales, a saber, Don Alonso de Aragón, obispo de Tortosa, que fue promovido a la iglesia de Tarazona, Don Hernando, prior de Cataluña y Don Enrique, abad de Nuestra Señora de la O, que falleció electo obispo de Cephalú. ZURITA, XX-64, págs. 496-97. Historia, fols. 34 r. - 34 v. J. NAVARRO LATORRE, págs. $51-52$.

(42) Historia, fots. 13 v. -14 v.

(43) En su lecho de muerte Juan II requirió a su hijo y heredero, Fernando el Católico, que abrogase por el casamiento de su nieto, Don Juan, con Doña Maria López de Gurrea, «rica fembra”, considerada la heredera más preciada en toda España, Historia, fols. 31 r. - $31 \mathrm{v}$. asi como fols. 14 r. -14 v., 25 v., 29 r., 30 v.

(44) Historia, fols, 32 r. -32 v.

(45) JOSEPH CALMETTE, Louis XI, Jean /l et la revolution catalane, Paris 1902 (repr. 1977), $57-67$.

(46) Real Academia de la Historia, Memorias, págs. 248 y sig.

(47) Historia, fol. $17 \mathrm{r}$.

(48) ZURITA, XVII-53, p. 464

(49) Historia, fol. 17 v. ZURITA, XVII-55, p. 474. Ver asi mismo, E. MATEU LLOPIS, «Los recursos económicos de Juan II en Lérida y Tárrega durante las turbaciones del Principado en 1465», Hispania, 8 (1942), 407-57.

(50) Historia, fol. 18 v. ZURITA, XVIII-3, p. 519.

(51) ZURITA, loc. cit.

(52) ZURITA, XVIII-6, p. 431.

(53) Historia, fols. 24 r. $-21 r$

(54) ZURITA, XVIII-4, p. 522.

(55) Historia, fols. $19 \mathrm{v} .-20 \mathrm{r}$.

(56) Historia, fols. $21 \mathrm{v},-22 \mathrm{r}$.

(57) Historia, fols, 22 v. -23 v. Sobre el condado de Ribagorza, su extensión y poderío, ver, M. SERRANO Y SANZ, Noticias y Documentos históricos del Condado de Ribagorza hasta la muerte de Sancho Garcés III, Madrid 1912. El 8 de julio de 1473, en pos de los festejos que siguieron a la retirada de las fuerzas francesas de Perpiñán, Juan II y su primogénito, el rey Fernando, extendieron la concesión del condado de Ribagorza a Don Juan de Aragón, hijo natural de Don Alonso y Doña María lunques, ver, Historia, fols. 25 v. - 26 v. ZURITA, XVIII-56, p. 720.

(58) La oferta de los catalanes al conde de Anjou aparece en J. CALMETTE, Louis XI, págs. 265-77. Sobre las implicaciones de tal oferta consultar VICENS VIVES, Fernando el Católico, Príncipe de Aragón, Rey de Sicilia, 1458-1478, Madrid, 1952, págs. 255-59. Ver así mismo, J. ERNESTO MARTÍNEZ FERRANDO, Nueva visión y sintesis del gobierno intruso de Renato d'Anjou, Barcelona 1941

(59) Historia, fol. 21 r. ZURITA, XVIII-11, p. 558; XVIII-17, p. 577; XVIII-23, págs. 603-04. 
(60) ZURITA, XVIII-16, p. 571. Historia, tol. $21 \mathrm{r}$.

(61) ÁNGELES MASIÁ DE ROS, Gerona en la guerra civil en tiempos de Juan II, Barcelona 1943, págs. 160 y sig.

(62) ZURITA, XVIII-37, p. 658. Historia, fol. $24 \mathrm{v}$.

(63) Historia, fol. 24 r. A. de Palencia, Crónica, II, p. 482.

(64) ZURITA, XVIII-37, págs. 657-58.

(65) Historia, fol. $24 \mathrm{v}$.

(66) Historia, loc. cit.

(67) ZURITA, XVIIl-38, p. 660. Historia, loc. cit.

(68) ZURITA, XVIII-44, págs. 683-84. Sobre la capitulación de Pedralbes y la política Juanista, consultar, VICENS VIVES, Juan II, págs. 337-40.

(69) J. CALMETTE, Louis Xl, págs. 144-69.

(70) Historia, fols. 25 r. - 25 v. ZURITA, XVIII-54, 55, págs. 712, 716. A. de Palencia, Crónica, III, págs. 154-55. Ver así mismo J. CALMETTE, «La monarchie aragonaise et la campagne des français en Roussillon en 1474-1475", Annales du Midi 61 (1948), págs. 96 y sig.

(71) Historia, fols. 26 v. -27 r. ZURITA, XVIII-59, p. 731.

(72) MOSÉN DIEGO DE VALERA, Crónica de los Reyes Católicos, p. 38. Alonso de Palencia, Crónica, IV, p. 58. ZURITA, XIX-30, p. 135. Historia, fols. 27 r. - 27 v. Sobre los antecedentes del conflicto, consultar, ORESTES FERRARA, Un pleito sucesorio: Enrique $\mathrm{IV}$, Isabel de Castilla y la Beltraneja, Madrid 1945. TARSICIO DE AZCONA, Isabel la Católica, Madrid 1964, págs 229-307.

(73) FERNANDO DEL PULGAR, Crónica de los Reyes Católicos, ed. Juan de Mata Carriazo, Madrid 1943, 2 vols., I, p. 66. ANDRÉS BERNÁLDEZ, Memorias, p. 28. C. TORREZ SUÁREZ, "Don Rodrigo Téllez Girón, Maestre de Calatrava", Anuario de Estudios Medievales, 11 (1981), 777-82.

(74) La desilusión de Don Alonso ante la ingratitud de los Reyes Católicos, le hizo forjar planes de inmediato regreso a Aragón, ver, Historia, fols. 28 v. - 29 r. ZURITA, XIX-49, p. 204.

(75) FERNANDO DEL PULGAR, Crónica, págs. 230-43. Sobre la Santa Hermandad, su administración e influencia en la política real, ver MARVIN LUNENFELD, The Council of the Santa Hermandad, Miami 1970, esp. págs. 9-14. Sobre la guerra de Granada, MANUEL BALLESTEROS GAIBROIS, Isabel de Castilla, Reina Católica de España, 2da. ed. Madrid 1970, págs. 9396. TARSICIO DE AZCONA, Isabel, págs. 503 y sig.

(76) Sobre la invasión portuguesa y las consecuentes batallas ver, CÉSAR SILIO CORTÉS, Isabel la Católica, Madrid 1943, ed. 1967, págs. 131-98.

(77) Historia, fols. 27 v. - 28 r.; ver el juicio similar de Mosén Diego de Valera, Crónica de los Reyes Católicos, p. 47; A. de Palencia, Crónica, IV, págs. 89-97.

(78) FERNANDO DEL PULGAR, Crónica, págs. 151, 165, 173, 178.

(79) Historia, fol. 28 r. ZURITA, XiX-40, 43, págs. 171, 177. FERNANDO DEL PULGAR, Crónica, p. 198. MOSÉN DIEGO DE VALERA, Crónica de los Reyes Católicos, p. 84. A. de Palencia, Crónica, págs. 139-140, 149.

(80) ZURITA, XIX-45, p. 187-88. Historia, fol. 28 v. A. de Palencia, Crónica, IV, p. 183.

(81) Historia, fol. 29 r. A. de Palencia, Crónica, IV, 298-301. MOSÉN DIEGO DE VALERA, Crónica de los Reyes Católicos, págs. 94-95. ZURITA, XIX-57, p. 232. Ver así mismo J. FERNÁNDEZ DOMINGUEZ, La guerra civil a la muerte de Enrique IV: Zamora, Toro, Castronuño, Zamora 1929. VICENTE DIEZ CARBAJO, «La batalla de Toro», Ejército, 35 (1942), p. 35 y sig.

(82) Historia, fol. 29 v. ZURITA, XIX-61, p. 245.

(83) El gran aprecio de la reina para su dama quedó corroborado años más tarde cuando Doña Leonor de Soto fue escogida como su único cortejo en la ceremonia de bautismo del príncipe heredero Don Juan, ver, ANDRÉS BERNÁLDEZ, Memorias, c. XXXIII, p. 75.

(84) ZURITA, XX-3, 4, págs. 262-65. Historia, fols. $30 \mathrm{r}$. $31 \mathrm{v}$.

(85) ZURITA, XX-6, 13, 30, págs. 268-69, 299, 365. Historia, fol. 30 r. FERNANDO DEL PULGAR, Crónica, págs. 243, 289, 294, 358. MOSÉN DIEGO DE VALERA, Crónica de los Reyes Católicos, págs. 124-125. 
(86) FERNANDO DEL PULGAR, Crónica, págs. 294-95.

(87) ZURITA, XX-12, p. 292. A. de Palencia, Crónica, IV, págs. 425-426.

(88) Historia, fol. 34 r. ZURITA, XX-41, p. 403.

(89) ZURITA, XX-56, p. 465. FERNANDO DEL. PULGAR, Crónica, págs. 23 y sig.

(90) A. de Palencia, Crónica, V, p. 48.

(91) ZURITA, XX-44, p. 417. Historia, fol. 34 r. De acuerdo al intinerario de los Reyes Católicos, éstos estuvieron en Linares entre el 8 y el 10 de octubre, fecha en que se sitúa la muerte de Don Alonso. Ver ANTONIO RUMEU DE ARMAS, Itinerario de los Reyes Católicos, 1474-1516. Madrid 1974, p. 135.

(92) A. de Palencia, Crónica, V, p. 216. Historia, fol. 34 v. ZURITA, XX-64, p. 496.

(93) Quizás ésta fue la intención del anónimo autor de la Historia cuando comenzó su obra recalcando la fidelidad de su abuelo, Fernando de Antequera, hacia su difunto hermano y su sucesor, el futuro Juan If de Castilla, Historia, fols. $1 \mathrm{r}$. $-1 \mathrm{v}$. 


\title{
APROXIMACIÓN A LA DEMOGRAFÍA BAJO-MEDIEVAL DE LA COMARCA DEL MEDIO VINALOPÓ (ALICANTE)
}

\author{
A. M. POVEDA NAVARRO
}

(U. N. E. D.-Elche)

INTRODUCCIÓN

Ante la pregunta ¿cuántos pobladores habitaban la comarca del Medio Vinalopó (1) en la época medieval?, hemos de reconocer que la respuesta entraña grandes dificultades, a veces insalvables. Esas mismas dificultades son comunes a la demografía del reino de Valencia en la Edad Media.

La ausencia de fuentes y de estudios demográficos, que traten de responder a esa pregunta, son los principales obstáculos por el investigador.

Para la población de época medieval de la comarca del Medio Vinalopó, apenas contamos con unas referencias marginales de J. B. Vilar y de J. Hinojosa (2) sobre la naturaleza de esa población, y de V. González y de A. M. Poveda (3) sobre el número de sus componentes.

Las fuentes latinas ubican en las proximidades del valle medio del río Vinalopó dos ciudades ibero-romanas, ELLO (AD ELLO) y ASPIS (4), que la arqueología y la toponimia las identifican con yacimientos de las actuales ciudades de Elda y Aspe, respectivamente.

Posteriormente, en época visigoda, hay unos pocos textos que citan una ciudad hispanorromana lo suficientemente importante como para ser sede de un efímero obispado (el elotano, del s. VII). Tal ciudad visigótica sería ELO (antigua Ello), Elda (5).

Nada más llegar los árabes a la Península Ibérica se establece un pacto, el de Teodomiro, entre visigodos y árabes, que en el año 713 informa de 
algunas poblaciones importantes existentes en la cuenca del Vinalopó. Según algunos autores (6) aparecerían citadas Elda, como IYYA, ILLA o AL(A)H, y Novelda-La Mola en las grafías árabes NWILLA-NWLA.

Desde esta época y hasta el siglo XII las fuentes escritas y las arqueológicas quedan prácticamente mudas. Fenómeno que se ha interpretado en alguna ocasión como despoblamiento del área comarcal que analizamos. Solamente poseemos unas cortas citas de la ruta del valle del Vinalopó. Se trata de la aparición de los topónimos EDELLE y ELOE, que pertenecen respectivamente a fuentes de los siglos IX y XII y se refieren, en alusión corrompida, a AD ELLO y $\operatorname{ELO}(7)$.

También en un itinerario del s. XI, recogido por el árabe Al-c Udrt, aparece citada otra población del valle medio del Vinalopó, es la antigua Aspis que ahora aparece en grafía árabe como AȘF. De igual forma aparecerá en el siglo siguiente con Al-Salà (8).

Con la llegada del siglo XIII se recuperan las referencias a poblaciones del Medio Vinalopó, tanto en fuentes árabes, como en cristianas (9): Așf/Asp, Aspe; Illa o Al(a)h/Ella, Elda; Nompot, Monforte; Munawar/Montnóver, Monóvar; Nwilla y Mwla/Noella y (La) Mola, Novelda y La Mola; BitrTr/Petrer, Petrel; Salinas; y $S(a) g(a) s / S a i x$, Sax.

Desde 1243-44 ( $y$ hasta 1304-5 en que pasa a Aragón) el valle medio del Vinalopó pasa a depender del reino de Castilla, pero sus habitantes siguieron siendo mayoritariamente los musulmanes hasta la primera década del s. XVII. Sin embargo, contemplaron el lento e indeciso asentamiento de algunas familias cristianas llegadas de Castilla y de Aragón. Dichas familias pasaron a depender del vicariato, fueros y alcaldes de Elche, donde también se verían sus pleitos y alzadas, según dispuso el hermano del rey Alfonso $X$ don Manuel, señor de casi toda la cuenca del Vinalopó durante casi toda la segunda mitad del siglo XIII (10).

\section{EL SIGLO XIII (LA REPOBLACIÓN)}

La carencia de datos sobre este período ocasiona un casi total desconocimiento del mismo.

Sin embargo, hay un hecho evidente, la repoblación de las comarcas alicantinas produjo un asentamiento de población cristiana llegada del norte. A medida que avanzaba el s. XIII los asentamientos se hicieron más definitivos y más numerosos. 
Dentro de la actual provincia de Alicante se intuye una más intensa repoblación al norte de la frontera establecida en el pacto de Almizra, que en la parte de la misma provincia que aparece al sur de esa frontera, donde se ubica la comarca del Medio Vinalopó, que fue más débilmente afectada por el proceso repoblador.

Proporcionalmente, sabemos que las poblaciones de esta comarca acogían una mayoría poblacional musulmana y una minoría cristiana, y a veces otra minoria judía (caso de Elda y quizá de Petrer, Aspe o Novelda). Pero dado que nos movemos en momentos históricos preestadísticos no contamos con cifras concretas. Cuando hallamos cifras, éstas vienen referidas a vecinos o cabezas de familia, por ello intentar obtener cifras más explícitas supone multiplicarlas por coeficientes hipotéticos, y meramente aproximativos. Nosotros emplearemos el coeficiente 5 para los mudéjares y moriscos; el 4,5 para los cristianos; y el 4,7 para la población indeterminada.

Nuestra metodología partirá de la conjugación de un documento fiscal oriolano, de principios del 1300 , y de un censo de cristianos del valle del $\mathrm{Vi}$ nalopó, elaborado en Elche a primeros del 1400. Además, se tendrá en cuenta la evolución demográfica general del reino de Valencia en los siglos XIV-XV, y los primeros censos del siglo XVI.

Pero para el siglo XIII no podemos aplicar nada de todo ello. Hemos de conformarnos con acercarnos a la población de forma cualitativa y no cuantitativa.

En los momentos iniciales, después de pasar el valle medio del Vinalopó a manos cristiano-castellanas (1243-44), cualquier intento de asentar nuevas gentes en su término comarcal era baldio, las familias castellanas dispuestas a ubicarse en el Medio Vinalopó (o en cualquier nuevo territorio castellano) serían escasas; incluso los dueños del señorío o donadío no solían hacer efectiva la toma de posesión del mismo, pues frecuentemente se marchaban sin arraigar en el lugar. Lo cual tuvo que combatirse legislativamente.

Además, sabemos que en los inicios de la repoblación del reino de Murcia (al que pertenecía esta comarca hasta primeros del siglo XIV) por los castellanos, éstos chocaban con el predominio poblacional musulmán. Predominio que en el Medio Vinalopó se mantuvo hasta la primera década del siglo $\mathrm{XVII}$.

Si a estos hechos añadimos la falta de indicios que reflejen evacuaciones poblacionales musulmanas por los castellanos, y la opinión de Del Estal de que en todo el reino de Murcia no ocurrió ni un solo caso de vaciamiento po- 
blacional mudéjar (11), entonces debemos suponer que durante la segunda mitad del siglo XIII no hubo una auténtica y sustancial alteración, ni cualitativa ni cuantitativa, en la población del Medio Vinalopó, pues ni hubo llegada masiva de castellanos, ni éstos expulsaron a los moradores mudéjares de la comarca; lo que tampoco debieron hacer los valenciano-aragoneses que posteriormente se asentaron en la misma.

A partir de 1257 se aceleró y acentuó el proyecto de repoblación castellana, en virtud de la propia actuación directa del rey Alfonso $X$ el Sabio. En ese mismo año este monarca entregaba la villa y el castillo de Elda a su hermano don Manuel, ampliándole su gran señorío del Medio Vinalopó (12), y convirtiéndole en relevante figura repobladora en la provincia de Alicante. Don Manuel contaba en la misma inmensas propiedades en las comarcas del $\mathrm{Vi}$ nalopó ubicadas entre Villena y Elche-Sta. Pola, es decir, todo el Medio Vinalopó.

Con don Manuel debieron darse los primeros asentamientos castellanos importantes en la comarca. De modo que se formaría una pequeña comunidad cristiana (universitas) en los valles del Vinalopó, que justificaría la adscripción de los mismos al obispado de Cartagena y al vicariato de Elche, y la obra legisladora de don Manuel que ordenaba que los pleitos y alzadas de los cristianos de Elda y Novelda debían verse en Elche, mediante los fueros y alcaldes de esta misma población (13).

Además, en 1265-66 Jaime l intervino en los valles del Vinalopó para sofocar a los mudéjares de esas tierras, que se habían levantado contra don Manuel, su dueño, y don Alfonso X, su monarca.

La intervención de Jaime I tuvo éxito y también repercusión repobladora, pues debió realizar donadios a los cien caballeros aragoneses-valencianos que asentó en las tierras ubicadas entre Alicante y Villena, con el objeto de vigilar esa importante ruta-frontera (14).

La consecuencia de tales hechos fue el asentamiento de nuevas familias cristianas, ahora valencianas, que se sumaron al supuesto número reducido de familias castellanas asentadas anteriormente, con Alfonso X. De este modo aumentaría ligeramente el número de habitantes cristianos del Medio Vinalopó.

De todas formas, la población musulmana continuó siendo mayoría casi exclusiva en las comarcas del Vinalopó (Elda, Petrer, Monóvar, Novelda y Aspe), pues la auténtica y eficaz repoblación se desarrolló en Alicante, Elche, Orihuela, Villena y el norte de la actual provincia de Alicante. 


\section{LOS SIGLOS XIV-XV}

Ante la falta de cifras reales y explícitas para esta etapa medieval, nos vemos obligados a utilizar datos que, indirectamente, nos ofrezcan unas cifras aproximativas a la realidad demográfica del Medio Vinalopó bajomedieval.

De los primeros años 1300 data una tributación de algunas poblaciones de la Gobernación de Orihuela (15), entre las que aparecen Aspe, Elda y Novelda, que respectivamente pechaban al año 3.800 sueldos, 24.000 sueldos y 12.303 sueldos.

El pecho pagado por Elda lo hemos podido desglosar en tres partes, las correspondientes a las tres comunidades que la habitaban: mudéjares, cristianos y judios. Sabiamos que los mudéjares pechaban con 20.000 sueldos y los judíos con otros 100 , de modo que los 3.900 sueldos restantes, hasta completar el total de 24.000 , correspondian a los cristianos de Elda en los principios de 1300 .

Si observamos la proporcionalidad entre las tres comunidades contribuyentes en dicho pecho, resulta que los mudéjares pechan algo más de cinco veces que los cristianos, y doscientas veces más que los judios. Esta misma proporcionalidad es la que suponemos debe existir entre el número de individuos que pertenecen a cada una de esas tres comunidades.

Si admitimos esa proporcionalidad a nivel fiscal y demográfico, estaremos admitiendo también una presión fiscal por cabeza idéntica en las tres comunidades. Hecho que es probable pues el trato, incluido el fiscal, para con el mudéjar y el judío debía ser bueno con tal de que no se marchasen de la ciudad, ya que eran los principales sustentadores de la economía de la misma. También el trato fiscal debía ser aceptable para la última comunidad asentada, la cristiana, de otro modo no accederían a establecerse definitivamente en la zona. Hay que tener en cuenta que un mal trato fiscal podía obligar a la población a marcharse, tal y como hicieron 80 familias de Orihuela en 1353 (16).

Otro documento importante, de primeros del 1400, nos aporta el censo de cristianos de Elche y el valle medio del Vinalopó (17).

Nuestro interés se centra en los cristianos de ese valle, cuyo número viene ofrecido en casats o fuegos, a los que aplicaremos el coeficiente 4,5 por cada casat, que es el índice aplicado por V. Gozálvez para Elche (18). 
CUADRO 1. CRISTIANOS DEL MEDIO VINALOPÓ HACIA 1400

ASPE

$\begin{array}{r}\text { casats } \\ \hline 6 \\ 30 \\ 2 \\ 11 \\ 4 \\ 8 \\ \hline\end{array}$

TOTALES

61

habitantes

27

135

9

49

18

36

274

Nuestra hipótesis de trabajo se sustenta en la conjugación de los datos fiscales de 1300 con los datos demográficos de 1400, pero siempre y cuando aceptemos que en ambas fechas había igual población. Es bien sabido que el aumento demográfico acumulado en la primera parte del siglo XIV, fue totalmente anulado en su segunda parte a causa de una larga serie de calamidades letales.

Mediante reglas de tres conjugaremos esos datos e iremos obteniendo los censos poblacionales, en las villas medievales del Medio Vinalopó.

Comenzaremos por Elda, única población de la que tenemos los pechos desglosados por comunidades.

ELDA.-Aceptando que los 135 cristianos de 1400 existian en igual número en 1300, de los cuales solamente eran imponibles 117 (19), y sabiendo que pechaban 3.900 sueldos anuales, es fácil deducir por reglas de tres cuántos mudéjares serian los que pecharian 20.000 sueldos, y cuántos judíos debían existir para que pagasen 100 sueldos del pecho total del 1300 .
117 crist...............
3.900 sueldos
117 crist 20.000 sueldos
$A=135$ crist.
C judíos
3.900 sueldos
100 sueldos
$B=600$ mudéj.

$$
A+B+C=
$$
Población: 738 hab.

CUADRO 2

\begin{tabular}{lcccc} 
& pechos hacia 1300 & & habitantes/casats hacia & $1300-1400$ \\
\cline { 2 - 2 } mudéjares & 20.000 sueldos & & 600 & 120 \\
cristianos & 3.900 sueldos & & $117(135)$ & $26(30)$ \\
judíos & 100 sueldos & & 3 & $1(0,6)$ \\
\cline { 2 - 3 } \multicolumn{1}{c}{ TOTALES } & 24.000 sueldos & & $720(738)$ & 147
\end{tabular}


Con estos datos de Elda ya podemos deducir los censos de Aspe y Novelda, pues las tres poblaciones pecharian en las mismas condiciones, ya que tenían el mismo recaudador, Orihuela.

NOVELDA

24.000 sueld. (Elda) 720 hab. (imponibles de Elda)

12.303 sueld. (Novelda). $x$ hab. (Novelda) $x=369$ hab. 369 hab. -49 crist. $=320$ mudéjares.

ASPE

24.000 sueld. (Elda) 720 habit. (Elda)

3.800 sueld. (Aspe)

114 hab. -27 crist. $=87$ mudéjares.

Para restituir un censo aproximado de Petrer y de Monóvar hemos tenido que deducir un índice, que sea la razón media menos errada entre cristianos y mudéjares de una población del Medio Vinalopó.

En Aspe la razón entre mudéjares y cristianos es de 3,2 a favor de los primeros; en Novelda 6,5 a favor de los mudéjares; y en Elda 5,1 a favor de los mudéjares. Entonces se obtiene la razón media entre ellas:

$$
\frac{6,5+3,2+5,1}{3}=4,9 \text {. }
$$

Además buscamos la razón media de error, que obtenemos al restarle a cada una de las tres razones anteriores la razón media 4,9, luego los resultados de las tres sustracciones los sumamos y dividimos por tres:

$$
\frac{0,2+1,6+1,7}{3}=1,1 \text {. }
$$

Finalmente, obtendremos la razón media más aproximada al dividir la razón media 4,9 por la razón media de error

$$
\text { 1,1: } \frac{4,9}{1,1}=4,4 \text {. }
$$

Este último índice es el que multiplicaremos por los cristianos de Petrer y Monóvar, obteniendo así sus respectivos mudéjares.

PETRER. -18 crist. $\times 4,4=$ mudéjares. Total población: $18+79=97$ habitantes.

MONÓVAR. -9 crist. $\times 4,4=39$ mudéjares. Total población: $9+39=48$ habitantes. 
CUADRO 3. POBLACIÓN MUDÉJAR-CRISTIANA HACIA 1300

\begin{tabular}{|c|c|c|c|}
\hline & mudéjares & cristianos & total habit. \\
\hline ASPE & 87 & 27 & 114 \\
\hline ELDA & 600 & 135 & 735 \\
\hline MONÓVAR & 39 & 9 & 48 \\
\hline NOVELDA-LA MOLA & 320 & 49 & 369 \\
\hline PETRER & 79 & 18 & 97 \\
\hline SALINAS & - & 36 & 36 \\
\hline TOTALES & 1.125 & 274 & 1.399 \\
\hline
\end{tabular}

Con todo el proceso descrito, paso a paso, hasta aquí, hemos podido confeccionar una restitución aproximada del censo del Medio Vinalopó hacia 1300.

En los inicios de 1300 las poblaciones debían contar, en general, con casi los mismos habitantes que a principios de 1400 .

El esquema general de la evolución demográfica de la Corona de Aragón, del Reino de Valencia (20) y de Orihuela (21), entre esos mismos años, se caracteriza por un incremento poblacional en la primera mitad del siglo XIV nunca inferior al 40 ó 50\%, respecto del censo de 1300. Sin embargo, desde mediados del XIV (1348-51), tal crecimiento fue frenado y anulado por las calamidades sufridas en la segunda mitad de dicho siglo (epidemias, malas cosechas, hambre, belicismo, alta mortandad).

Nosotros vamos a seguir ese esquema general del siglo XIV, aplicando un hipotético incremento del $45 \%$ sobre el censo que hemos restituido de 1300 en el Medio Vinalopó. De forma que, el censo que ahora confeccionamos (cuadro 4) nos informa de la hipotética población de esta comarca hacia mediados del siglo XIV. De todas formas, al final de este siglo, el crecimiento acumulado en su primera parte ha sido totalmente anulado.

Tal evolución demográfica es la que explica que el censo de 1300 y el de 1400 sean semejantes.

CUADRO 4. POBLACIÓN MUDÉJAR-CRISTIANA HACIA 1350

\begin{tabular}{|c|c|c|c|}
\hline & mudéjares & cristianos & total habit. \\
\hline ASPE & 126,5 & 39 & 265,5 \\
\hline ELDA & 870 & 60,7 & 930,7 \\
\hline MONÓVAR & 56,5 & 13 & 69,5 \\
\hline NOVELDA-LA MOLA & 464 & 71 & 535 \\
\hline PETRER & 114 & 26 & 140 \\
\hline SALINAS & - & 52 & 52 \\
\hline TOTALES & $1.631,0$ & 397,7 & $2.028,7$ \\
\hline
\end{tabular}


La evolución demográfica del siglo XV fue favorable en su saldo final, y permitió un aumento poblacional general sobre el censo de 1400 , aunque en 1492 se expulsó de España a los judíos. Éstos constituian en el Medio Vinalopó una comunidad numéricamente irrelevante.

En Elda sabemos que existió una pequeña comunidad israelita, quizá tres o cuatro familias en su mejor momento. También tenemos ciertos indicios de que en Petrer y en Aspe hubiese algún judío. Pero por su ínfimo significado numérico, no hemos tenido en cuenta a los judios a la hora de confeccionar los censos. De modo que tal expulsión judia apenas mermaría la población del Medio Vinalopó.

La población de esta comarca, a principios del siglo $X V$, sería prácticamente la misma que hacia 1300 , que quedó reflejada en el cuadro 3, y que es igualmente válido para este momento.

Por otra parte, merece interés la existencia de dos auténticos censos, aunque sean solamente de cristianos, que datan del 26 de agosto de 1400 y del 8 de marzo de 1401, cuya confección corrió de parte del Conçell de Alicante y del de Elche, respectivamente. Este último ya lo hemos reflejado con el cuadro 1.

El censo de 1400 (22) lo conocemos indirectamente, por lo cual ignoramos su distribución por villas, sólo contamos con la suma total de fuegos, que es lo que podemos contrastar con el censo de 1401 :

$\frac{1400}{\frac{\text { casats }}{52} \frac{\text { habit. crist. }}{234}} \quad \frac{1401}{\frac{\text { casats }}{61} \frac{\text { habit. crist. }}{275}}$

Nos aparece muy evidente que entre uno y otro censo hay un aumento de 9 casats, es decir, de 40 cristianos (aplicando el índice 4,5) pero desconocemos cómo se distribuiría tal aumento entre las villas del Medio Vinalopó.

Ambos censos son de índole fiscal pero bastante fiables.

Para conocer la demografía de la comarca al finalizar el siglo XV hemos de analizar un censo fiscal de 1510 (23).

Dicho censo se confeccionó con motivo de las Cortes de ese año, a celebrarse en Monzón. Ésta es la razón de que se detecten ocultaciones, además de no existir exhaustividad de los pueblos recogidos. 
Sin embargo, la aplicación del test de J. Dupaquier referido a la frecuencia de la cifra de las unidades, efectuada por R. García Cárcel (24), ofrece cierta fiabilidad para el censo de 1510.

\section{CUADRO 5. 1510: VILES E LOCHS DEL BARÇ MILITAR}

\begin{tabular}{|c|c|c|c|}
\hline & Cases & Habitantes & Bestiars \\
\hline ASP & 315 & 1.480 & 896 \\
\hline ELDA & 206 & 968 & 88 \\
\hline MONÓVAR, LA MOLA E XINOSA & 99 & 465 & 2.697 \\
\hline NOVELDA & 230 & 1.081 & 1.625 \\
\hline PETRER & 99 & 465 & 1.436 \\
\hline SALINES & 22 & 99 & 88 \\
\hline TOTALES & 971 & 4.558 & 6.830 \\
\hline
\end{tabular}

Este cuadro recoge los datos que el censo de 1510, del reino de Valencia, aporta sobre las villas del Medio Vinalopó. Pero la columna de habitantes la hemos confeccionado aplicando el índice deducido 4,7 al número de cases (hogares), excepto en las cases de Salines, donde por ser lugar de cristianos viejos hemos aplicado el índice 4,5.

Hasta aquí, hemos presentado los datos demográficos bajomedievales de la comarca del Medio Vinalopó, y ahora debemos relacionarlos con la coyuntura histórica que influyó en esa demografía y fue influida por ésta.

\section{LA COYUNTURA}

Desde finales del siglo XIII, Jaime II de Aragón favoreció la llegada de inmigrantes valencianos, catalanes y aragoneses, lo que unido a un importante crecimiento vegetativo en los mudéjares preexistentes y los primeros asentamientos cristianos (de Alfonso $X$ y de Jaime I), originó un crecimiento demográfico, en la primera mitad del siglo XIV, que como mínimo fue del 40 . $50 \%$, respecto del censo de 1300 .

Sin embargo, las frecuentes razzias granadinas y castellanas creaban un clima de total inseguridad en la comarca del Medio Vinalopó, ubicada en una zona fronteriza por excelencia. Además, la prolongada contienda de los dos Pedros entre Castilla y Aragón, que se convirtió en guerra total en el Bajo Segura y el Vinalopó, ocasionó la tala de los campos y graves daños en las poblaciones de esas comarcas. «El hambre, el hierro, las plagas y las epidemias, fueron de la mano durante esa contienda interminable, injusta y bárbara» (25). 
De entre tan negro panorama destaca el hambre de 1333; la peste bubónica, que no cesó desde 1348 hasta 1351, aunque luego se dieron rebrotes, el más mortal el de 1363, sobre todo para los niños, y nuevas epidemias en $1374,1375,1383$ y 1384, 1394 y 1398; además, las plagas de pulgón, de roedores y especialmente de la langosta, abatieron los campos y la huerta entre 1358 y 1459.

El fatal resultado de este proceso fue que, en la segunda parte del siglo XIV, se anuló el incremento poblacional del 40-50\% sobre el censo de 1300 , que se había conseguido en su primera parte.

También contribuyó al descenso demográfico del Medio Vinalopó la emigración a la zona castellana próxima, es decir, Murcia, además de al reino de Granada, y sobre todo que Orihuela quedó tan despoblada que necesitó traer gente de diversas comarcas, pero sobre todo de los valles de Elda y Novelda (26), que parece que fueron más débilmente afectadas por la peste (27).

Las hambres cíclicas, la reaparición esporádica de las epidemias, las fugas a Murcia y el nuevo conflicto castellano-aragonés, convirtieron en lenta y laboriosa la recuperación del siglo XV.

La evolución demográfica del Medio Vinalopó fue muy favorable durante el siglo XV, y debió ser muy semejante a la desarrollada en la capital de la Gobernación, Orihuela (28), sin embargo, la tónica demográfica general en Europa Occidental y en el País Valenciano era a la baja (29), sobre todo de 1451 a 1487, aunque de 1487 a 1593 hay alza, y a partir de 1499 fluctuaciones heterogéneas (30).

Volviendo al crecimiento poblacional del Medio Vinalopó, debió ser decisiva la compra de Ximén Pérez de Corella a la Corona de las villas y castillos de Elda y Aspe, en octubre de 1424, y algo más tarde de Petrer y Salinas. Dicho señor pudo favorecer la llegada de nuevos cristianos — valencianos-. con los que el Medio Vinalopó pudo aumentar en número de habitantes (31).

Un indicio de la pujanza económica y demográfica de esa comarca, creemos que debe ser la creación de un mercado (1426) y una feria (1466) en Elda, y un mercado (1466) en Aspe (32).

Sin embargo, el belicismo entre Castilla y Aragón de los años 1429-30 afectó profundamente a Monóvar, Novelda, La Mola y Chinosa, pues debido a ello presentaban una extrema despoblación, los campos estaban abandonados y el ganado había desaparecido, por ello Alfonso $V$ decide favorecer 
la comarca «guiando por cinco años al ganado de tiro, lanar y caprino que se llevara a estos términos y a sus carnicerías» (33).

El resultado demográfico de esa política económica (de mercados, feria y ganadería) desarrollada en el Medio Vinalopó por el rey Alfonso V, nos parece altamente positiva si observamos el censo de 1510, donde la comarca aparece bastante poblada y con riqueza bestiar.

En suma, la demografía del Medio Vinalopó al final de la Edad Media parece más vigorosa y positiva que en la mayor parte del reino de Valencia, fenómeno ratificado por la demografía del siglo XVI.

CUADRO 6.

POBLACIÓN DEL MEDIO VINALOPÓ EN LA BAJA EDAD MEDIA (sS. XIV-XV)

\begin{tabular}{|c|c|c|c|c|c|c|}
\hline ASPE & 114 & 265,5 & 114 & 1.480 & 902 & 1.560 \\
\hline ELDA & 735 & 930,7 & 735 & $1.168(a)$ & $1.455(b)$ & $1.637(b)$ \\
\hline MONFORTE & - & - & - & - & $640(c)$ & $740(c)$ \\
\hline MONÓVAR & 48 & 69,5 & 48 & 465 & 830 (d) & $830(d)$ \\
\hline NOVELDA & 369 & 535 & 369 & 1.081 & 1.095 & 1.245 \\
\hline PETRER & 97 & 140 & 97 & 465 & $465(e)$ & $485(e)$ \\
\hline SALINAS & 36 & 52 & 36 & 99 & $99(f)$ & 108 \\
\hline SAX & - & - & - & - & $787(g)$ & $675(\mathrm{~g})$ \\
\hline TOTALES & 1.399 & $2.028,7$ & 1.399 & 4.758 & 6.273 & .280 \\
\hline
\end{tabular}

NOTAS DEL CUADRO 6

(a) El censo de 1510 da para Elda la cifra de 968 habitantes, que para nosotros es baja, sobre todo si la confrontamos con las cifras dadas para Elda en los censos de 1563 y 1565-72. De tal confrontación deducimos que podemos subir la cifra de 1510 en un par de centenas, es decir, hasta 1.168 habitantes como mínimo.

(b) Estas cifras son resultado de reajustar los censos de 1563 y 1565-72, después de contrastar sus datos sobre Elda:
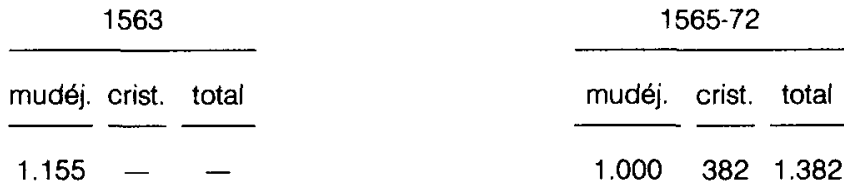
Nuestra propuesta de reajuste es:

1563

$$
\frac{\text { mudej. }}{1.155} \frac{\text { crist. }}{300} \frac{\text { total }}{1.455}
$$

$1565-72$

$\frac{\text { mudéj. }}{1.255} \frac{\text { crist. }}{382} \frac{\text { total }}{1.637}$

(c) Al igual que para Elda, hemos contrastado y reajustado los censos para Monforte:

$$
\text { mudéj. crist. total }
$$$$
\stackrel{\text { mudéj. }}{\text { crist. }} \frac{\text { total }}{715}
$$

Propuesta:

$$
\frac{\text { mudéj. }}{25} \frac{\text { crist. }}{615} \frac{\text { total }}{640}
$$

$$
\frac{\text { mudéj. }}{+ \text { de } 25} \frac{\text { crist. }}{715} \frac{\text { total }}{740}
$$

(d) 830 son únicamente la población morisca a la que habría que sumar la población cristiana en 1563. El censo de $1565-72$ arroja 670 moriscos, censo estimado disminuido, y más si tenemos en cuenta la cifra del censo anterior, respecto a Monóvar. Por ello sustituimos la cifra de 670 por la de 830 , como minimo.

(e) 465 es la población de 1510, a falta de datos para 1563, pensamos que en Petrer existirian para esta fecha, de 465 habitantes hacia arriba. Para 1565-72 tenemos sólo los moriscos, 485, a los que habría que añadir los cristianos existentes en esa fecha.

(f) 99 habitantes son los existentes en Salinas en 1510, de esa cifra hacia arriba sería la población de 1563, año para el que nos faltan datos de su población.

(g) 787 es la población de Sax en 1552, y 675 es la de 1575 (34). 


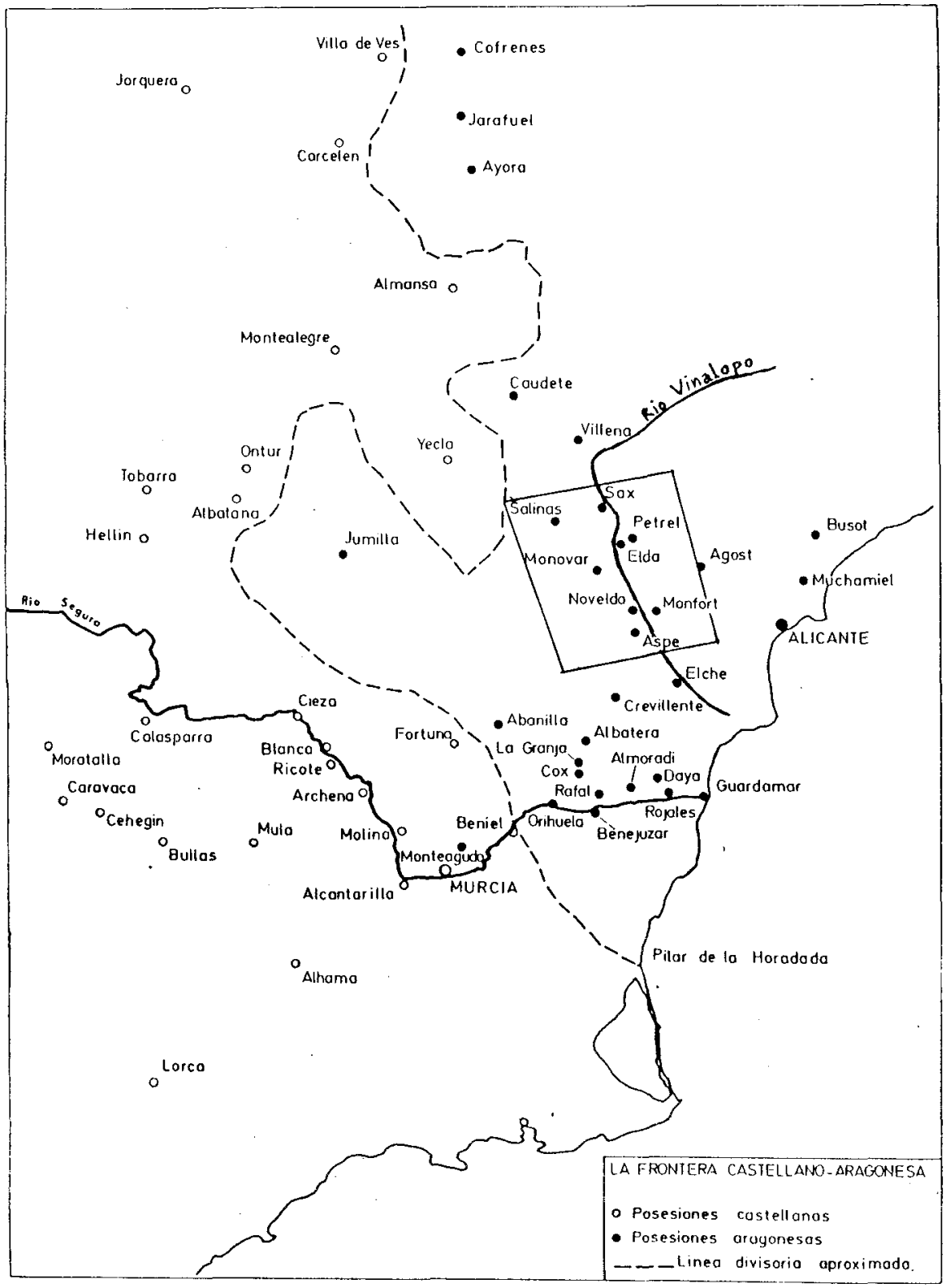

Mapa 1.-La comarca del Vinalopó Medio (en el cuadrado) y la frontera castellano-aragonesa en la Baja Edad Media. 


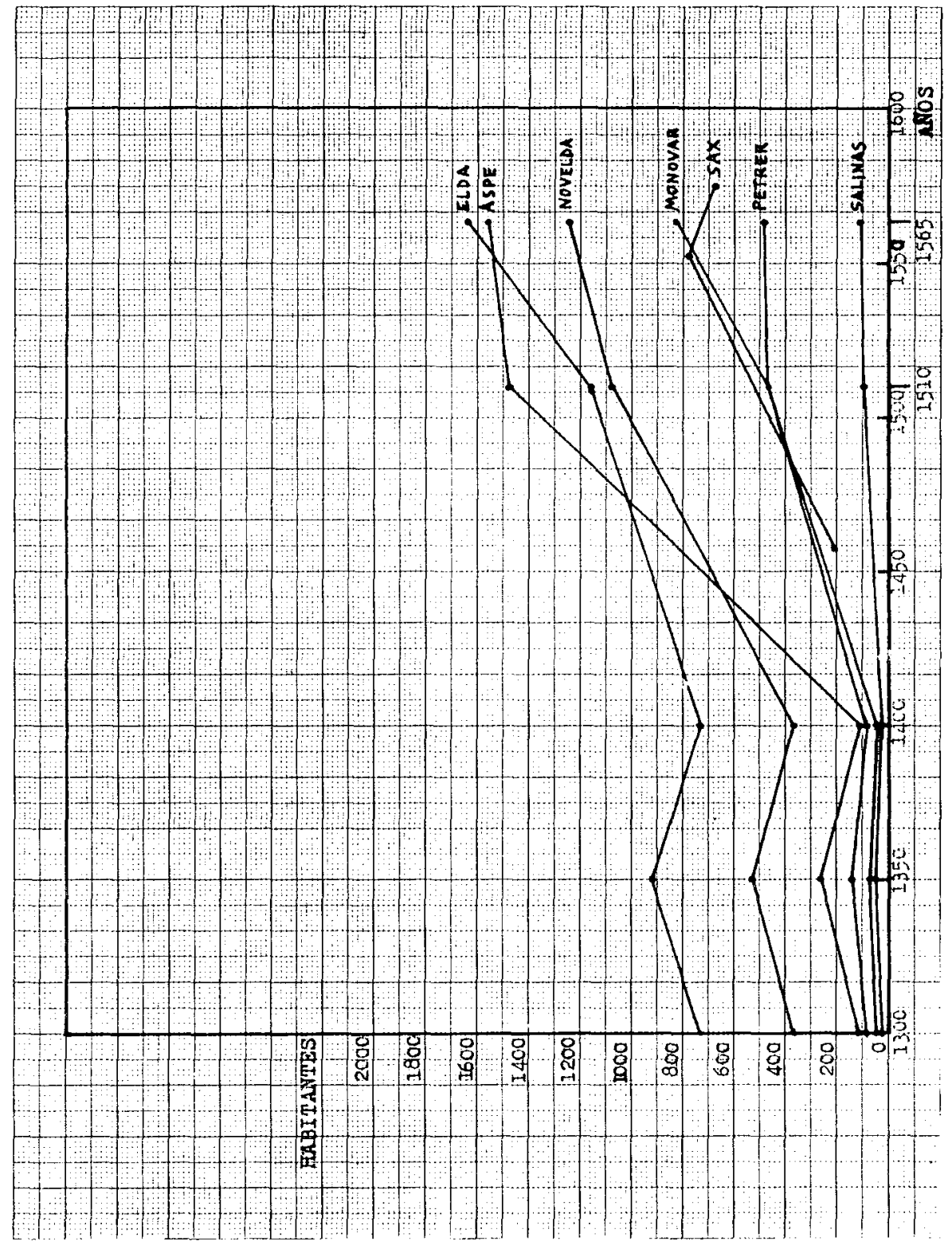

Gráfico 1.-Evolución aproximada de la demografia bajomedieval de las villas del Medio Vinalopó. 
NOTAS

(1) Salinas, Petrer, Elda, Monóvar, Novelda-La Mola, Aspe y Monforte, a cuya lista añadiríamos Sax por su evidente vecindad con Salinas, Elda y Petrer, y por su historia semejante a todas ellas en el período medieval.

(2) J. B. VILAR, Los siglos XIV-XV en Orihuela, Murcia 1977, pp. 51 y 56.

J. HINOJOSA, Historia de la provincia de Alicante, Murcia 1985, p. 340.

(3) V. GOZÁLVEZ, La ciudad de Elche. Estudio geográfico, Valencia 1976, p. 195.

A. M. POVEDA, "Demografía mudéjar, cristiana y judía en Elda, en la Baja Edad Media (ss. XIV-XV)", Alborada, XXXII, Elda (Alicante) 1985, pp. 44-48.

(4) Itinerario de Antonino.

E. A. LLOBREGAT, «Relectura del Ravennate: dos calzadas, una mansión inexistente y otros datos de la Geografía antigua del País Valenciano", Lucentum, II, Universidad de Alicante, 1983, pp. 238-8; y la bibliografía que recoge.

A. M. POVEDA, La Terra Sigillata de Elda. Memoria de Licenciatura, Alicante 1984 (inédita).

(5) E. A. LLOBREGAT, op. cit. nota 4, p. 236; y bibliografía que recoge.

(6) E. A. LLOBREGAT, op. cit. nota 4, p. 237

M. J. RUBIERA, Villena en las calzadas romana y árabe, Villena-Alicante 1985, pp. 31-42.

(7) E. A. LLOBREGAT, op. cit. nota 4, pp. 225-242.

A. M. POVEDA, op. cit. nota 4; op. cit. nota 3, p. 44.

(8) R. AZUAR, Castellología Medieval Alicantina, Alicante 1981, pp. 55-6.

(9) R. AZUAR, op. cit. nota 8.

M. J. RUBIERA, op. cit. nota 6.

A. HERRERO, «Toponimia premusulmana de Alicante a través de la documentación medieval", Anales de Historia Medieval, 3, Universidad de Alicante, 1984, pp. 7-56.

(10) A. M. POVEDA, "Vilia et castiello de Ella (Elda) en el s. XIlt", Anales de Historia Medieval, 4, Universidad de Alicante, 1985 (en prensa); y bibliografía aportada.

(11) J. M. DEL ESTAL, Documentos inéditos de Alfonso $X$ el Sabio y del Infante, su hijo Don Sancho, Alicante 1984, pp. 14-16.

(12) A. M. POVEDA, op. cit. nota 10; y bibliografía aportada en nota 29.

(13) A. M. POVEDA, op. cit. nota 10; ídem nota 40.

(14) A. M. POVEDA, op. cit. nota 10; ídem nota 37. 121-3.

(15) CODOIN AGCA, XXXIX, Rentas de la antigua Corona de Aragón, Barcelona 1871, pp.

J. B. VILAR, op. cit. nota 2 .

A. M. POVEDA, op. cit. nota 10, op. cit. nota 3, pp. 46-7.

(16) J. HINOJOSA, op. cit. nota 2, p. 317. 
(17) A. M. de Elche, Llibre de Conçells, número 1 (antiguo 696), 8-III-1401.

(18) V. GOZÁLVEZ, op. cit. nota 3.

(19) La nota 17 recoge un documento que precisa, entre otras cosas, que en Elda había 30 casats cristianos viejos (135 habitantes), 4 de ellos miserables, es decir, que eran pobres (18 habitantes) y por lo tanto no pagarian pecho alguno.

(20) VICENS VIVES-NADAL OLLER, en Historia Económica de España, Barcelona 1967, pp. $161-3$.

(21) J. B. VILAR, op. cit. nota 2, p. 17.

A. M. POVEDA, op. cit. nota 3, p. 47.

(22) P. HERRERO, Aproximación a la Historia de Novelda, Novelda (Alicante) 1978, p. 29.

(23) A. R. V., Real 514, ter, ff. 57-61.

R. GARCIA CÁRCEL, "El censo de 1510 y la población valenciana de la primera mitad del s. XVlm, Cuadernos de Geografía, 18, Valencia, 1976, pp. 49-66.

(24) J. DUPAQUIER, «Problémes de contrôle des dénombrements», Annals de Demographie Historique, 1972, pp. 203-214.

R. GARCIA CÁRCEL, op. cit. nota 23.

(25) J. B. VILAR, op. cit. nota 2, p. 21.

(26) J. B. VILAR, op. cit. nota 2, p. 24.

(27) J. HINOJOSA, op. cit. nota 2, p. 316.

(28) J. B. VILAR, op, cit. nota 2, pp. 18-20.

(29) P. PEREZ PUCHAL, "La población del Pais Valenciano hasta la época estadística", Cuadernos de Geografía, 10, Valencia, 1976, p. 6.

V. GOZÁLVEZ, op. cit. nota 3, p. 195.

(30) R. GARCÍA CÁRCEL, op. cit. nota 23, pp. 62-3.

(31) A. C. A., Reg. 2.920, fol. 102

L. FULLANA MIRA, Historia de la villa y condado de Cocentaina, Valencia, 1920, p. 297 y ss.

A. M. POVEDA, «Elda y la familia de los Corella (s. XV)», Alborada, XXIX, Elda 1983, s/p.; op. cit. nota 3, p. 48.

(32) M. RUZAFA, "El mercado y la feria de Elda en el s. XV», Alborada, XXX, Elda 1984, p. 40 ; y bibliografia aportada.

(33) J. HINOJOSA, op. cit. nota 2, p. 320.

(34) Datos facilitados amablemente por G. PONCHE HERRERO, de su Memoria de Licenciatura, Sax: evolución demografica y potencial económico, Alicante 1981, p. 235 (inédita). 


\title{
ESPACIO Y HOMBRE EN LA ESPAÑA NORTEÑA EN LA EDAD MEDIA*
}

\author{
José Ángel Garcia de Cortázar \\ Universidad de Cantabria
}

En el arranque de estas páginas, la conocida idea de Marc Bloch: "los campos sin señor son campos sin historia». Los espacios sin señor son espacios sin historia podríamos remedar nosotros al internarnos por unos territorios, los que van del Deva astur-cántabro al Bidasoa y del Cantábrico al Ebro, que con tanta morosidad se han incorporado a nuestro conocimiento histórico. ¿Porque no tuvieron señor hasta muy tarde o porque los señores que tuvieron median su dominio y sus exigencias sobre el espacio con categorías distintas de los hombres que, a la postre, iban a hacer su historia, esto es, a tratar de comprenderlos, de adoctrinarlos, de aculturarlos? Porque, en definitiva, lo que se plantea en un trabajo con este título es la observación de los comportamientos, de los intercambios entre naturaleza (el espacio) y cultura (el hombre) de una determinada área geográfica. $Y$ de ese seguimiento lo que surge es una historia que tratará de poner de relieve, sucesivamente, tres grandes capítulos: la variedad de espacios; la articulación de los espacios; la jerarquización de los espacios. En cada uno de ellos, los hombres tienen un papel crecientemente protagonista. Al frente de ellos, de forma cada vez más ostensible, los señores. Gracias a ellos, también nuestros espacios tienen historia.

\section{VARIEDAD: LA EXTREMA DIVERSIDAD DE LOS ÉSPACIOS NORTEÑOS}

Nada más seguro que cinco imágenes documentales para dar cuenta de esta variedad. Y nada más expresivo que presentarlas en una secuencia cronológicamente inversa a como realmente se produjeron. 
Primera imagen. El 26 de mayo de 1480, los Reyes Católicos se dirigían, desde Toledo, a las autoridades de las villas de «Santander e Sant Vicente de la Barquera e Laredo e Castro de Ordiales, e todas las otras villas e valles, concejos, merindades, filigresías, que son en las merindades de Castylla Vieja e Trasmiera e Asturias de Santyllana con el marquesado de Santyllana e Liebana e Pernia e las merindades de Campos e los otros lugares así realengos como abadengos, behetrías e señoríos que fasen juntas e ayuntamientos, así de esas hermandades como otros qualesquier, ...» a fin de reclamar su ayuda para poner en pie una armada debidamente aparejada. La esperanza de ver atendida su solicitud la basan en que, «desde tiempo ynmemorial a esta parte, el reyno de Galicia, el principado de Asturias e el condado de Vyscaya a la leal provinçia de Guipuscoa con la çiubdad de Vytoria e Alava e las Encartaciones e las otras villas de la costa de la mar siempre fesieron sennalados servicios a los reyes que fueron de Castilla y León...». Como se ve, el texto no tiene desperdicio para nuestro objetivo. En escasas palabras da la medida exacta de la multiplicidad de espacios que, a fines del siglo XV, eran visibles en el Norte peninsular.

De su simple enumeración no parece temerario deducir ya algunas consecuencias. Al menos, en dos órdenes de cosas. El primero, la variedad de espacios socio-jurídicos; bien por la calidad de su titular, lo que los ordena en realengos, abadengos, señoríos y behetrías; bien por la red de relaciones administrativas, que los organiza en merindades, valles, concejos, feligresias, de un lado, y en ciudades, villas y lugares, de otro. El segundo, la percepción de cada uno de los espacios mayores y el grado de su individualización. A este respecto, es fácil señalar un hecho llamativo. Desde la óptica de los Reyes Católicos, esto es, de la administración territorial a fines del siglo XV, existen, dentro de ese espacio, una serie de unidades espaciales. La provincia de Guipúzcoa, que aparece como un todo únitario. El condado de Vizcaya, junto al cual, aunque, para entonces, formaban parte ya del Señorío de Vizcaya, se señalan las Encartaciones como espacio dotado de personalidad. Un territorio no calificado, el de Álava, dentro del cual se reconoce preeminencia a la ciudad de Vitoria; $y$, por fin, en lo que hoy es la comunidad autónoma de Cantabria, un mosaico de territorios; sin que ningún nombre englobador los agrupe, el mero hecho de que aparezcan juntos parece abonar la idea de una cierta unidad por encima de su diversidad. Dentro de ella, dos subconjuntos significativos: las Cuatro Villas de la Costa y las merindades de Asturias de Santillana Trasmiera, Liébana, Campoo.

Segunda imagen. Escenario: las Cortes de Gualajara de 1390, en vísperas de la muerte del rey Juan I de Castilla. En ellas, los prelados del reino 
se quejan al monarca de ciertos daños que les inflingen los nobles. Al enumerar los, comienzan por el territorio que nos ocupa. En efecto, los obispos se consideran «agraviados que en el obispado de Calahorra, do era la tierra de Vizcaya e de Alava e de Guipuzcoa, e otrosí en el Obispado de Burgos (dentro del cual, podriamos añadir nosotros, se hallaban las tierras de las Cuatro Villas y las merindades antes enumeradas), eran muchas iglesias que los diezmos della levaba el Señor de Vizcaya e otros muchos caballeros e fijosdalgo, e que era contra todo derecho, ca ningun diezmo non lo podia levar lego... E otrosí eran muchas iglesias en Guipúzcoa de las cuales levaban el diezmo legos; e que el obispo de Pamplona, en cuya juridicion son, diera aquellas iglesias a clérigos que oviesen sus beneficios en ellas, e que las sirviesen; e que ge lo non consintieran los legos tenedores de las dichas iglesias, antes hacian sus estatutos e ordenanzas que matasen a qualesquier que tales cartas troxiesen". Si las quejas episcopales dejan ver rasgos de una sociedad arcaica, la réplica de los nobles, que se debió probablemente a un alavés ilustre, el canciller Pedro López de Ayala, refrenda definitivamente esa impresión.

Tercera imagen. Tras la político-administrativa de 1480 y la social de 1390 , la económica que, unos doscientos años antes de esta fecha, recogía el documento de los falsos «Votos de San Millán». También en él la percepción del espacio reconoce una diferencia en el mismo sentido que advertíamos en el de 1480. De un lado, Álava, dividida, según el texto, en alfoces, dentro de cada uno de los cuales una serie de villae, aldeas, sevían de asiento a las domus que habian de entregar una reja de hierro al monasterio. Junto a ella, Guipúzcoa compartimentada en otra serie de alfoces, cada uno de los cuales debía aportar un buey. El mismo compromiso tenían los alfoces de Vizcaya. De ésta se distinguia el territorio de las Encartaciones, que, aunque no con ese nombre, to hace con el de algunos de sus valles: Salcedo, Sopuerta, Carranza, distribuidos en alfoces con sus correspondientes villae, de las que cada casa debía aportar singulas libras de cera. Por fin, el territorio al Oeste de las Encartaciones, esto es, el de la actual región de Cantabria, aparece distribuido en: valles (Iguña, Buelna, Toranzo); espacios sin calificación, compartimentados en alfoces (Guriezo, Sámano, Campoo, Valderredible) o no compartimentados (Asón, Soba, Ruesga); y núcleos concretos como los de Colindres y Laredo. De cada uno de ellos el monasterio de San Millán reclamaba un producto: cera, pescado, aceite de pescado, respectivamente. En su conjunto, el documento de los falsos «Votos de San Millán» ponía de relieve, fundamentalmente, dos cosas. De un lado, la unanimidad en la percepción del espacio en distintas unidades, cada una de ellas, con un valor diferente. De otro, la universalización del vocablo «alfoz» para deno- 
minar el territorio en que se subdividen unidades geográficas o geográficosociales más amplias o en que se inscriben unidades locales más reducidas. De esa forma, valle, alfoz, villa, domus parece la secuencia espacial que de mayor a menor tamaño nos recuerda el documento.

Cuarta imagen. Unos cien años antes de que el monje emilianense amañara el texto anterior, una serie de documentos de mediados del siglo X| se pronuncia sobre la división eclesiástica de nuestro espacio. De Este a Oeste del mismo, cinco sedes se lo reparten: Bayona, Pamplona, Álava, Burgos y Oviedo. No vamos a entrar en las vicisitudes concretas experimentadas por ellas, precisamente, en la segunda mitad del siglo $\mathrm{XI}$, en que cristalizan los pertiles geográficos de esta red episcopal. Bástenos señalar tres hechos importantes. Uno: contrariamente a la práctica de la Iglesia, una de las sedes, la de Álava, no lleva el nombre de una localidad sino la de un territorio. Dos: los límites entre cada uno de los obispados no sólo recuerdan sino que, en buena parte, reproducen las fronteras entre los pueblos prerromanos de la zona. Así, de Este a Oeste, marcan las que los romanos atribuían, sucesivamente, a vascones, várdulos, caristios, autrigones, cántabros. Y, por fin, tres: de las sedes episcopales mencionadas, sólo la de Álava radica en el territorio que estudio. Pero, por poco tiempo. Como sucederá en 1068 con la de Valpuesta, que, abarcando el territorio autrigón y parte del cántabro, se trasfiere a Burgos, en 1087, se extingue la de Álava, quedando sus territorios englobados en el obispado de Calahorra. Desde entonces, ningún obispado tendrá su sede en nuestro espacio.

Quinta y última imagen. A fines del siglo IX, la corte ovetense del rey Alfonso Ill se propone realzar las glorias de su monarca. Para ello, nada parece más oportuno que empalmar su reinado con el de los reyes visigodos. Al hacerlo, el cronista se detiene, especialmente, en las actividades de dos predecesores gloriosos. Alfonso II y Alfonso I. Si a aquél correspondió el restablecimiento de un ordo gothorum, al reinado de Alfonso I se atribuye nada menos que el bautizo de unas cuantas de las regiones de nuestro espacio. En efecto, tras campañas de devastación por tierras del Valle del Duero, Alfonso 1 llevó a los cristianos de la meseta a los valles cantábricos. Con ellos, a tenor de la crónica y entre otras regiones, repobló Asturias de Santillana, Liébana, Trasmiera, Sopuerta, Carranza y la primitiva Castilla. En cambio, Álava, Ayala, Orduña y Vizcaya se mantuvieron siempre en manos de sus propios habitantes. Por primera vez, nacian a la Historia los nombres de las regiones que nos ocupan. El de Guipúzcoa no lo hará hasta el año 1025. Por primera vez, también, la Crónica de Alfonso I/I nos anunciaba lo que textos posteriores nos confirmarán. La personalidad de una serie de territorios. Entre la fecha de su 
redacción y la del documento de los Reyes Católicos que proporcionaba la primera imagen, seiscientos años. $Y$, sin embargo, desde el punto de vista territorial, una impresión casi idéntica. Un reparto entre los mismos territorios nombrados a fines del siglo IX.

Mantenimiento de la personalidad de los territorios equivale a persistencia de las condiciones históricas diferenciadoras. $O$, para no caer en un estructuralismo casi geológico, cuando menos, a reiteración de condiciones históricas diferenciadoras. En su base, por tanto, una población que considera como suyo un determinado espacio y que conserva y transmite la memoria colectiva de la percepción y la valoración de ese espacio. Ello plantea, de entrada, un par de cuestiones importantes. La primera, la distinción fundamental se establece, por tanto, entre lo desierto, lo yermo, y lo poblado. La segunda tiene forma de interrogante: ¿quién nombra, quién bautiza los espacios norteños en el siglo XIII o en el IX?

La primera cuestión ha hecho ya correr si no ríos, sí, al menos, riachuelos de tinta. Recordemos al respecto las opiniones encontradas de Ramón Menéndez Pidal y Caludio Sánchez Albornoz, a propósito, precisamente, de la despoblación y repoblación del Valle del Duero. La polémica tiene, como sabemos, otra versión portuguesa en los mismos términos. ¿Desertus y populatus son vocablos que tienen un contenido rigurosamente demográfico $o$, mayormente, organizativo? Todos entendemos el primer sentido: desertus como ausencia total de población. El segundo es menos drástico: supondría solamente una desorganización administrativa del espacio al que se aplica el adjetivo. La población con poder y facultades para organizar el espacio lo ha abandonado, dejando tras de sí grupos reducidos y dispersos de gentes poco instaladas en un territorio preciso porque su dedicación económica fundamental reside en la ganadería. Necesitan espacios para ella pero no una fijación estricta de su habitación. Para un cerealista, y no digamos para un vitivinícola, ese espacio sin cosechas anuales que recoger o vides que podar, esto es, sin anclajes humanos, un espacio desierto. Para un ganadero es, sin duda, un espacio con el que cuenta para mantenimiento de su riqueza semoviente. No precisa títulos de propiedad sobre él; le basta con que los demás no le discutan su derecho a aprovecharlo a través de sus rebaños.

Primera conclusión, por tanto, cada dedicación económica estimula y cada organización social propone una forma de ejercicio de derechos de propiedad o de uso del espacio. A cada una le corresponde una distinta percepción de un mismo espacio. Las propias «fórmulas inútiles» de los documentos, sobre todo, de aquéllos que se refieren por primera vez a un territorio, proporcionan ya pistas sobre su ordenación. A través de ellas, distintos in- 
vestigadores y de modo especial José María Mínguez, han sabido detectar los niveles de organización de un espacio. $Y$, junto a ellos, la percepción económica y, quizá también física, del espacio objeto de referencia documental. Así, esas villas donadas, cum montibus, pascuis, pratis, terris, vineis, ortis.... muestran, según los casos, una variada imagen. La fiabilidad de sus apreciaciones parece desprenderse del hecho de que, en el área que estudio, salvo en Liébana, el redactor del documento nunca incluye las viñas, mientras las salinas, en plural y genérico, sólo constan en aquellos lugares en que sabemos de su existencia.

Pero la distinta forma de percibir un mismo espacio no depende sólo de dedicaciones económicas diversas o de distintas formas de entender la apropiación del mismo. Aun con unanimidad absoluta en ambos criterios, las ideas que del espacio se hacen, en nuestra zona, el gran propietario y el pequeño campesino varían entre sí. Los aldeanos de los valles de la Cordillera Cantábrica aspirarán, con el tiempo, a conseguir un policultivo en cada una de sus aldeas. Tal objetivo, en cambio, no coincide necesariamente con el de los grandes dominios monásticos. Asentados ya con firmeza para fines del siglo XI, los de Leyre, San Juan de la Peña, San Millán de la Cogolla o San Salvador de Oña tendrán, a propósito del mismo espacio, distintos intereses y designios económicos. Desde luego, los de Oña y San Millán no ocultan su preferencia por hacer de esos territorios un espacio de aprovechamiento ganadero. Mucho más el de Oña que el de San Millán. Éste cuenta ya, al lado mismo del centro monástico, con los montes y pastos de la Sierra de San Lorenzo.

Población que estima como suyo un espacio; memoria colectiva que transmite la percepción del mismo, según ese procedimiento que, a veces, mencionan los mismos documentos. A falta de textos escritos, lo que causa fe y pone limites a los términos de un espacio es, precisamente, el antiquus usus a senibus testificatus. Los ancianos como depositarios de esa memoria, que, tal vez, como se puede demostrar en disposiciones del Fuero Viejo de Vizcaya de 1452, no hace sino recoger prácticas (o intereses) que no tienen más allá de treinta o cuarenta años. Ellos son los que transmiten nombres de cosas y, sobre todo, de lugares. Ellos son los que pueden, en última instancia, demostrar que el espacio presuntamente desierto sólo era un espacio mal poblado, en el sentido que, todavía para un castellano de finales del siglo XIV, tenía la expresión. Casas apartadas unas de otras, dedicación ganadera.

Si la primera cuestión que planteábamos era la percepción de un espacio y su transmisión, la segunda tiene mucho que ver con ella. ¿Quién bautiza, quién pone nombres a los distintos espacios norteños? Como principio general, parece que son los otros quienes nos ven de una u otra manera y, 
en consecuencia, nos bautizan. La cuestión, en nuestro caso, radica en saber cuándo «los otros» dieron nombre a esos espacios. Probablemente, las fechas variaron de uno a otro; con seguridad, los investigadores no se pondrán de acuerdo. Un ejemplo bien significativo: la polémica entre Luis Michelena y María Lourdes Albertos. Para el primero, a un sustrato vasco o vascoide en la mayor parte de las actuales Guipúzcoa, Álava y Vizcaya, vino a sobreimponerse, en torno al 500 antes de Cristo, una población indoeuropea. Para la segunda, el proceso fue, precisamente, el contrario: sobre una zona de predominio indoeuropeo se fue extendiendo calmosamente una capa de población euskera. Probablemente, en época anterior a la que los trabajos de Schulten y Sánchez Albornoz daban a entender. Por ello, tal vez, y como reconoció finalmente el segundo, cuando, entre los siglos VI y VII, los vascones vasconizan la depresión vasca lo que hacen es reforzar, desde un punto de vista sociopolítico, lo que, desde el lingüístico, se detecta con anterioridad.

A tenor de todos los autores, cuando Alfonso I concluye sus correrías a mediados del siglo VIII, las cosas están ya lo suficientemente estabilizadas. Pero, desde nuestras preocupaciones por la percepción del espacio, diría que las seguridades no son tantas. De hecho, sigue en pie una cuestión sobre la que toponimistas e historiadores de la zona deberíamos indagar. ¿Cuáles son las dimensiones del espacio bautizado mayoritariamente por topónimos de origen indoeuropeo, ibérico, euskérico o romance en nuestra área norteña? Dentro de la pregunta incluyo dos series de cuestiones. Una, de densidad, esto es, de averiguación de las áreas en que son dominantes los topónimos de uno u otro origen, y la proporción en que resultan hegemónicos respecto a otros. Como sabemos, y a propósito de la división espacial de los dominios del latín o del romance y del euskera, el tipo de estudio más comúnmente efectuado por los filólogos ha tendido a señalar el área vascoparlante en sucesivas etapas históricas. A partir de sus trabajos, es visible cómo, en época medieval, la frontera entre castellano y euskera, fijada en el Nervión, coincide con una división entre obispados. Pero, también, cómo este tipo de división eclesiástica se superpone a la de las grandes variedades del euskera: vizcaíno, al oeste del río Deva, obispado de Álava, más tarde, de Calahorra; guipozcoano al este de aquel río, obispado de Pamplona. Pero lo que planteo es algo más matizado. Dentro de esas áreas vascoparlantes, ¿cuáles son las áreas e intensidades de un bilingüismo en época medieval? O cuando menos, ¿cuál es el reparto espacial de los topónimos de una y otra procedencia? Porque, sin salir de la orilla izquierda de la ría de Mundaca, la toponimia nos habla de indoeuropeos (Guernica), de latinos (Forua), de euskaros (Busturia), de romances (Bermeo). 
Pero, a propósito de la toponimia, hay una segunda serie de cuestiones, más a tenor de estas preocupaciones por el espacio y el hombre medievales. Es el carácter que, desde el punto de vista de la organización social del territorio, tienen estos espacios bautizados por topónimos de distintos orígenes. En resumen, ¿abundan más los topónimos indoeuropeos o latinos para nombrar espacios que llamariamos territoriales, por ejemplo, los valles y alfoces a que aluden los falsos «Votos de San Millán»? ¿Se conservan, en cambio, los euskeras para espacios muy locales, como pequeñas barriadas y, sobre todo, caseríos? O, en otra jerarquía de percepción del espacio, ¿los nombres de las villas o núcleos urbanos son, mayoritariamente, romances? Sabemos que, en Álava, Guipúzcoa y Vizcaya, la fundación de las villas fue ocasión frecuente para que el fundador sustituyera, y a veces de forma deliberada, el nombre euskera de la aldea sobre que se asentaba la nueva fundación por otro de raigambre romance. Gamíniz-Plencia, Gasteiz-Vitoria, HagurainSalvatierra,... serían algunos de los ejemplos de una larga serie de casos que la actual política de recuperación del euskera ha llevado hasta los extremos de bautizar en vascuence muchos de los topónimos del área occidental de la actual provincia de Álava donde jamás se habló.

Denominación de espacios, socialización de espacios. Por ello, nos importa tanto una respuesta a esa serie de cuestiones. $Y$, por la misma razón, nos preocupa saber cuál es, en cada momento, el espacio abarcado por un determinado topónimo; 0 , sobre todo, por los corónimos que se reparten nuestra área de estudio. $Y$ nos preocupa porque observamos en ellos una cierta movilidad. Más exactamente, una cierta expansión de los que acabarán imponiéndose. En ningún caso, esta expansión es tan espectacular como la que experimenta el nombre de Castilla, pero sí es perceptible en los casos de Guipúzcoa, Vizcaya y Álava. En los tres, desde una comarca muy concreta, el corónimo se extiende hasta abarcar, en la segunda mitad del siglo XII, prácticamente, el territorio actual. Lo reconoce el escriba emilianense al redactar los «Votos de San Millán». Como siempre, la duda está, también a esta escala, en saber cuándo bautismo historiográfico coincide con nacimiento histórico. En cualquier caso, el análasis de la expansión documentada del vocablo «Álava» me permitió hace unos años proponer que el territorio denominado Álava es, precisamente, el área que van dominando los «alaveses». Y éstos, normalmente, los barones et milites alavenses, parece ya demostrado, son algo así como los cabezas de grupos extensos de parentesco. Donde florecen no arraiga la institución concejil como representación de la comunidad local. Ello diferenciará contundentemente dos zonas dentro de la actual provincia de Álava. Al este del Bayas y, sobre todo, del Zadorra, la tierra de los seniores et principes terrae al frente del populus. Al oeste, la tierra de los pe- 
queños concejos; dirigidos quizá, todavía en los siglos $\mathrm{X}$ y XI, por potestates familiares, ofrecen ya un testimonio de representación local de base territorial.

De esta constatación pueden deducirse, al menos, dos consecuencias significativas. De un lado, que la expansión de un nombre en un espacio traduce la expansión de un poder (¿político?) en ese mismo espacio. Vizcaya ofrecerá, a esos efectos, un ejemplo bastante definitivo. El corónimo parece referirse, inicialmente, a las tierras centrales del área que se extiende entre el Nervión y el Deva guipuzcoano. Desde allí, irá, poco a poco, irradiando, para englobar primero todas las tierras situadas entre ambos ríos; más tarde, las de Durango, que ofrecen particularidades expresadas, incluso, en algún ordenamiento jurídico propio; después, las de las Éncartaciones, área que, idiomática y eclesiásticamente, correspondía al ámbito castellanoviejo; y, por fin, Orduña y su valle. Pues bien, en todos los casos, es la existencia de un Señor de Vizcaya la que permitirá ir aglutinando, en torno a un núcleo central, esta diversidad de espacios menores. En última instancia, la pervivencia histórica de Vizcaya tal como ha llegado hasta aquí depende, por tanto, de la pervivencia de un Señor de Vizcaya, esto es, de un proyecto político. Por el contrario, la falta de un nombre es, en cierto modo, la falta de un proyecto político. Tal sucedió en Cantabria, cuya personalidad está escondida tras la de las merindades que la constituyen.

La segunda consecuencia a deducir del reparto sociopolítico de nuestra área norteña puede ser más discutible. Pero, en principio, hay que enunciarla. Por si acaso, lo haremos en forma de pregunta: ¿la división que, a la altura de los años 1050-1100, se observa entre los espacios en que domina una representación política de base familiar y espacios en que es característica ya una representación de base territorial corresponde a la que puede establecerse entre territorios repoblados por Alfonso I y territorios siempre poseidos por sus habitantes? En una visión rápida y simplificadora, y basada exclusivamente en el caso alavés, ésa podría ser la conclusión. Pero, si examinamos atentamente el comportamiento de Trasmiera, espacio repoblado por el monarca asturiano, observaremos que es el mismo que el de Vizcaya, Áyala o Álava. También en ella los grupos familiares extensos se constituyen en vehículos de representación de los intereses de la comunidad, dejando escaso o nulo protagonismo a las comunidades locales de base territorial, las aldeas. Por el contrario, las tierras de la primitiva Castilla, fronterizas con las alavesas, vizcaínas o trasmeranas, desde muy tempranamente dejan ver la fortaleza, incluso política, de las familias nucleares agrupadas en sus precoces concilia. La observación tiene algo de perturbadora. Vendría a decir que, pese a la presunta despoblación y repoblación de espacios como el valle del 
Duero o como las tierras de la Castilla primitiva y la Cantabria, hacia el siglo $\mathrm{XI}$, la documentación volvía a dar cuenta de una división socioespacial que recordaba mucho a la que describieron los geógrafos romanos. Un norte cantábrico arcaico; una meseta aculturada en su más amplio sentido. Pero ¿ello mismo no empuja a poner sordina a los efectos tanto de la despoblación de la meseta por parte de Alfonso I como a la repoblación de los valles cantábricos por sus gentes en el siglo VIII?

La exploración de las diversidades del espacio norteño ha permitido sacar a relucir unas cuantas. Basten ellas para subrayar su casi infinita variedad. Esta arranca desde bases biológicas. Sin exagerarlas, recordemos algo que nuestos antepasados medievales desconocían. La población vasca ofrece, en Europa, uno de los más altos porcentajes de individuos de Rh negativo. Aún en mantillas, la paleopatología comienza a relacionar hematología e incidencia de pestes y epidemias. Pero vayamos a aspectos mejor documentados. $Y$ si, de los testimonios escritos u orales, pasamos a los materiales, que todavía podemos captar en el terreno, nuevas certidumbres de variedad. En la tipología arquitectónica, por ejemplo, cuatro modelos fundamentales se esparcen por estas tierras. La casa montañesa, de dos pisos y amplia solana que mira al sur; la cabaña pasiega, vivienda eventual de la comunidad de ganaderos de los valles en sus estancias estivales en los pastos de altura, que, geográficamente, desborda por tierras de Espinosa de los Monteros, en la Castilla primitiva. Y las dos variedades de caserío vasco. La cuadrada y maciza, reminiscencia de época de banderías bajomedievales, pero también, funcionalmente, en relación con explotaciones familiares de intereses cerealistas. Y la alargada que parece la proyección de un triángulo, y que, funcionalmente, debió ser la traducción a vivienda de una primitiva cabaña ganadera. Sin un análisis exhaustivo de sus áreas de difusión y de la relación que media entre el nombre de cada caserío y su, tipología arquitectónica, no es fácil ir más allá de hacer ver esa variedad, de la que no sería difícil trazar una cartografía.

Esa misma diversidad sale a nuestro encuentro cuando nos detenemos en la mortología de los núcleos de poblamiento. Tres modelos, igualmente documentados en la Edad Media, se reparten nuestro territorio. De mayor a menor densidad de vivienda y exigencia de sociabilidad: la aldea, el barrio, el caserío. La aldea muestra hoy una doble variedad. La aldea alavesa, de casas exentas pero sin huertos entre ellas, reunidas en torno a un único polo de atención, normalmente, la iglesia. La aldea lebaniega, también con una sola iglesia, pero, con frecuencia, dividida en dos o más barrios, muy próximos entre sí, pero diferenciables en el espacio a simple vista; constituidos por 


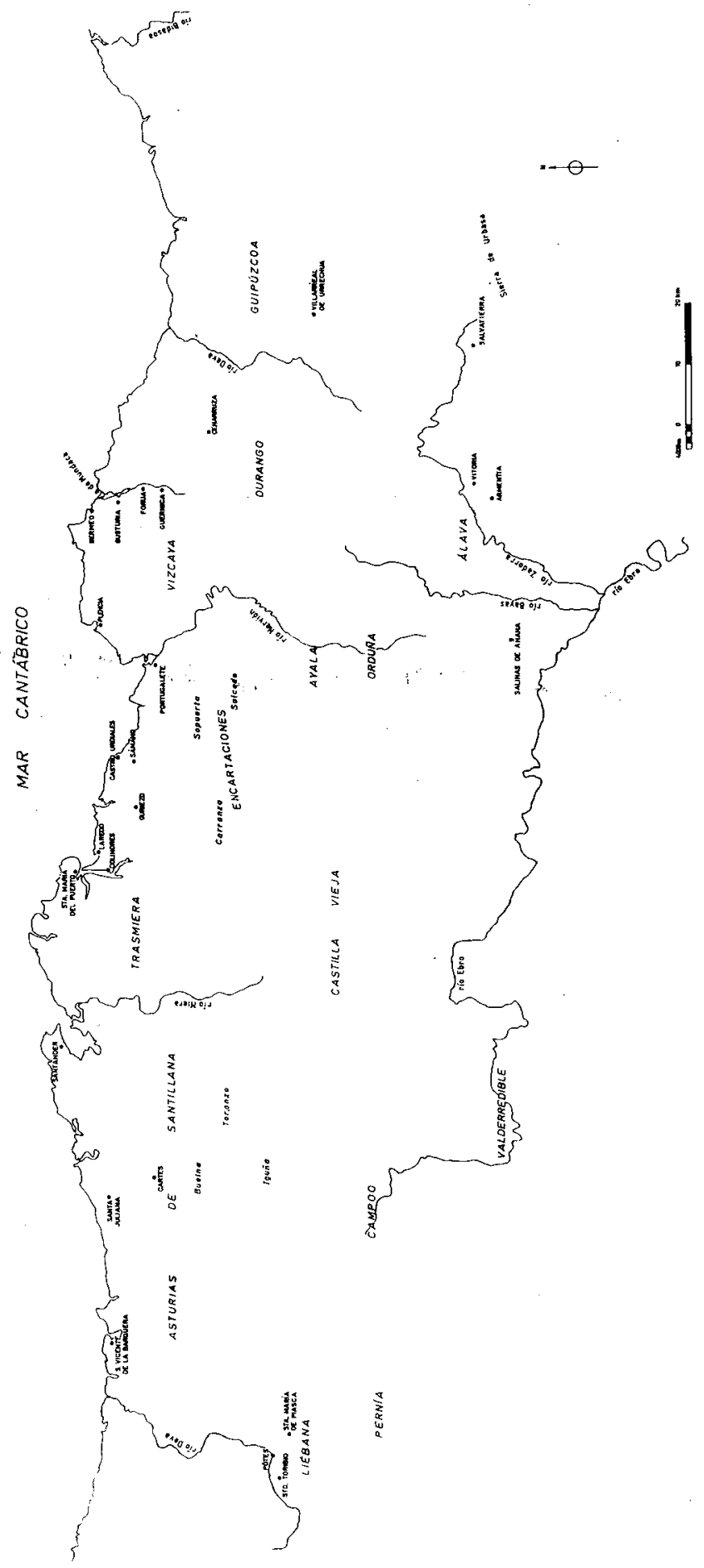


casas igualmente exentas, dejan a menudo entre ellas huertos y eras. El barrio también muestra una doble variedad bajo el denominador común de un reducido conjunto de viviendas agrupadas, sin aparente polo de nuclearización. En ocasiones, una pequeña ermita puede servir de ello. La primera variedad sería la del barrio trasmerano: en él, tres o cuatro casas se hallan adosadas compartiendo paredes medianeras y una misma orientación, que viene subrayada, visualmente, por la secuencia abalconada de las solanas. La segunda, la de la barriada vizcaína o guipuzcoana: el mismo número de casas que los barrios de Trasmiera, pero ya no adosadas, sino exentas; cada una, en edificación separada, con un cobertizo, resto, transformado, del antiguo garaixe u hórreo, y su horno; cada una con su nombre propio, por el que, más que por el apellido, serán conocidos los hombres y las mujeres que la habiten.

Por fin, el caserío morfológicamente individualizado, disperso en tierras de Guipúzcoa y Vizcaya, con un origen frecuente en seles o espacios de pastos altos acotados según medidas precisas. Su aparición histórica coincide con épocas de expansión demográfica dentro de una sociedad con un sistema de transmisión de la herencia que privilegia la trasferencia íntegra del patrimonio raíz familiar en beneficio de un solo heredero. De ahí que los siglos $X V$ y XVI y, más tarde, el XVIII, hayan visto nacer un buen número de los caseríos que hoy se desparraman por los montes vascos. La demostración de la secuencia bosque roturado-sel de pasto-sel de cultivo-cabaña estacionalcaserío permanente puede rastrearse a través de los contratos que se conservan de la Colegiata vizcaína de Cenarruza del siglo XV.

En definitiva, variedad biológica, variedad idiomática, variedad administrativa, variedad arquitectónica, variedad en la morfología del hábitat y del terrazgo y, progresivamente, variedad en las dedicaciones económicas. Ganadería de la vertiente norte de la Cordillera Cantábrica, cereal y viñedo de la sur; pero, más tarde, también, comercio y ferrerías del norte frente a actividad agrícola del sur. En todos los casos, una cierta compensación entre los distintos espacios bioclimáticos, pero, también, un distinto ritmo de desarrollo histórico. Porque si las variedades son tan abundantes como he apuntado, rara vez los rasgos diferenciadores se superponen delimitando con precisión los diferentes espacios. Más bien, según los criterios clasificatorios que empleemos, dos o más espacios aparecerán unidos dando una única imagen. Pero no serán siempre los mismos. Ello quiere decir que sus variedades son, en parte, producto de una geografía, pero, sobre todo, consecuencia de una historia. 


\section{ARTICULACIÓN: LOS INSTRUMENTOS DE ORDENACIÓN DEL ESPACIO NORTEÑO}

El área de difusión de una variedad lingüística, de un modelo arquitectónico, de un tipo de hábitat; la circunscripción de un obispado, de un alfoz, de una merindad constituyen dos de las modalidades del encuentro entre el hombre y el espacio. En la primera, parecen primar los aspectos meramente antropológicos de la relación; hay una acomodación al medio caracterizada por un alto grado de espontaneidad. En el segundo, parecen (y aquí, más que antes, subrayo el parecen) primar los aspectos políticos de la relación; hay una deliberada voluntad de limitar el espacio, de ordenarlo, independientemente de que, en aras del éxito, el poder ordenante se apoye en rasgos adquiridos por el espacio en la fase de presunta relación espontánea entre él y el hombre. El dibujo de las circunscripciones eclesiásticas en los siglos $X$ y $\mathrm{XI}$ sobre las fronteras de los pueblos prerromanos es un buen ejemplo de ello. Con menor conocimiento de causa, podríamos suponer que algo semejante ocurre con la división territorial de Álava en una serie de veinte circunscripciones, cada una de las cuales tiene un desigual número de aldeas y unos ciertos rasgos diferenciales. Es la imagen que ofrece un documento de 1025 conocido con el nombre de la Reja de San Millán.

En los dos casos, hay una ordenación del espacio. En el primero, su instrumento ha sido la autoridad eclesiástica que, en una etapa de fortaleceimiento de la Iglesia secular y en un deseo de precisar con seguiridad los límites de los espacios de percepción del diezmo, traza con rigor sus fronteras entre las distintas diócesis. Para hacerlo, aprovecha tradiciones espaciales anteriores. En el segundo, y dada la secular pervivencia de esa división territorial de Álava, podemos aventurar que, en origen, cada una de las veinte circunscripciones podría responder al espacio de dominio de un grupo de parentesco. Su fijación más estable acabaría conformando las diferentes aldeas de cada división. La hipótesis parece razonable si recordamos que, en Guipúzcoa y, sobre todo, Vizcaya, todavía en el siglo XV, los espacios comarcales aparecen claramente adscritos a ciertos linajes. Sus jefes, como se quejaban los obispos en las Cortes de Guadalajara de 1390, continuaban entonces percibiendo los diezmos de unas iglesias que estaban actuando como lentísimos polos de aglutinación del poblamiento en reducidos núcleos. Pero, como reclaman los obispos, hasta estas iglesias, ya parroquiales en sus funciones, siguen siendo denominadas monasterios por sus patronos en un intento de escapar, por esta vía, de la jurisdicción episcopal.

De este modo, fracciones gentilicias, o, más adelante, grupos de parentesco o de linaje y obispados son dos de los instrumentos de ordenación del 
espacio norteño. Aunque, en relación con un sistema cultural, unos y otros se hallan en sus antípodas respectivas, es curioso que los segundos adopten las mismas líneas de ordenación del espacio que los primeros. Son, probablemente, las consagradas por una vieja relación de transhumancia. Su extremo septentrional es siempre la franja costera cántabrovasca. Su extremo meridional varía. Puede ser la Sierra de Urbasa para los guipuzcoanos; la vertiente norte de la Sierra de la Demanda y alto Oja para los vizcaínos y alaveses; la vertiente sur de esa misma Sierra para las gentes de las Encartaciones, Ayala y la primitiva Castilla; y los macizos del Sistema Ibérico entre los cursos altos del Arlanza y el Duero para los trasmeranos y, sobre todo, los habitantes de las Asturias de Santillana. La disposición meridiana de las fortunas de los grandes monasterios de Oña y San Millán de la Cogolla, la política y geografía de las afiliaciones monásticas, el área de dominio de la familia de los Señores de Vizcaya, las concesiones de derechos de pasto en beneficio del Infantado de Covarrubias a fines del Siglo $X$,... todo ello induce a pensar en unas relaciones trazadas y mantenidas en función de precisos intereses de una ganadería extensiva. El hecho de que las primeras donaciones que recibe el monasterio de San Millán en territorio vizcaíno empalmen las que poseía antes en el alavés y, unas y otras, aparezcan instaladas, en el sentido de los meridianos, en un área que corresponde a una única variedad dialectal del euskera vizcaíno parece confirmar la verosimilitud de nuestro planteamiento.

Como se ve, entre los grupos de parentesco y los obispos, una variada gama de instrumentos trata de articular los espacios norteños. Por supuesto, la autoridad real. $O$, mejor dicho, las autoridades reales, ya que, en especial, el área vasca de nuestro espacio norteño oscilará, entre los años 920 y 1200 , entre los reinos de Navarra y Castilla. Con todo, el papel directo de los monarcas como ordenadores del espacio, al menos, hasta fines del siglo XII, será muy limitado. Se sobreimpondrán a él pero respetarán en líneas generales su ordenación. Por ello, para localizar los ordenadores más eficaces y directos del espacio norteño medieval, hay que volver la vista a otros tres protagonistas. Los monasterios, las villas, la nobleza regional. Y, de entrada, podríamos anticipar que la fuerza respectiva de cada uno de los tres depende de la que muestren los otros dos protagonistas en liza. En general, será variable según espacios y cronología.

Los monasterios. De guiarnos por la nomenclatura, aparecen en toda la zona en estudio una multitud. Las quejas de los obispos en 1390 nos han alertado ya sobre la necesidad de matizar el valor de los vocablos. En efecto, muchos de esos monasterios son simples iglesias propias; otros se han con- 
vertido ya, en el siglo XIV, en iglesias parroquiales. Si eliminamos unos y otros, el número de los que, realmente, sirven de asiento a una comunidad monástica o canonical se ve drásticamente reducido. Con esas características apenas quedaría ninguno en Guipúzcoa, uno en Vizcaya (la colegiata de Cenarruza), otro en Álava (la colegial de Armentia, resto de la sede espiscopal alavesa, una vez que su capital se trasfiere a Calahorra) y cuatro en las merindades cántabras: Santo Toribio y Santa María de Piasca en Liébana, Santa Juliana en las Asturias de Santillana, Santa María del Puerto en la Trasmiera. Son sólo estas seis instituciones las que han dejado huellas documentales de su quehacer; y de ellas, únicamente, de las cuatro últimas puede seguirse con cierta seguridad su papel como verdaderos ordenadores del espacio.

Los mecanismos de que se valieron han sido ya objeto de estudio y responden a una dinámica general de la historia del Occidente europeo. Su desenlace será la sobreimposición de unas estructuras feudales sobre el mundo de las aldeas, cuyos habitantes entrarán en una dependencia cada vez más clara con respecto a las instituciones monásticas. En ese papel, los monasterios, a veces, no hacen sino recoger la herencia de poder y fortuna de algunas de las familias más aculturadas de cada comarca. La idea merece la pena subrayarse. $Y$, junto a ella, otras dos. Una, la de que los cuatro monasterios del área cántabra actuarán, desde que hay noticia de ellos, en los siglos IX y X, como deliberados instrumentos de aculturación de signo mediterráneo en un espacio de tradiciones primitivas más que propiamente germánicas. El mensaje que, a través de mil caminos, tratan de imponer a la población de la zona es la superioridad del cereal, del culto católico, de la familia nuclear, del reparto individualizado de los espacios de producción. De esa forma, los cuatro monasterios actúan como verdaderos propagadores de esas nuevas formas históricas. La resistencia que, en Trasmiera, oponen los infanzones «malvados» a los intentos del de Santa María del Puerto de Santoña es buen ejemplo del sentido de los intereses monásticos. La ruptura de unas estructuras tradicionales. La segunda idea a retener es que el mapa de las posesiones de los cuatro monasterios de la zona cántabra, a la altura del año 1200 , presenta unos límites que se corresponden, prácticamente, con las actuales fronteras de la comunidad autónoma. Ello reitera una imagen espacial que ya expresaba claramente la Crónica de Alfonso III: la personalidad de las comarcas de Liébana, Asturias de Santillana y Trasmiera. Desde el punto de vista de los domicios monásticos, la primera es el área de expansión de Santa María de Piasca y Santo Toribio de Liébana; la segunda, la de la colegial de Santa Juliana; y la tercera, la de Santa María del Puerto. 
En los tres casos, la dinámica de expansión y, por tanto, de ordenación del espacio por parte de estos monasterios tiene un desenlace altamente significativo de lo que será la historia posterior de esta área cántabra. En efecto, en 1052, Santa María del Puerto se convierte en dependencia del monasterio riojano de Santa María de Nájera. A fines del siglo XII, les tocará el turno a Santo Toribio de Liébana, convertido en priorato del monasterio de Oña, y Santa María de Piasca, integrado en el dominio del no menos poderoso de Sahagún. Desde ahora, sólo la colegial de Santa Juliana mantendrá su independiencia. En esos momentos, en que, simultáneamente, alumbraban las primeras villas de la costa, no se podía saber. Hoy, sí: la pérdida de independiencia de tres de los cuatro monasterios más significativos de la región de Cantabria era el síntoma de lo que será uno de los rasgos históricos más permanentes de la misma. La excentricidad respecto a los centros de toma de decisiones que la afectan. Al constatarlo, las generosas concesiones de pastos que, en favor del infantado de Covarrubias y del monasterio de Oña, habían hecho, a fines del $\mathrm{X}$ y comienzos del $\mathrm{XI}$, los condes de Castilla, adquirian el tono de premonición. Cantabria como periferia ganadera de un centro cerealista situado en Castilla.

Segundo factor ordenador del espacio, las villas. En el área cántabrovascongada, la primera creación tiene lugar en 1140 y corresponde a la hoy alavesa Salinas de Añana; la última, en 1383, a la guipuzcoana Villarreal de Urrechua. En medio de una y otra, 72 , lo que hace un total de setenta y cuatro fundaciones repartidas en un territorio de 12.000 kilómetros cuadrados. Una simple ojeada al mapa nos mostraría lo desigual de tal reparto. Una cronología de los nuevos villazgos confirmaría, también en el tiempo, y, por tanto, en la coyuntura histórica, la misma desigualdad. Ambos procesos han sido ya analizados en otras ocasiones, y las conclusiones llaman la atención sobre un hecho aparentemente sorprendente. Veinticinco villas se fundan en Guipúzcoa, veintitrés en Álava, veintiuna en Vizcaya y tan sólo cinco en Cantabria, pese a que este territorio dobla en extensión a cada uno de los otros por separado. De la constatación no parece arriesgado deducir dos corolarios. Uno, a mayor protagonismo de los monasterios en la primera fase de la ordenación del territorio, menor protagonismo de las villas en la segunda. La aseveración cobra todo su valor cuando observamos que, de las cinco villas cántabras, dos han nacido en y por los dominios monásticos existentes: Santillana, Santander, y, con ocasión de la fundación de las otras tres, el monarca, siempre el mismo en las cinco ocasiones, Alfonso VIII de Castilla, ha debido pactar con los poderes monásticos o nobiliares de la zona para adquirir el terreno en que alzar la nueva puebla. El segundo corolario es todavía más evidente: el territorio vascongado debe, históricamente, su ordenación 
a las 69 villas creadas en él. Y la afirmación conserva su validez hasta nuestros días.

Con todo, habría que matizarla desde un principio. Una villa, en efecto, nace en una coyuntura histórica determinada. Puede, por ello, ser hija del estimulo mercantil, como, en general, las creadas en nuestra zona entre 1140 y 1330 . Pero, también, una villa puede ser hija de una deliberada voluntad de reordenación social del territorio y ello fue así en las villas creadas entre esa fecha y 1383. En todos los casos, no hay que olvidar que alguien con facultades para hacerlo ha tomado la decisión de crear una nueva puebla o de reconvertir en villa una vieja puebla. En Vizcaya, salvo en los casos de Valmaseda y Orduña, siempre el señor. En Cantabria, Álava y Guipúzcoa, siempre el rey. Esto convierte a las villas en un instrumento deliberado de ordenación del espacio en manos del rey o del señor de Vizcaya. Ellos tienen obligación de «acrescentar siempre sus señoríos ... (lo cual se hace ganando e cobrando) la tierra de los enemigos ... y de defender e amparar e juntar lo que esta ganado ... (lo cual) se faze faciendo e ordenando ciudades e villas cercadas e castillos e otras fortalezas do puedan los homes vivir vienaventuradamente e seguros». Por ello, hay que enmendar un tipo de poblamiento disperso, como es tan característico de estas tierras norteñas; hay que concentrar población. Hay que ordenar el espacio.

En el caso de los monasterios, la ordenación aparecía como un resultado. En el caso de las villas, la ordenación es una premisa. Una premisa que afecta de puertas afuera de la villa, pero, antes, de puertas adentro de la misma. En efecto, la morfología de las villas norteñas, en especial, vascongadas, deja ver claramente la voluntad de ordenación urbanística que, desde el punto de vista arquitectónico, preside su fundación. Dos, tres, cuatro y hasta siete calles paralelas, cortadas por cantones o callejones, reparten el caserío de casi todas estas villas en una red ortogonal. La formalización del plano y la rigurosa distribución del espacio intramuros en solares de idénticas dimensiones, con frecuencia, seis metros de ancho por doce de largo, proclama la ordenación de la vida colectiva desde el comienzo de la existencia de la nueva villa. Sólo con una aceptación unánime de las disposiciones constructivas puede erigirse en la forma y con la rapidez y regularidad con que se hicieron el conjunto de villas vascongadas. Rodeadas inicial o finalmente por una cerca, ésta separa visualmente el espacio urbano de la tierra llana aldeana. Como sabemos, algo más que visualmente. También desde el punto de vista económico, social y político, unas ciertas diferencias se establecen entre los núcleos murados y las aldeas. El disfrute de un mercado semanal y, eventualmente, de una feria anual, el reconocimiento de una cierta jurisdicción de 
las autoridades de la villa sobre el entorno rural de su término..., todo ello crea una jerarquía de intereses en el espacio. Las antiguas unidades homólogas, las aldeas, empiezan a ser subordinadas a esta naciente entidad.

La respuesta aldeana fue enormemente variada. En Álava, la incorporación de las aldeas al término de las villas más significativas se hizo por la vía de la compra por parte de los burgueses de Vitoria y Salvatierra. En Guipúzcoa, las villas consiguieron sustituir a los viejos "valles» y «tierras» en la tarea de aglutinar el poblamiento. Salvo un reducido espacio en el centro de la provincia, constituido por las alcaldías mayores de Arería, Sayaz y Aiztondo, el resto se repartió entre los términos de las veinticinco villas. Cada una de éstas pasó a ocupar la cabeza, en una especie de traducción «sui generis" de las comunidades de Villa y Tierra castellanas. Por fin, en Vizcaya, la historia fue más compleja. Las villas, al menos, las más poderosas, con la de Bilbao a la cabeza, tendieron a hacer una interpretación rigurosamente territorial de los párrafos de la carta-puebla en que se disponían los términos de cada villa. De esa forma, donde el fundador había respetado los diversos status sociales de los habitantes asentados en el término, muchos de ellos hidalgos, las autoridades bilbainas, bermeanas o duranguesas, en especial, a fines del siglo $\mathrm{XV}$, sintieron tentaciones de desconocer ese respeto.

Según ellas, en la práctica, todo lo que estaba dentro de los límites fijados en la carta de población caía bajo su autoridad, fuera cual fuera el status sociojurídico de sus vecinos. La reacción de éstos, en especial, en el caso de lo que interpretaron como imperialismo bilbaíno, fue fulminante. En el año 1500 , los hidalgos de las anteiglesias del entorno llegaron a hacer triunfar su tesis de que la jurisdicción de Bilbao acababa en la sombra que proyectaba su cerca. Durante tres siglos y medio, a Bilbao sólo le quedó el consuelo de ejercer algunos gestos de autoridad en su entorno rural. Aunque pocos, fueron casi siempre recibidos con hostilidad por los hidalgos de las anteiglesias vecinas. Que éstos conservaran el fuero no debe hacer olvidar que la villa se alzó con el huevo de la ordenación del territorio.

Tercer protagonista de la articulación del espacio, la nobleza. Acabamos de ver a los hidalgos vizcaínos enfrentados a la villa de Bilbao. Poco antes, veíamos al Señor de Vizcaya como promotor de, al menos, dicienueve de las veintiuna villas del Señorío. $Y$, todavía antes, nos referiamos a la resistencia de los infanzones de Trasmiera a las pretensiones del monasterio de Santa María del Puerto de Santoña. En las tres ocasiones, miembros de la nobleza tomando postura beligerante en los problemas de ordenación del espacio. Lo mismo podríamos decir del primero de los nobles del reino, el propio mo- 
narca, inductor de la mayoría de las fundaciones de villas norteñas. De los cuatro ejemplos, es fácil deducir, con todo, dos actitudes claramente contrapuestas. Una a favor, otra en contra de esas creaciones urbanas que modificaban la composición de fuerzas sociales en un territorio dado. En general, puede decirse que la nobleza regional se opuso, en principio, a tal ordenación urbana porque tenía la suya propia. Así, puede verse con absoluta claridad en Álava y Vizcaya o en las merindades cántabras; sólo en Guipúzcoa la nobleza regional se mantuvo en una actitud menos belicosa. La razón hay que buscarla, sin duda, en el distinto tratamiento que el estatuto hidalgo iba a recibir en las villas recién creadas. En Vizcaya, se aspiraba a igualarlo con el de los restantes vecinos; un mismo territorio inducía un mismo status sociojurídico. En Guipúzcoa, en cambio, los hidalgos podían incorporarse a las villas en la seguridad de que su status iba a ser respetado. No había, por ello, razón para un enfrentamiento frontal a la nueva realidad urbana.

De hecho, tampoco la tuvieron los hidalgos vizcaínos mientras la densidad demográfica del Señorio les permitió reproducir su modelo extensivo de organización del espacio. Basado en la ganaderia, prácticamente, hasta fines del siglo XIII, no tuvo oposición alguna. Ello quería decir que los distintos grupos de linaje en que, en estas fechas, aparece dividida la sociedad rural vizcaína, tenian reconocidos, según áreas comarcales, unos derechos de aprovechamiento de pastos y montes. Ello permitirá la instalación más fija de los miembros del linaje en los caseríos de las distintas barriadas que surgen entonces y, más adelante, en los caseríos absolutamente individualizados y diseminados. Todo ello configura pequeños espacios de dominio de los diferentes grupos familiares. Las rivalidades banderizas de los siglos XIV y XV entre oñacinos y gamboínos los pondrán de manifiesto, permitiendo cartografiar en líneas generales las grandes manchas de los asentamientos de los linajes de uno y otro bando. Precisamente, una de las razones, y no la menor, de esos enfrentamientos banderizos fue, sin duda, la convicción de que el modelo extensivo de organización del espacio empezaba a chocar con otras realidades. Concretamente, con la de una progresiva territorialización de los intereses económicos y del poder político.

La territorialización del poder político la habian impulsado decididamente las villas desde su creación. Más aún, ellas representaban el trunfo de ese modelo con su tendencia a delimitar con claridad términos, jurisdicciones, status sociojurídicos dentro y fuera de un determinado espacio. En cierto modo, esa territorialización sirvió de pauta para que la organización del espacio de base familiar empezara a su vez a cobrar conciencia de la necesidad de territorializar y precisar sus ámbitos geográficos de competencias. A asimilar y 
estimular la nueve realidad contribuyeron los nuevos intereses económicos. Frente a una ganadería extensiva, para la que era casi igual el valor de cada uno de los espacios, aparece ahora, de un lado, un creciente interés cerealístico e incluso vitivinícola por parte de las familias instaladas en sus caseríos, $y$, por otro, sobre todo, una aceleración de los intercambios mercantiles, inducidos por las villas, y el despertar de una industria ferrona. A tenor de estos cambios, cada parcela del espacio adquiere un valor diferente. Proximidad - lejanía de una villa, de un puerto, de una encrucijada caminera; pero también derecho o no a participar en la explotación concreta de un monte más poblado de árboles o de un riachuelo de caudal más regular y seguro para mover los ingenios de las ferrerías que surgen por doquier. Cada fragmento del espacio adquiere así un valor distinto.

Los nobles vizcaínos empezaron a ser conscientes de ello poco después de 1300 , precisamente, cuando las ferrerías alavesas perdían valor económico por la deforestación de los bosques. La carta-puebla de Portugalete muestra ya signos inequívocos de una tensión entre habitantes de las villas e hidalgos rurales por la instalación de las ferrerías. Veinte años más tarde, en 1342, los vizcaínos, para conocimiento de su señor Juan Núñez de Lara, ordenan en un capitulado las prácticas usuales en materia penal, pero aprovechan los últimos diez renglones para ponerse en guardia contra posibles intentos del Señor o de las villas de reducir los aprovechamientos de monte y bosque por parte de los hidalgos. El interés por la explotación del hierro es ya, para esos momentos, evidente. Ella dará nuevo sentido a la organización social del espacio propugnada por la nobleza regional. Al menos, en el caso de Vizcaya, que, en este sentido, acogerá a muchos de los linajes a los que la roturación de la Llanada alavesa y la deforestación de los bosques que la rodeaban ponía en dificultades. El clima más húmedo de Vizcaya y las posibilidades que ofrecía el comercio no pasaron desapercibidos para estos nobles de las tierras más altas de Álava. Alguno de ellos lo confesó paladinamente, reconociendo que su padre le había animado a emigrar hacia la costa, "donde no le faltaría con que amatar la gana de comer».

El interés por la producción del hierro, por los beneficios del comercio, por las rentas de los caseríos de nueva creación en espacios del linaje, por la percepción de los diezmos de las iglesias, todo ello contribuía a reorientar las modalidades de ordenación del espacio que, hasta entonces, habian escogido los nobles regionales y, en principio, a valorar aquél de forma más cuidadosa. Su respuesta, con todo, varió según los distintos territorios. En Guipúzcoa y Vizcaya tomó los derroteros de una incorporación más o menos convencida a las nuevas realidades del comercio y la industria del hierro. En Ála- 
va, se acercó igualmente a las villas, pero éstas, salvo Salinas de Añana, Vitoria y Salvatierra, no mostraban ya, desde mediados del siglo XIV, el dinamismo de sus compañeras de la costa. Por ello, para muchos nobles alaveses, sólo se abrió un modesto pasar, de base cerealera, a la sombra de algunos de los grandes linajes: los Ayala, Gamboa, Mendoza.

Por fin, en las merindades cántabras, pese a la proximidad de la costa, la respuesta se pareció un tanto a la alavesa. A la sombra de los grandes señores de la Vega, Castañeda, Santillana, el interés de los pequeños fue ampliar, a base de modelos ya ensayados desde muy antiguo, en especial, la presión fiscal y las exacciones sobre los campesinos, sus pilares de sustentación. Los pleitos que, a fines del siglo XV, se suscitan en los Nueve valles contra el marqués de Santillana recuerdan los que, desde fines del siglo $\mathrm{XI}$, al menos, habian expresado la resistencia campesina a la imposición feudal. Como dato complementario, los intereses exteriores de la más alta nobleza de origen alavés o cántabro se mostraban mucho más sólidos que los de los hidalgos vizcaínos o guipuzcoanos. También desde este punto de vista, mientras Guipúzcoa y Vizcaya se constituian en espacios económica y políticamente dotados de personalidad, de autosuficiencia decisoria, Álava y, sobre todo, las merindades cántabras volvían a evidenciar su engarce sociopolítico, esta vez, a través de los intereses de un reducido grupo de casas nobiliares, con espacios más meridionales. Como había sucedido con la primera ordenación espacial gestada por los monasterios, la nobleza cántabra iba, otra vez, a diseñar para la región un destino de periferia de sus intereses centrados prioritariamente en Castilla. La saga familiar de los marqueses de Santillana puede ser un paradigma. La de los Velasco, otro.

\section{JERARQUIZACIÓN: LA SECUENCIA HISTÓRICA DE LAS FORMAS DE ORGANIZACIÓN SOCIAL DEL ESPACIO NORTEÑO}

Monasterios, villas, nobles, desde diversos planteamientos y cronologias, habían actuado como ordenadores, como articuladores del espacio norteño. Al compás de su actuación, van tomando forma, y después fortaleza, unos cuantos espacios y, sobre todo, unas cuantas modalidades de percibir, de sentir, el espacio. Al final del recorrido, de una situación inicial de intercambio entre espacio natural y hombre, entre naturaleza y cultura, se ha pasado a otra en que el hombre ha puesto nombres a los espacios, los ha socializado y los ha ordenado, adquiriendo conciencia de su diversidad, de sus límites, de su valor. La sucesión de sentidos del vocabio euskaro ola puede simbolizar el proceso. En un primer momento, significó lugar en el sentido más vago de la expresión, esto es, sitio de algo. En un segundo, pasó a ser cabaña 
del ganado. $Y$, desde fines del siglo XIII, ferrería. La historia de los significados de una sola palabra ejemplificando la historia de los significados del espacio.

Al término del proceso, en el siglo XV, la configuración física de las villas cercadas por sus murallas, en claro contraste con el entorno rural sin ellas, constituía la imagen misma del final de la antigua situación de intercambios espontáneos entre naturaleza y hombre. Desde esas villas, a través de la difusión de sus medidas específicas, de Durango, de Cartes, de Santillana, de Potes; a través de su papel de motor de una actividad mercantil, estimuladora de los cambios monetarios, siempre escasos en el medio rural del área norteña, y de los circuitos de transporte entre localidades de la región o entre ésta y el exterior, el espacio físico va adquiriendo una precisa jerarquización. Pero lo mismo sucedía con el social; en Vizcaya, sobre todo, la fortaleza institucional de los linajes hidalgos, reforzada en su Fuero Viejo de 1452, llega a producir una verdadera división social del espacio: el villazgo de un lado, el infanzonazgo de otro. A la vez, se fortalecen los respectivos centros del espacio político de la comunidad hasta llegar a adquirir el valor de símbolos supremos de la misma. El árbol, en unos casos; el atrio del templo, en otros; la casa del concejo, más tardíamente, en los menos.

Árbol, atrio, casa. Árbol de Guernica, de Guerediaga, de Avellaneda; atrio de San Emeterio de Goicolegea, de Santa María de Galdácano, de San Pedro de Dima; casa del concejo de Bilbao, de Elgoibar, de Vitoria. La propia secuencia habla de dos procesos. El tránsito histórico de unas comunidades fundamentalmente ganaderas a otras con dedicaciones económicas más sedentarias será el primero. La evolución de una base numénica a otra cristianizada y, por fin, secularizada del poder sería el segundo. Junto a ellos, una observación que matiza los comportamientos en nuestro espacio norteño. La conservación del árbol como símbolo del centro del espacio político de la comunidad proclama el vigor que, todavia en la Vizcaya del siglo XV, tenía la representación a escala territorial en manos de los hidalgos. Para esas mismas fechas, las Juntas generales de Guipúzcoa se habían reunido ya con frecuencia en el coro de la iglesia de San Salvador de la villa de Guetaria. También desde ese punto de vista simbólico, parecía mantenerse una diferencia antes señalada: las villas guipuzcoanas habían conseguido integrar a los hidalgos en su red sociopolítica. Las villas vizcainas parecian arrinconadas tras sus cerca y una clara división del espacio social del Señorío era su resultado.

Ya hemos reiterado que no fue la única. El documento de los Reyes Católicos de 1480 con que comenzaba mi exposición dio cuenta de otras muchas más. En él el espacio era mirado con ojos de administrador, de poder 
político. Pero otro de los testimonios que situé en el pórtico de estas páginas hablaba de una distinta forma de ver el espacio. Me refiero al diploma de los falsos "Votos de San Millán", que subrayaba una secuencia de valles, alfoces, aldeas, casas. De mayor a menor dimensión, una escala de percepciones espaciales. pero, a la vez, una jerarquización de marcos de sociabilidad. En definitiva, sumando unas y otras, una serie de etapas de organización social de nuestro espacio. No voy a reiterar ideas que no hace mucho expuse por escrito y sobre las que seguimos investigando en Santander. Pero mi exposición quedaría incompleta si, al menos, a modo de conclusión, no recuerdo la hipótesis de engarce entre esos espacios captados por el monje emilianense de mediados del siglo XII.

El hilo conductor lo podemos situar en el proceso de aculturación de las comunidades ganaderas del Norte peninsular, que, a través de los estímulos y de los instrumentos puestos a disposición de sus jefes por parte del feudalismo, tienden a formas progresivamente más rigurosas, más individualizadas, de apropiación del espacio. A cada etapa significativa de ese proceso corresponde un marco característico de sociabilidad, con sus dimensiones espaciales y sus exigencias sociales. El primero, el valle o tierra, que, con frecuencia, aunque no siempre, tiene un valor morfológico desde el punto de vista físico, es el asiento de la comunidad rural constituida por una fracción coherente de un grupo étnico más amplio. Su percepción del espacio se basa en sus intereses ganaderos extensivos, y tiene una dimensión comarcal. Su representación política queda en mano de sus jefes familiares que, unidos a los de otros valles o tierras, asumen la autoridad de todo el conjunto $y$, por extensión, del espacio en que se asienta. El valle de Iguña en las Asturias de Santillana, el valle de Ayala en las tierras bajas, atlánticas, de Álava, serian buenos ejemplos de esta realidad. Su organización sociopolítica puede estudiarse aplicando el modelo bien conocido del Señorío de Vizcaya. Hasta fines del siglo $X V$, éste ofrece, a esos efectos, la imagen de organización territorial propia de un «valle» o de un conjunto de «valles». Ello quiere decir que, hasta esa fecha, al menos, la representatividad política estaba en manos de la nobleza rural, cada uno de cuyos miembros más relevantes, los parientes mayores, actuaba como cabeza de un grupo de emparentados claramente jerarquizado.

El segundo marco socioespacial percibido por el monje emilianense es el alfoz. Para él, suponía una circunscripción fraccionada del valle, en torno a un polo de nuclearización, y con límites mejor conocidos que los del valle; tal vez, porque eran más recientes y, también, más deliberadamente puestos por los hombres. En nuestro espacio norteño, el vocablo alfoz vendrá a bauti- 
zar lo que, en seguida, va a ser la parroquia. Su población daba muestras de un mayor grado de instalación fija en el territorio; precisamente, en función de una dedicación agrícola de carácter estable, basada, sobre todo, en el cereal. Ello favorecía, o, mejor, reclamaba la instalación de grupos familiares de menor tamaño esparcidos por el amplio espacio del alfoz y del valle para atacar, desde distintos puntos, la masa arbórea en medio de la cual aparecian inicialmente perdidos. Con frecuencia, el polo nuclear de sociabilidad lo constituye un templo, en manos de los monasterios regionales en Cantabria o de los parientes mayores en Vizcaya y Guipúzcoa. Los mensajes expresos y simbólicos de superioridad de cereal y viñedo, de familia nuclear y de capacidad individual de disponer de fracciones del espacio, que, desde esos templos, se emitieron, contribuyeron, sin duda, a acelerar, más en Álava y Cantabria que en Vizcaya y Guipúzcoa, una percepción del espacio a la escala de esta dimensión más reducida. La cristalización de la red parroquial, enormemente lenta en estas tierras, en especial, las vizcaínas, marcaría, en cada caso, el ritmo del proceso.

La cristalización de la red parroquial significaba otras cosas. Una de ellas que, por encima del conjunto de pequeñas ermitas, iglesias y monasterios de la primera hora, uno de los templos erigidos en el espacio ocupado por la comunidad rural del alfoz se convertía en núcleo sociorreligioso del conjunto al que quedaría subordinado el resto de las pequeñas células religiosas existentes. Ello permitia trazar la reticula parroquial. Con frecuencia, le correspondió otra de carácter sociopolítico: una de las modalidades del concejo rural venía a coincidir, en efecto, con las dimensiones de la parroquia, esto es, con el marco socioespacial que creemos que el monje emilianense hacia equivalente al alfoz. Pero este último incluía otros marcos de sociabilidad de menor tamaño, las aldeas.

Con o sin iglesia que fuera su eje de cristalización social, las aldeas aparecian como las unidades básicas de la red de poblamiento y un paso más avanzado en el proceso de apropiación del espacio. Con un sentido territorial mucho más arraigado, aldeas, barrios, barriadas o ledanías, según las áreas, constituyen una célula de organización deliberada de los aprovechamientos del espacio. No se trata ya de una percepción del espacio desde fuera del mismo o desde los usos extensivos del ganado. Se trata de un esquema de integración de tres elementos: un grupo humano, un espacio de aprovechamiento económico claramente delimitado física y socialmente y un conjunto de relaciones entre el primero y el segundo. Implica siempre un alto grado de territorialidad, aunque sus niveles variaron en la época medieval en nuestra zona. En general, lo que los textos evidencian es una tendencia a la diso- 
ciación, aquí siempre muy imcompleta, entre espacios de habitación, de cultivo y de aprovechamiento ganadero. El reducidísimo tamaño de la mayoría de las aldeas norteñas deja esa tendencia en el nivel de hipótesis conveniente al modelo, aunque los datos existentes permiten comprobarla en Liébana y Álava. Como grupo humano, aunque pequeño, la aldea ofrece también un embrión de representación politica que, por sus propias dimensiones, acaba siempre oscurecido en nuestros textos por el concejo del conjunto de la parroquia o, en Vizcaya, de la anteiglesia.

Desde el punto de vista de las relaciones entre espacio y hombre, la aldea norteña es un producto que parece derivar naturalmente de la progresiva reducción del tamaño de las estructuras familiares en función de una dedicación económica más productiva y más valorada de las distintas fracciones del espacio. Pero no hay que olvidar que esa misma aldea, en cuanto reunión de grupos familiares de carácter nuclear copartícipes de un espacio, resulta, en gran medida, producto de una deliberada política señorial. La que propende a fortalecer los rasgos, los perfiles del cuarto marco socioespacial, el solar familiar. Frente a la indefinición del espacio del valle, la rigurosa definición territorial, pero también personal, del solar como medida del esfuerzo de producción, de aportación de trabajo al señor o de rendición de cuentas de una fiscalidad. El solar, la casa, el caserío se convierte así, como reitera machaconamente el documento de los Votos de San Millán, en la célula fundamental del sistema y, según aquél, aparece, precisamente, en los espacios más aculturados. Por ello, no lo menciona en Guipúzcoa y Vizcaya. Pero fuera de ellas, por todas partes, omnes domus son las requeridas para pagar el censo al santo. Todas las casas, cada casa, es la cantinela de cualquier contrato agrario desde mediados del siglo XII. Y a perfilar sus dimensiones y sus facultades sí contribuyó decisivamente el pọder feudal.

En un sistema que aspiraba a obtener rentas, fundamentalmente, de la tierra, la existencia de casas y solares poblados era, en definitiva, la garantía de que los campos se labraban, las viñas se cultivaban, los ganados se cuidaban y las prestaciones se efectuaban según una medida. La cristalización del solar familiar, del domicilio fiscal fue, en el Norte peninsular, como en otras regiones europeas, el éxito final del proceso de feudalización. Agrupado en barrios y aldeas, o absolutamente diseminado, el solar familiar se instaura como la medida de todos los esfuerzos en la relación entre el hombre y la naturaleza. Las obligaciones hacia - y el sentido de - la comunidad serán muy diferentes según esos modelos de caseríos, pero, en los dos, se habrá afianzado vigorosamente la idea de la necesidad de una transmisión intacta del patrimonio familiar. 
Como sabemos, su individualización en forma de solares y caseríos rurales fue uno de los desenlaces posibles de nuestra historia. El otro, hoy tan visible como el anterior, fue el de la agrupación voluntaria, deliberada, de estas familias, de estos solares, en forma de villa, de ciudad. Parecía como si a la disgregación final de las viejas comunidades rurales de valle, la nueva realidad física y social de las villas ofreciera una compensación. La de una asociación de esos mismos troncos familiares ahora ya reducidos a su expresión conyugal nuclear. Pero una asociación en términos de aparente igualdad sociojurídica, de deseada igualdad de base territorial. Por los dos lados, el del caserío y el de la villa, un único final: territorialización económica, individualización social. Los dos necesitaban la existencia de una célula pequeña, manejable, desasida de otros vínculos más extensos. El caserío para incorporar nuevos espacios marginales a la realidad del cereal o de la ganadería estante; la villa para reunir, en una morfología geométrica, racional, aparentemente ajena de la vieja concepción antropológica del valle, a los solares familiares. En definitiva, por todas partes, en todos los escenarios, desde fines del siglo XII y de forma progresivamente acelerada en toda la España norteña, la comunidad familiar de casa se aprestaba a constituirse en la nueva y fundamental unidad de relación entre espacio y hombre.

* El presente texto constituyó, en su momento, la ponencia que su autor presentó a la «XVI Semana Internacional de Estudios Medievales", celebrada en Barcelona en junio de 1986 sobre el tema El espacio y el hombre en la Edad Media. Lo acompaña un mapa que recoge la toponimia mencionada en el texto y que ha sido elaborado por Esther Peña Bocos, colaboradora en las tareas de investigación. 


\title{
LA DINÁMICA ESTRATÉGICA HACIA UCLÉS Y SUS PUNTOS DE ENCUENTRO
}

\author{
Félix Manuel Martínez Fronce
}

Un continuo estar alerta, norma permanente de actuación en el frecuente brujulear por los fondos bibliográficos a mi alcance, me ha hecho llegar al conocimiento de cierto material que voy a procurar concordar, en un intento más de desempolvar añejas presencias en aconteceres pretéritos.

Repasando el número 9 del «Anuario de Estudios Medievales» (páginas 393 a 404), hace una década ya que - desde la universidad norteamericana de Gainesville - John E. Slaughter vuelve a tratar «De nuevo sobre la batalla de Ucléss. Su contenido resulta todo él interesante, pero quiero pararme especialmente a considerar una faceta, que pormenoriza en cuatro gráficos, relativa a los movimientos de tropas habidos, en armonía con los antecedentes históricos que maneja.

Nos presenta el planteamiento de que la acción se inició en Granada, con un primer cuerpo expedicionario, incrementado por otro contingente que se le unió en Jaén. Razones de estrategia, aconsejaron a los musulmanes no seguir el camino marcado por la «senda galiana» que, salvando Despeñaperros, atravesaba la Mancha de sur a norte, pues, al haber solicitado colaboración armada a los gobernadores de Valencia y Murcia, trataron de unificar las fuerzas, concentrándolas en el área Chinchilla-La Roda. Viene la Fig. 3 a situar las huestes de Tamin en esta última zona, a cuatro jornadas de su final, y frente a un derrotero de fácil desplazamiento, puesto que sólo habrían de concretarse a seguir la marcha que, por las altiplanicies manchegas, les llevara ante los muros de Uclés.

Como los límites entre los reinos moros y cristianos generalmente no representaban mayores dificultades de tránsito, ha de aceptarse que -correla- 
tivamente- llegó información a Toledo de lo que se iniciaba en Granada. Sólo así puede comprenderse la posibilidad de una movilización oportuna entre las gentes de Alfonso VI. De allí se enviaron mensajeros, en solicitud de ayuda de armas, hasta Alcalá de Henares y Calatañazor, a la vez que se preparaba la propia a la plaza en propósito de conquista por el enemigo. Es natural que, en la convocatoria, para establecer el grueso de las fuerzas expedicionarias cristianas se eligiera un lugar de confluencia, hacia el que convergerian: por una parte los toledanos y, por otro lado, las huestes soriano-alcarreñas. Entiendo que, como tal punto de encuentro, bien pudo haber sido designado el territorio taranconero, y trataré de razonar el porqué, en base a las consideraciones a exponer, y puesto que - en el fondo- - todo se reduce (como así lo analizarían en su día los estrategas encargados de desarrollar el hecho histórico contemplado) a una coordinación de dos elementos; los factores de espacio y tiempo, sobre los que habría que jugar en base a las disponibilidades humanas de recluta y desplazamientos.

Para situarnos mejor ante la panorámica geo-estratégica global, se han establecido dos mapas de rutas, que se definen por sí solos, y que pretenden ilustrar sobre el posible acontecer que nos ocupa. Con esta apoyatura cartográfica, desarrollaremos un ensayo de interpretación, basándonos en aquellas referencias bibliográficas que hemos estimado como aplicables al caso y que detallamos seguidamente:

- «Poema del Cid» (en lo sucesivo: PDC). Anónimo, versión R. Menéndez Pidal, col. Austral, n. ${ }^{\circ}$ 5, sexta edición. B. Aires, 1943.

- «Descripción de España» (en lo sucesivo: DDE), por Abu-Adb-AllaMohamed-Al Edrisi, interpretación E. Saavedra. Madrid, 1901.

Textos ambos de carácter comparativo, considerados en razón a la proximidad de su datación con el hecho histórico singularizado, puesto que los dos se fechan dentro del siglo XII.

- «Repertorio de todos los caminos de España» (en lo sucesivo: RCE), por Pero-Juan Villuga. Medina del Campo, 1546, reimpresión facsímil, Madrid, 1950.

Utilizado como elemento de contraste, por cuanto a la persistencia de itinerarios cuatro siglos después.

- «Diccionario Geográfico-Estadístico de España y Portugal» (en lo sucesivo: DGE), por Sebastián de Miñano. Madrid, 1826/28.

Traído hasta aquí por la diversidad del noticiario que contiene. 
- «Cantar del Mío Cid» (en lo sucesivo: CMC), por Ramón Menéndez Pidal, 3. ${ }^{a}$ edición. Madrid, 1954 (3 tomos).

Monumento analítico, respaldado por el magisterio de su autor. A todos ellos se une el texto del trabajo que ha motivado las presentes disquisiciones, y que se identificará por las iniciales AEM. Como fuentes primordiales de análisis de distancias citemos: El «Plano General de Carreteras de España», del Servicio Geográfico Militar, y el de «Vías de Comunicación de Cuenca», intercalado por su autor en la «Guía Larrañaga». Por cuanto a la situación de poblaciones, es un calco de la «Península Ibérica», publicación del Instituto Geográfico y Catastral, copias que, por conveniencias de impresión, se han venido a presentar en escala reducida.

Seleccionando cuanto consideramos que pudiera ser de aplicación a nuestro propósito, nos adentramos en el texto del PCD. Podemos apuntar que los desplazamiento narrados lo han sido a distintos ritmos, condicionados por las circunstancias de cada acción relatada. Así nos los encontramos con:

\section{A) A PASO DE CORTEJO}

1) Traslado de la familia a Valencia. (Cantar 2. ${ }^{\circ}$ Copla 83, Pág, 121). Minaya Alvar Fañez, desde San Pedro (de Cardeña) mandó a Valencia tres caballeros, con mensaje para el Cid, diciéndole: «De aquestos quinze días/si Dios nos curiare de mal/sernos i yo e su mugier/e sus fijas que él a/...” (Pág. 122).

Entre la provisión de vestimentas y caballerías adecuadas al traslado de las damas, y el encuentro con los prestamistas judíos, debieron pasarse un par de días, por lo que, al tercero iniciaron la marcha los 165 caballeros, el cortejo y las damas. (Pags. 123 y 125).

«De San Pedro fasta Medina/en çinco dias van» (Pag. 124). Si analizamos el derrotero, la primera etapa nos puede llevar hasta Covarrubias (35 Kms.); la segunda acabaria en Huerta del Rey, identificada como la antigua Espinaz de Can (28 Kms.), más reducida, pero no hay que olvidar la segura parada en Santo Domingo, monasterio de especial devoción cidiana. Al tercer día (después de $36 \mathrm{Kms}$.) pernoctarían en San Esteban de Gormaz, para rendir viaje del cuarto trayecto en Berlanga de Duero, con sólo $29 \mathrm{Kms}$., pero con la rémora de tiempo que representa la operación de atravesar el río Duero (por el lugar de La Rasa, posiblemente). La quinta jornada, por Caltojar y remontando el curso del río Torete o Bordecorex, les presentó ante las puertas de Medinaceli, una vez recorridos $52 \mathrm{Kms}$. más. Se habian superado, pues, 
180 kilómetros, lo que nos proporciona una media de 36 diarios. Para este mismo tramo - aunque con la salvedad de una medición en línea recta - CMC da $160 \mathrm{Kms}$. (a 32 por día). Hay que advertir que el itinerario elegido para el análisis hasta San Esteban de Gormaz es uno de los dos que se referencian en RCE, algo más largo - y que yo vengo a denominar «ruta de peregrinaje»- en contraste con el más corto (unas cuatro leguas de diferencia), que califico de «ruta estratégica».

\section{B) A CABALGADA}

1) ... «elelos en Medina/las dueñas de Alvar Fañez./Direvos de los cavalleros/que levaron el mensaje:/... (Pág. 124), recado que tardaría las mismas 7 fechas en llegar a destino, si nos atenemos a las siguientes etapas (va entre paréntesis el kilometraje estimado para cada tramo): Burgos-Espinaz de Can (63)-Berlanga (65)-Medinaceli (52)-Molina de Aragón (60)-Albarracín (60)Alpuente (70)-Valencia (90), que arroja, para los $460 \mathrm{Kms}$., un promedio de unos $66 \mathrm{Kms}$./dia. No debe calificarse como desproporcionada la apreciación de las distancias señaladas para los dos recorridos últimos, si consideramos que es trayecto realizado a través de territorios moros tributarios o con declarada amistad hacia el Cid, lo que permitiria a los tres jinetes — dada la calidad de la nueva que portaban- espolear a sus cabalgaduras, procediendo al siguiente día su desplazamiento con animales de refresco, e incluso el último cambiar de caballos a mitad del camino (hacia Villar del Arzobispo, por ejemplo). DDE, para un itinerario intermedio, nos da como referencia: «De allí (Medinaceli) a Santa Maria de Ibn Razin, hay tres jornadas cortas, y a Alpuente 4 jornadasss (Pág. 28).

El Campeador señala los componentes de la delegación que, en su nombre, se hará cargo de su familia. El día $8 .^{\circ}$ transcurre en preparar el desplazamiento, y al $9 .^{\circ}$, allá va el obispo don Jerónimo, los caballeros Hustioz, Bemúdez y Antolínez, arropados por los cien hombres de armas: ... «cavalguedes con ciento/guisados pora huebos de lidiar/...». (Pág. 124).

\section{C) A FORMACIÓN MONTADA}

1) «Esto era dicho/pienssan de cavalgar/e quanto que pueden/nos fincan de andar/Troçieron a Santa María/e vinieron albergar a Fronchales/e el otro día vinieron/a Molina posar/m. (Pág. 124).

Debemos entender que este tramo - Valencia Bronchales - sería cubierto en 3 días, en razón a la distancia que media entre ambas plazas, unos 175 Kms. (el de Albarracín-Valencia en dos fechas, ya descrito, debe calificarse 


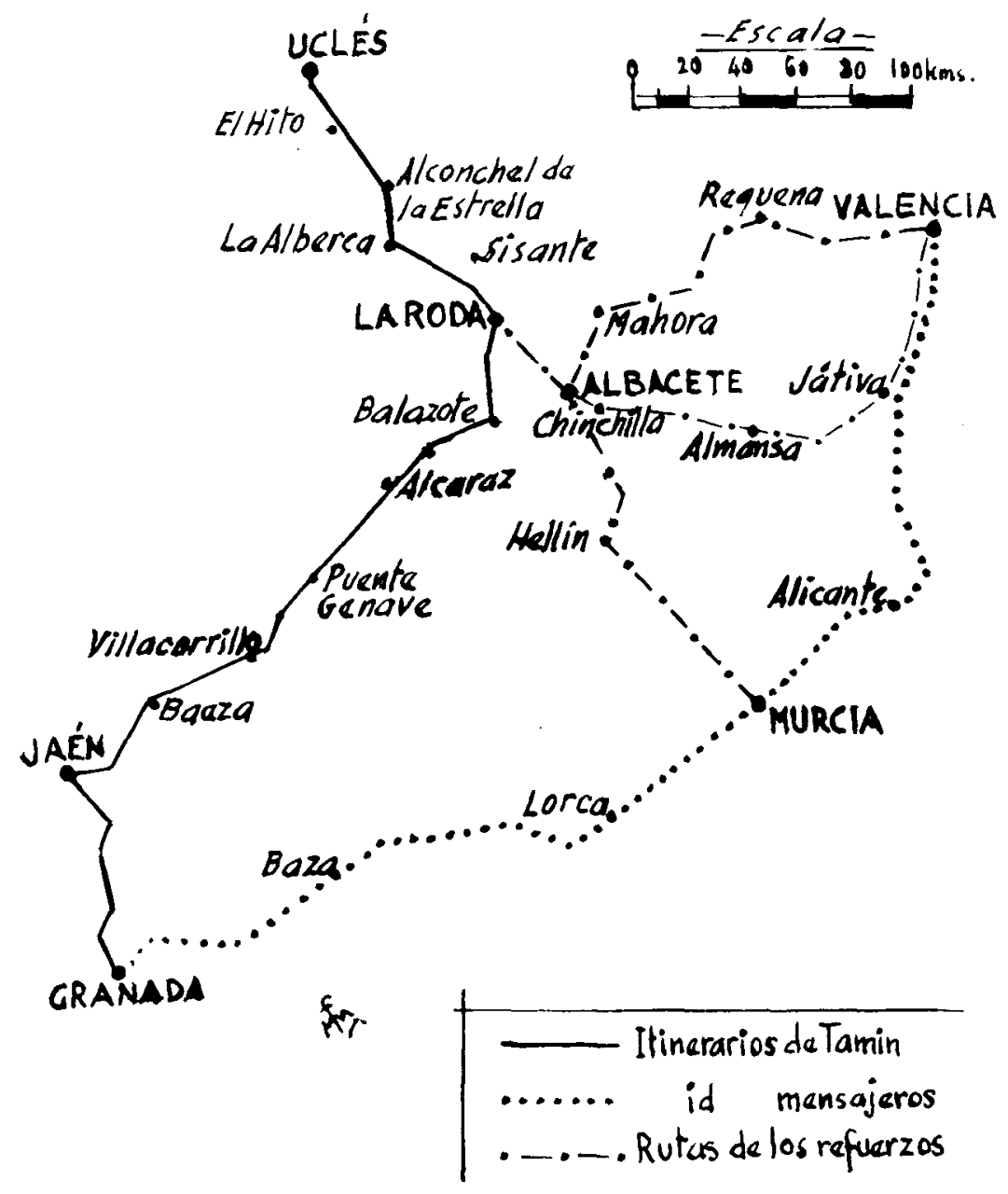




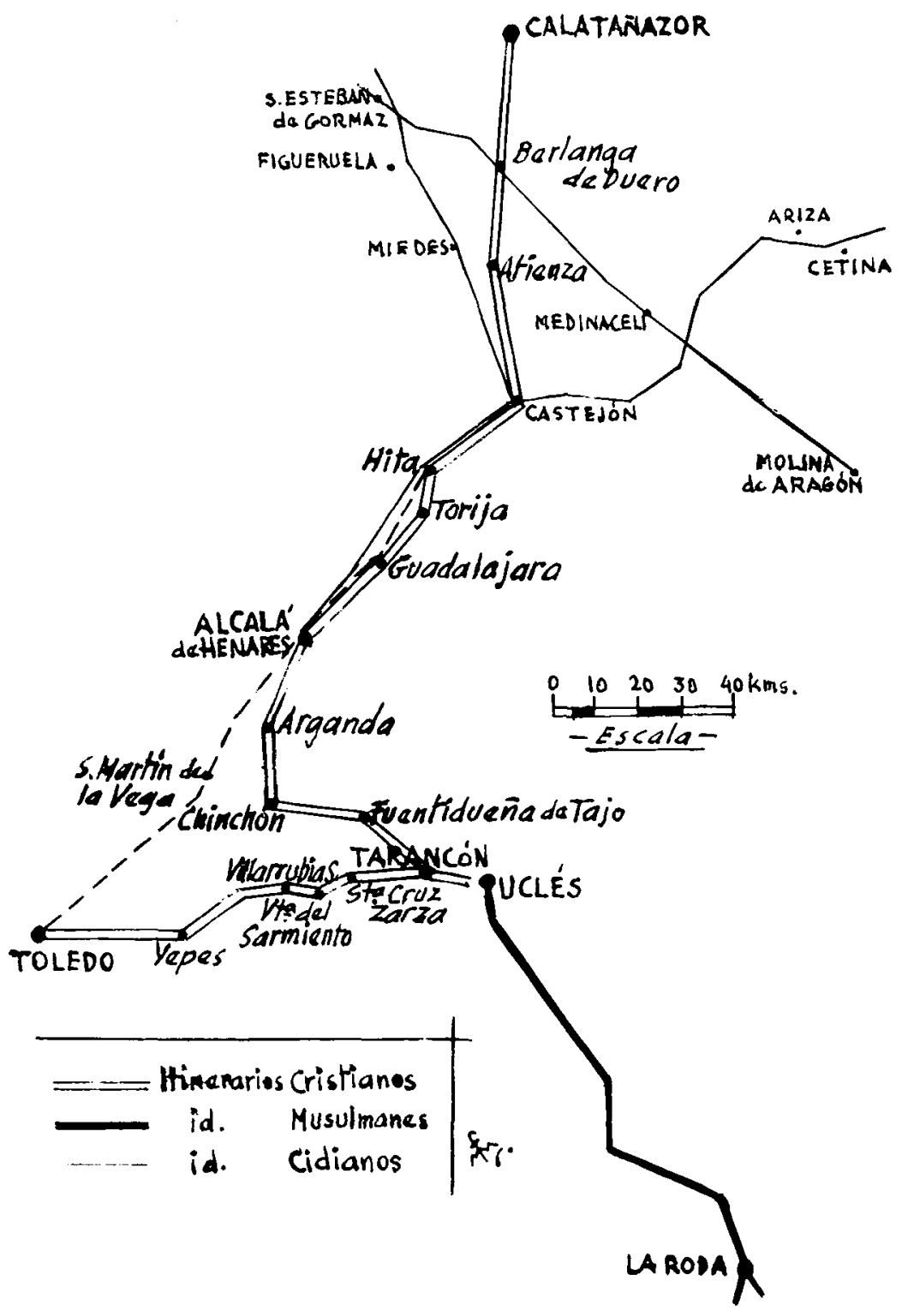




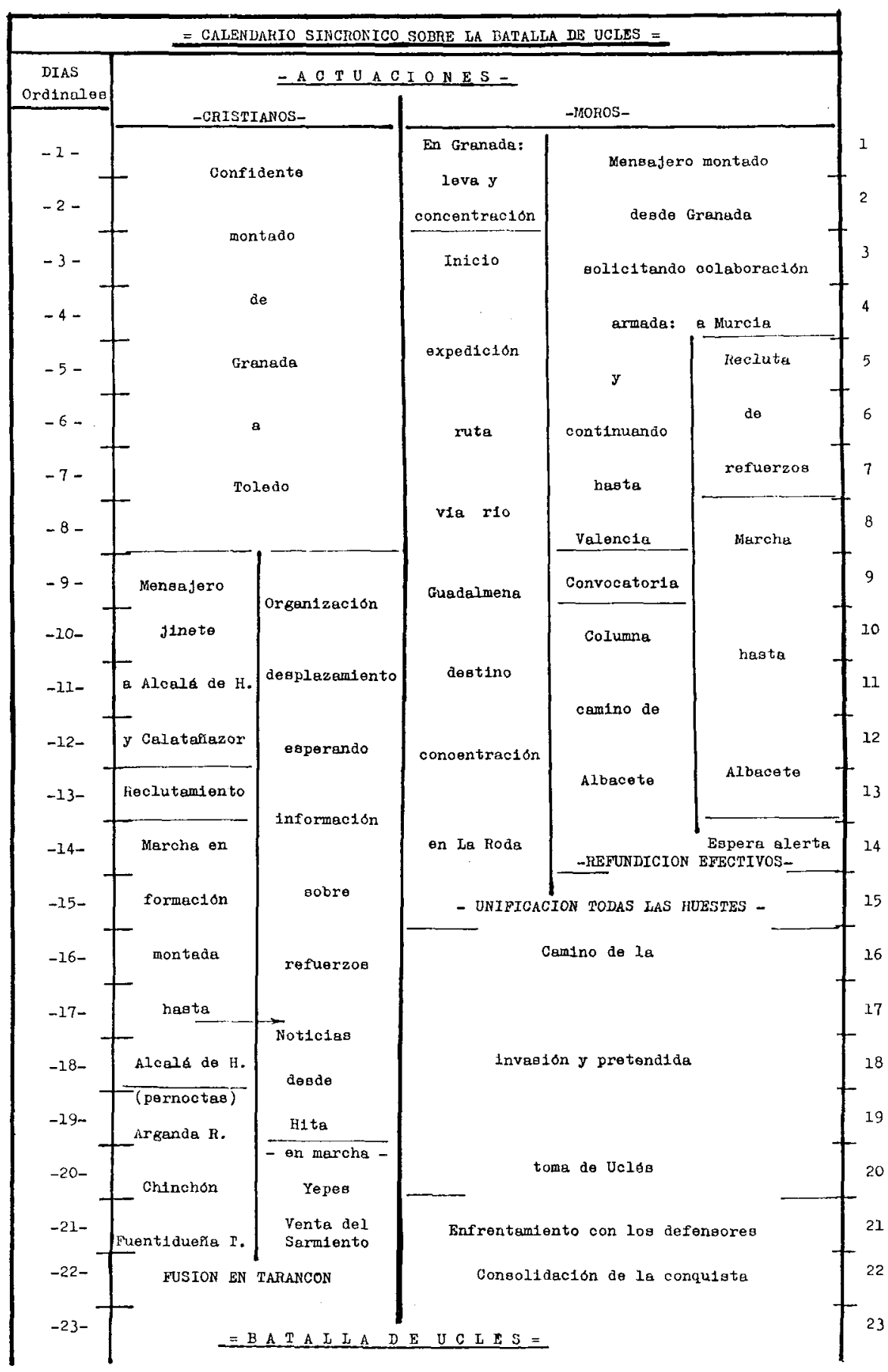


de excepcional). Al $12 .^{\circ}$ pernoctarian en Molina. Incrementada la comitiva con el alcaide Albengalbón y doscientos de los suyos, llegada es a Medinaceli, después de una caminata de unos 280 kilómetros a lo largo de 5 días (lo cual viene a representar un promedio de $56 \mathrm{Kms}$.). Ampliaremos que CMC acota: Para Bronchales, por Molina, a Medina, 103 Kms. (Pág. 41) y, con un espacio de $15 \mathrm{Kms}$. en blanco, de Albarracín a Valencia «hay leguas para tres jornadas». (Pág. 68).

\section{D) A PASO DE TROPA}

1) Destierro del Cid. (Cantar $1 .^{\circ}$ Copla 18, Pág. 40)...» en San Pedo a matines/tandrá el buen abbat/la missa nos dirá/de santa Trinidad,/la missa dicha/penssemos de cavalgar,/ca el plazo viene açerca/mucho avemos de andar».

A los sesenta pendones que nos refiere la copla 3 (pág. 16) se le unen ciento quince jinetes, según la copla 17 (pág. 38). Así, pues, la mesnada se muestra crecida. Después de la dolorosa separación, «commo la uña de la carne» (copla 18, pág. 42), sueltan riendas y espolean a las cabalgaduras, tratando de apurar los desplazamientos, pues el plazo marcado por el rey Alfonso $\mathrm{Vl}$ está cerca de cumplirse. Se nos dice - $\mathrm{CMC}$ - que «gastó tres jornadas antes de llegar a la Sierra de Miedes, que dista de Cardeña 122 kilómetros en línea recta», marcando la primera noche hacia Huerta del Rey -unos 50 kms. - (pág. 41); rinde la segunda en La Figueruela —otros 50 kms.y sitúa al Cid en la Sierra -22 kms. más allá- antes de ponerse el sol, vencido ya el límite de Castilla (pág. 46). Allí recuenta a su gente: ... «sin las peonadas/e omnes valientes que son/noto trezientas lanças/que todas tienen pendones", detalla la copla 21 del PDC (pág. 46). La 22 (pág. 47) refiere la nueva estrategia cidiana de efectuar las marchas nocturnas. Dos debieron ser, fundamentalmente, las razones de tal determinación: una estratégica, la reseñada de pretender no ser notado; la otra es de humanidad, ya que se podía combatir mejor desplazándose que inmóviles en descampado los efectos de las largas y frias noches invernales alcarreñas. Si sitúo en esta época del año el desarrollo del destierro es porque así nos lo concreta el propio PDC en su copla 2 (pág. 16) al referir que "ovieron la corneja», y sabido es que esta ave tiene la consideración de migratoria, procedente del norte de Europa, adonde vuelve llegada la primavera. De ahí, en consecuencia, que el machadiano verso "quema el sol, el aire abrasa» no deba interpretarse más allá de una licencia poética ambiental.

Mas, volvamos al itinerario descrito. Al no existir condicionantes técnicos que los modifiquen sustancialmente, es de razón pensar que los derroteros 
utilizados en el siglo XII seguirían teniendo vigencia en el XVI. Acudimos al RCE (págs. 58/59) y en la ruta Cuenca-Burgos (LXVII leguas) -la «estratégicas- podemos comprobar el tramo Miedes-S. Esteban G.-Huerta del ReyBurgos, con una andadura (corregida desde la Sierra, para coordinarla con los datos descritos) de 21 leguas, viniendo a representar la correspondencia de las mismas a razón de $5,81 \mathrm{kms}$. c/u, medida próxima a los $5,572 \mathrm{kms}$. con que se determina la particularizada como Vulgar o Itineraria.

Hemos inventariado ya cuatro posibles ritmos de marcha. Tratemos ahora de confirmarlos ante situaciones similares que también se describen en el PDC, descartando la referenciada bajo C) por no tener aplicación al fin último que se pretende en este trabajo, así como un segundo caso en $A$ ), el regreso de las hijas del Cid, después de la afrenta de Corpes (Cantar $3 .^{\circ}$. Copla $n .^{\circ}$ 132, pág. 220), al detallar un itinerario ya descrito en A) 1. Tampoco se localiza alguna otra narración en la que se reseñen marchas clasificables como D).

Nos quedan, pues, otros casos B), que podemos pormenorizar, siguiendo el texto:

2) Vendido Castejón, que conquistara, el de Vivar dirige a sus caballeros hacia tierras zaragozanas dependientes del moro valenciano. Caminan Henares arriba; pasan la Alcarria y el Tajuña, albergándose entre Ariza y $\mathrm{Ce}$ tina (copla 26, pág. 55), tras una algarada de 77 kms. (CMC, pág. 41).

3) El Cid vende Alcocer a los moros de los pueblos vecinos, y parte presuroso: «Aguijó mio Cid/ivas cabadelant,/y ffincó en un poyo/que es sobre Mont Real;» (copla 46, pág. 78). Desde su anterior posesión al nuevo asentamiento habian recorrido sobre $60 \mathrm{kms}$., en itinerario de un solo día, a contracorriente del Jiloca.

4) Al rey Tamin habian llegado noticias de que el Cid era dueño del castillo de Alcocer y envía tropas, tratando de reponer su autoridad en la zona usurpada: «Tres mil moros cavalgan/a pienssan de andar/ellos vinieron a la noch/en Segorve posar./Otro dia mañana/pienssan de cavalgar/vinieron a la noch/a Çelfa posar./... «lxieron de Çelfa/la que dicen de Canal,/andidieron todo l'dia,/que vagar no se dan,/vinieron essa noche/en Calatayuth posar». (Copla 32, pág. 62). Lo que se traduce en una primera jornada más bien corta, de unos $50 \mathrm{kms}$. Valencia-Segorbe, una segunda, larga, para llegarse a Cella -105 kms. - (RCE, en pág. 26, acota: «Hay de Teruel a Valencia XXIII leguas", que representa 3 y $1 / 2$ leguas menos que hasta el segunfo final registrado). La tercera, más cumplida aún, aunque -eso sí- después de un descanso adecuado, esperando la incorporación de los refuerzos fronterizos, mar- 
$\mathrm{ca} \pm 115 \mathrm{kms}$. Excepcionales desplazamientos, que reseño como muestras de la capacidad de movimientos en determinadas circunstancias. $Y$, como de un Cantar de Gesta se trata, el protagonista principal no puede quedar menospreciado ante los hechos descollantes realizados por sus adversarios, y nos presenta (Cantar $2 .^{\circ}$. Copla 72, pág. 107) la superación de los mismos, con un Cid saliendo de Murviedro una noche y «aguijando privado", amanecer en tierras de Monreal, pregonando su propósito de sitiar a Valencia, después de una cabalgadura impresionante de 140 kilómetros, hazaña sin parigual hoy, pues la que más se le aproxima es la que, hacia el final de los años 30 (según AEM, pág. 396), organizaba, en los ejercicios de Fort Bliss, Texas, la caballería de los EE.UU., con una distancia a cubrir de 100 millas (160 kms.) pero en 24 horas.

El copista Per Abbat nos trasladó testimonios de otras correrías, pero que dejamos de considerar analíticamente, dadas las inconcreciones de temporalidad que presentan.

Con los elementos comparativos hasta aquí deducidos, y aquellos otros de los que se dirá oportunamente, trataremos de reconstruir el desarrollo de las acciones previas que pudieron llevar a cabo los contendientes, antes de llegar al enfrentamiento directo armado en la batalla ucleseña.

Lo primero que hemos de tratar es la armonización de distancias, a fin de llegar a conclusiones válidas, sobre un terreno cuya configuración física permanece prácticamente inalterable hasta hoy.

La precedente exposición puede resumirse en: (conclusiones sobre PDC)

A) A paso de Cortejo. Media diaria del caminar: $36 \mathrm{kms}$.

B) A Cabalgada. Media diaria del caminar: $66 \mathrm{kms}$.

C) A Formación Montada. Media diaria del caminar: 56 kms., y

D) A paso de Tropa. No podemos aceptar como normales el par de desplazamientos de $50 \mathrm{kms}$. diarios, que fueron realizados bajo unas exigencias de plazo que obligó a avivar el ritmo y a apurar el tiempo disponible. Busquemos otra fuente de análisis.

Dos son las denominaciones con que los manuales militares diferencian a la cadencia de marchas para infantes, en cuanto a las aplicables al caso: 1. " "de paso largo" $(5,400 \mathrm{kms}$. hora), que hemos de desechar, por resultar humanamente insostenible para largos trayectos, y $2 .^{\circ}$ "paso ordinario"; éste sí aceptable, considerando su ritmo de 120 de ellos por minutos, a $65 \mathrm{cms}$. 
de longitud cada uno, lo que nos proporciona un avance de $4,680 \mathrm{kms}$., al que hay que deducir un mínimo de 10 minutos como descanso cada par de horas, lo que nos reduciría la distancia de recorrido real a: $65 \times 120 \times(60-5)=$ $-4,290 \mathrm{kms}$. a la hora-.

Hay otra medida, que DGE cita con frecuencia al referenciar situaciones entre pueblos de la zona centro: «las horas de camino militarm. Concretamente señala (pág. 390, columna 1. ${ }^{a}$ ) que, desde Perales a Tarancón hay 7 y $1 / 2$ hs., y Santa Cruz de la Zarza dista 4 y 1/2 hs. Estos dos solos ejemplos nos dicen de las disparidades de estimación, ya que _-para los $43 \mathrm{kms}$. del primer caso- nos da una media horaria de $5,73 \mathrm{kms}$. que, para los $16 \mathrm{del}$ segundo, quedarían en unos 3,55 solo, un tercio menos, cumplidamente. Por contra, al tratar de Saelices, registra « 5 horas de camino militar» hasta Tarancón, representando - respecto a los $21 \mathrm{kms}$. reales- una media horaria de 4,2 kms., que sí encaja en el «paso ordinario». Constituye una contrariedad estas abultadas diferencias en el contravalor kilométrico de las medidas en tal unidad, pues su armonía nos hubiera llevado al planteamiento directo del supuesto que pretendemos desarrollar. Habremos, pues, de buscar otras correspondencias, en base a unidades distintas, que se nos presentan en los materiales de consulta. Así, DDE nos habla de «millas» y «jornadas». Las primeras no hay que entenderlas como las que aún perviven en los países anglosajones, pues, teniendo presente que pertenecen a citas testimoniadas en el siglo XII, las considero más bien como una perduración de la antigua «milla romana». Convirtamos ésta en kilómetros, sabiendo que la misma equivalía a 8 estadios; el estadio a 125 pasos geométricos; el paso geom. a 5 pies, y -por último- el pie $= \pm 28 \mathrm{cms}$. Ello nos dará: $28 \times 5 \times 125 \times 8=1,400$ $\mathrm{kms}$. (con un redondeo de 7 metros, que no distorsiona los resultados, pero que -en cambio-facilita las operaciones aritméticas). Comprobando, veremos que señala (pág. 34) a Huete y Uclés como distantes 18 millas, y como hay entre ellos $26 \mathrm{kms}$., la relación queda establecida en $1,444 \mathrm{kms}$., que viene a confirmar los cálculos matemáticos.

Por cuanto a las segundas, en la pág. 29 se nos ofrece ya hecha la conversión. Dice allí: «De Mequinenza a Tortosa se cuentan dos jornadas o 50 millas». Lo que, aritméticamente, nos da: (50:2).1,4 = $35 \mathrm{kms}$./día., valoración perfectamente asumible para los casos en A), y que se ratifica en el siglo XVI, según podemos corroborar analizando el recorrido que Teresa de Jesús realiza desde Villanueva de la Jara hasta Toledo, una vez consagrado el nuevo «palomarcico» que alli estableciera la santa. El P. Efrén, en las «Obras Completas" de la fundadora, apunta que "salió el 20 de marzo de 1580 y llegó el día 26» (pág. 11), después de seis jornadas de monótono vaivén en el pe- 
queño carromato entoldado que constituyó su vehículo habitual de desplazamiento. Se nos argüirá que los días transcurridos, entre ambas fechas inclusive, son siete, cosa evidente, mas no asi por cuanto a la materialidad real del viaje, y ello en razón, no a unas conveniencias de ajuste para un resultado final predeterminado, sino porque el accidente tenido dos días antes de la partida, de cuyas resultas se lastimó por segunda vez el brazo izquierdo, aconsejarían emprender la marcha algo entrada la mañana, para no añadir a su dolencia la contrariedad viajera que representaban las frías madrugadas manchegas de marzo. Hace la ruta por itinerarios de «La Manchuela» y, en El Provencio, toma ya el camino real que - proveniente de Murcia - le lleva hasta la ciudad imperial, tras un derrotero de $206 \mathrm{kms}$. a razón, por tanto, de 34,333 kms. diarios de promedio, con pernoctas (en base a RCE, pág. 50) que señalaríamos en: Sisante (24 kms.) - El Provencio (33) - Manjavacas (31) - El Molinillo (31) - Tembleque (30) - Almonacid (35) - Toledo (22).

El ritmo, por jornada, en D), está en función a la armonización de desplazamiento, por lo que se analizará para cada caso en singular.

Sólo nos queda, ya, la parte más árida del desarrollo pretendido, como es la del establecimiento de los presuntos movimientos estratégicos que efectuaron ambos contendientes hasta llegar al choque frontal armado. Siguiendo para ello - en lo posible- las pautas generalizadoras que se exponen en AEM, ilustrándolas con una pormenorización racionalizada que entendemos pertinente.

El arranque de los hechos tuvo lugar entre los almorávides granadinos. Estos decidieron intentar la conquista del bastión cristiano de Uclés y procedieron a pregonar la recluta de gente para estableceer la expedición. Simultáneamente despacharon mensajeros para Murcia y Valencia, haciéndoseles saber el inicio de la operación y solicitando refuerzos a ambas plazas, tropas que habrían de situar en la zona de La Roda, para proceder allí a la unificación de todos los efectivos. Sigamos a estos correos: arrancan de Granada, por la ruta de Guadix-Baza-Lorca-Murcia (283 kms.), a cuyas puertas se presentan al final de la 4 . $^{a}$ jornada, tras un desplazamiento medio diario de unos $71 \mathrm{kms}$., a ritmo B), perfectamente realizable, dentro de un aceptable margen de diferencia, conseguible al tener presente que los cabalgadores salen de refresco y apuran el rendimiento de sus caballos, máxime si contamos con la posibilidad de sustituirlos por nuevos animales al reemprender su cometido desde aquí. Así lo hacen al siguiente día y, tras otras 4 jornadas de cabalgada a lo largo de $244 \mathrm{kms}$. pasando por Alicante-Alcoy-Játiva y Alcira, se presentan ante las puertas de Valencia, con un promedio de $61 \mathrm{kms}$. en cuyo 
resultado queda reflejada ya la fatiga de los jinetes. No obstante, si refundimos ambos trayectos $(283+244=527 \mathrm{kms}$.) y calculamos la media (527:8 = $65,875 \mathrm{kms}$.) comprobaremos que cuadra con el supuesto básico en B).

Entretando, ¿qué han hecho los mentores del plan? Dado el volúmen del contingente a organizar, consumirian en ello un par de días. Al tercero partirian de Granada, en columna de marcha «y avanzaron hacia Jaén... Desde Jaén se dirigieron hacia Uclés... pudieron haber seguido otro itinerario (no el de Despeñaperros), yendo a Baeza-La Roda-Chinchilla... Aunque larga, esta ruta permitía el encuentro con las fuerzas de Murcia y Valencia, antes de penetrar en territorio cristiano» (AEM, pág. 398). Haciendo nuestro dicho viaje, suponemos 6 días de andadura, sin apurar jornadas, pues el camino pendiente es mucho y las prisas no atosigan, al tener que coordenar la acción con la de los murcianos y levantinos. Marquémosles 7 horas de marcha efectiva, y nos dará, conforme a D): $(4,29 \times 7) .6=180 \mathrm{kms}$. recorridos, poniéndonos al alcance de Villacarrillo (185 kms.) enfilando, prácticamente, la vieja vía de fluidez, a contracorriente del Guadalmena, utilizada ya por las gentes del neolítico, en uno u otro sentido.

El lector se preguntará sobre la actitud, en este intervalo, de los cristianos. AEM nos comenta: «No hay duda de que algún espía descubrió en Granada los propósitos de Tamin (¿como no, si la leva era publicada?, apostillo) y que enviaría desde allí esa información a Toledo, es decir, a unos $350 \mathrm{kms}$. de distancia... el tiempo necesario para enviar un mensaje de Granada a Toledo. Por lo menos, ocho o nueve días» (pág. 400). Ello nos proporciona, aceptando como tiempo el de 8 jornadas: $350: 8=43,750 \mathrm{kms}$./dia, perfectamente aceptable, si consideramos que a $\mathrm{C}$ ) hubiera rendido más, pero no hay que olvidar que se desenvolvía en territorio enemigo, y que su itinerario no podría desarrollarse por los caminos tradicionales, al tener que eludir encuentros que hubieran dado al traste con su misión. Mas no fue así; el confidente llegó (y hacemos esta aseveración porque, de lo contrario, los subsiguientes movimientos de tropas no hubieran sido posibles y, por tanto, la batalla irrealizable). Toledo, a la vez que organiza el contingente propio, operación que se efectúa pausadamente, al tener que sincronizarla, envía «mensajeros a las ciudades que debían proporcionar refuerzos. La carta de Tamín dice que acudieron (a Uclés) cristianos de Toledo, Alcalá y Calatañazor (pág. 400)... La distancia entre Toledo y Alcalá es de unos $95 \mathrm{kms}$. (90, por la ruta RCE, pág. 9), y entre ésta y Calatañazor, casi $180 \mathrm{kms}$. (sobre mapas actuales yo totalizo 163): un mensajero tardaría alrededor de día y medio en ir de Toledo a Alcalá; desde aquí a Calatañazor necesitaría otros dos días y medio o tres" (pág. 402). Comprobemos: total del desplazamiento: $90+163=253 \mathrm{kms}$. Días 
utilizados: 4. Resultado: $253: 4=63,250 \mathrm{kms}$. $/$ día, capacidad de marcha homologable a B), y perfectamente mantenible por la disponibilidad de caballerías sustitutorias en el trayecto. El día $13 .^{\circ}$ se destina al reclutamiento en Calatañazor, no debiendo extrañar tanta celeridad en la realización, ya que su relativa proximidad a la frontera y como núcleo primordial de socorro ante eventuales refuerzos de retaguardia, su estructura estaba presta a responder a cualquier requerimiento inesperado. Así, al $14 .^{\circ}$, con la fresca brisa mañanera de mayo, tan agradable de disfrutar por aquellas tierras sorianoalcarreñas, y que tanto favorece al mejor desarrollo del ritmo de desplazamiento, los primeros refuerzos parten, camino de Berlanga de Duero, adonde pernoctarian, al socaire de su recinto murado, después de $29 \mathrm{kms}$. de andadura.

Volvamos al bando opuesto. Allí tenemos tres focos de atención, que vamos a pormenorizar singularizadamente:

1. ${ }^{\circ}$ Murcia. Sabedores del retraso que había de suponer su encuentro con los valencanos, se dedican a ordenar la recluta de refuerzos sin agobios de tiempo, destinando a ello los días $5 .^{\circ}$ al $7 .^{\circ}$. Al $8 .^{\circ}$ arrancan hacia Albacete, teniendo por delante 143 kms., a través de Cieza-Hellín y Pozo Cañada. Salvan la distancia en 6 días, «a paso de tropa ordinario», y con una jornada corta de marcha efectiva, durante 6 horas al día, ya que no necesitaban más para alcanzar su objetivo de concentración, según puede confirmarse: $(4,29 \times 6) .6=154 \mathrm{kms}$. Nos hallamos, pues, al final del $13 .^{\circ}$ día.

2. Valencia. Aquí la convocatoria de reclutamiento se desarrolla con mayor celeridad, cosa factible ya que la incertidumbre de su frontera occidental les obligan a estar en permanente alerta. De ahi que le adjudiquemos solamente el día $9 .^{\circ}$. Al siguiente se inicia su propósito de colaboración armada, posiblemente por la ruta Requena-Casas Ibáñez-Mahora-Albacete (173 kms.) aunque no hay que descartar la alternativaa que representa el paso por JátivaAlmansa-Chinchilla-Albacete ( $167 \mathrm{kms}$.), sensiblemente igual en cuanto a distancia, pero acaso con posibilidades de poder aportar durante el recorrido un más sustancioso contingente de refuerzos, si nos fijamos en las plazas por que pasarian. De cualquier modo, el tiempo que pudieron consumir para llegarse a destino, «a paso de tropa" y en jornadas de 8 horas, hubiera sido el de 5 días, conforme se comprueba por la siguiente operación: $(4,29 \times 8) .5=$ $172 \mathrm{kms}$. La columna, pues, rinde jornada al terminar el $14 .^{\circ}$ día, desde el inicio de la movilización en Granada, refundiendo sus efectivos con los aportados por los murcianos, que ya esperaban alertados allí desde el día anterior.

3. ${ }^{\circ}$ Granada. Al $9 .^{\circ}$ día prosiguen, desde el área de Villacarrillo, donde antes los dejáramos, decidiendo reducir una hora el tiempo efectivo de anda- 
dura, con el fin de evitar la fatiga a los hombres de a pie. $Y$, por Villanueva del Arzobispo-Puente Genave-Alcaraz-Balazote (desde donde envían mensajeros hasta Albacete), acampan frente a La Roda, consumida la jornada 15. ${ }^{a}$, y unificándose todas las huestes, ya que las otras dos columnas reanudaron su marcha tan pronto supieron de la proximidad expedicionaria, cubriendo los $37 \mathrm{kms}$. de distancia en una sola fecha. Habian recorrido en los 7 días otros $180 \mathrm{kms}$., según puede verse: $(4,29 \times 6) .7$. El total teórico a que llegamos es de $180+180=360 \mathrm{kms}$.; el real, inventariado sobre cartografía, sensiblemente igual (357). (En AEM -pág. 398- se registran: $130+205=335$ ).

Nos encontramos, por tanto, con todo el conglomerado invasor al pie del -como manifestaban los declarantes en la «Relación» ordenada por Felipe II (utilizo para ello la edición 1983, preparada por D. Pérez Ramírez, sobre la de 1927 del P. Zarco Cuevas) - «paso derecho y ordinario desde Cartagena, Murcia e Valencia a Toledo y Castilla la Vieja (respuesta 1, pág. 450), y ante una ruta sabida y cómoda, puesto que el trazado del camino «es antiquísimo, y se tiene memoria en esta tierra que lo hicieron los romanos..." y su eherchura es muy notable, porque va todo empedrado en forma de calzada con muchos aljibes» (resp. 57, pág. 460). Se están refiriendo a la misma calzada romana que - como de Sigüenza a Chinchilla- describe Francisco Coello en la comunicación que, fechada en Madrid el 25-oct.-1893 dirige a la Real Academia de la Historia, quien la publica en su «Boletín» (págs. 437/441) al tomo XXIII, cuaderno VI, noviembre del mismo año. Allí la descripción es minuciosa, haciéndosela pasar por Uclés, precisamente. El camino, por consiguiente, no ofrecía duda. Por cuanto a las etapas del mismo, su desarrollo (128 kms.) podría sintetizarse así, armonizándolo con lo anterior: La Roda, a rendir jornada sentando los reales en descampado, a la altura de Sisante (entre Pozo Amargo y Vara del Rey), que quedaría a la derecha (26 kms.) para continuar una fecha más hasta La Alberca (29), acampando al día después en Alconchel de la Estrella (27), volviendo a rendir jornada a EI Hito (23) y llegando el quinto día (20. ${ }^{\circ}$ de la expedición) junto al río Bedija (21), a media hora de marcha del destino final. El tramo reseñado habría de subdividirse a la vez en dos: un primero (La Roda-Alconchel, de 82 kms.) cubierto en 3 días, a razón de 6 horas cumplidas diarias; el segundo, que discurre por territorios próximos al objetivo, hay que ocuparlo con avanzadas en orden de descubierta, lo que repercute sobre el grueso del cuerpo expedicionario en la demora de su desplazamiento; por ello queda reducido sensiblemente el montante de avance (44 kms. para dos días).

AEM (pág. 398) nos relata «que al amanecer del 27 de mayo $\left(21 .^{\circ}\right.$ de los relacionados por nosotros) los almorávides avistaron la plaza amurallada 
y la cercaron al galope completamente... Ferozmente presionada, Uclés cedió y los sarracenos irrumpieron en ella. Los habitantes huyeron hacia la ciudadela o alcazaba, que en seguida fué atacada». $Y$, mientras el casco urbano caía en poder del invasor, veamos cómo se habian desarrollado los acontecimientos en el campo cristiano.

Amaneció el $15 .^{\circ}$ día en Berlanga de Duero y, con ello, el cuerpo armado reinició su traslado hasta Atienza (32 kms.) - Castejón (33) - y hacia Torija (35) mas, en este último trayecto, al pasar por Hita (25 kms.) se despacharon mensajeros a Toledo, informándole de su situación e intenciones del recorrido. El desarrollo de esta derrota, que DDE concreta en distancia de 2 jornadas (cap. IV, pág. 35) - a caballo, aclaro, pues las de a pie resultan inaplicables-, y que en RCE (pág. 9) queda puntualizado detalladamente, nos permite establecer la siguiente pormenorizada actuación:

- Media jornada (25 kms.) hasta Guadalajara; $1 .^{a}$ completa, con final en San Martín de la Vega (63), y otra tercera, corta, rindiendo viaje en Toledo (53): en total, 141 kilómetros, al concluir el $19{ }^{\circ}$ día. Como la tropa, tanto de caballeros como de infantes, se hallaba presta y de refresco, aprovecharon que ya los días en la última decena de mayo alargan sus horas de luz, sin resultar de ambiente bochornoso en esta zona de la Mancha Alta, y -ante la premura de fechas - se llegaron hasta Yepes ( $35 \mathrm{kms}$.) La segunda acampada debieron realizarla hacia el lugar que después vino a ocupar la «Venta del Sarmiento» - localizada por RCE (pág. 58) entre Villarrubia de Santiago y Santa Cruz de la Zarza-, posiblemente en el despoblado que testimoniara el itinerario Antonino como mansión «Vicus Cuminarius», y de la que aún perdurarian restos de estructura urbana aprovechables para proceder a una pernocta (30 kms.) Un tercer tramo (25 kms.) les llevaría a rendir viaje en Tarancón. Entretanto, los refuerzos sorianos se llegaron a apurar jornada (la 18. ${ }^{\circ}$ en el cómputo general de desarrollo) ante Alcalá de Henares (34 kms.): habian, pues, consumido cinco fechas para un traslado de $163 \mathrm{kms}$., lo que nos proporciona una media de $32,600 \mathrm{kms}$./día y de 7,5 horas de marcha efectiva, a cadencia de paso en D). Al respecto, AEM comenta (pág. 402) que «el contingente de Calatañazor debio de necesitar unos cinco o seis dias para llegar a Alcalá». Observará el lector que, hasta aquí, las concordancias de apreciación entre nuestro personal punto de vista y la exposición habida en AEM han resultado frecuentes, en cuanto a determinados planteamientos parciales, pero en la fase final que se describe a continuación no se puede decir lo mismo, puesto que, al pretender «elaborar un marco cronológico de los esfuerzos cristianos durante esa crisis» (pág. 402), un desajuste previo obliga al autor a tener que situar el arranque de Calatañazor en el día $17 .^{\circ}$, con solo 
seis fechas disponibles para recorrer -y a paso de D) - una distancia de 251 kilómetros, o lo que es igual, en marchas forzadas próximas a los $42 \mathrm{kms}$. por día, inadmisibles para el propio comentarista, quien nos advierte (pág. 396) que «el promedio diario, durante un largo período de marcha, sería aproximadamente de unas 15 millas $(24 \mathrm{kms}$.)", conclusión frontalmente contradictoria con cuanto antes queda expuesto, aunque, también es cierto, admite la posibilidad de llegar a conseguir hasta las 20 millas (32 kms.) techo que aún queda bastante por bajo del resultante que nos ocupa, y que, por otra parte, viene a concordar con la valoración base de rendimiento en avance con que han sido calculados en el presente ensayo los trayectos que han discurrido con tratamiento en D).

Tras esta aclaración, que entendiamos pertinente, volvamos con la reforzada columna de auxilio, encontrándonosla en la mañana del $19 .^{\circ}$ día partiendo de Alcalá de Henares, presta para recorrer - aunque a la inversael tramo que RCE (págs. 30/31) inventaría al describir el viaje Valencia-Alcalá de Henares. Ello nos permite señalar las pernoctas sucesivas en: Arganda (24 kms.) - Chinchón (22) - Fuentidueña de Tajo (23) y Tarancón (19), fundiéndose aquí estas mesnadas con las procedentes de Toledo, al finalizar el $22 .^{\circ}$ día, constituyéndose así la hueste definitiva que, acaudillada por el infante Sancho, presentó combate a los almorávides el siguiente día en una dura batalla, que en los anales históricos ha quedado recogida como «la de Uclés».

Por último, comprendiendo que la posible monotonía de las argumentaciones y desarrollos utilizados - aunque fueren los únicos aplicables al casohayan podido llegar a fatigar la atención del lector, queremos ofrecerle un cuadro-resumen expositivo de cuanto literariamente se ha establecido a lo largo del presente trabajo, visión de conjunto que pretende testimoniar un planteamiento que consideramos más racional que el presentado en AEM, y no lo definimos así porque sea propio, si no por mostrar un desenvolvimiento presunto de los acontecimientos más desmenuzado $y$, consecuentemente, con una apoyatura más pragmática. No obstante, a la pública consideración queda aquí expuesto. 


\section{TRASPLANTE DE LA CIVILIZACIÓN FRONTERIZA DE LA ESPAÑA MEDIEVAL AL NUEVO MUNDO: NOTAS AL FUERO DE SEPÚLVEDA}

Antonio Linage Conde

Cronista oficial de Sepúlveda

A mi paisano José-Manuel Ortiz, ganadero «in pectore»

Julio Senador, personaje hoy olvidado, es innegable fue uno de los hombres de más acusada individualidad en la España de su tiempo, tanta que quizá por eso tampoco tuvo en su misma época una audiencia correspondiente a lo desbordante de su dicha «humanidad». Notario, desdeñó los ascensos que en la realidad profesional y la estimación social de entonces suponian sustanciosas ganancias y jugoso prestigio, prefiriendo ejercer en pueblos escondidos de la paramera castellana, teatro propicio al ahondamiento de sus amargas y solitarias meditaciones en torno a su geografía y su historia, de donde salían sus libros explosivos, combinatorios de las propensiones anarquizantes con las aspiraciones a la planificación económica y todo envuelto en un sentimiento castellanista hijo del contacto inmediato con el país y no de ordenamiento arbitrista alguno impuesto o siquiera llegado de fuera. El notario de Frómista por autonomasia, que con su sello en tinta que de tal le acreditaba hacía estampar todos los ejemplares de sus ediciones.

En 1919 publicaba en Madrid La canción del Duero. Y con un radicalismo historiográfico detonante para el ambiente e incluso los tiempos sostenía en ella que la realidad de la Reconquista nada tenía que ver con lo que a los estudiantes contaban en los institutos, sino que habia consistido en la lucha del bárbaro pastor cristiano contra el civilizado agricultor árabe. Naturalmente que tal visión estaba más alejada todavía de la veracidad (1) que cuanto en los incriminados institutos pudiera contarse. 
Pero nosotros la hemos traído aquí a colación precisamente a propósito de lo que de trasfondo real había en ella, es decir una cierta constante ganadera innegable en la España reconquistada, hija, no de unos sentimientos ancestrales, raciales o inclusos religiosos, como de las diatribas del notario de Frómista hubiera podido deducirse, sino de la misma base geográfica y humana de aquella evolución histórica.

$Y$ resulta curioso que Julio Senador, pretendiendo arrumbar con toda la interpretación religiosa y heróica de la historiografía más tradicional, incurre en el error irreparable de otra visión unilateral, precisamente por mantenerse aferrado sin darse siquiera cuenta de ello al punto de vista meramente militar de la historia en juego, es decir a la Reconquista sin más y nada más, desconociendo la gemela realidad de la repoblación a ella consecutiva.

Pero la Reconquista, que desde luego existió y fue, sin discusión posible, el factor más decisivo del hacerse peninsular, estuvo acompañada de la repoblación de los territorios con motivo de ella misma vaciados o de los que ya anteriormente eran patrimonio de la tierra de nadie. Lo que nadie pone en duda, aunque si se haya discutido mucho la despoblación previa sustentada sobre todo por don Claudio Sánchez Albornoz. Y habiendo a la postre de reconocerse que alguna despoblación hubo de haber para que la repoblación fuera posible, puesto que no en todos los casos, extremo éste en el que tampoco la vacilación cabe, se trató de un vaciamiento provocado por las operaciones militares reconquistadoras inmediantamente antecedentes.

Así las cosas, dependiente la repoblación de la reconquista a corto o mediano plazo, se trató casi siempre de una repoblación de frontera, fuera esta frontera de contacto próximo y bajo la amenaza cotidiana y permanente del enemigo, o lo que desde luego era mucho más corriente, con el desierto estratégico, sencillamente la calendada tierra de nadie si lo preferimos, de por medio.

Repoblación que por ser de frontera era arriesgada, y en consecuencia requería de un señuelo para atraerse a los repobladores, señuelo que consistía en un derecho privilegiado, el de los fueros municipales que constituian el ordenamiento jurídico de cada lugar cabeza y su alfoz, el de las autónomas comunidades de villa y tierra. Es la composición de lugar de la búsqueda de gentes para la nueva tierra que, a propósito de la tan audaz repoblación de Sepúlveda por Fernán González el año 940, verdadero salto de tigre entonces por mucho que viniera favorecido por la batalla de Simancas, ha evocado de esta manera con su espléndida prosa fray Justo Pérez de Urbel (2):

Yo también iría -exclama un tercero-, pero no quiero ser tonto. Esos leoneses lo que quieren es que les saquemos nosotros las castañas del fuego. jMuy bonito poblar una ciudad allá, cerca de la 
frontera musulmana, para que antes que llegen a su tierra los toledanos y los cordobeses, los habitantes de Osma, de Gormaz, de Roa y ahora los de Sepúlveda, reciban el primer choque! Yo luché en Simancas como cualquiera de ellos, aquí en el brazo derecho llevo todavía la cicatriz que me dejó una flecha, y mientras ellos se apoderan de las tierras fértiles del Duero - ahí es nada: Baños, Rivas, Ledesma, Salamanca!-, nos dejan a nosotros desiertos y pedregales.

Y con lo que queda dicho ya hemos podido detectar una de las motivaciones del predominio ganadero, sí, solamente con la realidad de estos factores históricos y humanos y al margen de los casos en que hubiera convenido también aquel más que el agrícola por imperativo de la geografía física.

Pues no cabe duda de que a un asentamiento fronterizo y cara a una tierra eremada, le es más favorable la movilidad ganadera, propicia tanto a la expansión como al repliegue según las circunstancias, que el sedentarismo agrícola, cortador de vuelos en las horas alegres y gestador de más irreparables desastres en las tristes.

Incluso antes de la Reconquista ha comprobado para la Mancha lo que acabamos de apuntar uno de los mejores conocedores del tema, Julio González, quien así escribe (3): «La tierras de la Mancha ya habian padecido un proceso despoblador antes de la entrada de los musulmanes. Sus núcleos más importantes de la edad antigua llegaron a sumirse en el silencio; todavía hay discusiones en el intento de identificar las antiguas ciudades con los yacimientos arqueológicos». De manera que «tal circunstancia de decadencia facilitó el éxito de los musulmanes en el siglo VIII, los cuales no hallaron obstáculo en su marcha hacia Toledo. Y se comprueba el asentamiento de bereberes baraníes en el reparto, así como con las revueltas ulteriores». $Y$ ahora estos párrafos que no tienen desperdicio: «La Mancha vino a quedar marcada entre los musulmanes como tierra muy buena para la ganadería y en segundo lugar para los asentamientos agrícolas, dificultados por el paludismo y las razzias. Precisamente su riqueza viaria y su posición céntrica habían de convertirla muy pronto en tierra de tránsito de combatientes y mercaderes, tránsfugas y políticos, así como en tierra de contiendas. No olvidemos que es el puente de unión del Sur con el Centro, Norte y Levante de España (4)».

\section{UN PARALELO EN LA SIGNIFICACIÓN DEL ESPACIO}

No cabe, pues, duda, de que la historia medieval de España se desarrolla en el marco de una tierra nueva. Nueva en cuanto hay que repoblarla con 
de ser trasplantadas de fuera. Novedosidad, en consecuencia, a la que no afecta el remoto arraigo de los pueblos anteriores a la despoblación sufrida (5).

¿Y si ahora volvemos la vista a América? ¿Puede, por su parte, cabernos vacilación alguna de que también tierra nueva es como teatro de nuestra colonización?

Creemos que con lo dicho basta para convenir en que una similitud innegable se da entre la metrópoli y el Nuevo Mundo -epíteto el de nuevo que nada tiene, dicho quede de paso, de lugar común- desde ese punto de vista de la significación en ambos de sus sendas parcelas del espacio para la evolución de sus correspondientes aglomeraciones de humanidad.

Es decir una analogía específica, concreta, permisiva para el historiador del establecimiento de un paralelo que la mera referencia al espacio no justificaría en cuanto toda historia requiere el marco de una geografía.

Una tierra que pedía hombres y no a la inversa. Cierto que con modalidades y a densidades muy diferentes según los casos, pero sin que en este sentido se pueda hacer tampoco de la Península y de las Indias sendos compartimentos estancos, ya que las tales diferencias se daban dentro de cada uno de ambos territorios. Acabamos de citar, por ejemplo, el caso de la Mancha, «tierra de paso». Volvamos la vista al valle del Duero, «tierra desertizada", y en busca del contraste, al campo murciano y andaluz, tierra de colonización mediante el esfuerzo de las poblaciones vencidas en buena parte.

Diferencias que unas veces son herencia de la situación anterior y otras de la que se crea por la reconquista acá y la conquista allá. Pensemos en las que tan difícil hacen el cotejo entre Andalucía y el Levante citado, por mencionar dos territorios de repartimiento, y ambos poblados hasta el momento de su incorporación por la victoria militar. Y en cuanto a América, ¿a qué buscar en las crónicas lo que la diversidad racial hoy, de unas a otras fronteras, nos está pregonando?

Tierra, pues, demandadora de hombres. Demasiado vasta en ambos casos casi siempre para los recursos demográficos de que se dispone.

¿No se ha hablado del problema para la repoblación peninsular? Así escribe Salvador de Moxó (6) de una de sus parcelas llamadas a más aureolada repercusión a la postre: «El volumen de la despoblación en el solar primitivo de Castilla y en el de la segunda Castilla de Burgos y Amaya contribuye a explicar, junto con la habitual actividad ofensiva militar de esta comarca, lo paulatino y azaroso de la repoblación, así como lo poco tupida que se ha- 
llaba aún la red de ésta a fines del siglo IX. Las presuras de tierras yermas continúan a lo largo del siglo $X$ y la expansión de los límites fronterizos cristianos se hace aqui con mayor lentitud que en la zona occidental del reino asturleonés».

Y en cuanto al Nuevo Mundo, baste con echar una ojeada al mapa y tener en cuenta que a lo largo de toda la etapa del imperio ultramarino España no pasó de oscilar entre los ocho y los doce millones de habitantes. «Uno de los rasgos más importantes de este medio fue su tamaño gigantesco, y por lo tanto el gigantesco tamaño del imperio - ha escrito Salvador de Madariaga (7)-.. A decir verdad, lo que ha menester explicación no es tanto el derumbe del imperio como el milagro de su persistencia trisecular. Los territorios confiados al dominio español excedian en un quinto al continente europeo; pero además su forma peculiar, con un reino al norte del istmo, y todos los territorios del sur dispersos en arco de círculo en torno al Brasil y entrecortados por la cadena de montañas menos franqueable del mundo después del Himalaya, más las islas dispuestas en otro arco de círculo a través de la parte más vulnerable del Atlántico. Así destartalado de polo a polo, ofrecía el Nuevo Mundo español en sus millares de leguas de costas centenares de bahías, de estuarios, de islas» (8).

\section{LA CONSTANTE GANADERA}

Pero aun creyendo posible, como queda dicho, descubrir sin demasiado esfuerzo un parentesco entre la España del Viejo y la del Nuevo Mundo en el desafío del espacio al hombre y la toma de postura de éste frente a ése, no vamos a negar que los lazos son mucho más íntimos si pasamos al análisis del aprovechamiento ganadero (9) que quizás sea la clave de la tal respuesta humana a la dicha exhortación geográfica e incluso histórica (10).

Una respuesta la ganadera que se dio ya en la repoblación monacal (11), de los siglos VIII al $X, y$ luego en la concejil de las dos centurias siguientes, es decir, anteriormente a la supuesta fundación de la Mesta en 1272, y que coadyuvó al acuñamiento de la psicología colectiva del hombre de aquella Castilla como nuevo territorio dotado de propia personalidad al volver a la vida el marco físico de su desarrollo (12), acuñamiento para el que resultó esencial la condición trashumante, hasta más allá de la sierra de Guadalupe y de los montes de Toledo.

Pero cuanto en detalle tratáramos de decir en este capítulo sería ocioso luego de la eruditísima puesta al día del estado de la cuestión por CharlesJulian Bishko (13) a los sesenta años de la publicación de la monografía deci- 
siva sobre el tema de su compatriota Julius Klein (14).

$Y$ que ese alarde de «benedictina" sapiencia libraria nos llegue de los Estados Unidos no es en este caso una confirmación más de la apertura de ese país al cultivo de los dominios foráneos. Ni mucho menos.

\section{SU EXTENSIÓN A LA AMÉRICA ÁNGLICA}

Puesto que en los vastos territorios otrora hispanos por los cuales extendió el poderoso vecino del norte su frontera meridional, y aun más allá, esa civilización fronteriza asentada en una economía y una mentalidad pastoriles sobrevivió al cambio de dominio.

Es lo que se ha hecho notar una vez más recientemente (15) al estudiar el rancho colonial importado de la madre patria. En tanto que las otras dos instituciones en juego, la misión y el presidio (16), se quedaron como memorias nostálgicas, desde luego que bien, ejemplarmente mantenidas en el recuerdo tal por los nuevos dominadores al cambiar los límites territoriales.

Y es esa ganadería de frontera la matriz de toda esa marcha hacia el oeste, esa epopeya deformada por el desaprovechamiento cinematográfico, que la sacrificó estúpidamente a la suficiencia falsa y la violencia burda, de una especie literaria digna de mejor suerte. $Y$ ahí está el libro de Pierre Chaunu, L'Amérique et les Amériques, de los más jugosos entre los suyos y ya es decir, con su evocación de ese hervidero de inquietud espiritual que en dicho Extremo Occidente se manifestó a través de la eclosión desbordante de sectas religiosas. En enlace consecuente, y no en oposición explicatoria por la ley del contraste, con toda esa misma civilización del cow-boy (17).

\section{LA FRONTERA ABIERTA DEL ALFOZ SEPULVEDANO}

Así las cosas, vamos a retornar a los invocados precedentes del proceso peninsular.

El año 940 Fernán González repuebla Sepúlveda. Ello implica un formidable avance, lleno de riesgos, hacia la línea musulmana. Circunstancia que no podemos preterir. Como tampoco la topografía de la villa, pintiparada fortaleza natural, un escarpe medianero entre los cañones del Duratón y el Caslilla, ni más ni menos.

Sobre todo la primera, aunque coadyuvando también esta segunda, nos explican sin más que la población, rediviva después del interludio subsiguiente a su eremación en las campañas de Alfonso I, sea la cabeza de aquella Extremadura castellana, con la leonesa la única respondente a su etimología, 
de tierras extremas del Duero. Si bien no discutiremos este detalle semántico muy controvertido.

Y el elemento diferenciador de aquella Sepúlveda era su derecho privilegiado, su ordenamiento jurídico propio, su fuero. Ordenamiento jurídico no sólo peculiar sino autónomo, teniendo en cuenta las facultades en él mismo atribuidas al concejo que acabaron de hecho convirtiendo a éste en órgano creador de derecho a su vez, en el núcleo aglutinante de la evolución consuetudinaria de aquel derecho foral mismo, y así transformador a la postre de aquel fuero breve latino en el correspondiente castellano extenso.

Y es curioso cómo en este trance historiográfico, cuando un tanto liberados de la obligada servidumbre del atornillamiento bibliográfico de nuestras afirmaciones, por habernos ya sometido a él en varias ocasiones de alguna coincidente temática y otro enfoque, nos hemos concedido una vacancia meditadora, vemos las cosas más claras, aun reconociendo que sujetas, ¿cómo no?, a revisión.

Y es esa indole del derecho de Sepúlveda como equivalente al derecho de esa Extremadura sin más. Y no sólo del de la Extremadura castellana, sino por la prioridad cronológica respecto de ellas y la comunidad de la coyuntura fronteriza y repobladora ante todo, también del de las otras Extremaduras anteriores a la definitiva de hoy, la leonesa y la aragonesa. Ahí está la problemática de las conexiones con él del Fuero de Béjar (18) y su indubitada concesión tardía a Teruel y Albarracín.

"Y dentro del derecho castellano (19), Sepúlveda es el centro creador de su especialidad de Extremadura, que modela la organización jurídica de toda Castilla, directamente o mediante el Fuero de Cuenca», pero teniendo en cuenta que este «Fuero de Cuenca es la fijación tardia y por escrito (20) del derecho de Extremadura" nada más, o sea la redacción del derecho sepulvedano creado en y desde Sepúlveda. Y es más, "cuando a principios de la Edad Moderna se revisa la historia del derecho medieval, y las leyes de Toro armonizan las contradicciones surgidas en su seno, la nueva síntesis tiene como rasgo dominante la decisión del derecho castellano y Sepúlveda es la sede del Derecho civil común de Españan. Estas afirmaciones de Rafael Gibert, al editarse al fin rigurosamente el derecho sepulvedano (21), no han perdido su valor ante las aportaciones, desde luego bastante numerosas y densas, de la bibliografía surgida en los treinta años posteriores.

Pues bien, dejando ahora de lado estos horizontes de su propagación, y volviendo al momento del otorgamiento regio del ordenamiento jurídico sepulvedano y de la consiguiente autonomía (22) de su comunidad de villa y 
tierra, o sea del alfoz de Sepúlveda, nos interesa fijarnos en los límites territoriales de éste según aparecen determinados en el fuero latino, o sea en el genuino de Alfonso $\mathrm{VI}$, el año 1076 (23). Concretamente en el detalle de carecer de frontera meridional, o sea cara a la tierra enemiga (24). Atilano González Ruiz-Zorrilla (25) comenta a ese propósito que tal inexpresado linde «podía muy bien estar formado por las sierras que se extienden desde el nacimiento del Ayllón hasta el nacimiento del Pirón». Pero Jean Gautier-Dalché (26) ha sabido ver posteriormmente con agudeza que no hubo tal. Sino que sencillamente el monarca otorgante no quiso poner puertas al campo sureño y que al alfoz le quedaba una expansión ilimitada por aquel lado de la tierra de nadie, al otro lado de la cual se toparía con la media luna; tan ilimitada como sus fuerzas y su audacia se lo permitieran (27).

¿Y es mucho pedir por nuestra parte si ahora, sólo por un momento, reclamamos de nuevo trasladarnos al panorama de los ranchos de Indias?

\section{LABRADORES CONTRA PASTORES}

En un interesante estudio, el letrado segoviano Manuel González Herrero (28), escribió que «el ordenamiento pastoril de Sepúlveda se inspira en el respeto y protección de los intereses de la agricultura, como corresponde a un derecho de frontera - derecho de la Extremadura castellana- nacido para servir las finalidades de la empresa de fijación y repoblación del territorio, y preocupado por tanto de favorecer mediante un estatuto personal, político, jurídico y económico privilegiado, el asentamiento de las gentes en las tierras recién ganadas y el laboreo de las mismas». Y efectivamente, consiguió citar en su apoyo unos cuantos preceptos forales que protegían las tierras de labor contra los daños en ellas ocasionados por los rebaños.

Y nosotros no vamos a negar que las aspiraciones de la potestad condal o regia repobladora eran el asentamiento definitivo de los repobladores en la nueva tierra, tal y como ninguna otra ocupación cual la agricultura sedentaria puede proporcionarla. Pero por eso mismo no podian pasar de ser una aspiración a largo plazo. Pues la frontera no estaba segura ni se sentía como fija. Ya que en otro caso, aun habiendo la tal frontera existido, ni la civilización hubiera sido fronteriza ni el derecho foral necesario. Eso por un lado. $Y$ por otro, la contrapartida. Pues esa misma falta de fijación de la tal frontera, si de un lado actuaba en el sentido de moderar exigencias y conformarse con lo que a la vista había, de otro implicaba un estímulo a ensancharla, a llevarla más allá, a tornar esa su misma indeterminación en el propio beneficio. Y nada mejor para ello, aparte la atención al elemento bélico estricto, que la for- 
mación de unos intereses ganaderos necesitados de expansión por la parte del mediodía. La de la trashumancia, no lo olvidemos, la de los pastos de invierno, una constante biológica señuelo desde las aves hasta los hombres. De ahí que aquellos preceptos de protección a la agricultura haya más bien que mirarlos como las obligadas y mínimas limitaciones a un contexto abrumadoramente pastoril. «Y lo aumentó, dándola más término sobre los límites que antes tenía», es la frase de don Juan de la Reguera Valdelomar (29) que en las postrimerías del antiguo régmen captó lo esencial de aquella situación y la mentalidad a ella conformada. Como don Ignacio-Jordán de Asso y del Río y don Miguel de Manuel y Rodríguez (30), al referirse al derecho coetáneo extremo-castellano todo (31), hablen por su parte, y acentuando ya más lo castrense específico y primigenio de «las condiciones y pactos en que convinieron para servir en la guerra contra los africanos» $y$ «un código militar» a su servicio".

\section{LA APERTURA DE LOS CAMPOS}

Yo diria que en los textos legales o en los doctrinales y aun literarios con cierto valor de observancia - tal aquellos códices del abad o codices regularum donde, en el estadio monástico prebenedictino se contenía la regula mixta o sea la disciplina cenobítica aplicable - anteriores a las modernas codificaciones sucesoras del más o menos barroquismo legislativo del Antiguo Régimen, el orden de los factores sí que alteraba un poco el producto. Es decir, que la colocación de los preceptos jurídicos denotaba un tanto su rango legislativo.

$Y$ en este sentido, podemos aquí fijarnos en el título primero del Fuero Extenso de Sepúlveda, con la contundencia de su titulación, que toda Estremadura sea tenida de venir a Sepúlvega a fuero.

Es la consagración por el derecho escrito de aquella la verdad histórica alumbrada también por la geografía y a la que arriba nos referíamos de ser Sepúlveda la cabeza de Extremadura.

Rotundidad en el dicho título que no cede un ápice en los pormenores de su desarrollo. Pues si bien su sustancia es una referencia a la delimitación de los términos del alfoz ya hecha en el preámbulo -aprimas do e otorgo a los que moran en Sepúlvega e a los que son por venir Sepúlvega con todo su término - el corolario que a su vez explaya la misma no deja de implicar una cierta vocación de campo sin puertas. Un tanto la gozosa nostalgia de aquella la siempre abierta frontera - jo carencia de ella! - meridional de antaño. Con montes et con fuentes, estremos, pastos, ríos, salinas, venas de 
plata e de fierro e de cualquiere metallo. Estremos, o sean pastos de invierno de la trashumancia (32) con caminera vocación de libertad y horizontes (33). Campos abiertos, como precisaba la confirmación por Alfonso VIII desde Riaza, a 20 de julio de 1207, del acuerdo entre los concejos de Sepúlveda y Fresno de Cantespino: super illo quod debet esse "extremum", videlicet, quod non laboret illud nec populet concilium de Sepúlvega nec concilium de Fresno set quod remaneat per ad los pastos et los pastos sint de comun (34).

Campos abiertos como los de la Nueva España y el Nuevo Mundo tout court. Campos abiertos como los que hacia el Oeste pasaron tardíamente la frontera de la América ánglica. Con su forzado encarrilamiento jurídico a la postre por la Mesta que, si de un lado, llevaba consigo el reconocimiento de haber algunas puertas en los horizontes ya trillados, al menos consagraba la libre potestad natural de vagar a su través. 


\section{NOTAS}

(1) Creemos que en el momento actual, un cierto peligro de alejarse de la realidad histórica sería ceder a las lisonjas de una cierta apologética de lo árabe. Concretamente en el ejemplo de Julio Senador, no vamos a negar las virtudes labradoras de ellos en nuestra tierra, pero no olvidemos, por botón de muestra, la reciente tesis del origen romano y no islamita de los regadios de la huerta valenciana. Cfr. F. UDINA MARTORELL, La Reconquista española, en «La cristiantà dei secoli XI e XII in Occidente: Coscienza e strutture di una società» (VII Semana de Mendola, 1980; Milán, 1983), pp. 85-101.

(2) Fernán González, el héroe que hizo a Castilla (Buenos Aires, 1952) pp. 85-6.

(3) La repoblación de la Mancha, en el volumen colectivo "VII centenario del infante don Fernando de la Cerda. 1275-1975; (Ciudad Real, 1976), pp. 1-3 de la separata.

(4) Apostillando todavía que «las luchas civiles del siglo IX con sus campañas y razzias contribuyeron a mantener y aun aumentar la desertización». Por lo tanto no podía quedar mejor preparado el terreno para la necesidad repobladora subsiguiente a la reconquista: «La muy escasa densidad humana durante el siglo $X$ se prolongó en el $\mathrm{Xl}$ ».

(5) En este sentido yo vengo calificando repetidamente de segundo nacimiento el que para la villa de Sepúlveda tiene lugar con la repoblación de Fernán González.

(6) Repoblación y sociedad en la España cristiana medieval (Madrid, 1979) p. 41.

(7) Cuadro histórico de las Indias (2. ${ }^{\mathbf{a}}$ ed., Buenos Aires, 1960) p. 369.

(8) Cfr. A. Rumeu de Armas, América en el horizonte. (Glosas ante la efemérides del $V$ centenario), en «Revista General de Marina», 203, octubre 1982, 183-6.

(9) Don Ramón de Carande ha escrito que «ninguna manifestación de la vida económica española tiene en su historia el arraigo que la ganaderíam, Carlos $V$ y sus banqueros, I (Madrid, 1943) p. 47

(10) C. J. BISHKO (The Iberian background of Latin America History: recent progress and continuing problems, en «Hispanic American Historical Review», 36, 1956, 50-80; y The peninsular background of Latin American Gattle ranching, en ibid., 32, 1952, 491-512) valora conjuntamente la doble influencia del pasado reconquistador y repoblador fronterizo ("of the frontiers) en el trasplante americano, a saber la herencia de sthe long southward advance against powerful military foes, the acquisition of abundant territory and the necesity of colonizations.

(11) Y más que en la etapa inicial y predominante de ésta en su consolidada sucesión en los grandes centros consecuencia de la concentración monástica, o sea en su etapa ya señorial y latifundista.

(12) R. PASTOR, La lana en Castilla y León antes de la organización de la Mesta, en «Moneda y Crédito", núm. 112 (marzo 1970), 47-49; y C. J. BISHKO, The Castilian as Plainsman: The medieval ranching frontier en la Mancha and Extremadura, en "The New World looks at its history", ed. A. R. Lewis y T. F. McGann (Austin, Tejas, 1963); traducido, El castellano hom- 
bre de llanura, en “Homenaje a Jaime Vicens Vives», I (Barcelona 1965), pp. 201-18.

(13) Sesenta años después: «La Mesta» de Julius Klein a la luz de la investigación subsiguiente, en «Historia. Instituciones. Documentos», 8 (1982), 1-49 (separata).

(14) The Mesta: a Study in spanish economic history. 1273-1836. ( Harvard Economic Studies» 21; Cambridge, Mass., 1920) Cfr. F. CHEVALIER, La formation des grands domaines au Mexique: terre et societé auX XV/e-XV/le siècles (París, 1952); y él mismo, Vingt-cinq ans de nouvelles recherches sur les grands domaines au Mexique: un bref bilan, en «Melanges de la Casa Velázquez», 11 (1973), 119-29. Para vinculaciones a otros territorios, H. EPSTEIN, The origins of the domestic animals of Africa (Nueva York-Londres, 1971), pp. 1-191 (en torno al «misterio" de la oveja merina). Bishko concluye que «a menos que consideremos que el pasado es sólo el campo de juego de la econometría, La Mesta no puede ser relegada a la categoria de un manual útil sólo para el conocimiento de los aspectos institucionales, administrativos o de historia événementielle".

(15) S. L. MYRES, The Ranching Frontier: Spanish institutional backgrounds of the plains cattle industry, en «New Spain's Far Northern Frontier. Essays on Spain in the American West, 1540-1821. Ed. David J. Weber" (Universidad de Nuevo Méjico, Alburquerque, 1979), pp. 79 94. Antes: W. P. WEBB, The great plains (Boston, 1931); y O. FAULK, Ranching in Spanish Téxas, en «Hispanic American Historical Review», 44, (1965), 257-66. Intentos revisionistas de esta tesis: J. D. W. GUICE, Cattle raisers of the Old Southwest, en "The Western Historical Quarterly" 8, (1977), 167-87; y T. JORDAN Early Northeast Texas and the evolution of Western ranching, en «Annals of the Association of American Geographers» 67 (1977), 67-87.

(16) En el sentido de fortaleza, por supuesto. Véase H. E. BOLTON, The Mission as a frontier institution in the Spanish American colonies, en "The American Historical Review» 23, (octubre 1917), p. 42.

(17) Escribe Myres (p. 84 de su libro citado en la nota 15): «Both the roundup and the drive were perfected by the spanish ganaderos («cowmen») long before the first Texas cowboy ever tossed a rope over a Longhorn Steer". Para no perder de vista los factores precedentes a la conquista, cfr. C. MINGUET, Alexander de Humboldt historien et géographe de l'Amérique espagnole. 1799-1805 (Paris 1969), pp. 205-6.

(18) Véase J. GUTIÉRREZ CUADRADO. El fuero de Béjar (Salamanca 1975). El criterio de su editor, de atender a la precedencia entre los textos escritos, y aun a los manuscritos conservados más bien, en detrimento de la que afecta a la sustancia de lo en ellos consignado, o sea del contenido, nos lo hace poco aprovechable a nuestros propósitos. Cfr. A. LINAGE CONDE, De Sepúlveda a Teruel y Albarraciín: en torno a la prioridad foral, en «thomenaje al profesor Martín Almagro Basch»IV (Madrid, 1983), pp. 147-54; y el mismo, El Fuero de Sepúlveda en la gestación del derecho de Teruel, en «Jerónimo de Zurita. Cuadernos de Historia», núms. 49-50 (1984), pp. 7-29.

(19) La réplica de A. GARCIA GALLO (Aportación al estudio de los fueros, en «Anuario de Historia del Derecho Españob 26 (1956), 387-446) no tuvo en cuenta esta limitación de las aseveraciones que transcribimos a la Extremadura castellana. O sea que era más bien terminológica. La contrarreplicó el mismo GIBERT [El derecho municipal de León y Castilla, en íbid. 31 (1961), 695-753]. Una reseña del mismo Garcia Gallo [ibid. 50 (1980), 733-7], publicada casi un cuarto de siglo después, nos parece ser un cierto asentimiento a la postura por él al principio combatida, una vez deshecho el tal equivoco y hecha más luz por las investigaciones posteriores.

(20) Pero «la fijación por escrito es propiamente la decadencia del derecho castellanom. Insiste en la limitación a este ámbito subordinado de la prioridad conquense, aun sin conceder la sepulvedana, J. MARTÍNEZ GIJÓN, El régimen económico del matrimonio y el proceso de redacción de los textos de la familia del Fuero de Cuenca, en «Anuario de Historia del Derecho Español» 29, (1959), 45-151. 
(21) E. SÁEZ, él mismo, M. ALVAR Y A. GONZÁLEZ RUIZ-ZORRILLA, Los Fueros de Sepúlveda (Segovia, 1953), pp. 547-8.

(22) Cfr. M. GONZÁLEZ HERRERO, La entidad histórica de Segovia. Raíz y fundamentos de la autonomía (Segovia 1981); y A. GARCÍA SANZ y J. MUÑOZ, Manipulación y falseamiento de la historia de Segovia y de Castilla. A propósito de la cuestión autonómica segoviana (Madrid 1982). También J. VALDEÓN, Aproximación histórica a Castilla y León (Valladolid 1982); a la p. 115 de esta última, «ahora bien, la búsqueda de las señas de identidad específica de Castilla y León no es tarea fácil». Y a la p. 30, su confirmación de que "Castilla y León nacieron en el transcurso de este proceso repoblador de la cuenca del Duero cuyas primeras fases se desarrollaron en los siglos IX y $X » 0$ sea en los días de la repoblación sepulvedana

(23) No nos interesan ahora sus precedentes concesiones descie Fernán González, que no nos han llegado escritas, y de las cuales el texto alfonsino se presenta como la confirmación, aunque podamos suponer sea modificatoria en algún extremo. Pues la persistencia el año 1076 del estado de cosas a que vamos a aludir, va toda a favor de nuestra argumentación aquí.

(24) El inserto de Lozoiha usque huc quantum Butrago habuit in sua potestate es ensanchador, un añadido, pero no un límite.

(25) Autor de la parte dedicada a los «términos antiguos de Sepúlveda» en el volumen citado en nuestra nota $21 ;$ p. 877.

(26) Recherches sur I'histoire urbaine en Leon et en Castille au Moyen Age (tesis inédita, París 1971); versión sin notas ni documentos, Historia urbana de León y Castilla en la Edad Media. Siglos IX-XIII (Madrid 1979)

(27) En el fuero extenso, dos siglos más tarde y ya con otras potestades cristianas constituidas al dicho mediodia, repoblado con creces y antes de lo que al parecer en 1076 se había previsto - recordemos esa fecha tan cercana a este año del 1085-la situación era radicalmente diferente, y en consecuencia la frontera sur aparece trazada con la misma precisión que la de los otros tres puntos cardinales.

(28) Sobre la jurisdicción de la Mesta en Sepúlveda, en «Estudios Segovianos» 18 (1966), 5-20 (separata).

(29) Extracto de las leyes del Fuero Viejo de Castilla, con el primitivo Fuero de León, Asturias y Galicia. Se añaden el antiguo Fuero de Sepúlveda y los concedidos por San Fernando a Córdoba y Sevilla. Formado para facilitar su lectura y la instrucción de sus disposiciones (Madrid 1798), núm. 16 del prólogo sin paginar.

(30) El fuero Viejo de Castilla, sacado y comprobado con el ejemplar de la misma obra que existe en la Real Biblioteca de esta Corte y con otros manuscritos (Madrid 1791), p. vi.

(31) Cfr. A. M. BARRERO, El derecho local, el territorial, el general y el común en Castilla, Aragón y Navarra, en «Diritto comune e diritti locali nella storia dell'Europa», actas del Congreso de Varenna de 1979 (ed. Giuffré, 1980), pp. 274-5, nota 23.

(32) Lo que sin embargo no nos induce a derivar la etimologia de la actual Extremadura de "tierra de invernación de los ganados», sino del corrimiento de la frontera hacia el sur. ¿Y la segunda parte del vocabio, el Durii? ¿Y los ejemplos de los otros corrimientos, leonés y aragonés, y el castellano mismo en tierras de Castilla la Nueva?

(33) Bishko hace constar que en Castilla la Vieja sólo han sido documentadas las mestas de Sepúlveda y Barco de Ávila; artículo citado en la nota 13, p. 25.

(34) Edición citada en la nota 21,p. 726. Cfr. título 105, del qui cerrare carrera o exido; y 252 , del que oviere erencia en frontera. 



\title{
LAS RELACIONES COMERCIALES DE BARCELONA CON LA ESPAÑA MUSULMANA A FINES DEL SIGLO XII E INICIO DEL XIII
}

\author{
CARMEN BATLLE \\ Universidad de Barcelona
}

Las noticias que permiten tratar el tema de las relaciones comerciales de los catalanes con los musulmanes hispanos son escasas, por desgracia. Por este motivo hemos preferido asociar a la conexión mercantil de estos dos ámbitos el estudio de la almostalafía, derecho que también abarcaba las costas africanas.

Los puntos de contacto entre los dos mundos hispánicos eran sobre todo los puertos mediterráneos, aunque seguramente habría que añadir Sevilla, puerto al cual siguieron acudiendo los catalanes una vez conquistado y organizado por Fernando III de Castilla y su hijo (1).

Las naves catalanas frecuentaban especialmente el de la Ciutat de Mallorca, que era al mismo tiempo un nido de piratas perseguidores de los catalanes, por lo cual se desencadenó la campaña de castigo, según lo cuenta el mismo Jaime l en el «Llibre dels feyts». Más o menos los mismos contactos existían con Valencia, como se deduce de la concesión real de 1185 referente a la almostalafía, en la que se alude a ello indirectamente.

Es interesante constatar que, en concreto, los Adarró, que fueron almostalafes como veremos, protagonizan algunas de las expediciones hacia España por conocer bien el país y al mismo tiempo para aprovechar sus viajes de exeas. Parece probable que además de estas actividades desarrollaran otra más oficial al servicio de los condes-reyes, la de cobrar parias en los países musulmanes en nombre de sus señores.

Nos sugiere esta idea la noticia del préstamo concedido por Arnau Adarró el 24 de mayo de 1155 a Ramón Berenguer IV consistente en 100 mora- 
batinos aiadinos y lupinos, a cuenta de la paria de España (2), que él mismo podía encargarse de cobrar y así, de modo directo, resarcirse de la deuda con comodidad y celeridad.

Como el mes de mayo era muy a propósito para la navegación, podríamos sugerir que el préstamo tuvo lugar antes de la partida de Adarró hacia estas tierras. La idea adquiere más verosimilitud cuando observamos una fecha idéntica en el testamento de Pere Adarró, hermano del anterior, escrito anes de partir en una galera hacia España el 17 de mayo de 1169 (3); seguramente era el continuador de los negocios de su hermano mayor, que ya había muerto cuatro años antes.

El viaje hacia la España musulmana lo realizaban también otras galeras, por ejemplo la de Bertrán Català, puesto que éste se comprometía en Tarragona el 11 de octubre de 1187 a saldar una importante deuda (300 mazmudinas) con las primeras ganancias obtenidas en este viaje; para la liquidación de la misma a los hombres de Tarragona se estipulaba que el pago podía efectuarse en cualquier punto de la costa catalana, desde el grau de Tortosa hasta el cabo de Creus; además el itinerario de esta galera incluía la isla de Mallorca (4).

Los monarcas, que sacaban buenos ingresos de los derechos cobrados a los mercaderes procedentes de España, se preocupaban del comercio entre Barcelona y la zona musulmana y procuraban proteger a los catalanes cargando más impuestos (31 dineros) a los negociantes sarracenos, judíos y mozárabes. Sin embargo, todos los procedentes de España estaban obligados a pagar 41 dineros en Barcelona, fuese cual fuese la mercancía importada, y además la autoridad obligaba a sus súbditos a regresar a Barcelona, ya que en caso de no hacerlo deberian pagar igual el derecho de $41 \mathrm{di}$ neros y otro de pasaje en moneda de oro, según lo constatamos en la lezda de fines del siglo XII (5).

Suponemos que Arnau continuaba sus actividades en esta área geográfica en 1222 dentro de su dedicación bancaria, cuando se comprometió a realizar una operación de préstamo en nombre de Pere Grony y a favor de Vidal d'Espanya, cuyo nombre indica un origen bastante concreto para este judío (6).

A la muerte de Adarró, que coincidió más o menos con la conquista de Mallorca, sus herederos de momento no siguieron el camino trazado por sus antecesores hacia el Sur de la Península y se limitaron a ejercer sus negocios de préstamos y otros en Barcelona o fuera de la ciudad por medio de coman- 
das entregadas a gestores. Más adelante reemprendieron los viajes hacia el Norte de África, como veremos.

Los Eimeric, que más o menos tenian las mismas tareas propias de los armadores de naves y cambistas de la burguesía barcelonesa, participaron, por lo menos uno de ellos, en un negocio en relación con España. Fue Arnau Eimeric quien entregó una suma para el armamento de una nave, un leño en concreto, que Busca, Guerau y Bernat de Colliure dirigieron hacia España antes del 15 de octubre de 1230, fecha en que el capitalista nombró procurador a su pariente Bussot para cobrar su parte (7).

Creemos que con frecuencia se cargaba en estos barcos un producto objeto de un intenso tráfico, el vino, pero solamente lo podemos documentar a mediados del siglo en el leño de Pere de Solicrup, el cual llevaba, entre otras mercancias, 20 cahíces de vino propiedad de Bernat de Ruvira con destino a tierras sarracenas, o sea de España. No sabemos qué clase de contrato habian firmado, acaso una sociedad, sólo que el flete de este vino corría a cargo del mencionado patrón (8).

Además del armamento de naves, los capitalistas podían invertir su dinero en comandas de viaje, muy numerosas en el siglo XIII, algunas de las cuales iban dirigidas a puertos de la España musulmana.

Éste era el objetivo de algunas de las comandas de los Sesfonts, Bernat y su hijo Jaume, ambos pañeros, en la segunda mitad del siglo: una del 28 de noviembre de 1276 se dirige a España y Berbería con vino, pimienta, telas de lino, etc. (9), otra es del 7 de octubre de 1283 y manda sólo a España mercancías por valor de 32 libras, 16 sueldos y 7 dineros de moneda de Barcelona de terno en la barca de Pere de Pera por medio de dos gestores, Bernat de Pallejà y Arnau d'Olivera (10), y la tercera es del 18 de marzo de 1288 y procede de Mallorca, donde los Sesfonts tenían parte de la alhóndiga y de donde salía el barcelonés Pere Gotmar en su leño hacia Almería y Ceuta llevando 10 libras de Valencia del comandante invertidas en mercancias no detalladas (11).

En dos de estas tres comandas el barco que las transporta tiene un doble objetivo: un puerto hispánico y otro del Norte de África, porque ésta era la antigua ruta comercial normal ya hacia 1200 en dirección a las costas africanas desde Barcelona con escalas en Valencia, Denia, Alicante, Murcia y Almería, como se constata por la actividad de los barceloneses y también de los de Vic (12). 
Las mercancías son variadas con predominio de telas, especias y vino, llegando a exportar un cargamento bastante importante, como el valorado en 241 libras, 15 sueldos y 3 dineros de la segunda comanda.

Un caso aparte lo constituye el galeote sarraceno enviado a España por Bernat d'Alfou el 30 de noviembre de 1211, a pesar de ser propiedad de otros, porque forma parte de una transacción; si fracasa el asunto, Bernat deberá pagar 8 libras de dineros de Barcelona salvas en tierra a Berenguer Ribot (13). De todos modos se trata de un cautivo transportado hacia el país musulmán en una fecha muy temprana.

A su regreso los mercaderes traían las mismas mercancías contenidas en la lezda mencionada antes y también telas de lujo, como el «panno albo de Ispania" que cubrió el cuerpo del cambista Bernat de Vic el día de su entierro para ser vendido luego en beneficio de los pobres (14).

Otras telas menos suntuosas procedían del mismo país, como la funda de uno de los tres colchones del pañero Burget de Banyeres (tercium matalaf est cum cohoperta panni de Ispania), que también tenia en su casa cuatro almalafes o vestidos usados por musulmanes, seguramente del mismo lugar de procedencia (15).

\section{LA ALMOSTALAFÍA}

Almostalafía, palabra escrita con algunas variantes por su etimología árabe, fue utilizada de modo esporádico en la documentación catalana de los siglos XII y XIII, en la cual apenas encontramos la de almostalaf —un sola vez-.

Así se denomina el oficio del almostalafe, funcionario de la España musulmana, según Ducange. En realidad, este oficio se encuentra documentado en Cataluña por primera vez a principios del siglo XII y por última vez en 1270 como una regalía en manos del conde de Barcelona y luego del rey de Aragón. Una explicación del significado de esta palabra consta en un juicio de la curia condal promovido por las reclamaciones de Ramón Guillem de Montcada, que había recibido de Ramón Berenguer IV la tercera parte de Tortosa; por este motivo el Dapifer Ramón Guillem reclamaba al conde su parte proporcional en la almostalafía de dicha ciudad, que Ramón Berenguer había concedido a un burgués tortosino. Al final de la sentencia fechada hacia 1158 se precisa que en primer lugar la concesión era muy amplia porque abarcaba dicha ciudad y un territorio muy extenso, luego que el almostalaf había pagado al conde por este concepto y que, además, Ramón Berenguer recibía dinero de los cautivos sarracenos (16). 
Como comprobamos, se trata de una regalía derivada del hecho de ser el conde el responsable de los sarracenos cautivos, sobre cuyas fugas y delitos había legislado (17).

Hallamos más precisiones sobre esta regalia en la primera de las concesiones conservada, la de mediados de abril de 1105, que favorecia a cuatro judios: Mosse, lafia, Honen y Abotaib, a cambio del pago de 22 libras de plata. La donación abarcaba todas las tierras de Ramón Berenguer III, que reservaba a los judíos la exclusiva bajo pena de una multa de una libra de oro cobrada por el conde en este caso, y debia durar hasta que los 4 almostalafes recuperaran la suma entregada a Ramón Berenguer. Gracias a este privilegio sólo ellos podían conducir a la España musulmana sarracenos y sarracenas para su redención, una vez pagado su rescate, se supone; sólo estos judíos o sus encargados podían aceptar o no en su nave a otros judíos o cristianos que desearan ir alli para sus negocios (18).

Con los detalles de la concesión ya tenemos una idea bastante clara sobre la almostalafía, que, siguiendo una evolución general de las regalias y otros asuntos, va pasando de las manos de los judíos a las de cristianos, más concretamente barceloneses hasta fines del siglo XIII. Una particularidad que desconocemos es la suma cobrada por el almostalafe, pero podría ser la indicada en el fuero de Teruel: la décima parte de la cantidad del rescate (19).

El primer barcelonés favorecido con la concesión, previo pago de una suma de dinero, es Arnau Pere d'Arcs, perteneciente, como indica su nombre, al burgo de los arcos antiguos, o sea, del acueducto romano, situado a la salida de la puerta de las murallas de la misma época llamada del Obispo.

Esta concesión fechada el 12 de enero de 1144, fue otorgada por Ramón Berenguer IV, titulado conde de Barcelona, marqués e ínclito dominador del reino de Aragón por Pere, el presbítero escritor del documento (20). Como no consta ninguna indicación geográfica, creemos que abarca todos los dominios del cedente, que se compromete a respetar la donación por la que recibe de Arcs 150 morabatinos, sin precisar nada más sobre la clase de dicha moneda. De esta suma Arcs recuperará 50 procedentes del mismo oficio, siempre bajo la protección condal, pero del resto no se concreta nada.

Arcs habia adquirido el derecho cuando ya poseía una nave dispuesta a realizar los viajes necesarios a las costas de España y del Norte de África a fin de cumplir su compromiso con el conde. Sólo una vez es posible comprobar uno de estos viajes gracias a la noticia indirecta referente a una deuda de Bernat Palau de 8 morabatinos jovecios, que éste el 14 de marzo de 1147 
se comprometía a pagar a Gandulf Mafor a la vuelta de la nave del almostalafe, o por Pascua, si el barco no volvía (21).

Este ciudadano barcelonés patrón de nave y además almostalafe puede ser comparado a los traficantes judios mencionados antes y a los exeas aragoneses, que en nombre de la Corona hacian circular libremente los esclavos musulmanes rescatados o canjeados por cristianos. También podría ser que él se ocupara de su nave y del traslado de cautivos a su lugar de origen, mientras sus colaboradores realizaban las tareas complementarias en tierra. Suponemos que al lado de Arcs se iniciaría en el negocio algún Adarró o exactamente Arnau Adarró, barcelonés, cuyo nombre indica su procedencia de las inmediaciones del castillo de la Geltrú, donde ha perdurado este topónimo.

\section{LOS ADARRÓ ALMOSTALAFES}

Podemos suponer la existencia de una colaboración entre Arcs y Adarró por varios motivos. En primer lugar, comprobamos la conexión de los Adarró con tierras musulmanas por hallarse en poder de Arnau Adarró el 24 de mayo de 1155100 morabatinos aiadinos y lupinos de oro bueno que prestó a Ramón Berenguer IV, conde de Barcelona, príncipe de Aragón y marqués de Tortosa y Lérida, con la promesa de su devolución cuando éste cobrara la paria de Yspania el próximo mes de septiembre (22). El hecho de tener en su poder estas monedas musulmanas ya indica un contacto directo con el Sur de la Península; además tenía cautivos en su poder cuando murió, acontecimiento que tuvo lugar lejos de Barcelona, acaso en España, ya que el testamento sacramental fue jurado por dos testigos, Ramón Ferrer y Gil sobre el altar de San Félix de la iglesia parroquial de los Santos Justo y Pastor (23).

Además, otro Adarró, llamado Pere, en su testamento del 17 de mayo de 1169 indica que se va en una galera hacia Yspania, y precisamente por eso dictaria sus últimas voluntades confiando su ejecución a su hermano Arnau, a su cuñado Joan Mateu y a otros dos albaceas. Desde luego no era su primer viaje, ya que no era muy joven porque tenía esposa y dos hijos, y el único legado por su alma fue el de 30 morabatinos destinados al rescate de tres cautivos, a los cuales, sin duda, había visto y tratado en tierras hispanas y africanas (24).

Por otro lado las dos familiar, Arcs y Adarró, enlazaron por medio de un vínculo matrimonial que afectaba a la almostalafía, como veremos, por la cual se interesó directamente Bernat Adarró en 1185.

En esta fecha, exactamente en el mes de abril, el rey Alfonso, que se hallaba en Barcelona, hizo una concesión del derecho de traslado de cautivos 
sarracenos a su patria, o sea-la almostalafía, a favor de Bernat Marcús y de Bernat Adarró, que podían viajar libremente ellos o sus enviados bajo protección real sin impedimento de los batlles $u$ otros oficiales del monarca. Éste se reservaba la almostalafía de Tarragona hasta Tortosa y aludía a la de Valencia ya concedida a otros, sin hacer constar ninguna suma de dinero (45).

Merece ser destacada la asociación de Marcús con Adarró después de haber hallado al padre y al tío del primero como testigos de la concesión de 1144 comentada más arriba. ¿Tendrian ya, en este momento, alguna relación con la almostalafía?

Aunque así fuera, la extinción de la familia, después de su perduración por línea femenina a principios del siglo XIII, facilitó la adscripción del derecho mencionado a los Adarró en exclusiva.

En su poder se hallaba el 13 de abril de 1206, fecha en que a causa del matrimonio de Arnau Adarró precisamente su madre, Berenguera d'Arcs, y no su padre Bernat, le concedía en forma de donación su propio esponsalicio, los derechos sobre bienes de su esposo y además la almostalafía de Barcelona y Valencia, dejando a salvo el dominio del rey, a quien el joven debía proclamar su único señor, junto con los batlles reales, en todo lo referente a dicho derecho. Al día siguiente Arnau correspondió a la cesión materna con la donación de la almostalafía a Berenguera mientras viviera, con la condición de entregar al hijo cada año por Pentecostés un censo consistente en media libra de buena cera; naturalmente a la muerte de la madre el derecho volvería a manos de Arnau sin ningún problema. Al mismo tiempo el joven se comprometia a vivir con su esposa en la casa paterna, que también recibía como donación por nupcias junto con el huerto contiguo, y a pagar a sus padres los gastos de alimentación, vestido y demás necesidades de la casa, que se hallaba situada en el arrabal de Barcelona cerca de la iglesia de Sant Cugat del Rec. En caso de discordia entre los dos matrimonios, la finca sería propiedad de la madre mientras viviera y ella cobraría la mitad de las rentas; en cambio, si ella muriera, al marido sólo le correspondería una cuarta parte (26).

De todo ello se deduce la importancia de la almostalafía y de la fortuna de los Arcs, aportada por ella al casarse con Adarró.

Al cabo de unos años Arnau Adarró ya tenía en sus manos y sin restricciones la almostalafía, a la cual dedicaba una parte importante de su actividad por tratarse de un buen negocio basado en moneda de oro musulmana. Lo comprobamos hacia fines del año 1214 en el contrato firmado por Pere 
Umbald y su avalador Arnau Umbald o Ombau a favor de su pariente el almostalafe, a quien el primero reconoce deber 30 mazmudinas de oro nuevas "contrafactas", o sea, falsificadas en país cristiano imitando las del Miralmomenín, personaje que podemos identificar con el Emir al-Muminín Muhamad al Nasir, el califa almohade vencido en la batalla de las Navas de Tolosa. El motivo de la deuda es el precio del rescate de un sarraceno llamado Maimón -él es la garantía-, en cuyo asunto intervino Ermengol de Banys junto con el almostalafe; se saldará la deuda dentro de los 15 días siguientes a la llegada a Barcelona del leño de Bernat Caramella patroneado por Simó Bru, cuya procedencia es Bona, pero la operación se realizará según la costumbre de la almostalafía de Barcelona en Bona. Esta última cláusula es reveladora de la tradición existente desde antiguo en cuanto a las relaciones entre los dos puertos, que pueden remontarse a los primeros años del siglo XII, según la documentación de la almostalafía comentada hasta ahora; además puede interpretarse que, de acuerdo con la costumbre mencionada, en caso de muerte del cautivo con la consiguiente pérdida del rescate la deuda quedaba anulada, según indica Garcia Sanz (27).

Como en este viaje Pere Ombau actúa seguramente en nombre del almostalafe Adarró, puede ser considerado su colaborador, ya que en realidad él no era el arrendador del derecho, según la suposición del citado García Sanz.

Creemos que entre 1222 y 1226 Arnau Adarró seguía actuando como almostalafe, ya que recibía cautivos sarracenos como garantía de sumas de dinero. El 9 de noviembre de 1222 recibió uno llamado Sulmanatyat, como garantía de una deuda de 19 libras, con un valor de 75 sueldos por marco de plata; lo entregaba Bernat Ermengol, el cual se comprometía a continuar alimentándolo (28).

Al mismo tiempo se alude a un tal Meimet en una deuda de 100 morabatinos, en la que está implicado Guillem Roig de Sant Cugat, como heredero de su difunto padre (29).

Por estas fechas Adarró firma como garantizador de un préstamo de 25 besantes, moneda básica en el comercio con el Norte de África, en el que continuaría participando (30). Nos llama la atención la presencia repetida de dos testigos, Ramón Perpetua y Berenguer Vidal, en este grupo de documentos y nos atrevemos a sugerir la posibilidad de que se tratara de unos colaboradores de Arnau Adarró.

Es lógico que en Barcelona los Adarró negociaran con besantes y mazmudinas procedentes de sus operaciones en la España musulmana y en el 
Norte de África siendo almostalafes y banqueros de los caballeros de las milicias catalanas al servicio de los sultanes africanos, según veremos en nuestro estudio dedicado a las relaciones con esta zona geográfica.

A principios de siglo lo hacía Bernat Adarró junto con Ponç Gazol y su sobrino Pere de Toló, cada uno de los cuales tenía una tercera parte en la suma de 600 mazmudinas (31).

Todavia en 1262 negociaba con esta moneda su nieto, dedicado a los negocios, aunque en esta fecha la almostalafía ya no estaba en manos de la familia, como comentamos al final.

Berenguer, aunque nunca consta como cambista, efectuaba negocios bancarios con judíos y cristianos, por lo cual firmaba recibos de sumas de dinero valoradas en sueldos y morabatinos. Sin embargo, alguna vez recibió mazmudinas, como las 30 mazmudinas «duplices amírias» entregadas por Guillem d'Espiules mediante el correspondiente instrumento notarial a mediados de 1262 (32). El motivo es que Berenguer continuó la tradición familiar con sus negocios en el Norte de África, exactamente en Túnez, donde se hallaba en 1260, como expondremos en el estudio de las relaciones de catalanes con puertos africanos.

\section{3. ÚlTIMAS NOTICIAS SOBRE LA ALMOSTALAFÍA}

Suponemos que durante las campañas de Jaime I en Mallorca y Valencia este derecho fue recuperado por el monarca de manos de los Adarró, precisamente cuando podia convertirse en un magnífico negocio; por ello quedó en poder del batlle de Barcelona, que se preocupó de arrendarlo algunas veces.

Creemos que el derecho estaba vinculado al centro de los negocios marítimos de nuestra ciudad, es decir, a la alhóndiga real vecina de la iglesia de Santa María del Mar.

Por este motivo hallamos a Pere de Citjar, lugarteniente del batlle real de la ciudad que en 1263 era el judío Benvenist de Porta, firmando un recibo por valor de 10 sueldos por razón del derecho de almostalafía debido al rey y pagado por el sarraceno Maffumet. Éste, que había sido cautivo de Pere de Llissac, el responsable de la alhóndiga en nombre de Jaime I, quedó libre y recibió el permiso oportuno del mencionado arrendador para quedarse y residir en la ciudad, si tal era su deseo (33).

Unos años más tarde, en 1270, el battle de Barcelona, que entonces era Guillem Grony, realizó la venta de diversos derechos reales, entre los cuales 
consta la mostalafia de Barcelona adquirida por Pere de Santa Creu y sus socios por la módica suma de 110 sueldos (34).

Parece que pasados los años prósperos de la afluencia de cautivos a la ciudad procedentes de las campañas en Mallorca, Valencia y Murcia, el derecho estudiado ya no representaba un buen ingreso para el administrador real y por eso lo arrendó en una suma tan modesta como la mencionada a un personaje presente como testigo en el documento anterior, el de 1263, y sobre el cual no tenemos más información.

Podria ser que por este motivo los catalanes perdieràn interés en el arriendo del derecho y fueran sustituidos por sarracenos. Lo deducimos de la concesión hecha el 3 de agosto de 1277 por el rey Pedro el Grande a Ali y Muhammad Abcocon, de Tánger (35).

En la época siguiente la palabra almostalafía pasó a referirse al derecho pagado por los escasos musulmanes residentes en Barcelona, es decir, esclavos manumitidos, que en caso de querer emigrar pagaban una tasa de embarque en el puerto antes de salir hacia su lugar de origen (36); pero esto ya pertenece a una etapa posterior a la estudiada.

\section{CAUTIVOS Y PRODUCTOS COMERCIALIZADOS}

Sólo nos interesa tratar de la esclavitud como un aspecto más de las transacciones efectuadas en los puertos mediterráneos, sobre todo Barcelona.

Considerados simples objetos, la importación de cautivos estaba gravada con el pago de una lezda, como cualquier mercancía, eran utilizados al igual que objetos de plata y de valor como simples garantías de un préstamo (37) o podían ser regalados a los hospitales junto con camas, ropas $u$ otros utensilios domésticos.

El comercio de esclavos, que estuvo en manos de judíos durante la Alta Edad.Media, fue pasando a las de cristianos durante el siglo XII y ya lo monopolizan en el siglo siguiente negociantes catalanes con escasa intervención judía, en una evolución paralela a la constatada en el caso de la almostalafía.

Para los barceloneses era un negocio muy lucrativo la venta de cautivos musulmanes, llamados siempre sarracenos, procedentes de campañas victoriosas de Jaime I o capturados durante escaramuzas navales.

Tanto su venta como el posterior aprovechamiento de su trabajo, especialmente si tenian un oficio, constituía una importante fuente de ingresos, que no desdeñaba ninguna clase social.

Gracias a la existencia de una gran demanda, la venta se realizaba de un modo casi permanente en mercados y también en ferias anuales, pero 
las transacciones aumentaban durante los meses de las campañas militares y una vez terminadas éstas, es lógico que las subastas tuvieran lugar en la ciudad más próxima a las operaciones bélicas, como Valencia, aunque luego los compradores trasladaban los esclavos hacia centros donde existía más demanda, como Barcelona, Maliorca, Génova, desde donde eran distribuidos a toda Italia, y también a Sicilia a partir de su conquista.

El rey era uno de los principales beneficiarios de este negocio que efectuaban en su nombre y por orden suya unos intermediarios en pública subasta. La venta (almoneta) tenía lugar en diversas plazas, según la ubicación de las campañas bélicas, pero sólo conocemos la realizada en Valencia por Guillem de Colomer después de una campaña victoriosa del nuevo monarca, $\mathrm{Pe}$ dro el Grande, contra Montesa en septiembre y octubre de 1277 (88).

El 5 de enero de 1278 es la fecha de la venta de un lote de 10 sarracenos, 7 hombres y 3 mujeres, procedentes de buena guerra, por 86 libras y media de reales de Valencia. Interesa destacar en esta operación llevada a cabo según el fuero de la misma ciudad, que el comprador fue Simón Ferré, de Barcelona, a donde regresó con sus 10 esclavos. Se conserva el documento de la compra, escrito por el notario público de Valencia Arnau Astruc, y un albarán de papel sellado con cera en el dorso, en el cual Berenguer de Conques, lugarteniente del batlle real Jucef Ravaya, atestiguaba la adquisición y prohibía a posibles recaudadores el embargo del lote de sarracenos con motivo del cobro del quinto. Una vez en Barcelona el comprador acudió el 19 de marzo ante el notario Bartolomé Marc para que hiciera copia de los dos documentos (39), seguramente con el propósito de vender pronto los esclavos en la ciudad.

En este caso, como en muchos otros, se hace constar que los cautivos proceden «de buena guerra», no siendo, por tanto, producto de robo, y su lugar exacto de procedencia, en general la zona Sur de Valencia, Murcia o Hispania. Todo ello se hacía según la costumbre de Valencia o de Barcelona, aludida en las cláusulas de los contratos e indicadora de una tradición arraigada en unos mercados acreditados.

Además se especificaba siempre las características personales del cautivo objeto de la transacción, como el color de la piel, blanca o negra o lora, o sea, la propia de los mulatos, así como el oficio de los esclavos era muy variado hasta el punto de figurar un médico entre los cautivos adquiridos por el pañero Sesfonts, de la calle de Montcada.

Muchos de estos cautivos eran apresados o adquiridos para colocarlos en las naves como galeotes, calificados dos de ellos como bacallar en dos 
documentos. En el primer caso, un contrato expedido en Tarragona el 11 de octubre de 1187, se concreta que, según la costumbre del país el patrón de una galera asigna a uno de sus nauclerios un sarraceno bacalar y una cama (40). En el segundo, escrito en Barcelona el 30 de noviembre de 1211, Bernat d'Alfou, que debe ser el patrón de la nave, firma un trato con Berenguer Ripot, acaso nauclerio de la misma: el primero envía a España un galeote de Guillem de Paiars y d'Alegret y al cabo de un mes recibirá un buen sarraceno bacalar suyo de 30 años, bien de miembros, fuerte, sano, blanco o negro; si fallara el intercambio, Bernat pagaría a Berenguer 8 libras de dineros de Barcelona, valiendo el marco de plata 44 sueldos (41).

Esta suma puede ser el precio del cautivo, puesto que en los recibos reunidos constan, en general, sumas que oscilan entre 10 y 15 Libras.

Suponemos que los dos contratos se refieren al mismo tema, al de los galeotes cautivos y adscritos a los nauclerios de las naves por los respectivos patronos. En cuanto al adjetivo bacalar, que significa «rústico», «villano» y acaba siendo un insulto por lo menos un par de siglos más adelante, creemos que debe aplicarse a estos esclavos precisamente por ser los de categoría más vil.

Los propietarios de esclavos, gentes de todas las categorías sociales que tenían suficiente dinero para comprarlos, eran responsables de los mismos y ante la justicia respondían de los delitos cometidos por ellos; siempre tenían la obligación de indemnizar a los perjudicados tanto si intervenía la justicia como si el asunto se arreglaba amigablemente. No conocemos ningún caso concreto en Barcelona, pero sí en las cercanías, en Molins de Rei, donde tenía su casa fuerte el caballero Guillem de Fonollar. Uno de sus esclavos, Mahomet, sarraceno, hirió a Bernat Lunes, que sanó gracias a los cuidades del cirujano Arnau de Montbrú y recibió una indemnización de 10 cuarteras de trigo del noble después de la intervención de cuatro familiares del herido, tres hermanos y un sobrino. Éstos consiguieron el pago de los gastos de la curación de las heridas, además de la indemnización, el 6 de junio de 1262 (42).

Como los Fonollar, gentes de toda la comarca podían adquirir sarracenos en Barcelona, que era un mercado de esclavos desde antiguo, ya localizado a la puerta de la ciudad desde el año 1002 (43), o sea, exactamente en el lugar donde siempre se venía celebrando el mercado, al pie del Castell vell del vizconde y luego del veguer.

Barcelona parece ser un buen mercado de esclavos durante todo el año, pero creemos que el auje de las transacciones debe situarse en el mes de julio, durante la feria, ya que en este mes hallamos numerosas adquisiciones, como las realizadas por Ramón de Banyeres (26 de julio de 1263), Joan de 
Banyeres (7 y 25 de julio de 1279 y 1282), Pere d'Espiells, decano de la catedral (27 de julio de 1284).

La mayoría eran hombres y mujeres comprados para el servicio domestico de familias acomodadas, que llegaban a tenerlos en gran número, por ejemplo Berenguer Durfort tenía siete, además de criadas, hacia 1260. Si tenian un oficio, eran explotados por su trabajo por el mismo dueño o por otros, a quienes éste los entregaba en comanda (44).

En algunos casos sólo eran tratados como una mercancía adquirida en la feria o en una subasta para ser reexpedida hacia otro mercado con un tratamiento igual al de las especias importadas o las mercancías locales entregadas por grandes negociantes como los Banyeres, Sesfonts o por gestores de comandas (45).

Al mercado barcelonés acudian negociantes forasteros, sobre todo de países de la Corona de Aragón, para realizar sus adquisiciones, incluso un siciliano vino de Mesina para comprar esclavos y otras cosas suponemos; acudian vendedores de Olivella, Reus, Tarragona, Murcia, Aragón, etc (46).

Junto a los mercados de Valencia y Barcelona hay que mencionar el de la Ciudad de Mallorca, cuya importancia es considerable por su situación privilegiada en las rutas de navegación y parece que supera pronto al barcelo. nés (47).

Pocas esperanzas de libertad podia tener la población cautiva en tierras catalanas, ya que la fuga era dificil y el pago de un rescate exigia mucho dinero. Otra posibilidad era la manumisión por voluntad de los dueños y, sobre todo, de las dueñas. Era normal que ellas se preocuparan de sus esclavos hasta el punto de concederles la libertad en sus testamentos, casi siempre con condiciones, si consentían ser bautizados; la salvación de sus almas era un argumento muy importante.

En cuanto a los cautivos cristianos la opinión pública estaba muy sensibilizada, como se aprecia en los legados para su redención contenidos en los testamentos de los barceloneses, sobre todo después de la fundación de la orden de los trinitarios a fines del siglo XII. Uno de los hombres dedicados a la redención de cautivos con más resonancia en Barcelona fue Pere Noslac, que se autodenominaba recaudador y custodio de las limosnas para los cautivos en 1231 (48), más o menos en la época de la fundación de la orden de la Merced.

No es posible dejar de lado otro aspecto de los intercambios, las comandas, ya que este sistema constituye una forma normal del comercio de la época y no podía faltar en las relaciones entre Barcelona y la España musulmana. 
El año de 1239 podría ser la fecha de la primera de ellas si su destino, tierra de sarracenos, fuera interpretado como España musulmana y no como Norte de África (49).

Más tarde, en 1276, una comanda segura hacia España y Berbería es la de Bernat Sesfonts (50), que de nuevo envia otra en 1283 confiada a Bernat de Pallejà y Arnau d'Olivera, embarcados en la barca de Pere de Pera; consistía en 32 libras, 16 sueldos y 7 dineros invertidos en el común valorado en 241 libras, 15 sueldos y 3 dineros (51), según consta en el memorial en poder de Olivera.

Sesfonts, el pañero barcelonés de la calle de Montcada, fue un gran inversor en los negocios marítimos y en todas las direcciones, como ya hemos comentado.

El armamento de naves destinadas a España con transporte de comandas no es muy frecuente porque los puertos de las costas musulmanas eran sólo una escala hacia el Norte de África o Sevilla; sólo hacia España conocemos el viaje del leño de Busca, Guerau y Bernat de Colliure antes de 1230, fecha en que el parsoner Arnau Eimeric reclamaba su parte en la ganancia (52). Si en este caso se trata de un leño, en los dos viajes mencionados al comentar las comandas de 1276 y 1283 el medio de transporte es una simple bar$\mathrm{ca}$, sin definir, que aparece pocas veces en nuestra documentación.

Las mercancias exportadas desde Barcelona son telas, especias, vino, que constan en las comandas, mientras las importadas son paños de lujo y las que hallamos en la lezda de fines de siglo XII ya comentada.

El comercio con la España musulmana es sólo un aspecto concreto de la actividad marítima de los barceloneses, cuyas familias y negocios estamos estudiando dentro de nuestro trabajo sobre la Barcelona del siglo XIII. 
NOTAS

(1) Los privilegios concedidos por Alfonso X el Sabio y su sucesor a los mercaderes catalanes están publicados por A. de Campany, Memorias históricas sobre... la ciudad de Barcelona, reedición, Barcelona 1962, II, docs, $n .{ }^{\circ} 31,34-37$, y otras noticias que incluimos en el estudio sobre el Norte de Átrica

(2) Véase el inicio del apartado siguiente. Parece que Arnau disponia de capital para invertir unas buenas ganancias en préstamos, ya que a su muerte la abadesa de Sant Pere de les Puelles le debía una suma elevada, por la cual le había entregado varias prendas valiosas: un cáliz, un incensario y unas vinajeras de plata (Archivo de la Catedral de Barcelona, ACB, PA 4-1-70).

(3) Documento de ACB, PA 4-15-111, publicado en el apéndice.

(4) El contrato (ACB, perg. 1-5-294), está transcrito en el apéndice. Pocos dias después, el 3 de noviembre, antes de partir Bertrán reconoce deber a un tal Bernat 100 mazmudinas y 10 maravedies, que se compromete a devolver en Mallorca (García Sanz-Ferrer, Assegurances i canvis maritims medievals a Barcelona, Barcelona, 1983, II, doc. 2).

(5) Se mencionan los producto importados de España: blanco de España, pez, greda, un tipo de resina (classe), anyzon, cristal, hierro y papel, por los que paragarán los mercaderes 21 dineros además de los 41 dineros como sanción (J. Sobrequés i Callicó, La lleuda de BarceIona del siglo XII, "Miscel-lània Aramón i Serra», IV, Barcelona, 1984, páginas 334-335).

(6) El 14 de febrero de 1222 Grony reconocía que Adarró se constituía en deudor de 11 libras melgoresas en nombre suyo, suma que Adarró se comprometía a hacer efectiva la próxima fiesta de San Juan con un interés de 8 dineros por libra al mes; Grony se lo devolveria a petición de Arnau, sin que éste tenga que acudir a la justicia. El documento lo hizo ante Pere y Burget Ballester y el notario Ponç de Sarrià (ACB, perg. 1-6-2834). Otros judíos presentes en Barcelona llevan este nombre, como Lobell d'Espanya en 1236 y Bon Nin d'Espanya en 1281 (ACB, perg. 1-6-3862 y 4102).

(7) El documento, escrito por el presbitero y notario Pere Adam ante Guillém de Castries, Bernat de Riudor y Ferrer Janer, pudo ser extendido en Colliure u otro puerto, pero no en Barcelona, donde actuaban notarios públicos. Arnau cobró seguramente sus derechos puesto que el pergamino, muy pequeño, está cancelado a tijeretazos, como todos los relativos a deudas pagadas (ACB, perg. 1-6-786).

(8) Bernat de Ruvira deja constancia de este negocio en su testamento del 20 de mayo de 1259 (PA 4-3-129). 40 .

(9) Madurell-Garcia Sanz, Comandas comerciales barcelonesas de la baja Edad Media, n. ${ }^{\circ}$

(10) La suma indicada va en el comú valorado en 241 libras, 15 sueldos y 3 dineros y especificado en un memorial entregado a Pere d'Olivera (ACB, perg. 1-6-61).

(11) Documento escrito en la Ciutat de Mallorca (ACB, perg. 1-6-1513). 
(12) A. Garcia, Contractes comercials vigatans de pincipis de segle XIII, «Ausa», IV (1961. 63), págs, 321-329. El 10 de mayo de 1227 Guillem d'Almería y su esposa Ramona venden su huerto del barrio dels Arcs (S. Claramunt, La documentación del siglo XIII conservada en el archivo de la basilica de santa Maria del Pino de Barcelona, en "Jaime I y su época», 3, 4 y 5, Zaragoza, 1982, páginas 456, doc. 2). Podria ser un ex-esclavo procedente de esta ciudad.

(13) Las 8 libras podrian ser más o menos el precio del esclavo, que es utilizado como garantía; el documento es el recibo del sarraceno (ACB, perg. 1-6-2682).

(14) Así lo dispuso él mismo en su testamento del 5 de septiembre de 1295 (ACB, perg. 4-2-4).

(15) Inventario de 1256 publicado por $\mathrm{C}$. Batlle, La familia i la casa d'un draper de Barcelona, Bernat de Banyeres (primera meitat del segle XIII), "Acta Mediaevalia", 2 (1981), pág. 84

(16) Pere de Marca, Marca hispánica, París, 1688, reedición anastática Barcelona, 1972. apéndice 444, col. 1342 con fecha de 1165. También lo publica P. Flórez, España sagrada, XLII, Madrid, 1859, pág. 294. Lo cita con fecha de $1158 \mathrm{~J}$. M. ${ }^{a}$ Font Rius, Origenes del régimen municipal de Cataluña, "AHDE», XVI (1945), pág. 522.

(17) Usatges de Barcelona, por J. Rovira, Barcelona, 1933, págs. 212, 238.

(18) Y. Baer, Die Juden im Christlichen Spanien, Berlín. 1929-36, I, doc. n. ${ }^{\circ}$ 13. Utilizamos la palabra «almostalafe» por ser parecida a la hallada en la documentación consultada y ser la aceptada en la Enciclopedia juridica española. En catalán se usa también mostalaf, pero Dufourcq, L'expansió catalana a la Mediterrània occidental segles XIII i XIV. Barcelona, 1969, pág. 51, utiliza sólo "exea».

(19) García Sanz-Ferrer, Assegurances, I, pág. 38. Dufourcq, op. cit, pág. 51 indica la suma cobrada en Valencia.

(20) Se ha conservado en un traslado en pergamino escrito el 20 de mayo de 1198 por Pere de Corró, escribano real y de la catedral de Barcelona ante Ramón, presbítero, y los testigos Guillem Ramón, senescal, o sea, el Montcada, Bernat de Belloch y Guillem de Subirats, nobles, y Guillem y Bernat Ponç, Bernat y Ramón Marcús, que eran ciudadanos de Barcelona (ACB, perg. 1-5-111 citado por P. Bonnassie, La Catalogne, I, pag. 8517. Publicado en el apéndice (21). Garcia Sanz-Ferrer, Assegurances, I, pág, 37 y doc. $n .{ }^{\circ} 1$.

(22) El documento de ACB, perg. 1-5-150, fue publicado por J. Miret i Sans, Los ciudadanos de Barcelona en 1148, "Boletin de la Real Academia de Buenas Letras de Barcelona», IX, (1917-20), pág. 139. Aquí mismo se comprueba la presencia de Adarró, Arcs y Marcús entre los burgueses de Barcelona que prestan sumas de dinero a Ramón Berenguer IV para continuar el asedio de Tortosa en 1148.

(23) Fecha del testamento: 30 de octubre de 1165 (ACB, perg. 4-1-70).

(24) Los otros dos albaceas son Berenguer de Calaf y Guillem d'Espiells. La esposa del testador, Guillema, recibirá esponsalicio de 200 maravedies en la finca y bienes aportados por ella misma al matrimonio en bienes del marido. El hijo mayor Arnau tendrá casas y pertenencias donde vive la familia, en parte heredadas y en parte adquiridas por el testador. Arnau y el hijo que ha de nacer serán herederos, mientras la hija, Ramona, tendrá una dote de 400 maravedíes, el doble de la de su madre. Si murieran todos, la herencia, incluida la finca de Guillema, sería para los hermanos del testador o para Arnau Mateu, hijo de la hermana. Lo escribió Pere de Corró ante los testigos Berenguer de Cavallería, Guerau Laudon y Berenguer Pipó (ACB, perg. 4-15-111). Publicado en el apéndice.

(25) El documento se conserva en una copia del 12 de junio del mismo año, que lleva firma real, y la de Berenguer, arzobispo de Tarragona, Bernat, obispo de Barcelona, Bernat de Pinell, Pere sacristán de Barcelona y de Guillem Eimeric veguer de Barcelona, además de la del notario real Berenguer de Parets (ACB. Div. B, 140). Publicado en el apéndice.

(26) Los tres documentos llevan casi la misma fecha: uno es del 13 de abril y dos del 14. y como son privados sólo los firman los interesados sin testigos ni notario. Siguen a la donación por nupcias, que es del día 12 (ACB, pergs. 1-6-675, 677 y 1975).

(27) El reconocimiento de la deuda es del 27 de octubre de 1214; en este documento los dos Umbald obligan sus bienes y renuncian a cualquier derecho y costumbre que les pudiera amparar, ante los testigos Pere Sabater y Pere Forner y el notario Pons Sarrià $(A C B$, perg. 1-6- 
2029), publicado por Garcia Sanz-Ferrer, Assegurances i canvis maritims medievals a Barcelona, I. Barcelona, 1983, págs, 38 y $48,1 \mathrm{l}$, doc. $\mathrm{n} .{ }^{\circ} 7$. Vease en el apéndice.

(28) Si el sarraceno sufría algún percance o moria, Ermengol se comprometía a idemnizar a su acreedor ante los testigos Ramón Perpetua, Berenguer Vidal y Guillem Ros (ACB, perg. 1-6-740).

(29) Guillem Roig, hijo de Bernat, el 13 de septiembre de 1222 le pasa a Arnau Adarró una deuda de Guillem Ermengol y Bernat Umbald a su padre, pero si no la cobra, se compromete a pagarla él ante los testigos Ramón Perpetua, Bernat de Marina, Bernat d'Olzet, Bonanat d'Olivera y Guillem d'Olmet (ACB, perg. 1-6-2305).

(30) Arnau aparece como garantizador del matrimonio formado por Bernat de Torres y Agnès en el prestamo de Guillem Ponç el 16 de diciembre de 1222, y luego el 11 de febrero de 1226 en otro de Guillem Ponç a Bernat y Pere Ponç ante los testigos Ramón Perpeta y Berenguer Vidal (ACB, pergs. 1-6-2977 y 3244)

(31) Una vez muertos Bernat, ab intestato, y Gazol, su viuda Serena, casada ya con Guillem de Bonastre, y Toló reclamaron su parte y el lucro a Arnau Adarró, hijo de Bernat, y llegaron a un acuerdo el 10 de abril de 1207 (ACB, perg. 1-6-3002).

(32) A la muerte de Guillem, su madre Anglesa el 28 de noviembre de 1262 nombró procurador a otro de sus hijos, Berenguer, para recuperarlas, objetivo que éste consiguió el 18 de enero siguiente de manos del mismo Berenguer (ACB, pergs. 1-6-290 y 2836).

(33) El documento del 17 de octubre de 1263 fue expedido ante los testigos Jaume Carbonell y Pere de Santa Creu, a quien encontramos pocos años después como arrendador del mencionado derecho (ACB, perg. 1-6-69).

(34) ACA C, reg. 19, fol. $1 \mathrm{~V}$.

(35) J. Vincke, Königtum und Sklaverei in aragonischen Staatenbund wärend des 14 jarh. linderts, «Spanische Forschungen des Görresgesellchaft», 25 (1970), págs. 19-122. Trata el tema Verlinden, L'esclavage, págs. $165-168$ y ss., según Garcia Sanz Ferrer, op. cit págs. 37-38.

(36) D. Romano, Musulmanes residentes y emigrantes en la Barcelona de los siglos XIV$X V$, «Al Andalus» XLI, (1976), págs. 49-86.

(37) Tres sarracenos fueron dejados en prenda en Tortosa por una deuda de 14 maravedies por Guillem Jornet, quien lo recuerda en su testamento y lega otro sarraceno poseído a medias con su sobrino a su hermana Guillema (ACB. PA 4-3-132). Otros casos posteriores se refieren a los Adarró, en el apartado sobre la almostalafía y a los Sesfonts en nuestro trabajo sobre los catalanes en Sicilia. (XI Congreso de Historia de la Corona de Aragón, Palermo, 1983, II, págs. 147-185).

(38) F. Soldevila, Pere el Gran, IV, cap. 1. Coincide con estas campañas la compra hecha por el pañero Dorca en Valencia el 29 de octubre de 1276: una sarracena blanca adquirida a uno de Murcia.

(39) La mayoria de los cautivos eran de Ayora: Fath Abin Apdalla, Mahomet Aben Haltz, Azmeth Abogerffre y la mujer Axa Aben Noserig, de Atzara eran Mahomet Juniz y Ali Aben Mohamet, de Palaz, que ahora es un despoblado, eran Fátima Aben Rumaya y su hija pequeña, $y$ de Xerafol eran Jucef lbn Affrim y Ali Abina Hobeyt (ACB, perg. 1-6-2398).

(40) Perg. 1-5-294 comentado en el apartado sobre España.

(41) El otorgante obliga sus bienes y su esposa Ermessenda los suyos a Berenguer Ribot ante los testigos Pere Ferrer y Pere Desmas y el escribano Ramón Diaca (perg. 1-6-2682).

(42) Pere, Ramón y Guillem Lunes y Jaume Moragosa, el sobrino, fueron los árbritos de la cuestión terminada con la renuncia del herido a presentar demanda contra el caballero y a reclamar más, bajo pena de 300 sueldos y su juramento; el documento fue escrito por Pere de Romana, presbitero de Sant Joan Despi, ante todos los implicados y Arnau Lunes, Berenguer Payssa y Llorens Joan que firman y dos testigos (ACB, perg. 1-6-1735).

(43) Documento del Cartulario de Sant Cugat del Vallés publicado por J. Rius Serra, II, Barcelona, 1946, pág. 25 y comentado por J. Balari, Origenes de Cataluña, Barcelona, 1899, pág. 502. Verlinden, L'esclavage, pág. 131, discrepa de esta localización dada ya por Balari, porque Verlinden no vio el testamento. 
(44) Lo comprobarmos en el oficio de los calafates: unos tienen esclavos y otros los reciben en comanda de los dueños, que recibirán $3 / 4$ de la ganancia (Madurell-García Sanz, Comandas, doc. 1 ya comentado por $\mathrm{Ch}$. Verlinden).

(45) .Joan de Banyeres entregó sarracenas en comanda con destino a Sicilia y a Ultramar (ibid. docs. 2 y 5 ).

(46) La compra de una esclava a una judía de Barcelona es del 24 de abril de 1286 . Uno de estos compradores, Burges Dessa, ciudadano de Jaca, murió aquí a fines de octubre de 1254 después de disponer en su testamento de tres esclavas y un esclavo sarraceno, 19 piezas de tela de Lérida, 190 besantes de oro y otros 40 repartidos en parte por su alma, un cubrecama de lunes y otros bienes (ACB, perg. 1-6-3521).

(47) Véase Verlinden, L'esclavage. Incluso un notario barcelonés se ocupa de la venta de esclavos: Pere de Cardona es nombrado procurador de Jordà Despuig, jurisperito, el 12 de mayo de 1264 para vender la sarracena Fátima de dicho Jordà en el documento escrito por Pere de Roders, notario mallorquín, ante tres testigos, uno de los cuales es Jaume Mercer, acaso de la familia barcelonesa del barrio del hospital de Colom (ACB, perg. 1-6-1848).

(48) Con esta denominación firmó un recibo por valor de 50 sueldos el 29 de octubre de 1231 a los albaceas de Maimó Gombau, que dejó 100 sueldos para la redención de cautivos; la suma procede del precio de venta de una viña del difunto situada en el territorio de Barcelona, sobre la curia condal (ACB, perg. 1-6-1246). Trata el tema de la presencia de los frailes en el Norte de África. Dufourcq, L'expansió, págs. 47-55.

(49) Es una comanda de Vic (Madurell-Garcia Sanz, Comandas, pág. 69).

(50) Ibid., $n{ }^{\circ} 40$.

(51) Documento escrito por el notario Berenguer Llobet (ACB, perg. 1-6-61).

(52) ACB, perg. 1-6-786, ya aludido más arriba. 


\section{APÉNDICE DOCUMENTAL}

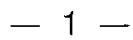

1144, enero, 6

Concesión del derecho de almostalafía por Ramón Berenguer IV a Arnau Pere d'Arcs por 150 morabetinos.

ARCHIVO DE LA CATEDRAL DE BARCELONA, perg. 1-6-111

Hoc est translatum scripture donationis de almoctalafia, cuius series scripture sic se habet. Cunc- / torum noticie sit manifestum qualiter ego Raimundus, Dei gratia Barchinonensium comes et marchio et / Aragonensium regni inclitus dominator, dono tibi Arnallo Petri de Archubus totam ipsam amoctalafiam / integriter et sine ulla diminutione salvis meis directis qui recto usatico mihi inde exire debent, / ut tu eam habeas et teneas in sana pace potenter et integriter, et omnes qui per te et per meam vocem ad / comodum tuum tuamque utilitatem in eadem amoctalafia fuerint tibi et tuis secure et quiete eam / possideant. Et nichil amplius in prefata amoctalafia a te repetere possim nec te / inde aliquo modo reptare nisi te exinde mihi culpabilem judicialiter comprobare va- / lerem. Accipio quoque a te pro hac donacione CL morabetinos, quorum predictorum morabetinorum recu- / peres $L$ morabetinos de meo recto usatico eiusdem amoctalafie sine tuo engan. Si ego aut aliquis meorum hec tibi infringero aut infringerint, ea que a te accipio ad comodum tuum / de te adquisitore duppliciter emendem vel emendetur et preterea hec donatio firma perma- I neat omni tempore. Que est acta II idus januarii anno VII regni Lodoyci junioris.

(Sig + num Raimundi comes. Sig + num Guillelmi Raimundi senescale. Sig + num Bernardi de Bellog. Sig + num Guillemi de Subirads. Sig + num Gui- 
llelmi Poncii. Sig + num Bernardi Marcucii. Sig + num Raimundi Marcucii. Sig + num Bernardi Poncii.

(Sig + num Petri presbiteri, qui hoc scripsit cum litteris emendatis in linea IIII, die et anno quo supra.

(Sig + num Bernardi presbiteri. Sig + num Bernardi Poncii. Sig + num Bernardi Arberti Poncii. Sig + num Raimundi presbiteri. Nos qui huic translationi presentes adfuimus. Sig + num Petri de Corron, scriptoris, qui hoc translatum scripsit XIII kalendas junii anno Domini M C XC VIII.

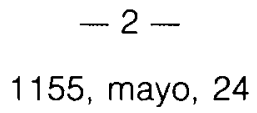

Carta por la que el conde de Barcelona y príncipe de Aragón Ramón Berenguer IV reconoce deber a Arnau Adarró 100 morabetines aiadinos y lupinos que le pagará cuando reciba la paria de Hispamia.

$A C B$, perg. 1-5-150

(Sit notum cunctis quod ego Raimundus, Dei gratia comes Barchinonensis et princeps Aragonensis, Tortose et llerde / marchio, debeo tibi Arnallo Adarroni $C$ morabatinos aiadinos et lupinos bonos in auro sine engan / quos convenio tibi et tuis, qui per tuum perfectum demandaverint, per bonam fidem sine tuo engan reddere et pac- / care de illa paria de Yspania primi venturi mensis septembris ad tuum salvamentum sine tuo engan, / sicut tibi juraverit per me in illo sacramentali Raimundus de Podio Alto et Berengarius de Torroga, atque Guillelmus de Castrovetulo, nisi quantum remanserit per tuam exprolongationem. Actum est hoc VIIII / junii anno XVIII regni Lodovici Junioris.

(Sig + num Raimundi Comes.

(Sig + num Raimundi de Podioalto. Sig + num Berengarii de Torraga. Sig + num Guillelmi de Castelvel.

(Sig + num Petri de Corron; scriptori, qui hoc scripsit... (ilegible).

$$
\begin{gathered}
-3- \\
\text { 1169, mayo, } 17
\end{gathered}
$$

Testamento de Pere Adarró, casado con Guilleuma, con motivo de emprender un viaje en galera hacia España.

ACB, P. A. 4-15-111 
(In Dei nomine. Ego Petrus Adarroanis vadens in quadam galera in Yspaniam facio meum testamentum, in quo eligo manu- / missores meos: Arnallum Adarronis, fratrem meum, et Johanem Mathei, cognatum meum, et Berengarium de Calaf atque / Guillelmum de Spidellis, quibus precipio ut, si me mori contingerit antequam aliud testamentum faciam, ita distri- / buant res meas et honorem meum sicut hic ordono. Primum dimitto uxori mee Guillelme CC morabetinos pro suo spon- / salitio, quos habeat in meis rebus ad suam voluntatem faciendam. Dimitto filio meo Arnallo domos meas in quibus / habitó cum omnibus suis pertinenciis, sicut melius habeo et habere debeo paterna voce sive materna et per meam / emptionem. Dimitto filie mee Raimunde CCCC morabetinos quos habeat de meis rebus mobilibus et pignoribus / Et si / ipse infans, de quo uxor mea est pregnans, erit femina dimitto eam Sancto Petro Puellarum ut sit inde deo- / data cum $C$ morabetinos, quos habeat Sanctus Petrus de meis rebus. Et si erit masculus, habeat $C$ morabetinos de meis / rebus et insuper habeant ipse et predictus Arnallus filius mei omnia alia res meas, honorem et mobile et / avere ubicumque habebo et habere debeo que superius non nominavi. Dimitto et laudo predicte uxori mee Guillel- / me omnem illum honorem et res suas que ipsa mihi dedit, ut habeat et teneat in vita sua et / post obitum eius revertatur predictis infantibus meis qui sunt create de me in illa. Relinquo uxorem / meam dominam et potentem dum legaliter in viduitate permanserit ad utilitatem et perfectum infan- / tum meorum in rebus meis cum ipsis infantibus meis. Et si aliquis infantum meorum obierit sine infan- / te legitimo, hereditas sue revertatur ad alios. Et si omnes infantes mei obierint sine infante legi- / timo, medietas totius ipsius honoris quem uxor mea predicta mihi dedit, remaneat nepotibus / meis filiis et filiabus Johannis Mathei et sororis mee. Et de alia medietate faciat uxor mea vo- / luntate. Et si omnes infantes mei obierint sine infante legitimo, remaneant fratri meo Arnallo / Adarronis et suis predicte domus mee, in quibus habito, et medietas de omnibus aliis meis rebus hono- / ris et mobilis ubicumque habeo et habere debeo, alia II medietas revertatur nepoti meo Ar- / nallo, filio Johannis Mathei. Et mando meis manumissoribus ut donent $X X X$ morabetinos / ad redimendis tribus captivis pro anima mea. Actum est hoc XVI kalendas junii anno XXXII regni / Ludovici iunoris. Sig ++ num Petri Adarronis qui hoc laudo et firmo firmarique rogo. Sig + + num Guillelme, uxoris eius, que hoc laudo et firmo..

(Sig + + num Arnalli Adarronis. Sig + + num Johannis Mathei. Sig + + num Berengarii de Calaf. Sig + + num Guillemi / de Spidellis. Sig + + num Berengarii de Cavalleria. Sig + + num Geralli Laudon. / Sig + + num Berengarii Piponis alterius testis sunt. Sig + + num Arnalli Mathei / Sig + + num Petri de Corron, scriptor, qui hec scripsit cum litteris superpositis in linea $\mathrm{V} / \mathrm{I}^{\mathrm{a}}$ et dampnatis in XXII / die et anno quo supra. 
1184, agosto, 26

Testamento de Guillem Jornet, propietario de una "sagetia", de fincas y de esclavos sarracenos. Nombra albaceas a Berenguer Bou, Guillem d'Alfou Berenguer Ferrer, Arnau Jordá, Guillem Jordà y Mateu, su sobrino, y divide su fortuna entre sus hijos Guillem y Guillema, que quedan bajo la protección de Dolça, su esposa. En caso de que ambos hijos mueran sin descendencia, todo pasará a los sobrinos.

ACB, P. A. 4-9-132

(In Dei nomime. Ego Guillelmus lorneti detentus infirmitate, pleno sensu et memoria integra, facio meum testamentum, in quo eligo manumissores meos scilicet Berengarium Bovis, Bur- / getum, Guillelmum de Alfodio juniorem, Berengarium Ferrarii, Arnaldum Jordani, Guillemum Jordani atque Matheum, nepotem meum, quibus precipio caritative ut si mori me / contigerit antequam aliud testamentum faciat, ita distribuant res meas et honorem meum, sic hic invenerint ordinatum. Primum accipio de meo pro anima mea CCC solidos, I de quibus dimitto ecclesie sancti Jacobi et clerico suo XX solidos cum meo corpore quod ibi sepeliatur, et dimitto Barchinone cononice $X X$ solidos pro anima mea et canonici veni- / ant ad meam sepulturam, et ecclesie Sancti lusti VII solidos pro anima mea, et sancto Petro Puellarum solidos $X$, et Sancto Paulo de Campo VII solidos, et Sancte Eulalie de Campo VII / solidos, et ecclesie sancti Michaelis et suo clerico $V$ solidos per missas. Dimitto Villane, femine, VII solidos et Laurete, femine, $V$ solidos. Mando et volo quod Ermengardis, nutrix mea, / habeat victum in domo mea et si illa recipere noluerit, dentur ei de meo XXVIII solidos, et si aliud quod superaverit de predictis CCC solidis, detur ad meam sepulturam. / Dimito Dulcie, uxori mee, suum sponsalicium sicuti ei feci ad diem nuptiarum suarum et mediatatem omnium pannorum qui sunt in domo mea. Dimito infantibus / meis, Guillelmo et Guillelme, totum quantum habeo et habere debeo in Bachinona et extra Barchinonam vel n quibuscumque locis ego habeo et habere debeo aliquibus modis ac vocibus, scilicet domos, / vineas, terras, pignora, pannos, mobile et sarracenos atque ligna, ut habeant equaliter. Et si aliquis de predictis infantibus meis obierit sine prole legitima, eius he- / reditas revertatur alteri et si forte ambo obierint sine infante legitimo, omnia eorum hereditas et omnia eorum directa reverterentur omnibus nepotibus meis equaliter. I Dimito meos infantes cum omnibus eorum directis in potestate et in gubernatione Dulcie, uxoris mee, dum steterit sine viro et sit domina et potens tam de filiis / suis et meis quam de 
rebus eorum, dum permanserit in viduitate et quod nutriat filios suos et diligat fideliter sicuti bona mater debet facere. Dimito in po- / testate Guillelme, sororis mee, et meorum nepotum filiorum eius illud meum nutricatum Guillemetum et pro amore mei nutriant eum et dimitto ei $C$ solidos, quos habeo in illo sarraceI no Guillelmi de Torsa, nepotis mei, quem meo solvo ei, et ita de illis XVIII libris, quas predictus nepos meus mihi debet, non remanent nisi XIII libras et quando erit adultus / et de etate, donent ei predictos $\mathrm{C}$ solidos. Dimito predicte Guillelme, sorori mee, mediatatem illius sarraceni quem habeo cum filio suo predicto et meum mantellum de presseto / viridi. Maletus, iudeus, et filii sui debent mihi XXIII libras denariorum, sicuti resonat in carta quam ipsi mei fecerint et Petrus Macer debet mihi VII libras et XI / solidis. Gregorius tenet unum meum ciphum argenti in pignore pro XXXV solidis. Debeo Salomoni Cerz VI libras et Guillelmo Nas XXII solidos, et debemus inter me et nepo- / tes meos filios de Cima de Mari in renovando ipsam sagittiam $\mathrm{C}$ masmotines. Petro Galec et Bartholomeo XXII solidos et ipsi persolvant suam partem et ego persolvam / meam partem.

(Laudo illis et concedo ut quando, erunt adulti et de etate possent petere omnia sua directa. Mando ut ipsa mea vela vendatur ad utilitatem meorum / infantum, et habemus apud Dertosam ego et nepotes mei, filii de Cima de Mari, tres sarracenos qui sunt in pignore pro XIIII morabetinis, in duobus habeo medietatem et ipsi / aliam medietatem et in tercio habemus duas partes, ego medietatem et ipsi similiter aliam mediatatem; directum meum predictorum sarracenorum dimito predictis infan- / tibus meis. De hoc toto quod dimitto infantibus meis facio dominos et potentes Berengarium Bovis et Arnaldum lordani atque Matheum, nepotem meum, ut cum Dulcia, uxo- / re mea, bene et fideliter gubernent, custodiant atque augmentent ad utilitatem meorum supradictorum infantum et insuper hoc volo et rogo quod Arnaldus lordani disponat / domui mea et accipiat omnia directa meorum infantum et omnem peccuniam ad utilitatem et augmentum illorum et quod sit inde potents et quod persolvat omnia debita / mea et recipiat similiter a debitoribus meis. Et est certum quod in meo anatgario (1) filii de Cima de Mari habent medietatem. Debeo Geraldo de Marimo (sic) XLIII solidos / malguriensium et XXII solidos barchinonensium. Dimito Bernardo Marcutii unum ciphum argenti quem mihi debet et III morabetinos quos mihi debet, et quando Guillelmus de / Alfodio vel Raimunda, uxor eius, vel sui redimerint illud pignus quod ego teneo ab illis, dimitto inde eis $X$ morabetinos. Actum est hoc VII kalendas septembris anno Domini / M. ${ }^{\circ} \mathrm{C} .^{\circ} \mathrm{LXXX}{ }^{\circ} \mathrm{IIII} .^{\circ}$

(Sig + num Guillelmi lorneti qui hoc laudo et firmo firmarique rogo. Sig + num Berengarii Bovis. Signum Berengarii Ferrarii. Signum Arnaldi lor- 
dani. / Sig + num Guillelmi lordani. Sig + num Mathei de Regomir. Sig + num Petri Ballisterii. Sig + num Bernardi de Gerunda. Sig + num Ste- / phanis Correger. Sig + num Guillelmi Jenoves. / Sig + num Burgetus. Sig + num Guillelmi de Alfodio. Sig + num Gregorii. Sig + num Guillelmi Rivirubii. Sig + num Giraldi de Maurimon. / Sig + num Berengarii, levite Sancti lusti, qui hoc scrpsit die et anno quo supra.

(1) Se lee de forma clara anatgario, cuyo significado desconocemos.

\section{$-5-$}

1185, abril, Barcelona

Donación de toda la almostalafía real, excepto la de Valencia y la de Tarragona a Tortosa, firmada por el rey Alfonso de Aragón en favor de Bernat Marcús y Bernat Adarró, para el traslado de cautivos sarracenos por mar y por tierra. Se conserva en una copia del 12 de junio del mismo año.

ACB, perg. 1-2-140

(Hoc est translatum fideliter factum. Notum sit cunctis quod ego lldefonsus, Dei gratia rex Aragonum, comes Barchinone et marchio Provin- / cie, dono atque in perpetuum concedo tibi, Bernardo Marcucii et Bernardo Adaronis, et vestris, totam illam meam almaztalafiam tocius mee terre, / quam vos et vestri habeatis et teneatis per me et per meos, potenter et sine contradictione per omnia loca, tali scilicet modo quod nullus / preter vos possit extrahere vel ducere captivos sarracenos de tota terra mea in terram sarracenorum nisi assensu et voluntate / vestra. Preterea mando et dono vobis licentiam quod nullus meus baiulus vel alius homo possit vobis contradicere vel vetare quin eatis vos et / vestri quando cumque vestri vexelli parati fuerint. Preterea recipio in mea protectione et deffensione et in meo securo ducatu, omnes ho- 1 mines qui vobiscum vel in vestris vexellis omnes ho- / mines qui vobiscum vel in vestris vexellis vel cum vestris hominibus ierint in eundo et redeundo per mare et per terram, dum ibi remanere / voluerint, ita quod nullus sit ausus eos in aliquo gravare vel perturbare, sed sint et vadant salvi et securi per omnia loca. / Qui autem hoc meum donum et mandatum disrumperet, iram meam incurret et erit cum omnibus suis rebus incurrucutus in meo / posse. Et mando omnibus meis baiulis et vicariis ut hoc totum faciant vobis compleri et vetent quod nullus sit ausus / hoc contradicere in aliquo. Excepto hoc quod non sit in hac conveniencia vel dono illa almoztolafia Valencie quam dedi et / retineo de Terrachona usque ad Dertosam et in super hec omnia supradicta semper maneant firma. Acta carta apud Barchinonam / mense aprilis, anno Domi- 
ni M. ${ }^{\circ} \mathrm{C} .{ }^{\circ} \mathrm{LXXXX} \cdot{ }^{\circ} \mathrm{V} .{ }^{\circ}$. Sig + num Ildefonsi regis Aragonum, comitis Barchinone et marchionis Provincie. / (Signum) Berengarius Terrachonensis archiepiscopus. Ego Bernardus Barchinonensis episcopus subscribo. / Sig + num Bernadi de Pinel. Petrus sacrista Barchinone. Sig + num Guillelmi Aimerici, vicarii Barchinone. / Sig + num Berengarii de Parietibus, notarii domini regis, qui hanc cartam eius mandato scripsit. Sig + num Guillelmi presbiteri. Gerardi presbiteri (signum). Sig + num lohannis levite. / Sig + num (signo) Guillelmi presbiteri, qui hoc translatum fideliter scripsit II idus iunii, anno Domini $\mathrm{M} .{ }^{\circ} \mathrm{C} .{ }^{\circ} \mathrm{LXXX}$ V. ${ }^{\circ}$.

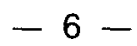

1187, octubre, 11, Tarragona

Bertrán Catalá reconoce que Ricard de Tarragona es su garantizador en la deuda de 300 macemutinas de oro ante los hombres de Tarragona, suma que promete pagar con las primeras ganancias conseguidas con su galera en el viaje a España. Para mayor seguridad pone en manos de Ricard la galera, cuyos nauclerios y marineros quedan bajo la potestad de éste.

ACB, perg. 1-5-294

(Sit notum cunctis quod ego Bertrandus Catalanus recognosco tibi Richardo de Tarachona quod ego misi te firmantiam et fideiussorem CCCtarum masmutinarum / hominibus Tarrachone; has autem CCC masmutinas convenio persolvere tibi vel tuis vel mandatario tuo de primo lucro et de prima pecu/ nia sive de primis rebus, quas volente Domino galea mea quam modo / in Hispania mitto, habere poterit et lucrari vel ego ipse in galea vel per galeram (1). Et convenio eas tibi / persolvere salvas in terra de gradu Dertose usque ad caput Crucum sine omni dolo et sine omne contradictione. Et ut sis inde secu/ rior, mitto inde tibi in potestatem tuam et in manum tuam galeam meam, quam hic habeo cum omnibus rebus suis et cum tota / exarcia sua pro retorn, ita quid (sic) quod tu ducas et reducas eam sicut volueris quocumque et quandocumque volueris et sit in mandato tuo / ipsa galea et omnes nauclerii et marinarii, sicut debent esse in mandato meo ex sacramento mihi prestito, donec ex toto tibi / persoluta sint tibi vel tuis vel mandatario tuo predicte CCC masmutine salve in terra. Ad maiorem vero securitatem iuro ego / sic tibi attendere sine omni dolo et sine omni sophismate per Deum et hec sancta llllor evangelia. In eundem modum iurant / hec mecum ex mandato meo Bernardus de Muto et Guillelmus de Torsa, quibus mando ut tibi obediant in omnibus sicut mihi ipsi tenentur ex sacramento / obedire. Et si voluntas mea, et voluntate 
tua discordaverit tibi et non mihi obediant nauclerii omnes et marinarii et / teneantur tibi et non mihi de sacramento mihi prestito. Et ego Bernardus de Muto et Guillelmus de Torsa hoc totum convenimus atten- / dere tibi Richardo de Tarrachona et tuis per Deum et hec sancta Illlor evangelia. Preterea dono ego Bertrandus Catalanus tibi Richardo quartam / partem nauxerie, sicut dari solet in terra ista, et unum sarracenum bacalar et unum lectum, sicut solet dari naucleris in terra ista. / Actum est hoc $V$ idus octobris anno $\mathrm{M}{ }^{\circ} \mathrm{C} .{ }^{\circ} \mathrm{LXXX}{ }^{\circ}$ VII. ${ }^{\circ}$ Dominice incarnacionis. / Sig + num mei Bertrandi Catalani. Sig + num Bernardi de Muto. Sig + num Guillelmi de Torsa, qui hoc sicut distinctum superius iuramus et firmamus et a testibus / firmari rogamus. Sig + num Durandi Cavaler. Sig + num Arnalli Bover. Sig + num Guillelmi de Viciana. Sig + num Petri de Sancta / Fide. Sig + num Petri de Viciana. Ego Petrus de Tarrachona, tarrachonensis notarius, hoc scripsi et supscripsi in linea Illa ubi dicitur vel ego ipse in galea vel per galeam, die et anno / (signo) prefixo.

(1) Vel ego..., interlineado.

\section{$-7-$}

1214 , octubre, 27

Pere Umbau reconoce que debe a Arnau Adarró 30 macemutinas nuevas contrahechas de oro en concepto de redención del sarraceno Maimó, que pertenece a éste y a Ermengol de Banys. Promete pagarlas salvas en tierra 15 dias después que el leño de B. Caramel haya regresado del viaje a Bona o cuando se tengan noticias suyas.

ACB, 1-6-2029. A. García Sans-M. T. Ferrer, Assegurances i canvis marítims medievals a Barcelona II, Barcelona, 1983, n. ${ }^{\circ} 7$

(Sit omnibus notum quod ego Petrus Umbaldi debeo tibi Arnaldo Adarronis et tuis triginta mace / mutinas novas contrafactas de tallio Miralmomenini in auro sine enganno et recti pensi, quas / confiteor tibi debere pro redempcione illius sarraceni nomine Maimoni, qui erat inter te et Ermengau- / dum de Balneis, et quem ego recepisse concedo; quas $X X X$ macemutinas convenio paccare tibi / vel tuis salvas in terra ad XV dies ex quo lignum Bernardi Caramelle, quod ducit Simon Bruni, rever- / sum fuerit a presenti viatico de Bona vel at suum sabuth, tamen ad morem moztalafie de Barchinona ad / Bona. Dono etiam tibi plivium datorem Arnaldum Umbaldi (1), qui mecum et sine me hoc tibi attendat. Nos / itaque ambo prenominati, tam debitor quam fideiussor, quisque pro toto convenimus tibi Arnaldo Adarronis et tuis / ac omni homini pro tuo bono petenti prescriptum debitum paccare super nos et in 
rebus nostris mobilibus et / immobilibus et in quibus accipere volueritis unde sis paccatus in statuto termino, ut predictum est, sine tuo engan-/ no. Ne vero aliquis nostrum possit in hoc pro altero excusari omni iuri et consuetudini quantum ad hoc renunciamus. I Actum est hoc VI kalendas novembris anno M.CC quartodecimo. Sig + num Petri Umbaldi. / Sig + num (signo) Arnaldi Umbaldi, qui hoc laudamus et firmamus. Sig + num Petri Sabaterii. Sig + num Petri / Furnarii. / Sig + num (signo) Poncii de Serriano, qui hoc scripsit, die et anno quo supra.

(1) Firma autógrafa. 


\title{
ALCALÁ DE GUADAIRA EN EL SIGLO XIII Conquista y repoblación
}

\author{
MANUEL GONZÁLEZ JIMÉNEZ \\ Universidad de Sevilla
}

\section{LA CONQUISTA DE ALCALÁ DE GUADAIRA}

La conquista de Andalucía por Fernando III se desarrolla a lo largo del segundo cuarto del siglo XIII, entre 1225 y 1248, año este en que se procede a la ocupación de Sevilla, capital de los territorios peninsulares controlados por los almohades. Tras unos tímidos tanteos y la conquista de importantes enclaves en el Alto Guadalquivir (Andújar, Baeza, Quesada y Úbeda, entre otras plazas), en 1236 tiene lugar la conquista de Córdoba, cuya repoblación se ultima entre 1240-1241. A partir de este momento los acontecimientos se precipitaron, sin duda porque, tras la desaparición del caudillo murciano lbn Hud, asesinado en Almería en 1237, y la crisis final del Imperio almohade, ningún obstáculo serio se oponia a los avances de los ejércitos castellanos. El único obstáculo podía haber sido el rey de Granada Muhammad Ibn Alhmar. Pero la pérdida de Arjona, su ciudad natal, en 1244, habia puesto de manifiesto su incapacidad para enfrentarse con posibilidades de éxito al rey de Castilla. En 1246 entregaba Jaén a Fernando III, declarándose además vasallo suyo. Granada quedaba asi al margen de la contienda (1).

Las operaciones preparatorias del cerco de Sevilla debieron iniciarse en el verano de 1246, aunque la Primera Crónica General, fuente de información casi única para todo lo que se refiere a los aspectos militares de los años finales del reinado de Fernando III, parece fechar tales acontecimientos en 1247. En efecto, en el cap. 1071, se afirma que el rey, tras la conquista de Jaén, permaneció en la ciudad durante ocho meses (2). Si esto fue así, la ocupación de Alcalá de Guadaira habría que fecharla en 1247 y no en 1246 como parece lo más probable y lógico (3). 
La conquista de Alcalá fue resultado de una operación de tanteo contra Sevilla organizada por el rey apenas concluido el asedio de Jaén y firmado el pacto de vasallaje del rey de Granada (4). La Crónica refiere la operación como si de una expedición de tanteo se tratara. En efecto, las tropas del rey, a quien acompañaban su hermano el infante don Alfonso de Molina, su hijo el infante don Enrique y los maestres de las Órdenes de Calatrava y Santiago, «non passauan por trezientos caualleros arriba», a las que habría que añadir la caballería y el peonaje del concejo de Córdoba. Un ejército muy menguado, en el cualquier caso, como para acometer la empresa del cerco de Sevilla (5). Ello explica, sin duda, que el rey se limitase a saquear las tierras de Carmona (6) y a tantear las defensas de Alcalá de Guadaira, cuyos habitantes, temerosos de los efectos de una resistencia imposible, se apresuraron a pedir del rey una honrosa capitulación. Por otra parte, la presencia en la hueste de Fernando III de un importante contingente de caballería mandado por el propio rey de Granada, que cumplía así su deber de vasallo del rey castellano, facilitó las cosas. Los de Alcalá se entregaron al rey granadino, y éste a su vez entregó la villa y la fortaleza a Fernando III (7). Era, si hemos de aceptar la fecha tradicional, el día 21 de septiembre de 1246, festividad de San Mateos. Según el analista sevillano Ortiz de Zúñiga, el rey dejó por frontero en Alcalá al noble castellano don Rodrigo Álvarez, al frente de la guarnición que se hizo cargo de la importante fortaleza de Alcalá (8)

\section{SITUACIÓN DE LOS MUDÉJARES}

No se nos ha conservado el texto de la capitulación otorgada por Fernando III a los moros de Alcalá en 1246. Pero, de todas formas, es seguro que tal acuerdo existió, ya que a él se alude en el privilegio en virtud del cual Alfonso $X$ concedió el señorío de la villa al cabildo de la Catedral hispalense. En sus líneas básicas debía ser semejante a otros acuerdos de esta indole concedidos por el mismo rey en años anteriores, y cuyos textos también han desaparecido.

Pero manejando toda la información dispersa que sobre los mudéjares andaluces nos ofrece la documentación de tiempos de Alfonso $X$, he podido reconstruir buena parte de los aspectos generales que debian contemplar las capitulaciones otorgadas por el rey a los moros. Los más importantes serían los siguientes:

$\left.1 .^{\circ}\right)$ Mantenimiento de su ley y de sus «fueros.

$\left.2 .^{\circ}\right)$ Permanencia de la estructura tradicional de la aljama o comunidad, presidida por su alcalde o alcayad, en la que se integraban especialmente los viejos y personas de más prestigio de la localidad. 
$\left.3 .^{\circ}\right)$ Mantenimiento también del mismo régimen fiscal que tenian en época almohade.

$\left.4 .^{\circ}\right)$ Respeto a sus costumbres y modo de vida tradicional, como se comprueba en la autorización de tener baños, tiendas, molinos y alhóndigas «a la costumbre de los moros", como se lee en un acuerdo con los moros de Morón hecho en tiempos de Alfonso $X$.

$\left.5 .^{\circ}\right)$ Por último, derecho a marchar libremente a donde quisieran.

Al amparo de estas garantías, buena parte de la población musulmana de Alcalá, debió permanecer en la villa gobernada por su alcalde o alcayad Hamet Abén Paxat.

De todos estos aspectos, el mejor documentado es el que se refiere a la situación fiscal de los mudéjares, que, en esencia, reproducía el esquema tradicional, que consistía en el pago al rey del diezmo de todas las cosechas; un impuesto de capitulación, llamado genéricamente en los documentos «el pecho de los moros» o alfitra, y un impuesto sobre la tierra conocido con el nombre de almarjal. Es posible que también pagasen un impuesto sobre el ganado, llamado en la documentación valenciana de la época azaque, y que en algunos casos los moros estuvieron sometidos a prestar ciertos servicios personales para la reparación de las fortalezas o para el mantenimiento de edificios de cierta importancia, como sucedía en Córdoba, donde los carpinteros, serradores y albañiles moros debían trabajar gratis dos días al año en las obras de conservación de la mezquita catedral (9).

El régimen fiscal de los mudéjares - aunque se presente como prolongación del anterior - distaba mucho de ser generoso, y es probable que los castellanos se encargasen de endurecerlo aún más en los años que siguieron a la conquista. Ello explicaría, entre otras, la sublevación casi general de los mudéjares andaluces y murcianos en la primavera de 1264 y la emigración de muchos de ellos a Granada, antes incluso de producirse la revuelta (10).

\section{PRIMERA REPOBLACIÓN DE ALCALÁ}

Hasta 1253, fecha del repartimiento de Sevilla, Alcalá de Guadaira no fue sino una pieza importante del sistema militar recién consolidado por la conquista de la ciudad. En consecuencia, la población cristiana debía limitarse al reducido contingente de soldados acantonados en su fortaleza. Es posible, que por estas fechas — rompiendo de alguna forma lo pactado en 1246la población mudéjar hubiese sido ya desplazada de la villa al Arrabal, y que 
sus casas comenzasen a ser ocupadas por un primer grupo de repobladores de los que casi nada sabemos.

De todas formas, parece que esta primera implantación de pobladores cristianos en la Villa, de la que ningún vestigio claro nos ha llegado, debió ser de escasa importancia, o todo lo más, acabaría integrándose en el grupo de soldados/repobladores que pudieron asentarse en Alcalá tras haber recibido tierras en su término y casas en la villa como pago a los servicios prestados en la conquista de Sevilla y/o, como parece probable, por su condición de repobladores.

Este grupo de soldados/repobladores recibió casas en Alcalá y heredades en la aldea o hacienda de Borgalhamar, que el rey habia reservado inicialmente para sus galeras. Los beneficiarios pertenecian a cinco cuadrillas de almogavares o peones, a las órdenes de sus respectivos jefes de grupo o almocadenes. A cada uno de ellos se entregaron lotes de tierra, de acuerdo con su categoría militar. $Y$, así cada uno de los cinco almocadenes recibió un lote consistente en dos yugadas de tierra de labor (unas 60 has.), dos aranzadas de viña; tres aranzadas de olivar, y una aranzada y media de huerta; mientras que cada uno de los almogavares - 57 en total- recibió una yugada de tierra de labor; dos aranzadas de viña; dos de olivar y una de huerta. Así pues, el total de bienes repartido ascendió a 60 casas, 61 yugadas de tierra de labor (unas 1.830 has.), 117 aranzadas de olivar, otras tantas de viña y unas 58 y media de huerta.

De ser correcta la suposición de que los beneficiarios de este reparto-que figura en el repartimiento de Sevilla, al final de los donadios menoresestaríamos ante la nómina más antigua y autorizada de repobladores cristianos de Alcalá de Guadaira (11).

Pero los repartos efectuados en término de Alcalá no beneficiaron sólo a repobladores de la villa. La gran extensión del antiguo término de Alcalá, que se prolongaba hasta el Guadalquivir, englobando el de Dos Hermanas, y lo exiguo del poblamiento cristiano de la villa, asentado a la sombra del castillo, explican las numerosas donaciones hechas por Alfonso $X$ que registra el libro del repartimiento de Sevilla.

Los lugares y fincas que figuran en dicho texto pueden agruparse, en razón de sus beneficiarios, en las siguientes categorías:

1) Lugares y fincas entregados en bloque o en parte a beneficiarios de donadios mayores (miembros de la familia real, alta nobleza y Órdenes Militares): 
- BORGABENALCADI, dada al infante don Enrique, hermano de Alfonso $X$.

- BORGABENAUN, donde la Orden de San Juan recibió undonadío de diez yugadas de tierra de labor (unas 300 has.)

- BORGABENHALDON, donde la Orden de Uclés recibió, junto con la torre de la finca, 30 yugadas de tierra de labor (unas 900 ha.)

- BORJASANTAREM, concedida íntegramente a don Ruy López de Mendoza, almirante de Castilla.

- CERRAJAS, dada a don Rodrigo Gómez de Galicia (12).

- FOXAT, donadío de don Rodrigo Álvarez, primer alcalde cristiano de Alcalá.

- MACHAR AZOHIRI, entregado a don Fernando, hijo del antiguo rey moro de Baeza.

- VILLANOVA AZEQUILLA, donadío de don Gutiérrez Suárez de Meneses.

- ZAHELA, la mitad de la cual, con un cortijo y una torre, fue entregada a don Rodrigo Álvarez, ya citado.

- GANDUL y MARCHENILLA, donde recibió tierras de labor el mentado don Rodrigo Álvarez.

2) Alcarias donde recibieron tierras beneficiarios de donadíos menores:

MACHAR ABENHAQUIM, cortijo atribuido inicialmente a las galeras del rey y entregado a 28 hombres de las «Compannas» del infante don Enrique.

3) Tierras reservadas por el rey para su almacén:

El rey se reservó como propias, en diversos sitios, unas 1.050 aranzadas de olivar y unas 94 yugadas de tierra de labor (unas 2.820 ha.) ubicadas en Bulbal, Tavilla, Facaxtalmi, Bibares, Arenales y Carchena (13).

4) Aldeas reservadas para las galeras del rey:

De las tres que inicialmente se reservó el rey para este fin sólo retuvo la de BORGABENDARIZ (14).

5) Por último, una larga serie de cortijos y alcarias entregado al concejo de Sevilla para heredar en ellos a los pobladores de la ciudad: 
- ALCARIAS: ALJUBET, BORGABENHALDON, BORGABENÇOMA, MACHAR ABDILQUIVIR, MACHAR AXARAFI, MACHAR YANCO, MALIX, QUINTOS, QUARTOS, TOCORICOBIZ y ZAHELA.

\section{- CORTIJOS. CORTIGENA y LA MEMBRILLA (15).}

En conjunto las tierras entregadas ya sea a beneficiarios de donadíos 0 a pobladores, ascendieron a una 900 yugadas de tierra de labor (unas 27.000 ha.) y a unas 20.000 aranzadas de olivar e higueral, cultivos absolutamente predominantes en el término de Alcalá de Guadaira, especialmente en su sector norte. Algunas alcarias, como las de Borgabendariz, Borgabenalcadí, Borgabençoma y, en especial, la de Abenhaquín estaban dedicadas casi por completo al cultivo de la higuera. De todas formas, el olivar aparece en el texto como el cultivo rey, si bien el arbolado de algunas fincas, como la de Quartos, debió quedar, tras el asedio de Sevilla y por su proximidad al campamento cristiano, literalmente devastado. Sólo así se justifica que en una superficie de 1.160 aranzadas quedasen tan sólo 3.000 pies de olivar o lo que es lo mismo, a razón de 50 pies por aranzada, una superficie en explotación de nada más que 60 aranzadas.

Entre los bienes repartidos en término de Alcalá ocupan un lugar preferente los molinos harineros ubicados en las márgenes del rio Guadalquivir o junto a los «caños» que conducian el agua a Sevilla. Algunos de ellos están perfectamente documentados, como el de Abén Haroça, entregado por el rey a don Pedro Pérez, canciller de doña Juana de Ponthieu, viuda de Fernando III (16); o el molino de Abén Ocba, que perteneció a Hamet Abén Paxat, el alcalde de los moros que permanecieron en Alcalá de Guadaira tras la conquista (17); o los nueve o más molinos otorgados por Alfonso $X$ al concejo de Sevilla, «que son en la azequia de la montanna de Alcalá de Guadayra» (18); o, finalmente, los molinos concedidos por Fernando III a la Orden de Alcántara, «los que son más çerca de la puente por ó passé yo con mi hueste quando vine de Alcalá sobre Sevilla" (19). También los habia en Cerrajas, y de gran valor, ya que la Orden de Calatrava los retuvo cuando cedió la propiedad de la alcaria citada(20).

\section{ALCALÁ BAJO LA JURISDICCIÓN DE SEVILLA}

La presencia masiva en término de Alcalá de propiedades de vecinos de Sevilla o, al menos, atribuidas al concejo hispalense para ser repartidas entre pobladores de la ciudad, se explica sólo por la vinculación jurisdiccional de la villa con respecto a la urbe. Todavía no se había acuñado la expresión que definía a Alcalá como "guarda e collación de Sevilla»; pero, induda- 
blemente, la villa cumplía ya algunas de estas funciones. Desde luego, desde el punto de vista militar, su castillo era para la ciudad una garantía de seguridad absolutamente irreemplazable. Pero, además, Alcalá estaba íntimamente asociada al abastecimiento de la ciudad: el agua, los molinos y el mismo pan de Alcalá significaban mucho para Sevilla. Sólo así se entiende que, desde el primer momento, Alcalá aparezca tan estrechamente asociada a Sevilla y que por eso mismo el rey la sometiese a su jurisdicción.

Efectivamente, en diciembre de 1253, concluido ya el repartimiento de Sevilla, Alfonso $X$ concedió términos propios a la ciudad, al tiempo que le confirmaba el fuero otorgado por Fernando III años antes. Pues bien, entre las villas incorporadas a la jurisdicción y fuero de Sevilla figura Alcalá de Guadaira.

En este mismo privilegio el rey se reservó las rentas de los almojarifazgos o aduanas de Tejada, Sanlúcar la Mayor, Aznalcázar, Constantina y Alcalá de Guadaira, villas todas ellas dependientes de la ciudad, y vinculó de tal manera a sus pobladores con la ciudad que en la práctica les otorgó la condición de vecinos de la propia Sevilla. El texto es de un gran interés y dice como sigue:

«Et tengo pora mí e pora todos aquellos que regnaren después de mi en Castiella e en León las rentas de los almoxarifadgos con sus pedidos de taxada, de Solúcar la Mayor, e de Heznalcáçar e de Alcalá de Guadayra e de Costantina, en tal manera que todos los christianos que son hy oy pobladores e serán daquí adelante pora siempre iamás en estos cinco logares sobredichos, que fagan con el conceio de Seuilla todos aquellos fueros e todos aquellos derechos que fazen e que farán los que son e que serán pobladores e moradores en Seuilla e en sus términos, e que ayan esse fuero mismo" (21).

En cuanto villa dependiente de Sevilla, Alcalá recibió el fuero de la ciudad, por el que continuó rigiéndose en adelante, aún en los momentos en que dejó de depender de la jurisdicción sevillana.

\section{ALCALÁ, SEÑORÍO DE LA IGLESIA DE SEVILLA}

En septiembre de 1258 Alfonso X entregó a la Iglesia Hispalense «la villa et castiello» de Alcalá de Guadaira, a la que segregó de la jurisdicción del concejo sevillano. Este importante acontecimiento hay que interpretarlo dentro de las medidas adoptadas por el monarca para dotar económicamente a la Iglesia de Sevilla (22). Ésta era una tarea absolutamente inaplazable ya 
que, a pesar de que hacía ya diez años que se había producido la conquista de la ciudad, la sede arzobispal y el cabildo catedralicio hispalenses no habian recibido los bienes que correspondian a su rango. Por razones que desconocemos, Alfonso $X$ dejó pasar la oportunidad que le ofreció el repartimiento de Sevilla, en el que la Iglesia hispalense recibió muy pocos bienes: algunas rentas de dinero, otorgadas ya por Fernando III, y la propiedad de todas las mezquitas de la ciudad, y poco más.

Hasta finales de 1257 el infante don Felipe retuvo la dignidad y las rentas de la mitra hispalense, de la que era arzobispo electo a pesar de haber contraido matrimonio en 1252 con la princesa doña Cristiana de Noruega. En 1258 la sede arzobispal sevillana aparece en la documentación real como «vaga» o vacante, aunque, sin duda, el rey hacia tiempo que tenía decidida la designación de don Remondo, obispo de Segovia. En realidad el obispo segoviano, hombre de confianza el rey, hasta el punto de haber organizado las operaciones del repartimiento de Sevilla en 1253, venia administrando la Iglesia hispalense desde hacía años. Y a instancias suyas debió iniciarse en 1258 el proceso de dotación de la Iglesia sevillana, precisamente con la concesión de Alcalá de Guadaira al cabildo de la catedral. A partir de este momento y hasta 1279, Alfonso $X$ cumplió con generosidad esta tarea ineludible. $Y$, así, el arzobispo y el cabildo hispalense se convirtieron en pocos años en señores de Alcalá de Guadaira y Constantina (1258); Cazalla, Brenes, Tercia, Umbrete y Solúcar de Albaida (1260); Gelves (1272); Gelo (1274); Cambullón, Torre del Alpechín y Las Chozas (1277); Almochachar y Rianzuela (1278), y, finalmente, Almonaster y Zalamea (1279).

Con la excepción de las dos primeras donaciones -Alcalá y Constantina, dos villas pertenecientes inicialmente a la jurisdicción de Sevilla-, el resto eran aldeas o alcarias de poca importancia demográfica. Cazalla (hoy Puebla de Cazalla) debia tener muy poca población, aunque era villa de un cierto valor estratégico. Pero la más sorprendente de todas estas donaciones era la de Alcalá. Y es que resulta extraño que el rey desvinculase de Sevilla una localidad tan próxima a ella y de la importancia estratégica y económica de Alcalá. Por otra parte, la defensa de su castillo, el pago de los salarios de una guarnición permanente y la reparación de su fábrica eran algo que desbordaba la capacidad económica de a Iglesia sevillana. La única explicación plausible que se me ocurre para este hecho es suponer que Alfonso X estaba convencido de que ya no eran necesarias tantas precauciones defensivas, ya que Alcalá habia perdido su significación estratégica. Si éste fue el pensamiento del rey, los acontecimientos posteriores — la revuelta mudéjar de 1264, la guerra con Granada y la intervención en la misma de los benimerines- se encargarían de demostrarle dramáticamente que no estaba en lo cierto. 
La concesión de Alcalá a la Iglesia sevillana se nos ha conservado en un precioso privilegio rodado, fechado a 13 de septiembre de 1258, que se guarda en el Archivo de la Catedral de Sevilla. En sus primeras líneas el rey justifica la entrega de la villa y del castillo de Alcalá

por grand sabor que auemos de heredar e de fazer bien e onrra alla (sic) eglesia cathedral de Sancta María de la noble çibdad de SeuiIla, la que ganó e fundó el muy noble e much onrrado, el rey don Ferrando, nuestro padre, e nos con él, e le ganamos de moros e la poblamos de cristianos a seruiçio de Dios de de la Virgen Sancta María, e de la Eglesia de Roma...»

El privilegio reproduce las cláusulas habituales en documentos de esta indole. El rey entrega la plena posesión de la villa - «con todas sus entradas e con todas sus salidas... con montes, con ríos, con pastos e con todos sus términos poblados e por poblar...»-, con sus rentas y derechos al cabildo de la Catedral de Sevilla. Como era norma, el rey se reserva el impuesto de la moneda forera, la propiedad de las minas que pudieran descubrirse en el término y el señorío eminente de la Corona en cuestiones de ámbito supralocal - «que faga por nos guerra e pas»- y generales («que entre hy nuestro Adelantado, assi commo entra en todas las otras villas de la Frontera que son de las Ordenes e de les eglesias cathedrales").

El rey obliga a los nuevos señores a respetar las propiedades o heredamientos concedidos en Alcalá tanto por su padre como por él mismo. $Y$, al mismo tiempo, mantiene a Alcalá dentro del término o tierra de Sevilla, de forma que los vecinos de ésta y de su tierra, y los de Alcalá pudiesen seguir gozando de comunidad de pastos y aguas en sus términos respectivos. El mantenimiento de la vinculación con la ciudad se extiende también a los aspectos legales y jurídicos, aún reconociendo al cabildo de la Catedral la capacidad de nombrar en Alcalá alcaldes y alguaciles. Pero, en los demás Alcalá de Guadaira siguió rigiéndose por «el fuero de Seuilla, onde an el Fuero de los Juyzios" o Fuero Juzgo, estableciendo el rey como jueces de apelación o de alzada a los alcaldes de Sevilla.

Finalmente, Alfonso $X$ obligó al cabildo de la catedral hispalense a respetar a los moros que permanecian en la villa las capitulaciones y «pleytos que an connusco, assi como dizen las cartas que de nos tienen».

Con estas salvedades, el rey reconoce al cabildo plena autoridad en la villa y absoluta capacidad para instalar pobladores cristianos y recibir de ellos los impuestos que estableciesen, asi como los otros derechos que correspon- 
dían anteriormente al rey, dejando naturaimente a salvo el señorio eminente de éste, expresado en las limitaciones mismas de la concesión.

\section{SEGUNDA REPOBLACIÓN DE ALCALÁ}

No se sabe con exactitud cuándo dejó de pertenecer Alcalá de Guadaira al señorío de la catedral de Sevilla. Es probable que Alfonso $X$ recuperase para el realengo la villa y el castillo a raíz de las incursiones benimerines iniciadas en 1275 (23). Podriamos, incluso, suponer que fue el propio cabildo catedralicio quien renunció a la responsabilidad de mantener en tan difíciles circunstancias la defensa del alcázar alcalareño. En cualquier caso la devolución se hizo, que sepamos, sin compensaciones de ningún tipo. Ello explicaria la ausencia de documentos que permitan fechar el acontecimiento. Desde luego, en 1279-80 la defensa de Alcalá y de su castillo estaba a cargo del concejo de Sevilla, según veremos más adelante.

Las razzias de los benimerines, que se prolongaron en la zona sevillana hasta finales del verano de 1277, debieron afectar gravemente al poblamiento de Alcalá de Guadaira. Sabemos, en efecto, que los alrededores de Sevilla y la comarca del Aljarafe fueron saqueados ferozmente en agosto de 1277. El cronista Ibn Abi Zar afirma que los marroquies tomaron al asalto los castillos de Cantillana, Guillena y Alcolea, destruyendo sus fortificaciones, y que incendiaron las casas y castillos del Aljarafe (24). Parece probable que, tras estas incursiones, la población de Alcalá quedase reducida casi a la guarnición que defendía su castillo.

Así las cosas, a fines de 1277 se produjo la intervención personal de Alfonso $X$ para remediar el estado de despoblación y abandono a que había llegado Alcalá de Guadaira. Para restaurar la villa, el rey ordenó una nueva repoblación de Alcalá. La operación formaba parte de otra más compleja tendente a reestructurar el sector fronterizo sevillano con el reino de Granada, el más trágil de toda la frontera. Años antes, a raíz de la revuelta mudéjar, Alfonso $X$ había decidido dar mayor participación a las Órdenes Militares en la defensa de la línea fronteriza. De esta forma, en 1264, la Orden de Calatrava recibió Osuna, con el encargo de trasladar a esta villa el «convento mayor» de la Orden que estaba, como es sabido, en Calatrava la Nueva. Tres años más tarde, la Orden de Santiago recibió la importante plaza de Estepa. Ahora, tras el fracaso de Alfonso $X$ ante los muros de Algeciras y la amenaza de nuevas incursiones de los benimerines, habia que completar la militarización de la frontera. Fue así como la Orden de Alcántara recibió el encargo de defender los castillos de Morón y Cote, y la de Calatrava, el de Cazalla. Sólo 
faltaba reforzar la posición de Alcalá de Guadaira, verdadero antemural de Sevilla y punto hacia el que convergían todos los caminos de penetración desde la frontera.

Desde esta perspectiva podemos entender sin dificultades la compleja operación a tres bandas emprendida por el rey en diciembre de 1279. El 15 de dicho mes la Orden de Calatrava recibía la villa y castillo de Cazalla, que pertenecia a la Iglesia de Sevilla desde 1260, a cambio del lugar de Cerraja y los demás heredamientos que la Orden poseia en término de Alcalá de Guadaira, con la excepción de los molinos. Al día siguiente Alfonso $X$ otorgaba al cabildo de la catedral de Sevilla Almonaster y Zalamea a cambio de CazaIla. $Y$ el 11 de enero de 1280 el rey aprobaba el trueque efectuado entre el cabildo de la catedral y el concejo de Sevilla el día 4 del mismo mes, en virtud del cual aquél entregaba a la Orden de Calatrava Cazalla en nombre del concejo hispalense, y recibía de éste a cambio Almonaster y Zalamea (25).

En apariencia, el concejo de Sevilla obtuvo una pobre compensación: Cerrajas a cambio de Almonaster y Zalamea. Pero, sin duda, la operación que hemos descrito significaba más de lo que la documentación indica. De entrada, con la disponibilidad de Cerrajes se conseguian más tierras para repartir entre repobladores y, de paso, se alejaba de Sevilla la posibilidad de que la Orden de Calatrava pudiese crear en torno a la finca un núcleo de población separado de la jurisdicción sevillana. Pero, además, mediante la instalación de Alcalá de un grupo reaimente importante de pobladores que asumiesen la tarea de vigilar la villa y defender su castillo. Sevilla se liberaba de la pesada carga que ello suponía para las arcas municipales (26). Y, por último, con la cesión al cabildo de la catedral de unos lugares hasta entonces dependientes de la jurisdicción sevillana se cerraba el paso a cualquier reclamación que en el futuro la Iglesia hispalense pudiese efectuar sobre Alcalá de Guadaira.

\section{LA CARTA-PUEBLA DE ALCALÁ}

La atracción de pobladores emprendida por Alfonso $X$ a finales de 1279 culminaría en mayo del siguiente año con la concesión a los pobladores de Alcalá de Guadaira de una carta-puebla. Este precioso documento ha desaparecido en su versión original y desconozco si en el Archivo Municipal de la villa o en alguna otra parte existe una copia del mismo. Por fortuna, el P. Leandro Flores publicó un amplio extracto del privilegio real, copiándolo de un Inventario de Papeles del Cabildo que se conservaba en el Archivo alcareño a comienzos del siglo pasado (27). 
La carta-puebla de Alcalá reviste la forma de un contrato entre el rey y los 150 pobladores que se pretendía instalar en la villa. Se trata, pues, de un típico contrato «ad populandum», redactado en forma de privilegio real, donde se consigna, por un lado, una serie de concesiones y exenciones hechas por el monarca a los pobladores, $y$, por otro, las obligaciones que en contrapartida asumen los que estaban dispuestos a instalarse en la localidad.

El primer dato de interés que nos ofrece el documento es el número de pobladores previstos para Alcalá: 150, cifra que, dadas las circunstancias, habría que cońsiderar como alta si la comparamos con los contingentes de pobladores asentados en otras localidades repobladas a mediados o a finales del siglo XIII (28).

El conjunto de pobladores recibió una serie de heredamientos, adquiridos expresamente para ser repartidos entre los nuevos repobladores: Cerrajas y, tal vez, las heredades que habian sido de Rodrigo Esteban, alcalde de Sevilla, Diego Alfonso, alcalde de Córdoba, y Nuño Fernández; o cedidas por el concejo de Sevilla, como la alcaria de Zahela, que había correspondido en parte al heredamiento de la ciudad en el repartimiento de 1253 (29); o, finalmente, propiedades que, por haber sido abandonadas por sus primeros titulares o por cualquier otra causa, pertenecian a la propia corona. La cartapuebla consigna con exactitud en casi todos los casos la ubicación, extensión y nombres de los anteriores propietarios de las tierras entregadas a los repobladores de Alcalá, tal como se refleja en el cuadro siguiente:

\begin{tabular}{|c|c|c|c|}
\hline ALCARIA & ANTERIOR PROPIETARIO & TIERRA DE LABOR * & OLIVAR * \\
\hline \multirow[t]{2}{*}{ ZAHELA } & Concejo de Sevilla & - & - \\
\hline & Don Rodrigo Álvarez & - & 830 \\
\hline FOXAT & Don Rodrigo Álvarez & - & 1.200 \\
\hline CERRAJAS & Orden de Calatrava & 20 & 1.000 \\
\hline BENABORRA & Orden de Calatrava y de & 16 & - \\
\hline ONRRATA & Santiago & 6 & - \\
\hline \multirow[t]{2}{*}{ LERENA } & Antón de Farias & 4 & - \\
\hline & Per Ibáñez de la Calzada & 3 & - \\
\hline \multirow[t]{3}{*}{ BENAGIRA } & Hijo de Pedro de la Calzada & 3 & - \\
\hline & Esteban de Ferrera & 6 & - \\
\hline & Gutierre Pérez & 6 & - \\
\hline \multirow[t]{2}{*}{ CORTIGENA } & Hijos de Martín Meléndez & 12 & - \\
\hline & TOTAL ....................... & 79 & 2.030 \\
\hline
\end{tabular}


Algunas de las personas reseñadas figuran en la documentación, como el alcaide don Rodrigo Álvarez, que había recibido en el repartimiento de Sevilla la alcaria de Foxat o Frostad, la mitad de la de Zahela, con 300 aranzadas de olivar, un cortijo y una torre, y 220 yugadas de tierra de labor entre Gandul y Marchenilla. Esteban de Ferrera y Martín Meléndez fueron caballeros hidalgos heredados en Sevilla con los 200 caballeros de linaje establecidos por Alfonso $X$ en la ciudad (30). Por desgracia el documento extractado por el $P$. Flores no permite valorar la entidad de las propiedades de olivar, higueral, tierras de pan y huertas que poseian en Alcalá los alcaldes de Sevilla y Córdoba citados en el texto, y Nuño Fernández, que bien pudiera ser uno de los varios caballeros hidalgos que figuran con este nombre en el libro del repartamiento de Sevilla (31).

Además de estas heredades, Alfonso X otorgó a los repobladores de Alcalá exención total de pechos, pedidos y préstamos, hospedaje y facendera, como era normal en muchas localidades de frontera.

En contrapartida, los repobladores se comprometían individualmente a participar en las velas y atalayas del castillo y en la vigilancia del Arrabal, morando «en el castillo con vuestros cuerpos». Más aún, para garantizar tanto la repoblación de la villa como su defensa, los repobladores se comprometieron a no disponer de los heredamientos recibidos hasta pasados seis años. La única excepción que contempla el privilegio alfonsí es en el caso de que el titular del heredamiento cayese cautivo de moros. En tal supuesto, podía disponer de sus bienes, pero siempre que el comprador se comprometiese a hacer vecindad en la villa, cumpliendo de esta forma los servicios y prestaciones militares a los que estaba obligado el vendedor. 



\section{NOTAS}

(1) Sobre la conquista de Andalucia ver J. GONZÁLEZ, «Las conquistas de Fernando III en Andalucia", Hispania, 25 (1948).

(2) Primera Crónica General de España; ed. R. MENÉNDEZ PIDAL, Madrid, 1955, cap. 1071, p. 747. "Ocho meses moro y el rey don Fernando en Jahen desque la aouo ganada..."

(3) Todo hace suponer que la conquista de Alcalá se afectuó en 1246. Y, aunque la Crónica General fecha los acontecimientos en 1247, sabemos que cuando se inició el cerco de Sevilla en el verano de dicho año, el rey salió con sus huestes desde Alcalá, lo que indica que ya estaba conquistada.

(4) Jaén debió conquistarse a fines de marzo o a comienzos de abril de 1246. Un documento de 13 de abril aparece fechado "Eo videlicet anno que rex Granate factus est vassallus regis Castelle et osculatus est manu eius, et in signum domini Jahenni tradidit illi». Archivo Histórico Nacional, Órdenes Militares, Santiago, Alanje, cajón 52, n. 7.

(5) Primera Crónica General, cap. 1072, pp. 747-48.

(6) Ibid., p. 748.

(7) Ibid., p. 748, «Et estando alli el rey don Fernando en Carmona, veno y a el rey de Granada, su vasallo, con quinientos caualleros, quel venia a seruir. Et desque el rey don Fernando ovo talado et astragado a Carmona, mouio ende su hueste et fuese para Alcala de Guadaira; et los moros de Alcala, quando sopieron que el rey de Granada yua y, salieron et dieronse a el, et el dio luego el castiello a su sennor el rey don Fernando".

(8) Diego ORTIZ DE ZUÑIGA, Anales eclesiásticos y seculares de Sevilla, Madrid, 1795, aก̃o 1247,8 .

(9) Tomo estos datos de mi ponencia presentada al V Coloquio de Historia Medieval Andaluza (Córdoba, noviembre, 1986) en prensa.

(10) En 1253 el alcalde Abén Paxat había ya abandonado Alcalá de Guadaira, según consta en un documento en el que se alude a un molino "que tue de Hamet auén Paxat, alcayat que fue de los moros que fincaron en Alcalá de Guadayra". Edito el doc. en Diplomatario Andaluz de Alfonso $X$ (en prensa) n. 96.

(11) Cfr. J. GONZÁLEZ, Repartimiento de Sevilla (2 vols.), Madrid, 1951, Il, pp. 107-109. Doy el texto integro de este reparto en Apéndice I.

(12) En 1256 Alfonso X autorizó a don Rodrigo Gómez de Galicia a ceder a la Orden de Calatrava la alquería de Cerrajas, permaneciendo esta propiedad en poder de la Orden hasta 1279. Diplomatario Andaluz de Alfonso X, n. 170

(13) J. GONZÁLEZ, ob. cit, II. p.

(14) De todas formas, el rey entregó 175 ars. de olivar a cinco beneficiaros $=100$ ars. a Pedro González de Quesada y a su hermano Gutierre González; 30 ars. a Martín Muñoz; otras 
30 a Arias Pérez, botero, y 15 ars. a Juan Díaz, caballerizo del rey. Cfr. J. GONZÁLEZ, ob. cit., il, p. 155.

(15) En realidad el concejo de Sevilla recibió algunas alcarias más en el término de Alcalá. Se trata de lugares yermos que, en consecuencia, no fueron valorados por los repartidores. Entre ellos figuraban Giçirat Fisicar (J. GONZÁLEZ, ob. cit. II, p. 116) o Gezira Faxequit, según doc. de Alfonso $X$ de diciembre de 1253, que edito en Diplomatario..., n. 99 y Machar Abnalget (J. GONZÁLEZ, ibid.)

(16) Diplomatario..., n. 91. Estos molinos pasarían por donación de su primer titular a la reina doña Juana, quienes los legó a su hijo el infante don Luis. Éste, a su vez, los daria en 1262 a Garcia Martínez. Diplomatario..., n. 260.

(17) El primer propietario cristiano de estos molinos fue Garci Martinez, ayo de la infanta doña Leonor. Lindaban con los molinos de Abén Haro'a y con los de Luet y Alcaxur, "que muele de una fuente». Diplomatario, n. 96.

(18) Diplomatario, n. 121.

(19) Ibid., n. 151. El puente aqui citado podría ser el de al-Qantara Talalhuat o «Puente de las Tablas», citado en un doc. de 1263. A. BALESTEROS, Sevilla en el siglo XIII. Madrid, 1913, ก. 126.

(20) Diplomatario, nn. 448 y 454

(21) Ibid., n. 80.

(22) Los datos que siguen proceden de mi artículo «Propiedades y:rentas territorales del cabildo de la Catedral de Sevilla a fines de la Edad Media", Cuadernos de Historia, Anexos de la revista HISPANIA, 7 (Madrd, 1977), pp. 177-178.

(23) Cfr. Ibn ABI ZAR, Rawd al-Qirtas, trad. de Ambrosio HUICI MIRANDA, vol. II, Valencia 1964, p. 592 ss.

(24) Ibid., pp. 611-612.

(25) Todos estos documentos se editan en mi Diplomatario, nn. 448, 449 y 454 . Los dos últimos (concesión de Zalamea y Almonaster al cabildo, y aprobación del trueque de Cazalla por los dos lugares citados) fueron editados por A. BALLESTEROS, ob. citada, nn. 221 y 223.

(26) En el acuerdo entre el concejo de Sevilla y el cabildo de la catedral, de 4 de enero de 1280, aquél reconoce que uestos heredamientos (se refiere a los que la Orden de Calatrava poseia en término de Alcalá) nos dieron a nos pora poblarlos e darlos a pobladores de Alcalá de la lazería e de la coyta e de la costa pora siempre iamás de la guarda de Alcalá de Guadayra, e del destaio e de las escuchas escusannas que nos auiemos de pagar cada annon.

(27) P. Leandro José de FLORES, Memorias históricas de Alcalá de Guadaira, Alcalá de Guadaira (Excmo. Ayuntamiento), 1983, pp. 33-34. Ofrecemos nuestra versión en Apéndice II.

(28) Cfr. M. GONZÁLEZ JIMÉNEZ, En torno a los origenes de Andalucia. La repoblación del siglo XIII. Sevilla 1980, pp. 50-53. Zahela.

(29) Como indiqué más arriba, don Rodrigo Álvarez había recibido 300 ars. de olivar en

(30) Esteban de Ferrera, Repartimiento de Sevilla, II, pp. 133 y 227. Martín Meléndez, ibid., pp. 130 y 227. En el Archivo Municipal de Sevilla, Sec. tÇ, carpeta 1, n. 1, se conserva el privilegio de Alfonso $X$ concediendo a este caballero heredamiento en la ciudad. Edito el doc. en $\mathrm{Di}$ plomatario, n. 18.

(31) Repartimiento de Sevilla, II, p. 434. 


\section{APÉNDICE I}

1253

Repartimiento de la alcaria de Borgalhamar.

J. GONZÁLEZ, Repartimiento de Sevilla, II, pp. 107-109

Borgalhamar, ques de término de Alcalá de Guadaira; en que avía 3.000 pies de olivar e de figueral para 8.000 seras de figos, e por medida de tierra 1.100 arançadas.

Dióla el rey, que la tenía para sus galeas, a estos amocadenes e a estos almogávares que aquí sonescritos, en cambio del heredamiento que le/s/ diera el rey don Fernando, con su carta plomada, de Alcalá de Guadaira, desta guisa:

- al almocadén, dos yugadas de bueyes anno e vez, e dos arançadas de vinnas, e arançada e media de huerta, e tres arançadas de olivar;

- al peón una yugada de bueyes, anno e vez, e dos arançadas de vinnas, e una de verta e dos de olivar.

E todo esto montava 60 yugadas de bueyes, ann e vez, e 60 arançadas de vinnas, e 60 arançadas de vinnas, e 50 arançadas de olivar, e 60 pares de casas en Alcalá.

E dióles el rey don Alfonso esta aldea por este heredamiento a su ventura en donadío.

(1) Domingo Sancho, almocadén, es heredero con estos 15 peones:

- Juan de Bardía

- García Navarro 
- Juan Pérez de Alvires

- Pedro Gil de Segura

- Pedro de Agreda

- Martín Domínguez

- Mingo Negrillo

- Miguel García

- Juan de Agreda

- Per lbáñez de Alcaraz

- Aparicio de Alcaraz

- Don Gil de Ellón o Ello

- Juan Martínez de Segura

- Martín Rodríguez de Martín Pérez

- Mateo de Olvera

(2) Heredó el rey a Miguel Pérz de Alcaraz, almocadén, con estos peones:

- Gonzalo de Quesada

- Yagüe de Cuéllar

- Juanes de Baeza

- Juan Pérez

- Pedro Garcia de Tordehumos

- Martín Muñoz

(3) Heredó el rey a Domingo Perez, almocadén, heredero de Domingo Blanco, con estos 6 peones:

- Domingo Martín de Molina

- Don Gil, su hermano

- Martín de Huete

- Pedro García

- Vicente Miguel

- Domingo de Alarcón

(4) Heredó a Miguel de Vios e Ibros, almocadén, con estos 13 peones:

- Gil Pulgar

- Domingo Pérez

- Domingo Ibáñez de Ávila

- Domingo Martín de Alguinlas o Alguiulas

- Domingo Malatado

- Don Pascual de Cuenca

- Domingo de Segovia

- Rodrigo de Burgos 
- Domingo Pérez

- Pedro Ruiz de Zorita

- Domingo Pascual de Brihuega

- Martín Domingo de Ávila

- Fernando de Burgos

(5) Heredó a Esteban de Uclés, almocadén, con estos 11 peones:

- Bartolomé de Montamarta

- Bon Blanco

- Juan Pérez de Soria

- Pedro Macarena

- Martín, criado del adalid

- Domingo Ovieco

- Pedro Rodríguez, ballestero

- Domingo Gonzalo

- Bivas

- Blasco Miguel

- Domingo Miguel de Madrigal 
$\therefore$ 


\title{
APÉNDICE II
}

\author{
1280, mayo, 31, Sevilla
}

Alfonso $X$ otorga carta-puebla a los pobladores de Alcalá de Guadaira.

EDT. L. J. FLORES, Memoria Históricas de Alcalá de Guadaira, Alcalá de Guadaira 1983, pp. 33-34.

Extracto de un «lnventario de Papeles del Cabildo» que se conservaba en el Archivo Municipal de Alcalá.

Fecha la carta en Sevilla, viernes postrimero día de mayo, en era de 1318 /annos/"

Yo Millán Pérez de Aellón lo fice escribir por mandado del rey, en veinte e ocho annos que el rey sobredicho reinó. Juan Pérez».

(1) Alfonso $X$ concede a los 150 pobladores de Alcalá «todo el término de Alcalá de Guadaira», "olivares e figuerales e tierras de pan e huertas, le/ con lo que y á e huviere Rodrigo Esteban, nuestro alcalde de Sevilla, e con 10 de Diego Alfonso, alcalde de Córdoba, e con lo de Nuño Fernández».

(2) Les entrega las alcarias de Zahela y Frostad o Foxat, y «todo quanto á Cerrajes, alcaria arriba, que se tiene con lo que nos diemos a Arquier, nuestro criado, que es de alcaria ayuso».

(3) Les entrega además en Benaborra «o que tiene la Reina, que fue de la Orden de Santiago e de Calatrava", que ascenderia a unas 16 yugadas de tierra.

(4) En Onrrata y Lurena, 6 yugadas, y otras 4 que fueron de Antón de Faras, y otras 3 que fueron de Per lbáñez de la Calzada. 
(5) Les concede en Benagra, "que es de suso de Benaborra" lo que fue de Esteban de Ferrera y de Gutierre Pérz (unas 12 yugadas) y "de suso de Benagira», 6 yugadas que fueron del hijo de Pedro Garcia Barba.

(6) Por último, les da en Cortigena 12 yugadas de tierra de labor que fueron de los hijos de Martín Meléndez.

(7) Todos estos heredamientos los concede el rey «con sus entrada e con sus salidas, con montes e con pastos e con fuentes, e con todos sus términos, asi como siempre los hubieron en tiempo de moros".

(8) A cambio de estos heredamientos y por las franquicias y exenciones que el rey les hace, los pobladores estarán obligados a «velar cada año el castillo de Alcalá de Guadaira, e de no minguar vela ninguna de aquellos lugares acostumbrados de velar's.

(9) Además, deberían poner «montaraces de cada año, aquellos que entendiere el nuestro alcade que estuviere y por nos, que cumplan el atalaya de cada día en el castillo, e demás velar el Arrabal, según entendiere lque cumple/, e lo velen por siempre jamás en tal manera que moredes en el castillo con vuestros cuerpos".

(10) «Que non podades vender ni empeñar ni enagenar estos heredamientos que nos vos damos / si no seis años adelante de la era en que fue fecha esta carta /; e los seis años adelante, que lo podades / vender, empeñar o enagenar a quien vos quisiéredes", siempre que sea hombre que «quiera cumplir esto que vos / avedes a / cumplir»; y no sea hombre de Orden o religión.

(11) Si alguno de los pobladores muriese y dejase como heredero a un «fijo pequeño... que non sea de edad e non oviese quien lo cumplir, los otros que fincaredes vivos que vos paredes a servir por él fasta que los herederos sean de edad para servir, con los esquilmos de los heredamientos".

(12) «Otrosi, si por aventura si alguno fasta los seis años lo cautivasen que pueda vender este heredamiento para salir de cautivo a quienquier que faga vecindad en Alcalá e cumpla / el servicio / que él habia a cumplirs.

(13) «Et otrosi, por vos más bien e más merced, por este servicio que nos avedes a facer, que hayais la franqueza que han los vecinos de Sevilla, e que seais quitos e franqueados de todo pecho e de todo pedido e de préstamo, e de huéspedes e de toda facendera», y que hagan "vecindad con los vecinos de Sevilla, asi como los otros castillos de su término". 


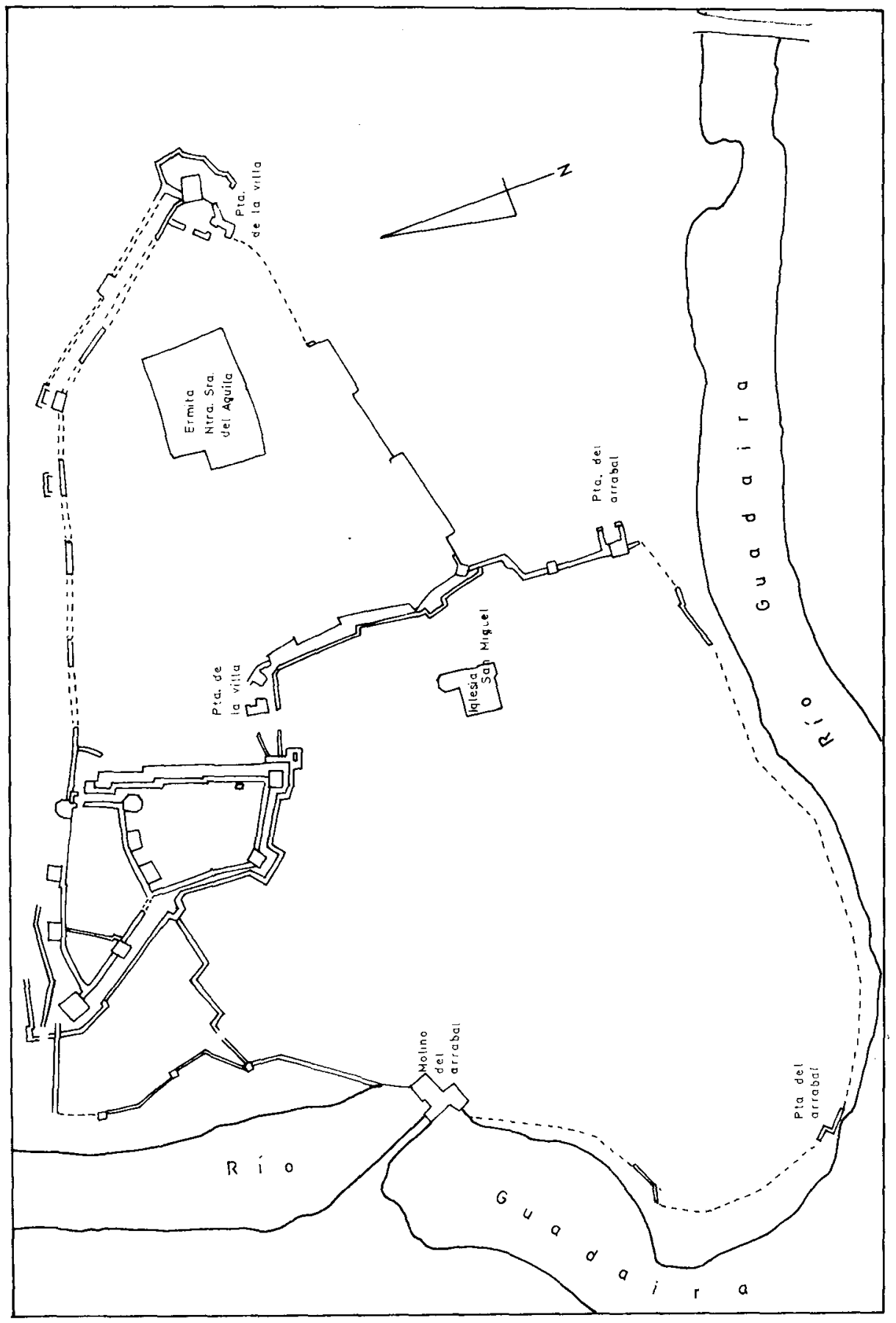




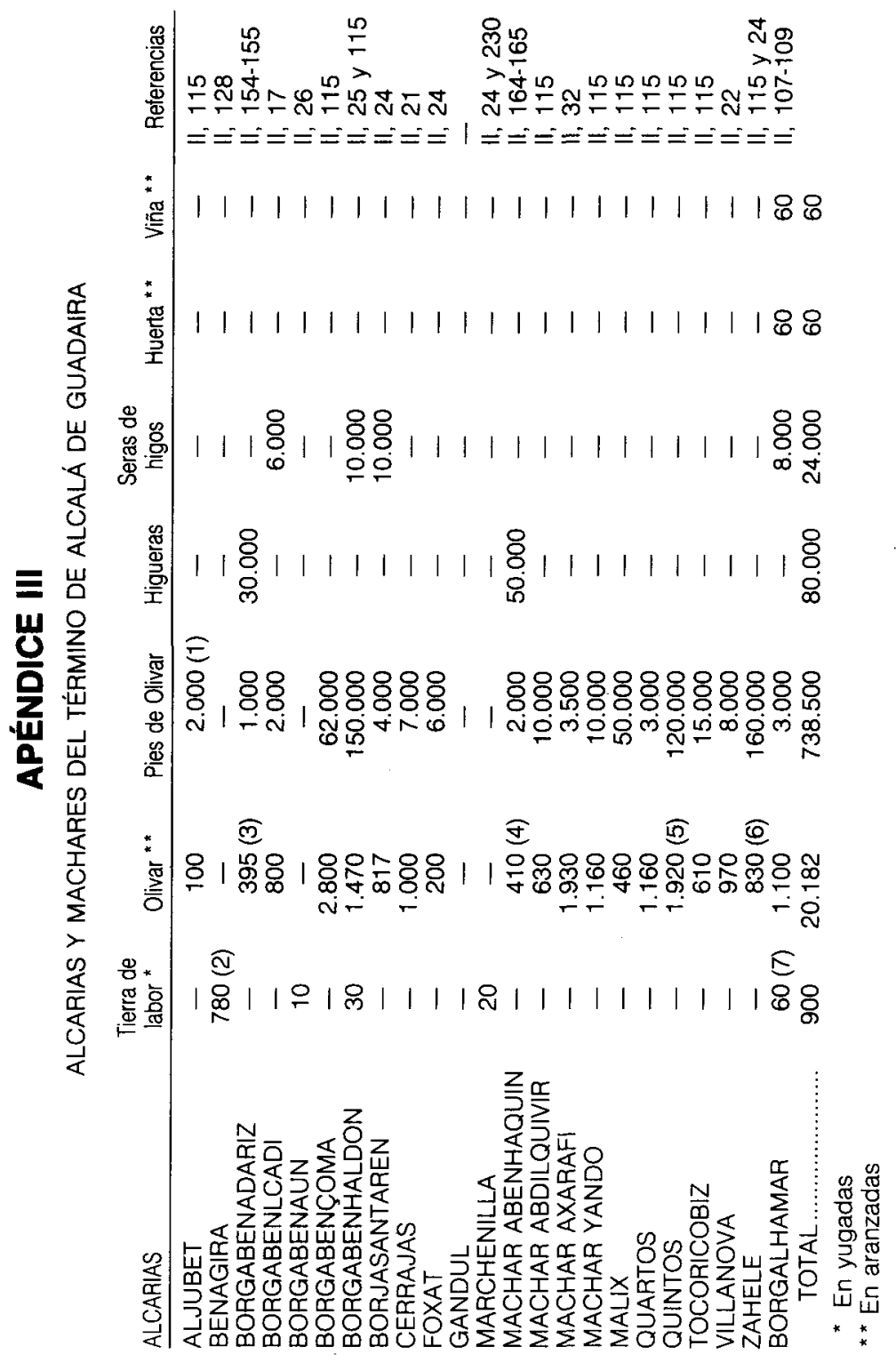

NOTAS:

(1) Olivar e higueral. Todas las referencias aluden al vol. II del Repartimiento de Sevilla, ed. por J. GONZALEZ.

(2) Se incluyen las tierras dadas en CORTIGENA, LA MEMBRILLA y otros lugares sin identificar. II, 207-225.

(3) Se computan 175 ars. dadas por el rey a diversas personas.

(4) Sólo se repartieron 337 ars.

(5) Se incluyen 100 ars. dadas a Guillén de Bec o Veque.

(6) Rodrigo Ávarez poseia la mitad de la alcaria, II, 115, 0, según otro pasaje (II, 24), 300 ars.

(7) No se indica con precisión la ubicación de las parcelas de tierra calma, viña y huerta. 


\title{
LA ECONOMÍA AGROPECUARIA ALICANTINA EN TIEMPOS DE ALFONSO X: APROXIMACIÓN A SU ESTUDIO
}

\author{
JOSÉ HINOJOSA MONTALVO \\ Universidad de Alicante
}

En la década de los años cuarenta del siglo XIII las tierras murcianas quedaban sometidas al protectorado castellano del infante don Alfonso, incluidos los términos de Alicante, Elche y Orihuela, posteriormente incorporadas a la Corona de Aragón (1). Pero se trataba de una soberanía nominal, de acentuado carácter militar, cuyo futuro no se veía muy claro, como lo demostró la revuelta mudéjar de 1264-65. A partir de entonces la situación dio un giro radical, de ciento ochenta grados, y la penetración cristiana fue total, encuadrándose el territorio en el marco feudal de la organización económico-social y política imperante en Castilla.

La evolución y transformación —en su caso- del marco económico de las tierras alicantinas fue un proceso lento, paralelo al del resto del reino de Murcia y que no se consolidará hasta principios del siglo XIV. Cada una de las tres localidades arriba mencionadas: Alicante, Elche y Orihuela, objeto de nuestro estudio, presenta una problemática peculiar, resultado de diversos factores, que va desde el propio ámbito geográfico en el que se sitúa - costa o interior, secano o regadío, etc. - hasta la coyuntura política del momento. Ello explica el desfase cronológico y la distinta función económica que ofrece Alicante frente a Elche y Orihuela. La villa alicantina, situada en un buen abrigo costero que posibilita el puerto, y con una importante fortaleza, era la avanzada castellana destinada a contener el expansionismo aragonés por el Sur del reino de Valencia, recién incorporado a la Corona de Aragón. Puerto y castillo marcarán el futuro desarrollo de la villa, en la que el comercio orienta y supera a la producción agraria. Desde 1246 en que queda bajo control de Castilla hasta 1252 la presencia cristiana en Alicante sería escasa, pero es 
a partir de ese año y durante el resto de la década cuando el apoyo real permite el nacimiento de la comunidad alicantina, desde la concesión de un Fuero y un término municipal, a la organización de la vida económica.

La importancia militar y económica de Alicante para el rey Sabio y su carácter de avanzada cristiana en el territorio que estudiamos es patente si lo comparamos con Elche y Orihuela, que no se organizan de manera definitiva hasta después de la revuelta mudéjar de 1265, y los modelos de Fueros y de organización local serán los de Alicante y Murcia, hacia las que se había volcado la actuación alfonsí.

Basándonos en la documentación del rey Sabio conservada y algunas monografías (2) - quedan privilegios inéditos- vamos a tratar de acercarnos en estas breves páginas a una visión conjunta de la economía de Alicante, Elche y Orihuela en el periodo que se extiende entre el protectorado castellano y la muerte de Alfonso $X$.

\section{AGRICULTURA}

\section{A) El paisaje agrario}

El paisaje natural que encontraron los repobladores en el momento de su instalación en territorio alicantino podriamos rastrearlo a través de la toponimia y de la documentación coetánea. Pero una y otra ofrecen dificultades. En el caso de la documentación, las escasas alusiones hacen dificil su reconstrucción, y otro tanto sucede con la toponimia, sobre todo la menor, ante la falta de estudios específicos sobre la zona. La reciente aparición de un volumen recopilando el listado toponímico de los municipios alicantinos (3) no ha aportado novedades al carecer de fechas indicativas de la aparición de estos topónimos, que, por otra parte, han sufrido desde el siglo XVIII un profundo proceso de castellanización, lo que hace más difícil la identificación de los propiamente medievales. Pero al menos es un instrumento de trabajo. Habría que profundizar en el estudio de la microtoponimia de cada uno de estos municipios y en un análisis a fondo de la documentación conservada.

El paisaje del territorio podría ordenarse en tres grandes marcos: el litoral, zona de marjales y albuferas; los grandes corredores de circulación, articulados en torno a dos ejes: el de Alicante-Elche-Orihuela-Murcia, donde se encuentra la mayor densidad de población y las localidades más importantes, y el del Vinalopó, que desde la Meseta permite el descenso al Mediterráneo, zona también bastante poblada y con ricos cultivos de secano; por último, las tierras del interior, montañosas, de dedicación ganadera y muy baja densidad humana. 
La franja litoral es posiblemente la que más destaque en las fuentes y la toponimia árabe confirma su perduración hasta nuestros días: almarjal, albufera, etc. Son tierras en las que la marisma y las charcas hacen muy difícil el asentamiento humano. De hecho, sólo Alicante merece citarse como población de importancia, situada por lo demás entre territorios lacustres: La Albufera y el Saladar. Las únicas menciones al paisaje natural que se hace en los primeros documentos son a estas albuferas y las salinas, cuyo aprovechamiento para caza, pesca y extracción de sal regula el monarca. Este paisaje continuaba a lo largo del litoral hasta la desembocadura del Segura y a lo largo de las márgenes del río. Un cordón de dunas separaba las albuferas y las tierras interiores del litoral. El topónimo Guardamar (río de las dunas) es el mejor ejemplo de esta realidad geográfica (4). La vegetación característica eran la mata, junco, sosa, barrilla, carrizo, etc. y la orientación salinera la principal fuente de ingresos. Los topónimos el Saladar, Salinas o Salinales, el Carrisal, el Almarjal, testimonian dicho paisaje lacustre.

En el pasillo Alicante-Orihuela vemos algunos topónimos expresivos de la vegetación autóctona, como: el Cañar, la Murta, el Palmeral -que ocupaba extensas superficies en todo este tramo, y que muy menguado aún puede contemplarse en nuestros días-, la Carrasca, la Pinada, Margallons, el Romeral, especies todas preferentemente de clima mediterráneo o subestepario. Lo que parece evidente es que ya por estas fechas la deforestación debía ser una de las características de este paisaje, al menos en árboles susceptibles de aprovechamiento industrial, y ante esta carencia Alfonso $X$ se vio obligado a eximir de peajes a los vecinos que trajeran madera a Alicante para construir sus viviendas (5), e igual sentido tenía la orden de Pedro III para que se autorizara el paso de troncos castellanos por el río Júcar con destino a construir los conventos franciscanos de Alicante y Murcia (6).

Para la cuenca del Vinalopó y comarcas aldeñas la toponimia nos ha dejado algunas noticias sobre el primitivo paisaje, en el que predominaba lo mediterráneo en la vegetación: Esparraguera, Ginebre, el Sabinar, el Madroñal, el Espino, etc. a la vez que aguas salinas dejaron también su impronta: les Salinetes, Charco Amargo, Agua Amarga, el Juncaret, etc. por no citar esa sorprendente formación geológica residual en el interior, el Arenal de Petrel. El libro de la caza de don Juan Manuel menciona abundantes espacios lacustres para la caza en Elda, Novelda, etc. a principios del Trescientos.

Pero los repobladores que acudieron a mediados del siglo XIII y en años posteriores no se encontraron con un territorio vacio, sino con un hábitat $y$ un paisaje que el hombre llevaba siglos transformando en su estructura agra- 
ria y urbana. De aquí se plantea una doble alternativa: la transformación del paisaje natural en paisaje agrario, y los cambios internos sufridos por ese propio paisaje hasta entonces en manos musulmanas, fenómenos ambos vinculados a la repoblación, y que sólo podremos conocer mejor a partir del estudio de la misma. Ahora nos limitaremos a una primera toma de contacto con la problemática.

La transformación del paisaje natural en agrario en estos primeros tiempos de asentamiento cristiano no es conocido. En principio cabe pensar que los lotes de tierras cultivados serian suficientes para satisfacer las necesida. des de los nuevos pobladores cristianos y no fuera necesario roturar tierras baldias y deforestadas en las márgenes, pudiendo dedicar éstas al aprovechamiento ganadero. Vilar, sin embargo, afirma que los cambios en agricultura «obedecerán a transformaciones en el régimen de propiedad y, sobre todo, la roturación de nuevas tierras", matizando más tarde que esa roturación se produjo al incorporarse estas tierras a la Corona de Aragón e incrementarse el número de habitantes (7). La toponimia no ha dejado huellas sobre posibles transformaciones de zonas incultas, tipo rozas, carboneras, etc. y el paisaje natural debió sufrir escasos cambios en estos años.

En cuanto a las modificaciones sufridas por el espacio cultivado no debieron ser muchas por cuanto los nuevos ocupantes no estaban en condiciones de llevarlas a cabo y prefirieron dejar las cosas como estaban, aprovechándose de las altas cotas alcanzadas por el agro musulmán, sobre todo en materia de irrigación, plasmado en la toponimia, y así, los azarbes, acequias, azud, aceña, etc. abundan por toda la vega del Segura. La eficacia del sistema estaba más que demostrada y no había ninguna necesidad de cambiarla. Algunos aspectos técnicos también se convirtieron en topónimos, como la partida La Tahúlla en Creviliente, pero son los menos.

Hay, no obstante, alguna noticia que nos habla de un deterioro del paisaje agrario, en zonas concretas como las márgenes del río Segura, resultado de una fuerte crecida de este río y el Guadalentín en 1258 que destruyó la Contraparada y alteró profundamente los sistemas de riego de Murcia y Orihuela, causando daños irreversibles. El agua dejó de circular por acequias y azarbes y el espacio de huerta disminuyó. «En las décadas de 1250 y 1260 fueron numerosos los paisajes que, reiteradamente invadidos por las aguas, se transformaron en marjales por falta de mano de obra experta en las fatigosas tareas del avenamiento. Su recuperación daría trabajo a varias generacioness (8).

La superficie cultivada se repartiría entre tierras de regadio y el secano, o como se indica en el documento de 1276 en que el infante don Manuel 
confirma las particiones de Elche: heredades, huertos, viñas, casas, olivares e higuerales (6). Es decir, un secano en el que predominan los cultivos mediterráneos: cereal, vid, olivo e higuera, estos tres últimos orientados no sólo hacia el consumo propio, sino hacia la exportación. No hubo, pues, ruptura brusca con el pasado.

El resultado es un paisaje agrario en el que en torno al núcleo de población se ordenan los campos de cultivo: huertas, allí donde el riego es posible, campos de secano y baldíos en los extremos, con una estructura de la propiedad mediana y pequeña en las huertas, y fundos de mayor extensión en el secano.

\section{B) Aspectos técnios agrarios}

De las técnicas de cultivo pocas noticias nos han llegado, aunque el binomio agriculura - ganaderia siguió siendo fundamental, disponiendo la cabaña de los pastizales naturales, rastrojeras y barbechos, siendo aprovechados sus excedentes como abono, prácticamente el único natural junto con los de las palomas.

En cuanto al instrumental técnico utilizado los datos son escasos, sobre todo porque no se ha conservado documentación municipal o particular de estos años, por ejemplo protocolos notariales, que a través de sus contratos o inventarios son los que suelen proporcionar las noticias más ricas en contenido. Hay que pensar que se utilizarían hoces, azadas, podones, trillos y otros instrumentos propios de los cultivos de secano. Los bueyes eran los animales más utilizados en las labores agrarias, y así lo vemos en un documento de 1261 en que se alude a los moros «que labraren con bueyes», aunque ignoramos el tipo de arado utilizado (10), siendo las labores lentas y poco profundas. La mula y el caballo no sustituyeron de manera definitiva al buey hasta el siglo XVIII (11). Ello, unido al deficiente abonado, hacia que los campos necesitaran frecuentes barbechos, siendo el sistema de año y vez el más frecuente.

Hay noticias de instalaciones agrícolas de carácter industrial, a tenor de la concesión hecha en 1258 a los vecinos de Alicante para poder construir molinos de viento, cuyo uso ignoraban los musulmanes alicantinos (12); quizá se relacione con una posible extensión de cultivo de cereales. Alicante prefirió dedicar sus tierras a cultivos especulativos, higos, vid para pasas y vino, o frutos secos, antes que a cereales, de escaso rendimiento y fáciles de importar. Un documento de 1271 confirma esta afirmación al afirmar que «ellos (se refiere a los de Alicante) non an tierra de pan sino poca", razón para que 
Alfonso $X$ ordenara al concejo de Elche que se les vendiera pan y vituallas cuando lo necesitaren (13).

Todos los historiadores del mundo agrario hacen hincapié en la relación existente en las economías preindustriales entre le crecimiento demográfico y el de la producción. Cualquier aumento de la producción ha de contar con un crecimiento humano y viceversa, a través de una expansión de los cultivos, una mayor productividad mediante la aplicación de mejores técnicas, o una especialización de los cultivos (14). En el período que estamos analizando las mejoras en las técnicas agrarias que comenzaron a extenderse por Occidente desde el siglo XI estaban ya plenamente difundidas, aunque con variaciones regionales, como era el uso del arado pesado o del caballo en lugar del buey, y no creo que de momento hubiera en las tierras de Alicante-Orihuela cambios espectaculares respecto al período musulmán en el instrumental, ni siquiera sabemos si la construcción de molinos de viento se llevó entonces a cabo. En el regadío, como veremos, se mantuvo lo anterior.

Respecto al crecimiento de la población está, por un lado la dinámica demográfica general a Occidente, según la cual los siglos XI al XIII fueron de aumento progresivo, aunque ya desde el último tercio del siglo XIII comienzan a apreciarse síntomas de crisis y el equilibrio población-subsistencias empieza a resquebrajarse. $Y$ éste es precisamente el marco cronológico que estudiamos: incremento demográfico pero dentro de una dinámica peculiar, que es la conquista y repoblación del reino de Murcia donde, ésto es fundamental, existía una importante población musulmana. Si la repoblación se hubiera hecho sobre un espacio vacio, el incremento de las fuerzas de producción representado por los pobladores cristianos se hubiera transformado automáticamente en un aumento de la producción, lo que también hubiera sucedido si estos repobladores se suman a la población musulmana. $Y$ aqui es donde radica el nudo gordiano de la cuestión: en el mantenimiento o expulsión de la población mudéjar, ya que de ello dependerá en buena parte el modelo económico-social que el territorio adopte en un futuro. Las posiciones son encontradas: Torres Fontes se muestra partidario de la despoblación y descenso del número de mudéjares y alejamiento de éstos hacia el campo (15), en tanto que para J. M. del Estal «está fuera de duda que no se dio la evacuación masiva de toda la población mora» (de Alicante), basándose sobre todo en criterios demográficos, económicos y políticos que aconsejaban su permanencia (16), aunque reconocen que la rebelión mudéjar debió originar una mayor salida de musulmanes hacia Granada y el Magreb. Pero no analiza el tema de la producción agraria. Sí lo hace, aunque marginalmente J. B. Vilar, quien afirma que será en el siglo XIV cuando se rebasen por primera vez 
los niveles de cultivo y producción de la época anterior a la conquista, hundidos por efecto del éxodo parcial de los mudéjares tras el derrumbamiento del estado musulmán y por el escaso número de repobladores que vinieron (17). El paralelismo con el modelo andaluz, donde, sin embargo, la emigración musulmana fue masiva, es claro.

Lo que parece estar fuera de toda duda es la perduración masiva de la población mudéjar en el área Orihuela-Alicante, sobre todo en el mundo rural donde era el elemento de trabajo básico; en el Valle del Vinalopó, por ejemplo, los cristianos apenas tuvieron fuerza demográfica hasta el siglo XVIII, tras la expulsión de los moriscos. Sin embargo, a partir de 1265 hay un predominio cristiano en las ciudades, quedando marginados los mudéjares en morerías.

¿Autoriza ello a hablar de un hundimiento de la producción tras la reconquista y repoblación del territorio, similar a lo que sucedió en Andalucia? Creo que no, al menos de una manera masiva. En cualquier caso nos movemos siempre en el terreno de las puras hipótesis, porque ni sabemos cuál era la demografía ni la producción en la etapa musulmana, ni cuántos ni quiénes fueron los supuestos emigrantes tras los sucesos de 1264.

En principio, en Orihuela nada cambió hasta 1265 y las disposiciones posteriores de Alfonso X se encaminaban a mantener la situación o a mejorarlas. Cierto que hubo problema, sobre todo de tipo técnico con los riegos, ya que muchos de estos repobladores procederian de regiones poco habituadas a ellos, y así vemos que el monarca concede en 1271 a los dueños de norias y aceñas la tercera parte del tercio real del diezmo para su reparación, ya que «les costava mucho en fazerlas et en tenerlas endreçadas» (18). Pero en el otro fiel de la balanza encontramos signos positivos, y en esa misma fecha (20-VIII-1271) reconocia y autorizaba todos los incrementos hechos por los vecinos en sus heredamientos «assi como en açarbes o en almarjales o alvar o ryo" (19). Dos años antes, 1269, creaba un mercado en la villa, garantizado así los indispensables circuitos comerciales entre productores y consumidores.

En Elche, los privilegios del infante don Manuel a los pobladores, coincidentes cronológicamente con los oriolanos se orientan en el criterio de mantener los niveles agrarios anteriores a la guerra, sobre todo los riegos y la población mudéjar. El privilegio de Alfonso X en 1271 - similar al de Orihuelapara que todos pudiesen hacer mejoras en sus propiedades y fronteras apunta hacia un crecimiento agrario (20).

En Alicante, las preocupaciones reales son más antiguas, y ya en 1252 disponía que los mudéjares del término uan de tener todos estos términos so- 
bredichos bien poblados", lo que implicaba mantener la producción agrícola. Y para estimular los rendimientos de una agricultura con vocación comercial, en 1257 exime a los vecinos de pagar el dinero de plata que le daban por los higos y pasas que recogían en sus heredades, y que, junto con el aceite, era su principal riqueza, según confesaron los enviados del concejo al rey en noviembre de 1269. Nada hace pensar en una crisis de producción, y las medidas liberalizadoras del rey Sabio en 1269 para el comercio de estos artículos serían un estímulo que vivificaría el campo alicantino.

Creo que puede decirse que no hubo una caída masiva de la producción, debiendo destinguirse la comarca de Alicante, con una agricultura de secano dinámica, competitiva y orientada a la exportación, cuyo nivel cristianos y musulmanes estaban interesados en mantener. En Orihuela, los problemas hidráulicos planteados a los repobladores y la emigración musulmana - difícil de evaluar en cifras - debieron causar una crisis de adaptación en los años posteriores a 1265, iniciándose pronto el camino de la recuperación con las medidas proteccionistas de la realeza y el propio esfuerzo de los colonizadores que fue ganando al "ager» terrenos hasta entonces insalubres.

En la zona Alicante-Orihuela el agua ha sido y sigue siendo el elemento clave en torno al cual gira gran parte de la agricultura. Conviene, pues, que hablemos algo de estos regadios de la época alfonsí. A modo de consideración general digamos que habría que hacer una doble distinción entre las comarcas huertanas, como la Vega del Segura, y aquellas en las que el riego ocupa una posición secundaria, caso del Camp d'Alacant, utilizando aguas foráneas. Ello se plasma en el paisaje agrario en una banda de riegos en sentido Norte-Sur, entre Alicante y Orihuela, cuyo gradiente de intensidad se orienta en dicho sentido, y en el que Elche juega un papel intermedio. La documentación refleja la importancia que en aquellos momentos tenía el regadío para estos concejos, contrastando la parquedad de noticias de Alicante con las muy abundantes de Elche y Orihuela. En Alicante, las aguas para el riego procederian en su mayor parte de fuera del término municipal, aunque no sabemos cómo se dispondría su uso en estos años. La desaparición del Archivo Municipal de Alicante de un volumen referente al reparto de estas aguas y a su aprovechamiento impide solucionar, de momento, la cuestión.

De Elche y Orihuela hay testimonios, y todos ellos apuntan en el mismo sentido: la preocupación por la monaquía -o en el caso de Elche de su señor- por conservar y mejorar, si era necesario, estos sistemas de riegos heredados de los musulmanes y que eran una de las piezas clave del sistema económico de la zona. Que los cristianos tropezaran con dificultades en los primeros momentos para adaptarse a unas técnicas y cultivos diferentes de 
los de sus comarcas de origen es evidente, pero también que éstas fueron superadas paulatinamente, a lo que contribuiría la permanencia de la población mudéjar con su experiencia secular en el agro. En otros casos, viejas instituciones musulmanas fueron adaptadas o sustituidas por otras a fin de garantizar el funcionamiento de este complejo sistema hidráulico.

Todo ello llamó ya la atención de nuestros eruditos y Pedro Ibarra Ruiz escribió una monografía sobre «Los riegos de Elche» (21), utilizando documentación conservada en el archivo municipal ilicitano. No vamos a detenernos en cada uno de ellos, sino a resaltar algunos aspectos que nos parecen interesantes. Por ejemplo, la separación existente entre la huerta de los cristianos y la de los musulmanes. A los primeros les corresponderían el diezmo del Franc, la huerta mayor, así llamada por estar francos de pechos, y el del Donatiu, en la partida de las Alquerías, quedando para los mudéjares el diezmo llamado del Magram, representando una sexta parte del término municipal (22). O la disposición de 5 de abril de 1268 para que el agua la tenga comunalmente el concejo, tanto la de Benicanal como la de otros lugares (23). En principio, la propiedad del agua era del señor, del infante don Manuel, quien dispone de ella en los repartos de tierra que se hacen, de modo que propiedad de la tierra y uso del agua marchen a la par. Como siempre, se trata de mantener la situación anterior, plasmada en la frase «según era en tiempo de moros".

La reorganización de la propiedad agraria supuso la del riego, y así en la concesión por el infante en 1276 de 10.000 tahúllas a los nuevos pobladores de Elche, al concejo le correspondió la cuarta parte, tanto de tierras como de aguas (24). Unos días antes, 20 de julio, al confirmar las participaciones dispuso que se trajera el agua desde Villena y que cada uno la tuviera según su heredad (25), lo que presupone la insuficiencia de agua local, quizá consecuencia del aumento de la superficie cultivada o de su transformación en tierras de riego.

En Orihuela la huerta fue objeto de la acción preferente de los repobladores, y contaba con una completa red de acequias matrices a ambas márgenes del Segura, ramificadas luego en azarbes y canales menores. De ellas merecen citarse la de Catral y Almoradí (26). La preocupación concejil y real por garantizar los regadíos fue patente en estos años, y en 1268 Alfonso $X$ confirmaba el acuerdo del concejo sobre las presas, o la concesión a los vecinos en 1271 de la tercera parte del tercio real del diezmo para poder reparar las norias y aceñas, posiblemente muy dañadas por la precedente revuelta mudéjar y las avenidas del río Segura. 
Desde el punto de vista institucional, la principal novedad es la creación del cargo de sobrecequiero en Orihuela a petición del concejo, que deseaba gozar de autonomía en cuestión de riegos con respecto a Murcia. En 14 de mayo de 1275 Alfonso X confirma en el cargo a Pedro Zapatero, elegido por sus convecinos, con autoridad sobre los demás acequieros y jurisdicción en cuestiones relativas al funcionamiento, conservación y mejora de los riegos (27). Era la culminación del proceso de reorganización del agro orcelitano, a medida que la consolidación de la repoblación requería unas ordenanzas precisas sobre el riego.

Pero un sistema tan complejo requería un esfuerzo colectivo para que toda la maquinaria funcionara a la perfección, lo que no siempre sucedia por la falta de colaboración de algunos vecinos en contribuir a los gastos de limpieza y mantenimiento de acequias y azudes, generándose una tensión social que llevó a la intervención real en 1271, por la que se autorizó al concejo a intervenir contra los infractores mediante el embargo de bienes e incluso la confiscación de la propiedad (28).

Esta institución del sobrecequiero la encontramos también en Elche -y cabe pensar que la hubo en Alicante-, siendo el oficio de duración anual y elegido por el concejo general, comenzando a desempeñarlo el 24 de junio, y siendo sus funciones entender y resolver todas las cuestiones pertenecientes a la acequia (29). El repartidor del agua tenía el cargo por arrendamiento y su misión era entender en cuanto convenía a la distribución del agua, realizada diariamente en la plaza pública.

El régimen de propiedad agraria tiene su origen en las particiones hechas tras la conquista, siendo difícil conocerlo en detalle por haber desaparecido o no estar publicados aún los libros de repartimiento (30). En el caso de Orihuela, que es el único conservado para tierras hoy alicantinas, los estudios se han centrado preferentemente en la mecánica del reparto, pero apenas se menciona la estructura de la propiedad. Se insiste, eso sí, en su carácter popular frente al sistema de gran señorío fronterizo que propugnaba Jaime I, pero apenas se recuerda el enorme donadío de Elche y otras tierras concedidas al infante don Manuel, que introducía una profunda cuña entre los concejos de Orihuela y Alicante. Régimen señorial que no puede calificarse de idílico a tenor de la revuelta antiseñorial que estalló en este dominio aprovechando la intervención de Jaime I en Murcia para someter a los sublevados mudéjares. La falta de espacio nos impide profundizar en el tema, aunque simplemente queremos reseñar que en las villas de realengo, Orihuela y Alicante, los repartos se hicieron en beneficio de los grandes, de los pode- 
rosos. Font Rius señala como fueron "caballeros, adalides y omes bonos de la villa» los encargados de realizar el tercer reparto en Orihuela (31), y ya Gisbert, a principio de siglo, recogiendo noticias del cronista José de Montesinos, al aludir al reparto de la parroquia oriolana de Santiago indicaba que la partición comenzó con la gente más noble, a los que se les dieron las tierras más cercanas a la población, las mejores, más fuertes y "con mas amenos huertos" (32). Todavía no se han formado los señorios oriolanos, pero los desequilibrios sociales nacidos del reparto de la propiedad están ahí y marcarán la pauta histórica del agro y de la villa de Orihuela.

\section{LA CAZA Y LA PESCA}

La caza ocupaba un importante apartado en la vida del campesino medieval, sobre todo desde el punto de vista de la dieta alimenticia, a la vez que era la diversión favorita de la nobleza. No insistiremos en ello, como tampoco en la riqueza cinegética de la región oriolana, tan bien recogia posteriormente por don Juan Manuel en su «Libro de la caza», en el que describe minuciosamente los parajes más ricos en caza y las principales especies (33). Las marismas costeras, los baldios interiores y las propias huertas de los alrededores de las poblaciones son el marco propicio para la actividad cinegética.

Consciente de su importancia, Alfonso X exime a los vecinos de Alicante del pago de cualquier derecho por razón de la caza, aunque, eso sí, se les prohibía el aprovechamiento de las albuferas, que se las reservaba el monarca en uso exclusivo (34), de forma similar a como Jaime I había hecho con la Albufera de Valencia, como futura fuente de ingresos y marco para expediciones cinegéticas reales.

De una política tan generosa en 1252 se pasa a un mayor controlen 1257 , y la anterior exención se transforma en la obligación de todos los vecinos de pagar al almojarife real los derechos por lo que cazaban (35). Pero el fracaso repoblador y las necesidades de abastecimiento obligaron al monarca a rectificar la presión fiscal y en 17 de julio de 1258 enfranquecía a los alicantinos del derecho de la caza, conforme al primer privilegio «que la non den en ningun tiempo por siempre jamas» (36).

Estas disposiciones estarían vigentes igualmente -al menos teóricamente - en Elche y Orihuela como consecuencia de la concesión de los fueros de Alicante y Murcia.

La pesca en las costas alicantinas es la de mayor riqueza de todo el litoral valenciano, y los siglos medievales no fueron una excepción, a pesar de 
los peligros que para los pescadores entrañaba la piratería. Cabe suponer que muchos mudéjares continuarán al principio desempeñando esta tarea, hasta ser suplantados por los cristianos, quizá tras la rebelión de 1264. Pero no sabemos ni la procedencia de estos pescadores, ni la estructura y organización de todo el proceso productivo, si bien a tenor de lo que sucede en la centuria siguiente se trataría de pescadores dueños de sus pequeñas embarcaciones, dedicados a la pesca en las aguas próximas al litoral. Cabe pensar que en el término de Orihuela algunas pesquerías fueran ya de propiedad concejil. El concejo orcelitano estuvo siempre muy preocupado por garantizar una regularidad en el abastecimiento del pescado a la urbe, y ya Alfonso $X$ intentó solucionarlo dando libertad de pesca a los vecinos y eximiendo de impuestos a los que llevaran el pescado al mercado (37).

Las disposiciones sobre pesca van siempre parejas a las de la caza y su evolución en cuestión de franquicias o tributos es idéntica en contenido. y fechas a las que arriba vimos sobre la caza.

\section{LA GANADERÍA}

La ganaderia en las comarcas de Alicante y Orihuela durante el período musuimán debió ocupar un lugar secundario (38). Pero una serie de factores permitieron que se estableciera una continuida con la gandería lanar musulmana, al igual que sucedió en el resto del reino de Murcia. Tales fueron las condiciones climáticas, la escasa densidad humana en gran parte del territorio, la emigración de mudéjares y subsiguiente abandono de tierras cultivadas, etc. que convirtieron la región en una importante reserva de pastos, en particular en los siglos XIV y XV, terminal de los ganados transhumantes castellanos $\mathrm{y}$ aragoneses.

Pero los comienzos debieron ser más modestos, sobre todo porque la falta de un control real de todo el territorio - sobre todo desde el punto de vista militar como del jurídico y sobre la propiedad del suelo, hacian del ganado una fácil presa ante ataques granadinos o mudéjares, a la vez que se dispondrían de escasos pastos. La política real de consolidación del territorio - desde la perspectiva humana y de la propiedad-debió producir un paulatino incremento de la ganadería cristiana, que se afirmaría a partir de 1265 , tras la pacificación del reino. Confirma esta impresión el hecho de que en los primeros privilegios concedidos por el rey Sabio a Alicante - spbre todo en los transcendentales de 1252 - se habla de comercio, caza, pesca, algo de agricultura, pero nada de ganadería, hasta enero de 1261 en que Alfonso $X$ exime a los vecinos de Alicante del pago del diezmo en Chinchilla, Murcia u otro lugar en razón de los ganados que trajeran para criar y para abasteci- 
miento (39). Podriamos considerar este documento como el intento real por organizar la cabaña alicantina, que tuvo escasa importancia en la economía local, frente al comercio y la agricultura.

De Elche no ha quedado ninguna noticia de este periodo, siendo las cuestiones agrarias, en particular el control del agua, el "leitmotiv" de la documentación. Para Orihuela hay, sin embargo, más noticias, y como antes indicaba, son de finales de la década de los sesenta las más antiguas. En $1268 \mathrm{Al}$ fonso $X$ deseando fomentar la cabaña local ordenaba - a instancias de las autoridades locales- que los almojarifes del reino de Murcia no exigieran impuestos a los ganados que venían de otros reinos. Es decir, pacificada la comarca, nos encontramos con una ganadera transhumante que utilizaba los pastos oriolanos como invernadero, y cuyo origen serian los reinos de Valencia, Aragón y las tierras castellanas de la Mancha. Una transhumancia que no creemos improvisada, sino posible herencia musulmana, al menos en los ganados valencianos.

La ganadería local, a menudo estante, era un importante complemento a la economía agraria, en un binomio habitual en el Medievo, sobre todo en las zonas del término dedicadas a cultivos extensivos. Junto al ganado lanar y cabrío, encontramos también la cría del ganado caballar, según se ve en un documento de 1274 en el que, a petición del concejo, se establece un acuerdo con García Martínez, dean y electo de la sede de Cartagena sobre el pago de los diezmos (40). Por otra parte, de los poseedores de potros y muletos. Qué importancia pudiera tener esta ganadería es desconocida, por cuanto el contenido de este documento puede considerarse de carácter genérico, y en 1275 vemos aplicar para Lorca y su concejo el mismo a acuerdo.

¿Qué especies eran las más abundantes y cuál era el número de esta cabaña? ¿Quiénes eran los propietarios? Preguntas por el momento de imposible respuesta, aunque a tenor de lo expuesto puede afirmarse que las extensas zonas yermas, aptas para pastizales, permitian aventurar un prometedor futuro a la ganaderia, tanto local como transhumante, lo que se consolidaría en el Trescientos. 


\section{NOTAS}

(1) Cfr. TORRES FONTES, J. Incorporación del reino de Murcia a la Corona de Castilla, Murcia 1973. VILAR J. Bta. Historia de la ciudad de Orihuela, tomo II. Orihuela musulmana, Orihuela 1976. DEL ESTAL, J. M. Conquista y anexión de las tierras de Alicante, Elche, Orihuela y Guardamar al Reino de Valencia por Jaime II de Aragón (1296-1308), Alicante 1982. Todos ellos recogen amplísima bibliografía sobre el tema.

(2) Cfr. Las obras fundamentales que hemos utilizado son las arriba citadas y Colección de Documentos para la Historia de Murcia (en adelante CODOM), por J. TORRES FONTES, J. I. Alfonso X el Sabio, Murcia, 1963. II Siglo XIII, Murcia, 1969; III. Fueros de Alfonso el Sabio al reino de Murcia, Murcia, 1973.

(3) Cfr. ROMÁN DEL CERRO, Juan Luis y Epalza, Mikel de. Toponimia mayor y menor de la provincia de Alicante. Listado de municipios, Alicante, 1983.

(4) Cfr. EPALZA, Mikel de. Guardamar («Río de las Dunas), Valdemoro («Rio amargo») y Mesieón («Posada de Fuentes»), tres topónimos árabes romanceados, I. D. E. A. 38, enero-abril, 1983. pág. 89-100

(5) Cfr. CODOM, III, documento n. ${ }^{\circ} \mathrm{XCVIII}$

(6) Cfr. CODOM, II, documento n. ${ }^{\circ}$ LXXVI.

(7) Cfr. VILAR, J. Bta. Historia de Orihuela, III, Orihuela, 1977, pág. 155-157.

(8) Cfr. VILAR, J. Bta. Historia de Orihuela, III, pág. 158. Si bien no dice las fuentes utilizadas para mantener tal aseveración.

(9) Cfr. CODOM, H, pág. 60. Archivo municipal de Elche. Libro de privilegios, fol. XXVI.

(10) Cfr. CODOM, III, documento n. ${ }^{\circ}$ LX, pág. 78. DEL ESTAL, J. M. Conquista y anexión, pág. 77 .

(11) Cfr. BERNABÉ GIL, David, Tierra y sociedad en el Bajo Segura (1700-1750), Alicante, 1982, pág. 69.

(12) CODOM, III, documento n. ${ }^{\circ}$ L. pág. 112

(13) Cfr. CODOM, III, documento n. ${ }^{\circ}$ Cll, pág. 112.

(14) Cfr. SCHILLER VAN BATH, Historia agraria de la Europa Occidental, pág. 20-23 BARRIOS GARCÍA, Ángel. Estructuras agrarias y de poder en Castilla: el ejemplo de Ávila. Salamanca, 1983, pág. 152 y sig. aplica estas hipótesis al territorio abulense.

(15) Cfr. CODOM, II, pág. XXXI.

(16) Cfr. DEL ESTAL, J. M. Conquista y anexión, pág. 53 y 73.

(17) Cfr. VILAR, J. Bta. Historia de Orihuela, III, pág. 157

(18) Cfr.CODOM, III, documento $\mathrm{n}{ }^{\circ} \mathrm{CV}$, pág. 114.

(19) Cfr. CODOM, III, documento n. ${ }^{\circ} \mathrm{CX}$, pág. 119.

(20) Cir. IBARRA Y RUIZ, Pedro, Historia de Elche, Alicante, 1895, pág. 57. 
(21) Cfr. IBARRA Y RUIZ, Pedro, Estudio acerca de la institución del riego de Elche, Madrid, 1914.

(22) Cfr. IBARRA Y RUIZ, Pedro, Historia de Elche, pág. 68-69.

(23) Cfr. CODOM, II, pág. 33.

(24) Cfr. IBARRA Y RUIZ, Pedro, Estudio acerca de la institución, pág. 91-92 CODOM, II, pág. 62 , documento n. $^{\circ}$ LXVI.

(25) Cfr. CODOM, II, pág. 60.

(26) Cfr. VILAR, J. Bta. Historias de Orihuela, tomo Ill, pág. 160. La de Catral se cita en textos musulmanes del siglo XII. La de Almoradí iba desde el Segura, a la altura de un portillo de la villa, a esa localidad.

(27) Cfr. A. Mun. Orihuela, Libro de privilegios, fol. 125. CODOM, III, documento n. ${ }^{\circ} \mathrm{CXXXVI}$, pág. 148. J. Bta. VILAR, Historia de Orihuela, tomo III, pág. 161-2.

ก. ${ }^{\circ} \mathrm{CXI}$

(28) Cfr. VILLAR, J. Bta. Historia de Orihuela, tomo III, pág. 163. CODOM, III, documento

(29) IBARRA Y RUIZ, P. Estudio acerca de la institución, pág. 152.

(30) Cfr. TORRES FONTES, J. Repartimiento de la huerta y campo de Murcia en el siglo XIII, Murcia, 1971; Repartimiento de Murcia, Madrid, 1960, FONT RIUS, J. M. El repartimiento de Orihuela, Homenaje a Vicens Vives, I, 1965, pág. 417.

(31) Cfr. FONT RIUS, J.M. El repartimiento de Orihuela, pág. 424.

(32) Cfr. GISBERT, Ernesto, Historia de Orihuela, Orihuela, 1903, t. III. pág. 48.

(33) Cfr. VILAR, J. Bta. Historia de Orihuela, tomo III, pág. 70-71.

(34) Cfr. CODOM. III, documento n. ${ }^{\circ}$ XIV, pág. 22.

(35) Cfr. CODOM, III, documento n. ${ }^{\circ} X L V$, pág. 61.

(36) Cfr. CODOM, III, documento n. ${ }^{\circ}$ XLIX, pág. 67.

(37) Cfr. VILAR, J. Bta. Historia de Orihuela, III, pág. 231.

(38) Cfr. VILAR, J. Bta. Historia de Orihuela, tomo III, pág. 186.

(39) Cfr. CODOM, III, documento LVIl, pág. 76.

(40) Cfr. CODOM, II, documento LX, pág. 56. 



\title{
LOS MUDÉJARES CONTESTANOS EN EL SIGLO XIII
}

\author{
JOAQUIN NAVARRO REIG
}

Centre d'Estudis Contestans

In memoriam frater meum

\section{INTRODUCCIÓN}

Con el avance del proceso repoblador hacia tierras meridionales, los cristianos van a encontrarse con una situación que les resulta nueva; deben, compartir su existencia con una masa numerosa de población musulmana. La convivencia de ambos grupos en un régimen de tolerancia mutua ha dado lugar a la acuñaciòn del término mudejarismo, aspecto éste que ha condicionado profundamente toda nuestra historia futura.

Isidro de las Cágigas (1948-9, p. 9-13, passim) pretende explicar su origen en la influencia política de los consejeros mozárabes de los monarcas cristianos. Excelentes conocedores del problema serán los que crearán el concepto sociológico y humano del mudéjar, recogiendo para ello una de las concepciones más hábiles de sus enemigos musulmanes, la doctrina coránica de protección, es decir la «dimma».

La valoración del fenómeno mudéjar no debe quedar reducida a su aspecto estrictamente religioso o racial, sino que donde alcanza su verdadera dimensión, no siempre comprendida, es en la problemática de las relaciones sociales intercomunitarias.

La raíz del mudejarismo valenciano hay que buscarla en las propias características de la conquista del reino. La caída de Valencia, Xátiva y Biar ante la presión armada aragonesa determinó a los consejos locales musulmanes a buscar una salida negociada a la crisis que les resultase lo más favorable posible. La corona, por su parte, interesada en atraerse a la población autóctona, más que enfrentarse con ella, le otorgó favorables capitulaciones 
a los residentes musulmanes que optasen por permanecer en sus hogares, lo que les permitía conservar una extensa autonomía a todos los niveles, después de la conquista. Gracias a estas capitulaciones que les concedian un amplio margen de libertad, muchos de los antiguos moradores decidieron permanecer en sus casas, conservando una parte de sus bienes; tan sólo una minoría, generalmente la clase más influyente, optaría por el exilio a tierras meridionales.

La revuelta de Al-Azracq imprimió un giro importante a la situación. Una parte importante de su población fue obligada a abandonar el reino y en su lugar empezaron a asentarse las primeras familias cristianas procedentes de los dominios aragoneses del norte y que abren, así, una nueva fase de mudejarismo interno.

Durante las primeras décadas, la dualidad cristiano-mudéjar llega a alcanzar un estado de equilibrio, dominando políticamente los primeros y numéricamente los segundos. Este equilibrio pronto se rompió en favor de los cristianos que impusieron su personalidad en este confuso mosaico de población (Barceló 1984, 92).

Lentamente la situación va evolucionando en el sentido de un mayor intervencionismo cristiano, alentado por la propia Iglesia de Roma y por la mentalidad de cruzado europeo. De este modo, los antiguos órganos municipales se fueron debilitando y perdiendo importancia. El contenido de aquellas favorables capitulaciones era una y otra vez pisoteado por unos y otros, convirtiéndose en letra muerta.

Esta degeneración de la situación originaria estimuló la emigración hacia el consolidado reino de Granada de las clases más relevantes de la sociedad mudéjar y tras éstos, siguieron su ejemplo, otros grupos importantes. La crisis económica y la propia política real incentivaron la emigración. Muchos perdieron o malvendieron sus tierras con lo que desaparecieron los únicos lazos que les ataban al solar de sus antepasados. Con la pérdida de sus propiedades, los mudéjares perdieron su independencia, y con la de sus líderes, su identidad cultural y religiosa que entró, a partir de ahora, en una fase de fanatismo cerrado (Torres Fontes 1961, 57-81). Acosados por los cristianos se verán obligados a vivir en un estado latente de rebeldía que será aprovechado por algún líder musulmán, más o menos improvisado, en su propio interés.

El peligro que esto representaba para la seguridad del Reino hizo que la corona no encontrase otra solución que su expulsión en masa, habida cuenta de que nadie pensaba, como factible, que esta minoría se convirtiera al cristianismo por el simple hecho de serlo sus señores, mas si tenemos en cuenta 
que la adopción de una determinada creencia no sólo tiene connotaciones puramente religiosas, sino que engloba todo el mundo cultural del invasor, o como diría R. I. Burns, del colonizador.

La medida, aunque lógica, era inapropiada en esos momentos. El problema radicaba en que no se disponía de los suficientes recursos humanos para sustituirles, por ello, los nobles, siempre atentos a defender sus intereses, adoptarán una postura de rechazo a la medida real de expulsión y la resistirán, amparándose, no sin razón, en las graves consecuencias económicas que dicha decisión conllevaba.

Sea por la oposición nobiliaria, sea por la imposibilidad real de ponerla en práctica, lo cierto es que la mayoría de los mudéjares permanecieron en sus hogares e iniciaron un largo proceso de relaciones con los cristianos en el cual van a ser los perdedores, ya que la fórmula de respeto mutuo habia muerto. Las causas pueden ser debidas a una falta de comprensión del problema mudéjar por parte de los cristianos, a lo que se sumaría una incomprensión del cambio de coyuntura, surgida tras la conquista, por parte de los mudéjares (Fernández y González 1866, 101 y ss.)

\section{ESTADO DE LA CUESTIÓN}

Resultaría del todo problemático el pretender estudiar tan peculiar fenómeno si nos ciñéramos exclusivamente a los datos proporcionados por la documentación local o foránea sobre el mudejarismo contestano. El Archivo de la Corona de Aragón cuenta con una vasta documentación al respecto (Burns 1981a, 453-498), pero se refiere a todo su conjunto y, por tanto, muy poco nos afecta directamente; por otra parte desconocemos los términos de la cartapuebla fundacional del arrabal contestano por Jaime I. Estas limitaciones obligan a aprovechar la documentación disponible procurando encuadrarla en el contexto general.

Sobre las consecuencias de la conquista cristiana para los mudéjares valencianos, las opiniones de los historiadores se han polarizado en torno a dos posiciones. Para Guichard $(1980,65)$ la ocupación cristiana del Reino de Valencia significó un duro revés, a todos los niveles, para los musulmanes valencianos, degradándose mucho más con el paso del tiempo.

Por otro lado, Roca Traver (1952, 115-208), Gual Camarena (1949, 165199), Burns (1981, 239-266), etc. consideran que la conquista no introdujo ningún cambio significativo en la vida de este pueblo sometido que pudo seguir libremente disfrutando de una situación de privilegio que resultaba envi- 
diable para gran número de cristianos. Con el tiempo este trato a favor irá siendo sustituido por otro de opresión, pero para ello habría que remontarse a las futuras generaciones. Creemos que las siguientes palabras de Barceló Torres $(1984,93)$ expresan claramente la realidad del momento: «La sociedad musulmana colonizada por catalanes y aragoneses en el siglo XIII fue objeto siempre del proselitismo cristiano. Desde las predicaciones hasta las ventajas económicas por la conversión, el musulmán caminó irremediablemente al bautismo forzado. Los acontecimientos le llevaron hacia el cristianismo y contra él. Sin embargo, el desarrollo de estos acontecimientos no fue uniforme, como era su distribución geográfica y poblacional. Alli donde constituian una minoría encerrada tras unos muros, las tensiones religiosas fueron mayores. Por el contrario, donde eran habitantes exclusivos su libertad religiosa pudo manifestarse de una forma más abierta y en cierto sentido más natural's.

Basan sus razones los defensores del continuismo en el estudio de las cartas-puebla, muchas de ellas publicadas por Gual Camarena, otorgadas a muchas comunidades mudéjares y en las que se observa un trato a favor, mucho mejor que el que disfrutaban durante la dominación almohade, pero «a pesar de ello, o quizá por esas circunstancias, y a pesar de la asimilación reciproca y pacifica convivencia de cristianos y mudéjares, una aversión profunda dividía a ambos pueblos. Este sentimiento fue, no sólo, más allá de actitudes convencionales o expresiones de desprecio mutuo, sino incluso más allá de la hostilidad que se podia esperar que provocarian las diferencias religiosas; ref́leja un antagonismo básico de culturas en una posición clásica de conflicto. Tal antagonismo tomó, finalmente, forma violenta en las revueltas y asaltos a las aljamas mudéjares que afectaron a todo el reino de Valencia hacia 1275. Estas revueltas, antes limitadas a unos pocos brotes localizados, y en conexión con el levantamiento de los mudéjares valencianos, se exten. dieron por todo el país, de Peñíscola a Cocentaina, durante varios meses, produciendo muchos años y tomando forma de levantamiento contra la política mudéjar de la monarquia» (Burns 1981a, 456).

Consideramos, en honor a la verdad, que la documentación oficial puede reflejar una situación que no siempre coincide con la realidad, por tanto somos de la opinión que desde el momento de la repoblación de las tierras conquistadas, los mudéjares debieron de empezar a sufrir los efectos negativos de su capitulación.

\section{CONTEXTO CONTESTANO}

La falta de referencia expresa en las crónicas sobre la conquista de Cocentaina hace preveer que su dominación no se produjo tras un enfrentamiento 
armado, sino después de una serie de contactos que desembocaron en su capitulación, previsión lógica si se tiene en cuenta la desaparición del poder central musulmán. Los musulmanes contestanos, abandonados a su suerte, faltos de recursos e incapacitados para reaccionar, ven en la capitulación la única salida viable a su delicada situación (Guichard 1980, 75).

La capitulación representa, para Gual Camarena (1949, 166), un compás de espera. Los mudéjares se consideran vencidos, pero no sometidos, $y$, por tanto, a la menor oportunidad se levantarán en armas contra los invasores (Furió y García 1983, 34).

Como consecuencia de las capitulaciones, la corona se avino a que los musulmanes contestanos tuvieren la facultad de poder elegir entre el exilio voluntario o permanecer en sus hogares «manteniendo intactas sus costumbres religiosas, jurídicas, sociales y de política locals (Burns 1981a, 453). Desgraciadamente la desaparición de la carta-puebla de la morería de Cocentaina nos impide hacer una valoración justa de su verdadera dimensión.

Los años anteriores a la primera revuelta debieron de discurrir al igual que la etapa anterior. Los mudéjares contestanos conservarían sus autoridades locales y su organización propia tal como la habían disfrutado hasta la fecha, incluso es posible que la tenencia de su castillo continuase en manos de su antiguo alcaide, a cambio de un juramento de fidelidad.

El alzamiento de Al-Azracq imprimió un giro radical a la situación. La conquista efectiva pasaba por el establecimiento de repobladores en estas tierras de frontera, los cuales empiezan a llegar a partir de 1248. Su número resultó insuficiente para el control de tan vasto territorio, más aún si tenemos en cuenta que su número real fue mucho menor. La llegada de éste y otros contingentes sucesivos se debió al señuelo de las concesiones territoriales que el rey otorgaba a todo aquél que estuviese decidido a establecerse en la villa. De esta forma se van a repartir las propiedades yermas o sin dueño y otras propiedades de las aljamas o residentes musulmanes. El cambio en la estructura de la propiedad, de comunal a privada, según Guichard (1980, 70) hirió de muerte los principios socio-económicos de la sociedad mudéjar y abrió un abismo entre ambas comunidades, que iria paulatinamente ensanchándose.

La llegada de los pioneros cristianos coincidió con la expulsión de los mudéjares decretada por Jaime 1 . Un total de unos 100.000 fueron los expulsados, la mayor parte de tierras de realengo. Guichard $(1980,29)$ considera que la población musulmana de Cocentaina se vio fuertemente afectada por 
la orden de expulsión y que su recuperación resultaría problemática. La documentación local no deja entrever nada que confirme tal afirmación.

La presencia cristiana en sus tierras hacía que el mudéjar se sintiese invitado en su propia casa, lo que hizo que se aferrase aún más en su propio pasado como forma de liberarse de ese intrusismo. A su vez, esa actitud hacia que el cristiano mostrase cierto rechazo hacia esa cultura y en esta situación, la convivencia no resultaba nada fácil, sobre todo para aquellos que tenian una mayor conciencia del problema que veían en la emigración a Granada o Tunicia la única salida válida. Todo ello no impide que la vida cotidiana se desenvuelva en constantes contactos entre ambos grupos, que si bien estaban separados por sus creencias y por otros motivos de índole material, las relaciones sociales y económicas permitieron que nuevas actitudes fueran transmitidas por ósmosis de una a otra comunidad (Burns 1975, 11).

Las interferencias culturales eran algo conocido por la Corona y la Iglesia. La convivencia y la libertad religiosa, en que se desenvolvía el vencido, podía generar algún caso de apostasía, por lo que la Iglesia dictó una serie de medidas tendentes a restringir la convivencia entre ambas comunidades religiosas, recogidas después en las órdenes reales (Barceló 1984, 94) con el fin de desalentar a las almas débiles. De este modo se conseguía detener el problema más no solucionarlo, ya que las causas permanecían inalteradas. Las insistentes cartas, como la recibida en Cocentaina el 11 de febrero de 1269 (Baño 1980) (Gual Camarena 1949, 170), en la que se prohibía la conversión al islamismo, habla por sí sola de la facilidad del contagio.

No se conoce en Cocentaina ningún caso de apostasía en los libros de la Cort de Justicia durante el siglo XIII, si bien, son muy pocos los conservados. El primero conocido data de 1303, durante la época turbulenta del asedio de Cocentaina por los «genets» granadinos; Joan de Vilaró fue condenado a la hoguera por haberse convertido al islamismo por dinero, después de abjurar el judaísmo y hacerse cristiano, disgustando seriamente a las autoridades esta actitud libertina del reo (A. M. C. 1303, 97).

Paralelamente a esta serie de medidas tendentes a evitar la influencia religiosa mudéjar, la Iglesia y la Corona unirán sus esfuerzos con el fin de estimular a los mudéjares a convertirse a la religión cristiana, otorgando al converso la igualdad jurídica con el cristiano y en el caso de esclavitud se le reconocía la libertad (Mateu y Llopis 1952, 39-43). La conversión interesada de muchos musulmanes obligará a las autoridades eclesiásticas y civiles a la adopción de algunas medidas restrictivas (Barceló 1984, 93).

Pero esta política de atracción del elemento mudéjar, necesaria para la buena marcha del reino, no contó con la colaboración de la población, de 
tal forma que si se producian conversiones, en ningún caso eran debidas a la vida ejemplar que llevaban los cristianos (Fuster 1962, 27) (A. M. C. 1277 , 25), sino al espejuelo de las ventajas sociales que la conversión conllevaba. Por todo lo cual, los cristianos desconfiaban de aquellos que abrazaban su religión, pue sabian que ésta era por conveniencia más que por convicción, por lo que se resistían a su integración dentro del ambiente cristiano (Barceló 1984, 93). Así, en vez de procurar formar el espíritu del converso, fue objeto de discriminación y malos tratos (A. M. C. 1277, 25), quedando el néofito en una situación de desamparo por parte de sus nuevos y antiguos correligionarios. Las quejas llegarán a oidos del rey que dictará severas medidas contra todo aquél que les hiciere deshonor (Aureum opus VI, Jaime II, XL).

Dentro de este contexto de rechazo-atracción se inserta el primer contencioso conocido de la villa contestana entre ambas comunidades. En 1269, el herrero Abdurhamet (A. M. C. 1269, 35v)acuerda con Bernat Busquet que su hijo permanecerá durante tres años en casa del primero como aprendiz. Apenas había transcurrido el primer año cuando el padre decide retirar a su hijo de casa del maestro en contra de la opinión de éste. La actitud del padre, violando lo acordado, hace que el herrero recurra ante las autoridades cristianas en demanda de justicia como era preceptivo (Barceló 1984, 47). Ante las mismas le acusa de incumplimiento de contrato. El padre reconoce el haber establecido un contrato de aprendizaje con el herrero, pero alega en su favor que ningún cristiano puede estar al servicio de un musulmán, por lo que según las leyes del momento el contrato de aprendizaje era ilegal (A. C. A. 38,72 ). La alegación del padre resulta sorprendente, pues sabido era que su hijo debía de convivir con el maestro durante el período del aprendizaje.

Parece evidente que la preocupación paterna por darle un buen porvenir a su hijo aprendiendo un oficio de tanto prestigio social (Hilton 1978, 41), se anteponía a una serie de prejuicios. El padre decide retirar a su hijo del proceso de aprendizaje, no porque considere incompente al maestro, sino presumiblemente por presiones sociales. La convivencia maestro-discípulo no debía resultar del agrado de la comunidad cristiana contestana y bastaría con cualquier nimio detalle para que sus convecinos viesen en ello la influencia nefasta de su maestro en materia religiosa. El fallo de la Cort de Justicia nos ha sido vedado, pero no debió de ser del agrado del maestro, pues a tenor de un acuerdo del consejo local el 29 de septiembre de 1275 (A. M. C. 1275 , 37), Abdurhamet debió de abandonar la villa hastiado por el tratamiento discriminatorio, pero reconociendo el consejo el inmejorable papel de sus servicios a la comunidad le concede las mismas franquicias fiscales que gozan los cristianos contestanos si se establecía de nuevo en la villa, también se le 
reconoce la posibilidad de tener hasta tres discípulos en su taller, siempre y cuando sean musulmanes. La oferta habla por si sola y nos hace ver la aparente libertad de movimiento de los mudéjares antes de 1275 y de la importancia económico-social del mudéjar cualificado (A. M. C. 1275, 37v) (Gual Camarena 1949, 171).

La vida fluía en Cocentaina dentro de una perfecta calma, que sólo se veía alterada por algún que otro acontecimiento como el narrado. La tolerancia hacia el vencido era la tónica general, pero hay que matizar que el mudéjar pagaba por ello un alto precio (Burns 1982, 397). La expansión económica y social de la población contestana se hará a costa de la minoría mudéjar. Los cristianos lentamente les irán usurpando sus menguados bienes, como si se pretendiese ensayar con ellos hasta donde llega su capacidad de resistencia (A. M. C. 1269, 40).

La presentación de los hechos de esta forma podría darnos una interpretación deformada de la realidad. Cocentaina está formada por dos demarcaciones urbanas bien claras: el arrabal y la «vila» (Navarro Reig 1985). La primera poblada por mudéjares considerados social y en otros aspectos inferiores; en la segunda, los cristianos, antítesis de la anterior. Los dos se complementan y se necesitan, son capaces de vivir en armonia y de enfrentarse, si llega el momento, pero, en el caso de producirse, los culpables de tales acontecimientos serán siempre los del arrabal. Esta situación tan peculiar no desaparecerá, ni con la conversión, ni con la expulsión, sino que es algo tan propio de esta villa que ha perdurado, aunque mitigado, hasta la actualidad.

Estas dos demarcaciones: social, psicológica y urbanísticamente diferentes, se relacionan mutuamente, pero dentro de unas condiciones de orden jerárquico.

Los cristianos aprovechan la experiencia mudéjar en el cultivo de la huerta, sus autoridades son consultadas e incluso llegan a pronunciarse jurídicamente en los problemas relacionados con el sistema de aparcería, incluso siendo uno de los litigantes cristiano; sus topónimos darán nombre a las partidas rurales; costumbres y vocablos serán asimilados de forma más o menos sensible; procuradores mudéjares representarán a cristianos y viceversa; compartirán el mismo rincón en la taberna, el mismo vino e incluso las mismas mujeres públicas, pese a lo que digan las disposiciones reales; los niños confraternizarán en el juego, sin ningún tipo de prejuicios, etc. (A. M. C. 1275, 4; 1277, 36, Burns 1981, 254).

Los mudéjares acuden en demanda de justicia ante la Cort, a pesar de tener su propio alcadí que entiende en los asuntos internos de la comunidad. 
La mayor parte de los litigios incoados ante la Cort de Justicia corresponden a mudéjares residentes en diferentes localidades. Intentar dar una justificación de esta actitud resulta problemática ya que oficialmente disfrutaban los mudéjares de un zalmedina, Abduluhabeb Albini, nombrado por la corona el 14 de julio de 1275 con jurisdicción desde Cocentaina sobre toda la Montaña (A. C. A. 20, 270v). Las únicas razones que podemos aducir es que o bien dicho cargo estuvo poco tiempo en ejercicio, siendo posteriormente suprimida dicha institución, o bien el justicia cristiano disfrutaba dentro del mundo mudéjar de una mayor autoridad. La Cort, por su parte, en ningún momento desatendió dichas demandas, sino todo lo contrario, dados los beneficios económicos que conllevaba, pero en las causas criminales fueron obligados a recurir ante el baile (A. M. C. 1275,4 ; 1294, 4; A. C. A. 19, 18; 13, 236).

El estallido de la segunda revuelta mudéjar va a acelerar el enfrentamiento entre las dos comunidaes. La coincidencia del movimiento con una crisis social en el seno de la comunidad cristiana, la aparición del bandolerismo y los excesos de las mesnadas concejiles y reales, van a poner al rojo vivo la convivencia entre cristianos y mudéjares.

Una fuerte sensación de inseguridad invadió a los cristianos, que temerosos de las «tornas" mudéjares abandonaron sus hogares en busca de lugares más seguros pese a las reiteradas amenazas de confiscación de bienes y destrucción de sus casas (A. M. C. 1276, 73).

interesante y muy esclarecedor de la realidad vivida en esos momentos es el bando Arnau Escrivá procurador general y baile de Valencia, ordenó publicar el 15 de julio de 1275 en su visita de esta villa y que transcribimos al castellano en las líneas siguientes (A. M. C. 1275, 37v):

1. Ordena a los habitantes de Cocentaina mantener y defender a los musulmanes del arrabal y a todo su término bajo penas corporales y económicas.

2. Se prohibe hacer comentarios en público sobre la guerra bajo pena de prisión.

3. Se prohibe a cristianos y musulmanes circular fuera de los caminos reales bajo pena de prisión.

$44^{\circ}$ Se permite a todos los moradores que puedan disponer del pan suficiente para sí y su familia, no en mayor cantidad, bajo pena de prisión y confiscación. 
5. ${ }^{\circ}$ Se recuerda a los vecinos la obligación de residir en la villa y en su defecto sea inscrito en los libros de la Cort.

6. ${ }^{\circ}$ Se insta a los «prohomens» de Cocentaina para que cuiden y mantengan a los musulmanes que vengan de Murcia y de Granada.

Si el miedo cristiano parece ser grande, no lo es menor el mudéjar, sospechosos de connivencia con los rebeldes. Su ganado sugre el expolio por los cristianos, pese a las reiteradas órdenes reales de protección y defensa de los mudéjares, el rey y sus oficiales se ven desbordados (A. M. C. 1277, 25).

No son sólo los bienes materiales los que están en peligro durante la revuelta, sino su propia integridad física. El caos reinante estimula a que grupos de desaprensivos o resentidos, residentes o foráneos, de forma más o menos improvisada, aprovechen la oportunidad para realizar excelentes negocios con el rapto de "moros de pau», es decir, mudéjares no sumados a los rebeldes, situados bajo la especial protección de la corona; y el asalto a sus aljamas, donde cometían todo tipo de excesos. Muchas de estas acciones no deben incluirse en los episodios de la guerra, pues el motor de estos acontecimientos lo constituye el problema social de enfrentamiento de los diferentes grupos cristianos surgidos con la repoblación, en donde los mudéjares sirven de válvula de escape para la tensión concentrada en las masas populares (A. M. C. 1276, 65 y 76).

La actitud de estas bandas hacia los pacíficos mudéjares no hacía más que complicar la situación, pues los más remisos se veían, de esta forma, alentados a tomar partido en favor de sus correligionarios de una forma más o menos encubierta: tráfico de vituallas, paso de información, cobertura para los rebeldes, etc. Todo ésto era bien conocido por las autoridades y por ello se tomaron las medidas oportunas. La documentación local rara vez alude al tema de la revuelta y si lo hace, emplea una forma indirecta (A. M. C. $1275,37 v)$.

Pese a las severas medidas reales para proteger a los mudéjares leales, éstos no van a verse libres de las acciones cristianas. La más célebre fue la de Berenguer Meler y Miguel de Valencia condenados, rspectivamente, a la pena capital y a la amputación de un pie, por su participación en el secuestro de un mudéjar de Bélgida, por el justicia de Cocentaina estando presente el propio Roger de Lauria (A. M. C. 1277, 27). Consecuencias mènos trágicas para sus protagonistas tuvo el asalto al arrabal contestano por los almocatenes castellanos que desde Murcia acudieron en ayuda del rey aragonés con el fin de reprimir la revuelta. Según el relato de un testigo presencial, éstos 
acordaron en la era situada extramuros de la villa asediar el arrabal y llevarse a sus tierras cuantos bienes y mudéjares pudiesen. El hecho, conodido por el rey, fue notificado a las autoridades murcianas con el fin de que reparasen el daño causado y se castigase a los infractores (A. M. C. 1277, 26v-27).

Aparte de estas acciones existen otras muchas de robos en la aljama y del apresamiento o rapto de mudéjares llevadas a cabo por los propios vecinos de la villa. En algunos casos el castigo por tales hecho era atroz, pero en la mayoría de los casos se limitaban a la confiscación de los bienes del raptor, aunque si se contaba con medios económicos y amigos influyentes se podía lograr fácilmente el perdón oficial (A. M. C. 1275, 55v; 1277, 24; 1278 , 50) (A. C. A. 23, 68v). Los peor tratados por la justicia fueron las bandas armadas que buscaban en sus acciones sólo el lucro personal y no la restauración de la autoridad regia.

La respuesta mudéjar a tantos desmanes no se hizo esperar. Al igual que los cristianos, formaron sus bandas armadas con el fin de capturar cristianos y venderlos como esclavos en tierras musulmanas. La identidad de intereses hace que unos y otros unan sus esfuerzos, en determinadas circunstancias, $\sin$ importarles las diferencias que les separaban. Los dos textos siguientes, que reproducimos en versión castellana, son lo suficientemente explícitos para comprender la realidad de la situación: "Guillem de Belcaire declara que al principio de la guerra se fue con Bernat de Limiñana, Bernat Savall, Pedro Pérez y Rodrigo, prendieron a cinco mudéjares, los metieron en una barca y los llevaron a Oliva, desde donde Limiñana y Savall los llevaron, junto con otros siete a lbiza. Pedro Pérez y Rodrigo, estando en Denia, oyeron decir que Limiñana estaba reclamado por la justicia, tuvieron miedo y se fueron, pasando tres semanas con Alcayd Mohamat, luego quince días en Pego, de aqui a Biar con Mohamat Alcbach y veinte mudéjares más, que tenian en una alquería de Penáguila a quince cristianos cautivos, matando a dos de ellos. De aqui, junto a un mudéjar, se fueron al castillo de Palma» (A. M. C. 1277 , 43). "Amet Aben Hibil confiesa que él, Noge, Monço, Mohamat Aben Hibil, su hermano Axir y Amet Al Rafa salieron del arrabal de Cocentaina con la idea de coger algún cristiano para llevarlo a la zona rebelde y cuando estuvieron en el higueral de Martín de Azagra, vieron dos cristianos, intentaron cogerlos, pero se les escaparon. De aquí se fueron a Planes y luego a Alicante, finalmente tomaron el acuerdo de ir a saltear al puerto de Albaida junto con otros seis compañeros" (A. M. C. 1277, 33v).

Mientras todos estos acontecimientos ocurrian, la revuelta iba debilitándose y la corona daba todo tipo de facilidades a los vecinos para realizar cabalgadas contra los que perseveraban en su rebeldía. Se determina la zona 
apta para el apresamiento de cautivos, se renuncia al quinto real, se liberaliza su tráfico, etc. (A. M. C. 1277, 18).

Al final tan sólo queda Montesa, con su caida los mudéjares entierran todas sus esperanzas. Ahora, desorientados, frustrados y faltos de confianza en sí mismos no les queda más que vegetar.

Un proceso curioso ilustra una vez más el sentimiento del pueblo vencido. El 20 de julio de 1277 Mohamet Alhoemi, hallándose en la taberna en claro estado de embriaguez, empezó a insultar al rey Pedro, llamándole traidor e indigno de ocupar el trono. Alarmadas las autoridades, es apresado y llevado ante la Cort. Alli declara que el rey había prometido a los mudéjares no talar sus campos de Montesa y poner en libertad a los prisioneros capturados durante la guerra, todo ello a cambio de un donativo de 14.000 sueldos. Cobrada dicha cantidad, no cumplió ni una cosa ni otra, pues su hermano, que se halla entre los prisioneros, aún está retenido en Valencia (A. M. C. $1277,23 v)$.

Mahomet ha tenido que recurir al vino para liberarse de la tremenda presión contenida en su interior. Sabe que las circunstancias han cambiado y que de un respeto aparente se está pasando a una creciente intransigencia. Ya no puede confiar en nadie, ni en la justicia cristiana, ni en la palabra real. No le queda más solución que aceptar su destino o emigrar. Algunos optarán por echarse al monte, sembrando el terror entre los viandantes, aunque su final está también cercano (A. M. C. 1294, 6v). La mayoría permanecerá en sus hogares y buscará, como Phameni Auxaumni (A. M. C. 1294, 40), la protección de Roger de Lauria o de algún otro personaje influyente que la defienda contra ofensas y embargos y le garantice la posibilidad de vivir tranquilamente en sus tierras. Al convertirse Cocentaina en señorío de Roger de Lauria, los mudéjares se integraron dentro de la economía señorial (Reglá 1968, 47) (Ciscar 1977, 107 y 137).

Paulatinamente los mudéjares han ido perdiendo sus recursos económicos, su condición jurídica y su valoración social, convirtiéndose en vasallos de segunda. En el aspecto religioso, su libertad se ve constantemente mermada, y en el campo cultural, su postración es abismal por la pérdida de sus elementos más cualificados emigrados paulatinamente a Granada. Ahora son meros instrumentos de trabajo cuya única ambición es el poder subsistir materialmente (Gil Olcina 1979, 24) (Martínez Ferrando 1963, 24) (Torres Fontes $1961,73-75)$. En ello no sólo influyeron las revueltas, sino que, como afirma Burns (1981, 263, 275 y 299), serán las pasiones del pueblo y del clero, sobre todo el regular, quienes lo exigirán. A todo ésto sólo faltará añadir el proceso de señorialización que está sufriendo el reino. 
La sociedad contestana, al igual que en otras partes del Reino de Valencia, estuvo formada por la adición de tres grupos religiosos: musulmán, cristiano y judío. Con toda seguridad, en el momento de su conquista por Jaime I estuvo formada exclusivamente por musulmanes, pues la minoria mozárabe debió de haber desaparecido de estas tieras bastantes décadas atrás (Epalza y Llobregat 1982, 24-31).

Con la llegada de los primeros cristianos repobladores se va a engendrar una nueva estructura social en la que «la minoría conquistadora trató de prescindir de la superioridad numérica mudéjar. En torno a sí creó la ilusión de su única presencia... Lo consiguió de la forma colonial tradicional: creando una superestructura urbana y señorial, dotando a su contexto inmediato de cualquier detalle que pudiera transportar a sus tierras de origen y tratando a la población autóctona como una casta inferior que habia que tolerar en ghettos cerrados". (Burns 1982, 666)

Junto a estos dos grupos hará acto de presencia un tercero, el judío, numéricamente poco importante, pero de un enorme influencia económica, sirviendo, al mismo tiempo, para romper esa rígida bipolarización social (Baer 1981, 157-8).

De los tres grupos sociales el que concretamente nos interesa en este caso es el mudéjar que constituía el elemento humano originario. Vivian diseminados por los campos contestanos en pequeños núcleos rurales, llamados alquerías, cuyos nombres, en ciertos casos, han resistido el paso de los años y en la actualidad designan alguna partida rural. Junto a esta población diseminada destacaba Cocentaina, núcleo urbano emplazado en la falda de su castillo. La reconquista cristiana va a incidir negativamente sobre ellos a todos los niveles y si no desaparecieron antes, fue, gracias al interés de la nobleza por conservarlos.

Las antiguas comunidades rurales asentadas en las alquerias pasaron a constituir el interesante grupo de los exáricos (que trataremos posteriormente), los arrendatarios o los jornaleros que explotaban los mismos campos que antaño, pero en beneficio de la clase cristiana ahora dominante. En el núcleo urbano de Cocentaina se verán reducidos a vivir en su arrabal, dedicándose, uno a los quehaceres agrarios, otros, más agraciados, a oficios artesanales: herrero, tintorero, albañil, etc.

Estos grupos, sin líderes políticos ni religiosos que les hiciesen tomar conciencia de sí mismos, iban sumiéndose en un profundo letargo cultural, reli- 
gioso, político, etc., transformándose en auténticas máquinas productivas para satisfacer las exigencias de sus señores, de tal forma que cuando pretenden autodefinirse, tendrán que hacerlo en contradicción a lo que representa el cristiano.

Cualquier estimación sobre el volumen de población mudéjar resulta, hoy por hoy, imposible de cuantificar (Burns 1982, 665) (Barceló 1984, 67). La carencia de una documentación oficial sobre los impuestos así como el hecho de que sus asuntos judiciales internos sean llevados por su alcadí dificulta el confeccionar cualquier estimación demográfica como la que hemos llevado a cabo para la población cristiana contestana del siglo XIII. Ni siquiera es posible establecer una proporcionalidad con la cristiana.

En los libros judiciales del Archivo Municipal de Cocentaina se recogen demandas incoadas entre cristianos y mudéjares. Su estudio, aunque no ha permitido acercarnos a su realidad demográfica, sí que, al menos, ha servido para aproximarnos a hacer una valoración de su estructura socio-económica.

En la sociedad mudéjar contestana, al igual que en otros lugares del reino, destaca una minoría selecta que encarna la representación política, económica y social de su comunidad al controlar en sus manos todos o la mayor parte de los recursos económicos: monetarios y territoriales, consentidos por los cristianos en función de su convivencia o de los términos de las capitulaciones (Barceló, 53-54). Esta hegemonía les hará acreedores del desempeño de los altos cargos políticos de su aljama. Como personalidades conocidas en el siglo XIII tenemos:

Ali Huarathateb que qbtiene en pública subasta las regalias de la alhóndiga y del mercado en 1269 por más de 1.000 sueldos. En 1275 alquila por 60 sueldos un huerto de Ximén Pérez de Oriz. Como persona pública desempeñó el cargo de alamín desde 1269, posiblemente ya antes, permaneciendo en su puesto al menos hasta 1275, incluso es posible que hasta 1294 (A. M. C. $1269,1 \mathrm{v} ; 1275,30 ; 1294,17 \mathrm{v}$ ).

Abdulhuaheb que en 1269 adquiere el almudín por 190 sueldos. El 14 de julio de 1275 Jaime I le nombre zalmedina del arrabal de Cocentaina. Ese mismo año compró a Ponç Guillem las rentas de las regalías que había obtenido en la subasta, 100 sueldos por encima del precio de adjudicación. También tuvo en arriendo el peaje por 480 sueldos que por gracia especial, dados sus desvelos por mejorarlo, se vieron reducidos a su mitad (A. M. C. 1275, 8v) (A. C. A. 20, 270v).

Amet Pascuyal compró a Martín Pérez de Gracia una vasta extensión de tierras en Penáguila por 820 sueldos en 1294. También durante ese mismo 
año aparece como acreedor de muchas familias tanto cristianas como mudéjares (A. M. C. 1294, 47v).

El Alfaqui Mosse, aparece durante 1269 envuelto en varias demandas, aunque ello no implique su residencia obligatoria en la villa (A. M. C. 1269, $20 \mathrm{v}$ y $24 \mathrm{v})$.

La «clase media» estuvo formada por profesionales autónomos que viven principalmente de la renta de su trabajo. Destaca el grupo de los artesanos libres, como Mohamat el Corretger, Abdurhamet el herrero, Ali el tintorero, etc. A estos podríamos añadir un pequeño grupo rural formado por la clase acomodada propietaria de ganado, como Aben Abençala; de tierras en la zona reservada a ellos o que arrienda propiedades cristianas para su puesta en explotación, como Mohamat Aben Ornagra (A. M. C. 1275, 9v y 50).

En la clase inferior se integraba la mayor parte de la población mudéjar por carecer de recursos económicos o de una preparación técnica profesional. Pertenecerán a ella el grupo de los asalariados agrarios que trabajan las tierras de los propietarios cristianos, como Mirdacix, o realizan trabajos urbanos por cuenta de otros, como Abnaxay (A. M. C. 1269, 47; 1275, 53). A continuación vendrían los exáricos, formado, presumiblemente, por una importante masa de población y que dada su singularidad dedicaremos un apartado espacial para analizar sus peculiaridades. Su estrato superior pudo, muy bien, compararse a la mencionada "clase media» y cuyas capas más bajas entroncan con los mudéjares esclavos. Los exáricos trabajaban las tierras de los propietarios cristianos en unas condiciones que dependerán de la voluntad de sus dueños y de la coyuntura del momento.

El peldaño más bajo de la escala social lo ocupan los esclavos. Su número debió de ser muy importante en el Reino de Valencia, en estos momentos, habida cuenta de los acontecimientos que siguieron a su conquista. Varlinden $(1934,283-448 ; 1935,361-424)$ que se ha ocupado del problema calcula para Cataluña un total de unos 10.000 , mientras que en Valencia su número debió de ser muy superior.

La mayor parte de los esclavos de estas tierras son de origen musulmán, pero junto a éstos compitieron otros de origen cristiano y judio. En Cocentaina sólo tenemos noticias de la presencia de esclavos musulmanes, aunque en las tierras montañosas limítrofes existió, durante la revuelta, un mercado de esclavos cristianos conectado con el gran mercado de Granada (Sanchís Llorens 1972, 35).

La legislación foral y la iglesia se hicieron eco del problema y dictaron una serie de medidas con el fin de mejorar la situación del esclavo, defender- 
les contra los abusos y malos tratos de sus dueños. La Iglesia se preocupó, especialmente, por las relaciones ilícitas entre el señor y sus esclavas, y sobre la suerte de la posible descendencia, primando, en todos los casos, el condicionamiento religioso, postura que se ve perfectamente recogida en los fueros.

Las revueltas mudéjares de 1248 a 1276 van a constituir importantes manantiales de suministro de esclavos. La corona delimitará, a modo de cotos de caza, aquellas zonas donde se permita la captura de musulmanes declarándoles «moros catius», es decir, musulmanes rebeldes susceptibles de poder se hechos cautivos en beneficio de su apresador, reanunciando la corona a su quinto real (A. M. C. 1275, 29 y 65v). Por el contrario, estarán sujetos a la especial protección del monarca (Burns 1981, doc. 25) los «moros de pau», es decir, aquellos que se mantuvieron fieles al monarca aragonés, amenazando con severas sanciones a todo aquél que les cause algún daño o privación de libertad (A. M. C. 1276, 76; 1277, 43). De hecho las autoridades no fueron con remilgos en este asunto y en Cocentaina conocemos, como ya hemos apuntado más arriba, la primera sentencia a la pena capital y amputación de miembro a dos integrantes de una banda armada cristiana que en 1277 habia secuestrado a un «moro de pau» en Bélgida (A. M. C. 1275, 24). Tan cruel sentencia no amilanó a las otras partidas, cristianas o cristianos, que se enseñoreaban por la zona.

El problema radicaba también en distinguir entre «moro catiu o de pau», cosa que no resultaba tan fácil. Por ello se facultó al baile general para que entendiese en estos puntos (Piles Ros 1970) (Roca Traver 1951, 188). «La primera condición necesaria para que una persona fuese declarada esclava era de que su cautiverio fuese declarado legal, o sea, que sea "aprocehit en bona guerra"» (Sanchís Llorens 1972, 18).

Por tanto, antes de proceder a la venta de un cautivo, el baile debía interrogarle para determinar si se le podía considerar esclavo, pero por desgracia todo aquél que caía dentro de las redes de la esclavitud, contaba con muy pocas posibilidades para poder escapar de ella por este conducto, pues era la palabra del esclavo contra la de su dueño. Una vez declarados, una forma de escapar de dicha condición era obtener licencia del baile para poder pedir limosna (acaptar) entre los musulmanes con el fin de pagar el rescate (Barceló 1984, 87).

Durante la revuelta, todo mudéjar que fuese encontrado portando armas, al ser reducido pasaba a propiedad del vencedor, que podía disponer libremente de él. Tras comunicarlo a las autoridades, estaba facultado para po- 
derlo vender, pignorar, ceder, dejar en herencia, etc. (A. M. C. 1269, 4v; 1275, $32 v$ y $67 \mathrm{v} ; 1277,15 ; 1278,40$ ) (A. C. A. $19,16 \mathrm{v}$ ). Pero junto a estas capturas legales, proliferaron para raptar al mudéjar solitario, que permanecía pacíficamente trabajando su tierra o cuidando el ganado, siendo rápidamente sacado del lugar y trasladado a Valencia, Ibiza, Castilla o cualquier otro lugar para ser vendido como esclavo (A. M. C. 1277, 24, 43 y 91).

Terminada la guerra, la fuente básica de tan preciado botín entró en una profunda agonia, con lo que el número de esclavos mudéjares fue lentamente disminuyendo. Unos gracias al rescate otros por huir de la residencia de sus propietarios, hastiados de sufrir vejaciones y malos tratos (Sanchís Llorens 1972,24$)$. El esclavo fugitivo se llevaba de casa de sus señores cuanto podía, por lo que a su condición de huido unía la de ladrón. Por ello se veía obligado a caminar campo a través lejos de los lugares más frecuentados, para evitar el ser descubierto, soñando con llegar a tierras granadinas donde podría encontrar su ansiada libertad. Las penalidades y los riesgos del viaje eran innumerables, pero la recompensa final bien valia el correrlos.

Los que no conseguian alcanzar la ansiada meta por ser descubiertos, eran encarcelados por orden del justicia, para luego proceder a su identificación y devolución a su dueño. Si resultaba desconocido, era encomendado a un "prohom" hasta que alguien lo reclamase. Pasado un tiempo prudencial sin haberse producido la reclamación, pasará a propiedad real y podrá ser vendido de nuevo en pública subasta (A. M. C. 1294, 5 y 5v) (Aureum Opus $X$ Pedro I, XXXV).

Las ventajas económicas que obtenían sus aprehensores derivadas del derecho a una parte del producto de venta del cautivo, hará que se organice todo un sistema encaminado a perseguir insistentemente a los esclavos fugitivos y desconfiar de aquellos que viajan fuera de los caminos reales, de ahí que se les conozca a los esclavos huidos como «descaminats» (Sanchís Llorens 1972, 25).

\section{A EXARIQUIA COMO SISTEMA DE EXPLOTACIÓN AGROPECUARIA}

La reconquista de las tierras levantinas influyó negativamente no sólo en la población musulmana sino también en la organización de su sistema económico. El campo se hizo eco de la nueva situación creada que suponen unas transformaciones que determinan toda una serie de sistemas de explotación.

El esfuerzo realizado para su conquista se justificaba sólo si se lograba amortizar los dispendios económicos y humanos realizados. Las disponibili- 
dades de tierras en todo el sur valenciano eran importantes, mientras que el número de colonos asentados fue durante las primeras décadas muy escaso, a pesar del interés que despertó a todos los niveles. Estos acontecimientos van a influir decididamente a la hora de organizar la explotación del suelo.

La abundancia de tierras permitía que, en principio, tanto los vencedores como los vencidos disfrutasen de la tenencia de propiedades e incluso que tengan acceso al mercado de la tierra, pero el problema no radicaba en su posesión, sino en torno a la posibilidad de explotación.

Pasados los primeros momentos, los cristianos fueron acumulando, cada vez, mayor cantidad de tierras en detrimento de los mudéjares, que ven perder lentamente sus propiedades; salvo algún personaje acomodado, en general, la mayoría pasa a engrosar el grupo de los agriculores sin tierras (A. M. C. $1294,47 v$ ).

En estas circunstancias los cristianos van a necesitar de los servicios de la población mudéjar, y de su trabajo va a depender, en buena medida, el bienestar de la comunidad cristiana. La estructuración de la producción agraria sobre la mano de obra mudéjar va a convertir a los vencidos en máquinas al servicio de los propietarios cristianos. El proceso, estimulado por la crisis económica y por la señorialización del país, va a ser lento, pero irreversible. Las condiciones primitivas (Renouvard 1962, 231-264) (Ciscar 1977, 107) contenidas en las cartas-puebla y en otros documentos jurídicos inician a partir de ahora un incontenible proceso de degradación que de una forma insensible va alejando la costumbre cotidiana de su punto de partida legal.

Los nuevos vecinos de Cocentaina procedían de lugares diversos y con una experiencia agraria no siempre válida en estas nuevas tierras. Las únicas concesiones de huertas se darán en Cocentaina (Ferrer Navarro 1982, 9-27) (Barceló 1984, 80). Su explotación requerirá de una experiencia que no siempre disfrutarán los nuevos propietarios, ello permite al campesino mudéjar continuar al frente de la explotación aportando sus modos de trabajo y sus sistemas jurídicos de explotación de la tierra (Furió 1982, 47 y 67) (Leví-Provençal 1965, 151).

Procedemos ahora a señalar los diversos tipos de regímenes de explotación deteniéndonos, especialmente, en la exariquía.

El régimen de explotación puede adoptar dos modalidades:

El directo, empleado preferentemente por el pequeño propietario.

El indirecto, propio de los grandes y medianos propietarios. Este régimen adopta las siguientes formas: 
A censo. Tiene como finalidad obtener una rentabilidad estable y segura que permita la dotación económica suficiente para la creación, generalmente, de obras pias y de previsión familiar (García y Sanz 1961, 286). El receptor del censal tiene la facultad de poder transmitirlo en herencia, venderlo, cederlo, subarrendarlo, etc., recibiendo el señor eminente el luismo y la fadiga. Su sentencia no sólo obliga al pago de las anualidades, sino que todos los gastos de mantenimiento y conservación van a su cargo, pudiendo en su caso ser demandado por el propietario si no presta el suficiente celo (A. M. C. $1275,41)$.

Por arrendamiento. En este caso el propietario se desentiende de la explotación durante un periodo reducido de años. El arrendatario entrega al propietario una cantidad fija en metálico y/o especies en una o en varias veces, generalmente, por San Juan o San Miguel, debiendo comprometerse a mantener en condiciones óptimas la explotación, bajo su responsabilidad. Igualmente está facultado para poderla subarrendar por un periodo no superior al tiempo de arrendamiento (A. M. C. 1275, 16 v y 52) (Gisbert 1950, 305-330). Este sistema fue bastante utilizado, arrendándose bajo tipo de propiedades, tanto a cristianos como a mudéjares (Barceló 1984, 83) (A. M. C. 1275, 16v y 29v).

Por asalariados. El propietario que, por las circunstancias que fuesen, no pueda ocuparse él de la explotación de sus tierras recurre a la contratación de mano de obra, cristiana o mudéjar, que recibirá por su trabajo una cantidad en metálico o en especies en concepto de salario (A. M. C. 1269, 47; 1305,118 ) (Furio 1982, 71). En la mayoría de los casos, el asalariado no cons. tituye una mano de obra estable, vinculada permanentemente a un mismo patrón, sino que está condicionada a la realización de una labor agricola determinada. Se le contrata para cavar, poder, arar, etc. la propiedad. Se le exige un trabajo bien hecho, según la costumbre de los «bon llaurador» (A. M. C. $1275,47 ; 1277,22 ; 1290, \mathrm{~s} / \mathrm{f})$. Este tipo de contratos pueden acordarse por una o varias temporadas, presentándose un serio problema sobre suvalidez si entretanto cambia la titularidad en la propiedad de la tierra. En esos casos el nuevo dueño no se siente obligado por los acuerdos firmados por su antecesor (A. M. C. 1275, 23).

Aparcería o exariquia. El estudio de este régimen de explotación presenta una mayor complejidad. La razón se debe, posiblemente, a que mientras éstos son utilizados hasta el día de hoy o como el censo que representa una modalidad bien conocida, el sistema de aparceria constituye una aportación de las minorías mudéjares de sus formas tradicionales de explotación agraria. 
Por todo ésto, a la hora de precisar el carácter específico de la aparcería y de su relación con la figura del exárico, encontramos serias dificultades que nos obligan a salirnos del marco estricto de la Cocentaina cristiana del siglo XIII y retroceder en el tiempo para encontrar sus raíces en la dominación musulmana.

Leví-Provençal $(1965,151)$ afirma que en las fincas de propiedad grande y mediana, el colonato era corriente en el conjunto de los territorios hispanos de Al-Andalus.

Estos colonos recibían varias denominaciones: «particeps» o aparecero, «munasif» o mediero, y "sharik» o asociado, de donde procede la forma latinizada "exaricus» que aparece en ciertos documentos aragoneses del siglo XII $y$ el «exaric» 0 "xaric» de los valencianos del XIII.

Con la conquista cristiana de las tierras del Ebro y del sur del reino de Valencia, en donde la presencia mudéjar es importantísima, el sistema de colonato de origen islámico no desaparecerá, sino todo lo contrario. Ante la necesidad de recurrir a la mano de obra mudéjar, y por el hecho de coexistir propiedades en manos cristianas junto a otras mudéjares, respetadas a causa de las capitulaciones, pervivirán los viejos contratos de aparcería musulmanes que serán aceptados como cosa propia por los propietarios cristianos, sufriendo, no obstante, las consiguientes transformaciones, consecuencia normal del uso de cualquier institución.

El «munasif» o mediero es una forma habitual de explotación agraria en la Cocentaina medieval e incluso actual. El propietario aporta la tierra y el agricultor las manos, pagado los gastos habidos, se reparte el excedente a partes iguales (A. M. C. 1275, 35v; 1314, 107v) (Guichard 1980, 72).

Para el «sharik», volvamos a Leví-Provençal, quien analiza los diferentes contratos-tipo de este modo de asociación.

Distingue tres modalidades:

Musara'a: colonato relativo a los cultivos de secano.

Musăqat: colonato especialmente aplicado a cultivos de regadío.

Mugărasa: colonato que afecta, sobre todo, a la arboricultura.

De estos tres nos llaman la atención especialmente los dos primeros.

En el «musara'a» - dice Leví-Provençal- «el propietario de la tierra y el colono contratante aportan cada uno, por un periodo de varios años, por ejem- 
plo, una cantidad igual de semillas: trigo, cebada, centeno... Uno y otro proceden a mezclar cada una de esas clases de grano y el colono se compromete a labrar y sembrar los campos que toma en aparceria, a segar la cosecha obtenida, a trillarla y luego a repartirla a medias con el dueño del campo cargando a su costa todos los gastos hechos, tales como compra de bestiar de labor o ajuste de obreros agrícolas. Cláusulas especiales prevén, a veces, la obligatoria entrega al propietario por el colono de carneros o corderos cebados en cada una de las dos fiestas crónicas musulmanas y en el dia de primero de años (pág. 151) (Cf. A. M. C. 1314, 71).

No todos los contratos siguen al pie de la letra el contenido de este contrato-tipo. Algunos rebajan la parte correspondiente al colono hasta 1/4, mientras otros resultan espléndidamente ventajosos al reconocerles el derecho a los $3 / 4$ (Pla 1982, 119-138).

Estos contratos de aparcería tienen carácter privado por lo que sólo obran en poder de los interesados y en los libros del notario que los extendió por lo que no resulta fácil encontrar constancia escrita de ellos libros de la Cort de Justicia de los archivos locales. La suerte ha querido que uno de ellos haya llegado hasta nosotros a raíz de la incoacción de un proceso entre propietario y colono, lo que hizo necesario el registro en el libro procesal de dicho contrato. El documento reza así:

«Hoc est traslatum bene et fideliter sumptum a quandam instrumento in papiro scripto, cuius series talis est: Avinieran se(sic) Ali Allobadi e Ramon de Canet sobre la lavor de la terra que ha en I.Alcudia, alcharia de Cocentayna, herma o poplata, regan e secan ab arbres e meyns d'arbres e que sia aço per meytat e que sia a la meytat d'En Ramon de Canet, e que meta la meytat en la sement, e qu'es pac lo deume e la primicia de comun, e entra a laurar mijant lo mes d'octubre primer d'aquel calendari, e que prenga I primer an lo terç del oli, e d'alli anant la meytat e fo la postura a VI, ans del calendari d'aquesta carta, e can(sic)ixcha que lex les olives e que prenga la lavor dels berbeytos, e que a'N Ramon no faça neguna mision en les olives, e que laure axi con sia bon, e que prenga del laurador avant dit en tots ans $V$ sous e III, gallines. Foren testimonis d'aço qu'em la primer rahbe de l'an de (ilegible), e que meta Ramon de Canet la meytat en les alfaceras e en las esponas, e que laure Allobadi ab un parell». Concluye con el nombre de tres testigos cristianos y tres mudéjares (A. M. C. 1275, 14).

El documento no precisa comentario, su relación con el contrato «musara'a” parece clara, más aún si no perdemos el hilo del proceso judicial. 
La demanda presentada ante el justicia cristiano por Alf contra Ramón de Canet va seguida de otra efectuada por éste contra aquél por impago de las rentas de los higos. El justicia, ignorante en este tipo de contratos, echó mano de la mayor experiencia del alcadí musulmán, transfiriéndole el proceso para que según la «çunna de moros» administrase justicia. El dato creemos que es sintomático sobre la influencia islámica de este contrato (A. M. C. $1275,22 v$ y $26 v)$.

El proceso va a ser rico en aportaciones, en cierto momento parece querer descubrirnos el segundo de los contratos-tipo, es decir, el de «musãqat».

Éste se utiliza para la explotación de tierras de regadio en donde el colono explota la huerta a cambio de un tercio de la cosecha. Desgraciadamente no disponemos de ningún documento como el anterior, pero durante el largo proceso entre Alí y Ramón, un hecho llamó nuestra atención: entre los testigos presentados por Ramón de Canet había uno que figura como «moça. quis» suyo. Hechas las pertinentes averiguaciones, podriamos interpretarlo como acequiero o aparcero de Ramón de Canet ocupado de sus tierras de regadío (A. M. C. 1275, 4v y 13v. Agradecemos al Sr. Guichard sus informaciones sobre el significado de esta palabra).

Visto todo este complejo mundo creemos conveniente el abordar el problema del término «exárico». Esta palabra aparece primero en el Ebro y luego en Valencia, sobre todo al sur del Júcar. La razón de que muchos repobladores sean oriundos de aquel lugar ha inducido a muchos historiadores a asociarlos o a creer que es una modalidad importada de Aragón.

Sabemos que «exárico» ("xaric» o "xarich» si se prefiere la terminología local) es de origen árabe y representa a un agricultor que establece un contrato con un terrateniente, sin especificarse qué clase de tierra explota (Burns 1977, 102-4; 1981, 254).

Hinojosa (1904, 523-531) que ha estudiado el problema considera que durante la Edad Media el término presenta dos aceptaciones:

- Primitiva y más lata, que significa aparcero o arrendatario libre, obligado al pago de una renta proporcional a los frutos de la cosecha.

- Derivada y más estricta, designa al adscrito a la gleba, obligado también al pago al señor de un canon en especie y que no debe ser confundido con el esclavo de origen árabe, aunque podría ser objeto de compra-venta y accedía a esta situación por nacimiento.

Contra esta afirmación de adscripción a la gleba (Aracil 1983,80-1) han levantado su voz historiadores como García de Valdeavellano $(1973,354)$ que 
reconoce que, en algunos lugares, se ha hecho pero de una forma ilegal. González Palencia $(1945,83)$ corrobora esta afirmación, pero otros historiadores prefieren militar en el partido de Hinojosa, así Julio Valdeón (Historia de España de Tuñón de Lara IV 1982, 267), García de Cortázar (1975, 272 y 281), Vicens Vives (1961, 223 y 253), Reglá (1968, 47), etc.

Desgraciadamente unos y otros al tratar el tema están pensando en Aragón, asociando el problema en Valencia.

Sin menoscabo de lo dicho hasta ahora, procedamos a aclarar el estado de la cuestión en el contexto contestano. En primer lugar debemos formularnos la pregunta: ¿Quiénes eran los exáricos?, por inercia contestaríamos: unos mudéjares que...». Nos plazca o no, la respuesta no resulta tan sencilla, pues en 1303 Bernat de Fraga dice ser exárico de Domingo de Cepillo y en 1305 , en otro documento, Bernat Sala se declara exárico de Sánchez de Gracia (A. M. C. 1303, 32v; 1305, 73v y 107).

Ante estas pruebas no tenemos más remedio de aceptar que tanto cristianos como mudéjares podian serlo, aunque bien podríamos intentar buscar una justificación, es decir, considerar a estos personajes como cristianos nuevos que adoptan dichos nombres al bautizarse. Lamentablemente tenemos pocas noticias sobre su vida en la villa, sabemos que en 1303 aparece Sala como vecino de la villa y que murió en 1314 dejando una hija de nombre Beneyta de corta edad (A. M. C. 1314, 63). Del segundo carecemos de noticias, pero tanto en uno u otro no parece viable su reciente conversión, por tanto no hay más remedio que aceptar lo dicho, dejando abierta una hipotética puerta sobre su ascendencia musulmana.

Continuando con el análisis, parece aceptado que el exárico es un agricultor que explota las tierras de un señor. Tal afirmación resulta incompleta. Si bien el exárico puede trabajar los campos, también puede se ganadero. En 1303 (Fol. 32v) Domingo de Cepillo pone en "exariquia» una cerda con cuatro crías, repartiéndose a partes iguales beneficios y gastos con Bernat de Fraga. Por tanto debemos aceptar que el contrato, además de agrario, puede ser ganadero.

Se ha firmado que el exárico tiene disminuida su capacidad legal. Este extremo parece apuntarse durante el proceso aludido anteriormente entre Alí y Ramón (Aracil 1983, 80-1; A. M. C. 1275, 42). Ante la sucesión de demandas formuladas por las partes, el justicia nombra a Juan de Vitoria, curador de la persona y bienes de Ali. Sabemos que hay necesidad de nombrar curador cuando la persona es menor de edad, circunstancia que aquí parece no 
darse; cuando se pierde la razón o se malgasta la hacienda, extremos igualmente descartables y cuando se carece de la capacidad jurídica para llevar las demandas. Creemos que éste sería el caso, no porque Alí no haya disfrutado de ella, sino porque durante la vigencia del contrato, no posee la capacidad completa para litigar con terceros y menos contra su señor.

En apoyo de esta afirmación recurrimos una vez más al proceso entre Alí y Ramón. Este último presenta varios testigos, unos cristianos y otros mudéjares. Los testimonios de los cristianos fueron rechazados por Alí aduciendo que éstos, según los fueros, no pueden dañar a mudéjar, pero al mismo tiempo rechaza el testimonio de un mudéjar por estimar que es «muçaquis" de Ramón. Pensamos que por estar vinculado a Ramón no podía testificar en pleito donde su señor fuese parte interesada o que su declaración no puede tenerse en cuenta por no reunir la capacidad jurídica necesaria (A. M. C. $1275,4 \vee$ y $13 v$ ). En otro lugar Abrahaym se obliga a pagar a Domingo de Cepillo cierta cantidad si no presenta ante el Justicia a Mohamet Achulani y a Alí Axatini, exáricos de Domingo Cepillo, posiblemente sin su consentimiento (A. M. C. $1295,4 v)$.

Hubiese resultado interesante el haber podido interrogar a Alí Allobadi sobre si se consideraba o no exárico de Ramón. Durante el proceso se presenta casi la ocasión, cuando el justicia le pregunta si bebió vino en la taberna. Alí responde que no fue él, sino el exárico de Ramón. Podríamos interpretar estas palabras como que Alí nunca se consideró exárico de Ramón, o que había dejado de serlo por rescindir el contrato. Creemos que es más factible lo primero (A. M. C. 1275, 10v).

Finalmente debemos preguntarnos ¿se es exárico a perpetuidad? parece que no y así nos lo hace saber Bernat Sala. Al ser requerido por el justicia cuando ocurrió cierto hecho, él respondió que cuando era exárico de Sánchez de Gracia (A. M. C. 1305, 73v).

En conclusión podemos definir a los exáricos «como mudéjares o cristianos que establecian un contrato de aparcería por varios años sobre un predio o ganado durante el cual el propietario cedía el terreno y pate de la simiente, mientras el aparcero aportaba el resto, los animales de labor y sus manos, repartiéndose la cosecha en la proporción acordada y viendo disminuida su capacidad jurídica y de movimiento mientras estuviese vigente».

Con estas líneas no pretendemos hacer una exposición definitiva del tema, pero sí estimular a los estudiosos a profundizar en un aspecto tan interesante de nuestra historia. 
La primitiva «Qustantaniya» musulmana debió de hallarse ubicada sobre la ladera oriental del cerro del castillo, entre la actual calle de la Santísima Trinidad, el lienzo occidental de la muralla y la zona llamada de la Costa, a tenor de los restos cerámicos encontrados en dicho lugar (Ferrer Marset 1984).

¿Se hallaba bajo la protección de una línea amurallada? La cuestión es difícil de contestar. Las crónicas de la época nada dicen al respecto (Malo de Molina 1857, 135-6). Podría darse el caso de que el núcleo musulmán estuviera exclusivamente protegido por el castillo y el alcázar, aunque sobre este último no estamos en condiciones de asegurar su existencia, tan sólo se han localizado restos de muros musulmanes en las recientes obras de reconstrucción. Asegurada la protección de las partes más vulnerables, el resto se dejaba en manos del relieve: por el sur, un pronunciado barranco descendía desde el cerro por la calle Santísima Trinidad y moría en el barranco del Alberri; por el norte, una pronunciada pendiente, hacía lo propio. No se descarta la posibilidad de que, al menos, por su parte oriental estuviese protegida por murallas, que posteriormente podían haber servido como lienzo occidental de las murallas de la villa cristiana.

Durante los repartimientos de 1248-9, los cristianos heredados en Cocentaina recibirán casas y tierras en ella o en sus alquerías. Por tanto, el primer asentamiento cristiano se produjo en las propias viviendas desocupadas de los antiguos propietarios musulmanes ahora exiliados.

Esta distribución entrañaba serios peligros para la reducida comunidad cristiana que era necesario abordar cuanto antes, pues la convivencia de las dos comunidades sobre un mismo solar no resultaba, en unos momentos tan críticos, aconsejable. El primer paso lo dio Jaime I fundando el arrabal como residencia exclusiva de los musulmanes contestanos. La fecha nos es desconocida, Agustín Arques recoge la noticia pero sin datarla. Pensamos que debió de ser antes de 1260, pues un documento fechado el 13 de febrero de 1260 alude a la separación de ambas comunidades (A. C. A. 11, 193).

Esto no implica que se tratase realmente de una nueva fundación, en el sentido material de la palabra, ya que alrededor de la mezquita del arrabal se han localizado restos cerámicos de siglos anteriores, lo que da pie a pensar en la existencia de un primitivo núcleo de población, quizás la alquería de "Atech", cuyo nombre desaparece, significativamente, de los topónimos posteriores al momento del repartimiento. Este lugar, ampliado con el asentamiento de la antigua población de la villa musulmana, dará lugar al arrabal o morería de Cocentaina. 
Agustín Arques (Manuscrito IV, 18v) se decanta por relacionar la fundación con la construcción de nueva planta, por ello la denomina "vila nova" a la zona ocupada por los mudéjares, es decir, al arrabal, pensando que los cristianos permanecerían instalados en la vieja villa musulmana.

Por el contrario, nosotros pensamos con Pierre Guichard (III, 1980, 84) que los cristianos tuvieron una tendencia a abandonar los incómodos asentamientos musulmanes, creando nuevos núcleos o "vila nova" en lugares más apropiados, por tanto, la fundación hay que entenderla, más que desde el punto de vista material, como una institución jurídica.

\section{RGANIZACIÓN JURIDICA DE LA ALJAMA CONTESTANA}

Las aljamas mudéjares conservaron sus antiguos funcionarios islámicos, pero por influencia de las instituciones cristianas fueron adoptando competencias similares a los funcionarios municipales de los núcleos cristianos.

\section{a) El alcadi}

"Las competencias del alcadí mudéjar no parece que variaran mucho con respecto a esta institución islámica. A él competía la vigilancia y control oficial de la propiedad colectiva, es decir, los hacibes o donaciones piadosas a la mezquita; el cometido de juez y notario y las atribuciones propias de su cargo, como matrimonios y repudios, sucesión o herencia, la situación de los huérfanos, los contratos y el castigo de los criminales» (Barceló 1984, 59). Para tan vastas competencias se requería la colaboración de varios subalternos y escribanos.

Los mudéjares fueron autorizados de acuerdo con los términos de la capitulación, a seguir rigiéndose según la "çunna» musulmana. Con el fin de que entendiese en todas las causas civiles de acuerdo con sus propias leyes, Jaime I creó en 1273 un gran distrito con centro en Cocentaina y que comprendía Planes, Gallinera, Alcalá, Penáguila, Guadalest, Polop y Tárbena, con sus términos y alquerías, al que dotó de un juez común para todos nombrado para dicho cargo a Mohamat Abenhalaiar, alcadí de Cocentaina, pudiendo recurrir sus sentencias ante el alcadi de Xátiva (A. C. A. 19, 18).

El alcadí administraba justicia al estilo de las autoridades cristianas. Presidía un tribunal constituido por el alamín, el zalmedina y los «vel/s» musulmanes. Con el asesoramiento y conformidad de estos dictaba sentencia (Roca 1952, 129).

En principio, las causas criminales se incoaban ante la Corte cristiana, lo que les proporcionaba sustanciosos beneficios por las sentencias dictadas, 
pero en 1264 el rey les concedió la gracia a los musulmanes de Cocentaina de recurrir ante el baile, y no ante la justicia, en estos casos (Roca 1952, 191). No debe ser interpretada la medida como una consecuencia de su política de protección al mudéjar, sino, como hemos dicho, son móviles económicos los que inducen al rey a concederles dicho privilegio (Mateu 1952, 31).

Pese a esta clara delimitación de competencias, en la Cort cristiana continúan incoándose causas por deudas, herencias, etc. habidas entre mudéjares y que deberían, a todas luces, competir al alcadí. No se crea que se trata de una usurpación de funciones promovida por el justicia, sino que son los mismos interesados quienes acuden voluntariamente ante él (A. M. C. 1269, 3) y pensamos que la razón se justificaría en su mayor efectividad para obtener satisfacciones en causas entre vecinos de diferente localidad.

Cuando los litigantes pertenecen a diferentes comunidades, cristiana y musulmana, el asunto incumbe al justicia, pero disponemos de un caso, ya mencionado anteriormente, en el que el alcadí de Cocentaina, Mohamet Hibnabihayr, sentencia en el contencioso habido entre Ramón de Canet y Alí Allobadi en presencia del justicia (A. M. C. 1275, 22v, 26v y 30v).

De todos los posibles mudéjares que detentaron el cargo de alcadí de Cocentaina a lo largo del siglo XIII tan sólo conocemos el nombre del arriba indicado y ello se debe, en gran medida, a que cuando se alude a su persona no se hace constar su nombre, sino solamente el cargo.

\section{b) El zalmedina}

«Juez en primera instancia y carcelero, encargándose de los fraudes (capciones), la prisión (alhapz) y el nombramieno de policias (exortivos) que le ayuden a ejercer la justicia” (Barceló 1984, 53). De este modo se conseguía aligerar el trabajo del alcadí.

En Cocentaina carecemos de noticias sobre su actuación, no hemos hallado ninguna cita documental durante los siglos XIII y XIV a pesar de constar su existencia en un privilegio del 14 de julio de 1275 por el que Jaime I nombra a Abduluhabeb Albini zalmedina de los sarracenos del arrabal de Cocentaina (A. C. A. 20, 270v).

c) El alamin

La población mudéjar requería de una organización administrativa semejante a la cristiana por lo que el rey Jaime instituyó a los alamines.

El alamín es un funcinario mudéjar que sirve de enlace entre las aljamas locales autóctonas y las autoridades reales. Empezó siendo un simple recaudador de impuestos reales y eclesiásticos (Barceló 1984, 94) pasando, con 
el tiempo, a ser gobernador efectivo y la figura central del sistema político mudéjar (Burns 1981, 264). Con la incorporación de estos territorios al Reino de Valencia, el alamín sufrió la influencia institucional cristiana, asimilándose a la noción jurídica de baile, lo que representó, en sí, un aumento de su poder real. Paulatinamente los aljamas fueron organizándose al estilo de los municipos cristianos.

El alamín del arrabal de la villa sólo ostentó su jurisdicción sobre dicho lugar, no sobre las alquerías y demás lugares del término contestano, ya que en cada uno de dichos lugares y alquerías había un alamín que representaba a su comunidad islámica, así por ejemplo los encontramos en La Alcudia, alquería del Perro, etc. (A. C. A. 82, 69).

Desde 1269 a 1275 y posiblemente antes y después de esas fechas, el cargo fue desempeñado por Alí Uharathatab. En 1277 lo regentó Abrahim Annaqy y en 1294 aparece como tal Mohamat Abn Omar, que al igual que el primero bien pudo desempeñarlo antes y después de esa fecha (A. M. C. 1269, 1v; 1275, 30; 1277, 9v y 1294, 12v).

\section{d) El moixerif (almojarife)}

Nombre de clara raiz árabe, representa a un funcionari que se ocupa del cobro de las rentas reales, del pago de las deudas asignadas a dichas rentas y de todo aquello que se refiera a la recaudación fiscal (Garcia de Valedeavellano 1973, 673).

Puede existir una almojarife cuya jurisdicción se extienda por una amplia zona, como la de la Montaña al sur del Júcar y a la cual pertenece Cocentaina (Burns $1981,462-8$ ) y otro que se ocupa de una pequeña población y cuyos cometidos se interfirieren con los del alamín; éste sería el caso del almojarife de la alquería del Perro (A. C. A. 82, 69). En Cocentaina nos resulta completamente desconocido.

\section{CONTRIBUCIÓN FISCAL DE LA MORERIAA CONTESTANA}

Las comunidades musulmanas y algunos de sus miembros contribuyeron a las arcas reales por el sistema de acuerdo o de avecinamiento previo (Burns 1981, 468).

«El musulmán suele estar obligado a utilizar los monopolios señoriales y a pagar ciertos derechos por su uso. Son estos los hornos, molinos, tiendas - taberna, carnicería, almacera... También están sometidos a impuesto ciertos servicios o uso de bienes, como son la alcaldía o alcaidía, esto es, la custodia del castillo señorial, las casas, mezquitas, el agua, obradores, barcas... 
El sector agropecuario... está gravado por una serie de derechos que, en general, son los pechos sobre la tierra, a veces llamados almagram o alfarda, las gallinas, las colmenas...». «A todos estos derechos hay que añadir también la azofra o çofra y una serie de servidumbres... el morabati, cabezaje o alfetra, besant, millarès...» "En el concilio provincial de Lérida de 1293 se acuerda que... los musulmanes, en tierras de señores cristianos, deben abonar el diezmo a la Iglesia, estando obligados también al pago de primicias...” (Barceló 1984, 88 y 100-1). Creemos que estas líneas resumidas nos permiten hacernos una idea sobre el complicado sistema fiscal.

El 24 de septiembre de 1257 tuvo lugar la primera contribución conocida de las aljamas mudéjares del Reino de Valencia. Cocentaina estuvo al margen sin que sepamos las causas, pero posiblemente se deba a efectos de la revueta (Chabas 1886,255$)$. Al año siguiente ya aparecen gravadas algunas alquerías con el impuesto del besante (Gual 1949, 188) y las «sofras de aga y madera" a todos los mudéjares de Cocentaina y Alcoy, de sus castillos y regiones (Burns 1981a, 458).

Unos años después, en 1269, el arrabal parece que aún no se ha repuesto de los efectos de la primera revuelta. La corona arrienda sus rentas a Rodrigo Martíez de Azagra y a Pedro Díez por la cantidad de 2.000 sueldos anuales pagaderos por mitades en agosto y enero, pero con el compromiso de duplicar las rentas al cabo de ese períod so pena de 2.000 y 1.000 sueldos de sanción respectivamente (A. C. A. 15, 136). La ausencia de noticias nos impiden conocer si dicho objetivo fue alcanzado. Creemos que a nivel general existía una honda preocupación por mejorar la gestión y recaudación de las rentas, como se hace notar en 1282 cuando la corona emprende la reforma de las morerías y para ello faculta a Pedro de Libiano a que tome las medidas pertinentes y exhorta a todos para que colaboren con él (Burns 1981, 464).

En 1283 el arrabal contribuyó con 2.000 sueldos más 100 del impuesto de la cena, lo que parece indicar que las rentas no mejoraron en los niveles deseados. La alfarda de 1286 no representa más que 200 sueldos, como en Alzira, lo que le permite a P. Guichard afirmar que tras la expulsión de los mudéjares la aljama contestana vio reducida enormemente su población (A. C. A. 51, 15) (Guichard III 1980, 62).

\section{MODO DE CONCLUSIÓN}

Realizada la letura de este modesto estudio podemos tener la sensación de dejar todo en el aire, verdaderamente nada definitivo podemos decir, pe- 
ro lo importante es, por una parte, contribuir en algo al mejor conocimiento del mudejarismo valenciano, y por otra, iniciar su estudio a nivel contestano.

Los musulmanes devinieron en mudéjares con su sumisión a los cristianos y con ello tuvo que producirse, se quiera o no, los primeros cambios provocados por los nuevos señores. Pensamos que en principio debieron de ser poco significativos, pero con la consolidación de la conquista, la reducción de las revueltas y la apertura del proceso colonizador la situación fue generacionalmente degradándose, pese a lo que apunten las cartas-puebla, de las cuales, la nuestra nos es desconocida.

La falta de una suficiente documentación hace que, proceder a un estudio intensivo de los mudéjares contestanos resulte demasiado aventurado. Creemos que tan interesante problemática hay que insertarla dentro del contexto general del Reino de Valencia; en Cocentaina debieron de darse situaciones comunes a todo el Reino, pero, al mismo tiempo, la realidad contestana debió deferenciarse de la castellonense (por nombrar un ejemplo). Su situación de frontera, su marco geográfico y la convivencia con los colonos cristianos tuvo que dar lugar a unas peculiaridades que habría que sacar a la luz. Para ello hace falta una proliferación de estudios locales en los que se comparase la realidad con la legalidad llegando así a una valoración media.

A ese afán por conocer la situación socio-económica de los mudéjares obedece el apartado sobre los «exáricos». Muy pocos han prestado atención al problema, bien por desconocimiento, bien por falta de documentación, bien por creerlo reservado al valle del Ebro, a pesar de la importancia que de hecho tiene.

La segunda mitad del siglo XIII debió de ser una época de cambios poco significativos, pero que inexorablemente iban royendo los cimientos de las cartas-puebla. Al final del siglo y durante el XIV la situación podía resultar extraña para un mudéjar de la primera generación. Lentamente se había generado una nueva forma de vida a los antiguos pobladores valencianos. Hay que continuar investigando en los archivos locales y dando a conocer los resultados con el fin de poder avanzar en un mejor conocimiento del mudejarismo. 


\section{BIBLIOGRAFÍA}

ARACIL, Rafael y otros (1983): «Els estudis d'historia agraria al Pais Valencià, I Col.loqui d'historia agraria, octubre de 1978, Valencia, p. 79-118.

ARCHIVO DE LA CORONA DE ARAGÓN (A. C. A.) Registros del sigio XIII.

ARCHIVO MUNICIPAL DE COCENTAINA (A. M. C.) Libros de la Cort de Justicia del siglo XIII. ARCHIVO PARROQUIAL DE SANTA MARIA. Cocentaina. Agustín Arques, Manuscrito $\mathrm{N}$.

AUREUM OPUS... (1972) Valencia.

BAER, Yitzhak (1981): «Historia de los judios en la España cristiana» I. Desde los origenes hasta el final del S. XIV. Madrid.

BAÑO ARMIÑNAN, R. (1980): «Registres de Jaume / a l'Arxiu Municipal de Cocentaina”, IDEA 29. BARCELÓ TORRES, Carme (1984): "Minorias islámicas en el País Valencia. Historia y dialecto», Universidad de Valencia.

BURNS, R. I. (1975): «Medieval Colonialism: Post Crusader Exploitation of Islamic Valenciam. Princeton University Press.

- (1977): crslam under the Crusaders: Colonial survival in the Thirteenth-Century Kingdom of Valencia", Princeton University Press.

- (1981): "Jaume li els valencians del s. XII", Valencia.

- (1981a): “Los mudéjares de Valencia: temas y metodología». I Simposium Internacional del Mudejarismo, p. 453-98.

- (1982): «El reino de Valencia en el siglo XII", Valencia.

CAGICAS, Isidro de las (1948-9): “Los mudéjares. (Minoria étnico-religiosa de la Edad Media Española)", Madrid.

CISCAR PALLARES, E. (1977): “Tierra y Señorio en el Pais Valenciano (1570-1620)», Valencia. CHABAS I LLORENS, R. (1866): Revista el Archivo, Denia.

EPALZA, M. de y LLOBREGAT, E. (1982): « ¿Hubo mozárabes en tierras valencianas? Proceso de islamización del Levante de la Peninsula (Sharq-Al-Andalus)», IDEA 36, p. 7-32.

FERNÁNDEZ y GONZÁLEZ, F. (1866): "Estado social y político de los mudéjares de Castilla, considerados en si mismos y respecto de la civilización española", Madrid.

FERRER MARSET, P. (1984): «Aportacions per a la cronologia de les construccions medievals del castell de Cocentaina", Rev. Moros y Cristians, Cocentaina.

FERRER NAVARRO, R. (1982): "La repoblación de una comarca alicantina", Anales Universidad de Alicante n. $^{\circ}$ 1, 9.27.

FURIO, Antoni (1982): "Camperols del País Valencia", Valencia.

FURIO, A. y GARCIA, F. (1983): "El feudalismo medieval valencia: un assaig d'interpretacio", Debats $n .{ }^{\circ} 5$.

FUSTER, Joan (1962); "Nosaltres, els valencians», Barcelona.

GARCÍA DE CORTÁZAR, J. A. (1975): «Nueva historia de España en sus textos», Santiago. 
GARCIA DE VALDEAVELLANO, Luis (1973): «Curso de historia de las Instituciones Españolas», Madrid.

GARCÍA y SANZ, A. (1961): "El censal», BSCC XXXVII, 281.

GIL OLCINA, Antonio (1979): «La propiedad señorial en las tierras valencianas», Valencia.

GISBERT y SÁNCHEZ DE LA VEGA, R. (1950): «Los contratos agrarios en el derecho medievals, Bol. Universidad de Granada XXII, 305-330.

GONZÁLEZ PALENCIA, A. (1945): "El régimen de riegos de Veruela», Al-Andalus X.

GUAL CAMARENA, M. (1949): “Mudéjares valencianos, aportaciones para su estudio», Saitabi VII, 165-199.

GUICHARD, Pierre (1980): «Nuestra Historia», Ill-IV, Valencia.

HILTON, Rodney H. (1978): «Siervos liberados. Los movimientos campesinos medievales y el levantamiento inglés de 1381\%, Madrid.

HINOJOSA, E. (1904): «Mezquinos y exáricos», Zaragoza, 523-531.

LEVI-PROVENÇAL, E. (1965): «España musulmana», tomo V Historia de España de Menéndez Pidal Madrid.

MALO DE MOLINA, M. (1857): «Rodrigo el Campeador», Madrid.

MARTÍNEZ FERRANDO, J. E. (1963): "La Valencia de Jaime /", Valencia.

MATEU y LLOPIS, Felipe (1952): «La repoblación musulmana del Reino de Valencia en el siglo XIII y las monedas de tipo almohade", BSCC, 29-43.

NAVARRO REIG, J. (1985); "Los orígenes de la Cocentaina cristiana», Rev. Moros y Cristians, Cocentaina.

PLA ALBEROLA, P. (1982): "Acerca de los contratos agrarios de los mudéjares valencianos: los capitols de Catamarruc", Anales Universidad Alicante, 119-138.

REGLA, Joan (1968): "Aproximació a la História del Pais Valenciá», Valencia.

PILES ROS, Leopoldo (1970): «Estudio documental sobre el bayle general de Valencia: su auto. ridad y jurisdicción», Valencia.

RENOUVARD, Yves (1962): "Les principaux aspects économiques et sociaux de l'histoire del pays de la Courounne d'Aragon aux XII-XIII et XIV siècle", CHCA VII, I, p. 231-264.

ROCA TRAVER, F. A. (1951): «La gobernación foral del reino de Valencia: una cuestión de competencias", EMA IV, 176-214.

$115-208$.

- (1952): "Un siglo de vida mudéjar en la Valencia medieval (1238-1338)", EMA V,

SANCHIS LLORENS, R. (1972): «Aportaciones de Alcoy al estudio de la esclavitud en el Reino de Valencia", Alcoy.

TORRES FONTES, Juan (1961): «Los mudéjares murcianos en el siglo XIIl», Murgetana XVII, 57-81

VALDEON, Julio y otros (1982): «Feudalismo y consolidación de los pueblos hispánicos (s. XIIXV)", Vol. IV Historia de España de Tuñón de Lara, Barcelona.

VERLINDEN, Charles (1934-5): “L'esclavage dans le monde lberique Medieval", AHDE XI, p. 283-448 y XIII, p. 361-424.

VICENS VIVES, Jaime (1961): «Historia de España y América», II, Barcelona 


\section{REGISTROS REALES DE LOS SIGLOS XIII-XIV EN EL ARCHIVO MUNICIPAL DE ALCOY

\author{
RICARD BAÑÓ ARMIÑANA
}

El Archivo Municipal de Alcoy (AMA) contiene una gran riqueza archivística. Sus fondos se extienden cronológicamente desde el año 1263 (Llibre d'Extravagants, anys 1263-65) hasta nuestros días.

Los registros más numerosos, refiriéndonos a la época foral, pertenecen a la serie del "Cort del Justícia» que cronológicamente abarcan el período 1308-1705, habiendo pocas lagunas de años, siendo estas faltas escasas a partir del siglo XVI.

Es lógico que entre tanto material documental el campo de investigación, no sólo a nivel local sino a nivel de Reino de Valencia histórico, es inmenso. Yo he querido ofrecer en este trabajo una de esas posibilidades de investigación: el de los registros reales durante los siglos XIII-XIV. Por supuesto que no son todos los que hay, al menos reflejo los que yo he encontrado, pero son una expresión de esa riqueza de la que he hablado antes. Estos 19 registros son en buena parte, o todos, inéditos, y yo destacaría de entre ellos el número $1 .^{\circ}$, por tratarse de un documento de Jaime I que no aparece en la relación de HUICl-CBANES. Habria que añadirlo a los 13 que encontré en el Archivo Municipal de Cocentaina (Revista del Instituto de Estudios Alicantinos, n. ${ }^{\circ} 29$, pp. 97-112).

Desde el punto de vista paleográfico he seguido las normas contenidas en el volumen «Elementos de Paleografia» (Valencia, 1972) de Cabanes Pecourt. Por lo que respecta a la toponimia y a los gentilicios he respetado la lengua autóctona del País Valenciano. En el caso de "Alcoy", aunque las normas lingüísticas prefieran «Alcoi», he optado por la grafía histórica y, por ende también correcta. He utilizado (...) para la(s) palabra(s) que no se pueden 
leer, casi siempre a causa de la humedad que afecta al folio, o las que yo no he sabido transcribir, ${ }^{\circ}(. .$.$) cuando la dificultad de lectura se ha debido$ a un agujero en el papel, y ( ) para mis anotaciones. El final de línea viene representado por / y el final del folio por // seguido de la numeración del folio siguiente.

\section{$-1-$}

1249, julio 31. Valencia

Jaime I, rey de Aragón, extiende el privilegio de enfranquimiento otorgado a Ponç Guillem de Vilafranca del Conflent a sus sucesores

AMA. Cort del Justícia 1313, fols. $33 r-34 v$

Hoc est translatum bene et fideliter sumbtum a quodam privilegio domini Jacobi regis Aragonum felicis / recordacionis, scripto in pergameno sigillato cum suo sigillo ceree rubeo pendulo XV ${ }^{\circ}$ kalendas madii / anno Domini millesimo $\mathrm{CC}^{\circ}{ }^{\circ}$ nonagesimo tertio cuius series sic habetur:

«Novernt universi quod nos Jacobus Dei / gratia rex Aragonum, Maioricarum et Valencia, cometis (sic) Barchinone et Urgelli et dominus Montispesulani / per nos et nostros concedimus de gratia speciali tibi Poncio Guillelmi de Villafrancha de Conflent et tuius, quod / illo privilegio quod nos tibi iam concessimus de franquitate henda super hereditatibus et possessionibus // (fol. 34v) tuis et tuorum (...) omnes filios et $(\ldots) /(.$.$) et spurios qui (\ldots) /$ alia qualibet racione (...) et (...) $\mathrm{Va} /$ lencie vel inquocumque (...) quam aliorum (...) fran $/$ quas (?), liberas et quietas (...) quod in dicto privilegio per nos tibi iam concesso (...). Et etiam / concedimus ills omnes alias franquitates qui predicto privilegio sunt per nos tibi (...) / baiu / lis, iusticiis, porteriis et omnibus aliis oficialibus nostris presentibus atque futuris quod predicto omnia (...) / observent et observari facere et faciant si in nostra gratia et amore confidunt.

Datum Valencia Il / kalendas augusti anno Domini Millesimo CC XL nono./

Sig(signo)num Dominici de Cepillo notarii publici Cocentaine et curie eiusdem, testis»./

Sig(signo)num A. de Pina, iusticie Cocentaine qui huic translato suam presticit auctoritatem et (...)./

Sig(signo)num Geraldi de Torroelles, notarii publicii Cocentaine, qui hoc scripsit et bene et / fideliter translatavit et a suo originali comprobavit et clausit die et anno predicto. 
1298 (1), febrero

Jaime II, rey de Aragón, otorga privilegio de enfranquimiento a la villa de Castalla, a causa de los avatares sufridos por ella en la guerra contra Castilla, a condición de que habiten y pueblen el arrabal de dicha villa

AMA. Cort del Justícia 1333, sin foliar

Açò és tresllat bé e felment transllatat secunda nonas marcii anno Domini Millesimo CCC. ${ }^{\circ} /{ }^{\circ}(..) \mathrm{X}$ d'un privilegi scrit en pergamí sagellat ab lo sagell del senyor rey de plo $/^{\circ}(\ldots)$ ab fils de seda grochs e vermells, la tenor del qual és aytal:

«Nos Jacobus / Dei gratia rex Aragonum, Maioricarum, Valencie et Murcie, comesque Barchinone ac sancte ro / mane ecclesie vexillarius, amirantus et capitanus generalis, atendens dampna que vos, homines / nostri de CastaIla, ratio guerre quod fuit et est inter regna nostra et Castelle sustinuistis et / cotidie etiam sistinetis ad augmentum et melioramentum loci predicti totaliter in $/(\ldots)$ per nos et successores nostros enfranquimus et liberos, franchos et inmunes / facimus in perpetuum vos omnes homines predictis de Castalla presentes et futuris, habitantes et / habitaturos in loco predicto ab omni questia, peyta, subsidio, servicio, cena, monecatico, exer / citum et cavalcata, lezda, pedagio, mensuratio, portatico tam per marem quam per terram / ab omni alia exaccione et iure regali que dicti nominarii possint seu etiam congitari et / redemptionibus eorundem.

Ita quod vos vel vestri in loco predicto habitantes et habitaturi non teneamini nobis aut nostris aliquo tempore aliquique solvere predictis vel aliquo pre / dictorum hoc tamen enfranquimentum et inmunitatem vobis facimus sub hac condicione / quod vos et vestri presesentes et futuris teneamini vos populare ac etiam habitare et // morari in ravali dicti loci et si omnes non posetis modo vel imposterum vos in ravali predicto populare seu etiam habitare que ad cognitione baiuli nostri vel nostrorum ge / nerale Regni Valencie qui pro tempore fuerint populetis vos et habeatis in villa nostra, loci / predicti subtus ravale predictum constituta et non in alio loco pro ut dicto baiulio melius (?) / ad comodum et utilitatem nostram visum fuerit expedire. Mandantes procuratoribus, iusticiis, baiuliis, portaticis, collectoribus, lezdariis, pedagiariis et universis a /

(1) Por el contexto del documento doy por válida la cifra «séptimo» de la data y lo fecho enn 1298, año en que el Reino de Valencia y el de Castilla están en guerra por el asunto de la conquista del Reino de Murcia. 
liis officialibus nostris presentibus ac futuris quod predictam concessionem nostram presentibus ac futuris quod predictam concessionem nostram / fimam habeant, observent et non contraveniant nec aliquem contravenire permi / tant (?) aliqua ratio.

Datum apud ${ }^{\circ}(\ldots)$ idus februarii anno Domini Millesimo CCC. ${ }^{\circ}$ (sic) ducentesimo (sic) septimo.

Signum (signo) Jacobi Dey gratia rege Aragonum, Maiori / carum, Valencie et Murcie, comesque Barchinone ac sancte romane ecclesie vexillarius, amiranti / et capitanei generalis./

Testes sunt Jazbertus de Castronovo, Philipus de Soluciis, Jacobus Petri Gondiçalbus, / Eximini Darenoso, Dalmacius de Castronovo./

Sig(signo)num Petri Marti scriptoris domini regis cuy mandato eiusdem hoc scribi, fe / cit et clausit die et anno (...) supras./

Senyal (signo) d'en Jacme Destadella notari de Castalla (...) aquest tresllat del horiginal / feelment de punt a punt treslatí e scrivi en lo dia e any desus dit e cloy.$$
-3-
$$

1307, agosto, 17. Barcelona

Jaime II, rey de Aragón, nombra, a instancia de na Saurina de Entença, a Gombau de Entença tutor de Carleto y de Berenguer, hijos de Roger de Llúria y de la dicha na Saurina.

AMA. Cort del Justícia 1308-10, fol. 20r - v

Pateat universis quod nos Jacobus / Dei gratia regi Aragonum, Valençia (sic), Sardinie et Corcissise (sic), comittique (sic) Barchinone ac sancte / romane ecclesie vexillario, amiranto et capitaneo generali, ex parte nobilis Saurine de / Loria, uxoris quondam nobilis Rogerii de Loria, amiranti nostri, fuit expositum et ostensum / quod cum dictus nobilis Rogerius decesserit relictis Karleto et Berengario impuberibus filiis / comunibus dictis Rogerio et Saurine nullo relicto eis tutorem et sedulum petendi // (fol. 20v) tutoris oficium sit a matribus exigendum et dicti filii tutoris remedio sibi et bonis suis e / geant necessario providire. Idcirco nostris fuit ${ }^{\circ}(. .$.$) ex parte dicte nobilie Saurine / humiliter su-$ plicatum ut dictis impuberibus nobile Gombaldi de Entença, avunculum / dictorum impuberum et consanguineum dicte nobilis Saurine, in tutorem detinere de / beremus. Nos igitur dicte nobilis dompne Saurine suplicatione ut iuri 
con / suna benigne admissa dictum nobilem Gombaldum de Entença, licet absentem, / in tutorem constituimus et decernimus Karleto et Berengario impuberibus supradictis, / licet absentibus. Volumus tamen et mandamus quod dictus nobilis Gombaldus permitet / et idonee pro rey qualibet sacesdet inposse Bernardi Dalmacerus, iusticie Valencie, publico notario, / nomine dictorum impuberum et eorum ominum quorum interest vel interesse possit stipulanti / et recipienti et iuret ad sacta Dei evangelia manibus eius corporaliter tacta omnia / et singula dictorum impuberum utilia facere et inutilia pretermitere et eorum personas, et res / bona fide custodire et inventarium facere de rebus eorum et administrationis sue / tempore debito reddere racionem cum intengra ressiduorum restitutione antequa actingat / administrationis dicte tutelle. Nos enim fidei et legalitati sue comittimus tutellem (?) / predictam cum testimonio presentis carte notre sigillo apendicio roborare. Mandates per presentem cartam omnibus oficialibus et subditis nostris ut dictum nobilem Gombaldum / de Entença pro tutore dictorum impuberum habeant et eidem de bonis eorum ut tutori faciant (...).

Actum Barchinone $\mathrm{XV} I^{\circ}$ kalendas setember anno Domini $\mathrm{M}^{\circ} \mathrm{CCC}^{\circ} \mathrm{V} / l^{\circ} \ll$. B. de Abbaticia.

\section{$-4-$}

1308. enero 9. Valencia

Jaime II, rey de Aragón, abuselve a Ramón Berenguer, vecino de Alcoy, de la muerte de Domingo Bellvert ya que ésta se ha producido debido a un accidente no imputable al dicho Ramón Berenguer.

AMA. Cort del Justícia 1308-10, fol. 16́v.

Jacobus Dei gratia rex Aragonum, Valencie, Sardinie et Corsice, comesque Barchinone ac sancte roma / ne ecclesie vexillarius, amirantus et capitanus generalis, dilecto fidelibus suis procuratori ${ }^{\circ}(.$.$) / universis et singulis baiulis,$ iusticiis ac aliis officialibus nostris Regni Valencie presentibus fu/turis vel eorum loca tenentibus ad quos presentes pervenerint, salutem et dileccionem. Raymundus Be/rengarii, vicinus de Alcoy, presens exposuit coram nobis quod cum ipse simul cum quibusdam aliis / hominibus dicti loci temporibus retróactis in festo Natalis Domini, iret armatus per villam ipsam de Alcoy, causa aliquorum lodurum quos in ibi faciebat, et idem Raymundus Berengarii / teneret eurem suum evaginatum quidam de illis qui simul cum eo erant in ludis predictis / nomine Dominicus Belver per se feriendo in ensem dicti Raymudi Berengarii casualiter exticit / (...). De quo vulnere processu temporis racione ne- 
cligencia (sic) ipsius Dominici contigit eum mori / propter quod suplicavit nobis humiliter quod cum ipse de dicta morte in nulla existeret culpa fratris / et (...) ipsius mortui quia mors illa segute fuerunt casualiter nullam querimoniam vel denunciacio / nem fecerint contra eum dignaremur eidem super predictis remisionis gratiam facere specialem. Qua / suplicatione benigna admissa vobis dicimus et mandamus quatinus si predicta veritate nitantur $/{ }^{\circ}(.$.$) Raymun-$ dum Berengarii non teneatis in reguardo racione dicte mortis nec per inde $1(.$.$) vel bonis suis questionem moveatis vel demandam aliquam faciatis. Quo-$ niam nos / (...) ut permititus (?) vera existunt omnem questionem et demandam et omnem penam civilem et / criminalem quam contra eum vel bona sua possemus penere vel infligere racione / predicte, sibi cum presenti carta nostra remictimus de gratia speciali.

Datum in Valencie $V^{\circ}{ }^{\circ} /$ idus ianuarii anno Domini millesimo trecentessimo septimo.

$$
-5-
$$

1308, febrero 16. Xàtiva

Jaime II, rey de Aragòn, ordena a los naturales de Alcoy que respondan de sus rendas a Jaufredia de Liúria ya que su hermano Rogeró, anterior señor de Alcoy, asi lo dispuso a cambio del castillo de Riciliani

AMA. Cort del Justícia 1308-10, fol. 18r - v

Jacobus Dei gratia rex Aragonum, Valencie, Sardinie et Corsice, comesque Barchinone ac sancte roma / ne ecciesie vexillarius, amirantus et capitanus / generalis, dilectis Petro Garcessi de Masones, Guillelmo de Pratis et fidelis Jacobi (?) Ça / guardia, manumesoribus nobilis Rogerii de Loria, quondam, salutem et dileccionem. Ex parte nobilis Jaufredine de Lauria, uxoris nobilis Roguerii de Sancto Severino, quondam, fili nobilis Thomasis de Santo (sic) Severino, comitis Mascisci, fuit nobis expositum quod inter ipsarn / Jaufredinam ex unam partem et Rogeronum de Lauria, quondam, fratrem suum, seu procuratores suis / ad hoc speciale habentes mandatum ex altera super dote dicte Jaufredine et Castro Riciliani / scito in instaciato (?) tale pactum sive convenio intervenit, quod dictus Roge / ronus solvere dicte Jaufredine suisque heredibus pro dote sua mille sexcentas viginti quinqui / uncias aurei ponderes (?) generalis propter quod recepit a dicta Jaufredina iusoram quibus I de dicta dotis quantitate per dictum virum suus fuerat enim cautum. Necnon et de dicto castro / Riciliani per ipsam tenendo et possidendo cum terris, hominibus, redditibus, iuribus et perti / nenciis suis toto tempore vite sue, raccio- 
ne cuiusdam castri dictus Rogeronus tenebatur / in super tradere et tradi facere ex causa comcambii seu permutationis dicte Jaufredine / castrum de Alcoy, situm in Regno Valencie, cum homnibus, redditibus, iuribus et pertinenciis / suis. De quibus redditibus quos per manum suam habet percipere et habere dicta Jaufredine / habet retinere centum uncias auri convertendos in sus (sic) suos. Et si quid super / fuerit de redditibus dicti loci de Alcoy habet restituere heredibus prefati Rogeroni / fratri, et quod de fuerit de dicta quantitate centum unciarum aurei habet enim com / pleri et dari de bonis Rogeroni predicti tanto tepore quanto dictus Rogeronus vel heredes suis tenuerint castrum Riciliani predictum. De quibus omnibus predictis fuit in cancellaria / nostra (...) publicum instrumentum. Et cum asseratur dictam Jaufredinam non dum havuisse / possessionem dicti castri et ville de Alcoy, nec sibi traditam fuisse, nec homines dicti loci / respondeant de redditibus eiusdem, nec ipsa per manum suam aliqui recipiat de eisdem, / nobis humiliter suplicavit ut faceremus convenciones predictas ad impelari et sibi castrum / et villam predictam cum hominibus, iuribus, redditibus et pertinenciis suis tradi plenarie et $/ /$ (fol. 18v) (...) suplicatione admissa nobis dicimus et mandamus quatenus predictum castrum et villa $(\ldots) /(\ldots)$ traditis plenarie potenter nobili Jaufredini $(. .) /.(.$.$) et pos-$ sidendum ex dita causa. Mandantes presentis universis hominibus de Alcoy I quod dictus Jaufredine vel cuy ipsa voluerit loco sui respondeant de omnibus redditibus et iuribus dici loci.

Datum Xative XIIII. ${ }^{\circ}$ kalendas marcii anno Domini $\mathrm{M} .{ }^{\circ} \mathrm{CCC} .{ }^{\circ}$ septimo.

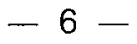

\section{8, febrero 17. Xàtiva}

Jaime II, rey de Aragón, ordena a los habitantes de Alcoy que cumplan las disposiciones que sobre sus rentas ha hecho a Rogeró de Llúria, anterior señor de Alcoy, a su hermana Jaufredina y que presten homenaje al noble Gombau de Entença, tutor de Berenguer de Llúria, actual señor de Alcoy.

AMA. Cort del Justícia 1308-10, fol. 20 r

Jacobus Dei gratia rex Aragonum, Valencie, Sardinie t Corsice / comesque Barchinone ac sancte romane ecclesie vexillarius, amirantus et capitaneus generalis, / universis hominibus habitantibus in loco de Alcoy et eius termino, salutem et gratiam. / Cum nos nobilem virum ac dilectum nostrum Gombaldum de Entençam in tutorem Berengarono / filio nobilis Rogerii de Loria, quondam, duxerimus assignandum. Ideo volumus ac vobis dicimus / et mandamus quatenus servatis obligationibus factis nobili Jafredine, filie nobilis Ro- 
gerii / supradicti per nobilem Rotgeronum fratrem dictem Jafredine de castro de Alcoy ac redditibus / et iuribus eiusdem, ut incarta inde facta latius continetur dicto nobili Gombaldo tanquam / tutori dicti pupilli homagium prestare curetis. Et hoc non differatis seu mutetis aliquam / rationem.

Datum Xative XIII. ${ }^{\circ}$ kalendas marcii anno Domini Millesimo CCC. ${ }^{\circ}$ septimo. 10. HIS.268

\section{$-7-$ \\ 1309, mayo 30. Barcelona}

Jaime II, rey de Aragón, ordena al justícia de Valencia que a todos aquellos que se han inscrito en la armada que comandará Bernat de Sarrià les sea prorrogado el plazo en el pago de sus deudas.

AMA. Cort del Justícia 1308-10, fol. 124r - v

Jacobus Dey gratia rex Aragonum, Valencie, Sardinie et Corsice, comesque Barchinone ac sancto romano ecclesie, / vexillarius, amirantus et capitanus generalis, dilecto suo Bernardo de Libiano, militi, salutem et dileccionem. Pro parte proborum / hominum et universitatis civitatis Valencie querelando propositum exticit coram nobis ${ }^{\circ}(.$.$) auctoritate / officii amiranrie (sic) in quo$ vices geritis dilecti amiranti et consiliarii nostri Bernardi de Sariano elongamento nomine / elongamenti conceditis aliquibus hominibus acordatis in presenti armata ne sua debita que non dolibet / in ipsis obligati appareant usque ad reditum viagii dicte armate solvere teneantur quod iusticie civita / tis predicte ne prohibatis hominum ad solvendum sua debita aliquot compellat totaliter in hiberis (?). Ex / quibus contra forum et rationem probi homines et universitas predicti multipliciter ad gravantur cumque de huiusmondi // (fol. 124v) elongamento concedendo vos vel aliquis alius noster (...)/ ${ }^{\circ}(.$.$) debita ad que-$ mius preternos (...) pertinant (...) spectet mirantes duobus quot (?) talia facere I supersistis vobis dicimus et mandamus (...) quatenus a premissis omnino visis presentibus desistate nec de / cetero ipsa elongamenta facere attemptesis per ${ }^{\circ}(. .$.$) quipe mandamus iusticie Valencie vel eius / locum tenenti { }^{\circ}(.$.$) talia$ alongamenta si qua per nos ${ }^{\circ}(.$.$) sunt servent aut teneant nec teneri aut / ser-$ vari faciat. Immo eadem irriter et anellet preterea elongamentum ${ }^{\circ}(.$.$) homini-$ bus acordatis / in dicta armata observari et teneri volumus dictum iusticie quatenus iuxta formam contentam in / (...) Regni Valencie fuerit observandum.

Datum Barchinone $1 \mathrm{II} .^{\circ}$ kalendas iunii anno Domini M. ${ }^{\circ} \mathrm{CCC}{ }^{\circ}$ nono. 
1309, julio 26. Cap de l'Aljub

Jaime II, rey de Aragón, prohibe a los justicias o a sus lugartenientes que encausen por motivos de deudas a Pere de Azagra o a algunos de sus 100 compañeros, ya que forman parte del ejército real en la campaña contra el Reino de Granada hasta que no vuelvan de dicha campaña.

AMA. Cort del Justícia 1308-10, fol. $129 \mathrm{r}$

Jacobus Dei gratia rex Aragonum... a tots los justícies o sos lochtinents que aquesta present / letra veuran. Sapien de nostra part que en P. de Çagra, almutacen nostre, va am (sic) nos en aquest / fet de Granada ab C companyons per que us deim e us manam que no destrengats nengun dels dits C hòmens per deute que deien ne les fermances qui per ells són tenguts de pagar entró / que sien venguts del dit viatge 0 altre manament aiats nostre.

Feta en lo Cap de l'Aljup / sots lo nostre segell secret XXVI dies anats de juliol anno Domini $\mathrm{M} \mathrm{CCC}{ }^{\circ}$ nono.

$$
-9-
$$

1309, julio 26. Cap de I'Aljup

La misma disposición que la del documento anterior para Laportis Adalill o algunos de sus 100 compañeros.

AMA. Cort del Justícia 1308-10, fol. $129 r$

Açò és treslat d'una letra del senyor rey en paper sagellada ab son sagell secret de la que / la teno és aytal:

Jacobus Dei gratia rex Aragonum... a tots los justícies o sos lochstinents que aquesta present / letra veuran. Sapien de la nostra part que Laportis Adalill va ab nos en aquest fet de Granada / ab C companyons per que us dehim e us manam que no destrengats nengú dels dits $C$ hòmens per / deute que deguen, ne les fermances qui per ells són tenguts de pagar entró que sien venguts / del dit viatge o altre manament haiats nostre.

Feta en lo Cap de l'Aljub sots lo nostre segell secret XXVI dies anats de juliyol (sic) anno Domini M. ${ }^{\circ} \mathrm{CCC} .{ }^{\circ}$ nono. 
1309, julio 29. Cap de l'Aljub

Jaime II, rey de Aragón, ordena a los justicias y jurados que reunan la mayor cantidad posible de animales de carga y los envien a Elx donde está Bernat Marti encargado de reunir a todos estos animales para llevarlos al ejército real. Al mismo tiempo ordena que al portador de la carta se le faciliten las cabalgaduras que precise.

AMA. Cort del Justícia 1308-10, fol. 129r - v

Aço és traslat d'una letra del senyor rey en paper sagelaba ab son sagell secret, la tenor / de la qual és aytal:

En Jacme per la gràcia de Déu rey d'Aragó... als amats justícies, batlles $e$ jurats / als quals les presents vendran, salut e dilecció. Co ya d'altres vegades vos aiam escrit / per aquesta rahó, encara ha cadahun de vos, dehim e manam, així expresament com podem, que tant / tost vistes les presents nos enviets totes aquelles bèsties de bast que trobarets, aixi muls com /I (fol. 129r) ${ }^{\circ}(.$.$) e rocins que veurets { }^{\circ}(. .$.$) / carga, e aquestes fets anar a Elg$ hon trobarets Bernat Martí sobre asembler nostre / qui.ls darà çò que auram (...) els quitarà d'aquí a evant e açò manants a tots / aquels de les dites bèsties en pena de les persones.

Encara vos dehim e us manam que si per $/^{\circ}($...) Martí de la Boça, porter nostre, que aquí enviam ab la present carta aurà obs de mudar / bèstie ni bèsties que los lus (sic) donets a açò no mudets.

Data en lo Cap de l'Aljub sots / nostre sagell secret dimarts XXIX dies anats de juliol anno Domini Millesimo $\mathrm{CCC}{ }^{\circ}$ IX. ${ }^{\circ}$

1309, noviembre 4. Sitio de Almeria

Jaime II, rey de Aragón, a instancias y ruegos de na Jaufredina, hija de Roger de Llúria, absuelve a Ferrer Puig, vecino de Alcoy, de la muerte de Bernat Domènec vecino de Albaida.

AMA. Cort del Justícia 1308-10, fol. 164r

Nos Jacobus Dei gratia rex Aragonum, Valencie, Sardinie et Corsice ac comes Barchinone ad / (...) et instanciam nobilis Gaufredine, filie nobilis Rogerii de Loria, amiranti nostri (...) / per nos et nostros absolvimus ${ }^{\circ}(.$.$) , renun-$ 
ciamus ac ${ }^{\circ}(. .$.$) relexamus tibi Ferrario de Pudio, vici / no de Alcoy, et tuis$ ${ }^{\circ}(. .$.$) omnem questionem, peticionem seu demandam et (...) penam civilem$ $(. .) /.(\ldots)$ quamqueque quam contra te seu bona tua nos vel nostri possemus (...) / racione mortis Bernardis Dominici, vicini Albayde, de qua fuisti ${ }^{\circ}(.$.$) in-$ culpato (?) ${ }^{\circ}(.$.$) ita quod (...) / in dicta morte culpabilis fueris sive non tu vel$ bona tua non possitis per nos seu officiales nostri / (...) capi, detinere seu in iudicio (...) te ${ }^{\circ}(.$.$) / civiliter iusticie complementum. Mandantes per presentes$ universis et singulis (...) / presentibus (et) futuris quod absolutionem, deficionem et remisionem nostram (...) / tibi et tuis et faciant inviolabiliter aobservari et non contraveniant nec ${ }^{\circ}(.$.$) / ne permitant aliqua racione. In cuius rey testi-$ monium presentem cartam ${ }^{\circ}(. .$.$) / pendenti iusimus sigillari.$

Datum in obsidione civitati Almerie IIII. ${ }^{\circ}$ nonas november anno / Domini $\mathrm{M} .{ }^{\circ} \mathrm{CCC} .{ }^{\circ}$ nono. Enrichus.

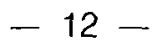

1314, enero 10. Valencia

Jaime II, rey de Aragón, reconoce deber a una serie de vecinos de Alcoy ciertas cantidades por los animales que le prestaron en su campaña de Almería.

AMA. Cort del Justícia 1321 , fols. $168 \mathrm{r}-169 \mathrm{~V}$

Die sabati XII kalendas aprilis.I

Hoc est translatum et fideliter sumptum a quandam litera domini regis sigillata / in dorso cere rubee cuius est tenor talis:

Jacobus Dei gratia rex Aragonum, Valencie, Sardinie et Corcisse, comesque Barchinone ac / sancte romane ecclesie vexillarius, amirantus et capitaneus generalis, fidelibus suis / collectori seu collectoribus quicumque fuerunt monetatici quod nos primo exigere et / habere contingat ab universitate hominum ville Xative, salutem et gratiam. Cum personis / subscriptis debenatur per curiam nostram quantitates pecunie infrascripte quas iam eis / alias asignaverimus super primis dinariis quos ab hominibus ville de Gandia racione // (fol. 168 v) subsidii vel alterius exactionis exigire nos contingeret ut per alia litera nostra te / noris qui sequitur continetur:

"Nos Jacobus Dey gratia rex Aragonum etc, atenden / tes quod per curiam nostram debentur vobis subscriptis hominibus de Alcoy quantitates / pecunie infrascripte cum albarano fidelis azemilarii nostri Bernardi Martini sub / sequitis: 
"Jo en Bernat Martí sobre azembler del senyor rey atorch e vench / de manifest que és degut als deius scrits homens d'Alcoy, és a saber, per loger I ferrar e esmena d'alcunes besties que tengueren el loger de la cort en lo viat / ge d'Almeria: Primerament an Bernat Giner per un mul seu que tenia en Jacme d'Oblites / e entra en loger lo dimecres XXV dies de juny e morí en lo setge d'Almeria lo / dimecres VI dies d'agost qui són XIII dies, fan a rahó de XII diners per cascun dia XIII sous/.

Item, li és degut per un peu de ferrar de tots los dies XIII, IIII diners, encara li és / degut per esmena del dit mul CC sous, e així és tot en suma çò que per la desus / dita rahó li és degut CC XIII sous, IIII diners.

Encara és degut a.n Johan de Fon / teś per un rocí seu qui en lo dit setge murí segons que pus largament en mon / libre dels albarans és contengut, CC LXXX II sous e VIII diners.

Encara és degut a.n Bernat Micó per una mula seua que.s perdé lo dimecres XVII dies de setembre / en la orta CC XXXVII sous IIII diners.

Encara és degut a.n Michell Picó per / un roci seu que morí en lo viatge com anaven ab la ost, C XXXIIII / sous IIII diners.

Encara és degut a.n Domingo Yvanyes per un mul seu qui.s perdé / en la orta d'Almeria, CC XLVII sous IIII diners.

Encara és degut a.n Matheu de Çagra per / una mula qui.s perdè el bovar d'Almeria, CC LXXX sous.

Encara és degut a.n Berenguer Maymó / per un mul seu que Pere Jordà d'Arenś se retench que no.I volch tornar a la / cort, CCCC IX sous IIII diners.

Encara a.n Ferrer de Vilabertran per un mul seu / que.I dit Pero Jordà vené ho alienà que no.I cobrà la cort, CC XCVII sous / IIII diners.

Encara a.n Guillem Berenguer per un mul e una mula escrits a ells el meu llibre // (fol. 169r) e cobrales don Johan de Vidaure, CCCC XVIII sous e VIII diners.

Encara a.n R. / d'Irles per una mula sus que cobrà com la host fo tornada del viatge, $\mathrm{CC} \mid \mathrm{X}$ sous / IIII diners.

Encara a.n Bernat Rovira per un mul seu que cobrà, lo qual tench don / Pero Martinis de Luna, CCIX sous IIII diners.

Encara a.n Guillem Guerau e a.n Bernat Guerau / per dos muls llurs que pensava Gil Martinez els cobraren d'en Pero Martinis de / Luna, CCCC XVIII sous VIII diners. 
Encara a.n Pere Centonge per un mul seu que pen / sava Pere Calp, lo qual cobrà d'en Pero Martinez de Luna, CC IX sous IIII diners.

Encara a.n Barceló Renau per un mul seu que pensava Martí Botí (?) lo qual li fo liçen / ciat que.l tragués de la ost ab voluntat del senyor rey, $\mathrm{XCl}$ sous VIII diners.

Encara / en Domingo Guardiola per un mul seu que cobrà XCl sous VIII diners.

Encara a.n Berenguer / Barberà per un mul seu que cobrà XCl sous VIII diners.

Encara a.n Domingo Muntllor / per un mul seu que cobrà, $\mathrm{XCl}$ sous VIII diners.

Encara a n'Andreu Marti per un ase seu que co / bra XLV sus $X$ diners.

Encara a.n Jacme Pardines per un ase que cobrà, $X L / V$ sous $X$ diners.

Encara a.n Vidal Berber per un ase seu que cobrà ho.I to liçenciat / XLV sous $X$ diners.

E aixi és tot en suma çò que als desus dits hòmens d'Alcoy és / degut per la desus dita rahó, segons que el mon libre dels albarans pus larga / ment és contengut, quatuor mille septuaginta unum solidos et duo dinariis barchinones, / de la qual cosa los fiu aquest albarà segellat ab mon sagell escrit en València, dimecres / XVII dies del mes de febrer, anno Domini Millesimo $\operatorname{CCC} \times{ }^{\circ}{ }^{\prime}$

Idcirco per presentem cartam nostram / asignamus vobis hominibus supradictis quantitates pecunie superius compresatas super primis / dinariis quos ab hom nibus ville de Gandie, ratione subsidii vel alterius exaccionis / exigere nos contingat. Mandamus itaque per presentem fideli tesausaurio nostro aut I cuicumque collectori dictorum denariorum quod vobis hominibus supradictis solvat dictis pecunie / quantitates pro ut in albarano inserto superius distincte. Solutis tamen asignationibus / prius factis et facta solucionem presentem a vobis recuperet cum apocha seu apochis // (fol. 159v) de soluto vos vero restituistis nunc in cancellare nostre albaranum predictum / quod fuit ibi pro cautela curie lateratum.

Datum Valencie V. ${ }^{\circ}$ kalendas aprilis anno / Domini M. CCC XII. ${ }^{\circ}$

Et de dictis quantitatibus non fuerint dictis personis aliquid ex / solutum ut costat per resignationem litere superius inserte et per certificationem / et magistris racionalis curie nostram factam in cancellare nostra que fuerunt / nunc 
in dicta cancellare restitute pro cautela curie laterate. Idcirco per presentes / vobis dicimus et mandamus quatenus denariis dicti monetatici dicti loci / Xative tribuatis et solvatis prefatis personis quantitates pecunie supradictis sint / superius continetur. Solutis tamen assignationnibus prius factis et facta solucione / recuperetis presentem literam cum apocha de soluto.

Datum Valencie IIII. ${ }^{\circ}$ idus ianu / arii anno Domini Millesimo CCC XIII. ${ }^{\circ}$ Exa. M.

\section{1, marzo 13. Valencia}

Jaime II, rey de Aragón, ordena a los tutores de Roger de Llúria, senyor de Alcoy, que respeten los derechos judiciales de Simó Guillem de Vilafranca en su pleito con Gondiçalbo Ivañez.

AMA. Cort del Justícia 1321, fols. 171v - 172r

Comperech en cort davant lo justícia en Gondiçalbo Ivanyez e presenta a aquell una carta / del senyor rey uberta e sagellada el dos ab lo sagell del dit senyor e una letra / del noble en Roger de Luria les tenors de les quals és aytal:

Jacobus Dey gratia rex Aragonum, Valencie, Sardinie et Corsice, comesque Barchinne ac / sancte romane ecclessie vexillarius, amirantus et capitanus generalis, nobili et dilecto / Petro de Queralto gerenti vices procuratoris in regno Valencie pro inclito infante Alfon / so (...) primogenito et generali procuratori nostro, salutem et dileccionem. Nuper provenit ad / nostram audienciam quod nobilis Rogeronis de Lauria et curatores eius gravaverant / Simoni Guillemi de Villafrancha in quibusdam processus factus inter Gondiçalbum Hivanyes // (fol. 172 r) vicinum de Alcoy ex una parte et eumdem Simonem Guillelmi ex altera super grimoniis (sic) civilibus / super quibus nos supplicatione ex parte dicti Simonis Guillelmi nobis oblata cognovimus et decre / vimus ipsos processus de iure et foro Valencie, fore iustos cum civilis iurediccione locorum / dicti nobili et nominanti in locis de Cocentaine et de Alcoy ubi lectigaverunt nostatur secundum / forum Valencie ad prestandum nobile Rogeronum super civili iurisdiccione quam habet et habere de / bet pro habitatores dictorum locorum vel quocumque alios ubi convenientes uniuscumque condicio I nis existant ${ }^{\circ}(.$.$) perturbari. Immo ipsum et curatores, procuratores et ofi-$ cials suos / manucteneatis (?) et etiam defendatis.

Datum Valencie III idus marcii anno Domini Millesimo CCC. ${ }^{\circ} / \mathrm{XX}$. 


\section{2, mayo 6. Xàtiva}

Alfonso IV, rey de Aragón, a instancias de su consejero Bernat de Sarrià, ordena al justicia y baile de Alcoy que liberen a un sarraceno, vasallo suyo, llamado Abdala, vecino de la alquería de Polop, que había sido preso por un almogaver llamado Miquel Maçana.

AMA. Cort del Justícia 1332, sin foliar

Alfonsus Dei gratia ex Aragonum, Valencie, Sardinie et Corsice ac comes Barchinone, fi / delibus nostris iusticie et baiulo de Alcoy vel eorum loca tenentibus, salutem et gratiam. Ex / positum fuit nobis per nobilem et dilectum consiliarium nostrum Bernardum de Sarriano quod / homines dicti loci de Alcoy ceperunt / quondam saracenum vocatum Abdala de Polop quin re / ceperint ab illis quos cepit Miquel Maçana almugacen ${ }^{\circ}(.$.$) unde cum ut dicto$ no / bilis aserit dicto omines iam dictum saracenum infra (?) terram et dominationem nostram / ceperint et proptere non debeant ipsum captum detinere. Idcirco ac dictis nobilis supli / cationem et quia si sic est non intendimus dictum saracenum capi debere vobis. / Dicimus et mandamus quatenus iam dictum saracenum cum bonis suis liberetis seu liberari ilico / faciatis.

Datm Xative $11 .{ }^{\circ}$ nonas madii anno Domini $\mathrm{M} .{ }^{\circ} \mathrm{CCC} .{ }^{\circ} \mathrm{XXX}$ secundo.

$$
-15-
$$

1355, agosto 21. Càller

Pedro IV, rey de Aragón, otorga a Pere de Xérica los lugares de Navarrés, Quesa, Ibi, Torre de les Maçanes, Margarida y El Llombo

AMA. Protocol Notarial 1356, sin foliar

Pateat cunc / tis quod nos Petrus Dei gratia rex Aragonum, Valencie, Maioricarum, Sardine / Corsiçe (sic) comesque Barchinobe, Rossilione et Ciritane (sic), servicia per / vos nobilem et dilectum consiliarium nostrum Petrum dominum / de Exerica, domicellum nobis, inpensa specialiter in hoc Sardine vi / agio laudabiliter atque prompte multimode merverunt ut / vos pro inde retributionis gratia prosecamur hic est quod in aliqua / lem remunerationem dictorum serviciorum. Tenore presentis publi (...) ci instrumenti perpetuis temporibus valituri gratis ex certa scientia et / spontanea voluntate pura profecta et irrevocabi donacione quod / dicitur inter vivos per nos et successores nostros 
perpetuo damus et conce / dimus vobis, dicto nobili et vestris successoribus inperpetuum (...) / (...) et iuxta consuetudinem Cathalonie honeratum tamen / et absque alicuius servicii prestationem potestate excepta (...) / de subscriptis quod nobis et nostris damus in feudum vobis et / vestris dare tenebamini vos et vestri omnem iurisdiccionem al / tam et baxam et merum ac mixtum imperium quas et quod / nos habemus et habere debemus et per nos et nostros officiales seu comissarios uti consuevimus in locis de Navarres, de Quesa // de Ibi, de Turri de les Maçanes, de Margali / ta et del Lombo seu eorum terminis appendicis et pertinen / ciis universis in Regno Valencie constitutis quod fuerunt nobi / lis Beatricis de Loria, matris vestre quondam. Ita quod a modo huius / pretextu donacionis in feudum vos et vestri successores perpe / tuo per nos et nostros officiales aut comissarios possitis / et nobis liceat exercendo dictam omnimodam iurisdiccio / nem altam et baxam ac merum et mixtum imperium punire / iuxta eorum demerita delinquentes quoscumque intra dicta lo / ca seu eurom terminis appendicia aut pertinentias pro ut / exhigerint criminum qualitates possitis inqua in dictis / locis et quolibet ipsorum et in eorum terminis et pertinenciiis ubi / cumque volueritis furcas et castellos erigere et / tenere ad vestri et vestrorum libitum voluntatis. Hanc / itaque donacionem in feudum per nos et nostros facimus vobis / et vestris perpetue sicut melius dici potest et intelligi / atque scribi ab bonum et sanum intellectum comodumque / et salvamentum vestri et vestrorum. Et extrahentes / predicta omnia et singula que nobis supradamus in feudum / de iure domino et posse nostri et nostrorum eadem in ius dominum et posse mitimus et transferimus / vestri et vestrorum irrevocabiliter pleno iure. Induncentes vos de predictis omni / bus et singulis in possessionem corporalem seu quasi omnium // predictorum ad habendum, tenendum omnique tempore pacifie pos / sidendum pro ut melius per nos vobis data sunt et superius / continetur. Et pro ut feuda que a nobis tenentur iuxta usa / ticos Barchinone et constituciones Gathalonie ge I nerales vendi consueverunt et possunt promitentos vobis / quod trademus vobis vel cuy volueritis loco vestri posse / ssionem corporalem seu quasi omnimum predictorum. Et nichillo / minus damus et concedimus vobis auctoritatem, licenciam et / plenum posse quod vos per nos vel alium nomine nostre auctori / tate vestra propia possitis possessionem seu quasi omnimum / predictorum et singulorum libere aprehendere et aprehensam lice / re retinere. Nos enim donet vobis dictam possessionem / tradiderimus vel vos eam aprehendiretis constitumus vos interim / predicta omnia et singula per vobis et vestro nomine precarie possidere. I Et ex causa huius donacionis in feudum cedimus per / nos et nostros vobis et vestris perpetuo omnia iura omnesque / acciones realies et personales mixtas, utiles et directas et alias quaseumque nobis competentes et competere de / bentes in predictis omnibus et singulis et 
contra quascumque / personas et res recione eorum. Quibus iuribus et ac accionibus / possitis vos et vestri et expediri agendo / et defendendo et alia comodolibet in indicione (?) // quem ad modum nos possemus autem huiusmodi vel extra // in feudum / donacionem et iurium cessionem.

Mandantes tenore / huius publici instrumenti quod vicem (...) gerere volumus (?) / in hac parte universis et singulis hominibus et feminis in / dictis locis de Navarres, de Quesa, de Ibi, de Turri / de les Maçanes, de Margalita et del Lombo et in eorum termi / nis pertinenciis habitantibus et habitaturis quod nos et / nostros que ad hec (sic) que nobis et nostris in feudum damus vos et vestros / pro dominis eorum habeant et teneant vobisque et vestris / pateant et respondeant in et super omnibus et singulis / in et super quibus nobis autem presentem donacionem de / bebant et tenebantur respondere ac etiam obedire ac pro / predictis vobis et vestris homagium faciant et fidelitatis etiam / iuramentum que illis qui pro nobis feuda tenent sunt fieri / asueta. Nos enim absolvimus de presenti omnes singulos homines et feminas predictos ab omni homagio et aliis quibus nobis astricti sunt pro predictis que vobis in / feudum damus, et sub tali pacto dictam dona / cionem in feudum nos et nostros facimus que vos et vestri / de hiis que nobis damus in feudum teneamini irati l et pactati nobis et vestris dare potestatem totius (?) quotiens per nos vel nostros successores fueritis requisti iuxta / usaticos Barchinone et constitutiones Cathalonie generales. Ad hoc // (1) gratiarum accione recipiens a vobis dicto domino (...) / huiusmodi in feudum donacionem per me et meos (...) / et firma stipulatione promito vobis dicto domino rege / presenti recipienti et vestris quod ego et mei pro eodem feudo / vobis dicto domino regi et vestris iuramentum et homagium fa / ciemus et potestatem debimus irati et paccati per vos dictum dominum regem superius est largius expressatus (?). / Et nichilominus tactis per me sacrosanctis quatuor e / vangeliis coram me possitis iuro et pro predicto feudo fa / cio vobis homagium ore et manibus comendatum iuxta usa / ticos et constituiones premissis. Et nos rex / predictus recipientes a vobis dicto nobili iuramentum / et homagium antedicta de dicto feudo per tradicionem unius / eusis vos presencialiter investimus in ipso feudo / iure nostro et quolibet alieno in omnibus semper salvo.

Man / dantes cum hoc eodem publico instrumento vicem epistolem / in se gerenti inclito et magnifico infanti Johanni / nostro primogenito carissimo, duci Gerundem (...) / Cervare, et nostris et suis universis et singulis successoribus et officialibus / presentibus et futuris quod huiusmodi in feudum dopa / cionem nobis et nostris teneant perpetuo et observent et // (1) contravenire

(1)Falta una línea que aparece cortada en el texto. 
permitant aliqua racione. Ivenius rei / testimonium presens instrumentum publicum fueri iussimus / nostre magistatis sigillo in pendenti munitum.

Datum / et actum in castro Calleri die vicesima prima / augusti anno a Nativitate Domini M. ${ }^{\circ} \mathrm{CC} .{ }^{\circ}$ quinquagesimo quinto. / Exa rus.

Sig(signo)num Petri Dei gratia regis / Aragonum, Valencie, Maioricarum, Sardinie et Corssice, co / mitisque Barchinone, Rossilione et Ciritane, qui hoc / laudamus, concedimus et firmamus.

Sig(signo)num Petri domini / de Exerica antedicti qui laudo, concedo et iuro ac ho / magium facio.

Testes huius rei sunt: nobilis Ber / nardus de Capraria, armatarum domini regis generalis ca (...) pitaneus, consiliarius et Garcias Luppi de Cetina / uxerinus armatorum dicti domini regis.

Sig(signo)num / Mathei Adriani prothonotarii sigilo tenentis dicti domini regis l et regia auctoritate notarii publici per totam terram et domina / cionem eiusdem qui predictis interfuit et ea scribi fecit cum / raso et escripto in tertia linea consuetudinem Cathalonie et / in quinta quod fuerunt et clausit.

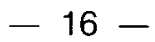

1356, enero 22. Cáller

Pedro $N$, rey de Aragón, otorga ciertas franquicias a todo aquél que se enrole en la armada fletada para volver a sus reinos peninsulares.

AMA. Llibre del Procurador General 1353-55, sin foliar

Nos Petrus Dei gratia / rex Aragonum, Valencie, Maioricarum, Sardinie et Corsice, comesque Barchinone, Ro / silionis et Ceritane, cum propter regressum nostrum quem in brevi Deo dante / facere debemus ad regna nostra ultra marina, ad hoc ut (...) / valeamus et aliis de causis nos oporteat arnatam (sic) facere de persone. Idcirco / in favorem ipsius armate cum presenti carta nostra elongamus ge / neraliter omnes illos qui in dicta armata nostra se acordaverint et in partibus / istis cum nostris galeis meaverint. Necnon debitores et fideiussores pro et / cum eis obligatos et bona eorum penis et usuris cessantibus quibuscumque ab omnibus / et singulis debitis quod per eos debeantur quibuscumque pesonis tam christiani quam / iudeis et sarracenis quacumque personis tam christiani quam / iudeis et sarracenis quacumque racione seu causa. Preterea guidamus et / asecuramus eosdem ab omnibus et singulis excessibus et criminibus seu de / veretis per eos quocumque modo com- 
missus dum tamen non sunt preditores // bausatores de sodomice, fractores itinerum, falsatores monete, comiten / tes lese magestatis nec aliis armatis fugerint aut de morte per / petrata in persona abbatis sancti Cucufatis inculpati non fuerint.

Mandan / tes cum presenti tenenti locum nostri necnon gubernatoribus, procuratoribus et / aliisque universis et singulis oficialibus nostris presentibus et futuris vel loca / tenentibus eorundem quod elogamentum et futuris nostrum huiusmodi quod / durare et valere volumus dum dicta nostra armata duraverit et postea / per unum annum continue subsequentem. Et super quocumque modo tangentibus per tempus superius expresatum / teneant omnino de et observent et contra non veniant nec aliquem venire / permitant aliqua racione in rei testimonium presentem fieri iussimus nostro / sigillo (...).

Datum in castro Catllari XXII die ianuarii ano / Domini $\mathrm{M} .{ }^{\circ} \mathrm{CCC}{ }^{\circ}$ quinquagesimo quinto.

\section{$-17-$}

1356, abril 12. Sant Mateu

Pedro IV, rey de Aragón, ordena a los lugares de Alcoy, Calp, Altea, Vall de Seta y Vall de Travadell que presten homenaje de fidelidad a Francesc d'Esplugues, tutor de Jofre de Jamvilla, hijo de Nicolau de Jamvilla, conde de Terranova.

AMA. Protocol Notarial 1356, fols. $69 \mathrm{v}-70 \mathrm{r}$

Petrus Dei gratia rex Aragonum, Valencie, Sardinie et / Corsice, comesque Barchinone, Rossilionis et Ceritane, fidelibus nostris / universis et singullis hominibus habitatoribus locorum de Alcoy, termini / de Calp, de Altea et vallium de Seta et de Travadell, salutem et gratiam. Ad instanciam fidelis nostri Francisci Desplugues, tutoris nobilis / Jaufredi de Jamvilla, filii et heredis nobilis Nicholai de Jamvilla / quondam comitis de Terranove, vobis dicimus et mandamus quatenus dicti tutori dicto / nomine predictis locis, faciatis homagium fidelitatis salvo tamen iure / nostro nobis quomolibet pertinenti, in castris et locis superius nomina / tis quacumque opposicione facta in contrarium per nostrum fischalem procura / torem in aliquo non obstante.

Datum in villa Sancti Mathei sub // (fol. 70r) nostro sigillo secreto XII die aprilis anno a Nativitate Domini $\mathrm{M} .{ }^{\circ} \mathrm{CCC} .{ }^{\circ} /$ quinquagesimo sexto. 
1356, octubre 30. Montesa

Pedro $N$, rey de Aragón, debido a la necesidad de dinero que tiene para hacer frente a la guerra contra Castilla, autoriza a Gilabert de Centelles y a Barenguer de Codinacs que puedan vender propiedades y derechos suyos.

AMA. Protocol Notarial 1356, sin foliar

Nos Petrus Dei gratia, rex Aragonum, Valencie, Maioricarum, Sardinie et Corsice, comesque Barchinone, Rossilione et Ciritane, constiruimus et ordimamus certos / et speciales procuratores nostros vos nobilem et dilectos con / siliarios nostros Gilabertum de Centillis et Berengarius de / Codinachs, magistrum racionalem curie nostre et (...) / nostrum insolidum. Itaquod occupantis (...) non / existat sed quod per unum inceptum fuerit per alium me / diari persequi valeat et finiri ad recipiendum mutuo / vel comandam quascumque peccunie quantitates quas inten / deritis necessarias vel utiles esse negociis guerre / quam habemus cum rege Castelle. Et per ipsis quantitatibus / peccunie vel comanda reçeptis (sic) obligandum specialiter / certs redditus aut certa loca vel iura iura nostra et generaliter omnia bona nostra. Et ad submitendum vos nomine / nostro foro et districtui eglesiastico (sic) cum sacramen / to et pena excuminicationis et aliis penis et cautelis // renunciatonibus et obligationibus de quibus vobis ${ }^{\circ}(.$.$) / et cum mutuo vel comanda dantibus { }^{\circ}(.$. con / venire. Necnon etiam ad vendendum ${ }^{\circ}(. .$.$) predictorum / per vobis et$ nomine nostro loca, redditus, iuridicciones et / quevis alia iura nostra ad certum (?) tempus longum vel / breve ad vitam hominis vel etiam ad inperpetuum / illis personis et per illo precio seu preciis cum quibus / et de quibus poteritis convenire. Concedentes vobis et utrique nostrum potestatem plenaria emptorem sive / emptores in possesionem inducendi et concedendi eisdem / licenciam aprehendendi ipsam possesionem eorum / propia auctoritate. Et de eniccione cavendi et per eniccione / omnia nostra bona specialiter et generaliter obligandi et / fideiussores per ipsa eniccione dandi et hominem seu homines / locorum que vendideritis a sacramento, homagio / et fidelitate liberandi, et eisdem in inungendi et mandandi et etiam si opus fuerit compellendi eosdem / ut emptori seu emptoris de ipsis iuribus / venditis respondeant et obediant eisque etiam / sacramentum et homagium ac fidelitate et cunc / ta alia adque tenevetur faciant et prestent et / iuramentum super predictis omnibus et singulis per vobis / et in animam nostram prestandis, et generaliter / omnia alia et singula faciendi et libere exercendi / que contractione et aliorum ominum 
et singulorum predictorum $/ /^{\circ}(.$.$) et natura (?) exhigent et requirent et de qui-$ bus etiam / cum contrahentibus conveneritus et que etiam vos facere et exer / cerepossemus si personaliter ad (...). Et etiam si mandatum / exhigant speciale et sint maiora graviora et magis ar / dua superius expressatis.

Conferentes vobis et utrique vestrum / liberam et generalem administracionem cum facultate plenis / suma super omnibus et singulis supradictis ac etiam permiten / tes sub vestra fide regia et virtute iuramenti a nobis / corporaliter (?) presenti. Nos ratum et firmum perpetuo (...) quatenus / quod super predictis omnibus et singulis vos et utrumque vestrum / actum (...) fuerit ac quomodolibet procuratum sub bonorum / nostrorum ominum ypotecha quantitates vero / peccunie quas excepcione mutui vel comande et ex pre / cio seu preciis predictorum habueritis converti per vos aut / deputandum seu deputandos a vobis in negociis / dicte guerre iuxta et ad vestri ordinacionem et ar / bitrium volumus et inbemus. In cuius rei testi / monium presentem fieri (?) iussimus nostro sigillo apen / dicio munita.

Actum est hoc in villa Montesoni / XXX die octobris anno a Nativitate Domini $\mathrm{M} .{ }^{\circ} \mathrm{CCC}{ }^{\circ}$ quinqua / gesimo sexto, nostrique regiminis vicesimo primo. Visa / Ratio.

Sig(signo) Petri Dei gratia regis / Aragonum, Valencie, Maioricarum, Sardinie et Cor / sice, comitusque Barchinone, Rossilionis et $\mathrm{Ce} /$ ritane, qui hoc concedemus, firmamus et iuramus.

Testes / huius rei sunt nobilis Bernardus de Capraria, Luppus / de Gurrea et Matheus Mercerii, camarlengi, Berengarius de Palacio et Petrus Jordani Durries, ma / iordomus, milites et consiliarii domini regis.

Sig(signo) / mihi Jacobi Castillionis, scriptoris serenissimi principis et / domini domini (sic) regis Aragonum et eius auctoritate notarii publici per totam / terram dominacionem suam qui predictis interfui et hoc de eius / mandato scribi, feci cum raso et emendato in linea prima / ubi dicitur Sardinie et Corsice et in linea XVII ubi / emendatur dicio munita actum est hoc in villa Montesoni / et clausi.

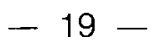

1361, mayo 18. València

Pedro IV, rey de Aragón, comunica a sus oficiales que ha firmado en Calatayud una tregua con el rey de Castilla al mismo tiempo que comunica que castigará severamente a todos aquellos que quebranten la dicha tregua.

AMA. Llibre del Procurador General 1359-62, fol. 110r - v 
De nos en Guillem Colom, procurador general per la molt alta e excellent / senyora, la senyora reyna d'Aragó en lo Regne de València, a I'hon / rat en Guerau Domènec, tinentloch nostre del riu de Xúquer enllà, saluts / e dilecció. Sapiats que.I senyor rey ha tramés la letra infrasegüent:

En Pere per la gràcia de Déu rey d'Aragó, de València, de Malorques, de Cerdenya / e de Corçega e comte de Barçelona (sic), de Roselló e de Cerdanya, als a / mats e feels nostres en Garcia de Loriç, portanveus de gobernador / general e en Pero Boyl, cavallers (sic) batlle general del Regne de València / e a lurs lochtinents, saluts e dilecció. Com entre nos e lo rey de Castella / sia fermada pau perpetual la qual és publicada ací en Cala / tayu, per manament nostre ab veu de crida e en loch de çà hon és // (fol. 110v) lo rey de Castella e vullam així com està en rahó e senblanment sia pu / blicada de vos de / him e manam expresament e de certa acientia que, en cotinent, ab veu de crida / façats solempnialment pública la dita pau ab imposició de pena de / cors e de béns a tothm de qualque condició sia que trenacarà la dita pau / e contra aquella faria en alguna manera, ans tots nostres sotmeses tin / guen e observen fermament la dita pau, no faen mal ni dan a sotsme / soso del rey de Castella en persones e béns, sabens que si.l contrari fahien serien punits en les dites penes e altres qui.s deuen inflingir a trencador / de pau donada per son rey, princep e senyor.

Datum en Calatayu sots nostre segell secret a XVIII dies de maig en l'any de la nativitat de / nostre sentor M CCC LXI. 


\title{
ANEXIÓN DEL CAMP D'ALACANT AL REINO DE VALENCIA
}

\author{
POR JAIME II DE ARAGÓN (1308)
}

(Comunicación al I CONGRES D'ESTUDIS DEL CAMP D'ALACANT. Alicante, 29.111.82)

Dividimos el estudio de aquella singular efemérides en tres capítulos, correspondientes a otros tantos actos del monarca de Aragón, Jaime II el Justo, cuyo final desenlace fue la incorporación formal de las tierras meridionales alicantinas o CAMP D'ALACANT al Reino de Valencia, por privilegio real del 17 y 25 de junio de 1308.

En el primer capítulo presentamos la ocupación y conquista del Reino castellano de Murcia por Jaime II de Aragón, desde el último tercio del mes de abril de 1296 a las postrimerías del 1300 , a base de nuevas fuentes documentales, desconocidas hasta la fecha y de relevancia transcendente para el seguimiento puntual de las expediciones militares aragonesas por el CAMP D'ALACANT, pudiendo corregir los datos cronísticos tradicionales, en lo referente a la fecha y modo de ocupación por el soberano aragonés de las villas de Orihuela, Alicante, Elche y de la propia Murcia, capital del Reino, por citar algunas como ejemplo, variando al respecto sustancialmente los resultados obtenidos de los nuevos fondos manuscritos consultados.

En el segundo capítulo acometemos el estudio de la constitución del amplio alfoz o término municipal alicantino, a base de un rico ámbito comarcal, trazado 44 años antes por ALFONSO X EL SABIO, el 1252, y de la consiguiente confirmación y delimitación más puntual y precisa, que efectuó Jaime ll del área exacta del mismo, con dos provisiones reales de los años 1296 y 1297, cuyo marco territorial abarcaba total o parcialmente, al menos, el término municipal que ostentan hoy los siguientes lugares alicantinos: VILLAJO. YOSA - ORCHETA - RELLEU - AGUAS de Busot - BUSOT - CAMPELLO MUCHAMIEL - SAN JUAN - SAN VICENTE DEL RASPEIG - AGOST - PE- 
TREL - ELDA - NOVELDA - NOMPOT o MONFORTE DEL CID - Puerto del PORTICHOL y DERRAMADOR DE SIERRA SANCHO, con «diez millas a la Mara», hasta el litoral, en término del ALTET, entre Alicante y Elche.

Por último, en el capítulo tercero, presentamos el ACTA DE ANEXIÓN - LA CARTA MAGNA, si se quiere, de las villas de ORIHUELA, ALICANTE, ELCHE y GUARDAMAR, por la que Jaime Il de Aragón incorporó formalmente el entero CAMP D'ALACANT al Reino de Valencia, en el verano del 1308.

Por aquel acto otorgaba el monarca aragonés a las villas y lugares citados los FUEROS DE LA CIUDAD Y REINO DE VALENCIA, respetando, no obstante, sus fueros propios y costumbres regionales, los COSTUMS propios, confirmados por privilegios reales precedentes, sentando con ello las mejores bases legales e Institucionales de una dinámica autonómica regional, que habría de perdurar hasta nuestros días.

Por todo ello, no dudamos en calificar de TRANSCENDENTE aquella singular ACTA DE CONEXIÓN de las tierras meridionales alicantinas al REINO DE VALENCIA, sancionada formalmente por Jaime II de Aragón, hace ahora exactamente 674 años, por aquello de que tan remota antigüedad, de casi siete centurias, es el fundamento medular histórico de la AUTONOMÍA VALENCIANA - ALICANTINA de la antigua Procuración y Gobernación de Orihuela, hasta nuestros dias.

\section{CONQUISTA DEL CAMP D'ALACANT POR JAIME II DE ARAGÓN (1296)}

Abordamos en este capítulo el problema de la conquista del Reino castellano de Murcia por Jaime II de Aragón y la incorporación del mismo a su corona, con la sustitución de la hegemonía castellana que habia durado algo más de media centuria (1243-1296), por la aragonesa, de mucho más corta duración (1296-1304).

Es ésta una etapa en la historia del reino cristiano de Murcia, apenas conocida, y las más de las veces silenciada, por lo poco o casi nada que ha sido estudiada. Fuera de los once capítulos que le dedicó Francisco CASCALES en sus DISCURSOS HISTÓRICOS DE LA CIUDAD DE MURCIA Y SU REINO (1), a mediados del siglo XVIII, en 15 páginas escasas, con un sentido crítico poco exigente, pero en líneas generales bastante aceptable, nada apenas se ha escrito sobre la historia global del Reino de Murcia, bajo esta égida de Aragón, durante los ocho años apuntados.

Tal silencio historiografico tiene una clara explicación: el carácter inédito de casi la totalidad de las fuentes manuscritas que nos hablan de aquel perío- 
do, consistentes en su mayor parte en las cartas de Jaime ll a diversos personajes de Castilla y Aragón, pero de manera muy especial en los Registros de este monarca, durante los años referidos, felizmente conservados en el Archivo de la Corona de Aragón, en Barcelona, a más de la rica colección de Privilegios, otorgados asímismo por él a la ciudad de Murcia y otras villas y lugares importantes del Reino, a lo largo de aquel breve espacio de tiempo (1296-1304). Espoleados por esta lamentable realidad, nos propusimos hace ya varios años acometer la empresa, nada fácil, de rellenar aquel vacio documental, y hoy podemos anunciar ya aquí, para satisfacción de los estudiosos de estos temas, que esperamos poder enviar a la imprenta el verano próximo el primer volumen de esta Colección de Documentos, concernientes al Reino de Murcia, bajo la corta hegemonía de Aragón. (Vol. editado ya: El Reino de Murcia bajo Aragón, 1296-1305. Corpus documental 1/1, Alicante, 1985, XXXIII + 474 pp. y 254 documentos).

Ante la carencia apuntada de estudios sólidos al respecto, vamos a responder de entrada a varias cuestiones previas, indispensables para desarrollar debidamente el tema de la conquista del Reino de Murcia por Jaime II de Aragón.

Es opinión generalizada y lamentablemente muy difundida que la conquista aragonesa del Reino de Murcia fue algo así como un "paseo militar», sin resistencia castellana existente, "ya que ciudades como Orihuela y Murcia se prepararon siquiera para la defensa, sino que antes de la llegada de la hueste (aragonesa, se entiende), efectuaron su proclamación» (2), lo que nada es cierto y que pueda menos ajustarse a la realidad documental. El propio CASCALES escribe: «Finalmente se le rindieron todas las villas y lugares del Reyno de Murcia, sino fueron Alcalá y Lorca (única excepción a su juicio); teniendo rendidos todos los castillos importantes, Villas y Lugares del Reyno. (Jaime II) era recibido de todos con gran fiesta y reconocido por señor» (3), lo que es del todo falso y opuesto a la realidad de los hechos.

Estimamos que la causa tal vez, de afirmaciones tan gratuitas, radique en el relato falseado, que sobre la conquista del Reino de Murcia por Jaime II de aragón, nos vierten los cronistas más renombrados de la época. Ramón MUNTANER, por ejemplo, coetáneo del monarca aragonés y cantor entusiasta sus gestas gloriosas, suministra la base de reducir tal campaña militar a un simple paseo triunfante por las villas y lugares del Reino, «los quals és ver que la major part pertanyen que devien ésser per just títol del dit senyor rei (Jaime II)» (Crònica, c.CLXXXVIII), por la sencilla razón, añade convencido, de que su abuelo y homónimo, Jaime I el Conquistador, treinta años antes 
(1266), asentara en ellos una colonia de catalanes repobladores, que suplantó a la indígena, sarracena, y a la castellana, lo que le permite afirmar sin escrúpulo que, sofocada la rebelión mudéjar por Jaime I y tomada la ciudad de Murcia el año 1266, la repobló a tope de catalanes, así como los demás lugares del Reino: E com la dita ciutat hac presa, poblàla tota de catalans, e aiximateix Oriola e Elx e Alacant e Guardamar, Cartagènia e los altres llocs; sí que siats certs que tots aquells qui en la dita ciutat de Mùrcia e en los davant dits llocs són, son vers catalans e parlen del bell catalanesc del món, é són tots d'armes e de tots fets» (Crònica, c.XVII), amparándose acaso en el relato igualmente desorbitado del Llibre dels feits del propio Jaime I, donde se afirma sin ambages el asentamiento de nada menos que diez mil catalanes caballeros y hombres de armas (c. 453: «poblam hi bé deu milia hómens d'armes»), lo que se hace inadmisible a todas luces, dada la escasa densidad demográfica de la capital murciana por aquella época y el alto índice poblacional sarraceno y judío, allí residente (MARTÍNEZ CARRILLO, 1980, 16 17, not. 14).

Versión que aparece corroborada igualmente, y contra la verdad documentada de los hechos, por la Crónica de Fernando IV de Castilla (4), y por el cronista castellano Jofre de Loaysa, al afirmar contundente también que todos los lugares, ciudades y villas del Reino de Murcia pasaron espontáneamente a la nueva hegemonía de Aragón, sin ofrecer la más mínima resistencia (5). Lo que nada podría estar más lejos de la realidad histórica, cuando ni una de las plazas fuertes reseñadas: Alicante, Orihuela, Murcia, Elche, Castillo de Monteagudo, Molina y Cartagena, abrió sus puertas espontáneamente a las tropas de Jaime II, debiendo conquistarlas todas ellas tras cierta lucha, y algunas de ellas, como Orihuela, Murcia, Molina, Cartagena y Elche, tras duro y largo asedio.

Es pues claro, que una vez más, no puede aceptarse el relato de las Crónicas, por antiguas y coetáneos que sean sus autores a los hechos referidos, como fuentes inapelables de información, sin una previa colación de su relato con la verdad de los documentos de cancillería, que una vez más se nos presentan como las fuentes primordiales y de primer orden de la época respectiva.

Y otro tanto ocurre con las fechas de su conquista, si se tomaran los datos suministrados por las Crónicas sin compulsarlos con la documentación referida de la cancillería aragonesa. Pues para MUNTANER (Crònica, c.CLXXXVIII) p.835) la ocupación de Orihuela no tuvo lugar sino después de la entrega de Elche, tras la firma de las treguas con su señor don Juan Ma- 
nuel, el 27 de julio de 1296, con un error de más de dos meses y medio de retraso. Y lo mismo se diga de la toma de la ciudad de Murcia, posponiéndola a la anterior con un error de precisión de 38 días de diferencia. Estas son sus palabras: «E con lo senyor rei hac ordonat Alacant... posá setge a Elx... Tant tenc assetjat Elx que l'hac, e es reté a ell. E puis hac Oriola e lo castell... $E$ aprés hac lo castell de Muntagut et la ciutat de Múrcia” (Ibid), cuando en realidad, tanto Orihuela como Murcia fueron tomadas por Jaime II mucho antes con exactitud el 10 y 19 de mayo respectivamente de aquel mismo año, con una antelación de 38 dias a dos meses y medio de diferencia. Error cronístico que vuelve a cometer luego ZURITA, copiando a MUNTANER: «Y después de haber ganado a Elche, se rindió al rey (Jaime II) la villa y castillo de Origüela", incidiendo también en el mismo retraso cronístico ya señalado. $Y$ al tratar más adelante de precisar la fecha de la conquista de la ciudad de Murcia, reincide otra vez en idéntico error, fijándola equivocadamente en ca: si dos meses y medio más tarde de cuando tuvo lugar realmente (6).

No es de extrañar por tanto que arrastrara tras de sí este error de los cronistas referidos a historiadores posteriores, que, sin cuestionar la verdad de sus relatos, les prestaron fiel crédito, ajenos a que pudieran no ajustarse a la verdad de los documentos auténticos de la cancillería real aragonesa. El carácter inédito de éstos fue la base inicial de afirmaciones emitidas por historiadores antiguos (7) y modernos (8), que no vacilaron en dar por válido y bueno el relato de los cronistas mencionados, pudiendo compendiar a todos ellos el biógrafo del propio Jaime II, J. Ernest MARTíNEZ FERRANDO, que nos describe asi la conquista del Reino de Murcia por Aragón: «La conquesta del regne de Mùrcia fou ràpida; pot assegurarse que l'escassa resistència es limità a l'aparatosa escala del castell d'Alacant $i$ al perllongat setge d'Elx. La resta de les operaciones fou un auntèntic passeig militar. Oriola i Múrcia s'hi reteren tot seguit. Aquesta facilitat que trobà Jaume II per a recuperar el regne perdut es comprèn si tenim en compte el crescut percentatge de catalans $\mathrm{i}$ aragonesos existent en la població del país des del temps de Jaume I... El comterei va donar. per acabada l'expedició militar de Murcia y Orihuela a primers d'agost de 1296» (9), situando la toma de Murcia y Orihuela después de la capitulación de Elche que tuvo lugar el 27 de julio de aquel año, lo que está en pleno desacuerdo con las fuentes documentales de tal efemérides.

A la vista de cuanto antecede, estudiamos en este capítulo primero la fecha y modo en que las villas y lugares del Camp d'Alacant fueron abandonando la obediencia y jurisdicción de Castilla para pasar a la hegemonía de Aragón. 


\section{CONQUISTA DE LA VILLA DE ALICANTE}

La respuesta cursada por el alcayde castellano del empinado castillo roquero de esta villa, Nicolás Pérez, a la carta conminatoria de Jaime II, debió ser de negativa rotunda, igual que la del alcayde de Orihuela, Pedro Roiz de Sant Cebrian, motivando en el monarca aragonés la necesidad de recurrir a las armas para obtener aquellas fortificaciones que, por razones diversas, decía que eran de su jurisdicción y soberanía. Y no se pierda de vista tampoco la consabida donación reiterada del Reino de Murcia por entero a la Corona de Aragón por don Alfonso de la Cerda.

Convencido por ello de la justicia de su causa, Jaime II se aprestó a la conquista por las armas de todo el Reino. Excepción rara serán las plazas que se le entreguen espontáneamente, sin resistencia.

Al decir de la Crónica castellana: «E en este mesmo tiempo movió el rey de Aragón con su hueste e fue al Reino de Murcia» (10), allegándose a él con una flota, para iniciar su ocupación por el castillo y villa de Alicante.

Es un compañero y testigo de armas del soberano aragonés, el Cronista Ramón Muntaner, quien nos describe, observador, la conquista del castillo, con su admiración acostumbrada (11), panigirizando de seguro la epopeya real.

Lo cierto es que Jaime II se adueñó de la villa y castillo de Alicante, tras reñida lucha y dando muerte al propio alcayde, Nicolás Pérez (12), cuyo cadáver ordenó que fuese arrojado a las bestias, en castigo a su felonía y traición al juramento de fidelidad y homenaje prestados al monarca aragonés en la Concordia de Monteagudo: «E con lo castell fo pres, lo senyor rei manà que l'alcayd no fos soterrat en cimenteri, ans lo donà per mal e féu gitar lo cos als cans» (13), haciéndolo sustituir acto seguido, añade el cronista citado, por el caballero catalán Berenguer de Puig Moltó: «comanà él lo castell a en Berenguer de Puigmoltó; e féu gran raó, que ben li ho havia servit» (14).

Este es el relato tradicional, habitualmente admitido por los historiadores como verosímil, acerca de la conquista por Jaime II del castillo y villa de Alicante. $Y$, en efecto, asi es en lo que concierne a los hechos generales, pero precisa de algunas puntualizaciones, recabadas de otras fuentes de información, mucho más fidedignas, como son los Registros de la propia cancillería aragonesa.

Por esta documentación sabemos que el alcayde puesto por Jaime II al frente del Castrum d'Alacant, no fue el mencionado por MUNTANER, el ca- 
ballero Berenguer de Puig Moltó, sino RAIMUNDO DE URTX, a quien hacia llegar, cinco días más tarde, el 27 de abril, la estimable suma alimentaria de 336 arrobas de harina, de manos del procurador del ilustre Roger de Lauria, Pedro de Guardiis, para asegurar en primera instancia el aprovisionamiento fundamental del castillo (15).

Y con referencia a la fecha de su ocupación debió ser el 21 de abril o el 22, ya que en esta última, data ya Jaime II su correspondencia oficial dentro de la villa de Alicante: «Data apud Alacant decimo kalendas madii, anno domini millesimo ducentesimo nonagesimo sexto" (ACA, Rg.340, fol.6 r.), prueba inequívoca de haberla conquistado ya en la última fecha.

Por entonces Jaime II retenía por único y legítimo soberano de Castilla a don Alfonso de la Cerda. Son numerosos los testimonios fehacientes del aserto (16).

Conquistada la villa de Alicante y su castillo, el 22 de abril, procedió Jaime ll a proveer los cargos municipales de mayor urgencia, como el de alcayde, bayle y justicia, colocando al frente de los mismos respectivamente a los caballeros y leales servidores suyos: PEDRO DE URTX (17), RAIMUNDO DE CUPIATH (18) y BERENGUER DE PUIG MOLTÓ (19).

A este último no olvidó el monarca agradecerle cuantiosamente los numerosos servicios prestados en grado heróico, desde el momento inicial de la conquista del castillo roquero de Alicante, contra la defensa reñida opuesta por su alcayde castellano, Nicolás Pérez, donde sobresalió tan singularmente este caballero catalán (20). En un primer momento le hizo objeto de un amplio heredamiento, sito en el arrabal de la villa de Alicante, a base de viñas, olivares, tierras de pan y huerta, molinos, palomares y otros bienes, confiscados al castellano rebelde, Pedro Núñez, otorgándoselo en libre y franco alodio a perpetuidad (21).

$Y$ al día siguiente, 26 de mayo, le faculta a canjear la donación anterior por otra que estime más rentable, en el término asimismo de Alicante, cuya producción alcance con creces la pensión anual que le otorgara, días atrás, de los mil sueldos barceloneses; en pago a los singulares servicios tan generosamente prestados hasta la fecha (22). Quedaba de este modo afincado en la villa de Alicante, con un amplio heredamiento de bienes urbanos y rurales, el caballero catalán que tanto contribuyó al afianzamiento de la conquista del Reino de Murcia por Jaime II en sus primeros momentos: don Berenguer de Puig Moltó.

Igualmente confirmará sus heredamientos, amplios también, al heredero y sucesor del noble castellano, Joffre de Loaysa, señor del Castillo de Petrel 
Juan García de Loaysa (23), haciéndolo objeto de numerosas franquicias en el Reino de Murcia, al par que a sus hermanas, Aldonza Jacomora y Guisaherel, a las que Jaime II escribe: «...queremos et otorgamos que vos Aldolza Jacomora e Guisaherel, fillas de don Garcia Joffre, ayades, tengades et possedexcades casas, heredades e bienes que avedes en Alacant e en su termino, assi como las avedes tenido e posseydo hasta aqui e recibimos vos en nuestra Comanda, Guarda e Servicio» (24), convitiéndolos en destacados hacendados alicantinos.

También sè ocupó Jaime II de los diferentes grupos étnicos y confesionales que integraban la población de la villa de Alicante: castellano-aragoneses, sarracenos y judíos, legislando a favor de los mismos (25).

El modelo de Alicante serviría al monarca de patrón a seguir e implantar en las sucesivas conquistas del Reino de Murcia.

\section{CONQUISTA DE GUARDAMAR}

A los tres dias escasos de haber conquistado el castillo y villa de Alicante, el 25 de abril, desplegaba ya Jaime II su acción militar hacia el Sur, por tierras del Reino de Murcia, con ánimo de incorporarlo por entero a su Corona.

Al día siguiente lo encontramos ya camino de Guardamar. Sigue el camino de la franja costera, por aquello de que las tierras colindantes con la villa de Alicante por el sur, integraban el Señorío ilicitano del noble don Juan Manuel, con cuyo Merino Mayor, Sancho Ximénez de Lanclares, estaba en negociaciones con miras a la firma de una tregua o capitulación de la plaza (26). Dejó asimismo otras tierras a su derecha, pertinentes al Señorío musulmán de Crevillente, cuyo arráez, Muhammad ibn Hudayr, era también amigo y vasallo del monarca aragonés.

El castillo de Guardamar se le rindió el propio día 26 de abril, sin resistencia de consideración, ya que el 27 data Jaime II un sinfín de documentos desde aquel lugar. Las treguas en marcha de Elche, y la amistad del ra'is de Crevillente con Aragón, jugaron tal vez un papel favorable al respecto.

Lo cierto es que Jaime II despacha ya en Guardamar varios correos a partir del 27 de abril, de singular interés (27).

El propio 27 de abril rebasó ya Jaime II Guardamar, adentrándose en el término de Orihuela, por Almoradí, en cuyas tierras efectuó la donación de un amplio heredamiento, denominado LA DAYA, a favor de su consejero real Guillen Durfort, en franco y libre alodio, entre los términos de Almoradí y Orihuela (28). 
Colocó al frente del castillo de Guardamar a Galcerán de Rosanes, como alcayde del mismo y del lugar, donde desarrollaría un papel estratégico de singular importancia para el acopio de vituallas y otras mercancías por mar (29).

Destacó Guardamar como lugar adecuado para la práctica de cabalgadas por tierras enemigas, en busca del codiciado botín. Por todo ello premió Jaime I los servicios prestados a la causa militar aragonesa al caballero Galcerán de Rossanes, a más del cargo de alcayde del lugar, con la cesión del quinto de las cabalgadas que arribasen con su botín a Guardamar (30).

La acción militar conquistadoras de Jaime II por tierras del Reino castellano de Murcia era ya un hecho incontenible.

\section{CONQUISTA DE ALMORADÍ}

Tras la conquista de Guardamar y el vasallaje amistoso de las tierras que, como Cox y Albatera, integraban el Señorio de Crevillente del ra'is, Muhammad ibd Hudayr, dejándolas a la espalda, se dirigió Jaime ll al lugar de Almoradi, que hubo de sitiar por espacio de tres días, 28 al 30 de abril, al cabo de los cuales se le entregó la plaza, pasando a la soberanía de Aragón (31).

Ese mismo día, 30 de abril, concluyó ya el asedio del lugar, pudiendo iniciar al día siguiente, el 1 de mayo, el cerco mucho más duro y difícil de la villa de Orihuela (32): «Datum in obsidione de Oriola Kalendas madii anno domini 1296».

\section{CONQUISTA DE CALLOSA DE SEGURA}

Durante el asedio prolongado de Orihuela, ocupó Jaime II otras plazas, entre las que debemos destacar Callosa y Abanilla, que pasaron a la obediencia de Aragón antes que la cabeza del concejo, con su amplio alfoz, que se rindió el día 11 de mayo de 1296.

Sabemos que el 8 de mayo, lo más tarde, Jaime II había sometido ya Callosa de Segura y constituido además su primer alcayde, bajo obediencia aragonesa, en la persona de Bernat del Puig, a quien ordena este día que no autorice el paso por su término a ningún hombre de armas de sus filas, sin la licencia correspondiente (33).

Callosa de Segura fue una plaza arrancada por la fuerza a la resistencia castellana, ya que el alcayde castellano de su castillo, Fernando Pérez de Gormesch, fue depuesto por Jaime II y despojado de sus bienes, por no rendir la fortaleza a las armas de Aragón. Por todo ello el mando del castillo fue confiado a otro servidor más leal, al aragonés Bernardo del Puig. 


\section{CONQUISTA DE ABANILLA}

La marcha de Jaime II hacia la cabeza concejil de la comarca, Orihuela, era ya imparable. Adentrándose algo más al interior, dentro ya del límite actual de la provincia de Murcia con Alicante, se llegó al lugar de Abanilla, para recabar del alcayde de su castillo, Miguel Garcia, la entrega pacífica del mismo.

Conocedor éste de los éxitos militares que acompañaban al monarca aragonés por tierras del Reino de Murcia y que, por otra parte, ostentaba aquél su legitimidad jurídica a la posesión del mismo, por la donación que reiteradas veces le hiciera su titular, don Alfonso de la Cerda, el verdadero rey de Castilla «illustri domino Alfonso, regi castellae, tam in regnis Castelle quam Murciae» (34), y al corriente asimismo de la intimación últimamente efectuada por el propio Alfonso de la Cerda, como Rey de Castilla, al concejo de Orihuela, el 3 de febrero pasado, para que se rindiese a las armas de Jaime II y lo aceptase como soberano y su señor natural, por haberle entregado él todo el Reino de Murcia (35), resolvió entregarle el castillo y prestarle homenaje, como a su nuevo rey y su señor natural (36).

Condicionaba sin embargo la entrega del castillo a Jaime ll a una cláusula, que estimaba de lealtad y obligado servicio al señor de Abanilla, don Guillén de Rocafull: «salvo quod possim salvare et reddere dicto nobili Guillelmo de Rochafolio castrum predictum de Favanella» (37), asintiendo complacido el monarca a su petición.

\section{CONQUISTA DE ORIHUELA}

Al exponer el cerco y conquista de Almoradi, tuvimos ocasión de ver cómo el monarca de Aragón estuvo acampado ante aquella plaza por espacio de tres días, hasta su rendición. Sin embargo, las tropas aragonesas atendían simultáneamente a dos o más frentes vecinos a la vez: Callosa de Segura, que capituló el 8 de mayo y el Castillo de Abanilla, cuyo alcayde prestaba el homenaje requerido, el 6 del mismo mes, estando uno y otro lugar sitos en el ámbito municipal de Orihuela.

A partir del 1 de mayo poseemos una larga serie documental, fechada en el asedio de Orihuela, jalonándonos día a día el estado de sitio de aquella ilustre villa, hasta su capitulación, acto que tuvo lugar el 11 de mayo de 1296. Recogemos tan sólo tres referencias clave: la del primer día del cerço, la última del asedio, y la tercera, concerniente a la ocupación aragonesa. La primera del asedio, y la tercera, concerniente a la ocupación aragonesa. La primera es una carta de Jaime II, fechada en el cerco de Orihuela el 1 de mayo: 
"Datum in obsidione de Oriola kalendas madii, anno domini millesimo ducentesimo nonagesimo sexto» (38). La segunda es una provisión real a favor del consejero real, Guillén Durfort, por la que Jaime II otorga a este su leal servidor un amplio heredamiento, denominado La Daya y sito en la localidad Daya la Vieja, del término de Orihuela actual, que fuera confiscado al castellano Fernando Pérez de Guzmán, por su actitud rebelde frente a Aragón. Y está fechada en el último día del asedio de aquella villa oriolana, el 10 de mayo: "Datum ut supra" (39), exactamente en la fecha del documento anterior "sexto idus madii anno domini 1296" (40). Y la tercera referencia documental la tomamos de otra carta del monarca de Aragón al Merino Mayor de don Juan Manuel, en el señorío de Elche, con fecha del 11 de mayo de 1296 (41). Este día estaba ya Jaime II dentro de Orihuela, pudiendo, a partir de esa fecha, el 11 de mayo, datar sus cartas y demás documentación apud Oriolam, Oriole o in Oriola, en la villa de Orihuela. Y así lo encontramos constatado de forma solemne en el acta municipal, que ese mismo día fue levantada en la iglesia de San Salvador, donde la corporación en pleno, en número de 32 miembros, juró obediencia y pleno homenaje al monarca de Aragón, aclamándolo públicamente: «per lur senyor natural et per rey del Regne de Murcia lo molt alt et poderos senyor, Jaome, per la gracia de Deu, rey d'Aragó, de Mallorques, de Valencia, de Murcia et comte de Barcelona» (42).

Es afirmación común, sin embargo, que el alcayde castellano del roquero castillo de Orihuela, Pedro Roys de San Cebrian, entregara sin resistencia su fortaleza al monarca de Aragón, tras la caída de la villa, el mismo día 11 de mayo (43), lo que contradice abiertamente los hechos constatados documentalmente, de los que se desprende que Pedro Rodríguez o Roys de San Cebrian, Alcayde del castillo de Orihuela, no entregó a Jaime II aquella fortaleza señera hasta el día 21 de junio, jueves, exactamente cuarenta días después de la fecha habitualmente consignada (44).

Puntualmente con lo acordado, el emisario regio especial, Pedro de Dios, entregó el castillo de Orihuela al Procurador General del Reino de Murcia, Jaime Pérez, en nombre del rey, en la fecha fijada del 21 de junio de 1296, reconfirmando en su cargo de alcayde del mismo a Pedro Roys de San Cebrian, en pago a su obediencia y lealtad a la Corona de Aragón, al haberse resuelto a aceptar a Jaime II como al nuevo soberano y señor natural del Rejno de Murcia, y asociándole, como bayles, a Pedro Rosselli y Guillen de Paratge, al objeto de ayudarle a la mejor administración y gobierno del concejo de Orihuela (45). 


\section{SEÑORIOO SARRACENO DE CREVILLENTE}

Entre los términos concejiles de Elche y Orihuela, había un amplio territorio, mayoritariamente poblado por sarracenos, que, desde Alfonso $\mathrm{X}$ el Sabio, disfrutaba por privilegio de autonomía propia, dentro de la hegemonía castellana del Reino de Murcia y constituía el denominado Señorío de Crevillente, gobernado por un arráez, reconocido y confirmado a todos los efectos políticos, judiciales y económicos por el monarca castellano (46).

Abarcaba tal Señorío musulmán las tierras correspondientes hoy a los lugares de COX, ALBATERA, ASPE, CHINOSA Y MONÓVAR, a los que sumaría Jaime Il el lugar de BENIOPA, en el reino de Valencia, próximo a Gandía, el 23 de mayo de 1296 (47).

Las relaciones amistosas de la Corona de Aragón con el arráez de Crevillente eran ya antiguas. Pedro III el Grande recomienda al ra'is de este señorío, Ahmad Abu Dja'far, por medio de la credencial que le hace llegar a finales de 1284 (GUICHARD, 21), y a principios el año siguiente parece ser que lo interesó en ayudarle al reclutamiento de mercenarios sarracenos para la lucha que lo tenía empeñado frente a Francia (48).

Jaime II prosiguió en idéntica línea de amistad que su padre. $Y$ a partir de la campaña militar para la conquista del Reino de Murcia, último tercio de abril de 1296, las relaciones entre ambos se estrecharon mucho más, cuidando el primero, sobre todo, de atraer a la órbita de Aragón al ra'is crevillentino. Son muchos los documentos que ilustran aquella efemérides, y a la cabeza de todos figura el Acta de sumisión del arráez de Crevillente, Muhammad ibn Hudayr, a Jaime II, reconociéndolo como soberano del Reino de Murcia, y por ello su señor natural, en virtud de la donación que le hiciera del mismo el rey de Castilla, don Alfonso de la Cerda y en la que le hace saber que ha colocado sobre la torre del castillo el guión o vexillo real de Aragón, en testimonio fehaciente de su abediencia y vasallaje (49).

Años más tarde, agosto de 1304, otorgaría Jaime II al arráez de Crevillente, Muhammad ibn Ahmad, hijo y sucesor del anterior, la competencia judicial sobre todos los musulmanes de la Procuración de Orihuela (50).

El papel del Señorio de Crevillente, merced a la excelente predisposición de sus arraeces, a favor de la causa de Aragón, en la conquista del Reino de Murcia, fue de importancia singular para el buen éxito de la misma, gracia al alto caudillaje espiritual y político que ello ejercieron sobre la gran población mudéjar de todo el Reino. 


\section{CONQUISTA DE ELCHE}

El proceso seguido por el monarca de Aragón para la conquista de esta plaza y Señorío de Elche fue idéntico al ya conocido con referencia a los lugares más importantes del Reino de Murcia: Alicante, Orihuela, Murcia, Cartagena, etc. Negociaciones, avenencias y «posturas», en primer lugar. Y agotadas éstas, asedios y acoso armado después, hasta lograr su capitulación o rendición, soliendo intermezclarse de ordinario los medios diplomáticos de la negociación con los de fuerza y expugnación alternativamente.

Elche es un ejemplo elocuente de cuanto queda dicho.

Apenas hubo Jaime II conquistado el castillo y villa de Alicante, el 21/22 de abril de 1296, se ocupó ya a los dos días de hacer saber al Merino Mayor del noble don Juan Manuel, Sancho Ximénez de Lanclares, que recabase de su señor el acatamiento de su soberanía en el Reino de Murcia, como a su rey y señor natural. Por haberle expresado anteriormente que requeria un plazo de tiempo para la reflexión y resolver en consecuencia, le propone ahora Jaime $\|$ el espacio de 26 días exactamente, a contar del de la fecha, 24 de abril, dentro de los cuales deberá entregar la villa y aceptar su soberanía. El plazo expiraba el 19 de mayo siguiente (51). Cumplía la tregua de 26 días, y la entrega de la villa de Elche no había madurado aún. Se celebraron entrevistas entre Almoradí y Elche, por ambos interlocutores apuntados, y el resultado de las negociaciones fue un aplazamiento y prórroga de la misma, por espacio de 15 días más. Si la tregua inicial expiraba el 19 de mayo, ahora se prorrogaba hasta el 2 de junio (52).

La resistencia por parte de don Juan Manuel a reconocer la soberanía de Jaime ll sobre el Reino de Murcia era todavía invencible. $Y$ en cierto modo era muy comprensible. Para un descendiente tan directo como era él de la dinastía de Castilla, nieto de Fernando III el Santo, y sobrino del Rey Sabio, conquistador y castellanizador del reino hudita de Murcia, tenía que resultarle muy difícil y como algo contra sus más hondos sentimientos de auténtica castellanía, volver la espalda a la corona de Castilla, negar lealtad a su rey Fernando IV, y acatar la soberania aragonesa sobre el Reino de Murcia prestando a su rey el homenaje requerido. Todo esto le repugnaba y en ello estriba gran parte de su resistencia y tan prolongada, por más de tres meses, a rendir obediencia al monarca de Aragón y entregarle la plaza y señorío de Elche.

El 27 de julio, por fin, se llegaba a un acuerdo, firmando unas avenencias o Treguas que cerraban aquel período de hostilidades. 
Se estipulaba que, habida cuenta que el noble don Juan Manuel era menor de edad y no reunía las condiciones idóneas para pronunciarse al respecto, hasta cumplir los 21 años, la adscripción de las tierras y gentes del señorío ilicitano a la soberanía y jurisdicción del monarca de Aragón habría de efectuarse reservándole de momento el beneficio de las rentas y demás ingresos del almojarifazgo en todos sus términos (53), hasta entonces.

La TREGUA firmada por Jaime II y don Juan Manuel ponía fin ciertamente a las hostilidades entre ambos, incorporando su amplio y rico señorío de Elche a la Corona de Aragón, pero abría por otro lado un paréntesis de siete años, relegando a la expiración de aquel plazo (1303) la palabra definitiva sobre el Acuerdo firmado. Durante este septenio consolidó Jaime II en efecto la conquista de todo el Reino de Murcia, reduciendo a su obediencia y plena soberania las plazas restantes, como las de Alhama, Mula y Lorca, últimas en acatar al monarca de Aragón, como a su señor natural.

Por cumplir don Juan Manuel los 21 años de edad el 5 de mayo de 1303, expiraba el plazo de las Treguas de Elche al día siguiente, conmemoración de San Juan ante Portam Latinam, como reza el texto. Transcurrido aquel plazo sin que el ilustre señor de Elche acatase a Jaime II como a su propio soberano y admitiese su señorío sobre el entero Reino de Murcia, éste no le devolvió el señorío ilicitano, de acuerdo con lo estipulado en la tregua.

Pero por muy poco tiempo. Tras no pocas vicisitudes y no menos dificultades, se llegó por parte de don Juan Manuel a la firma de sus esponsales (1303), de futuro con la infanta de Aragón, todavía una niña, doña Constanza, aquel mismo año, en la villa de Játiva (54), acatando la soberanía plena de su suegro sobre todo el Reino de Murcia y éste a su vez le devolvería el señorío todo de Elche, con todos sus viejos derechos y franquicias.

Un año más tarde, quedaría sancionado formalmente en la Sentencia Arbitral de Torrellas-Campillo (55), agosto de 1304, su dominio alodial pleno sobre el Señorío de Elche, al igual que lo retuviera con anterioridad, bajo la hegemonía castellana.

Concluía así la ocupación territorial por Jaime II de las tierras meridionales alicantinas, correspondientes al CAMP D'ALACANT, pudiendo iniciarse acto seguido el proceso de la delimitación municipal de sus términos y consiguiente incorporación al Reino de Valencia y confirmación de sus libertades y fueros de la que pasaría a denominarse entonces, a partir de 1304, la PROCURACIÓN DE ORIHUELA o Reino de Valencia ultra Sexonam, integrado sustancialmente por el referido Camp d'Alacant. 
Obtenido el sometimiento de la plaza y castillo de Alicante por el infante don Alfonso, antes de ceñir la corona de Castilla, procedió a confirmarle sus fueros y franquicias, apenas ascendido al trono, mediante un privilegio emanado en Murcia, a 29 de agosto de 1252. Solícito de su mayor bienestar e incremento de sus ingresos comunales, amplió el área de su término municipal, extendiéndolo a las aldeas circumvecinas de AGUAS, BUSOT, AGOST, MONFORTE, ASPE y NOVELDA, "Con todos sus castiellos et con todas sus rentas et con todos sus partidos et con todos sus terminos, con sus montes, con fuentes, rios, pastos, con entradas et salidas et con todas sus pertinencias assi como nunca mexor las hovieron» (56), englobando a todos estos lugares en su amplio alfoz municipal. Brindamos en un Anexo documental el texto de este diploma regio al objeto de que el lector pueda disfrutar directamente de su rico contenido.

Lo tomamos de un traslado notarial, efectuado en el s. XVIII por un notario del Reino de Valencia y escribano a la sazón del palacio consistorial de Alicante, Laurentius Maltes, quien lo extrajo, según confesión propia, de un Libro de Privilegios, otorgados por los reyes de Castilla y Aragón a la ciudad de Alicante, guardado entonces, escribe, «in archiuo dicte civitatis recondito». Subrayamos el entonces, porque el Códice aludido es a nuestro juicio el que lleva hoy la signatura Arm. 5, lib. 48, en el Arch. Munic. de Alicante, y no contiene ya el diploma alfonsino citado, por haberse extraviado apenas medio siglo después, cuando se compiló este manuscrito, a base de los privilegios y cartas reales de Alfonso $X$ el Sabio, que obraban en dicho archivo. (ESTAL, J. M. del, Documentos inéditos de Alfonso $X$ el Sabio y del infante su hijo don Sancho, Alicante, 1984, pp.3-8).

Tras la ocupación territorial de la villa de Alicante por Jaime Il de Aragón, en el tercio último del mes de abril de 1296, como queda expuesto en el primer capítulo de esta disertación, se ocupó inmediatamente aquel monarcá de confirmarle también sus privilegios y todas sus franquicias, mediante un elevadísimo volumen de provisiones reales, que muy pronto verán la luz en un Corpus Documental, que preparamos, cuyo primer tomo, referente a este monarca, está en vías de publicación, próximo a aparecer. (Ya publicado, Alicante, 1985. Vid. supra p. 302).

También dedicó Jaime II especial atención a asegurarle al concejo de Alicante el incremento de sus ingresos comunales, ampliando todavía más 
su ya conocido alfoz municipal. La ocasión se la brindó el peligro existente en el "Camino Mayor» de Alicante a Jijona, haciendo impracticable su andadura los numerosos salteadores y bandidos, que apostados a lo largo del mismo caían de improviso sobre los viandantes. Circunstancia que indujo al monarca a urgir a su lugarteniente y Procurador General del Reino de Valencia ultra Sexonam, Jaime Pérez, hermano suyo y señor de Segorbe, la inmediata creación de una guardia armada, que velase por el bienestar, seguridad y salud de los viandantes, que hiciesen tal camino. Por dos veces, en menos de un año, intervino Jaime II, con dos provisiones reales a tal efecto, emanadas respectivamente con fecha del 4 de noviembre de 1296, en Murcia (57), y Alicante, 3 de octubre de 1297 (58). Vid. Anexo -2-.

En la segunda hallamos la delimitación más exacta conocida del término municipal de la villa de Alicante, que confinaba por el norte con el de Villajoyosa, por el Barranco del Carrichal, «diez millas a la mar»; por el oeste, en el interior, por La Solana, la Sierra de Almadraba y la Carraschiella o el Carrascal; en la confluencia de los términos municipales de Castalla-Sax-EldaPetrel; y por el sur, con La Cañada, Mata de Martí Sancho, el Portichol y «diez millas a la mar», en colindancia con los términos de Crevillente y Elche, hasta el litoral por El Altet. En el Anexo 2 ofrecemos la transcripción completa del texto citado, al que adjuntamos un mapa (Anexo 3) de la división administrativa actual de la provincia de Alicante, con la ubicación de todos sus municipios y el enmarcamiento de todos aquellos, que por disposición de Alfonso $X$ y de Jaime II pasaron a integrar sucesivamente el alfoz municipal de la villa de Alicante. En doble numeración sucesiva, una que bordea el contorno municipal alicantino, y otra que señala la ubicación concreta dentro de su alfoz, se registran los topónimos expresados de accidentes del suelo en la primera, y el nombre de los concejos actuales que integraban entonces el término municipal tan amplio de la villa de Alicante, en la segunda, correspondiente en su gran parte al que hoy se denomina CAMP D'ALACANT. Dos columnas superpuestas de topónimos facilitan la fácil identificación y localización de cada uno de ellos. A un simple golpe de vista se aprecia la vastísima extensión del alfoz de Alicante, que incluía en todo o parcialmente cuando menos los siguientes términos concejiles alicantinos actuales: San Juan, Campello, Villajoyosa, Orcheta, Relleu, Busot, Aguas, Muchamiel, San Vicente del Raspeig, Agost, Petrel, Novelda, Monforte del Cid, Aspe, ALICANTE, hasta el término de Elche, por el Portichol. (ESTAL, Documentos inéditos de Alfonso $X$ el Sabio, Alicante, 1984, pp. 28-37 y 21, con facsímiles, transcripción y mapa).

En un segundo mapa, que ofrecemos (Anexo 5), de hace ya doscientos años (1786) se nos ilustra una vez más acerca del vasto ámbito del alfoz ali- 
cantino y de la pugna persistente entre los concejos de Alicante y Villajoyosa por ampliar a costa del otro sus términos municipales respectivos. Es curioso ver reflejada en él gráficamente esta lucha comunal, mediante el amojonamiento de una zona litoral, entre los Barrancos Linares y Carrichal, cuya pertenencia se adjudicaban a la recíproca uno y otro municipio, instalando los hitos de la división comunal dentro del término concejil vecino, apropiándose respectivamente el área que separaba los Barrancos sobredichos. (ESTAL, ibid., pp. 40-51). Vid. Mapa -5 bis-.

Y lo que hay que subrayar en este punto es el dato histórico del Tratado de Almizra (1244), esgrimido en el contencioso con Alicante por Villajoyosa, haciendo saber a su opositor, que apoyaba tales reivindicaciones territoriales en los límites que le fijara el. Procurador General de Orihuela, Bernat de EnSarriá, el 1300, de acuerdo con aquel pacto. El límite meridional de Villajoyosa quedaba fijado más al sur del Barranco del Carrichal, entre el Barranco del Parador y el río Aigües, exactamente en la línea imaginaria que del interior hacia el litoral componen estos topónimos orográficos: La Mola, Cantal del Barranco de la Mola, Alto de la Cola Negra, Tosal del Medio, Alto del Blanquinar, Alto dels Porchets de Arnau, Alto de la Guarda, Alto dels Estornells, la Torrosella y el Alto de las Rexas. Y desde La Mola al Puerto de Biar y Villena señala asimismo estos topónimos de picos y puertos de montaña, que en dirección hacia el interior y Albacete, delimitaban con precisión la frontera trazada en Almizra entre Castilla y Aragón: Sumo de Cabezo, Peña Forada, Alcantarella, Cabesonsuelo, Espino, Cabezo de Monegre, Escubilla o Alto de la Punta Subirana, Alto del Ventós, Estrecho de la Zarza de Petrel, Barranco de Castilla, Barranco de Sax, Alto de la Fosa del Moro, Sierra y Puerto de Biar y Villena. (ESTAL, o.c., pp. 38-51, con facsímiles, diagramas y textos correspondientes). Vid. Anexo -5 bis-.

Y en un esfuerzo de concreción ulterior, con ánimo sin duda de asegurar la pertenencia territorial al municipio de Villajoyosa, se ocupa el autor de este mapa de ofrecernos la parcelación de las tierras de cultivo, situadas entre el Barranco Linares y Río Aguas, con la relación de contribuyentes por las mismas al municipio de Villajoyosa, en número de 43 vecinos en total, lo que evidencia a las claras, por el registro de la propiedad, la pertenencia alodial de aquel área controvertida entre Villajoyosa y Alicante, a aquel concejo.

Por estímar de considerable interés la publicación de su amplio contenido textual, de carácter topográfico y antroponímico, ofrecemos su reproducción total, con una explanación del texto y la relación nominal de propietarios, con el número de la parcela o parcelas que le corresponden y la ubicación exacta de la misma. La relación de los topónimos expresados cierra la expo- 
sición de este capítulo. A la transcripción del texto referido añadimos además un facsímil del mapa en cuestión para facilitar al lector la ubicación exacta de cuanto queda dicho. Vid. Anexos 4 y 5 .

III

ACTA DE ANEXIÓN DEL CAMP D'ALACANT AL REINO DE VALENCIA (1308)

En este capítulo último abordamos la incorporación del CAMP D'ALACANT al Reino de Valencia, cual término lógico, final, de cuanto antecede. La meta última perseguida por Jaime II de Aragón en su campaña militar por el Reino castellano de Murcia no era otra, sino la de culminar el viejo sueño ancestral de su antepasados, engarzando al fin en su corona el dominio soberano de aquellas tierras aneladas del Sureste peninsular.

De momento fue el reino entero de Murcia el que pasó a engrosar la Córona de Aragón, por espacio de algo más de ocho años (abril 1296-agosto 1304).

Más tarde la concordia y avenencias, firmadas por los soberanos de Castilla y Aragón, en la Sentencia Arbitral de Torrellas, más las Vistas reales de Campillo, Tarazona y Soria, en agosto de 1304, condujeron a la parcial devolución del Reino de Murcia, desde el bajo Segura hacia el mediodía, a Castilla, reservándose el resto para Aragón, correspondiente en líneas generales a la región meridional alicantina o CAMP D'ALACANT, desde el bajo Segura hasta Biar-Jijona-Villajoyosa (59).

Por su parte Jaime II procedia seguidamente a la remodelación administrativa de estas tierras alicantinas y organización institucional de sus gentes, de acuerdo con los Fueros de la ciudad y Reino de Valencia, haciendo a sus hombres partícipes de los mismos, mediante su inserción formal en aquél.

La formalización de este acto constitucional y político fue llevada a cabo por el monarca aragonés, mediante la emanación de una Provisión Real solemne, en la que sancionaba la ANEXIÓN de las villas de ORIHUELA (60), ALICANTE (61) y ELCHE (62), et 17 y 25 de junio de 1308 respectivamente, al REINO DE VALENCIA, así como la de GUARDAMAR DEL SEGURA (63), un mes exactamente después.

Por ofrecer las cuatro Cartas-Privilegio un patrón común, elegimos para șu análisis la expedida a la villa de Alicante, por añadir dos ricos protocolos al texto primitivo original, de relevante interés para la historia local de su Consell. Al objeto de hacer más inteligible a un mayor público de lectores su rico contenido, ofrecemos su versión castellana, obra nuestra, en un Anexo final, n. ${ }^{\circ} 6$. 
Por ello nos dispensamos de presentar aquí su contenido, limitándonos a anticipar, en un extracto apretado, los puntos fundamentales, comunes en las cuatro, subrayando las diferencias que caracterizan a cada una de ellas.

Tras una arenga de alto valor ético, en la que expone Jaime II la obligación de los príncipes a esforzarse «por mantener a sus pueblos tranquilos en el camino de la justicia y de la paz», caminando siempre por la senda de la virtud, el orden y la rectitud, "respetando siempre los derechos de todos y de cada uno", pasa a exponer los motivos que lo han inducido a sancionar solemnemente al ANEXIÓN FORMAL de estas tierras y gentes de la Procuración General de Orihuela al REINO DE VALENCIA.

Destaca entre otros «la previa súplica y común consenso» de los estamentos que integran la comunidad de estos municipios, deseosos de su respectiva inserción total en aquel Reino, así como la convicción del monarca de ordenar tal anexión a una «más efectiva y plena posesión de su territorio, ya sometido a su alta jurisdicción soberana, seguro de que todo ello redundará en mayor beneficio para todos sus moradores», por cuanto todo ello son factores, añade, que lo han movido a emanar «esta Provisión real perpetua, en cuya virtud disponemos, mandamos y ordenamos su ANEXIÓN AL REINO DE VALENCIA, de suerte que las villas y lugares sean considerados ya parte integrante sustancial del mismo y todos sus vecinos se rijan y gobiernen de ahora en adelante por IOS FUEROS DE LA CIUDAD Y REINO DE VALENCIA, renunciando, prosigue, a los fueros antiguos salvo aquellos aprobados o confirmados por él mismo anteriormente», a tenor de los privilegios otorgados por él personalmente, declarándolos una vez más en su vigor pleno, ya que «Nos, continúa, les hemos confirmado los ya existentes, disponiendo por ello a su favor, que los usos y costumbres que hallaren en contradicción con los fueros de Valencia, si fueren del gusto y voluntad de mantenerlos, pese a todo, en vigencia y deseen proseguir ateniéndose a ellos en sus juicios, que puedan hacerlo y Nos, concluye, accedemos complacido a su petición», otorgándoles el disfrute pleno y cabal de los mismos, respetando plenamente sus COSTUMS, o usos y costumbres locales o regionales, siempre y cuando éstos se hallaren sancionados y reconocidos por el monarca y ellos por su parte desearan seguir ajustándose en sus juicios y demás actos públicos a los mismos (64).

Las costumbres locales,. o buenos usos y costums regionales, sancionados por el monarca, se reducen a diez fundamentales, que resumimos a continuación, y en los que observamos un favor positivo a estas tierras del Reino de Valencia ultra Sexonam o de la Procuración General de Orihuela y que constituyen como el DECÁLOGO LEGAL o CARTA MAGNA de gobierno de estas tierras y. gentes. 
Enunciamos los diez puntos por el orden sucesivo en que aparecen en la Carta de Anexión:

1.-El sueldo anual de Justicia local no será el estipulado en los Fueros de Valencia, sino el que asigne el Consell de los lugares mencionados, por este orden:

800 sueldos reales valencianos ORIHUELA y 400 su Asesor jurídico. 600 sueldos reales valencianos ALICANTE y 300 su Asesor jurídico. 500 sueldos reales valencianos ELCHE y 300 su Asesor jurídico. 350 sueldos reales valencianos GUARDAMAR y 150 su Asesor jurídicco.

2.- La calonia o multa contra los convictos de apelación judicial o reclam no será de 1/4, «pena del quart» de la suma adeudada, sino tan sólo de 1/10, el diezmo, convirtiéndola en una multa mucho menos gravosa y más benigna.

3.-La denuncia por adulterio contra una esposa solamente será válida cuando la formule el propio marido, rechazando las presentadas por un tercero.

4.-Los cargos y oficios de la administración y gobierno municipal serán cubiertos solamente por vecinos del lugar, y no tendrán voz activa ni pasiva en su elección individuos del sector nobiliario y clerical, reservando la participación en su nombramiento al estamento urbano-burgués, allí avecindado.

5.-Facultad de seguir sirviéndose a voluntad propia de la tahúlla, como medida agraria regional.

6.--Libertad de compraventa de cualquier tipo de bienes raíces, entre los vecinos del lugar, hombres de a pie o caballeros, sin exclusión de los últimos, quienes tenian vedado en los Fueros de Valencia incrementar su hacienda patrimonial con tales actos. Quedaban excluidos tan sólo los clérigos.

7.-Poder al Justicia local de absolver las calonias y sanciones fiscales, al igual que el Justicia Mayor de Valencia.

8.- Prohibición de ingerencia al Procurador General de Orihuela en los negocios internos de las villas y lugares referidos, de modo distinto a como se permite efectuarlo en Valencia.

9.-Pena capital para los reos convictos de rapiña de colmenas, en testimonio fehaciente del valor otorgado a la apicultura.

10.-La subasta de bienes públicos por la administración local habrá de ir precedida siempre, tras la de los acreedores, de una valoración inicial por encima de los cien sueldos, debiendo adjudicarse, a requerimiento del Justicia local, al mejor postor, al objeto de conseguir el mayor beneficio comunal. 
Se busca en todo la mayor promoción de los intereses comunitarios y defensa de los fueros del lugar, convirtiéndose por ello esta Carta Real de Jaime II en el primigenio Cuerpo Legal de sus principios autonómicos básicos, dentro del propio reino. 
(1) Discursos his. de la muy noble y muy leal ciudad de Murcia y su Reino, $2 .^{2}$ ed. Murcia 1775; ed. 4. ${ }^{\text {a }}$, Murcia 1980, pp. 75-90; BELLOT, P., Anales de Orihuela (a. 1622), ed. TORRES FONTES, J., 2 vols., Murcia, 1954 y 1956; GISBERT Y BALLESTEROS, E., Historia de Orihuela, 3 vols., Orihuela, 1901-1902; MERINO ÁLVAREZ, A., Geogr. hist. del Reino de Murcia, Madrid 1915; reimpr, offset, Murcia 1978; GARCIA SORIANO, La Reconquista de Orihuela, Madrid 1934; FONT Y RIUS, J. M., «La Reconquista y repoblación de Levante y Murcia», LA RECONQUISTA ESPAÑOLA Y LA REPOBLACIÓN DEL PAÍS, Zaragoza, 1961, pp. 85-126; TORRES FONTES, «El obispado de Cartagena en el s. XIII», Hispania, LII-LIII, 1953, pp. 339-401, 515-580; ID., «Relación murciana de los Lope de Ayala en los ss. XIII y XIV", Murgetana, XLV, 1976, pp. 5-35; VILAR, J. Bta., Historia de la ciudad de Orihuela, III Los siglos XIV y XV en Orihuela, Orihuela, 1977, pp. passim; TORRES FONTES, J. Murcia castellana, HISTORIA DE LA REGIÓN MURCIANA, III, Murcia 1981, 7-387. p. 379.

(2) TORRES FONTES, Murcia castellana, p. 379.

(3) Discursos históricos... c. II, p. 77.

(4) B. A. E., t. LXVI, Madrid 1953, p. 103; BENAVIDES, A. Memorias de Fernando $\mathrm{N}$ de Castilla, I Contiene la Crónica del dicho Rey, Madrid 1860, p. 32.

(5) Crónica, estudio y ed. de UBIETO ARTETA, A., Valencia 1971, p. 45.

(6) Anales, lib. V, c. XXI, ed. CANELLAS LÓPEZ, A. Zaragoza 1970, p. 501. Error por otra parte repetido hasta por historiadores modernos, dando fe al relato cronístico, sin confrontación documental: VILAR, J. Bta., Hist. de la ciudad de Orihuela, III, p. 43, donde pospone su conquista a la capitulación de Elche en estos términos: «Elche capituló al fin... El rey pudo llegarse a Orihuela sin temor a dejar a sus espaldas ninguna plaza importante en poder de los castellanos", cuando, como es sabido, esta plaza se rindió a Jaime II dos meses y medio largos antes que la ilicitana del noble don Juan Manuel.

(7) CASCALES, ob. c., p. 77: «Y después de haber ganado a Elche, pasó el rey a la villa y castillo de Origüela ... y rendimiento de Murcia».

(8) TORRES FONTES, Murcia castellana, Murcia 1981, p. 379; VILAR, J. Bta., o.c., III, p 243 y ss.; GONZÁLEZ MÍNGUEZ, C., Fernando IV de Castilla (1295-1312). La guerra civil y el predominio de la nobleza, Vitoria, Valladolid 1976, p. 102.

(9) Jaume II o el Seny català, 2. ${ }^{\text {a }}$ ed., Barcelona 1963, p. 151.

(10) BENAVIDES, o.c., I, p. 103.

(11) Crónica, c. CLXXXVIII, ed. SOLDEVILA, Barcelona 1971, p. 834-835.

(12) TORRES FONTES, J. Nicolás Pérez, alcaide de Alicante, Murcia 1964. Acerca de la importancia estratégica de este castillo, tanto bajo la hegemonía castellana, como bajo la de Aragón, v. nuestro trabajo: «Singular relevancia del Castrum d'Alacant a tenor de una provisión real inédita de Pedro IV de Aragón”, ITEM, 5, Universidad de Alicante 1981, pp. 51-63. 
(13) Crónica, c. CLXXXVHI, p. 835.

(14) Ibid; Revolución urb. en Murcia, 1395-1420.

(15) Carta de Jaime II a Raymundo de Urtx, alcayde del castillo de Alicante, Guardamar, 27 abril 1296, ACA, Rg. 340, fol. 51r.

(16) Embajada de Jaime Il al rey de Castilla, don Alfonso de la Cerda, Murcia, 21 mayo 1296, ACA, Rg. 340, fol. 79r; Murcia, 22 mayo 1296, ACA, Rg. 340, fol. 80 v.; don Alfonso de la Cerda efectuó la donación del Reino de Murcia a Jaime II en Serón (Soria), 4 febrero 1296, y un día antes había ordenado por carta del 3 febr. al concejo de Orihuela obediencia plena al monarca aragonés, Arch. Munic. Orih., Lib. becerro de Privilegios reales, fol. $9 \mathrm{v}-10 \mathrm{r}$. (publ. TORRES FONTES, CODOM II, Murcia 1969, p. 118-119; MARTíNEZ MORELLA, V., Cartas de los Reyes de Castilla a Orihuela, 1265-1295, Alicante 1954, p. 87. ESTAL, o. c., p. 111-112.

(17) ACA, Rg. 340, fol. 51r. (Aunque Raymundus es el antropónimo más frecuente).

(18) En carta que le dirige desde el cerco de Murcia, 17 mayo 1296, ACA, Rg. 340, fol. $70 \mathrm{v}$. le ordena el envio de las vituallas que aún no han sido descargadas en el puerto de Alicante, del barco de un tal Bezes, hacia Guardamar, para su aprovisionamiento, y aquéllas que tuviere descargadas ya, que las entregue a su consejero real, Jaime de Sta. Cruz, escribano real del Puerto de Alicante. ESTAL, o. c., p. 173.

(19) Jaime II le impone por carta del 19 julio 1296 la ejecución testamentaria, en función de su cargo judicial, de un legado respetable de 2.400 maravedís alfonsinos, a favor del convento de frailes Menores de Alicante, ACA, Rg. 340, fol. 246r.

(20) Vid. supr., not. 13.

(21) "Datum in civitate Murcie, VIII kalendas junii, anno domini millesimo ducentesimo nonagesimo sexton, 25 de mayo de 1296.

(22) ACA, Rg. 340, fol. 135r.

(23) Carta del 30 abril 1296, ACA, Rg. 340, fol. 52r., en confirmación del señorio de Petrel, Bañeres y otros lugares.

(24) Huerta de Almoradí, 28 abril 1296, ACA, Rg. 340, fol. 52r.

(25) ACA, Rg. 340, fol. 53r.; Guardamar, 27 abril 1296, ACA, Rg. 340, fol. 51r.; Murcia, 22 mayo 1296, ibid., fol. 85 v. - 86 r.; ACA, Rg. 340, fol. 120r. ESTAL, o. c., p. 194 s.

(26) Vid. supr., not. 13.

(27) Guardamar, 27 abril 1296, ACA, Rg. 340, fol, 1 v. ESTAL, p. 113-118.

(28) Sito en la localidad actual de La Daya Vieja, en el término de Orihuela. Ibid. 118-121.

(29) ACA, Rg. 340, fol. 70v.

(30) ACA, Rg. 340, fol. 53r, /bid.

(31) "tertio kalendas madii, anno domini 1296», ACA, Rg. 340, fol. 51v;; 52r. y 53r.

(32) ACA, Rg. 340, fol. 13v.

(33) «Datum in obsidione de Oriola, VIII idus madii anno domini 1296», dia 8 de mayo, ACA, Rg. 340, fol. 29r. ESTAL, ib., p. 124 s.

(34) Carta del alcayde del castillo de Abanilla, Miguel García, Orihuela, 6 mayo 1296, a Jaime II, para aceptar su soberanía plena sobre el reino de Murcia, prestándole por ello el homenaje requerido, ACA, Pergamino 642 de Jaime II, publ. TORRES FONTES, CODOM II, $n .{ }^{\circ} \mathrm{CXIX}$, p. $121-122$.

(35) «... al Conceio e a los homnes buenos de Origuela, salut...Commo Nos ayamos dado el Regno de Murcia con todos sus terminos...al muy noble don Jayme... rey de Aragon por las muchas e grandes ayudas...que recibiemos...Decimos vos espressamente e vos mandamos que obedescades al dicho senyor rey de Aragon...e quitamos vos de toda jura, fe e homenage et fealdat...que a Nos fuessedes tenudo. Dada en Seron, tres dias de febrero. Era de 1334», año 1296.

(36) Vid. supr, not. 34. ESTAL, o. c., p. 123-124.

(37) Ibid.

(38) ACA, Rg. 340, fol. 13v.

(39) ACA, Rg. 340, fol. 36r. ESTAL, p. 127.

(40) ACA, Rg. 340, fol. 35r. y v.

(41) ACA, Rg. 340, fol. 53v. D. Sancho Jiménez de Lanclares. 
(42) AMO (Arch. Munic. Orih.) Lib. de Privilegios, fol. 15r. y 16 v., publ. TORRES FONTES, CODOM II, n. ${ }^{\circ} \mathrm{CXX}$, p. 122; ESTAL, J.-M. del, «Nuevos datos sobre el asedio y conquista de Orihuela por Jaime II de Aragón», ITEM, 2, 1977, pp. 99-109; ID., El reino de Murcia bajo Aragón, n. ${ }^{\circ} 18$, pp. 129-132.

(43) VILAR, J. Bta., Hist. de la ciud. de Orih., III, p. 243.

(44) Sitio de Elche, 18 junio 1296, ACA, Rg. 340, fol. 150v. ESTAL, p. 215 s.

(45) ACA, Rg. 340, fol. 65r

(46) Un estudio monográfico acerca del origen y desarrollo de este señorío, bajo la sucesivas dominaciones de Castilla y Aragón, hasta su extinción, nos la ofrece GUICHARD, P., «Un seigneur musulman dans l'Espagne chrétienne le ra'is de Crevillente (1243-1318)", Mélanges de la Casa de Velázquez, IX, 1973, pp. 283-334; trad. castellana, Alicante 1976, con rico anexo documental. ESTAL, «Vasallaje de Crevillente a Jaime II de Aragón», Sharq al-Andalus, Estudios Árabes 2, 1985, pp. 81-99.

(47) ACA, Rg. 340, fol. 108r. y v. Ibid.

(48) DUFOURCQ, Ch. E., L'Expansió catalana a la mediterània occidental, segles XIII i XIV, Barcelona, 1969, pp. 174-179.

(49) ACA, Rg. 25, fol. 282r. y v.; publ. por GUICHARD, o.c., Anexo 1, pp. 68-70.

(50) «quod sitis judex omnium sarracenorum conmorantium in ravalło Oriole et termino eius, sicut Hameti Abinhudell (Muchammad ibn Hudayr) quondam Arraiç de Crivillen, pater vester, dictum judicatum tenebat", ACA, Rg. 231, fol. 58r., carta despachada en Elche, a 8 de febrero de 1307.

(51) Alicante, 24 abril 1296, ACA, Rg. 340, fol. 55r.

(52) ACA, Rg. 340, fol. 73v.

(53) Arch. Cat. Valencia, pergamino 567, publ. CHABÁS, R., «Treguas de don Jaime ll de Aragón con el noble don Juan Manuel, hijo del infante don Manuel, en 1296», BRAH, XXVIII, cuad. VI, 1896, pp. 433-439.

(54) ACA, Rg. 292, fols. 93r. - 94.v.; publ. GIMÉNEZ SOLER, Don Juan Manuel, biografía, n. ${ }^{\circ}$ XII, pp. 234-238.

(55) Texto del Fallo Arbitral de Torredellas en BENAVIDES, II, Colección Diplomática, Madrid $1860, n .{ }^{\circ}$ CCLXXIX, pp. 413-418; TORRES FONTES, CODOM II, Murcia 1969, n. ${ }^{\circ}$ CLIII, pp. 155-158; estudian la Sentencia Arbitral citada: TORRES FONTES, La delimitación del Sudeste peninsular (Torrellas-Elche), 1304-1305, Murcia 1951, pp. 4-18; ID., Historia de la región murciana, II Murcia castellana, Murcia 1981, pp. 385-387; GONZÁLEZ MÍNGUEZ, C., Fernando IV de Castilla, Vitoria-Valladolid 1976, pp. 179-191. ESTAL, o. c., pp. 362-389.

(56) AMA (Arch. Munic. Alic.), Arm. 1, lib. 3, fols. 298v. - 299 r.; vid. Anexo documental, 1.

(57) AMA, Lib. de Privilegios y Provisiones Reales, Arm. 1, lib. 17, fols. 119 r. - $120 \mathrm{v}$.

(58) Ibid., Un estudio monográfico de estas dos Cartas, vid. ESTAL, J. M. del «Delimitación del término municipal de la villa de Alicante por Alfonso X el Sabio y Jaime II de Aragón, 1252 y 1296", ITEM, 1, 1977, pp. 96-109; ID., El Reino de Murcia bajo Aragón. Alicante 1985, n. ${ }^{\circ}$ 143, pp. 262-267. ID., Documentos inéditos..., 32-37.

(59) Vid. supr., not. 55. Para un conocimiento documental más amplio acerca de estos extremos remitimos a nuestro estudio: Conquista y anexión de las tierras de Alicante, Elche, Orihuela y Guardamar al Reino de Valencia por Jaime II de Aragón, 1296-1308. Alicante 1982, pp. 192-282. ID., El Reino de Murcia bajo Aragón, Alicante 1985, pp. 89-103.

(60) ACA, Rg. 205, fol. 170r. y vi; AMA, Arm. 1, lib. 3, fols. 283r. - 284 v.; AMO, Lib. de Privilegios, Ms. 2588, fols. 26r. - 28 v.; AHN, Ms. 1398 B., fols. 52 v. - 55 r. (copia del s. XVI). Vid. ESTAL, Conquista y anexión..., n. ${ }^{\circ} 37, \mathrm{pp} .396-399$.

(61) ACA, Rg. 205, fol. 172r. - 173 v.; AMA, Arm. 16, Cax. 1, n. ${ }^{\circ} 2$. Traslado notarial efectuado el año 1369. Damos en Anexo documental, $n{ }^{\circ} 6$, versión castellana propia, con doble cometido, por obviar a su más fácil comprensión para mayor número de lectores y por el singular interés de sus dos protocolos, añadidos en la fecha indicada, vid. ESTAL, ibid. $n .{ }^{\circ} 38, p$. 399-403. 
(62) ACA, Rg. 205, fol. 173r, - 174 r.; AME (Arch. Munic. Elche), Arm. 2, Códice, Privilegio n. ${ }^{\circ}$ LXI, fols. LXVII v. - LXIX r. ibid., n. ${ }^{\circ}$ XCVII, fols. 100 r. - 102 r.; vid. ESTAL, ibid., n. ${ }^{\circ} 39$, pp. 403-406.

(63) ACA, Rg. 205, fol. 188r. - 189 r. Este registro se halla en muy mal estado de conservación y de imposible lectura en algunos de sus renglones, ESTAL, ibid., n. ${ }^{\circ} 40$, pp. 406-408.

(64) Todos los textos intercalados están tomados del Acta de Anexión formal de la villa de Alicante al Reino de Valencia, fechada el 25 junio 1308, y pueden consultarse en su contexto global en el Anexo documental, n. ${ }^{\circ} 6$, que añadimos, en la versión castellana, ESTAL, ibid. ก. ${ }^{\circ} 41$, pp. $409-414$. 


\section{FACSÍMILES Y ANEXO DOCUMENTAL}

(1) 1252, agosto, 29, Murcia. Carta-privilegio de Alfonso X el Sabio ampliando el alfoz de la villa de Alicante.

(2) 1296, nov. 4, Murcia - 1297, oct. 3, Alicante. Dos cartas del Procurador Gral. de Orihuela, Jaime Pérez, en que constituye una guardia armada en el Camino Mayor de Alicante a Jijona y describe el término municipal de Alicante.

(3) Mapa del término municipal de la villa de Alicante, a raíz de las Provisiones Reales de Alfonso X el Sabio y Jaime II de Aragón.

(4) Transcripción del texto de un Plano-mapa del término de Villajoyosa y área disputada con Alicante, año 1786.

(5) Facsímil del «Plano que expresa el término de Villajoyosa y término que se disputa» (5-1 y 5-2), entre el Barranco Linares y el Barranco del Parador (5-3 y 5-4), apropiado por Alicante, contra lo dispuesto en el Tratado de Almizra (1244) y la constitución del alfoz de Villajoyosa por obra del Procurador Gral. de Orihuela, don BERNAT DE ENSARRIÁ, en nombre de Jaime II, el año 1300. Y 5 bis.

(6) 1308, junio 25, Valencia. Traslado notarial de la Provisión real de Jaime ll en la que anexiona la villa de Alicante al Reino de Valencia, equivalente a su CARTA MAGNA constitucional, al respetar sus antiguos buenos usos y viejos COSTUMS, en el momento de implantar entre sus vecinos la vigencia de los FURS de Valencia, punto de partida de los principios autonómicos de esta región hasta nuestros días. Vid. facsimil (6).

(7) Mapa del Reino de Murcia. 
1252, agosto, 29. Murcia

Carta-privilegio de ALFONSO X EL SABIO por la que fija la delimitación del término municipal de la villa de ALICANTE que incluia los lugares-aldeas de: Novelda, Aspe el Viejo y Aspe el Nuevo, Nompot, Agost, Busot y Aguas.

AMA, Arm. 1, lib. 3, fols. 298v - $299 r$

Publ.: ESTAL, J. M. del «Delimitación del término muncipal de Alicante por Alfonso $X$ el Sabio...”, ITEM, 1, 1977, pp. 96-109. IDEM, Documentos inéditos de Alfonso $X$ el Sabio, Alicante, 1984, pp. 22-27.

El texto lo tomamos de un traslado notarial, efectuado a principios del siglo XVIII, por Laurentius Maltes, notario del Reino de Valencia y escribano a la sazón del Palacio Municipal de Alicante, quien lo extrajo, a su vez, de otro códice más antiguo, un Libro de Privilegios, como reza la apostilla última notarial.

Transcripción del texto:

\section{REY DON ALFONSO}

Aldeas de Alacant, Novelda, Aspe el vell y Aspe el nou, Nompot (Monforte), Agost, Busot y Aigues (Anotación escrita al margen izquierdo del texto). Este es traslado bien y fielmente sacado de otro priuilegio sellado / con sello del dicho sennor Rey don Alfonso de plomo colgado e dize assi: (1)

Conoscida cosa sea a todos los hommes que esta Carta vieren como yo don / Alfonso por la gracia de Dios, Rey de Castilla, de Toledo, de Leon, de Galliçia / de Sevilla, de Cordova, de Murçia, de Jahen, en una con la Reyna donna Yolant / mi muger, E con mi fiya la Ynfanta Donna Berenguela, por fazer bien et mer / cet a todos los Cavalleros e a los Cibdadanos et a los Marineros et a todos los / pobladores del Consejo (Concejo) de la Villa de Alicante et a los que agora hi son et / seran daqui adelante pera siempre jamas, assi de la Villa como de Aldeas / por el serviçio que me faran et por acreçerles en sus bienes y en sus franque / sas, doles et otórgoles que hayan por Aldeas et por sus terminos Noella / et Azp el Viejo et Azp el nuevo e Nompot (Monforte) et Agost et Busot et Aguas / (de Busot). Et todo esto les do con todas sus villas, e con todos sus Castiellos et con todas / sus Rentas Et con todos sus pedidos Et con todos sus drechos et con todos sus / términos, con sus montes con sus fuentes con rios, con pastos, con entradas e con salidas e con todas sus pertinencias assi como nunca mexor las / hovieron en tiempo de 
Moros, salvo onde si alguna cosa di por mais Car / tas, en alguno destos lugares sobredichos fasta al dia de la Era (la Era Hispanica del año 38 a. de C. con que data sus documentos Alfonso el Sabio) desta / Carta (hasta la fecha, 29 agosto 1252). Et ab Azeyt (Abü Zeyt) ha de tomar las rentas de Azpe el Viejo por toda su / vida (2), e despues de su vida, que finque estas rentas de Azpe el Viejo al / Consejo de Alicante (Concejo). Et an de guardar et de tener en todos casos a los Moros / destos lugares sobredichos a los pleytos Et a los acotamientos / que han conmigo, ansi como dizen las Cartas plomadas que tienen / de mi, et han de tener todos estos terminos sobredchos bien poblados /. Et mando et defiendo que ninguno non sea osado de hir contra / este priuilegio desde mio Donadio, nin de crebantarle nin de menguarle / en ninguna cosa. Ca cualquiere que lo fiziesse haurie / mi yra et pecharmie en conto X millia libre de oro. Et a ellos todo / el danno doblado. Et porque este priuilegio sea firme et estable man / delo sellar con mi sello de plomo (pendiente). Efecha la Carta en Murçia por mandado del / Rey ventinueue dias andados del mes de Agosto en / (folio 299r) Era de mil duzientos y nouenta annos (a. 1252). Et yo sobredicho Rey don / Alfonso regnant en uno con la Reyna donna Yolant mi muger et / con mi fiya la Ynfanta donna Berenguela en Castiella, en Toledo / en Leon, en Galliçia, en Seuilla, en Cordoua, en Murçia, en Jahen / en Baeça, en Badaloç (Badajoz) et en Algarue, Otorgo este priuilegio et / confirmolo.- $\mathrm{Y}$ sigue la lista, a dos columnas, de los ilustres testigos confirmantes:) Don Alfonso de Molina la confirmo, don Frederich la confirmo, don Henrrich la confirmo, don Manuel la confirmo, don Ferrando la confirmo (los cinco Infantes de Castilla), don Felipe electo (obispo) de Sevilla la confirmo, don Sancho electo (obispo) de Toledo la confirmo, don Joan obispo de Santiago la confirmo, don Aboabdille Rey de Granada vasallo del Rey la confirmo, don Mahomat aben Mahomat Abenyusi, Rey de Murcia vasallo del Rey (Ibn Hudt), don Aben Mahoç, Rey de Niebla vasallo del Rey la confirmo, don Apariçio obispo de Burgos, don Rodrigo obispo de Palençia la confirmo, Garci Suarez merino mayor del Reyno de Murçia la confirmo, don R (emondo) obispo de Segouia la confirmo, don P (edro) obispo de Siguença la confirmo, don Beneyto obispo de Avila la confirmo, don Aznar obispo de Calaorra la confirmo, don Lope electo (obispo) de Cordoua, don Adam obispo de Plazencia, don Pasqual obispo de Jahen, don frey P (edro) obispo de Cartagena, don Pedro Yanyes Maestre de la orden de Calatraua la confirmo, don Nonno (Nuño) Gonçalez la confirmo, don Alfonso López la confirmo, don Rodrigo Gonçalez la confirmo, Diego Lopez de Salzedo merino mayor de Castiella la confirmo, Maestre Eferrando notari en Castiella, don Gaston bisconde de Beart vasallo del Rey la confirmo. (Cierra el trasiado la apostilla notarial de Laurencio Maltes notario a la sazón del Reino de Valencia y escribano del 
Palacio Comunal de Alicante, en estos términos:) Presens transumptum priuilegii manu propria scriptum abstractum / fuit a quodam libro priuilegiorum civitatis Alicantis yn archiuo dicte ciuitatis / recondito yn quo sunt scripta quamplurima priuilegia per serenissimos / Reges tam Castelle quam Aragonum recolende memorie predicte civitati concessa / per me Laurentium Maltes auctoritate regia notarium publicum Regni Valencie scribam / aule predicte civitatis, yn quorum fidem et testimonium hic me subscribo / et meum artis notarialis apono signum num. Rubrica (3).

El Libro de Privilegios a que alude el referido notario y que contenía, según sus palabras, numerosos privilegios otorgados por los reyes de Castilla y Aragón a la villa y ciudad de Alicante, es a nuestro juicio el que se guarda hoy en el Archivo Municipal de esta ciudad, con la signatura Armario 5, libro 48 , folios 79 , compuesto a principios del siglo XIV, a la vista de los documentos originales, hoy en su mayor parte desaparecidos. En la actualidad falta el documento en cuestión y estimamos que ya en 1765, cuando fue nuevamente encuadernado el manuscrito, añadiéndole un encabezamiento que no responde a su contenido y un Índice, incompleto también, ya no se conservaba esta carta-privilegio de Alfonso X el Sabio (ESTAL, J. M. del, Documentos inéditos de Alfonso $X$ el Sabio, Alicante, 1984, pp. 3-8 y n. ${ }^{\circ} 11$, pp. 22-27).

\section{NOTAS}

(1) Sobre la conquista y anexión a Castilla por el entonces infante D. Alfonso de la parte septentrional del Reino de Murcia, correspondiente hoy a la provincia de Alicante, véase Juan TORRES FONTES, LA RECONQUISTA DE MURCIA EN 1266 POR JAIME I DE ARAGÓN, Murcia 1967, págs. 25-41. ESTAL, Conquista y anexión, 1982, p. 147-158.

(2) Acerca de la figura histórica y reino del célebre converso almohade Abü Zeyt, v. Antonio UBIETO ARTETA, ORIGENES DEL REINO DE VALENCIA. CUESTIONES CRONOLÓGICAS SOBRE SU RECONQUISTA, Valencia 1975, págs. 36-38 y 194-195.

(3) Archivo Municipal de Alicante (AMA), Armario 1, libro 3, fols. 298r - 299r. Se guarda en este Archivo también otro traslado notarial del mismo escribano, Laurencio Maltes, con la signatura Arm. 5 , libro 50 , fols. $4 \mathrm{r}$ - $4 \mathrm{v}$, con una grafía algo más borrosa e ilegible que la del traslado anterior.

\section{$-2-$}

1296, nov. 4, Murcia y 1297 , oct. 3, Alicante

Traslado notarial, confeccionado reiteradamente en 1319, en 1359, en 1384 y en 1558, a 12 de noviembre, en Alicante, por Perellors Bernabeu, de dos cartas del Procurador General del Reino de Murcia, JAIME PÉREZ, señor de Segorbe y hermano de Jaime ll de Aragón, despachadas en el lugar y fecha arriba consignadas, sobre el nombramiento de Pedro Miguel, vasallo suyo 
y vecino de Jijona, como Guarda de El Molinello, cabe este lugar, con el salario a percibir a razón de 4 dineros por bestia mayor de carga o moro cargado y por cabeza de ganado menor, una meaja, al objeto de asegurar el paso por el Camino Mayor y la incolumidad de los viandantes, desde Alicante a Jijona.

AMA, Arm. 1, lib. 17: Libro de Privilegios y Provisiones Reales, fols. 119r 120 v; ESTAL, J. M. del, Documentos inéditos de Alfonso X el Sabio, alicante, 1985, pp. 28-37.

Aço es Trellat be a feelment fet en Sexona die lune secunda die mensis Maij anno Domini Trecentisimo octoagesimo quarto (lunes, 2 mayo 1384). Tret de un altre trellat authentich fet de una carta o prouisio feta per lo noble en Jaume Perez sennor qui fonch de la ciutat de Segorb sobre lo fet de les guardes qui son y esta en lo cami entre Sexona y Alacant de una carta del Sennor Rey en Jaume de bona memoria Rey qui fonch de Arago les quales prouisions y carta son del tenor seguent.

Aquest Trellat es be y feelment fet apres disous a set dies del mes de nohembre anno a nativitate domini Millesimo Trecentesimo quinquagesimo nono (7 noviembre 1359) de un altre tresllat de una carta del noble en Jaume Perez sennor de Segorb y procurador en aquell temps del Regne de Murcia la thenor de la qual es aytal. Aquest trellat es be y feelment fet primo die calendis Aprilis anno a nativitate domini Millesimo Trecentesimo quinquagesimo nono (1 abril 1359) de una carta del molt noble en Jaume Perez sennor de Segorb y procurador en aquell temps del Regne de Murcia scrita en paper veta aldors abestany sagell corones de la puritat segellados la thenor de la qual es ay tal.

A todos quantos esta carta vieren de nos Jaume Perez / Senyor de Sogorbe e procurador del Reyno de Murcia salut / e honor. Sepades que por mays maleficios y danyos que son / fechos en el Molinielo de Sexona (1) y se facen hoy cadre / dia tien por bien nuestro Senyor el Rey en los que se guardan / porque de aqui adelante no reciban algun danyo (fol. $119 \mathrm{v}$ ) $\mathrm{ni} \mathrm{mal}$ y que todo hombre pueda passar saluo y seguro / y por esto nos hauemos puesto por guardador a Pero Miguel / nuestro vasallo vezino de Sexona ques hombre / que lo guardara bien y lealmente porque esto es seruicio / de nuestro Seanor el Rey y salvamiento de toda la tierra. Mandamos de parte de nuestro Senyor el Rey y nuestra que no embarguedes / al dicho Pero Miguel ni a sus companyeros ni / consentades que ninguno le faga mal al cuerpo nin I faga mas siniestro ni fuere a juda por razon deappe / llido por fuerça que 
algunos le fiziessen que le aju / dedes a mamparar y a defender en guisa que no tome / ningun danno ni aluoy (?) reciba fuerça hauemos ordenado que el que aya por su salario e trabajo esto que / aqui dejuso esta scrito es a saber de bestia mayor qua / tro dineros y de Moros quatro dineros y de ganado menudo / una meaja (2) por cada cabeça y destos sacamos (excluímos) Cauallero / escudero que no y pague porque nos teniamos nuestro / suelo acostumbrado. Mandamos sellar esta Carta / con el sello de la puridad. Dada en Murcia a quatro dias de nouiembre en el anno de nuestro Sennor Mil Trescientos (sic) nouenta y seis (3).

\section{-2 bis -}

E semblant de aço es altre trellat fet apres lo dit / dia e any damunt dit de on altre trellat de la tenor / seguent. Aquest es altre trellat feelment fet / apres primo die kalendas calendas Aprilis, anno domini mi / llesimo tercentesimo decimo nono (18 febrero 1319) de un altra carta del dit / noble Jaume Perez, scrita en paper, uberta al dors (fol. 120 r) ab lo seu sagell sagellada, la forma de la qual es aytal. Sapien / quantos esta Carta ueuran com Nos en JAUME PEREZ /, Senyor de Sogorb e Procurador del Regne de Murcia, per lo / Sennor Rey, uolem e otorgam que guarda sia puesta a quelles / termidos que uan de Alicant a Sexona, qui son de Monnegre / entre Cabeço, com aquells son atalades e guardados per los / guardadors del Cami Major de Sexona. Data en Alacant, a tres / dies de octubre, anno a natiuitate domini Millesimo Ducentesimo / Nonagesimo septimo/.

\section{Estos son los Terminos de la Villa de Alicante/:}

Primerament en la partida de Vilajosa (Villajoyosa) a la mar diez millas al Carrisalejo (Carrichal, al sur de Villajoyosa) pegado a la mar, y del Carrisal a la Muela (La Mola) / y de la Muela al Cantal del Spino, al cabo del barranco I de la Alcantarola (Cantalet) y del Cantal del Spino a Cabeçonsuelo (Cabezón), a la Penya forada (Canalobre-Penya Forada) del Cabeçon y Cabeçonsuelo al Vergeret (El Vercheret) / y del Vergeret a los Guardos Viejos / y de los Guardos Viejos (Venta del Guarda) a Monnegro (Monnegre) y del Monnegroa Lalcubilla (La Alcubilla-La Escobella) / y de Lalcubilla al Ventoso subre al barranco arriba del Maymon (Maigmo) y del / Maymon a las vertientes de la sierra fasta la sierra (La Solana), y / de la sierra todas las vertientes de la Solana, de la sierra al / Almadraua (Sierra de la Almadraba) y de la l'Almadraua a la Carraschiella (Carrascal) y de / la Carraschiella al Derramador de Boniomar (Tio Bonif) y del Derra / mador a la Forca de Novelda y de la Forca de Nouelda (Forca de Novelda) (fol. $120 \mathrm{v}$ ) al Alfagar Ramblajugo (Jagar Ram- 
blajugo, curso bajo del Vinalopó), a do se ajuntan los rie Aspe / y de Nouelda y de Monforte ay se ajuntan los terminos / y los terminos de la Quasgada de Nogala y de la Quajada (sic) / de Nogala (La Cañada) a la Mata de la Mota de Marti Sancho (Mata de Sancho - Torrosilla) a los Caua / leros dos bancales ensima la Torrosilla y de la Torrosilla / a la Sierra de Sancho (Mata de Martí Sancho - Sierra de Sancho), con las uertientes todas al Derramador / de la Sierra de Sancho, al Portichuelo (Portichuelo - Portichol) de ante Elche y de Alacant / (límite del término municipal de Elche y Alicante) y del Portichuelo a la mar dies millas a la mar/ (4).

Lo preinsert tresllat, prout jacet, escrit de ma de altre $/$, he tret yo Perellors Bernabeu, notari scriua de la Sala a peti / cio (?) dels Jurats y Consell de la Vila de Sexona, de on llibre/, hon estan continuats molts Priuilegis y particion dels / termens, reseruat en lo Archiu de la Sala del dit Consell/, lo qual dit tresilat a estat per mi tret a Jnstancia del / magnifich Guillem Johan Pasqual, Sindich de la ciutat de / Alacant, a dotse dias del mes de nohembre, anj mill / cinchcents cinquant y huit y en testimoni possi / ossi mon acostumat Sig (signo notarial propio) ne / (con la rúbrica original a continuación). 

(1) Lugar denominado así por la existencia en él ya de antiguo de un molino hidráulico, a la vera del río de esta villa, donde se erigió por entonces una Torre defensiva, en cuya construcción participaron con sus rentas vecinos de la villa de Alicante, razón por la cual Jaime II declara a estos, el 3 de noviembre de 1297, francos y exentos de todo derecho de lezda y peaje, al transitar por aquel lugar. Su carta privilegio dice asi: «No verint uniuersi quod Nos Jacobus dei gratia Rex Aragonum, Maiorice, Valencie et MURCIE, etc. Attendentes nos fideles nostros homines de Alacant soluisse et posuisse quandam summam pecunie in opere illius Turris, que fit in vestro loco, vocato del MOLINELLO.

Ideo per Nos et nostros enffranquimus et ffrancos facimus VOS omnes et singulos predictos de ALACANT et termini eius, presentes scilicet et futuros ab omni lezda sive pedaneo quod nunch soluituruel inde soluetur in Turri predicta sic quod vos uel uestri nunquam in dicta Turri teneamni aliquid soluere ratione lezde seu pedagii (por derechos de lezda o peaje) antedicti... Datum Turolii, tertio nonas nouembris, anno domini millesimo ducentesimo nonagesimo septimo. Provision real de Jaime ll a la villa de Alicante, despachada en Teruel, a 3 de noviembre del 1297 , AMA, Arm. 1, lib. 2, fol. 4r - 4v.

Quedando por ello ampliamente confirmada esta toponimia de EL MOLINELLO, en un paraje sito al lado mismo de Jijona, por la declaración además jurada de un alto número de vecinos de aquel lugar acerca de la ubicación exacta de los límites municipales de Jijona con la villa de Alicante, declaración que se conserva en un voluminoso MS del AMA, Arm. 14, Gijona 476 fols., "Sobre apeo y deslinde del término de la ciudad de Alicante con la ciudad de Gijona", compuesto por el notari y escribano público, Francisco Javier Pareces Granados, el año 1773.

(2) Moneda equivalente a la sexta parte de un dinero, fracción éste a su vez, como es sabido, del sueldo o sólido medieval barcelonés o valenciano.

(3) Error evidente del copista al transcribir esta data, cambiando el dos por un tres, y desplazando asi el reinado de Jaime ll a un siglo más tarde. La fecha de la segunda carta que ofrecemos, 3 de octubre de 1297, escrita por el mismo Procurador General del Reino de Murcia, en aquella ciudad, nos confirma en el lapsus referido del copista.

(4) En esta segunda carta del Procurador General del Reino de Murcia, Jaime Pérez, quedaba delimitado al detalle, con una profusión de topónimos, que nos sorprende satisfactoriamente el constatarlo, el alfoz de la villa de Alicante, coincidente en líneas generales con el amplio término municipal que, casi medio siglo antes, nos describiera Alfonso X el Sabio, por privilegio del 29 de agosto de 1252.

Para facilitar al lector mejor la apreciación gráfica del amplio alfoz de la villa de Alicante, presentamos un mapa de la provincia de Alicante, con la división administrativa actual y la ubicación de todos sus municipios, enmarcando el área municial alicantina, con una línea de puntos, que circunscribe abiertamente el área que por disposición real de Alfonso $X$, primero, y luego por Jaime ll y su Procurador General del Reino de Murcia, después, integraba el amplio alfoz de la villa de Alicante.

En su margen derecha superior, anotamos en dos columnas los nombres de los municipios que formaban parte del término municipal de la villa de Alicante, en condición de aldeas o lugares bajo su dependencia municipal, con el número que hoy les corresponde en la división administrativa de la provincia. Y a la derecha del mapa, destacamos los topónimos correspondientes a los números de la línea punteada, que bordea el término municipal de la villa de Alicante, con los nombres primitivos y los que mantienen en la actualidad. 



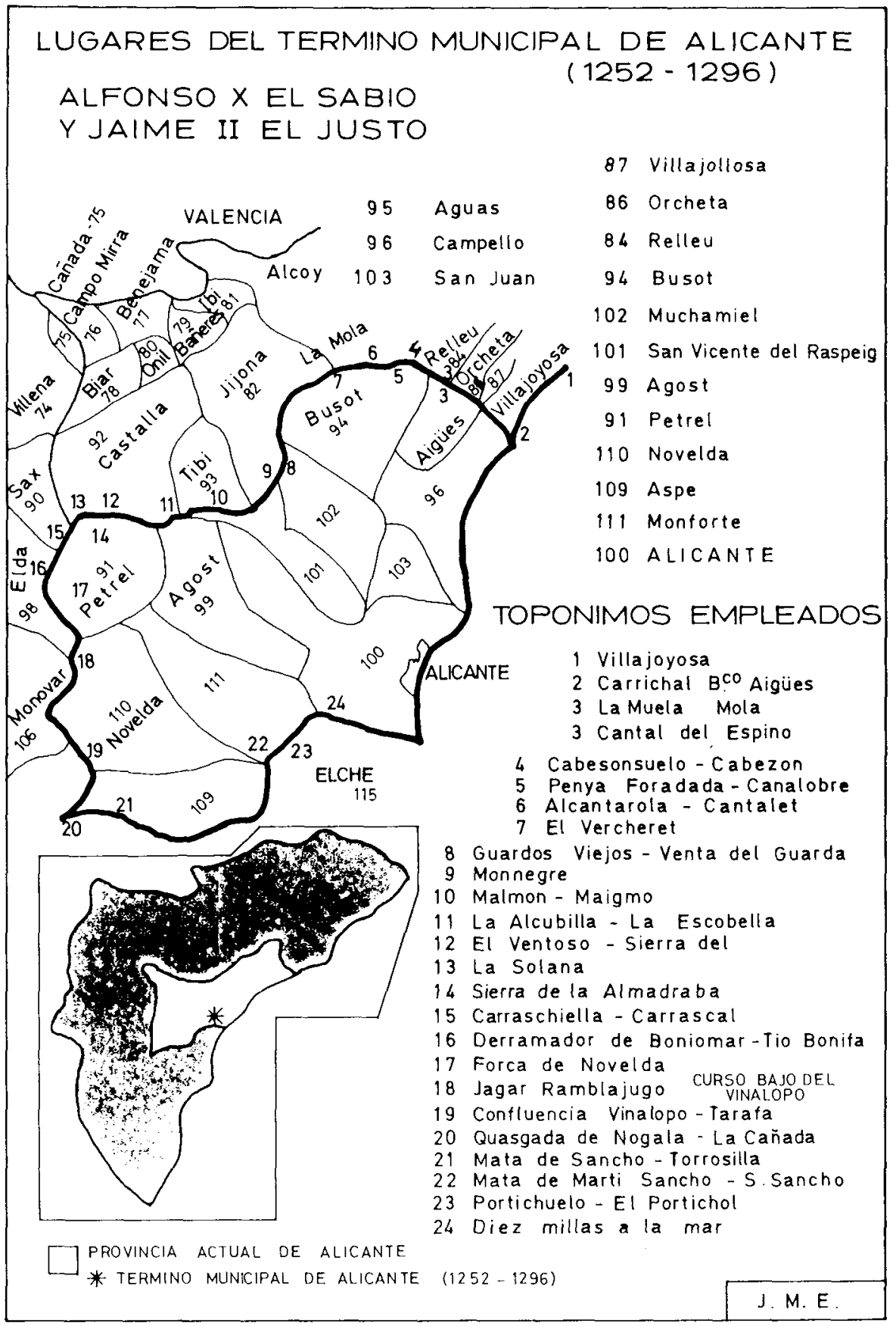

Facsimil 5-1 


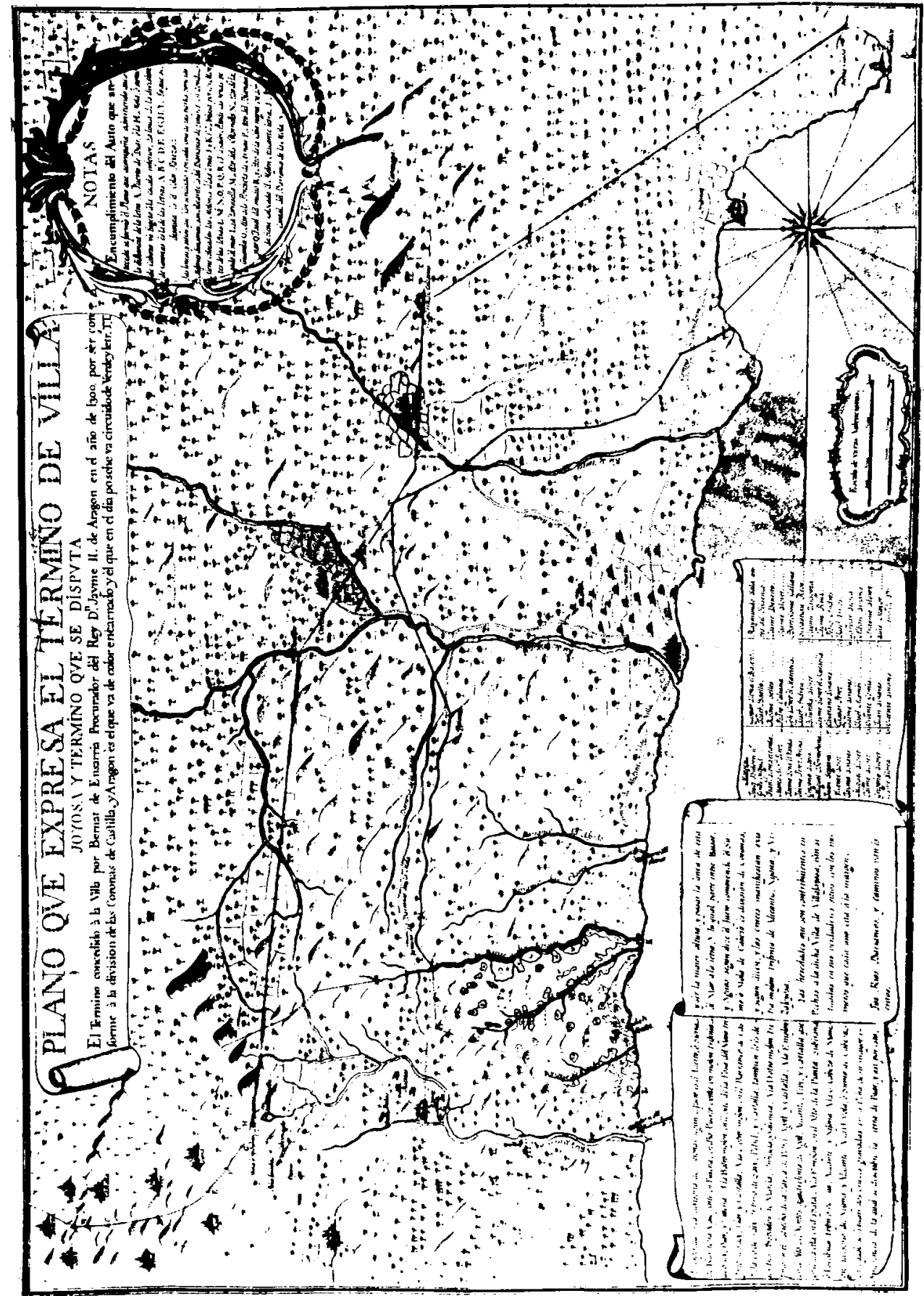

Facsimil 5-2 


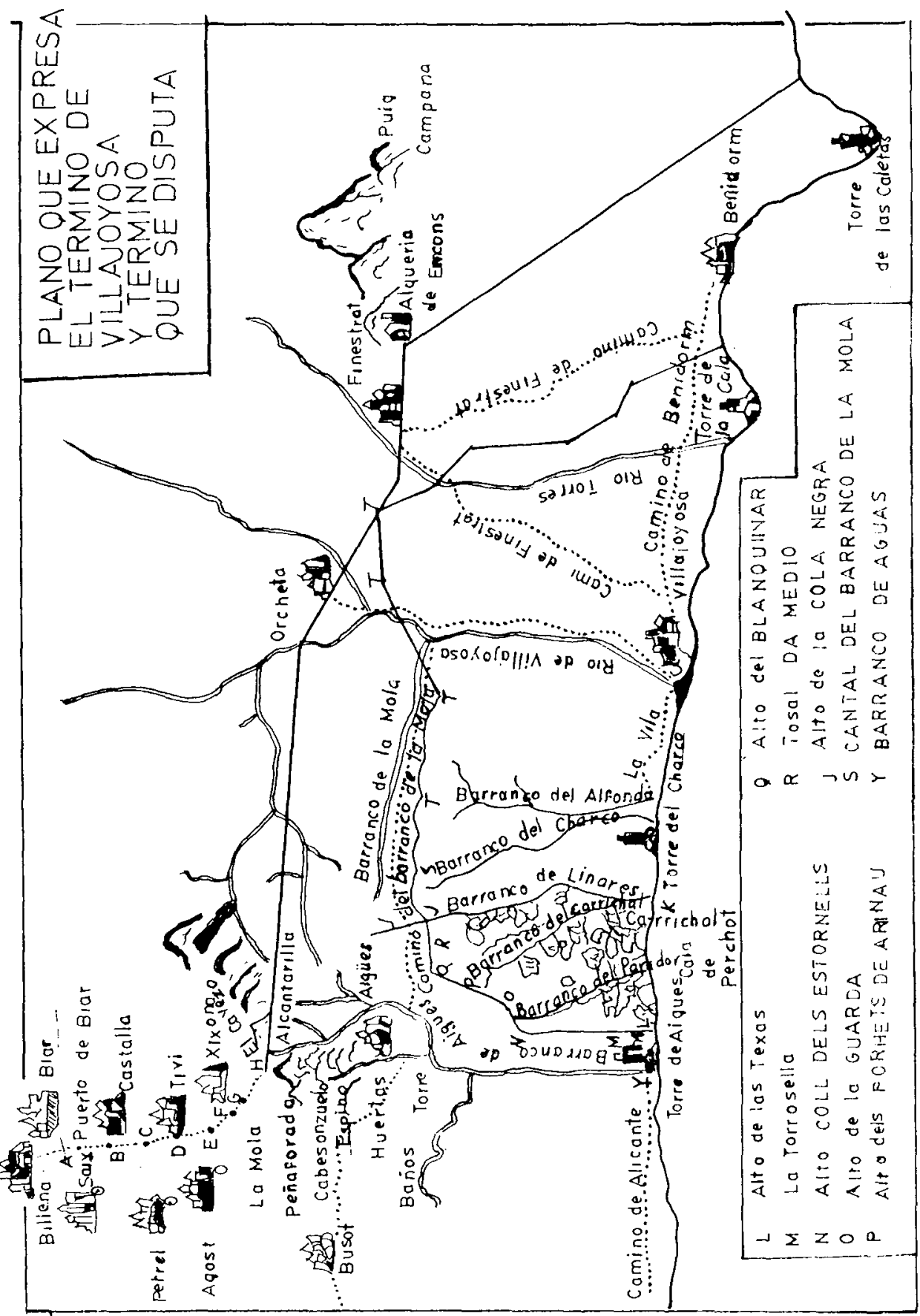

Facsímil 5-3 


\section{PLANO QUE EXPRESA EL TÉRMINO DE VILLAJOYOSA Y TÉRMINO QUE SE DISPUTA}

\section{a.1786}

El Término concedido a la Villa por BERNAT DE ENSARRIÁ, Procurador del Rey Don Jayme II de Aragón, en el año de 1300, por ser conforme a la división de las Coronas de Castilla y Aragón (Tr. de Almizra, 26.3.1244) es el que va de color encarnado (entre el Barranco de Linares y el B. del Parador y línea contigua en puntos), y el que en el día posee va circuido de verde y las letras T. T. T. (a lo largo de una línea que rodea todo su término municipal, en la fecha de 1786, sin el área antes señalada entre los dos Barrancos referidos, en su zona meridional, razón del contencioso con la villa de Alicante, que le había arrebatado aquella región occidental, contra lo establecido en el Pacto de fijación de la frontera castellano-aragonesa en el Levante peninsular, la que, arrancando entre Villena y Biar, hacia el Puerto de Biar, alcanzaba LA MOLA o Sumo del CABEZO, para descender hacia el Mar, por el cauce del RIO DE AIGÜES o BARRANCO DE AGUAS, para desembocar por el TORRENTE DEL AGUA, en la Mar, al Sur del BARRANCO DEL CARRICHAL).

\section{NOTAS}

En cumplimiento del Auto que antecede (Tr. de Almizra) se formó el PLANO que acompaña, advirtiendo que la distancia de la letra A (Puerto de Biar) a la letra $\mathrm{H}$ (MOLA o Sumo de CABEZO) va sujeta a la escala (o recuadro inferior izquierdo) inferior. La línea de la división de Coronas es la de las letras A B C D E F G H (y tomando aquí el lecho del BARRANCO DEL AGUA prosigue la demarcación hasta el Mar, señalando la desembocadura con la letra Y). Lo que se disputa es (el área comprendida entre el Barranco del Parador y el B. de Linares, de color rojizo) es el color pajizo: (descritas asi):

Las líneas y Sitios que han señalado y en cada una de las partes pone los Mojones divisorios, son: ALICANTE la línea del Barranco de Linares, en donde tiene colocados los Mojones a las letras $\mathrm{J}$ (a medio curso del Barranco) y la $\mathrm{K}$ (en su desembocadura exacta).

VILLAJOYOSA pone los Mojones (en cambio, comiendo parte del término municipal de Alicante) en los Montes de las letras $L M N O P Q R$ y J (arrebatando al término de Alicante, las tierras comprendidas entre el $B$. LINARES Y el B. DEL PARADOR, algo más al Sur, casi hasta el BARRANCO DEL AGUA, 
por donde salía al Mar la frontera fijada en ALMIZRA) es a saber: ALTO DE $L A S$ TEXAS pegado al Mar $L$ (señalado este punto con la letra $L$ ), la TORROSELLA M, ALTO DELS ESTORNELLS N, ALTO DE LA GUARDA O, ALTO DELS PORCHETS DE ARNAU P, ALTO DEL BLANQUINAR Q, TOSAL DEL MEDIO R, y ALTO DE LA COLA NEGRA, en donde tiene colocado ALICANTE el Mojón letra $J$ (vid. supra ALICANTE) y CANTAL DEL BARRANCO DE LA MOLA S (englobando las tierras disputadas por Villajoyosa a la villa y ciudad de Alicante. La descripción de los Mojones que señalaban la frontera castellano-aragonesa, desde VILLENA al Sumo de CABEZO figura en el recuadro inferior izquierdo, en estos términos bien expresivos:)

La referida línea divisoria de Coronas según el FUERO (Tr. Almizra) es el

(A) PUERTO o SIERRA DE BIAR letra A que parte de BILLENA, en dicho PUERTO existe un Mojón trifinio (de tres caras que delimitan tres términos municipales:) de SAIX (al sur), BIAR (al norte) y BILLENA (al poniente) a la B

(B) otro Mojón en el ALTO DE LA FOSA DEL MORO, trifinio de SAIX, BIAR y CASTALLA (estos dos lugares al Norte de la linea divisoria) a la $\mathrm{C}$

(C) otro Mojón en el BARRANCO DE CASTILLA e el BARRANCO DE SAIX trifinio de SAIX, PETREL (al sur los dos) y CASTALLA (al norte) y también lo es de los TRES OBISPADOS de Murcia, Orihuela y Valencia

(D) a la D otro Mojón trifinio en el ESTRECHO DE LA ZARZA DE PETREL, AGOST (al sur) y CASTALLA (al norte)

(E) a la E Mojón en el ALTO DEL VENTÓS quadrifinio de AGOST, ALICANTE (al sur los dos), TIVI y CASTALLA (al norte) que en el día está en disputa (en contencioso también a.1786)

(F) a la F Mojón en el ALTO DE LA PUNTA SUBIRANA o ESCUBILLA trifinio (a su vez de los términos municipales de) TIVI, ALICANTE (ambos al sur de la línea) y XIJONA

(G) a la G el CABEZO DE MONEGRE divisorio de XIJONA y ALICANTE

(H) a la H La MOLA O SUMO DE CABEZO (a cuyo sur se hallan PEÑA FORADA, ALCANTARELLA, CABESONSUELO y ESPINO) en el qual (CABEZO) se hallan dos cruzes gravadas en la PEÑA DE su Mayor Eminencia, de la qual se descubre la SIERRA DE BIAR, y assi por esto y ser la mayor altura, y pasar la linea (divisoria desde el SUMO DE CABEZO hasta el Mar, por la letra $Y$, a lo largo del Barranco del Agua): BARRANCO DE AGUAS: 
(Y) a la letra $Y$ la qual (linea divisoria) parte entre BUSOT y AGUAS segun dize el FUERO comprende el SUMO ó MOLA DE CABEZÓ. Es división de Coronas y según dizen, y las cruzes manifiestan existía mojón trifinio de ALICANTE, XIXONA y VILLAJOYOSA (revelando que el CABEZO y LA MOLA eran los cerros más altos que dividían los términos municipales de las villas de ALICANTE-JIJONA y VILLAJOYOSA. Y a continuación se indican las parcelas que, dentro del área en litigio, pagaban cabezaje o pechos a Villajoyosa, mediante un número que nos da en la lista nominal adjunta el nombre del propietario, según el Registro de la Propiedad del año 1786).

Las heredades que son contribuyentes en Pechas a la dicha Villa de VILLAJOYOSA, van situadas en sus verdaderos sitios (ubicación puntual) con los números que cada uno cita a la margen.

Los RIOS, BARRANCOS y CAMINOS van escritos (también y bien significados)

(Nombre del propietario y Número correspondiente al)

Josef Buforn (parte norte del área)

Ginés Miguel (parte norte del área)

MARGEN

1 y 1

2 y 2

Franc. Llorca el Tarda (N. Barr. CARRICHAL)

3 y 3

Marco Ant. ${ }^{\circ}$ Pérz (alto B. DE LINARES, parcela gr.)

Jaime Lora el Tarda (alto B. CARRICHAL)

Jaime Pérez Percha (medio B. CARRICHAL)

4 y 4

5 y 5

Gregorio Llopis (área norte)

6

7

Miguel Borrachina (alto CARRICHAL)

Juan Segarra (alto CARRICHAL)

Vicente Loret (medio LINARES)

Jayme Linares (alto B. PARADOR)

Miguel Lloret (alto CARRICHAL)

Jaime Lloret (medio CARRICHAL)

Gregorio Lloret (medio Carrichal)

Cosme Llorca (medio LINARES)

Gaspar Llorca el Balent (medio CARRICHAL) 16

Josef Baello (med. inter Carrichal y Linares) 17

Roque Selles (medio CARRICHAL) 18

Pedro Galiana (medio LINARES) 19

Josef Lloret el Marabells (m. CARRICHAL) 20

Josef Andreu ( $m$. inter Carrichal y Linares) 21 
Bautista Lloret ( $m$. inter Carrichal y Linares)

Jaime Lloret el Marabells ( $m$. inter Carrichal y Lina-

res)

23

Cayetano Linares (m. B. del PARADOR) 24

Gaspar Pérez (m. CARRICHAL) 25

Jaime Linares (cola del PESCHOL-Litoral) 26

Josef Alambi (inter letrsa L y M) 27

Vicente Gomis (inter Carrichal y el Parador) 28

Juan Linares (inter Carrichal y el Parador) $\quad 29$

Vicente Linares (bajo el Parador) 30

Raimundo Sala, antes del Yvisenco (bajo Parador) 31

Jaime Beneito (litoral junto a letra $L$ ) 32

Jaime Lloret (junto a litoral-cola del PESCHOT) 33

Bartolomé Galiana (cola del PESCHOT) 34

Sebastián Reos (litoral junto cola PESCHOT) 35

Jayme Zaragoza (litoral junto cola PESCHOT) 36

Jayme Ruiz (litoral junto cola PESCHOT) 37

Josef Vrrios (litoral junto cola PESCHOT) 39

Gaspar Llorca (bajo B. Linares) $\quad 40$

Pedro Andrés (Litoral inter CARRICHAL y PARA-

DOR)

38

Albaro Linares (bajo Linares-gran parcela) 41

Antonio Lloret (todo bajo CARRICHAL) 42

Luis Mayor (junto cola PESCHOT) 43

Año de 1786

Topónimos desde la costa septentrional hacia el interior y parte meridional:

Torre de les Caletes

Sierra Elada

Alfasos de Polop

Benidorm

Huertas

Deltriet

Alquería de Encoms

Pug Campana

Finestrat

Cortina

Camino de Finestrat

Camino de Benidorm

Torre de la Cala
Río de Villajoyosa

Barranco de la Mola

Camino del barranco de la Mola

BARRANCOS:

Del ALFONDO

Barranco del CHARCO

Barranco de LINARES

Barranco del CARRICHAL

Barranco del PARADOR

Barranco de GUAS o Río de Aguas

Torre del río de AGUAS

Torre

Tibi 
Río de Torres

Alcoco

Villajoyosa

Huertas

Sierra de Orcheta

Torre de Orcheta

Huertas

ORCHETA

Pantano

Sorell
Baños

Petrel

Huertas

Castalla

Busot

Espino

Biar

Cabesonsuelo

Saix

Peña Forada

Alcantarella

Mola ó Sumo Cavezo

Xijona

Agost

\section{$-6-$}

1308, junio 25. Valencia

Traslado notarial del privilegio de Jaime II por el que anexiona formalmente al Reino de Valencia la villa de Alicante, respetándole, no obstante, la libertad de proseguir, en determinados casos que enumera, antiguos usos locales y viejas costums o consuetudines memorables. Apógrafo original confeccionado por Francisco Alparmes, subnotario público de Alicante, legitimado y autorizado por Castell de Herlum, llohtinent del Justicia local, D. Tomás de Manterant, a 11 de agosto de 1369.

A. M. Alicante, Arm. 16, Caj. 1, n. ${ }^{\circ}$ 2. Pergamino. Versión castellana del autor

Aço es transllat be a feelment treyt e translladat en Alacant de un llibre de Priuilegis en lo qual es scrit un Priuilegi feyt e confermat por lo molt alt excellent Princep Senyor En Jacme per la gracia de deu Rey d'Aragon, la tenor del qual Priuilegi es sa tenor aytal / 2 com se seguex. (Hasta aqui el encabezamiento del traslado notarial de Francesc Alparmés a modo de protocolo).

En el nombre de Dios. Sepan todos que nos, Jaime, por la gracia de Dios Rey de Aragón, Valencia, Cerdeña y Córcega, y Conde de Barcelona, sopesando dignamente la obligación que urge ineludiblemente a los reyes y demás príncipes de la tierra a esforzarse por mantener tranquilos y quietos a sus pueblos y súbditos en el camino de la justicia y de la paz y a disponer con regia solicitud todas las cosas hacia el logro de la prosperidad y tranquilidad, de tal suerte que, erradicando el vicio e implantada la virtud, consigan complacer tanto al Rey de Reyes, como a sus propios dirigentes y a sí mismos, caminando siempre por la senda de la rectitud y respetando debidamente los derechos de todos y de cada uno, y considerando además la necesidad imperiosa que nos impele a procurar por todos los medios y solícito 
cuidado, la utilidad y mayor provecho de nuestros súbditos, según nos ha sido confiado de lo Alto, hemos deliberado, movidos por las razones expuestas y oído el parecer, diligente estudio y madura deliberación del Consejo Plenario Curial, y tras la previa súplica y común consenso de nuestros amados y leales caballeros y el de las personas generosas (o sector de los Caballeros de la villa) y el de cuantos habitan en las villas de Alicante, Elche, Orihuela y de Guardamar y todos sus términos, quienes con la ayuda de Dios han pasado a nuestro gobierno y jurisdicción y obediencia, que todos estos territorios, con sus respectivas pertenencias, al objeto de hacer más efectiva y plena nuestra posesión, por cuanto ya están sometidos a nuestra jurisdicción y dominio real, sean incorporados al Reino de Valencia, acto que efectuamos por esta Provisión Real Perpetua, en virtud de la cual disponemos, mandamos y ordenamos su ANEXIÓN AL REINO DE VALENCIA, de forma que las villas y lugares predichos sean considerados ya parte del Reino de Valencia, como territorios dentro del mismo, y que todos sus habitantes se rijan y gobiernen en lo sucesivo por los Fueros de la ciudad y Reino de Valencia, renunciando a los fueros particulares, tanto dentro como fuera del ámbito judicial, asi en los contratos como en cualquier otro negocio, de forma que a partir de ahora se gobernarán tan sólo por los Fueros del Reino de Valencia en todos los casos, deseos, cuestiones, asuntos, litigios y demás negocios de todo tipo, salvo estrictamente aquellos asuntos que se citan expresamente a continuación, y en lo que concierne en particular a la villa de Alicante, ajustándose al tenor de los Privilegios que Nos mismo le hemos otorgado, o bien confirmado los ya existentes, declarándolos una vez más en su pleno vigor, por lo que disponemos que los usos y costums que hubiere en esta villa, contrarios a los Fueros citados, si sus vecinos desearan mantenerlos en vigor $y$ atenerse plenamente a ellos, Nos accedemos complacido a su humilde petición y les otorgamos el presente privilegio real, por el que disponemos, en perpetuo, lo siguiente: que

1.-EI JUSTICIA de la villa de Alicante perciba anualmente por su trabajo, en calidad de salario, seiscientos sueldos reales de Valencia, a deducir del montante de la suma recaudada por calonias (o multas pecuniarias) y que su Asesor y Ayudante cobre trescientos sueldos reales de Valencia también. (Salario considerablemente superior al establecido por los Fueros para el resto del Reino.

2.- - Otorgamos, además, a los actuales y futuros moradores de la villa de Alicante, que si los convictos de apelación o reclam, incurriesen en la Pena del Quart, a tenor de los Fueros del Reino de Valencia (según la cual, los reos de la misma tendrían que abonar a la curia municipal la cuarta parte de 
la suma que adeudaban al acreedor, después de haberle satisfecho plenamente la suma adeudada, en su integridad) no tienen que abonar al fisco, tanto ellos como sus descendientes, nada más que la décima parte (el diezmo) de la deuda en cuestión, y no un cuarto de la misma, lo que les sería más gravoso, por ser éstas las costumbres o costums del lugar.

3.- Ordenamos asi mismo, queremos y mandamos que las mujeres que habitan ahora y habitarán en el futuro en la villa de Alicante, si fueren halladas reas de adulterio, que no puedan ser acusadas y absueltas más que por sus propios maridos.

4.-Concedemos también a los sobredichos vecinos de Alicante, presentes y futuros que, si a tenor de los Fueros de Valencia, los caballeros y hombres de armas no pueden participar en las elecciones de los cargos municipales, ni tampoco ejercer ni desempeñar aquéllos, los moradores en cambió de la villa de Alicante, cualesquiera que fuere su condición o dignidad, también puedan tomar parte en las elecciones de los cargos comunales, y desempeñarlos o ejercerlos, de acuerdo mutuo y a tenor de las usanzas y costumbres locales.

5.-Disponemos asimismo y ordenamos también que los referidos moradores de la villa de Alicante, presentes y futuros, puedan servirse para la división de sus tierras y fijación o deslinde de sus términos, de cierta medida agraria, que denominan tahulla (equivalente a la seisava parte de la fanega castellana y en uso hasta la actualidad en la provincia de Alicante) y que les es tradicional, a pesar de que en los Fueros se hable de otras medidas agrarias. En cuanto concierne, no obstante, a otros pesos y medidas para las demás cosas, los vecinos de Alicante deben ajustarse a lo establecido en los Fueros del Reino de Valencia.

6. - Otorgamos igualmente a los moradores de la villa de Alicante, presentes y futuros que, si bien a tenor de los Fueros de Valencia se prohibe a los súbditos enajenar cualquier propiedad de bienes raices, por actos de compraventa, a favor de los caballeros u hombres de armas y al clero o la iglesia, pueden, no obstante, los referidos caballeros y hombres de armas, siempre y cuando no sean a su vez hombres de iglesia o del clero o religiosos, comprar o adquirir por cualquier justo título, en propiedad, cuantos bienes raíces quisieren enajenar los vecinos de la villa de Alicante y de la misma manera dichos moradores alicantinos pueden a su vez adquirir posesiones y comprar bienes raíces y demás propiedades, pertenecientes a los caballeros, como han venido haciendo usualmente hasta la fecha. 


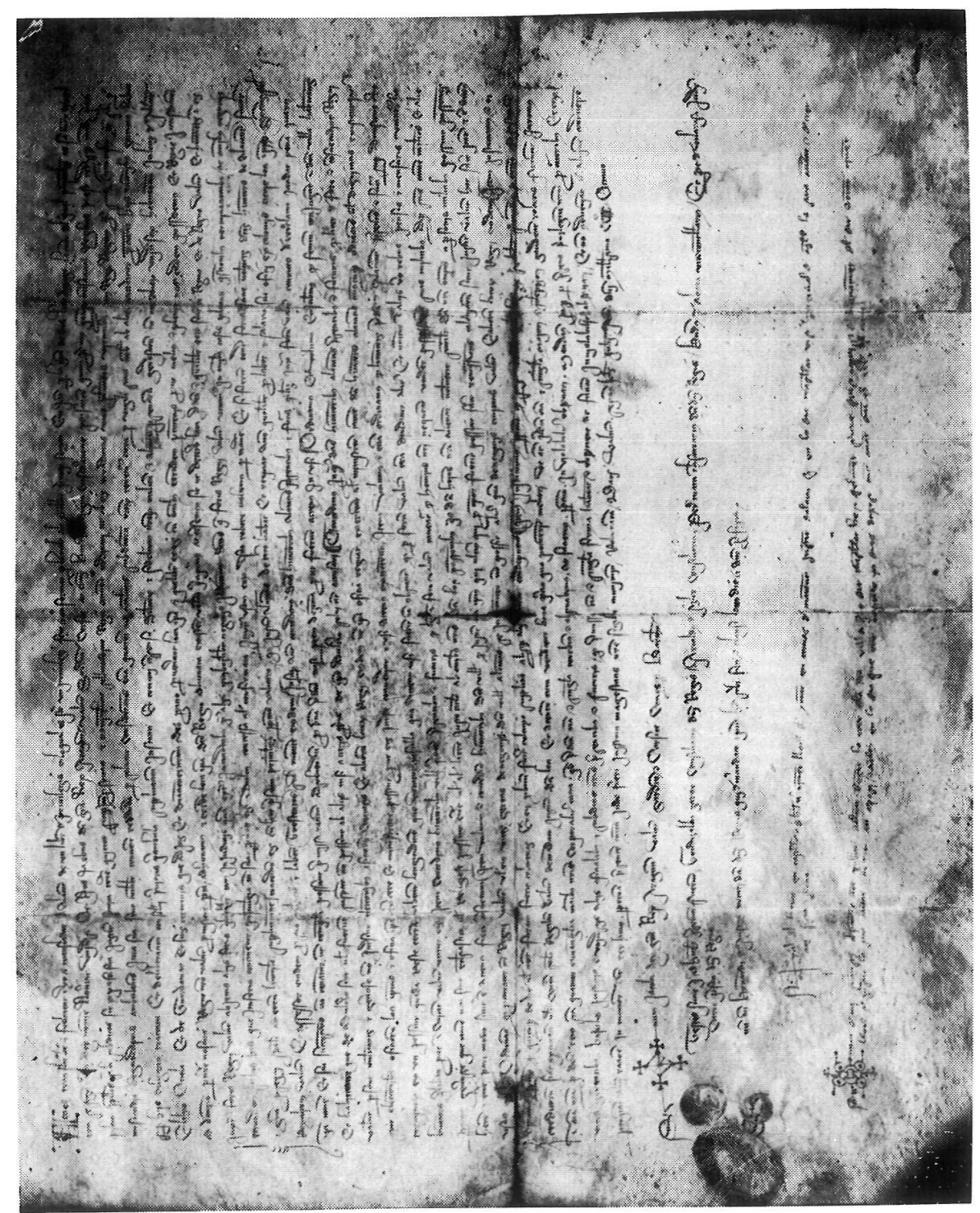

Facsímil 6 
7.-De igual modo disponemos que los Justicias de la villa de Alicante puedan condonar las calonias (o multas pecunarias) de sus vecinos, de la misma forma que viene haciendo el Justicia de Valencia habitualmente.

8.-Ordenamos también que el Procurador de nuestro Reino de Valencia o su Vicegerente (Portant-Veus) no se entrometan en los asuntos internos de la villa de Alicante, en modo distinto a como suelen hacerlo en los asuntos y negocios de la ciudad y demás lugares del Reino.

9.--Disponemos también a perpetuidad que todo aquél, que durante el día o de noche, robase colmenas y fuere convicto del latrocinio, sea condenado sin piedad a la última pena.

10.--Por último, dispnemos asimismo a perpetuidad que, cuando haya que proceder, previa demanda de los acreedores, a la venta o subasta de bienes raíces por parte de la Administración o Curia municipal, se haga siempre por anticipado y a requerimiento del Justicia local una valoración estimativa de dichos bienes inmuebles, y cuando menos superior o por encima de los cien sueldos reales del Reino de Valencia, y se efectúe la venta de los mismos a continuación, partiendo de la suma de cien sueldos reales inicialmente, y al precio mejor posible.

Al objeto de que todas y cada una de las cosas referidas anteriormente gocen de la mayor y más solemne firmeza, juramos a Dios por nuestra alma y por sus cuatro Evangelios, al par que los tocamos físicamente con nuestras manos, que nos comprometemos a guardar todas y cada una de las cosas arriba expresadas y que las cumpliremos y haremos suplir a perpetuidad inviolablemente.

Ordenamos además, por medio de esta Carta-Privilegio, a todos nuestros Procuradores y a sus Vicegerentes, asi como a los Bayles, Justicias y demás Oficiales públicos, súbditos nuestros, presentes y futuros, que acaten firmemente cuanto queda dicho y lo cumplan y hagan cumplir de modo inviolable. Les urgimos también que no lo contravengan en ningún modo y en ninguno de sus puntos, y que no permitana nadie infringirlo, bajo ningún concepto. $Y$ en fe de todo ello ordenamos confeccionar esta provisión real perpetua y hacerla corroborar con el sello de nuestra majestad.

Dado en Valencia, a veinticinco de junio del año del Señor mil trescientos ocho.

Signo (real de Jaime II) de Jaime Rey por la grcia de Dios de Aragón, de Valencia, Córcega y Cerdeña y Conde de Barcelona. 


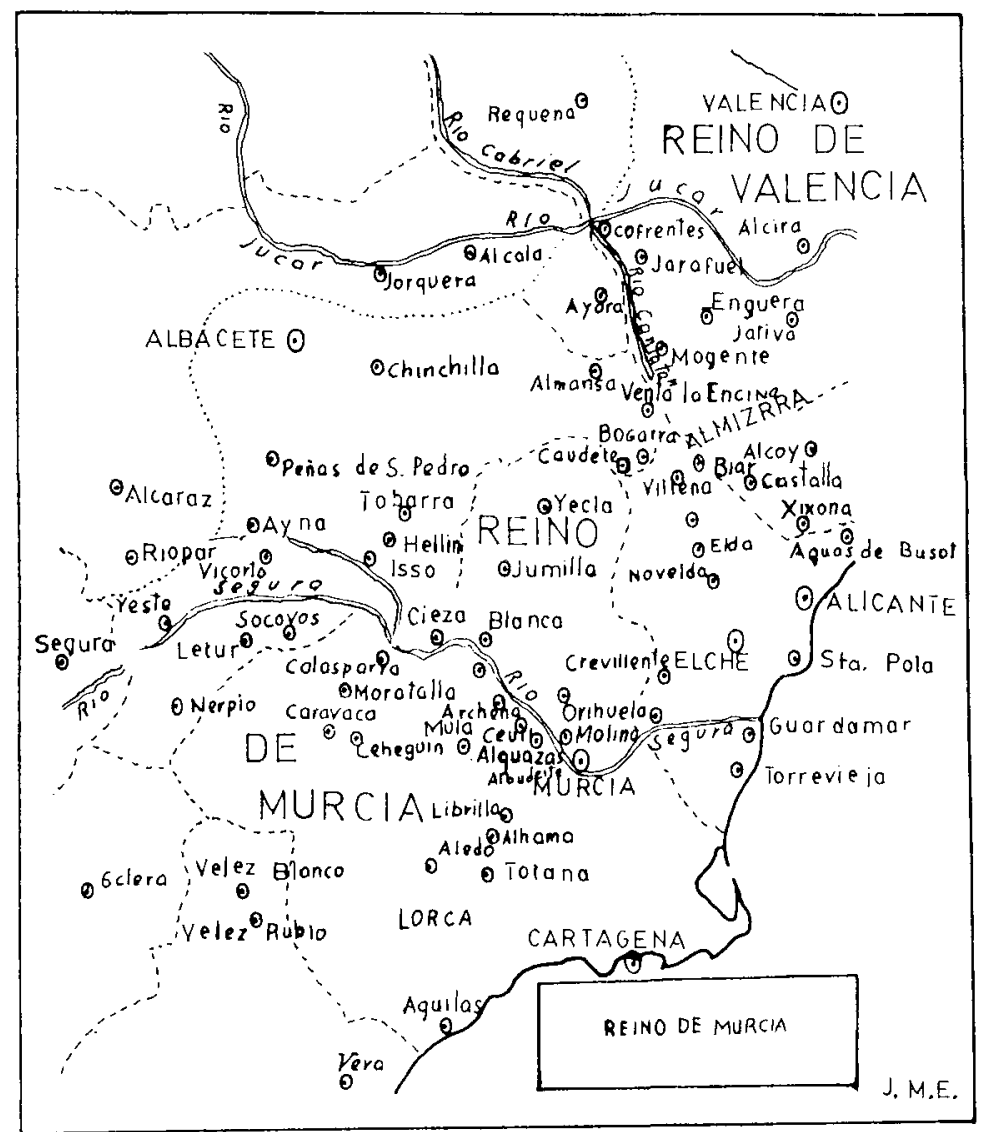

Facsimil 7

Reino Hudita de Murcia incorporado al Protectorado de Castilla por el Infante D. ALFONSO, en el Tratado de ALCARAZ (1243), y luego (1296) por JAIME II a la Corona de Aragón hasta el 1304 (Stcia. Arb. Torrellas) 
Asistieron en condición de testigos a la firma de esta Carta Real: Gonzalo García, consejero real; Artaldo de Azlor, consejero; Pedro Martí, tesorero real; Bernardo de Abbacia, Vicecanciller; y Pedro de Vilarasa, Juez de la Cancillería real.

Signo (notarial) de Bernat de Ausona, notario y guardasellos real, que por mandato del predicho Señor Rey hice extender este documento y lo cerré en el lugar (Valencia), día y años indicados (25 junio 1308).

(Siguen a continuación las apostillas notariales, que a modo de escatocolo final añadió al documento primitivo el notario de la Curia municipal de Alicante, Francesc Alparmés, con que grantiza la autenticidad y verdad del contenido de su Traslado notarial, amparándose en la fidelidad escrupulosa de la copia del mismo y en la autoridad del lugarteniente o Llochtinent del Justicia de la villa de Alicante, Don Castello de Hellum, que lo garantizó con su firma y testimonio fehaciente de verdad. Reza así:)

Sin (signo del Llochtinent del Justicia de Alicante) y la del locant, en Castello de Hellum, tinent-lloch del locant En Tomas de Manterant, Justit d'Alacant, que en lo dit transllat vist l'original d'aquell la sua autoritat et decret açi scripta e donà.

Sig (signo notarial de Alparmés) num de mi Francesch Alparmes, subnotari publich d'Alacant, Regent la Cort de la dita villa, que lo dit transllat he e feelment scriuer fiu e scriuy, e de manament del dit locant tinent-lloch del Justit la sua autoritat e decret açi aposi e acloy, en lo dia que ere contato XI dies d'agost, anno a natiuitate domini Millesimo trecentessimo sexagesimo nono (1).

(1) La tahulla, cafulla o tafulla, era una medida agraria murciana, equivalente a la seisava parte de la fanega castellana, esto es, 11 áreas, 17 centiáreas y 96 decímetros cuadrados, y que hoy sigue todavía vigente en lo que fuera antiguo Reino de Murcia y, sobre todo, en lo que luego se denominó Reino de Valencia ultra Sexonam o Procuración General de Orihuela, correspondiente a la región meridional de la actual provincia de Alicante. Vid. Medidas de superficie, TORRES FONTES, J., Repartimiento de Lorca, Estudio y edición, Introducción, Murcia 1977, págs. $L X|X-L X X|$ 


\title{
LA BATLLIA GENERAL DE LA PART DEL REGNE DE VALÈNCIA DELLÀ XIXONA
}

\author{
MARIA TERESA FERRER MALLOL \\ Institució «MILA Y FONTANALS", C. S. I. C.
}

La conquesta del regne de Múrcia per Jaume II, en el curs de la guerra contra Castella de 1296-1304 (1), comportà una nova configuració governativa i administrativa d'aquestes terres, seguint el model establert a Catalunya, a Aragó $i$ al regne de València, amb algunes modificacions de detall per tal d'adaptar-lo als privilegis locals. Així, doncs, el govern del regne fou confiat a un procurador i l'administració del Patrimoni reial fou encomanada a un batlle general del regne de Múrcia.

La partició del regne de Múrcia entre Castella i la Corona catalanoaragonesa, pactada a la sentència arbitral de Torrellas de 1304 (2), alterà aquest esquema només en l'àmbit territorial, més reduit, i en el nom de les institucions político-administratives, que ja no podien titular-se del regne de Múrcia, nom que, amb la capital, quedava per a Castella; tot primer, doncs, s'intitularen «de les terres dellà Xixona» i, després de llur anexió formal al regne de València el 1308 (3), "de la part del regne de València dellà Xixona».

\section{FUNCIONS DEL BATLLE GENERAL}

Com a Catalunya o com a Aragó i com a la resta del regne de València (4), també a les terres dellà Xixona el batlle general fou el cap suprem de l'administració del Patrimoni reial, que comprenia domini públic (mines, salines, pastures, boscos, aigües, drets de caça i pesca), monopolis reials de serveis públics (molins, forns, carnisseries, banys, etc.), rendes i drets dominicals o emfitèutics (delmes, tasques, etc., de l'una banda i censos, drets d'establiment emfitèutic, firma, lluïsmes, etc., de l'altra), impostos reials de diversa 
mena sobre les persones dels jueus i sarraïns, considerats com una part del «tresor» reial, impostos sobre pas marítim o terrestre de bestiar o mercaderíes, drets de duana, etc.

De la mateixa manera que el batlle era el receptor de les rendes i dels impostos reials, també era el pagador de les despeses de la Corona en el territori que administrava: salaris dels oficials reials, despeses de conservació o reparació d'edificis públics, castells, etc.

El batlle general només havia de retre comptes al mestre racional del rei o a qui el monarca designés, mentre que ell podia demanar comptes a tots els oficials menors dependents de la batllia general.

A més de la vessant pròpiament econòmica, el càrrec de batlle general tenia també una vessant judicial i governativa, ja que tenia competència en ambdues esferes sobre jueus i sarrïns, derivades de llur consideració, com ja hó hem dit, de tresor del rei. Tenia també jurisdicció sobre afers marítims i concedia, per exemple, llicències de navegació, autoritzava armaments en cors, etc. D'altra banda, també era competent en les qüestions judicials per causa de rendes $i$ drets patrimonials i fiscals.

El batlle general era, a més, el cap jeràrquic dels batlles locals i del personal lligat a la batllia.

El nomenament del batlle general solia fer-se a beneplàcit, és a dir, revocable a voluntat del monarca; només en alguns casos era concedit amb caràcter vitalici, sovint després d'un temps d'exercici de la persona afavorida amb aquesta distinció.

\section{BATLLIA GENERAL DEL REGNE DE MÚRCIA}

Com a antecedent immediat de la batllia de les terres dellà Xixona, ens ocuparem tambié de l'efímera batllia general del regne de Múrcia.

\section{Bernat Colom o Colomet}

El primer titular de la batllia general murciana fou Bernat Colom, en algunes ocasions citat com a Colomet, un ciutadà de València, a qui fou atorgada a beneplàcit amb un salari de 2.000 sous reials (5). Sens dubte la tasca de Bernat Colom fou feixuga: a la feina d'organitzar una nova administració , cosa sempre complexa, encara que pogués servir-se en part del sistema castellà anterior, hi afegia el control dels béns confiscats i llur repartiment entre els 
nous concessionaris. El 31 de maig de 1296, passat el termini donat pel rei Jaume II perquè els habitants del regne de Múrcia el reconeguessin com a rei, el monarca demanà informació a Bernat Colom sobre els béns que els rebels, que no havien efectuat aquest recononeixement, posseïen als termes d'Oriola, de Múrcia i qualssevol altres llocs i sobre la qualitat d'aquests béns: si eren francs o obligaven a prestar serveis a la Corona (6). Això vol dir que Bernat Colom i la gent que devia tenir a les seves ordres hagueren de treballar durament i ràpida per a fer l'inventari que el monarca sol.licitava. Ell mateix i el qui seria el seu succesor en el càrrec, Ferrer Descortell, figuraren entre els beneficiaris de les concessions de béns de rebels; Bernat Colom rebé unes cases que havien estat de Pero «Enriquín» de Arana, a la parròquia de Santa Maria de la ciutat de Múrcia (7), i Ferrer Descortell, que era llavors escrivà reial, rebé cases i vinyes a Múrcia i més tard els béns que havien pertangut a Martín Ximénez de Sádava (8).

\section{Ferrer Descortell}

Pel febrer de 1298, Bernat Colom o Colomet fou substituiit per Ferrer Descortell, el qual acumulà al càrrec de batile general del regne de Múrcia el d'escrivà de ració en el regne, amb l'encàrrec d'efectuar els pagaments a les tropes destinades a la frontera (9). A aquest efecte portava un llibre d'estipendiats, en el qual constaven els noms de les persones designades per a prestar servei a la frontera, amb el tipus de servei que prestaven: amb un cavall armat o alforrat, o més, a peu, etc. Aquest llibre servia de base per a fer els pagaments segons la categoria de cadascú (10). El control sobre l'administració dels castells també era competència seva, però no pas com a escrivà de ració de l'exèrcit fronterer, sinó com a batlle general; és per aquesta raó que hom pot trobar entre les cartes de Jaume II un albarà dels comptes que Rodrigo de Biscarra havia retut al batlle general per la tinença del castell de Cartagena (11).

Per aquest motiu, el primer de maig de 1303, Jaume II li envià la llista de les retinences que havia de pagar a cada castell del regne. Aquesta llista indica el nombre de soldats de la guarnició de cada castell i la despesa que suposaven per causa de la soldada, companatge i vianda que hom els proporcionava. El mateix document conté, a més, els salaris dels homes a cavall, amb distinció de cavalls armats i alforrats, que havien de defensar el regne, i els del seguici del procurador i les instruccions sobre la destinació que Ferrer Descortell havia de donar al «setmo» pertocant al rei en les cavalcades contra l'enemic. El «setmo», segons aquestes instruccions, havia de servir per a pagar les esmenes dels cavalls perduts a la guerra, per a pagar els salaris 
dels soldats i per a repartir entre els qui haguessin participat en les cavalcades, tal com era costum (12).

Una altra llista posterior, del 18 de maig, completa la que acabem de comentar amb la relació dels noms dels nobles i cavallers que servien en el regne de Múrcia i el nombre de cavalls armats o alforrats que tenien en servei. Sens dubte era la pauta que havia de servir a Ferrer Descortell per a pagar les soldades (13).

Però, certament, allò que li degué portar més feina degué ésser fer l'inventari de terres, cases i béns que havien passat al fisc a causa de la revolta - l'absència de llurs antics propietaris i llur nova concessió. El 28 de març de 1298, en efecte, Jaume II li donà poders per a establir per un temps determinat o a perpetuitat, amb un cens anual, aquelles heretats i béns (14). Sembla que, per motius d'honestedat en el càrrec, al batlle general no li era permès d'acudir com a comprador a la venda o l'establiment emfitèutic d'aquests béns si no era amb una autorització molt especial del rei; aquesta autorització li fou concedida, el 18 d'abril de 1303, perque pogués comprar els béns que Nicolás Pérez —el qui havia estat alcaid d'Alacant— i la seva muller posseïen a l'horta de Múrcia (15).

Sembla que durant alguns mesos Ferrer Descortell monopolitzà tota l'administració del Patrimoni del regne de Múrcia a les seves mans. Des del moment de la conquesta de les ciutats i viles del regne, Jaume II hi havia nomenat batlles locals en totes, com era habitual a les viles reials catalanes, per exemple. Però el 1303, constret, potser, a fer economies a causa de les despeses de la guerra amb Castella, decidí que hom podia prescindir dels batlles locals i que el batlle general podia administrar directament les rendes reials en aquests llocs. Així, doncs, el 30 d'abril de 1303, el rei manà a Ferrer Descortell que revoqués els nomenaments dels batlles locals $i$ administrés ell directament totes les rendes (16). Aquest procediment no degué donar gaires bons resultats, perquè abans d'un any, el primer de febrer de 1304, fou nomenat un nou batlle a Oriola (17) i, el 7 d'octubre del mateix any, un altre a Alacant (18).

\section{LA BATLLIA GENERAL DE LES TERRES DELLÀ XIXONA FINS A MITJAN SEGLE XIV}

\section{Ferrer Descortell.}

La partició del regne de Múrcia entre la Corona catalano-aragonesa i Castella, en virtut de la sentència arbitral de Torrellas, del 8 d'agost de 1304, obli- 
gà Jaume II a fer nous nomenaments dels oficials reials, la jurisdicció dels quals quedava restringida a la part que li havia correspost. Així, doncs, el 3 de desembre de 1304, Ferrer Descortell rebé el seu nou nomenament de batlle general del rei a la seva terra dellà Xixona («officium baiulie terre nostre ultra Sexonam») amb una durada subjecta al beneplàcit reial i salari de 2.000 sous anuals (19).

Hem trobat la definició de comptes atorgada pel mestre racional, Bernat Rodera, a favor de Ferrer Descortell donant per bons els comptes que li havia presentat $i$ que corresponien als darrers tres anys d'existència de la batllia general del regne de Múrcia i al primer de la batllia dellà Xixona, del primer de gener de 1302 al 31 de desembre de 1305. El 1302 els ingressos havien pujat a la quantitat de 59.666 sous, 6 diners de reials, mentre que les despeses de salaris d'oficials, retinences de castells, obres, etc., havien pujat a 57.974 sous, 10 diners, és a dir, que hi havia hagut un petit superàvit d'ingresos. El 1303 aquestes quantitats havien estat, respectivament, 51.623 sous, 6 diners i 50.260 sous, 6 diners. El 1304 els comptes foren una mica complicats perquè comprengueren tot el regne de Múrcia fins al novembre de $1304 \mathrm{i}$, de llavors fins a final d'any, només la part del regne corresponent a Jaume II; les rendes d'Elx hi foren computades des del 8 d'agost; tanmateix, Elda i Novelda no hi foren compreses perquè el rei havia donat aquestes poblacions i llurs termes a la reina. Tot plegat, els ingressos pujaren a uns 95.113 sous, 10 diners (les centenes, desenes i unitats no es llegeixen bé) i 400 cafissos de civada, mentre que les despeses pujaren a 89.884 sous, 9 diners i 400 cafissos de civada.

El 1305 els ingresos pujaren encara més perquè hi quedaren englobades durant tot l'any les rendes d'Elx, que compensaren amb escreix la pèrdua econòmica que significava la renúncia a les resta del regne de Múrcia. Els ingressos foren de 98.232 sous, xifra que fou superada per les despeses, que pujaren a 101.340 sous. L'extraordinari augment de les despeses fou motivat, segurament, per obres de reparació als castells; almenys hi ha constància que hom permeté a Ferrer Descortell retenir els 5.000 sous de superàvit que havia tingut durant els quatre anys, perquè les obres del castell d'Oriola pujaven ja a 6.837 sous, 6 diners. Però allò que crida més l'atenció és l'augment d'ingressos determinat per la inclusió de les rendes d'Elx. Només quatre mesos d'inclusió d'Elx havien fet passar les rendes del regne de Múrcia de 51.623 sous el 1303 (59.666 el 1302) a 95.113 sous el 1304. La inclusió de les rendes d'Elx de tot l'any, el 1305, malgrat la pèrdua de la meitat del regne de Múrcia, feren pujar els ingressos reials a 98.232 sous, com ja ho hem dit (20). A la vista d'aquestes xifres hom comprèn l'interès de Jaume II 
per a tenir la propietat d'Elx, que era de don Juan Manuel, a més de la jurisdicció.

El 1309, Ferrer Descortell afegí a les competències que ja tenia algunes altres, concretament la recaptació de determinats impostos als llocs pertanyents a la reina Blanca, és dir, a Elda i a Novelda i a Asp; la parella reial havia acordat que aquests impostos serien per al monarca, que els dedicaria exclusivament a pagar els salaris dels membres de la casa reial. Un primer document del 8 de gener de 1309, fet sobre el patró del destinat al batlle general del regne de València, deia que aquestes competències eren els esdeveniments judicials, és a dir, multes i totes altres penes pecuniàries, monedatge i drets de sortida dels sarraïns i de mercaderies per terra i per mar. En el mateix document, el rei exhortava el batlle general a exigir tots els drets reials i a lliurar-ne el producte integrament al tresorer, Pere Marc, que el destinaria a pagar els salaris i quitacions dels qui formaven la seva cort (21). Dos mesos després, el rei havia d'expedir una nova comunicació a Ferrer Descortell per a aclair i concretar les competències que tenia als llocs de la reina i que ell havia interpretat d'una manera massa àmplia. Pertocaria a Ferrer Descortell recaptar, en els llocs de la reina habitats per sarraïns, els esdeveniments judicials provinents de causes criminals, és a dir, si la pena de mort era commutada per una composició pecuniària; en cavi, pertocaria al batlle de la reina la composició que substituís, per exemple, una pena d'assots. D'altra banda, el monedatge, les quèsties i la redempció d'exèrcit ja li pertanyien i els feia exigir per col.lectors especials. En els llocs habitats exclusivament per sarraïns, Ferrer Descortell no podria intervenir-hi ni tan sols per a recaptar aquells esdeveniments, sinó que ho faria el batlle de la reina, el qual li retria comptes d'això i li ho lliuraria (22).

Finalment, un any més tard, pel desembre de 1310, a causa de la mort de la reina Blanca, l'administració de les rendes d'Elda, de Novelda i d'Asp passà a Ferrer Descortell, mentre que Bernat de Granyana, que era qui ho administrava fins llavors, fou advertit que deixés de fer-ho (23).

A part de la batllia, Ferrer Descortell es féu càrrec també dues vegades durant el seu mandat, el 1306-1307 i el 1312, de la col.lecta del monedatge o morabetí, impost que es pagava, com se sap, cada set anys i per al qual el rei designava un col.lector especial (24).

D'altres vegades, en casos d'emergència, hagué d'ocupar-se d'afers que eren competència del portantveus de procurador o del seu lloctinent, segurament perquè aquest era absent de les viles més pròximes a la frontera. Conservem una carta seva, del primer de juny del 1308, escrita a Elx, en la qual 
informava el rei Jaume II de les notícies que li arribaven a través dels espies moros que, d'acord amb l'arrais de Crevillent, havia enviat a Granada i d'altres espies enviats a Lorca pel batlle d'Oriola a requesta seva. Segons aquestes noticies, els granadins es preparaven per a envair les terres dellà Xixona, invasió que Ferrer Descortell considerava imminent. Per aquest motiu havia manat a Llop López de Vaylo i a Ferrer Descloquer que es tanquessin a Villena, ja que tothom es recollia a les fortaleses (25). Dos dies després, el 3 de juny, Ferrer Descortell tornà a informar el rei de les noves que li havien arribat des d'Oriola sobre la invasió granadina (26), ja que el justícia i el jurats d'Oriola procuraven mantenir informats tant el lloctinent, Pero López de Rufes, com Ferrer Descortell mateix (27), talment com si tots dos tinguessin una responsabilitat semblat en aquesta matèria, bé que, en realitat, l'organització de la defensa era competència del lloctinent. Igualment s'adreçaren a l'un i a l'altre el consell $i$ els homes de Guardamar per a demanar ajut quan temien, aquells mateixos dies, ésser l'objectiu de l'atac de l'exèrcit nassarita (28).

Els nostres documents proporcionen moltes més dades sobre l'actuació de Ferrer Descortell en les qüestions més diverses, cosa natural, atès el gran nombre de competències que tenia, però no ens en podem ocupar ara amb detall.

No coneixem, però, els motius pels quals fou destituit el 1314. És possible que fos en aquesta època quan adquiri el senyoriu d'Agost, en el terme d'Alacant, i que el fet d'ésser propietari d'un senyoriu d'importància fos incompatible amb la funció de batlle general. Més endavant, en efecte, mantingué un llarg plet amb Alacant a causa dels límits, dels emprius de pastura i llenya que els alacantins asseguraven tenir al seu terme i del cabeçatge dels sarrainns d'Agost que, segons Alacant, li corresponia de cobrar. Aquest litigi degué provocar penyores contra els habitants d'Agost, perquè el 1319 el rei posà sota el seu guiatge Ferrer Descortell, la seva muller, fills i familia i el lloc d'Agost amb els seus habitants, tant cristians com sarraïns, amb la prohibició de prendre'ls penyores (29).

Ferrer Descortell fou, segurament, un dels batlles generals més distingits dels qui actuaren a la frontera meridional. El 1306 el rei havia premiat els seus serveis enfranquint-lo amb çaràcter vitalici de quèstia, peita, cena, servei, subsidi, bovatge, monedatge, exèrcit, host i cavalcada i llur redempció (30) i, el 1316, dos anys després de la seva destitució com a batlle general de les terres dellà Xixona, li demostrava la seva estima atorgant-li el càrrec de batlle general del regne de València (31), que era força més important que el que havia tingut, tant per l'extensió del territori com pel prestigi de la seva major antigui- 
tat, que de fet li donava una preeminència sobre la batllia dellà Xixona en alguns aspectes, com ho veurem més endavant. Consta que morí abans del $1321 \mathrm{i}$, com que havia quedat a deure alguna quantitat important a la cort, el lloc d'Agost hagué d'ésser venut per a pagar el deute (32).

\section{Guillem Montserrat}

El 1314 Ferrer Descortell fou succeit al front de la batllia general de les terres dellà Xixona per un veí d'Alacant, Guillem Montserrat, un home de fidelitat a tota prova que, pel juny de 1296, havia sortit d'Elx, domini de don Juan Manuel, que no reconeixia la sobirania de Jaume II, per anar a establir-se amb la seva família a Alacant, sota el domini d'aquest monarca (23). Li fou assignat un salari anual de 2.000 sous reials, completat amb 300 més per la batllia de les valls d'Elda i Novelda, que havia estat agregada a la batllia general ja en temps de Ferrer Descortell, a causa de la mort de la reina (34).

\section{Joan Rolf}

Guillem Montserrat no ocupà el càrrec més enllà de set mesos. El mes d'agost de 1314 ja era succeilt per un altre veí d'Alacant, Joan Rolf, amb les mateixes condicions econòmiques i de competències que acabem de detallar en referir-nos a Guillem Montserrat (35).

Joan Rolf o Raolf tenia ja per concessió reial, des de 1301, l'escrivania pública d'Alacant amb caràcter vitalici, el dret a ésser succeït per un dels seus fills i la facultat, tant ell com el seu successor, de servir-la per mitjà d'un substitut (36).

Sabem que prengué possessió del nou càrrec el 14 d'agost de $1314 \mathrm{i}$ que l'exercí fins al desembre del 1317, en què mori (37). El 1316 Joan Rolf acumulà al seu càrrec de batlle el de procurador fiscal, la funció del qual era d'ocupar-se dels drets fiscals i castigar els oficials reials que incomplissin llurs obligacions. El portantveus de procurador, Arnau de Torrelles, havia recomanat al rei que creés aquest càrrec, que segons ell era necessari, i li havia indicat com a persona per a exercir-lo Arnau Vermell, d'Oriola. El rei traspassà la decisió sobre aquesta qüestió, tant la creació del càrrec com la designació d'Arnau Vermell, a Joan Rolf, però dos mesos després, li manà que el revoqués i assumís ell mateix el càrrec, ja que els cavallers i prohoms d'Oriola li havien fet saber que amb el batlle ja n'hi havia prou per a fer la feina de procurador fiscal (38).

Al començament de desembre, alguna malaltia devia fer preveure que Joan Rolf no viuria gaire temps, perquè el 10 d'aquest mes Jaume II concedí 
la batllia dellà Xixona, des del primer de gener següent, a Jaume Andreu, ciutadà de València, amb el salari acostumat (39).

En aquella data, el rei encara no sabia que Joan Rolf hagués mort, perquè li envià una comunicaciòn referent a un afer del seu càrrec (40). No degué trigar gaire a morir-se, però, perquè en el seu libre de comptes consta, com hem dit, que traspassà aquest mes i que Jaume Desclapers acabà els comptes d'aquell any, bé que a Joan Rolf li fou computat el salari de tot el mes de desembre (41).

Jaume Desclapers s'encarregà també de retre comptes a la cort de l'administració de la batllia de setembre a desembre, ja que Joan Rolf els havia retuts personalmente fins al 31 d'agost d'aquell any.

D'altra banda el seu marmessor, Ponç Bonivern, veí d'Alacant, degué encarregar-se de fer el balanç darrer de tot el que Joan Rolf pogués deure a la cort o viceversa, ja que, malgrat que els batlles generals lliuraven de tant en tant els excedents dels ingressos, deduïdes les despeses, hom no solia fer el balanç definitiu fins després de la mort o de la separació del càrrec. Fa suposar que la cort tenia algun interès especial en la tasca de Ponç Bonivern el fet que, per causa de la marmessoria, aquest darrer fos dispensat durant vuit anys de poder ésser obligat a acceptar els càrrecs d'assesor, de justícia o qualsevol altre ofici públic d'Alacant (42). De qüestions a resoldre no li'n mancaren: el 1321, per exemple, el batlle de Crevillent, Bartomeu Romeu, es queixà que havia estat lloctinent de Joan Rolf a Elx, mentre aquest n'era batlle general, i que no havia tingut cap recompensa ni pel treball ni per les despeses i demanà, per tant, un salari pel temps que havia treballat. Jaume II atengué la petició i manà a Llorenç Fritós, jurista d'Oriola, que li fes assignar un salari i l'hi fes pagar dels béns de Joan Rolf (43). No sabem si valia per a un cas com aquest el guiatge que el rei havia atorgat a la vídua, als fills, filles i béns de Joan Rolf poc després de la seva mort, el 10 de març de 1318, potser per a deslliurar-los d'exigències precipitades dels creditors (44).

\section{Jaume Andreu}

El successor de Joan Rolf, Jaume Andreu, havia estat abans batlle de Xàtiva (45). El seu nomenament com a batlle dellà Xixona sembla que fou una mena de compra del càrrec, ja que el mateix dia del nomenament el rei reconegué deure-li una quantitat de diners no especificada, que el monarca li assignà sobre les rendes de la batllia della Xixona; el document remetia per als detalls del deute al registre de tresoreria, on havia estat inscrit. Jaume II es comprometé a conservar-li el càrrec mentre no li retornés la quantitat deguda 
i deu anys després, el rei Alfons, fill i sucessor de Jaume II, ratificà aquest compromís el 25 de novembre de 1327 (46).

Jaume Andreu tingué un salari anual de 2.000 sous reials com els seus predecessors en el càrrec (47), però-no tingué tantes competències com els seus antecessors immediats: Ia batllia de la vall d'Elda, que comprenia Elda, Novelda i Asp, fou administrada primer per Joan Pérez d'Avesques, que ja era batlle de la vall el 1318 (48), i després, des del gener de 1320, per Joan Enric (49). A més hi hagué, almenys el 1324, un procurador fiscal que també li prengué competències (50). Finalment, però, el 1328, regnant ja Alfons el Benigne, fou desenterrada l'anul.lació del càrrec de procurador fiscal de temps de Joan Rolf i el rei la confirmà; per tant, suprimit el càrrec, les seves competències, quedaren, com en aquell cas, atribuïdes al batlle general (51).

Les competències que Jaume II concedí expressament a Jaume Andreu, quan li confià el càrrec de batlle general, foren les d'establir en emfiteusi, fixar censos de les terres i aigües del Patrimoni, etc., competències que solien anar implícites en la concessió del càrrec, però que alguna vegada, com en aquest cas, s'especifiquen a part (52).

Com en el cas de Ferrer Descortell, també es conserven a l'Arxiu de la Corona d'Aragó algunes cartes originals de Jaume Andreu al monarca. La primera, del 1320 , es refereix al perill d'un atac granadí que prenia perfils alarmants, puix que es deia que Múrcia i Lorca havien arribat a un acord amb els nassarites per a deixar passar llurs tropes, quan anessin a atacar terres oriolanes, sense declarar l'alerta i per a avisar-los, al contrari, si tropes catalanes travessaven el territori murcià per atacar el regne de Granada. Els rumors no eren pas sense fonament, com ho demostrà la carta que, un any després, l'adelantat de Múrcia adreçà a Jaume II (53). L'altra carta original de Jaume Andreu que hem trobat era una consulta al rei sobre el problema del càstig que havien de rebre els pastors aragonesos que, després de desobeir les prohibicions de passar el Segura amb llurs ramats, havien resultat capturats, alguns d'ells i una part de llurs ramats, pels genets granadins en el Camp de Cartagena. El batlle recomanava el càstig per a donar exemple i a més per reaons pràctiques, ja que les rendes d'Oriola, Alacant i Guardamar no bastaven per a pagar els salaris dels ofiçials ni per a mantenir els castells, i només podia confiar en els diners de les multes i penes judicials per a cobrir despeses (54).

\section{Joan Enric}

Jaume Andreu fou substituït per Joan Enric, que rebé el seu nomenament de batlle de la part del regne dellà Xixona el 14 de febrer de 1329 (55). 
Com ja ho hem dit abans, Joan Enric havia estat fins llavors batlle de la vall d'Elda i Novelda i precisament, en qualitat de tal, figura com a autor d'una de les cartes conservades a l'Arxiu de la Corona d'Aragó; una carta en la qual informava el rei sobre una incursió fronterera de castellans que havien robat bestiar (56)

\section{LA BATLLIA DE L'INFANT FERRAN}

La donació de la major part de les viles i dels llocs de la governació a l'infant Ferran, pel gener de 1330 (57), féu que el càrrec de batlle general d'aquella part del regne de València, com el de procurador, desaparegués per a passar a ésser el batlle particular de l'infant. Són ben poques, doncs, les notícies sobre l'administració d'aquelles terres que hem pogut recollir per a aquesta etapa. Un llibre de comptes de la batllia general dels llocs de l'infant Ferran, corresponent al 1355 amb algunes dades que arriben al 1356, ens informa que del 1355 al 1358 fou batlle general Joan Ximenis de Perencisa. Pel juny de 1358 fou substituitt per Aguerot Alvarez d'Espejo (58).

\section{LA BATLLIA GENERAL DEL REGNE DE VALĖNCIA DELLÀ XIXONA DES DE 1364}

\section{Joan d'Olit}

No tenim més notícies de l'administració d'aquell territori fins el 1364, un any en el qual Pere el Cerimoniós, després de l'assassinat del seu germà, l'infant Ferran, nomenà novament un batlle general del regne de València dellà Xixona, ja que aquelles terres es reincorporaven a la Corona, puix que l'infant no tenia descendència. El nomenament recaigué en Joan d'Olit, ciutadà de València, a qui fou assignat un salari de quatre animals diaris, més 20 lliures d'ajuda per al vestir (59). Després de poc, el rei l'afavoria encara amb la concessió de la batllia local d'Alacant (60). Però poca cosa degué poder fer, perquè ben aviat totes aquelles terres caigueren sota el control castellà a causa de les desgraciades vicissituds de la guerra amb Castella, dita dels dos Peres.

Pere el Cerimoniós recuperà aquelles terres meridionals el 1366 i, pel maig, Joan d'Olit començà a exercir el seu càrrec (61). Durant els mesos següents el rei anà precisant les competències del nou batlle: el 15 de juny el nomenà 
procurador fiscal; un càrrec que, com hem vist, havien acumulat alguns predecessors seus (62); també el 16 de juny li concedí poders per a establir en emfiteusi les terres i cases pertanyents al patrimoni reial i l'autoritzà a fer composicions amb els inculpats en qüestions civils o criminals derivades dels drets reials (63).

Després, pel setembre, el rei restringia involuntàriamente les competències de la batllia reinstaurada en confirmar una concessió vitalícia de la col.lectoria d'Elda, Novelda i Asp a Francesc Masquefa d'Oriola i un dels seus hereus, concessió que havia atorgat el 1364 . Però l'endemà mateix d'aquesta confirmació el rei la revocava en adonar-se del perjudici causat a l'ofici de la batllia general, a la qual, a més de competències, sostreia unes rendes que servien per a pagar las retinences dels castells (64).

La tasca de Joan d'Olit no degué pas ésser fàcil. Hagué d'enfrontar-se amb un país destruït per la guerra, on la població havia sofert una disminució molt forta, especialment de sarraïns i jueus, que eren els qui portaven més benefici econòmic al Patrimoni reial. Calia intentar atreure població als nuclis urbans i calia reconstruir sèquies, cases i molins i replantar els arbres i els ceps talats pels exèrcits. Calia també reconstruir castells i muralles afectats pels setges i tot això sense recursos: els camps havien restat improductius perquè la guerra no havia permès de sembrar-los i el rei no en podia cobrar les rendes, com tampoc no podia cobrar les rendes d'altres menes de conreus, arbres fruiters o vinyes si, com dèiem, havien estat talats i calia replantarlos. També es perdien els censos de les cases, molins, etc. destruïts, i no podia exigir la totalitat dels impostos personals als sarraïns si aquests darrers s'havien quedat pràcticament sense bestiar, sense collites i molts a la misèria.

La situació continuava essent molt difícil encara el 1368, després d'haver passat més de dos anys des de l'acabament de les operacions de guerra en aquest sector. Pel desembre d'aquest any, Joan d'Olit anà a trobar el rei Pere el Cerimoniós a Cervera per fer-li saber que els castells estaven a punt d'ésser abandonats pels alcaids, perquè ell no els podia pagar les retinences, i proposà que les rendes reials de Xàtiva fossin aplicades a aquesta obligació (65). Uns quants mesos després, el rei havia trobat una solució transitòria per a aquest greu problema, després d'haver-lo estudiat amb el mestre racional. Segons aquest alt oficial, veritable ministre d'Hisenda, el rei rebia en aquells moments 3.200 sous de renda a les terres dellà Xixona, mentre que els càrrecs que pesaven sobre les esmentades rendes ascendien a 26.000 sous o més. D'altra banda, el tresorer l'havia informat que no rebia rendes suficients en cap regne per a poder-les destinar a aquella obligació; així és que hi hagué 
d'aplicar 20.000 sous anuals dels que el tresorer de la reina lliurava cada any al monarca per al vestir i les altres necessitats de la seva cambra, ja que les rendes de la reina no estaven tan carregades com les seves pròpies (66). Una solució definitiva, almenys durant molts anys, per a aquest problema fou adoptada el 21 de juliol de 1376 . Consistí a transvasar 12.000 sous cada any de la batllia general del regne de València, més rica, a la de dellà Xixona, quantitat que havia de servir per a pagar les retinences dels castells (67).

Aquest transvasament de l'una batllia a l'altra suposà una supeditació, almenys en aspectes econòmics, de la batllia meridional a la gran batllia del regne de València. De fet, però, la batllia dellà Xixona ja li era en certa manera subordinada pel fet que Joan d'Olit era lloctinent del batlle general del regne $\mathrm{i}$ ensems batlle de la part meridional (68).

D'altres problemes derivats de la guerra, a més dels de la reconstrucció que ja hem citat, foren confiats també per a llur resolució a Joan d'Olit. Així, per exemple, el 25 de juliol de 1367 el rei Pere li encomanà la resolució dels plets contra els sarrains que havien estat lliurats com a rehenes o que havien estat captivats per les seves tropes a Elda, Novelda i Asp, i que fugiren i tornaren a llurs llocs d'origen, ocupats pel rei de Castella. Era un problema una mica complicat perquè hi havia persones que havien comprat aquests captius i que ara els reclamaven, mentre que, d'una altra banda, el rei havia posat sota el seu guiatge els sarraïns d'Elda perquè poguessin tornar en aquest lloc a viure-hi (69).

Pere el Cerimoniós reconegué la importància del serveis prestats per Joan d'Olit en circumstàncies tan difícils i ens consta que els hi recompensà: per l'agost de 1367, en una ocasió en què Joan d'Olit havia acudit a la cort, suposem que per afers del seu càrrec, li concedí un donatiu de 2.000 sous, que equivalia, més o menys, a dos terços del seu salari anual (70).

Més tard, el monarca confirmà la permuta que Joan d'Olit havia fet amb el notari alacantí, Miquel Sánchez de Linyan; aquest darrer li havia cedit l'escrivania de la duana del port d'Alacant i ell li havia cedit la batllia, que, com ja ho hem dit, li havia concedit el rei el 1364. El càrrec de batlle general no li permetia de residir a Alacant i li resultava molt carregós haver d'acudir-hi per a presidir el consistori o consell municipal; al contrari, l'escrivania de la duana, podia regir-la, per concessió reial, per mitjà d'un substitut (71).

\section{Domingo Borràs}

Joan d'Olit mori el 1376 i el substituí Domingo Borràs, que fou nomenat el 18 de juliol de 1376 (72). Com d'altres predecessors seus, Domingo Borràs 
era un escrivà del rei (73); el 1373, juntament amb Guillem Mir, havia recaptat el monedatge o morabetí a les terres della Xixona i potser fou aquesta circumstància la que féu que el rei pensés en ell per al càrrec de batlle general (74).

Pel que fa al salari, fou igual que el dels seus predecessors immediats: quitació de quatre bèsties, que corresponia a 3.880 sous, més 400 sous per al vestir.

Pel que fa a competències, degueren ésser també semblants a les dels seus predecessors; no tingué, però, el càrrec de procurador fiscal, que molts havien acumulat, ja que sabem que aquest càrrec fou exercit pel notari d'Oriola, Joan Castell (75). El 1380 el rei amplià les atribucions de Domingo Borràs autoritzant-lo a fer composicions amb les persones acusades de crims que no fossin heretgia, lesa majestat i fabricació de moneda falsa (76).

D'altra banda, sabem que havia estat dues vegades col.lector del morabetí o monedatge, l'una el 1373, abans d'ésser batlle general, i l'altra el 1379, quan ja ho era. La primera vegada compartí el càrrec, com ja ho hem dit, amb Guillem Mir, i la segona amb Francesc Marrades. Per ambdós treballs Pere el Cerimoniós li assignà, el 1382, un salari de 4.000 sous barcelonins (77). El 1381 el rei li confià a ell, a Pere Marrades i a Arnau Porta els afers relacionats amb un censal que havia obligat als banquers, Pere Pasqual i Arnau Esquerit, per a respondre d'un crèdit de 9.000 lliures, pel qual havia hagut de pagar un interés o mogubell de 6 sous per lliura anuals (el 30\%) (78).

El rei recompensà els seus serveis de diferent manera: d'una banda concedint-li la batllia d'Alacant, que ja havia tingut el seu predecessor, Joan d'Olit (79), i d'una altra amb algun donatiu extraordinari, com per exemple el de 5.000 sous barcelonins, que li concedí el 1380 i que ell cobrà de les rendes de la batllia l'any següent, 1381 (80).

Domingo Borràs renuncià al seu càrrec per l'abril de 1384, perquè ja era molt vell i no podia tenir-ne cura. El rei encomanà llavors la batllia general a Pere Mir, de la casa reial (81).

\section{Pere Mir}

Sembla que el nomenament de Pere Mir ja havia estat signat el 15 de març de 1384. El càrrec li fou concedit a beneplàcit amb el mateix salari que havien tingut els seus predecessors i l'exercí des del primer de maig de 1384 fins al 2 de març de 1387, en què prengué possessió el seu successor, Joan de Roncesvalls. S'ha conservat el seu llibre de comptes que comprèn aquests 
anys i també hem conservat l'albarà de quitament que li lliurà el mestre racional després de rebre els comptes, el 1388. Segons aquest albarà, les rebudes del primer any de la seva administració havien sumat 22.488 sous i 8 diners, 24.833 en el segon i 25.133 sous i 8 diners en el tercer: en total 72.455 sous, 4 diners. Pel que fa a les despeses, havien pujat a 20.062 sous el primer any, 26.439 sous, 11 diners el segon i 26.090 sous, 8 diners el tercer, de manera que les despeses totals havien pujat a 72.592 sous, 7 diners $i$, per tant, havien superat les entrades en 137 sous, 3 diners, que el mestre racional reconegué que la cort li quedava a deure (82).

\section{Joan de Roncesvalls}

Potser a causa de la virada política que suposà l'accessió al tron de Joan I, el qual substituí molts dels alts oficials nomenats pel seu pare, el batlle general dellà Xixona fou rellevat del seu càrrec, tal com també li havia esdevingut al governador general, i fou substituilt per Joan de Roncesvalls, un donzell que era cambrer de Joan I. El nomenament fou signat el 15 de gener de 1387 però, com ja ho hem dit, no prengué possessió fins el 2 de març d'aquell any (83). Un any després, el càrrec li era concedit amb caràcter vitalici (84) i, al cap de dos mesos, Joan de Roncesvalls era honorat encara amb la concessió del grau de cavaller (85).

Quan Joan I morí, Joan de Roncesvalls conservà el seu càrrec, malgrat les nombroses substitucions d'oficials reials que es produïren a causa del procés obert contra molts dels oficials i consellers del monarca difunt. Consta que el rei Marti manà al governador dellà Xixona i als altres batlles i justícies que no el molestessin en l'exercici del seu càrrec, ja que el tenia amb caràcter vitalici (86). Posteriorment, sembla que tingué alguna dificultat amb la cort, que s'aclarí amb una seva visita al monarca (87).

L'època en què Joan de Roncesvalls estigué al front de la batllia general dellà Xixona es caracteritzà per les dificultats amb què topà per a mantenir la independència i el rang d'aquella batllia, que corria el perill de convertir-se en un apèndix o una lloctinència de la batllia general del regne de València.

Ja hem dit que la guerra amb Castella havia arrasat aquelles terres de tal manera que passaren molts anys abans no començaren a refer-se'n i això incidí, com és molt natural, en les finances reials, que veieren com les entrades es reduïen a causa de les moratóries i condonacions d'impostos que calgué concedir a la població empobrida i a causa, també, de la pèrdua de béns (bestiar, arbres, cases o molins establerts a cens, etc.) i la disminució de població gravada pels impostos. 
D'altra banda, el rei s'havia desprès de totes les possesions que produïen rendes més considerables: Elx i Crevillent foren donades a l'infant Martí, després de la mort de l'infant Ferran, i Elda, Novelda i Asp foren donades primer a Hug de Calviley i després a la reina Sibil.la, possessions que més tard passaren a la reina Violant.

Sota l'administració de la batllia general quedaren, doncs, només Oriola i Alacant amb llurs termes, però ambdues viles, gairebé desproveïdes de llur població sarraïna, proporcionaven poques rendes i grans despeses a causa de llurs castells, que eren les claus de la frontera i necessitaven sovint obres de reparació molt costoses i el manteniment d'una petita guarnició.

Ja hem dit que els ingressos del Patrimoni a la batllia dellà Xixona no cobrien les despeses i que, el 1376, Pere el Cerimoniós hagué d'ordenar la transferència anual de 12.000 sous de les arques de la batllia general del regne de València a les de la batllia dellà Xixona, a fi que es poguessin pagar las retinences dels castells, especialment dels d'Oriola i Alacant.

La dependència econòmica comporta sempre dependència politica i administrativa; així que, insensiblement, el batlle general dellà Xixona anà perdent facultats reals de disposició, tant sobre els mateixos diners transvasats de la batllia general del regne de València com sobre la cura dels castells als quals anava destinada l'ajuda.

El 1384, mentre encara era batlle general dellà Xixona Domingo Borràs, el rei Pere li manà que retornés a la batllia general de València el que sobrés dels 12.000 sous traspassats per aquesta un cop hagués pagat les retinences i les obres dels castells d'Oriola i d'Alacant, ja que era just que la resta servís per a pagar els càrrecs d'aquella batllia (88).

Potser per tal de vigilar de prop la devolució d'aquestes restes i en general l'administració dels diners que sortien de la mateixa batllia, el batlle general del regne de València intervingué directament, més tard, en la decisió i l'execució de les obres que calia fer en els castells esmentats. El 1389, per exemple, Joan I recomanava a Ramon de Soler, que era llavors batlle general del regne de València, que inspeccionés el castell d'Oriola, ell o un seu lloctinent, i que hi fes fer les obres de reparació que fossin necessàries, ja que hom li havia dit que el castell, situat a la frontera amb Castella i un dels més insignes, amenaçava ruïna (89).

Més endavant, el 1394, Joan I disposava que, per tal d'evitar despeses inútils, els 6.000 sous de retinença que calia pagar a l'alcaid del castell d'Oriola els pagués directament el batlle del regne de València a l'alcaid d'Oriola (o 
al seu substitut), sense que haguessin de passar abans per les mans del batlle dellà Xixona com fins llavors (90). El mateix any, el rei destinà 5.000 sous a les obres de reparació de murs, torres, etc. del castell d'Oriola per a esmerçarlos en tres anys i uns altres 2.500 al d'Alacant, que també es trobava molt arruïnat; i ho comunicà no pas al batlle dellà Xixona, a qui hauria pertocat, sinó al batlle del regne de València, Ramon de Soler, a qui advertí que aquesta quantitat era de més a més del que ell hi destinava (91).

Ja en temps del rei Martí l'Humà, foren atribucions generals les que li foren discutides al batlle dellà Xixona. Així, per exemple, pel juny de 1397, Martí l'Humà li manà que no concedís llicències d'armar en cors, cosa que, deia, corresponia al batlle general del regne de València per costum antic. El rei reconeixia que el batlle no havia pas obrat sense base legal, puix que es referia a les llicències que havia concedit en vigor d'algunes cartes reials, però creia que,per a evitar danys, era millor que hi hagués un sol responsable de la concessió d'aquestes llicències en tot el regne (92). Sembla que aquesta actitud reial es devia als atacs de Joan Alvarez d'Espejo, veí d'Oriola, contra vaixells castellans i genovesos sota la protecció castellana a les mars de Castella, un fet que havia provocat represàlies contra mercaders catalans i habia posat en perill la pau amb Castella, segons ho assegurava el rei. Joan Alvarez d'Espejo habia armat una galicta a la governació dellà Xixona i havia donat fermances al batlle general d'aquesta regió comprometent-se a no atacar amics. El batlle el sentencià a mort per aquest fet, peró no fou trobat $i$ sembla que també hi hagué dificultats per a confiscar els seus béns i els de les fermances per a poder indemnitzar les víctimes, ja que la família de Joan Alvarez d'Espejo era molt poderosa a Oriola (93).

Fets com aquest s'esdevenien també en altres llocs i, bé que potser a l'extrem meridional de les terres catalanes les autoritats eren més benèvoles a causa de la situació fronterera, sembla que darrera d'aquests intents de retallar les competències del batlle dellà Xixona hi havia, en realitat, el desig del batlle general del regne d'assegurar la seva competència exclusiva sobre diverses qüestions.

No era cert que les llicènciés d'armar en cors haguessin correspost al batlle general del regne de València per costum antic. Alguns dels documents que hem vist demostren, ben al contrari, que el batlle reial dellà Xixona s'ocupava d'aquesta qüestió. El 16 de desembre de 1320, per exemple, Jaume Il comunicava al batlle general a la part del regne de Valéncia dellà Xixona que havia remès a Pere Ballester, de Guardamar, la fiança que havia fet a Garcia Salfamàs quan havia armat en cors a Guardamar. La fiança era exigi- 
ble perquè Garcia Salfamàs havia robat alguns cristians que calia indemnitzar (94). Si el batlle s'havia d'ocupar en principi d'exigir la fiança, sembla que era perquè el fiador era responsable davant seu. El 23 de desembre de 1321, d'altra banda, el mateix rei Jaume II cridà l'atenció al batlle general dellà Xixona, Jaume Andreu, perquè demanava als corsaris que armaven a la vila una part del lucre obtingut més gros del que havia estat fixat en els privilegis atorgats pels reis de Castella a Alacant i que havien estat confirmats per Jaume II (95).

Era cert, en canvi, que alguns tractats internacionals, com ara els de Gènova de 1386 i 1390, havien restringit als ports de Barcelona, València, Mallorca, Menorca, Eivissa, Caller i l'Alguer la possibilitt d'armar en cors, per tal d'assegurar un control més fort dels corsaris (96), i que això suposava, de fet, una limitació de les facultats del batlle general dellà Xixona.

Però aquesta dels armaments corsaris no era l'única prerrogativa reivindicada pel batlle general de València, que en aquests anys es preocupà d'assegurar la seva competència exclusiva sobre aquesta i d'altres qüestions i també la seva preeminència sobre el batlle dellà Xixona. Pel maig de 1399 el batlle general del regne, que era llavors un conseller del rei, Nicolau Pujades, s'havia queixat perquè els governadors i els altres oficials reials, tant deçà com dellà Xixona, no en tenien prou amb els límits de llurs jurisdiccions respectives i envaien les seves competències, establertes per provisions reials. El rei Martí encomanà al seu conseller, Ramon Tolzà, cavaller i doctor en lleis de València, que resolgués les contencions jurisdiccionals que es produïssin entre el batlle general i els altres oficials, tal com ja ho havia fet precedentment el rei Pere (97).

Per juliol, el batlle general del regne aconseguia una provisió reial molt important, que significava la seva victòria sobre els dos governadors del regne, que en virtud de delegaciones especials del rei intervenien en la resolució de qüestions diverses, sostraient-les de la jurisdicció ordinària.

En aquest provisió el rei revocava totes les concessions a oficials reials o a comissaris, atorgades pel rei Joan l i per ell mateix, que signifiquessin una minva de les atribucions del batlle general del regne de València i prohibia que cap governador, justícia, batlle o altre oficial del regne de València, tant deçà com dellà Xixona, ni cap comissari pogués concedir llicències per a armar vaixells en cors contra enemics ni licències per a treure coses prohibides del regne per mar i per terra, ni pogués atorgar llicència als moros per a emigrar a terres sarraînes ni per a demanar almoina dins dels seus regnes $i$, consegüentment, ningú fora del batlle general no podria decretar prohibicions 
sobre aquestes matèries (prohibicions d'armar en cors o de treure determinats productes, per exemple) ni jutjar-ne els infractors (98). Totes aquestes facultats eren competència també, fins llavors, del batlle general dellà Xixona (99) i algunes, com la de concedir llicències d'emigració o per a demanar almoina als sarraîns, així com també el càstig dels infractors, havien estat exercides pel governador general del regne de València per delegació expressa dels monarques, especialment del rei Pere el Cerimoniós, que alguna vegada, però, escoltant les protestes del batlle general, havia confirmat que eren competència d'aquest darrer (100).

No sabem si Joan de Roncesvalles recorregué contra aquesta decisió reial, que limitava les seves atribucions en matèries tan importants com la d'autoritzar l'extracció de mercaderies prohibides per mar o per terra cap a Castella o bé si acceptà la decisió reial. Com que no conservem llibres de comptes de la batllia general corresponents a aquests anys no podem comprovar aquest punt, que seria fàcilment verificable perquè, en els que tenim d'anys anteriors, hi consten sempre els ingressos per les llicències d'extracció de mercaderies prohibides.

De tota manera, sembla que la limitació de funcions fou efectiva, perquè a la darreria de desembre de 1403, alguns anys després d'aquella provisió, el rey Martí comunicà a Olf de Pròixida, governador llavors d'Oriola, i al mateix Joan de Roncesvalls que el batlle general de València, de voluntat seva, havia nomenat guardià de les fronteres i ports per a vigilar les mercaderies prohibides que es treien sense llicència del regne de València un tal Domingo de Borja, ciutadà de Xàtiva, que tindria jurisdicció des del Xúquer fins al regne de Múrcia. La preeminència del batlle general del regne semblava, doncs, clara (101).

Contràriament, malgrat els antecedents de la intervenció del batlle general del regne de València en la inspecció, decisió i execució d'obres del castell d'Oriola, ens consta que Joan de Roncesvalls s'encarregà per ordre del rei de pagar 500 sous anuals per a la reparació del castell d'Alacant (102).

El rei Martí defensà també łes atribucions judicials del batlle dellà Xixona $i$, el 1410, prohibí que en els afers judicials relatius a la batllia hi intervinguessin comissaris reials; només el batlle o el seu lloctinent podien intervenir-hi. A més, prohibí que hom pogués impugnar les demandes que el mateix batlle general dellà Xixona fes per causa de rendes i drets patrimonials (103).

Joan de Roncesvalls morí el 1411 durant l'Interregne, un any després de la mort del rei Martí. Segons Bellot, fou substituït per Bartomeu Togores, 
nomenat pel governador dellà Xixona, de qui era lloctinent, malgrat les protestes del lloctinent del difunt, que era Bartomeu Monsi de Castanyeda, a qui pertocava la substitució. Sembla que el consell d'Oriola protestà també per aquest nomenament, ja que el càrrec de batlle era incompatible amb el de lloctinent del governador (104).

\section{D'ALTRES CÀRRECS}

Depenien de la batllia general els batlles de les viles reials, Alacant, Oriola i Guardamar, però no ens n'ocuparem amb detall perquè potser és més adequat de fer-ho dins del marc de la història local de cadascuna d'aquestes poblacions.

Hi havia, encara, molts més càrrecs, des dels més importants, com el de lloctinent, fins als d'escrivans, col.lectors d'impostos o saigs.

\section{Lloctinent}

Sabem que el batlle general tenia sovint un lloctinent, però coneixem pocs noms d'aquests lloctinents. Només els de Bartomeu Romeu, que ho era el 1317 (105), Joan Castell, veí d'Oriola, que ho era entre 1379 i 1381 (106), Miquel d'Alcarràs, que ho era el 1385 (107), i Bartomeu Monsi de Castanyeda (108). No sembla que tinguessin un salari fix pequè tampoc no devien tenir feina seguida sinó ocasional, quan el batlle s'absentava. En alguns casos ja ocupaven d'altres càrrecs remunerats; per exemple, Joan Castell era procurador i advocat fiscal. Pel que fa a Bartomeu Romeu, la batllia li pagava cada any 150 sous perquè mantingués en servei del rei un rossí alforrat (109).

\section{Procurador fiscal i advocat assessor}

El de procurador fiscal era, en canvi, un càrrec remunerat, però no pas sempre independent del batlle. Ja hem dit que el portantveus de procurador, Arnau de Torrelles, havia recomanat al rei Jaume II, el 1316, que creés aquest càrrec a la batllia general dellà Xixona, a fi que s'ocupés de la defensa dels drets fiscals i del càstig dels oficials reials que incomplissin llurs obligacions. El càrrec fou concedit efectivament a Arnau Vermell d'Oriola, però després fou revocat a petició d'Oriola, que deia que no era necessari, i les seves competències foren adjudicades al batlle general (110).

La necessitat de la presència d'un jurista entre els oficials de la batllia s'havia fet tan evident, però, que al cap de dos anys, el 1318, el batlle general 
dellá Xixona, Jaume Andreu, obtingué el nomenament d'un advocat assesor, càrrec que recaigué en Bernat de Solsona, veí d'Alacant, amb un salari de 100 sous anuals (111). Segurament les competències devien ésser semblants a les que havia tingut el procurador fiscal però, havent estat rebutjat aquest càrrec feia tan poc de temps, hom acudí a una altra titulació.

El càrrec de procurador fiscal ressuscità, però, desprès de poc i, el 1324, era ocupat per Guillem Fibla, que cobrava, com l'advocat assessor, 100 sous anuals (112). És possible que aquest càrrec continués vigent en els anys posteriors. El 1356, almenys, sota el senyoriu de l'infant Ferran, ens consta que hi havia un advocat fiscal de funcions similars a les del procurador, que era Bernat Julià, que cobrava un salari de 300 sous anuals (113).

Quan Pere el Cerimoniós recuperà les comarques dellà Xixona, acumulà tot primer el càrrec de procurador fiscal al de batlle general i Joan d'Olit, que ja era batlle, rebé aquest segon nomenament el 15 de juny de 1366, però no el degué exercir més enllà de dos mesos, perquè el mateix any 1366 ja ocupà aquest càrrec i el d'advocat fiscal el notari Joan Castell, el mateix que també fou després lloctinent del batlle; com que cobrà un terç del salari anual previst, suposem que degué començar a exercir-lo el mes de setembre de 1366 (114). Sembla que Joan Castell ocupà el seu càrrec fins al 1387, almenys (115). És el darrer procurador fiscal del qual tenim notícia en l'època que estudiem.

\section{Escrivà de la batllia general}

Pel que fa a l'escrivà de la batllia general, era també un càrrec important; s'encarregava de rebre els comptes de l'administració de les rendes reials i de la col.lecta d'impostos dels oficials locals, dels col.lectors o dels arrendataris. Sembla que era auxiliat en la seva tasca per altres escrivans. El primer dels escrivans de la batllia dellà Xixona del qual coneixem el nom és Jaume Desclapers, veí d'Elx. S'ocupava d'questa tasca ja el 1316, amb un salari de 200 sous anuals (116), però no rebé el nomenament oficial fins el 1321. El 1325 Jaume II li concedi que tingués el càrrec amb caràcter vitalici (117), però uns anys després, el 1327, Jaume Desclapers es vengué l'escrivania a Berenguer Gavet, un veí de Xàtiva, que en pagà 400 sous. El rei Alfons el Benigne en confirmà la venda, puix que era d'una cosa patrimonial, el 1329, i concedí el càrrec a Berenguer Gavet, el comprador, també amb caràcter vitalici (118).

No sabem el nom de cap més escrivà fins el 1356, en què ens consta que el notari Pere Romeu regia l'escrivania de la batllia general amb un salari 
superior al que havien tingut els seus predecessors: 300 sous (119). El 1366, recuperat aquest territori perdut durant la guerra amb Castella, s'ocupà de l'escrivania durant un període breu, uns quatre mesos, el notari Jaume de Mora, que fou succeit aviat per un altre notari, Castelló de Bellver (120). EI 1366 l'escrivà ja havia canviat i era ara Joan Morató (121), mentre que del 1379 al 1385, almenys, ho fou Joan Diez, auxiliat pel notari Bernat Morrelles (122). Bé que Joan Díez apareix com a escrivà de la batllia en els comptes d'aquesta institució, des del 1379 , el seu nomenament oficial no es produí fins el 1382, després de la mort de Joan Morató. És possible que aquest darrer hagués estat substituit per vellesa o malaltia per Joan Díez i que aquest sigui el motiu pel qual el trobem com a escrivà des d'abans del seu nomenament. En la concessió a Joan Díez el monarca féu constar els valuosos serveis prestats per aquest notari durant la guerra amb Castella (123).

\section{Escrivans de ports i duanes}

Quant als escrivans, és difícil destriar els casos en què eren uns assalariats d'aquells altres en què l'escrivania era un monopoli arrendat o cedit, com d'altres, amb caràcter vitalici per a recompensar uns serveis, o bé a canvi d'un cens anual o bé de manera gratuita.

L'escrivania del port d'Alacant sembla pertànyer al grup de les que eren regides per un assalariat; fou cedida poc després de la conquesta d'Alacant a Jaume de Santa Creu, el qual havia de retenir el seu salari de les rendes que produia la duana (124). El seu successor, Pere de Lagunes, de casa del rei Jaume II, a qui fou concedit el càrrec amb caràcter vitalici quan mori Jaume de Santa Creu el 1314 (125), figura en els comptes de la batllia del 13161317 entre les persones que reberen un sou de la batllia general, en el seu cas 10 diners diaris, situació en la qual continuà segurament fins a la seva mort, esdevinguda el 1324 (126). El seu successor, Bartomeu Pedriça, que pertanyia a la cambra de la reina i que fou nomenat el 1325, sembla que tingué el càrrec en les mateixes condicions que ell (127).

Ens manquen les notícies d'aquesta escrivania fins el 1357, en què el rei la donà, juntament amb les de les cúries del justícia i del batlle, al notari alacantí, Miguel Sánchez de Linyán, a precs de l'infant Pere, comte de Ribagorça i Prades, i del seu conseller, Bernat de Cabrera, per tal de premiar els serveis de l'esmentat notari en l'adquisició del lloc, el 1356, durant la guerra amb Castella (128); aquesta concessió fou confirmada el 1366, després que Alacant hagué tornat a mans del rei Pere el Cerimoniós, a finals de l'esmentada guerra, perquè Miquel Sánchez de Linyán s'havia esforçat per fer tornar la 
vila a l'obediència de la Corona (129). Consta que aquest any 1366 cobrà com a salari del seu càrrec d'escrivà i també de guarda de la duana d'Alacant pels mesos que l'exerci, després de la recuperació del lloc, la quantitat de 112 sous, mentre que el 1368 cobrà el salari íntegre de 300 sous (130). El 1369, Miquel Sánchez de Linyán permutà la seva escrivania de la duana amb la batllia d'Alacant, que tenia Joan d'Olit (131).

Sabem, i aquestes son les darreres notícies que en tenim, que el càrrec de guarda del port d'Alacant fou ocupat entre 1377 i 1382 per Garcia de Verdú, que cobrà 300 sous anuals. Suposem que, com en temps de Miquel Sánchez de Linyán, els càrrecs de guarda i d'escrivà de la duana eren una sola cosa (132); el salari, almenys, era el mateix. El 1384 apareix com a guardià del port d'Alacant Pere Gallo, però els anys següents desapareix aquesta partida dels llibres de comptes (133).

Sembla que les altres escrivanies de duanes i ports funcionaren amb un règim semblant, algunes vegades associades, com en els darrers casos citats d'Alacant, amb el càrrec de guarda; així per exemple a Guardamar, on el guarda del port, presumiblement també escrivà, era de 1379 a 1386 un tal Bartomeu Ivanyes, que cobrà un salari de 100 sous anuals (134).

Malgrat que Elx estingué separat del Patrimoni reial durant molt de temps i que precisament la major part dels libres de comptes de la batllia que es conserven coincideixen amb aquestes èpoques i que, per tant, no hi ha comptes relatius a Elx, hem pogut reunir diverses notícies sobre l'escrivania de la duana dels sarraïns d'Elx i la del port del Cap de l'Aljub, on sembla que l'escrivà tenia, com a les anteriors, el caràcter d'assalariat.

Quant a la duana dels sarraïns d'Elx, l'escrivà fou des del 1310 Bernat Saverdú. El 1321 el rei li nomenà un successor, quan encara vivia, en la persona de Gil d'Omest, mestre de l'infant Pere (135), però finalment fou un sarraí d'Elx, Jahie Alunbeni, que ja hi treballava, qui se'n féu càrrec el 1323 amb un salari de 10 diners diaris, idèntic al que hem vist a la mateixa època a laduana d'Alacant, més una taxa que es cobrava pels albarans (136). Alunbeni era, des del 1318 , col.lector dels impostos reials que es cobraven a la duana d'Elx, com ja ho veurem més endavant.

Molt més tard, abans del 1358, quan Elx pertanyia a l'infant Joan, sabem que l'escrivania fou encomanada al jueu d'Elx, Jucef Abentaurell, que, a més, ostentava el càrrec de torsimany o traductor d'Elx i de Crevillent i «testimoni» de la duana d'Elx, càrrec aquest darrer que semblava una mateixa cosa amb el d'escrivà (137). Per l'octubre d'aquest mateix any, després de l'assassinat 
de l'infant a mans de Pere el Cruel de Castella, Pere el Cerimoniós li confirmà aquests càrrecs i el 1360 ho féu la reina Elionor en nom de l'infant Martí, que havia esdevingut senyor d'Elx i de Crevillent (138).

Ben poc temps després, perd, Jucef Abentaurell tingué algunes topades amb els oficials de l'infant a Elx, els quals tot primer l'acusaren de cobrar una comissió de tot el que venia l'aljama sarrainna d'Elx, cosa que no s'havia acostumat mai de fer, i després fou pres perquè, segons ho afirmava el procurador d'Elx, no li havia retut comptes de la seva administració. La reina encomanà a Berenguer Togores que investigués la qüestió de les comissions que cobrava i la informés sobre els càrrecs de testimoni i d'escrivà de la duana, així com del de torsimany, salaris que cobraven els qui els ocupaven, etc.; d'altra banda, quan fou pres, la reina volgué que hom li concedís el benefici de la llibertat sota fiança, com corresponia a fets civils, cosa que Domingo Llull, el procurador de la reina a Elx i a Crevillent, no volia concedir-li, i a més manà a l'alcaid de Crevillent, Berenguer Togores, que procurés que tingués defensor i temps per a preparar la defensa (139).

Un cop solucionades, sembla, aquestes qüestions, sorgí el problema de si el càrrec de testimoni de la duana podia ésser ocupat per un jueu i no havia d'ésser exercit necessàriament per un sarraí. La reina demanà informació a Elx sobre aquesta qüestió (140), però suposem que fou solucionada favorablement per a Jucef Abentaurell, perquè pel novembre del mateix any 1361 la reina li fixà el salari per als seus càrrecs: 300 sous per al d'escrivà i 150 per al de torsimany (141).

Consta que el 1363 la reina envià a Elx Pere Martí per a repassar els comptes del procurador i batlle, Domingo Llull, i els de Jucef Abentaurell, així com dels altres moros $i$ jueus que haguessin exercit càrrecs administratius (142).

A finals de l'any 1367 fou destituilt Jucef Abentaurell i fou nomenat per a ocupar ambdós càrrecs, tant el de testimoni-escrivà de la duana com el de traductor, un altre jueu d'Elx, Abrafim Abenbahe, amb un salari més baix, de 300 sous en total (143). Malgrat això, posà tant d'entusiasme en la seva feina que aconseguí fer augmentar el producte de les rendes d'Elx, que abans disminuïen contínuament; la reina Elionor el recompensà per aquest motiu, el 1372, amb la donació de 400 sous (144). Més endavant, gaudí també de la confiança de l'infant Martí, que el féu domèstic seu i li encomanà altres tasques: el 1375 la col.lecta dels impostos de les moreries d'Elx i de Crevillent i l'administració de les obres que calgués fer a la Calaforra, a l'alcàsser, als molins, banys, presons i duana d'Elx i al castell, a les anomenades «cases de senyorm, molins, banys, taverna i presó de Crevillent (145), el 1378 la re- 
captació del que els jueus i els moros li devien per dret de segell (146) i, el 1384, juntament amb Jaume Juny, batlle d'Elx, la col.lecta de 150 florins que l'aljama de jueus d'Elx li havia de pagar (147).

El 1385, no sabem si perquè les obres que li havien estat encomanades pujaven més que el pressupost de què disposava o bé perquè havia fet algun préstec a l'infant, la cúria d'aquest darrer li devia 5.200 sous que, a partir d'aquest any, Abrahim Abenbahe hauria de recuperar del que rendissin els «esdeveniments» de Crevillent, és a dir, les multes i totes altres penes pecuniàries derivades de l'administració de la justícia (148).

L'infant premià els seus serveis, el 1377, amb un donatiu de 60 florins d'or (149) i el posà sota el seu guiatge especial a ell i la seva família (150). El 1385, potser coincidint amb el final de la seva gestió com a col.lector d'impostos, li féu una remissió de les penes en les quals pogués haver incorregut (151).

Hem parlat de l'escrivania de la duana d'Elx i ens hem desviat una mica del tema per tal de recollir les notícies sobre altres tasques encomanades als qui la regiren. Ara ens ocuparem de l'escrivania del port del Cap de l'Aljub, el port d'Elx. Abans del 25 de febrer de 1317 la tenia un veí d'Elx, Bernat Despuig, que en fou privat en aquesta data a favor d'un altre veí de la vila, anomenat Convent Rayner; el rei Jaume II, però, es repensà després i decidí que, tan aviat com l'últim nomenat hagués tingut el càrrec un any, retornés a Bernat Despuig, que era un home expert. A la darreria de desembre, el càrrec li fou concedit, en efecte, de manera vitalícia, bé que amb l'obligació de mantenir un cavall o rossí alforrat per a la defensa del lloc (152). A la seva mort, el 1319, el succeí en el càrrec amb les mateixes condicions Pere Robert, de la casa del rei (153), que, però, malgrat que el tenia amb caràcter vitalici, hi renuncià el 1320 . Fou nomenat llavors Jaume de Santamaria amb les mateixes condicions (154).

És ben difícil saber si les altres escrivanies de les quals tenim notícies eren regides per assalariats o bé si eren cedides en emfiteusi o arrendament. Ens fa l'efecte que les que anaven lligades a la percepció de determinats impostos solien ésser regides per assalariats, mentre que les d'activitat més pròxima a la funció notarial solien ésser cedides en emfiteusi o arrendament. Creiem, doncs, que, a més de les escrivanies de les duanes ja ressenyades, l'escrivania de la partició de les aigües del rei o del senyor, a Elx, per exemple, devia ésser regida per assalariats. La partició de les aigües era una operació que es feia cada dia i de la qual calia portar un control molt acurat; sabem que en fou escrivà Jaume Vidal, des d'abans del 1307 al 1313 i que, després de la seva mort, ho fou Jaume de Vilanova (155). 
Igualment és probable que fos regida per un assalariat l'escrivania del mercat d'Elx; sabem que, d'abans del 25 de març de 1315, n'era titular un metge jueu d'Elx anomenat Abrahim, que fou substituït en aquesta data per Convent de Convent, un veí d'Elx, potser d'origen italià; el càrrec li durà poc perquè pel setembre fou concedit a un veí de Barcelona, Pere Falet, a qui un any després li fou atorgat amb caràcter vitalici (156). Potser oblidant aquest condicionament, el rei la concedi el 1322 a Esteve d'Ançano, veí d'Elx, també amb caràcter vitalici; no sabem si aquesta qüestió originà cap plet (157).

Les altres escrivanies que foren administrades més aviat com a monopolis, és a dir, cedides a cens o arrendades, tant aquelles de les quals tenim constància com les que suposem que es trobaven en aquest cas, les deixem per a tractar-ne en una altra ocasió.

\section{Col.lectors d'impostos}

També trobem entre els assalariats de la batllia general els col.lectors d'impostos; quan no eren arrendats, la batllia havia de tenir gent que es fes càrrec d'aquesta feina. Així, per exemple, el 1316, Bernat Saverdú era el col.lector del quirat i de l'almoixerifat d'Elx i cobrava també el lloguer de tendes, molins etc. que pertanyien al Ppatrimoni, mentre que Bernat Despuig cobrava els drets del Cap de l'Aljub (158). Recordem que ambdós personatges regentaven al mateix temps les escrivanies de la duana d'Elx i del port del Cap de l'Aljub, respectivament, de manera que llur feina era compensada amb el salari de l'escrivania.

A més, hi havia els col.lectors especialitzats en impostos sarraïns. Per a aquesta tasca calia gent que comprengués l'algaravia, cosa que no era gens freqüent entre els cristians (159); per això els col.lectors eren, generalment, sarraïns o jueus.

Però no ens ocuparem ara en detall d'aquests col.lectors, perquè ens obligaria a comentar els impostos gestionats per la batllia; això ens allargaria massa i desbordaria els límits d'aquest article. Ja els comentarem en una altra ocasió (160). 


\section{NOTES}

1) Sobre aquest tema cf. J. M. del ESTAL, Corpus documental del reino de Murcia bajo la soberanía de Aragón (1296-1304/5). Colección de documentos Medievales Alicantinos 1/1, Alacant, 1985, i M. T. FERRER I MALLOL, Moros i cristians, almogàvers i collerats a la frontera d'Oriola (s. XIV), tesi doctoral inèdita.

2) Cf. la bibliografia de la nota anterior, i, a més, J. TORRES FONTES, La delimitación del Sudeste Peninsular (Torrellas-Elche), 1304 y 1305, Múrcia, 1951.

3) Cf. la bibliografia de la nota 1 i, a més, J. M. del ESTAL, Conquista y anexión de las tierras de Alicante, Elche, Orihuela y Guardamar al reino de Valencia por Jaime II de Aragón (1296-1308), Alacant, 1982.

4) Sobre la batllia general del regne de València cal consultar les obres de L. PILES ROS, Estudio documental sobre el bayle general de Valencia, su autoridad y jurisdicción, València 1970, i M. TINTO SALA, Cartas del Baile General de Valencia, Joan Mercader, al rey Fernando de Antequera, València 1979.

5) ACA, C, reg. 340, ff. 94 r. (1296, maig, 31)

6) ACA, C, reg. 340, ff. 182v. - 183r. (1396, maig, 31).

7) ACA, C, reg. 194, ff. 262v. (1296, agost, 11) i 284v. - 285 r.

8) ACA, C, reg. 194, ff. 229v. i 229 v. -230 r. (1296, agost, 9) i reg. 195 , ff. 85 r.-v. i $87 \mathrm{v}$ - 88r. (1297, octubre, 31).

9) ACA, C, reg. 195, ff. 123v. - 124r. (1298, febrer, 9).

10) El 13 de febrer de 1301, per exemple, el rei li manà que apuntés en aquest llibre el seu ballester Bernat Desbanch, que serviria a la frontera amb un cavall alforrat, i disposava també que li fossin donades heretats en el regne: ACA, C, reg. 199, ff. 46v. (1301, febrer, 13) i 46v. $-47 r$.

11) $A C A, C, c r$. Jaume II, núm. 3.460 (1301, abril, 3).

12) $A C A, C$, reg. 231, ff. 52r. - 53 r. (1303, maig, 1).

13) ACA, C, reg. 231, f. 54r. (1303, maig, 18).

14) ACA, C, reg. 196, ff. 170v. - 171r. (1298, març, 28).

15) ACA, C, reg. 200, f. 21zv. (1303, abril, 18)

16) $\mathrm{ACA}, \mathrm{C}$, reg. 231, f. 53r. (1303, abril, 30).

17) Fou Berenguer Colrat: ACA, C, reg. 231, f. 54v. (1304, febrer, 1).

18) Fou Bernat Rovira: ACA, C, reg. 231, f. 55r.-v. (1304, octubre, 7).

19) ACA, C, reg. 231, f. 56r. (1304, desembre, 3). La concessió hagué d'ésser refeta més tard pequè Ferrer Descortell l'havia perduda: ACA, C, reg. 232, f. 366v. (1311, abril, 7).

20) ACA, C, cr. Jaume II, núm. 2.673

21) $A C A, C$, reg. 231, f. 60r. (1309, gener, 8).

22) ACA, C, reg. 232, f. 365r. (1309, març, 6). 
23) ACA, C, reg. 232, f. 366r. (1310, desembre, 3 i 6).

24) ACA, C, reg. 304, f. 140r. (1306, desembre, 14), f. 140v. (1306, desembre, 14) if. 141r. (1312, abril, 13).

25) ACA, C, cr. Jaume II, núm. 4.185. El lloctinent de procurador, que era Pero López de Rufes, devia ésser a Alacant; hi era almenys el dia 9: cf. ACA, C, cr. Jaume II, núms. 3.545 i 3.546 (1308, juny, 9) i 3.553 (1308, juny, 12).

26) ACA, C, cr. Jaume II, núm. 3.523 (1308, juny, 3) i A. GIMÉNEZ SOLER, La Corona de Aragón y Granada, «Boletín de la Real Academia de Buenas Letras de Barcelona», IV (19071908), p. 364.

27) ACA, C, cr. Jaume II, núm. 3.524 (1308, juny, 4).

28) ACA, C, cr. Jaume II, núm. 3.535 (1308, juny, 6).

29) ACA, C, reg. 164, f. 72r. (1317, novembre, 30); reg. 216, f. 127v. (1319, abril, 3) | reg. 171, f. 169r. (1321, febrer, 24).

30) ACA, C. reg. 203, f. 213 v. (1306, desembre, 14). El seu germà, Bernat, també havia estat agraciat amb un privilegi semblant el 9 d'octubre del mateix any: ibidem, f. $197 \mathrm{v}$.

31) ACA, C, reg. 232, ff. 341r. - 342v. (1316, juny, 22). Al càrrec de batlle general del regne, hi acumulà també el de procurador fiscal: ibídem, ff. 342v. - 343 r. (1316, juliol, 17).

32) ACA, C, reg. 171, f. 169r. (1321, febrer, 24).

33) ACA, C, reg. 340, f. 120v. (1296, juny, 4)

34) ACA, C, reg. 232, f. 368v. (1313, maig, 2) i ACA, C, reg. 232, f. 370v. (1314, febrer, 24).

35) ACA, C, reg. 232, f. 372v. (1314, agost, 1).

36) ACA, C, reg. 198, f. 268r.-v. (1301, febrer, 25).

37) ACA, RP, MR, reg. 1701, vers de la fulla de guarda.

38) ACA, C, reg. 232, f. 375r. (1316, maig, 21) i ibidem (1316, agost, 14).

39) ACA, C, reg. 232, f. 379r. (1317, desembre, 10)

40) ACA, C, reg. 244, ff. 205r. - 206r. (1317, desembre, 10).

41) $A C A, R P, M R$, reg. 1701 , vers de la fulla de guarda i ff. 26 r. i 32 r.

42) ACA, C, reg. 215, f. 255r. (1318, març, 12).

43) $A C A, C$, reg. 172, f. 73v. (1321, octubre, 24).

44) ACA, C, reg. 215, f. 255r.-v. (1318, març, 10).

45) Havia substituït $A$. d'Antist: ACA, $C$, reg. 232, f. 337v. (1315, març, 6).

46) ACA, C, reg. 232, f. 379r.-v. (1317, desembre, 10) i ACA, C, reg. 504, f. 75r.-v. (1327, novembre, 25).

47) ACA, C, reg. 232, f. 379r. (1317, desembre, 10).

48) ACA, C, reg. 164, f. 151r.-v. (1318, gener, 1).

49) ACA, C, reg. 232, f. 385v. (1320, gener, 27).

50) ACA, RP, MR, reg. 1.702, f. 8 r.

51) ACA, C, reg. 504, f, 87r.-v. (1328, març, 24).

52) ACA, C, reg. 232, f. 380v. (1318, febrer, 7)

53) ACA, C, cr. Jaume II, núm. 6.439 (1320, juny, 18) i núm. 6.785 (1321, juliol, 14), pub!. per. A. GIMÉNEZ SOLER, La Corona de Aragón y Granada, «BRABLB», 4, p. 83.

54) ACA, C, cr. Alfons III, núm. 201 (1328, març, 29).

55) ACA, C, reg. 504, f. 102r. (1329, febrer, 14).

56) ACA, C, cr. Alfons III, núm. 109. (1328, febrer, 20).

57) ACA, C, reg, 480, ff. 13r. - 22r. (1329, desembre, 28), publ, per E. ABAD NAVARRO, El castillo de la Mola en la ciudad de Novelda. Trabajo histórico y arqueológico, Múrcia, 1928, doc. 16.

58) $A C A, R P, M R$, reg. 1.721, f. $1 \mathrm{r}$.

59) ACA, C, reg. 1.200 , f. $580 \mathrm{v}$. (1364, juny, 18).

60) ACA, C, reg. 1.198, f. 253v. (1364, juliol, 5).

61) ACA, RP, MR, reg. 1.711, f. $27 \mathrm{r}$.

62) ACA, C, reg. 1.078, ff. 79v. - 80v. (1366, juny, 15).

63) ACA, C, reg. 971, ff. 161v. - 162v. (1366, juny, 16). 
64) ACA, C, reg. 971, f. 166r.-v. (1366, setembre, 15).

65) ACA, C, reg. 1.222, f. 126r. (1368, desembre, 28).

66) ACA, C, reg. 1.081, f. 72v. - 73r. (1369, juliol, 12).

67) ACA, RP, MR, reg. $1.722, f .21 r$.

68) ACA, C, reg. 1.090 , f. 8r.-v. (1373, novembre, 8).

69) ACA, C, reg. 914, f. 79v. (1367, juliol, 25) i reg. 737, f. 59r.-v. (1367, juliol, 25).

70) ACA, C, reg. 1.217, f. 215r. (1367, agost, 7).

71) ACA, C, reg. 972, ff. 66v. - 77r.-v. (1369, setembre, 14) Més tard, pero, Miquel Sánchez de Linyán es queixà al rei perquè Joan d'Olit, com a batlle general, havia posat un lloctinent seu a Alacant, que retallava les competències d'aquell darrer i, per tant, resultava perjudicat en la permuta. El rei decidi que M. Sánchez de Linyán havia de tenir el càrrec de batlle exactament amb les mateixes condicions que el tenia Joan d'Olit: reg. 1.232, f. 20r.-v.

72) ACA, RP, MR, reg. 1.722, f. 3r.

74) Figurava com a tal el 19 d'abril de 1371: ACA, C, reg. 1.350, ff. 79v. - 80r. Cf. també RP, MR, reg. 1.723, f. 1 r. -v.

75) ACA, RP, MR, reg. 1.722, f. $127 \mathrm{~V}$.

76) ACA, C, reg. 1.267, f. 133v. (1380, juny, 25).

77) ACA, C, reg. 1.280, f. 1r.-v. (1382, setembre, 10) D'aquesta quantitat en cobrà 3.377 sous, 1 diner el mateix any 1382; sembla que la resta ja l'havia cobrada abans: ACA, RP, MR, reg. 1.722 , f. $183 \mathrm{v}$.

78) ACA, C, reg. 1.000, f. 166r.-v. (1381, maig, 15).

79) ACA, RP, MR, reg. 1.722 , f. $127 \mathrm{~V}$.

80) ACA; C, reg. 1.267, f. 85r. (1380, abril, 25) i RP, MR, reg. 1.722, f. 164r.

81) ACA, RP, MR, reg. 1.722, f. 3r. i reg. 1.723, f. tr.v.

82) ACA, RP, MR, reg. 1.723 i reg. 653, ff. 161r. - 162v. i $162 \mathrm{v} .-163 \mathrm{r}$.

83) ACA, C, reg. 1.920, f. 7v. (1387, gener, 15). El rei el recomanà al batlle general del regne de València i als altres oficials reials: ACA, $C$, reg. 1.920, ff. 72v. - 73r. (1387, juny, 26).

84) ACA, C, reg. 1.920, f. 139v. (1388, desembre, 9).

85) ACA, C, reg. 1.920 , f. 192r. (1389, febrer, 3).

86) ACA, C, reg. 2.223, f. 10v. (1397, juliol, 6).

87) ACA, C, reg. 2.223, f. 45v. (1399, abril, 1).

88) ACA, C, reg. 1.105, f. 95r. (1384, març, 4).

89) ACA, C, reg. 1.920 , f. 149r. (1389, novembre, 2).

90) ACA, C, reg. 1.885, f. 174r. (1394, abril, 2).

91) ACA, C, reg. 1.983, f. 118v. - 119r. i 121 r.-v. (1394, juny, 1).

92) ACA, C, reg. 2.223, f. 12v. (1397, juny, 28).

93) Cf. per exemple sobre aquesta qüestió: ACA, C, reg. 2.111, ff. 62r.-v. (1397, juliol, 30) i 65 r. i reg. 2.119, ff. 28r.-v. (1398, octubre, 1), 97r.-v. i 97v. - 98r. (1399, febrer, 17 i 18), reg. 2.121, f. $105 \mathrm{r}$. -v. (1399, febrer, 17) i reg. 2.118, f. 141v. (1399, abril, 22). L'afer encara durava el 1406: reg. 2.152 , ff. 39r, - 40r. (1406, juny, 23).

94) ACA, C, reg. 219, f. 178v. (1320, desembre, 16).

95) ACA, C, reg. 172, f. 209r. (1321, desembre, 23). Cf. aquests privilegis relatius al cors concedits pels reis de Castella a Fueros y Privilegios de Alfonso X el Sabio al Reino de Murcia, ed. per J. TORRES FONTES, Múrcia, 1973 («Colección de documentos para la Historia del Reino de Murcian, III), doc. 14.

96) M. T. FERRER I MALLOL, La pace del 1390 tra la Corona d'Aragona e la Repubblica di Genova, "Miscellanea di Storia Ligure in memoria di Giorgio Falco", Genova 1966, p. 163.

97) ACA, C, reg. 2.223, ff. 44v. - 45r. (1399, maig, 20).

98) ACA, C, reg. 2.223, ff. 47v. - 48v. (1399, juliol, 12).

99) Sobre les llicències per a armar en cors cf. les notes $92,93,94$ i 95 . Sobre llicències d'emigració cf. ACA, C, reg. 1.080, ff. 181v. - 182r. (1369, febrer, 13) i reg. 1.090, f. 8r.-v. (1373, novembre, 8 ) 
100) ACA, C, reg. 1.056, f. 131r.-v. i f. 132v. (1340, juliol, 15) i M. T. FERRER i MALLOL, Els sarraïns de la Corona catalano-aragonesa en el segle XIV. Segregació i limitació de llibertats, en curs de publicació, docs. 79 i 132.

101) ACA, C, reg. 2.223, f. 87r.-v. (1403, desembre, 24).

102) ACA, C, reg. 2.239, f. 76r.-v. (1397, novembre, 3).

103) ACA, C, reg. 2.223, f. 166v. - 167r.-v. (1410, gener, 30).

104) P. BELLOT, Anales de Orihuela (siglos XIV-XVI), estudio, edición y notas de J. TORRES FONTES, Oriola, 1954-1956, I, p. 240

105) ACA, RP, MR, reg. 1.701, f. $34 \mathrm{r}$.

106) ACA, RP, MR, reg. 1.722 , ff. 130v. - 131r. i 162r.

107) Pere el Cerimoniós, assabentat que tenia un rossí molt bo, li demanà que el vengués a un preu convenient al batlle del regne de València, Pere Mir, que el compraria per a ell: ACA, C. reg. 1289 , f. 158 r. (1385, abril, 20).

108) Cf. nota 104.

109) ACA, RP, MR, reg. 1.701 , f. $33 \mathrm{v}$.

110) Cf. abans, nota 38 .

111) ACA, C, reg. 232, f. 384r. i cr. Jaume II, núm. 6049 (1318, desembre, 17).

112) ACA, RP, MR, reg. 1.702 , f. 8 r.

113) ACA, RP, $M R$, reg. 1.721 , f. $23 \mathrm{v}$.

114) ACA, RP, MR, reg. 1.711, f. $28 \mathrm{v}$.

115) ACA, RP, MR, reg. 1.712, f. 30r.; reg. 1.722, ff. 127v. i 198 r. i reg. 1.723 , ff. 26v., 31v., 40v. i 46v.

116) ACA, RP, MR, reg. 1.701, ff. 10r, i 20 r.

117) ACA, C, reg. 233, f. 123v. (1321, gener, 24) 133 v. - 134r. (1325, abril, 27), Cf. també RP, MR, reg. $1.702, \mathrm{f} .1 \mathrm{r}$.

118) ACA, C, reg. 504, f. 114r.-v. (1329, juny, 29).

119) ACA, RP, MR, reg. 1.721, f. 24r.

120) ACA, RP, MR, reg. 1.711 , ff. 28v. i $29 r$.

121) ACA, RP, MR, reg. 1.712, f. 30r.

122) ACA, RP, MR, reg. 1.722, f. 128v., 140v. i reg. 1.723, ff. 29r.-v. i 35v.

123) ACA, C, reg. 1.279 , ff. 167v. - 168r. (1382, octubre, 19).

124) ACA, C, reg. 340, f. 200r. (1296, juliol, 5).

125) ACA, C, reg. 232, f. 373r. (1314, setembre, 28).

126) ACA, RP, MR, reg. 1.701, ff. 9r. i 19v. i reg. 1.702, f. $7 \mathrm{v}$.

127) ACA, C, reg. 233, f. 133r. (1325, març, 9)

128) ACA, C, reg. 966, f. 99r.-v. (1357, març, 25).

129) ACA, C, reg. 910, ff. 122v. - 123r. (1366, setembre, 22).

130) ACA, RP, MR, reg. 1.711 , ff. $28 \mathrm{r}$., reg. 1.712, f. $29 \mathrm{v}$.

131) Cf. abans nota 70.

132) ACA, RP, MR, reg. 1.722, ff. 132r., 145r., 153v., 183r. i reg. 1.723, ff. 27r. i 33v.

133) ACA, RP, MR, reg. 1.723 , f. $28 \mathrm{v}$ $42 v$.

134) ACA, RP, MR, reg. 1.722, ff. 128r., 140r., 152v., 181r., 198r. i reg. 1.723, f. 27r., 33v.,

135) ACA, C, reg. 232, f. 365v. (1310, octubre, 19), 370r. (1314, gener, 16), f. 382r. (1318, març, 14), reg. 233, f. 124v. (1321, febrer, 15).

136) ACA, C, reg. 233, f. 128v. (1323, juliol, 1).

137) ACA, C, reg. 1.547, f. 20v. - 21r. (1358, octubre, 28).

138) ACA, C, reg. 1.569, f. 36r.-v. (1360, gener, 10).

139) ACA, C, reg. 1.569, f. 74 r. (1360, novembre, 12), publ. per J. BOSWELL, The Royal treasure, pp. 502-503 (aquest autor, però, llegeix Abencavarell on nosaltres llegim Abentaurell). Cf. també al mateix registre, f. 80r. (1361, febrer, 20) i f. 80r.-v. (1361, febrer, 13).

140) ACA, C, reg. 1.569 , f. 93r. (1361, maig, 22). 
141) ACA, C, reg. 1.569, f. 121r. (1361, setembre, 24).

142) ACA, C, reg. 1.572, f. 26r.-v. (1363, novembre, 13).

143) ACA, C, reg. 1.572, f. 73r. (1367, desembre, 1).

144) ACA, C, reg. 1.578 , f. 128r. (1372, juliol, 10)

145) ACA, C, reg. 2.064, ff. 195r. - 196r. (1375, desembre, 10)

146) ACA, C, reg. 2.067, f. 127v. (1378, octubre, 24)

147) ACA, C, reg. 2.072, f. 110r. (1384, febrer, 8)

148) ACA, C, reg. 2.074 , f. 63r. (1385, novembre, 20) i 63v. i $64 \mathrm{r}$.

149) ACA, C, reg. 2.066, f. 177v. (1377, novembre, 5).

150) ACA, C, reg. 2.067, ff. 120v. - 121r. (1378, octubre, 22).

151) ACA, C, reg. 2.087, f. 144r.-v. (1385, novembre, 22)

152) ACA, C, reg. 232, f. 377r.-v. (1317, febrer, 25), f. 377v. (1317, març, 8) i ff. $378 \mathrm{v}$. 379r. (1317, desembre, 11).

153) ACA, C, reg. 232, f. 384r. (1319, març, 7).

154) ACA, C, reg. 232, f. 386v. (1320, maig, 23).

155) ACA, C, reg. 231, f. 58r. (1307, febrer, 8) i reg. 232, ff. 369v. - 370r. (1313, juliol, 13).

156) ACA, C, reg. 232, f. 373v. (1315, març, 26), f. 374r. (1315, setembre, 23) i 376v. (1316, setembre, 25).

157) ACA, C, reg. 233, f. 127v. (1322, novembre, 4).

158) ACA, RP, MR, reg. 1.701 , f. 1r.-v.

159) D. ROMANO, Judíos escribanos y trujamanes de árabe en la Corona de Aragón (reinados de Jaime I a Jaime (1), "Sefarad", XXXVIII (1978), p. 72.

160) Els impostos pagats pels sarrains, d'altra banda, els tractem a l'estudi Les aljames serraïnes de la governació d'Oriolà, en curs de publicació. 



\title{
UNA ECONOMÍA TENTACULAR. LA RELACIÓN ECONÓMICA MURCIA-ORIHUELA EN LOS FINALES DEL SIGLO XIV
}

\author{
M. a DE LOS LLANOS MARTÍNEZ CARRILLO \\ Universidad de Murcia
}

La muerte de Pedro I en Montiel en 1369 después de muchos años de guerra civil en Castilla, y muchos más de graves alteraciones del sistema económico social de occidente del que aquella participó, dio paso a una nueva dinastía caracterizada en sus primeros eslabones por los intentos de reconstrucción proyectados para Castilla y solamente en parte realizados; la economía fue un pilar fundamental de esa política de los nuevos reyes Trastámaras, como lo habia sido en las destructivas etapas anteriores, porque el cambio dinástico se iniciaba sobre unas bases agostadas por la doble acción de una profunda crisis económica y las consecuencias internacionales de la guerra civil, según las cuales el nuevo rey, Enrique II, se vio en la necesidad de tener que saldar las fuertes deudas contraidas con los contingentes militares extranjeros, que le habian ayudado a alcanzar el trono de la forma más rápida y expeditiva posible.

La crónica es sumamente gráfica: «el rey don Enrique, estando en Toledo, ovo su consejo, que por quanto avia de facer grandes pagas a mosen Beltran, é a los estrangeros que con él vinieron, é otro si á los suyos, que non lo podia complir, por grandes pechos que en el Regno echase; de más que su voluntad era de guardar e non enojar á muchas comarcas del Regno que tovieron su voz. E por todo esto, acordo de mandar labrar moneda...» (1)

Para el nuevo rey castellano, la imposibilidad de derramar los impuestos necesarios para saldar la totalidad de las deudas, sin poner a prueba las deterioradas bases sociales del reino, lo obligó a encadenar una serie de acuñaciones monetarias claramente devaluatorias (2), que le permitiesen pagar sin agotar más, si ello era posible, una economía casi paralizada. 
El cronista localiza en Toledo la inicial toma de decisiones por parte de Enrique II para organizar la acuñación de nuevas monedas con las que poder saldar cuentas con los extranjeros y hacerles salir del reino inmediatamente, una vez culminada su ayuda militar, pero la documentación existente permite retrotraerlas a su previa estancia en Sevilla, cuando se dio cuenta de que el petrismo era una fuerza y un sentimiento no extinguidos, a los que una torpe política económica de derramas fiscales podría proporcionar nuevos impulsos; no había más salida que reorganizar el sistema monetario y fue en mayo de 1369 en Sevilla, donde el rey arrendaba las casas de moneda y organizaba las nuevas acuñaciones (3).

Las casas de la moneda afectadas por el arrendamiento eran las de Sevilla, Córdoba y Murcia (4), aunque en el caso de esta última al rey se le presentaba un importante problema de seguridad; si bien el 24 de marzo, inmediatamente después de la muerte de Pedro I, comunicaba al concejo murciano el nombramiento de Juan Sánchez Manuel, conde de Carrión, como nuevo adelantado mayor del reino de Murcia (5), la inestabilidad en este territorio de la Corona era muy fuerte por la ayuda y cobijo que los petristas recibian en el muy próximo territorio de la gobernación de Orihuela y en general en toda la Corona Catalano-Aragonesa, desde donde continuaron operando algún tiempo de tal manera que, en la mente de Enrique II, Murcia no estaba firmemente asegurada y el funcionamiento de su ceca se presentaba problemático.

A las dificultades encontradas para la reconstrucción, generales a toda Castilla, en el reino murciano había que contar además con la política, anexionista unas veces y perturbadora otras, que practicaba respecto al mismo Pedro IV de Aragón, quien siempre aprovechó la ayuda prestada a Enrique de Tratámara para intentar recobrar en pago de ella el reino de Murcia (6); la frustración de estas pretensiones fue un factor más a tener en cuenta en el endurecimiento económico desarrollado a lo largo del reinado de Enrique II, convirtiendo lo que tradicionalmente fue un proteccionismo mercantil en la primera mitad del siglo XIV, en una casi completa autarquía a nivel murciano.

La misma proximidad a la frontera aragonesa había convertido a Murcia en plaza aduanera permanente en la administración castellana desde el siglo XIII, juntamente con Cartagena en la costa, y a partir de la entronización de Enrique $\|$ en ella se acusó el refuerzo de las prohibiciones que tradicionalmente pesaron sobre la exportación de caballos, cualquier tipo de ganados de tiro $o$ arada, armas, cereales y monedas, cuya salida a territorio aragonés había sido muy frecuente durante la guerra y continuaría siéndolo de forma clandestina en los años siguientes (7), a pesar de la tajante prohibición de que 
fue objeto. El enrarecimiento de la frontera fue tan radical a partir de 1370 que el oriolano Francés Dexines tuvo que pedir un seguro especial al concejo murciano, para poder venir a vender en Murcia paños y vidrios y tener «casa cierta» en la ciudad (8) y solamente se le concedió cuando el adelantado mayor hubo dado su aprobación para ello.

Este cúmulo de circunstancias generales y regionales dieron lugar a un global empobrecimiento del comercio murciano, al que contribuyó en buena medida el rechazo de que era objeto entre la población la moneda devaluada que se estaba acuñando y la entrada cada vez más intensa de moneda falsa castellana acuñada en Aragón.

\section{INCIDENCIA DE LAS DEVALUACIONES}

En 1371, al año de que las cortes de Medina del Campo de 1370 fijaran el valor de las monedas un tercio por debajo del que habian tenido anteriormente, la nueva moneda apenas tenía circulación en Murcia, pues «...las gentes desta çibdad que desechaban mucha de la moneda de los reales asy de los que eran buenos como de los otros y por esto era encareçido el pan y el vino $y$ todas las otras cosas que las gentes avian menester para su provisyon...» (9); la introducción de veedores de las monedas ordenada en las cortes de Toro de 1371 y la decisión de taladrar todos los reales que tuviesen un valor superior al establecido, fueron medidas tendentes a regular el caos monetario que en la economía regional se estaba sintiendo, y sus consecuencias inmediatas de elevación de precios en un medio social políticamente no fortalecido.

Los arrendadores de rentas reales fueron un elemento básico en el funcionamiento del sistema monetario, al exigir con contundencia que los cobros se hiciesen en cruzados y no admitir los valores del real ordenados en 1370 , buscando con ello el no verse afectados por las falsificaciones aragonesas de reales que inundaban los mercados del reino. Igualmente la Iglesia rechazaba con rigor cobrar sus censos en la moneda de plata devaluada, obligando a los censatarios a «...que les den dinero en oro...» (10), mucho más seguro en su valor.

La presencia del adelantado mayor Juan Sánchez Manuel fue fundamental en la marcha de la economía del reino en estos años, sobre todo a partir de la fijación de valores efectuada en las cortes de Toro de 1373 que elevaba al valor de las monedas, una vez saldadas las deudas internacionales que habian dado origen a las devaluaciones anteriores. Las rentas que cobraba de sus tierras y oficios se estaban viendo afectadas por el proceso inflaccionista, y la falta de productividad general y el empobrecimiento le salpicaban 
de lleno; su actuación económica compensatoria de este hecho fue muy intensa y se manifiesta claramente a través de la obtención de su despensero mayor, el judío Moisés Aventuriel, del arrendamiento de los almojarifazgos del reino entre 1371 y 1374 sin que se pueda delimitar textualmente sí el judío actuaba por sí mismo o como hilo conductor de los intereses del adelantado mayor, pero el estar encargado de la recaudación el también canciller del conde Juan Martínez y los problemas que encontró en la ciudad para cobrar los derechos correspondientes (11), permiten deducir que era el conde de Carrión el vértice superior del arrendamiento, y que en él confluían todos los derechos paramercantiles del almojarifazgo.

Ésta y otras intervenciones económicas del conde de Carrión produjeron su inmediato rechazo por parte de los murcianos (12) a partir de la entrada en vigor de los nuevos y más altos valores monetarios de 1373, como consecuencia de una fuerte desconfianza hacia su persona despertada por las oportunistas maniobras económicas del conde, y ahondada por la lejanía murciana respecto a los centros neurálgicos de la economia castellana; todo ello junto a la pobreza general del territorio, si se excluye el área regada por el Segura, explica el que la economía tuviese en aquellos años en el reino de Murcia unas característcas puramente tentaculares respecto a la general de la corona de Castilla.

La moneda de 1373, la «moneda nueva», de valor reforzado respecto a la devaluadisima de las primeras acuñaciones enriqueñas, la «moneda vieja», como empezaron a ser diferenciadas unas y otras, no tuvo tampoco una implantación drástica y clara en la economía del reino, por lo que la utilización de unas y otras de forma simultánea contribuye aún más a complicar el análisis de las tendencias económicas de aquellos años.

\section{MONEDA FALSA Y MONEDA NO CASTELLANA}

Junto a la moneda real tan duramente afectada por la política de intereses dinásticos de Enrique II, en Murcia se apreció desde los comienzos del reinado un uso creciente de moneda falsa, lo cual fue un fenómeno general al siglo XIV derivado del impacto que estaba produciendo el desmesurado uso de monedas en economías de muy bajo nivel de producción; en 1371 su circulación era tan abundante y perturbadora, que el concejo murciano ordenaba su embargo al «alcalde de las monedas» y a un notario auxiliar, para proceder judicialmente contra los culpables de introducirlas o utilizarlas deliberadamente en cualquier tipo de operación económica.

El paso siguiente que se dio para tratar de depurar el sistema monetario, fue el nombramiento de dos «veedores de la moneda», Francisco Solsona y 
Pedro Fernández, para que recogiesen toda la que entraba fraudulentamente en el reino, contabilizándola y poniéndola «en buena arca» para que pudiesen ser descubiertos y apresados todos los que introdujesen reales, cruzados o cualquier otra moneda falsa procedente de Aragón, sin que pudiesen ser liberados hasta que el rey proveyese en consecuencia.

Eran sobre todo reales falsos las piezas que entraban de Aragón y «...de los otros que son buenos dudan mucho las gentes de tomar la moneda buena por la mala e por esto eran encareçidas las viandas y todas las otras cosas que los omes an mester para su mantenimiento y espeçialmente pan..." (14), por to que de la agudización de la crisis monetaria desatada por las devaluaciones y la abundancia de falsificaciones se derivaba un peligro despoblador del reino, siempre temido y nunca totalmente superado en Murcia; no hay en este caso exageración documental, al valorar la carestía existente en el pan y su escasez en la ciudad, a la que contribuía en gran medida la complejidad monetaria existente y su constante enrarecimiento.

El concejo murciano recurrió al rey buscando soluciones al problema de las falsificaciones que inundaban el mercado local procedentes de Aragón, reales, cruzados y coronados, sin que Enrique II pudiese hacer más que reiterar las medidas adoptadas apenas un mes antes, según las cuales se retirarían antes del 1 de enero de 1374 todas las oportunistas acuñaciones emitidas después de la guerra civil, dejando consecuentemente a los emisores de falsificaciones fuera de juego; los reales, cruzados y coronados asi retirados se refundirian con los valores de la moneda que circulaba antes de 1369, doblas de oro, reales de plata, coronados, sueldos, novenes y cinquenes (15).

Las falsificaciones efectuadas en Aragón recibian asi un fuerte golpe, a pesar de que contaban con todo el apoyo de Pedro IV tanto en su acuñación como en su circulación; el monarca aragonés les había utilizado muy hábilmente como peligrosa arma económica contra Castilla, donde producian inflacción y encarecimiento en el mercado que a su vez actuaban como fermentos de inestabilidad social, aparte de los beneficios intrínsecos que sus emisiones reportaban a la corona, calculados por Gil Farrés en más de 10.000 florines anuales (16), solamente con las acuñaciones falsas que salían de las cecas reales.

Pero no eran solamente las falsas monedas castellanas el único factor de perturbación económica procedente de Aragón que actuaba en la economía del reino murciano; es preciso tener en cuenta igualmente la fluidez con que la moneda aragonesa habia circulado siempre en territorio murciano, prociada sin duda por la complementariedad de intereses existentes con la veci- 
na ciudad de Orihuela y toda la cuenca baja del Segura, así como la marginalidad del reino Murciano respecto a los demás territorios de la Corona de Castilla.

Fue sobre todo en el reinado de Juan I, cuando la moneda aragonesa circuló en territorio murciano como moneda de uso ordinario que suplantaba a la castellana en infinidad de ocasiones; los testimonios de los arrendadores y recaudadores de rentas exigiendo moneda castellana en los cobros de las mismas, son elocuentes de la amplitud del fenómeno, que desde que en 1373 Enrique II habia mandado retirar todas sus acuñaciones anteriores fijando definitivamente el valor del monedaje castellano, había ido en aumento: «...en esta dicha çibdat non ha nin viene otra moneda castellana salvo esta moneda de realejos de Aragón...», se decía en 1380 (17) ante una negativa de los recaudadores a admitirla.

Cabe plantearse si la intensidad del comercio con Aragón que facilitaba la entrada de esta moneda era de más valor y fluidez que la correspondiente al mantenido con los territorios castellanos del interior, si los factores de proximidad y homogeneidad geográficos pesaban más que el marco políticoinstitucional en el que el reino de Murcia estaba encuadrado y del que no recibía suficiente moneda cuando no era acuñada en la propia ciudad, tal como ocurría desde las últimas acuñaciones de Enrique II. La precariedad monetaria murciana era tal en los comienzos del reinado de Juan I, que el rey autorizó la recaudación de una derrama de monedas, en «...reales de Aragon que andan en el presçio y numero de los cornados castellanos...» a petición del concejo murciano (18), para que la escasez monetaria y las dificultades de pago de los murcianos derivadas en parte de ella, no contribuyesen a agravar las consecuencias sociales de la gran presión fiscal que pesaba sobre el reino.

A pesar de la autorización real, la resistencia de los recaudadores a admitir los reales aragoneses fue constante porque no era moneda tan usada en ningún otro territorio castellano, «...salvo a menos presçio de lo que alla vale...» (19); moneda infravalorada en toda Castilla respecto a Murcia como consecuencia de la crónica desmonetarización sufrida en esta ciudad, que era una de las razones de las constantes dificultades fiscales que Murcia y su reino vivieron; de ahi también la frecuencia con que el concejo buscaba créditos fuera del reino, tratando de encontrar los intereses más bajos posibles en Orihuela o en la propia Valencia (20).

El caso del florín no es comparable al de los «realejos» aragoneses; a pesar de su pérdida de valor desde las primeras acuñaciones ordenadas en 1346 
por Pedro IV, y de que sus falsificaciones también fueron frecuentes y no fáciles de detectar entonces y ahora (21), su utilización como moneda fuerte apreciada fue constante en el reino murciano, incluidas sus fracciones como el "seixmo" (22), que permitían en la cuantificación una más fácil acomodación a los valores pequeños que caracterizaban el mercado de productos, trabajo e impuestos en el que se movía la sociedad murciana.

Relacionado con el uso tan continuado que se hacía de la moneda aragonesa en el reino murciano estaba la fáctica supervaloración de las monedas de oro y plata castellanas, de circulación más restringida de lo normal en Murcia, en comparación a lo que valían en el resto de los territorios de la Corona Castellana (23):

Valores monetarios en maravedis correspondientes a 1384

\begin{tabular}{|c|c|c|c|}
\hline & $\begin{array}{c}\text { dobla } \\
\text { Castellana } \\
\end{array}$ & $\begin{array}{c}\text { dobla } \\
\text { morisca }\end{array}$ & $\begin{array}{c}\begin{array}{c}\text { florín } \\
\text { aragonés }\end{array} \\
\end{array}$ \\
\hline Murcia & 38 & 36 & 22 \\
\hline Resto de Castilla & 37 & 35 & 21 \\
\hline
\end{tabular}

De que las recaudaciones de impuestos se hiciesen utilizando los valores bajos, como pedían los recaudadores, que intentaba hacer buenos el concejo murciano, dependía una mayor o menor dificultad en las recaudaciones que el vecindario acusaba.

El alza de los valores en el mercado local fue una constante no enturbiada por las características hiperbólicas de la documentación; de los 21 maravedís que valía el florín de oro aragonés en los comienzos del reinado de Juan I se fue ascendiendo progresivamente, a tenor del mayor endeudamiento social y concejil, porque a mayores necesidades mayores exigencias de los prestamistas que acababan convirtiendo los valores extraordinarios del florín en otros puramente ordinarios: en 1387 el florín aragonés rebasaba los 22 maravedís, aún con sintomas evidentes de que muchos de ellos habian disminuido de peso y valor real, «...menguados et cerçenados en derredor..." (24).

La acentuación de la escasez y revaluación de las monedas fuertes de oro y plata y la depreciación del vellón fueron consecuencias de la guerra de Portugal y su gran coste económico, recrudeciéndose la crisis en los años ochenta lo que propició una nueva entrada de falsificaciones procedentes de Aragón en territorio murciano. Reactividas las falsificaciones al compás de las primeras acuñaciones de Juan I, realizadas en 1382 en Burgos y Sevilla (25), en mómentos en los que la devaluación daba lugar a un tirón ascendente de los precios, afectaron también al florín en su doble forma de falsificación total 
o alteración fraudulenta de peso y ley, precediendo el nombramiento concejil de Francisco Mallol como veedor a la orden real de que se investigase quienes eran los autores, si no materiales sí cómplices de la falsificación, para interceptar la difusión de esta moneda falsa, entre ella los florines aragoneses «...mucho faltos e menguados de peso...» (26).

En las cortes celebradas en Briviesca en 1387 se intentó poner un orden práctico en el desequilibrio económico monetario que la guerra de Portugal y sus compromisos posteriores acentuaron y agravaron; la devaluación de las blancas de 10 dineros que valían anteriormente a 6 "dineros llanos» (27), fue la medida económica más política de todas las adoptadas, al permitir automáticamente una bajada de precios y salarios.

\section{CONTROL ECONÓMICO DE LA FRONTERA}

Durante la guerra civil y los años inmediatamente posteriores, el comercio de Aragón se había estado efectuando de forma clandestina y sin ningún tipo de contrapartida fiscal para la Corona Castellana, de tal modo que en 1373 y 1375 Enrique II ordenó la realización de dos investigaciones en la ciudad para averiguar quienes y cuántos habian sido los exportadores y repartir entre ellos dos cantidades complementarias en concepto de multas y derechos no pagados (28).

Los aproximados 400 y 1.800 maravedía que se pagaron respectivamente en ambas ocasiones no fueron sólo la multa impuesta por unas obligaciones no cumplidas con la administración de aduanas, sino que tuvieron más bien el carácter de un ensayo de reparto fiscal que intentaba regularizar y hacer ordinario el cobro de un impuesto sobre el comercio de exportación (29); si el sistema fracasó fue por su complejidad y las dificultades sociales que entrañaba al realizarse a través de unas enojosas pesquisas, individuo por individuo, símbolo de las cuales y del peligro social que encerraron fue la quema en el concejo de los testimonios escritos y toda la documentación complementaria de los dos padrones elaborados «... por que non pareciese dello cosa alguna por que escandalo nin peleas non acaesçiesen entre las gentes por esta rason.... (30). Los fraudes y ocultaciones que se hicieron por muchos afectados en la primera investigación forzaron a Enrique II a ordenar la segunda, a ampliar la cantidad a pagar que debía resultar ridícula dada la magnitud de lo exportado de forma clandestina.

Estos intentos de regulación fiscal de las aduanas del reino, con referencia a los cinco años transcurridos desde el final de la guerra civil, se producian en momentos en los que la política aduanera frente a Aragón se endure- 
cía en el marco de las consecuencias de la guerra castellano aragonesa, que había llevado a los murcianos a tomar el castillo de Crevillente mientras las propiedades de sus vecinos en Orihuela, Elche y Alicante eran embargadas (31). La guerra había empezado en marzo de 1375, pero desde septiembre del año anterior había sido perceptible en Murcia una corriente de avecindamiento en la ciudad de individuos procedentes de territorio valenciano, la mayoría de Orihuela; algunos vivian ya en Murcia algún tiempo como simples «moradores» dedicados a actividades mercantiles y si decidieron solicitar la vecindad en los momentos en que la tensión bélica amenazaba con romper la actividad económica de la que vivían, fue porque la misma se centraba más en Murcia que en sus tierras de origen, admitiéndoseles sin dificultades porque la presentación de fiadores y el capital que aportaban garantizaban que no serían gravosos con su estabilidad en Murcia.

Algunos como Bartolomé de Ávila que se avecindó procedente de Orihuela con un capital de 500 maravedís (32), habian sido en aquella ciudad vecinos de ocasión mientras sus actividades así lo requirieron, por el contrario Joaquín Cardona y su hijo que aportaban otros 500 maravedís, Miguel Sánchez (33), Antón Tomás, Juan Martínez y Elisey de Moncada, mujer de Alonso Jiménez de Mendieta, procedían originariamente de tierras catalanoaragonesas, que algunos dejaban con muchas dificultades, como Antón Tomás y sus hermanos que teniendo ya fiadores en Murcia, no recibieron permiso de Orihuela para dejar la ciudad hasta no quedar libres de compromisos en ella.

En los momentos de iniciarse la guerra con Aragón se añadieron a los anteriores un mínimo de 10 nuevos vecinos que presentaban capitales mínimos de hasta 50 maravedís, entre los que se contaban individuos que en los años anteriores ya habian desempeñado actividades económicas en Murcia y que en adelante las seguirian desempeñando más intensamente como vecinos, tal fue el caso de Huguet de Soteros, Esteban de Pamiés y Jaime Terrés, cuyos negocios en el comercio de carnes y tintes en los años ochenta y noventa fueron muy continuos.

En estas condiciones, se llegó por parte castellana a la expulsión de los ganados aragoneses que pastaban en territorio murciano, decretada por Enrique II, porque además de explotar los pastizales eran utilizados para sacar cereales y otros ganados castellanos mezclados con ellos (34), paliando así el hambre padecida por entonces en Aragón y Valencia; era ésta una modalidad de comercio clandestino que sangraba la economía castellana en dirección al reino vecino, sin compensaciones algunas por lo que la prohibición 
fue total: «...de aqui adelante non consintades que ganados ningunos del regno de Aragon nin de Valençia entren a paçer en la nuestra tierra...»

A petición del concejo de Murcia el rey prohibía también la saca por vecinos y mercaderes aragoneses y genoveses de cualesquier productos vedados, caballos, armas, oro y plata, pan y ganados, que posiblemente eran los productos que en años inmediatos se habían estado exportando clandestinamente en mayor volumen; ellos traían sus mercancías a Murcia previamente y los productos de retorno eran estos vedados, en lugar de los permitidos y menos necesarios a la economía castellana, por tanto no vedados, lino, higos, miel, cera, etc. «...e que por esto viene danno a esa çibdat e que sy asy ouiese de pasar que se despoblaria por ello...» (35)

Desde 1374 la radical reglamentación del control aduanero hizo que aragoneses o genoveses viniesen menos a Murcia y que los cuatro productos citados que controladamente se podían exportar, no tuviesen venta, cuando eran productos que todos los vecinos poseían en cantidades variables; la excepción fue la saca del pan de forma coyuntural para traer del valle del Guadalquivir y cubrir así la gran necesidad atravesada por aquellos años en Murcia.

El bloquo de la frontera comercial con Orihuela en 1375 llegó a ser casi total al coincidir con una de las peores etapas de las relaciones castellanoaragonesas, y más tratándose de evitar el flujo de moneda cuya salida no podía justificarse, ni siquiera como ocasionada para abastecer a la comunidad de productos o servicios trascendentales, ni siquiera para traer de Orihuela dos muelas para los molinos «de aquende» del río Segura, explotados por Antón Abellán que «...non las podia faser traer por quanto non osa sacar de la çibdat moneda alguna que sea de oro, nin de plata, nin otra moneda monedada.." (36); con licencia concejil y dada la importancia de las piezas importadas pudo traer las dos muelas pagándolas con 34 quintales de higos que se le permitió exportar para tal fin, no sin antes haber comunicado la operacioń mercantil al adelantado mayor Juan Sánchez Manuel, en su calidad de alcalde mayor de las sacas que era.

En circunstancias tan difíciles, el proceso de recaudación de aquellos retroactivos dos impuestos aduaneros fue lento y estuvo lleno de incidencias, algunas de las cuales pusieron de manifiesto la intensidad del tráfico mercantil con Orihuela. El primer gran problema lo presentaron a la recaudación los clérigos «...e sus mancebas e paniagudos...», por la razón evidente de sus frecuentes e intensos lazos, intereses y viajes mantenidos con dicha ciudad; el concejo murciano ordenó averiguar cuantos eran los que tenian que pagarlo y en qué proporciones debían hacerlo, pero se encontró con la amena- 
za del obispo de poner a toda la ciudad en entredicho porque el aguacil había apresado a Pascual Martínez, criado del clérigo Jaime Piquer, vecinos ambos de la parroquia murciana de San Bartolomé, y obligados a pagar 28 y 26 maravedís respectivamente; la negativa de Pascual Martínez a entregar los correspondientes a la segunda imposición, ocasionó su apresamiento y la negativa concejil a entregarlo a la jurisdicción eclesiástica y a la cárcel del obispo, por no sentar un precedente con los demás clérigos de corona. La defensa de los derechos de la Iglesia mantenida con contundencia por el obispo Gumiel (37), impidió la participación de la sociedad eclesiástica en este impuesto al mismo nivel que la laica correspondiente.

En un impuesto en el que se pagaron cantidades variables, entre 1 dobla y 175 doblas (38) como cantidades extremas, tres cuartas partes de los 252 vecinos afectados pagaron entre 1 y 5 doblas, correspondientes al comercio efectuado con las pequeñas cantidades excedentes de sus cosechas o sus ganados o a las modestas transacciones realizadas por artesanos de la ciudad; era este tipo de comercio el que predominaba con respecto al vecino reino de Valencia, no el de los grandes mercaderes, muy pcos, que actuaban preferentemente en el interior de Castilla o de cara a Italia.

De la importancia de este comercio efectuado en territorio aragonés da idea la pormenorizada reglamentación de la «quema» valenciana, efectuada en 1376 (39), en momentos en los que Enrique II sentaba las bases de una politica aduanera que alcanzaba las mayores cotas de proteccionismo y control conocidas hasta entonces. El comercio clandestino y el puro trueque fueron las consecuencias directas imposibles de cuantificar, dada la inexistencia de datos al respecto, por razones evidentes de ilegalidad y pequeñez de los volúmenes y los valores más frecuentes. 

NOTAS

(1) LOPEZ DE AYALA, P. La crónica del rey don Enrique segundo de Castilla, Biblioteca de Autores Españoles, tomo LXVIIJ, Ediciones Atlas, pág. 3.

2) VALDEON BARUQUE, J. Las reformas monetarias de Enrique // de Castilla, en «Homenaje al profesor Alarcos Garciam, Universidad de Valladolid 1965-1966, y Reflexiones sobre la crisis bajomedieval en Castilla, en «Estudios dedicados al profesor don Ángel Ferrari», vol. II, Universidad Complutense, Madrid 1984.

3) Sevilla, 1369-V-11, Archivo Municipal de Murcia (A. M. M.), Cartulario Era 1405-1418, fol. 15-16r., transmitido por CASCALES, F. Discursos históricos de Murcia y su Reyno, Academia Alfonso X El Sabio, Murcia 1980, pág. 157.

4) Sobre los antecedentes de la ceca murciana, TORRES FONTES, J. La ceca murciana en el reinado de Alfonso XI, en uLes Espagnes Médievales. Aspects économiques et sociauX» Mélanges offerts a Jean Gautier Dalché. Faculté des Lettres et Sciences Humaines de Nice, 1983.

5) A. M. M. Montiel, 1369-III-24, Cartulario Era 1405-1418, fol. 15r.

6) BERMÚDEZ AZNAR, A. El proceso de consolidación del Reino de Murcia en la Corona de Castilla (1243-1375), en «Studia Histórica in honorem Vicente Martínez Morellá, Alicante 1985, pág. 16-17.

7) A. M. M. Real sobre Braganza, 1369-X-1, Cartulario Era 1405-1418, fol. 29-30r. y Medina del Campo, 1370-111-27, Cartulario Era 1405-1418, fol. 36.

8) A. M. M. Actas Capitulares Era 1409-1410, fol. 82r. (12-6-1372).

9) A. M. M. Actas Capitulares Era 1409-1410, fol. 59 (8-10-1371) y 66r. (6-12-1371).

10) A. M. M. Burgos, 1372-VIII-12, Cartulario Era 1405-1418, fol. 61.

11) A. M. M. Valladolid, 1371-V-20, Cartulario Era 1405-1418, fol. 69-70r. y 1374-I-6, Act. Cap. Era 1412, fol. 47r. y 48r.

12) MARTÍNEZ CARRILLO, M. ${ }^{a}$ de Los Llanos Manueles y Fajardos, Academia Alfonso $X$ El Sabio 1985

13) A. M. M. Act. Cap. Era 1409-1410, fol. 24r. (22-7-1371) y 59 (18-10-1371).

14) A. M. M. Act. Cap. Era 1409-1410, fol. 77r. (23-1-1372), MARTÍNEZ CARRILLO, M. ${ }^{\text {a }}$ de los Llanos Manueles... pág. 88 y sig.

15) A. M. M. Toro, 1373-XI-1 y Castroverde, XII-7, Cartulario Era 1405-1418, fols. 76-79r

16) GIL FARRES, O. Historia de la moneda española, Diana Artes Gráficas, 1958, pág. 142.

17) A. M. M. Act. Cap. 1417, fol. 154 (5-6-1380)

18) A. M. M. San Esteban de Gormaz, 1379-VII-2, Cartulario Era 1405-1418, fol. 162r. y 1380-VII-1, Cartulario 1384-1391, fol. 133r.

19) 1381-III-12, Cartulario 1384-1391, fol. 52.

20) En $138 \%$, por ejemplo, se escribía al oriolano Pedro Ripoll para que viniese a Murcia por «...sy podrian fallar en el barato de dinero...», A. M. M. Act. Cap. Era 1419, fol. .7 y sig. (30-11-1381) 
21) GIL FARRES, O. Historia de la moneda..., pág. 141 y RUEDA SABATER, M. El florín: un «dolar» bajomedieval. En «Estudios dedicados al profesor don Ángel Ferrari Núñez», vol. II, Universidad Complutense, Madrid 1984.

22) A. M. M. Act. Cap. 1389, fol. 25 (20-11-1389)

23) A. M. M. Act. Cap. 1384, fol. 73 (26-11-1384), GIL FARRES, O. Historia de la moneda... pág. 216.

24) A. M. M. Act. Cap. 1387, fol. 46 (30-7-1387)

25) A. M. M. Ávila, 1382-1-12, Cartulario 1384-1391, fol. 44r.

26) A. M. M. Act. Cap. Era 1420, fol. 110 (31-1-1383); Guadarrama, 1383-II-26, Act. Cap. Era 1420 , fol. 141 (17-3-1383) y Cartulario $1384-1391$, fol. 63 .'

27) A. M. M. Briviesca, 1387-XII-1, Cartulario 1384-1391, fol. 156, Act. Cap. 1387, fol. 156 $(30-5-1388)$

28) A. M. M. Toro, 1373-XII-22, Act. Cap. Era 1412, fol. 17r. - 18r. y Cordoba, 1375-I-7 y 8. Cartulario Era 1405-1418, fol. 91 y 92 r.

29) MENJOT, D. Las aduanas del reino de Murcia en el siglo XIV, en «Fiscalidad y sociedad", Academia Alfonso X El Sabio 1986, pág. 328.

30) A. M. M. Act. Cap. 1374, fol. 180r. (18-5-1375)

31) A. M. M. Act. Cap. 1374, fol. 154 y sig.

32) A. M. M. Act. Cap. Era 1412, fol. 62r. (24-9-1374)

33) A. M. M. Act. Cap. Era 1412, fol. 71. (30-10-1374), 85 (8-12-1374), 100r. (16-12-1374) y $144(13-3-1375)$

34) A. M. M. Segovia, 1374-VIII-31, Cartulario Era 1405-1418, fol. 86r.

35) A. M. M. Segovia, 1374-X-2, Cartulario Era 1405-1418, fol. 85 y Act. Cap. Era 1412, fol. 78 r. $(5-11-1374)$

36) A. M. M. Act. Cap. Era 1412, fol. $110(17-1-1375)$

37) A. M. M. Act. Cap. 1375, fol. 29r. y sig. (20-8-1375). TORRE FONTES, J. Tres obispos y un obispillo, en «Murcia Medieval. Testimonio documental Il», Murgetana 53, 1978.

38) MARTÍNEZ CARRILLO, M. ${ }^{\text {a }}$ de los Llanos. Las aduanas murcianas en el reinado de Enrique II, en «Homenaje al profesor Juan Torres Fontes", Univ. de Murcia, Academia Alfonso $X$ el Sabio, 1987.

39) A. M. M. Act. Cap. Era 1413, fol, 83r. (5-2-1376). PASCUAL MARTINEZ, L. Notas para el estudio de una institución: el alcalde-comisario de la frontera castellano-aragonesa, Miscelá nea Medieval Murciana II, 1976. 


\title{
NOTAS SOBRE LA ECONOMÍA FRONTERIZA CASTELLANO-ARAGONESA EN LA BAJA EDAD MEDIA
}

\author{
FRANCISCO DE MOXÓ Y MONTOLIU \\ Centro de Estudios Universitarios (Madrid)
}

Una de las zonas peninsulares en donde la huella del Medievo ofrece mayor interés es sin duda la que constituyó la frontera entre Aragón y Castilla: desde el punto de encuentro de ambos reinos con Navarra, al norte de Agreda, hasta las costas mediterráneas entre Murcia y Alicante. Zona cuyos límites se fueron fijando laboriosamente por diversos tratados al compás del avance reconquistador de ambos reinos, pero pese a ello nunca plenamente definidos (1), y sometida a fuertes tensiones de una y otra parte que la hicieron escenario de la aparición de importantes estados «tapón» de tipo señorial como Molina de Aragón, Albarracín y Villena, de una comarca castellana con denominación tan curiosa como la "Mancha de Montearagón" o de una «isla" aragonesa en territorio castellano como fue calificado el señorío de Caudete (2).

Sin pretender abarcar aquí toda la amplia problemática de la zona, y supuestas las peculiaridades de cada sector de la misma, ya bien estudiadas por diversos autores (3), creemos que es posible hablar de algunos aspectos económicos comunes a los que dicha situación fronteriza diera lugar. Si es evidete que esa particular posición política de tránsito, con una cierta como «ósmosis» de personas y mercancias en una u otra dirección, favoreció su prosperidad económica, no lo es menos que los no infrecuentes momentos de conflictividad bélica, con las devastaciones y rapiñas consiguientes, entorpecieron constantemente su desarrollo.

Vamos a verlo con más detención apoyados en los datos que nos suministra la historiografía y aportando al mismo tiempo alguna nueva luz documental. 


\section{LA GANADERIA: FACILIDADES Y PREVENCIONES}

La zona fronteriza coincidentre con el Sistema lbérico hasta sus últimas estribaciones meridionales era eminentemente ganadera y maderera. Ya M. Colmeiro en su «Historia de la Economía Política en España» observaba que «en la corona de Aragón abundaban los pastos y había partidos enteros, como el de Albarracín, cuya riqueza consistía casi exclusivamente en ganados. Los de Zaragoza y otras partes del reino iban a herbajar a esta comunidad o pasaban la frontera, dirigiéndose a Valencia, Murcia y Andalucía. La finura de las lanas de Albarracín se debía al cuidado de los naturales, que procuraron mejorar las castas, cruzándolas con las de Soria y otras partes de Castillaw (4). S. de Moxó, tratando de las posesiones de los Albornoz en Moya y Valdemeca, a las que se agregarían luego Beteta y Tragacete y otras poblaciones próximas a la frontera, recuerda que «el bosque y la ganadería constituían en el S. XIV -como hoy mismo- sus principales bases económicas; observando más tarde su relación con la tierra aragonesa colindante de Albarracín «cuya riqueza en ganados era proverbial y los cuales acostumbraban a cruzarse con los de las comarcas fronterizas de Castilla - como la conquense- con beneficio mutuo" (5).

Es interesante el caso del señorío de Villena, ganadera y cerealista, que, adjudicado en Torrellas (1304, en cuanto a la jurisdicción al rey de Aragón, si bien la propiedad quedaba para don Juan Manuel (6), acabó decantándose otra vez plenamente del lado castellano (7). El 10 de enero de 1340, se-

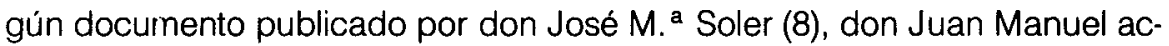
cedía desde Madrid a la petición de los habitantes de Villena «en razón de las cosas de vuestra criança e de vuestra cogida, que me pediades por merced que lo pudiesedes sacar a Aragón para vos aprovechar dello, et que non pagasedes diezmo ninguno pues erades de la conquista de Aragón»; pero dejando bien claro «que todos aquellos vuestros vezinos que quisieren sacar ganado de Castiella por Villena o a Aragón que paguen sus derechos».

No se mostró igualmente favorable Juan I en 1382 cuando los de Murcia, citando el privilegio anterior, le enviaron «a pedir por merced que os la ficiesemos de poder sacar para Aragón el pan que toviesedes de vuestra labranza, e los ganados que oviesedes de vuestra crianza, segund que se solía usar, e segund que lo sacan los de Villena, por el privilegio que de ello tienen». El rey les contestaba que «por agora non es nuestra merced de os dar esta saca, por la megua de ganados que hay en esa tierra por la pestilencia e mortandad que en ellos ha habido este añon (9).

Esta actitud restrictiva no era nueva en el S. XIV. Ya en 1330 Alfonso IV de Aragć $:$ se quejaba a Alfonso XI de la prohibición de sacar «ganado groso 
o menudo» del reino de Castilla, lo cual — decía - «es en daño del reino de Valencia y no lo acostumbraron sus predecesores» (10); y al mes siguiente rogaba al rey castellano no escuchase a los que acusaban a Pedro Ruiz de Azagra de haber sacado ilegalmente caballos de Castilla (11). Años más tarde, después de la época conflictiva del reinado de Pedro el Cruel, pero antes de la paz definitiva de 1375 entre Aragón y Castilla, era Enrique Il quien renovaba esa actitud en las Cortes de Medina del Campo de 1370 y nombraba un alcalde comisario para el comercio entre ambos reinos; pese a lo cual, como observa Valdeón, se siguió produciendo la salida de mercancías prohibidas, como el ganado y viandas en general, de Castilla a Aragón (12).

\section{EL TRASFONDO MONETARIO}

En el fondo estaba la cuestión monetaria y la mayor prosperidad económica de Aragón que, patente en la primera mitad del XIV, culminó en la creación del florín de oro por Pedro IV en 1346 y se mantuvo sustancialmente pese a las sucesivas devaluaciones del mismo, índice de una progresiva decadencia, en la segunda mitad de la centuria (13).

A ello se añadió la circunstancia, que recoge la Crónica de Alfonso XI, de no haberse labrado moneda en Castilla durante la minoría y primeros años del reinado de dicho monarca, y por ello uera muy apocada la moneda que mandara labrar el rey don Fernando su padre, et por esto en todas las villas de la frontera de Aragón et en todo el arzobispado de Toledo corría la moneda del rey de Aragón en esta guisa: los dineros jaqueses en prescio de coronados et los dineros reales en prescio de dineros novenes», cosa que sucedía también en otras fronteras de Castilla, por lo cual el rey ordenó que se volviese a labrar moneda de la misma ley y talla (14).

Por su parte Jaime II, en 1323, no habia accedido a la petición de don Juan Manuel de acuñar moneda propia en Villena (15). Pese a ello, pocos años después (1331), la Crónica de Alfonso XI nos informa de que don Juan Manuel hacía labrar coronados en Cañevate, añadiendo la interesante observación de que, para traer plata «facía levar fuera del regno muchos ganados e mucho pan e muchas mercaderías...» (16). La misma pretensión de acuñar moneda-privilegio que acompañaba al título ducal-subyace a la insistencia de don Juan Manuel por obtener el mismo, sea de Alfonso XI de Castilla (17) sea de los reyes de Aragón Alfonso IV y Pedro IV. Estos últimos, al concederle el título ya de príncipe ya de duque, excluyeron sin embargo expresamente dicha facultad (18).

En 1371, poco después de las Cortes de Medina del Campo de que an-

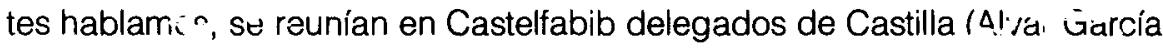


de Albornoz uno de ellos) y de Aragón para tratar de llegar a un acuerdo por mediación del Legado Pontificio. Y, entre otras instrucciones, los embajadores aragoneses llevaban la de decir que cesaría la acuñación de moneda castellana en Aragón «a cambio de detenerse la acuñación de florines aragoneses en Castilla» (19). Aunque de este dato no podamos deducir una superioridad de la moneda aragonesa, si es significativo que el mismo año, al comprar el Infantado al marqués de Villena, los Albornoz lo pagasen - «a modo de divisa internacional» en expresión de S. de Moxó (20)- en 30.000 florines de Aragón (21). Y aún lo es más el que, al llegarse en 1375 a las paces de Soria entre Aragón y Castilla, se fijasen preferentemente tanto la dote de Leonor de Aragón en su boda con el infante Juan (compensada con la misma cantidad entregada a Enrique de Trastámara cuando su lucha por el trono) como la reparación de éste a Pedro IV por los gastos hechos en favor de su causa, en florines de oro de Aragón (22).

El aprecio de la moneda aragonesa se manifestaba todavía en tiempo de Juan I cuando los habitantes de Murcia, en la petición de 1382 que antes mencionamos, aducian para apoyárla la razón de ser «más ricos en moneda» al poder sacar a Aragón sus mercancias (23).

\section{MADERA PARA EL ESTRECHO}

Hemos dicho que la riqueza de buena parte de esa zona fronteriza, en el sector coincidente con el Sistema Ibérico, era no sólo ganadera sino también forestal. Impresiona todavía hoy recorrer los magníficos pinares que se extienden desde Cañete hasta Moya o de Tragacete a Valdemeca y hasta la sierra de Albarracín. Tenemos constancia documental de cómo la madera de la zona limitrofe castellana era llevada, no sin dificultades e impedimentos a veces, Guadalaviar abajo hasta Valencia, de donde en ocasiones era enviada al Sur de la Península para cubrir las necesidades de las plazas del Estrecho.

En el Archivo de la Corona de Aragón hemos encontrado un interesante documento consistente en una carta de Alfonso XI, que ya empezaba a planear su nueva acción sobre Gibraltar, escrita el 20 de enero de 1347 a Pedro IV protestando del embargo realizado a mercaderes de Moya que llevaban madera a Valencia (24). Pocos días después (7 de febrero) Pedro IV comunicaba a su vez a Alfonso XI que, dada la reciente sequia, no podía permitir al despensero de don Juan Manuel transportar por el río Guadalaviar «la fusta quel dito $D$. Johan de vuestro mandamiento ha feyto tallar en los montes de Moya por bastecer la vuestra ciudad de Algezira» sin que pague el derecho equivalente al de los regantes perjudicados (25). Seguramente, vencidas 
las dificultades, esa madera llegaría por fin a Algeciras, como lo sugiere la relación de estos textos con el del capítulo 273 de la Crónica de Alfonso XI, por más que este último se refiera al anterior cerco de Algeciras en 1342:

«Et porque los de la hueste oviesen madera para facer casas, envió mandar el rey que de los pinares de Moya traxiesen madera a Valencia, que es en Aragón, et dende la traían por la mar fasta Algecira: et fallaron los omes en esto grand ayuda para facer moradas, ca las tiendas todas eran rotas con el fuerte tiempo que les avia fecho: et algunos dellos traían fechas las casas de la madera, que non avian de facer al, si non asentarlas»(26).

Añade la Crónica que también de Vizcaya trajo por mar mucha madera don Juan Núñez de Lara; y menciona en capítulos sucesivos «bastidas de madera" (c. 275), "una bastida de madera alta en guisa de torre» (c. 279), «tablas et cuentos de madera» en la cava o trinchera (c. 289) y «un castiello muy alto... et muy sotil» (c. 290).

\section{ROBOS $Y$ «PENDRAS»}

No era raro, aun en tiempos de paz entre Aragón y Castilla que con cierta frecuencia se produjesen robos y daños a una y otra parte de la frontera, que los respectivos monarcas trataban de remediar (27). A este respecto es interesante la carta de Jaime II en 1314 a Ramón de Avinyó, vicario general tarraconense «super facto peccunie et aliarum rerum subrreptarum infra regnum Aragonie per quosdam de regno Castelle, que erant archiepiscopi prelibati». A la propuesta que le hiciera el vicario de resarcirse con bienes castellanos contesta el rey que prefiere utilizar la vía diplomática, ya que «terrarum nostrarum conamur, quantum possumus, frontarias tenere quietas» (28). Otra vez es Alfonso XI quien pide a Alfonso IV (1331) corrija los abusos de súbditos suyos que roban en el señorío de Molina y pasan la frontera para vender lo robado en Aragón (29).

Estos robos eran a veces remediados directamente por los habitantes de uno y otro lado de la frontera por el sistema de «pendras» (prendas) o compensación consistente en embargar bienes de habitantes del reino vecino en tanto no se hubiese devuelto lo robado o satisfecho en justicia; lo cual daba lugar a nuevas reyertas y altercados que más que arreglar, empeoraban la situación. Se prefirió pues la vía del convenio o de la amigable composición.

Ya en 1262 se registran acuerdos particulares entre las hermandades de Teruel y Molina para remediar, entre otros, los asuntos de robos (30). En 1286 los reyes de Castilla y Aragón nombraban respectivamente a Sancho Martí- 
nez de Luna y Lope Ferrench de Luna para evaluar y enmendar los daños mutuos ocasionados entre hombres de Aragón y Castilla (31). En las vistas de Tarazona de 1329 celebradas con ocasión del enlace matrimonial de Alfonso IV con Leonor de Castilla, hermana de Alfonso XI, trataron ambos reyes de resolver esas querellas fronterizas por mutuas injurias entre particulares sin llegar a una solución evectiva, como lo manifiesta la correspondencia entre ambos monarcas en 1331 en la que se propone nombrar personas de uno y otro reino para acabar con el problema (32). En 1332 Alfonso IV declaraba que la imposición de una multa de 2 dineros por libra no habia resultado y proponía de nuevo se buscase una resolución defintiva del asunto (33). Todavía en el verano de 1335 se registra un intercambio de correspondencia entre Alfonso XI y Alfonso IV, a propósito de hechos acaecidos en las comarcas de Medinaceli, Molina y Daroca, que termina con la prohibición de las "pendras» por parte de Alfonso IV y la propuesta a su cuñado el rey de Castilla de enviar dos delegados, uno por cada reino, a la comarca de Molina para resolver en justicia (34). La muerte del Benigno a principios del año siguiente daría fin a tan bienintencionados tratos sin haber seguramente resuelto el endémico problema.

\section{DEVASTACIONES BÉLICAS}

Sin embargo los momentos más graves para las poblaciones fronterizas fueron los de las confrontaciones bélicas entre los dos Estados, o entre ambos y los señoríos limítrofes, que las afectaron de un modo particularmente negativo. Así sabemos por ejemplo del daño «grande» que hizo en 1284, don Juan Núñez de Lara en las comarcas de Teruel desde Albarracin (35). Poco después, en 1289, la Crónica de Sancho IV nos relata la entrada de este rey por Agreda hasta Tarazona, desde donde «fizo fazer muy cruda guerra en el reino de Aragón, matando, robando, quemando, cortando las olivas e los árboles e poniendo fuego a toda la tierra» hasta la ribera del Ebro (36). Aún a tiempo de tregua en la guerra Aragón-Castilla, en 1296, se quejaba Jaime Il al merino mayor de don Juan Manuel «contra la rapiña de algunos de sus hombres al asaltar a ciertos vecinos de Murcia (recién ocupada por el aragonés) que transitaban por sus tierras con bestias cargadas de trigo, escanda, granos, paños y otras mercancías, sin atender a que, en virtud de la tregua vigente, unos y otros debían disfrutar de seguridad en sus movimientos» (37).

Conflicto particularmente devastador fue el iniciado en 1356, de cuyas repercusiones fronterizas se ocupó ampliamente hace unos años A. Gutiérrez de Velasco por lo que nos limitaremos a exponer algunos eiemplos (38). La guerra fue dura desde sus inicios en que se registran ya mutuas invasio- 
nes. Zurita consigna que «los de Molina entraron en Aragón corriendo y talando los lugares y aldeas de Daroca, y quemaron dos que se dicen Ojos Negros y Blancas». Más al Sur, por obra de los aragoneses «se quemaron más de 50 aldeas y el arrabal de Requenan (39). Al año siguiente (1357) Pedro I entraba en Aragón talando y destruyendo los campos de Calatayud y Daroca (40).

De los efectos demográficos del conflicto con la destrucción de poblaciones y el trasiego de los habitantes pueden darnos idea las instrucciones dadas por el rey de Aragón. Disponía que si llegaban los enemigos a Munébrega (como sucedió) "se pegase fuego a la villa fuera del cortijo" y lo mismo se hiciese en Bubierca; que los habitantes de Santet pasasen a Jaraba; que se despoblase Brijuesca; que los hombres de Ateca se refugiasen en lbdes y las mujeres y niños en Calatayud, en donde habian de reunirse también los habitantes de Santos, Sabiñán, Paracuellos y Morata. Se despobló la villa de Alhama, cuyos habitantes subieron al castillo, y asimismo se despoblaron Cervera, Añón y la mitad de Torijo, etc. (41)

La guerra se prolongó como es sabido, aun después de terminada la guerra civil castellana en 1369, hasta 1375, época en que Molina, Cañete y Moya se pasaron a la obediencia del rey de Aragón (42). En Aragón se recogieron los ganados y se sacaron de las fronteras (43); y Pedro IV ordenó al gobernador de Aragón hiciese segar los «panes» (trigales) y llevarlo todo a las fortalezas (44). En 1374 serían el conde de Medinaceli y otros castellanos quienes penetrasen devastando por la comarca de Molina (45). $Y$ al firmarse la paz en 1375 con la devolución de Molina a Castilla se ofreció a los vecinos de esta villa que lo deseasen la posibilidad de irse a Aragón (46).

No sólo la invasión extranjera sino también el mantenimiento del propio ejército y las requisas y desmanes de las guarniciones dañaban la economía de las poblaciones fronterizas. Hubo quejas de que los capitanes se habían apoderado sin pagar nada de las provisiones reunidas en los castillos de Ateca, Alhama y Bubierca; y Pedro IV hubo de atender a la reclamación de los hombres buenos de las aldeas de Calatayud sobre la devolución del ganado que el gobernador de Aragón les mandara requisar. En Ariza los capitanes de la guarnición se apoderaron de 6.790 ss. que se negaban a devolver, por lo que el rey mandó que se descontasen de sus pagas (47).

No menos perjudiciales fueron las contiendas castellano-aragonesas del s. XV. En 1429 Juan II de Castilla "embió mandar a todas las villas de las fronteras que hiciesen guerra cruel en los reynos de Aragón e Navarra» cuyo resultado fueión ' Jrandes daños e talas e quemas» (48). Poco después el pro- 
pio rey, acompañado del condestable D. Alvaro de Luna, entraba en Aragón por Ariza, que era la primera villa pasada la frontera; ante lo cual «se despoblaron todos los lugares de la frontera que no eran defendederos» «e la mayor parte de la villa fue quemada» (49). Rehecha, de nuevo en 1475 sufriría el ataque del conde de Medinaceli (en guerra con el señor de Ariza), cuyos hombres talaron la vega y quebraron los molinos (50). No tardó en reaccionar Alfonso $V$ quien, partiendo de Calatayud, tomó a Deza por sorpresa llevándose a moros y cristianos; y aunque a éstos los soltó luego, fue con la condición de que no volviesen a Deza. La villa fue saqueada «haciendo mucho mal e daño; e créese que llevó más de diez mil cargas de trigo y cevada, e muchos muebles e ganados de los vecinos de aquella tierra» (51).

Años después, en 1447, las turbulencias del infante D. Juan, rey de $\mathrm{Na}$ varra, que acabaron arrastrando consigo a Aragón, devastaban los pueblos de una y otra parte de la frontera. Avanzando por tierras de Soria «los robos que los del rey de Navarra hacian destas fortalezas todo lo llevaron a vender al reyno de Aragón e eran allí acogidos»; por lo cual el alcaide de Peña del Alcázar tomó «la fortaleza de Verdejo que es en el reyno de Aragón, frontero de Castilla», con lo que atajó "el paso de los robos que se hacian desde Atienza e los traian a vender al reyno de Aragón» (52).

Otros puntos fronterizos más al sur fueron pronto afectados. En 1449 los castellanos de Molina intentaron robar los ganados de Cutanda, Rubielos, Cossa y Bañón. D. Juan de Luna, capitán general de las fronteras de Daroca, hubo de poner gente de guerra en Torralba de los Frailes, muy próximo a la frontera, desamparado por su población (53). Y en el mismo año entraban por Requena y Utiel en Castilla «gente del reino de Aragón, que serían docientos de caballo e quiñientos peones... e robaron ende hasta doce mil cabezas de ganado menor» (54); dato que, de paso, nos confirma cuanto dijimos anteriormente de la riqueza ganadera de la zona.

Balance de los efectos de esos años de confrontaciones bélicas es el resumen de la situación que la embajada aragonesa a Nápoles, en 1452, exponía a Alfonso $V$ reclamando su presencia: «Grandes despoblaciones de lugares en las fronteras, señaladamente en tierra de Teruel y Albarracín y en las comarcas de Daroca, Calatayud y Aranda, y ya no se labraban ni cultivaban las tierras: y no solamente se había seguido este estrago de los enemigos, pero de la gente de armas que estaban en servicio del rey de Navarra y de los que residian en las guarniciones... y se les sufrian sus insultos y robos porque no recibían gajes ni sueldo alguno». Además se habia gastado «en res- 
cates de prisioneros cuatrocientos mil florines» y había cesado «el trato y comercio de Castilla y Navarra" (55).

Así afrontaba esa zona singular del territorio hispano el tránsito a la Edad Moderna, que llevaría aparejado el fin de su condición fronteriza, bien que durante la época de los Austrias y aún hasta la posterior extinción de los señorios en el s. XIX conservase alguna que otra de las características del pasado. La división provincial de 1833 alteró un tanto la antigua línea fronteriza, llevando a las poblaciones de Utiel, Requena y Villena (1836) a integrarse en la región valenciana pese a su secular adscripción a Castilla. Pero, cualquiera que fuese el resultado final, sí podemos afirmar como conclusión de todo lo dicho que, al salir del Medievo, la riqueza pecuario-forestal y la posición comercial privilegiada de la zona se habian visto ampliamente contrarrestada por el efecto negativo de las confrontaciones bélicas a las que su situación la hiciera particularmente sensible. De ahí que, al perder su carácter fronterizo, esas comarcas interiores quedaran afectadas - y tanto más cuanto más interiores, más alejadas de las vías modernas de comunicación y más enriscadas en el Sistema Ibérico- de un cierto adormecimiento letárgico que ha penetrado su vida urbana hasta nuestros días. Muchas lo han ido superando con meritorio esfuerzo: en todo caso creemos que los estudios consagrados en nuestros días a la reavivación de la conciencia de su identidad histórica habrán de contribuir a preparar a las mismas un más próspero futuro. 


\section{APÉNDICE DOCUMENTAL}

1347, enero, 20. Villa Real.

Alfonso XI ruega a Pedro $N$ mande se resuelv en justicia el asunto de unos mercaderes de Moya que llevaban madera a Valencia y se les embargó.

ACA, CR, Pedro IV 4556

Al much alto e muy noble Dón Pedro, por la gracia de Dios rey de Aragón et de Valencia et de Mallorca et de 1/ Córcega et de Sardenia et de Rosellón et de Ceritania et conde de Barcelona. Don Alfonso, por esa misma gracia rey $2 /$ de Castiella, de Toledo, de León, de Gallisia, de Sevilla, de Córdova, de Murcia, de Jahen, del Algarbe, de Algesira et sennor de 3/ Molina. Salud como a rey que mucho amamos et que mucho preciamos et para quien querriemos tanta vida et salut como para 4/ Nos mismo. Rey, fasemos vos saber que algunos nuestros vasallos mercadores et otros omes viandantes de la villa de Moya et de 5/ otros logares de nuestro sennorío se nos querellaron et disen que ellos que an cartas vuestras de los reyes de Aragón onde Vos venides de 6/ seguramiento et de guiajes que vayan salvos e seguros con todas las sus cosas et mercadurias asi madera como otras cosas quales7/ quier que levaren a la cibdat de Valencia et a qualesquier otras villas et logares del vuestro sennorío; et que no sean prendados ni marcados ni embargados ellos ni las sus mercadurías. Et que aviendo ellos levado fusta a la dicha cibdat de Valençia et a otras partes de 9/ su regnado, que algunos ofiçiales et otras personas de Valençia et de otras partes de vuestro sennorío, que les an tomado et embargado la 10/ dicha su madera sin razón ni derecho por algunos fechos estrannos a que ellos non son tennidos ni obligados. Et en esto que reçiben 11/grandes agravios et que pierden mucho de lo que an por menguá de derecho, non les guardando las cartas de 'os quia'jes et 
segura-12/ miento que ellos diz que an de Vos et de los reyes onde Vos venides en esta razón, ni les guardando el fuero de la dicha cibdat 13/ de Valençia que an los mercaderes et todos los otros omes viandantes que y fueren con sus mercadurías. Et que comoquier que por muchas $14 /$ veses an requerido e afrontado a los ofiçiales de la dicha cibdat de Valençia et a los vuestros comisarios que por estos fechos libra-15/ diestes en que les fisiesen guardar et mantener las dichas vuestras cartas et de los dichos reyes de seguramiento et guiages que 16/ tienen ellos en esta razón, que lo non quisieron nin quieren facer, nin pueden ende aver complimiento de derecho. Et pidieron nos merced $17 /$ que les madasemos dar nuestra carta para Vos sobresta razón. Por que vos rogamos, rey, que tengades por bien de enbiar 18/ mandar a los ofiçiales de la çibdat de Valencia et a los vuestros comisarios que para librar estos fechos avedes dado, et que vean 19/ las cartas de seguramiento et de guiages que los nuestros vasallos tienen de Vos et de los reyes onde Vos venides en esta razón como 20 / dicho es. Et que gelas guarden et façan guardar segund que en ellas se contiene. Et si alguna madera o qualquier otra mercaduría les $21 /$ an tomado o tienen embargado, que gela fagan dar et desembargar. Et esto tened por bien de lo mandar así complir et guardar. Et 22/ de derecho a los de la vuestra tierra que alguna querella 23/ oviesen de los de la nuestra. Et desí quitaredes prendas et dannos dentre las vuestras gentes et las nuestras. Dada en Vila 24/ Real, veynt dias de enero era de mill et tresientos et ochenta et cinco annos (Signo) Yo Johan Ferrandis lo 25/ fis escrivir por mandado del rey (Signos). 


\section{NOTAS}

(1) E. MITRE, en una valiosa monografía dedicada a la delicada situación a que se llegó en tiempo de Enrique II al ostentar D. Alfonso de Aragón la titularidad del Marquesado de Villena, ha podido hablar de una «amplia difuminación de los límites» entre los dos grandes estados peninsulares "Señorío y frontera (El Marquesado de Villena entre 1386 y 1402)» en uMurgetana», vol. XXX, Murcia 1969. Prescindimos en este análisis de la zona fronteriza más próxima al Mediterráneo, entre las actuales provincias de Murcia y Alicante, estudiada ya en notables trabajos por los Dres. Torres Fontes y Del Estal y a la que ha dedicado recientemente su Tesis doctoral la Srta. M. a TERESA FERRER I MALLOL: «Moros i cristians, almogàvers i collerats à la frontera d'Oriols (s. XIV)" (Univ. Barc. 1984)

(2) «Insula Valentiae in Castellae regione" (Mapa de Abraham Ortelio de 1584; cf. J. M. ${ }^{a}$ SOLER «Historia de Villena» págs. 97 y 140). Sobre la Mancha de Montearagón (zona de Chinchilla) ver Crón. de Pedro I, cap. LXVI, nota 4 de la ed. «Bibl. de autores españoles" $t$. LXVI, págs. 420-421; Crón. Enrique II, $4^{\circ}$ año, cap. II, ibidem t. LXVIII, pág. 2; así como la Comunicación de A. PETREL al Congreso de H. ${ }^{\text {a }}$ de Albacete de 1983 (ed. 1984, II, págs. 263-271): «En torno al concepto y límites de un topónimo olvidado: la Mancha de Montearagón».

(3) S. CARRERES ZACARÉS «Tratados entre Castilla y Aragón. Su influencia en la terminación de la reconquista" (Tesis doctoral) Valencia 1908; R. CHABÁS «División de la conquista de la España mora entre Aragón y Castilla» (I Congr. de H. ${ }^{a}$ de la C. de Aragón 1908, t. I, págs. 139-141); J. TORRES FONTES «Las delimitaciones del Sudeste peninsular. Torrellas-Elche 13041305» en "Arales de la Univ. de Murcia 1950; "La conquista del Marquesado de Villena en el reinado de los RR. Católicos" en «Hispania» $L$ (1953); “La Hermandad del Marquesado de Villena en 1386» en «Villena» 23, Alicante 1973; J. M. DEL ESTAL «Conquista y anexión de Alicante al reino de Valencia» en «Rev. del Instituto de EE. Alicantinos», 15 (1975), págs. 127-158; «Problema sucesorio de Castilla y anexión de Alicante a la C. de Aragón», VII Centenario del Inf. D. Fdo. de la Cerda (1975), Ciudad Real 1976, págs. 237-263; «Las tierras levantinas de Albacete en la dinámica expansionista de Castilla y Aragón en los dos tercios últimos del $\mathrm{s}$. XIII e inicios del XIV , Congreso de Historia de Albacete, II Edad Media, Albacete, 1984, pp. 49-79; "Historia política de Alicante en la Edad Media (1238/1243-1479)", Historia de la Provincia de Alicante II, Alicante 1985, pp. 169-286; "Vaivén político del Señorio de Villena entre Castilla y Aragón (siglos XIII y XIV)» Congreso de Historia del Señorío de Villena, Albacete 23-26 octubre 1986 (en prensa); A. GIMÉNEZ SOLER «Don Juan Manuel. Biografía y estudio crítico» Zaragoza 1932; J. M. " SOLER GARCIA «Historia de Villena" (publ. en fascículos del Dep. de Cultura del Ayuntamiento de Villena). M. ALMAGRO BASCH «Historia de Albarracín y su sierra t. III y IV, Teruel 1959-1964; Catálogo de los Archivos Municipales Turolenses (IV vols.), Ins. de EE. Turolenses 1982-1985. J. SANZ DIAZ «H. a verdadera del Señorío de Molina», Guadalajara 1982; M. ROMERO SAIZ “Cañete, Historia y Leyenda», Cuenca 1978; J. GONZÁLEZ «Repoblación 


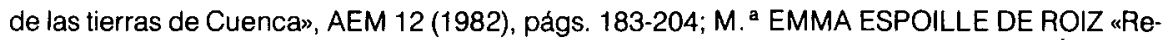
población de Cuenca (ss. XIII-XVI)», AEM 12 (1982), págs. 205-239; A. PETREL MARÍN «Conquista y primeros intentos de repoblación del territorio albacetense», IEA, Albacete, 1986; «Don Juan Manuel, Señor de la llanura», IEA Albacete, 1982; J. L. PASTOR ZAPATA «Un ejemplo de apanage hispánico: el señorío de Villena (1250-1445)», en «Rev. Inst. de EE. Alicantinos» 31 (1980), págs. 15-40. En el Congreso de $\mathrm{H}^{\text {a }}$ de Albacete de 1983 se presentaron otros valiosos trabajos de índole económica (F. A. VEAS, M. RODRIGUEZ LLOPIS, etc.), cuya mención omitimos por no hacer propiamente referencia a la relación fronteriza con la Corona de Aragón.

(4) "H. " de la Economía política en España» I, Madrid 1965, págs. 343-354.

(5) «Los Albornoz. La elevación de un linaje y su expansión dominical en el siglo XIV» en «Studia albornotiana» vol. XI, 1972, págs. 34 y 43 . A ello hay que añadir en algunas villas el intenso tráfico comercial y aduanero que la situación geográfica favorecía. M. ROMERO (o. c. pág. 55) recuerda como Cañete tenía un gran mercado. Ver también la Memoria de Licenciatura de MARÍA DEL CARMEN GARCIA HERRERO «Aportaciones al estudio de las relaciones comerciales entre Aragón y Castilla. La aduana de Calatayud 1445-1446» (Univ. Complutense de. Madrid 1982)

(6) J. M. del ESTAL «Problema sucesorio...», págs. 252-253.

(7) Ello se produjo insensiblemente a lo largo del s. XIV. La Crónica de Pedro I (1360, c. XXIII, pág. 510) dice que al morir en Sevilla D. a Blanca de Villena, nieta de D. Juan Manuel, «fincó toda su tierra en el rey (D. Pedro)». Pero Enrique de Trastámara la consideró suya en virtud de los derechos de su mujer D. ${ }^{a}$ Juana Manuel y al cabo de 6 años, con solución diplomática, la dio a D. Alonso de Aragón con el título de Marqués (1366). Despojado éste, se incorporó a fines del siglo a la Corona de Castilla (cf. E. MITRE, o.c., págs. 9 y 10 , y J. M. ${ }^{a}$ SOLER o.c. págs. 106).

(8) O.c. pág. 93. El procurador de Villena recordaba este privilegio a Juan II ante la prohibición de sacar al reino de Aragón ganados y otras mercaderías (ib. pág. 135)

(9) Adiciones a la Crón. de Juan I, IV, pág. 147.

(10) ACA R. 523, f. $121 \mathrm{r}^{\circ}$ (Calatayud, 9 sept. 1330)

(11) ACA R. 523, f. 136 r. $^{\circ}$ (Cella, 1 oct. 1330)

(12) J. VALDEÓN «Enrique II de Castilla: la guerra civil y la consolidación del régimen (13661371)», Valladolid 1966, pág. 340.

(13) Las devaluaciones tuvieron lugar en 1351,1363 y 1365 , llegando en este último año a) $75 \%$ de su valor nominal. Sobre el estado económico de Castilla en la primera mitad del siglo ver J. VALDEÓN «Aspectos de la crisis castellana en la 1. a mitad del s. XIV» en «Hispania»XXIX (1969) págs. 5-24. Sobre las reformas monetarias de Enrique II ver del mismo autor: «Enrique II...” págs. 341-348.

(14) Crón. Alfonso XI, c. XCV (B. A. E., t. LXVI, pág. 230)

(15) J. M. a SOLER, o.c., pág. 88.

(16) Crón. Alfonso XI, c. XCVIII, pág. 233. Ello provocó la «creciente invasión de numerario

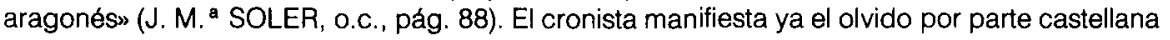
de lo establecido en Torrellas pocos años antes y considera las tierras de D. Juan Manuel como formando parte del reino castellano. El mismo D. Juan Manuel había hecho manifestar en 1310 a Jaime II que la sentencia de Torrellas era para Castilla «una espina al cor que ya mes nols exirá; e car veen que zo que don Johan a en Castella es escut del Rei d'Aragó e de sa terra entre ell e el Rei de Castella, la qual defén de Tarasona tro a Alacant». A continuación manifestaba el disgusto también de D. Juan Núñez de Lara «per zo car lo Rei li ten Albarrasiı» (G. SOLER «Don Juan Manuel»; Ap. doc. CCIX pág. 377; 18 julio 1310)

(17) Crón. Alfonso XI, c. CVII, pág. 241.

(18) Príncipe: 7 marzo 1334 (ACA R. 544 f. 98; G. SOLER, doc. DXVI, pág. 604); príncipe o duque: 15 mayo 1336 (RAH Col. Salazar A-3 f. 62 V. ${ }^{\circ}$ ) Ver también Col. Salazar A-3 f. 61 y A-4 f.9 (en G. SOLER docs. DXXXV y DXXXVIII); J. M. a SOLER págs. 89-91.

(19) ACA R. 1232 f. 118 r. ${ }^{\circ}$. ${ }^{\circ}$; Zur. An. X, 14; J. VALDEON «Enrique II...», pág. 267.

(20) O.c. pág. 49. 
(21) AHN, Osuna, leg. 1724 n. 9 y 1730 n. 4 y 5.

(22) 200.000 florines la primera y 180.000 la segunda. Sólo en el caso - añade Zuritade que no se hallase «tan grande cantidad de florines, se habian de dar doblas castellanas que no fuesen alfonsies, contando cada una de ellas a razón de 35 maravedis y el florín a 20; y si en doblas marroquies se hiciesen las pagas, se habrá de contar cada dobla por 32 maravedís». Dinero que se aseguraba sobre las villas fronterizas castellanas de Requena, Utiel y Moya, entregadas a representantes de Aragón (Zur. An. X, 19).

(23) Ver nota 9.

(24) ACA, CR Pedro IV 4556. Ver en nuestro Apéndice Documental.

(25) G. SOLER, o.c., doc. DLXXXI, pág. 648. El texto no parece sugerir la denegación absoluta de permiso que indica el «regesto" de G. SOLER. Don Juan Manuel, unido por estrechos lazos familiares con la corte aragonesa, sería nombrado el 24 de julio del año siguiente por Alfonso $X i$ adelantado de la Frontera musulmana y falleceria en Córdoba yendo a preparar la futura campaña de Gibraltar. Cf. nuestro trabajo «La política aragonesa de Alfonso XI y los hijos de Leonor de Guzmán», notas 34-36, en el vol. de homenaje a D. Claudio Sánchez Albornoz, «En la España Medieval» V, Univ. Complutense 1986, pág. 706.

(26) Crón. Alfonso XI, c. CCLXXIII, pág. 348. Para la relación Moya-Albornoz y la presencia de D. Gil en Gibraltar ver L. V. DÍAZ MARTíN «tinerario de Pedro m Valladolid 1975; y S. DE MOXÓ, o.c. págs. 33-42.

(27) La relación de proximidad no dejó de provocar en ocasiones situaciones conflictivas y recelos de una y otra parte. J. L. MARTíN, tratando de la escisión de las OO. Militares, habla de las etierras de pastos situadas en el Sistema Ibérico y disputadas por la ganadería de Castilla y de Aragón» («La Península en la E. Media», 1976, pág. 671). J. VALDEON observa que «a lo largo de la zona montañosa del Sistema lbérico castellanos y aragoneses mantenían unas relaciones de vecindad difíciles. Amparados en las condiciones naturales eran frecuentes los asaltos de una y otra parte que consistian generalmente en el robo de ganados, aunque a veces también en la captura de rehenes" («Enrique II..." pág. 216).

(28) J. VINCKE «Documenta selecta mutuas Civitatis arago-cathalaunicae et Ecclesiae relationes illustrantia», Barcelona 1986, doc. 213, págs. 143-144. Pocos años antes (1306) D. Juan Manuel se había quejado al rey de que almogávares de Aragón habian robado en Buendía cuatro moros a su mayordomo mayor Juan Sánchez llevándolos a Albarracín y otras partes (G. SOLER, o.c., docs. CLV y CLVII, págs. 339-340).

(29) ACA, CR. Alfonso IV 1424. Ver F. DE MOXO «La relación epistolar Alfonso XI-Alfonso IV en el $A C A$ » en «En la España Medieval» III, Univ. Complutense 1982, págs. 173 ss.

(30) M. ALMAGRO, o.c., t. III pág. 216.

(31) ACA, R. 70, f. 27 r. ${ }^{\circ}$ Pocos años antes (1279) Pedro Ill había comisionado a Rey Ximénez de Luna, procurador del reino de Valencia, para la determinación de los límites con Castilla con el representante de Alfonso X. Ver nuestra tesis doctoral (en prensa) «La Casa de Luna (12761348)», Ap. docs. 30 y 9 (ACA, R. 41, f. 103 r. $^{\circ}$ ).

(32) ACA, CR Alfonso IV 1656 (4 sept.); R. 525 ff. 47v.-r. (16 nov.)

(33) ACA, R. 525 ff. 146v. - 147 r.v. (24 febr.)

(34) ACA, R. 530 ff. 192 v., 194 r.v. y 255 r.v.

(35) Zur. An. IV, 44.

(36) Crón. Sancho IV, c. VI, pág. 81.

(37) J. M. a SOLER, o.c., pág. 72.

(38) A. GUTIÉRREZ DE VELASCO «La guerra de los dos Pedros y la frontera castellanoaragonesa en el s. XIV" (Tesis doct. inédita) Madrid 1947; "La financiación aragonesa de la guerra de los dos Pedros» en «Hispania» LXXIV (1959); «Las fortalezas aragonesas ante la gran ofensiva castellana en la guerra de los dos Pedros" en "Cuad. H. ${ }^{a}$ Jerónimo Zurita» 12-13 (1961); «La contraofensiva aragonesa en la guerra de los dos Pedros" en "CHJZ» 14-15 (1963); «Molina en la Corona de Aragón (1369-1375)» en «Teruel» 6 (1951), págs. 75-128.

(39) Zur. An. IX, 3. 
(40) J. SANZ y DIAZ «H. verdadera del señorío de Molina», pág. 122. G. DE VELASCO ( ¿La financiación..." pág. 4) resume asi el inicio de la contienda: «Difundido el pánico en las zonas de contacto, la gente abandona el campo y comienza el despoblamiento en masa de las tierras indefensas, retirándose ganados, víveres y enseres. Todo ello se traduce en un desastre para la economía agrícola y ganadera del país». Ariza, Aranda y Cetina quedaron pronto arruinadas por las incursiones guerreras (págs. 14-15).

(41) Zur. An. IX, 7.

(42) Zur. An. X, 5.

(43) Zur. An. X, 8.

(44) J. VALDEÓN «Enrique II...» pág. 215.

(45) Zur. An. X, 17.

(46) Zur. An. X, 19.

(47) ACA R. 1379, f. 170 r.v.; R. 1382 f. 76r.; G. DE VELASCO «La financiación...» págs. 25-26.

(48) Crón. Juan II, 1429, c. XXIV, pág. 462-463.

(49) Crón. Juan II, 1429, c. XXVII, pág. 464.

(50) Zur. An. XIX, 34.

(51) Crón. Juan II, 1429, c. XXXIV, pág. 467.

(52) Crón. Juan II, 1447, c. IV. págs. 654-655. Es interesante respecto a la complejidad demográfica de estos lugares fronterizos la observación de Zurita de que algunos de Verdejo eran castellanos y se alzaron por el rey de Castilla (An. XV, 51).

(53) Zur. An. XV, 56.

(54) Crón. Juan II, 1449, c. I, pág. 661.

(55) Zur. An. XVI, 5. En el capítulo siguiente añade Zurita los daños causados todavía en ese mismo año por la guerra contra el conde de Medinaceli y los suyos. 


\title{
JUDEUS E CONVERSOS CASTELHANOS EM PORTUGAL
}

\author{
MARÍA JOSÉ P. FERRO TAVARES \\ Universidad de Nova de Lisboa
}

A mobilidade dos judeus é conhecida desde o início da sua Diáspora. No entanto, razões de ordem económica e, sobretudo, sócio-religiosa, como as perseguições e expulsões que sofreram durante a Idade Média, com maior acentuação nos séculos XIV e XV, fizeram com que esta minoria religiosa, tolerada entre os cristãos se visse obrigada a emigrar para regiões mais favoráveis: cidades italianas, Península Ibérica e norte de África. Porém, durante a centúria de trezentos, o nordeste e o centro hispânico foram também fustigados pelo vendaval antisemita, quer por ocasião da peste negra (1), quer posteriormente por acção das pregações de Vicente Ferrer e outros (2). A morte ou a conversão eram os dois gritos que se faziam ouvir. Nestes tempos conturbados, Portugal devia parecer aos perseguidos ou aos convertidos pela força, um paraíso, devido à quase ausência de levantamentos populares antijudaicos (3).

Esta conjuntura peninsular seria acompanhada em Portugal por um agravamento legislativo da separação entre cristãos e judeus. As ordenações visando o encerramento destes em bairros, o uso de sinal, a proibição de circularem nas zoas cristãs, após o toque das Avé Marias foram de novo promulgadas e confirmadas por D. João I (4). Amador de los Rios falou de intolerância e de perseguição aos judeus durante os reinados de D. João 1 e D. Duarte (5). Não cremos que a sua leitura esteja correcta. Se estas medidas respondiam às necessidades internas do reino, saído de uma guerra pela independência que levara a uma nova família reinante, e à imigração de judeus e conversos peninsulares, elas acabavam efectivamente por se traduzir numa protecção real por parte do soberano para com a minoria judaica, ante o aumento de tensão nas relações dos cristãos com este 
Pouco sabemos sobre o impacto que a entrada desta primeira vaga de judeus e conversos foragidos provocou no reino. Certamente que o seu número não seria suficiente para desestabilizar a sociedad cristã e romper o equilíbrio entre esta e a minoria judaica, residente no reino, como viria a suceder nos finais de quatrocentos. Não nos consta que ocorressem tentativas de uniões populares. Apenas a legislação nos permite ver uma certa tensão social que iria exigir a restrição de poder para os judeus. Estes deveriam obedecer e não, ser obedecidos. Era o cerceio do domínio social e económico que os procuradores dos concelhos exigiam nas cortes, ao que o soberano respondia com a limitação das actividades da minoria judaica, na cristandade e com a sua marginalização física o espacial. «Tendo subjacente um antagonismo religioso, comum a todo o mundo cristão, o ódio ao judeu traduz-se em Portugal, pelo que conseguimos apurar, aos níveis do poder e da economia e não dentro do espírito de intolerância e fanatismo religioso que promove os levantamentos ocorridos no resto de Península, nesta época” (6).

Era óbvio que este cerceio de poder não atentava tanto nos judeus, naturais do reino, donde sobressaíam como cortesãos umas escassas duas famílias: os Negro (Ibn Yahia) e os Navarro, estes últimos provavelmente imigrantes dos meados de trezentos e cujo nome de família foi esquecido e substituído pelo novo, de origem toponímica. O receio dos procuradores dos concelhos e, sobretudo, de Lisboa, iria certamente para os novos recém-vindos que ameaçavam ser perigosos concorrentes na economia nacional e no poder, pela sua aproximação da corte. Alguns trariam atrás de si o prestígio de um nome e a riqueza, como os Abravanel.

Por isso mesmo, como forma de ataque aos prófugos castelhanos, os cristãos utilizavam a arma de denúncia por relapsismo, alegando que tinham sido baptizados no reino vizinho e aqui se tornavam judeus (7). D. João I não tomaria qualquer medida contra aqueles que, tendo sido forçados à conversão, aqui voltavam ao seu nome judaico e a viver como crentes na Lei (8); pelo contrário, em 1392, publicar-se-iam as bulas papais de protecção aos judeus e prohibir-se-ia a conversão forçada ( 9 ). A pesar destas medidas, aquele soberano apelaria à conversão livre, concedendo amplos privilègios aos que abjurassem a fé mosaica (10).

Seria, a partir dos finais do século XIV, que a imigração de judeus castelhanos em Portugal se tornaria mais notada, a través de permanência dos topónimos de origem, na onomástica judaica. Toledano, de Leão, de Ávila, Castelão, Burgalês, Villadiego, Segoviano, etc. acrescentavam-se a outros topónimos, transformados em nome de familia como Franco, Navarro, Saragocim, Valencim, Carmonim, de Narbona, Aragonês, Catalão, etc. 
Em raríssimos casos permaneceu o nome judaico. Conhecemos os Abravanel, provenientes de Sevilha, e talvez tivessem tido origem no reino vizinho os Latam e os Palaçano. Curiosamente estas três familias, juntamente com os Negro, judeus cortesãos de origem portuguesa, iriam deter nas suas mãos o grande comércio com ligação à Europa e à África, as rendas reais, além de estarem próximo da corte e da família de Avis. O seu poder e prestígio reflectiase na comuna de Lisboa à qual todos pertenciam e onde exerciam cargos importantes.

Os Abravanel deviam ter entrado em Portugal na primeira década de quatrocentos. A mais antigua referência documental que conhecemos, encontrase no testamento do infante $D$. Fernando, filho de D. João I. Por ele sabemos que este príncipe era devedor de 52.000 reais a um Abravanel (11).

Juan Sánchez de Sevilha, ex-Samuel Abravanel, fora forçado a baptizarse nos levantamentos de Sevilha de 1391. Segundo Netanyahu teria, por volta de 1414, fugido para Portugal, juntamente com os filhos (12). Se a sua estadia no reino não deixou qualquer marca perceptível na documentação, o mesmo já não sucedeu com seu filho Juda e outros dois indivíduos, provavelmente irmãos deste: José e Ya (13). Juda seria referido, entre 1446-49, como mercador, rendeiro e tratador das moradias reais, enquanto José apareceria a aforar uma casa na rua do Picoto, na judiaria grande de Lisboa (14). Por outro lado, um documento de 1441 mencionava um Judas Bravane, um José Bravane e um Ya Bravane a residir em Lisboa (15).

A genealogia conhecida, publicada pela Encyclopaedia Judaica (16), está incompleta e não nos ajuda muito a conhecer os vários romanos desta família, talvez a mais célebre do século Xv peninsular, pela sua multifacetada incidência nos campos político, económico e cultural. No entanto, a escassez das informações só nos permite levantar uma hipotética árvore genealógica, nem sempre concordante com a obra atrás mencionada. A repetição dos nomes próprios, o silêncio sobre as mulheres, a rara indicação de filiação, sempre referida pela linha masculina, os casamentos endogâmicos que caracterizavam não só esta, mas a generalidade das mais importantes famílias judaicas portuguesas, dificultam-nos muito seguir, hoje a evolução dos Abravanel, que ainda seriam encontrados, com nome cristão, no século XVI (17).

Desde o seu aparecimiento, na história portuguesa, os encontramos ligados à família real. Por isso e, pelos privilégios com que viriam a ser agraciados, podemos considerá-los judeus cortesãos. Como tais seriam definidos, em 1455, Judas e Samuel Abravanel (18), Isaac, em 1463 e 1479 (19) e Ya, 
em 1480 (20). Todos eles eram «servidores» de D. Alfonso $V$ e Isaac acrescentava a este o ser também «servidor» do duque de Bragança (21).

Os privilégios concedidos eram coincidentes com o seu estatuto social. Samuel Abravanel, em 1453, ficava isento do pagamento dos direitos reais que todos os judeus do reino deviam pagar ao soberano, e podia fazer-se transportar em besta muar com sela e freio e com armas (22). Dois anos mais tarde, além destes, $\mathrm{D}$. Afonso $\mathrm{V}$ outorgava-the as isenções de pagamento de pedidos e empréstimos ao rei, da paga dos impostos à comuna, do serviço de aposentadoria e do uso do sinal distintivo, além da permissão de pousar entre os cristãos (23). Em 1463, foi a vez de Isaac Abravanel (24) e, em 1472 , de Ya Abravanel, o moço (25). Mais do que as isenções, certamente importantes eram-no as distinções de carácter social, como a permissão de se transportarem em mula com sela e freio e de usarem armas, as quais thes conferiam o estatuto social de cavaleiros.

Alguns membros desta família desempeharam cargos na comuna de Lisboa, como José Abravanel, homem bom da câmara de vereação, no ano de 1464 (26).

Participaram activamente na economia do reino, quer como capitalistas, através de sociedades que firmaram com mercadores italianos e flamengos, sitos em Lisboa, quer como mercadores-banqueiros do rei e da casa de Bragança, quer inclusivamente como proprietários rurais.

Em data difícil de determinar, mas certamente dos finais da primeira metade de quatrocentos, dois judeus, Catalão e Abravanel, apresentavam a D. Alfonso $\mathrm{V}$ uns "conselhos" sobre economia política, como hoje diriamos. Aí se explanavam considerções sobre mercantilismo comercial, a guerra monetária entre Portugal e Castela, o lavramento abundante de boa moeda de ouro e de prata, a relaão entre a má moeda e o aumento do custo de vida, a defesa da exportação de mercadorias nacionais contra a fuga da moeda e dos metais preciosos, etc. Propunham ao jovem soberano medidas atinentes a evitar a drenagem dos reais brancos de bolhão para Castela e outros lugares, e criticavam as emissões de reais pretos, demasiado dispendiosas para o erário régio, devido à carestia do cobre. Defendiam a paridade entre os escudos portugueses e as dobras castelhanas, estas sempre um pouco mais elevadas que aqueles, apesar do mesmo toque e peso das duas espécies. Condenavam as cunhagens excessivas de moedas subsidiárias, diminuindoas na proporão directa do valor dos submultiplos existentes em circulação. Referiam a necessidade de proibir a exportação de moeda e metais preciosos, assim como a limitação de determindas profissões a estrangeiros, quer 
como mercadores e cambiadores, quer como ourives, entregando o seu exercício apenas a naturais do reino. Advogavam o justo preço das mercadorias e bens necessários e alegavam que «toda franqueza he chamada gouernança e regimento de boa justiça a quall he dar a cada hũa cousa seu merecer e dar ao omen o que he pera os omens uiverem em regra de grande fartura e riqueza fora de toda mingoa e pobreza que he catiueyro contra franqueza: $E$ asy todos sendo avonddos he força senhor vos serdes riquo»... (27)

Catalão e Abravanel, ao defenderem os interesses dos naturais do reino, assumiam-se como tal e tentavam irradiar da concorência os mercadores italianos, os mais sérios rivais desta burguesia judaica. Quando ñão o conseguiam, associavam-se a eles...

Em 1475, Afonso Rodrigues, estudante em Perúsia, tinha uma conta de 200 ducados de câmara, em Florença, creditada por Isaac Abravanel e mestre Latam, por intermédio de Bartolomeu Marchione (28).

Desde 1446, encontramos sociedades de mercadores-banqueiros a arrematarem os pagamentos das tenças aos moradores da casa real. Entre este ano e 1454, Judas Abravanel associou-se a João Dias Beleágua, Leonardo e Marco Lomelino (29).

Mercadores, estes judeus aumentavam o seu capital com a arrematação das rendas, contratos e monopólios reais. Isaac Abravanel e Moisés Latam obtinham, em 1477, o contrato das 200.000 coroas dos casamentos da casa real (30). Ya Abravanel teve, nos anos de 1477-1480, o contrato das moradias da casa de D. Diogo, duque de Viseu (31). Aliás seriam as dívidas para com estes judeus, por parte do duque que levariam um descendente destes, cristão, Henrique Fernandes Abravanel, a receber de D. Manuel 800.000 reais, como herdeiro que era de Ya Abravanel, seu avô, e de Juda Abravanel, seu tio (32).

Samuel Abravanel e seu filho José, genro de Isaac Abravanel, participaram no comércio do açúcar da Madeira com a Europa. Pela carta de perdão de Benvinda, viúva daquele, sabemos que «por nossa parte (de D. João II) foy enbargada toda a fazenda, beens que se tratava e nomeava em nome de Yoçe Abravanell e asy a que ficou em pose e cabeca de casall Bemvinda, sua (de Samuel) molher, o quall enbarguo the asy foy posto por çertas auções, rrazões que hii avia pera ello, s., por se dizer que o dito Yuçee Abrabanell e Jaco Abravanell, seus filhos, que ora sam lancados em Castella, eram herdeiros da dicta fazenda $e$ allem de asy serem herdeiros aviam per ella seus casamentos e que por serem sabedores e partyçipantes na treiçam do duque de Viseu, perdiam pera nos toda sua erança e tanbem que por o dicto 
Samuel Abravanell em sendo vyvo e ella, dicta Bemvinda, saberem parte da fazemda que aos dictos seus filhos pertençia e asy de alguũa fazemda de Isaque Abravanell e todo callaram e encobriram sem enbarquo dos pregões, pennas de perdimento de beens que forom postas a quem ho nom descubrisse. $E$ asy por se dizer que o dicto Isaque Abrabairell e os dictos seus filhos serem lançados em Castella, o dicto Samuell Abrabanell e ella, Bemvinda, sua molher, enviarom ouro, prata, joyas, dinheiros, cartas e rrecados aos sobredictos e rreceberam outros rrecados delles sem enbarguo de nossas defessas, penas que sobre ello eram postas. $E$ ora ha dicta Bemvinda por sy e pr seus filhos que ora neste rregnno tem, nos pidio por merçe que ouvesemos piadade com elles e nos prouvese reçebermos em serviço huũ milhãao de rreaes por todallas ditas suas fazendas allem de todo ho acuquar, dinheiros e cousas que nos atee agora teemos tomadas, avidas e despesas do dicto Juçe Abrabanell, asy na ilha da Madeira como em estes rregnnos e em quaesquer outras partes...» (33)

O trato da vintena da Guiné coube a Juda Abravanel, durante os anos de $1482-83$ (34)

Foram igualmente banqueiros do rei e da família real. Já referimos o caso de um Abravanel, credor do infante D. Fernando, morto em Fez. Pela carta de quitação de João Afonso, tesoureiro da casa de moeda de Lisboa, sabemos que Isaac Abravanel recebeu 200 mil reais, quantia que emprestara a $\mathrm{D}$. Afonso $\mathrm{V}$ para pagamento de 1.500 ducados, em Roma (35). Mais tarde, surgiria como financiador da infanta $D$. Beatriz que the pagaria a dívida com a concessão do arrendamento das rendas da ordem de Cristo (36).

A ligação dos Abravanell com a casa de Bragança de Viseu fá-los-ia cair em desgraça junto a $D$. João II e fugir para Castela, terra dos seus antepassados. Entre as acusações feitas a Isaac Abravanel, encontravam-se as de financiar as conjuras contra o rei, por parte dos diques de Bragança e de Viseu. Pelas sentenças de D. Gutierres Coutinho, de Isaac e de seu genro, José, filho de Samuel Abravanel, sabemos que o crédito para pagamento de homens e armas orçava os 20.000 cruzados de ouro, ou seja, 9.500 .000 reais, além da possibilidade de movimentar cerca de 38 milhões de reais (37).

A sua riqueza e privaticidade com a corte transpareciam na própria sentença de Isaac Abravanel: «por o dito Reeo seer muito gramde servidor e amigo dos ditos dom Fernando e dom Joham, e de toda sua casa, e por seer homẽ mui rico, e muy afazemdado, e entemdido, e industrioso, averido isso meesmo os sobre ditos mester dinheiro, que pera a dita maldade e traiçam aviam mester, Ihe vieram a descobrir o dito trauto, treiçam e maldade, que contra 
nos tiinham trautado e hordenado, mamdandolhe que sse viesse a nossa corte, e o que sentisse que contra elles se fazila e dezia os avisasse e tho escprevesse..." (38)

O impacto da sua fortuna e o seu prestígio na sociedade portuguesa tornaram-nos imortais nos versos do Cancioneiro Geral, para já não falarmos de Isaac e de seu filho Juda, o célebre Leão Hebreu, na cultura europeia da quatrocentos e de quinhentos:

"estes sam os do cuydar

sem o poderdes neguar

os mores oyto senhores.

Sera primeyro Latam,

o segundo Samuel,

o terceyro Salamam

o quarto sera Fayam

o quinto Abrauanel.

«Namorado he Palaçano

Gualyte, tambem Jaçee, poys que cuydam todo ãno, mas cuydã em dar seu pãno

mays do que val ala fe.

Cuydam no arrendamento, quando cuydam demcampar

E cuydam quee perdimento, quando cuydam que por çento

trinta he pouco ganhar» (39)

Os Abravanel não foram os únicos imigrantes castelhanos que a documentação portuguesa refere. Mais difícil de destrinçar, na sua mobilidade, seriam os Caro, os Benveniste, os Abeacaar, os Abenazo, os Alhaquim, os Abet, os ben Adret, os Abopa, os Barzelai, os Benarroio, etc., cujos nomes de família deveriam ser comuns a toda a Península. Outros poderão ser detectados mais facilmente, quer como servidores dos reis de Portugal, quer como mesteirais da corte, quer como magistrados nas comunas. A onomástica com base nos topónimos, permite-nos localizá-los por todo o reino, perfeitamente integrados na sua nova pátria adoptiva (40)

Jacob Castelão, servidor de D. Afonso V, optou por residir em Braga. Em 1443, recebia uma carta de privilégio que o isentava do pagamento dos direitos reais, dos impostos e serviços à comuna, de aposentadoria e the permitia andar em besta muar (41). Em 1450, por nova carta, os serviços à co- 
muna eram sustituídos pela isenção do pagament de pedidos e empréstimos ao rei (42).

Moisés Castelão residia em Montalegre e obteria também daquele soberano a isenão do exercício de cargos na comuna, c̀o serviço de aposentadoria e recebia autorização para usar armas e pousar entre os cristãos (43). A um homónimo deste, morador no Porto, servidor de $D$. Afonso $V$, era concedida a permissão para andar em mula (44) e para colocar nos portais e janelas de sua casa, um castelo e um alão, como brasão (45).

Mestre Samuel Verdugo, natural de Castela, veio residir para Elvas onde se dedicaria ao fabrico das armas, pelo que obteria a protecção do rei e do concelho (46). O mesmo sucederia com Salomão Ardutel, alfaiate (47) e com Abraão Cençarrado (48) que optariam por Lisboa, ou com m Abraão Cabanas, físico, natural de San Felices, que viria casar a Gouveia (49).

Moisés Franco, natural de Valladolid, e radicado em Portugal, obteria permissão para casar com Estrela, judia portuguesa, depois de ter apresentado um documento de divórcio de su primeira mulher que permanecera em Castela (50). Mestre Moisés Abarrizo, cirurgião, morador em Messejana, receberia autorização de $\mathrm{D}$. João II para poder vender, pelo reino, pano de Castela a retalho, pois era judeu castelhao radicado em Portugal pelo casamento e pela sua família (51).

A segunda metade do século $X V$ tornaria a conhecer períodos de verdadeiro terror, quer contra os judeus, quer contra os conversos, como o que ocorreu em Toledo, em 1449. Estes momentos críticos levavam à partida das duas minorias para outros lugares, onde o antisemitismo não fosse tão agressivo. Portugal perfilharia as simpatias de ambas. Talvez por isso, alguns defenderiam uma posição pró-portuguesa, contra os Reis Católicos, como rabi Jacob ou alguns conversos de Ciudad Real (52).

As últimas décadas de quatrocentos conheceriam o agravamento das relações entre cristãos e judeus e cristãos e conversos, estes acusados de heresia criptojudaízante. Para prevenir ao aumento de tensão, Isabel e Fernando optariam por expulsões pontuais, como as dos judeus de Andaluzia, antes de se decidirem pela expulsão geral, ordenada em 1492. Sevilha, Bilbau, Trujillo, Ávila, etc. foram achas numa imensa fogueira que a entrada da Inquisição agravaria.

Todo este clima adverso à vida das comunas levaria à saída paulatina dos seus membros. Conversos e judeus abandonavam Castela e optavam 
por residir temporária ou definitivamente noutros lugares da Península, da Europa ou de África. Portugal foi o reino peninsular que mais afectado acabaria por ser, pois, à entrada pontual de uma ou outra família, acabaria por suceder a entrada em massa de judeus, com a expulção de 1492, e com eles a de conversos judaízantes.

A sua vinda desorganizaria o precário equilibrio existente nas relações entre as comunas portuguesas e a maioria cristã, o qual se vinha deteriorando desde o terceiro quartel de quatrocentos. O medo contra hipotéticas concorrências profissionais por parte dos adventícios, agravado pelos surtos epidémicos e pelas superstições que viam nestes o castigo dos pecados, instalaou-se, quer entre a minoria judaica, natural do reino, quer entre os cristãos e provocaria o ruir rápido de um entendimiento de séculos.

Da luta de interesses que, há muito, se vinha fazendo ouvir nas vozes dos procuradores às cortes, à perseguição ao herege e reflexamente ao judeu, iria um passo. D. João Il, sob cujo governo, a crise iria rebentar, usaria uma política férrea, extremamente legalista de protecção às comunas contra as uniões cristãs, sacrificando para tal os conversos e os judeus castelhanos.

As vagas de indivíduos, fugitivos à acusação de hereges e à Inquisição castelhana, na sua maioria em trânsito para outras paragens, geravam, nas principais cidades do reino, como Lisboa e Porto, uma onda de ódio aos conversos. Em 1485, este concelho recusava-se a recebê-los, alegando que «sam estrangeiros e daquella casta de que hy ha sospeicam» (53). Dois anos mais tarde, com o pretexto de que residiam aqui muitos estrangeiros, a câmara decidiria dar-lhes o prazo de três dias para sairem da cidade (54). O objectivo era a irradiação dos conversos castelhanos, tal como ocoria noutros lugares do reino (55). D. João II cortaria cerce estas exorbitâncias, mas dar-Ihesia razão ao criar os primeiros inquisidores, «rrelligiossos e pesoas outras que pellas comarcas do regno honde os dictos marranos estam, vaão saber e se enfformar de como vivem e viveram atee qui pera os que se achar que nom sam boons christaãos averem aquella condenaçam que por tall caso merecem» (56). Nos primeiros dias de Abril de 1487, sob a alçada dos bispos das várias sés do reino, começaram a actuar os primeiros inquisidores portugueses. Ao mesmo tempo, o soberano proibia, sob pena de morte, a saida do reino de todos os castelhanos, a fim de que as investigações iniciadas pudessem ser completadas e devidamente castigados o relapsos. No entanto, esta medida viria a ser levantada por demasiado lesiva dos interesses dos naturais de Castela que não eram conversos (57).

Portugal começava a ser palco de autos da fe, mesmo sem a presença da Inquisição. Embora as notícias sejam escassas, os cronistas já se referi- 
ram vagamente a elas (58). Em Santarém, João de Niébla era queimado por judaízar em casa de um Arondim, ourives, com quem festejara a Páscoa das Cabanas (59). Já anteriormente, em 1485, Lisboa tinha sido abalada por levantamentos populares que se seguiram à prisão de um converso castelhao (60).

A 2 de Outubro de 1488, don João Il tentaria cortar pela raíz o problema dos criptojudaízantes castelhanos, para evitar que Portugal se transformasse na fogueira que era o reino vizinho. Assim, promulgaria a proibição de estes entrarem no reino, sob pena de serem entregues aos oficiais de justiça dos Reis Católicos (61). Por fim, nesse mesmo mês, ordenaria a saída de todos os que não estivessem sob a alçada dos inquisidores, para outras zonas da Europa, vedando-lhes o norte de África (62). No entanto alguns decidiriam embarcar clandestinamente para esta região, a fim de mais facilmente poderem retornar à fé de origem. Sobre os desrespeitadores da proibição régia, mestres e donos das caravelas transportadoras dos «marranos» e dos seus haveres caía dura a justiça real: perda da vida e confisco dos bens, incluindo os barcos, para a coroa (63).

Más a grande debandada dar-se-ia com a publicação do édito de expulsão de todos os judeus de Espanha, em Março de 1492. A partida fazia-se penosamente: era uma nova diáspora que se iniciava e que muitos interpretavam como o castigo de Deus pelos pecados cometidos pelo seu povo, remontando-os à adoração do bezerro de ouro. A necessidade de vender os bens em prazo tão curto, três meses apenas, acarretaria obviamente a depreciação das propiedades e das mercadorias que a legislação proibia exportar como ouro, prata, moedas, armas, cereais, etc. O caminho era duro e sem regresso para muitos. Se, em Castela, uns cristãos os ajudavam, como alguns cavaleiros e oficiais das comarcas fronteiriças, em troca de uma parte da fazenda que os expulsos levavam, como os de Cáceres e Arroyo el Puerco (64), outros exigiam-lhes portagens e impostos ilegais, como em Fresno de los Anjos, Cidade Rodrigo (65) e no caminho que ia de Bobeda para Samora (66), e outros ainda, matavam-nos para os roubar, como o assassinato de judeus que vinham para Portugal, nos arredores de Placência (67).

Este reino fora, de facto, a nova pátria escolhida por uns e aceite pelo soberano, ou um mero local de passagem para outros lugares. Contra a maioria do seu conselho, don João 'll responderia favoravelmente aos representantes dos judeus castelhanos, autorizando a entranda e permanência no reino, de um certo número de famílias. Desconhecemos ao certo quantos entraram, quer oficial, quer clandestinamente, par aqui se fixarem ou para utilizarem Portugal como lugar de trânsito para o norte de África ou para o Levante me- 
diterrânico. Em contrapartida, o monarca procurava obter dinheiro para a cruzada contra os mouros e experientes profissionais de certas artes, ligadas à actividade bélica.

Os cronistas não coincidem nas informações que nos transmitem. Rui de Pina preocupou-se mais em assinalar o parecer desfavorável dos conselheiros e a reacção contrária dos povos, perante a entrada dos judeus castelhanos a qual viria acompanhada pela peste. Estes teriam oito meses para abandonar o reino, sob pena de ficarem cativos para coroa. O rei comprometia-se a colocar barcos à disposição dos que se encontravam de passagem (68).

Garcia de Resende limitar-se-ia a relatar a versão oficial, sem fazer eco da oposição do conselho nem dos povos. Segundo ele, o cativeiro seria apenas para os que tivessem entrado clandestinamente no reino (69).

O cômputo apresentado pelos contemporâneos seria bastante díspar. Damião de Góis escrevia que entraram em Portugal mais de 20000 casais, alguns com dez e doze pessoas, o que somaria mais de 100000 indivíduos (70). Abraão Zacuto mencionaria 120000 judeus castelhanos aqui imigrados (71). Segundo aquele cronista, destes uns pagavam oito cruzados per capita, excepto as crianças de colo cuja entrada não fora taxada, e os mesteirais de arte do ferro que entregavam metade daquele valor, no caso de cá quererem ficar (72).

Samuel Usque falaria do imposto de dois escudos que os adventícios pagariam, enquanto Jerónimo Osório referida oito escudos (73).

Os cronistas espanhóis indicar-nos-iam cerca de cem mil, os judeus que teriam entrado em Portugal (74).

Aboab, um século mais tarde, confirmaria a entrada das 600 «casas» que permaneceriam em Portugal. O Porto receberia trinta famílias que se fixariam na rua de $S$. Miguel (75).

Don João II, ao autorizar a entrada dos judeus castelhanos, limitou-lhes os portos de entrada no reino. Segundo os cronistas espanhóis, estes seriam: Bragança, Miranda, Vilar Formoso, Marvão e Eivas (76). A estes lugares de recepção, onde se encontravam os recebedores do rei, correspondiam os lugares fronteiriços castelhanos de Puebla de Sanabria, San Felices de los Gallegos, Ciudad Rodrigo, Valência de Alcântara e Badajoz (77).

Os oficiais castelhanos vigiavam para que os emigrantes não saíssem de Castela com mercadorias defesas, no que eram auxiliados por alguns cristãos, certamente em troca de alguns bens dos judeus: «Sepades que a nos 
es fecha relaçion que de tres meses a esta parte diz que algunos judios de los que biven en las villas de Caçeres e Arroyo el Puerco e en otros lugares de la comarca han sacado fuera de nuestros reynos para el reyno de Portugal y para otras partes, oro e plata e moneda amonedada y que algunos caballeros de las dichas villas e sus comarcas les han dado para ello ayuda e consejo y les han favoresçido" (78). Os portugueses fiscalizavam as entradas, interrogavam sobre os lugares de proveniência por causa da peste e colectavam o tributo para a permanência ou a passagem pelo reino. No entanto, muitas familias judaicas passariam clandestinamente a fronteira.

Como de costume, a documentação não é abundante em informações sobre o total de dinheiro e de pessoas entradas no reino. Pelas cartas de quitação dos recebedores, podemos distinguir três qualidades de judeus castelhanos:

- os judeus das 600 «casas» que viriam a ser tributados em 8 cruzados de ouro e distribuidos por Lisboa, Évora, Porto e Coimbra;

- os judeus em trânsito, taxados também em 8 cruzados, por cabeça;

- e os mesteirais do ferro, colectados em 4 cruzados.

Pela carta de quitação, dada por don Manuel a Fernando Afonso, sabemos que este recebeu, em Lisboa, 8390220 reais dos judeus castelhanos (79).

João Mendes Cicioso, recebedor em Évora, ficou quite da soma de 8 951312 reais, distribuida por:

- 5106169 reais e meio dos judeus das 600 "casas»;

- 3610618 reais e meio dos judeus taxados a 8 cruzados por cabeça;

- 187590 reais dos ferreiros e latoeiros inscritos, à razão de 4 cruzados cada;

46935 reais, entregues por Antão de Gigueiredo, recebedor-mor destes dinheiros na corte (80).

Pela quitação de João Álvares de Almada, sucessor deste no cargo de recebedor-mor da capitação dos judeus castelhanos na corte, sabemos que entraram no cofre 26356957 reais, assim repartidos:

- 3183961 reais de Fernando Afonso, recebedor em Lisboa do dinheiro das 600 «casas», a 8 cruzados;

- 751000 reais de Pedro Pessoa, recebedor das mercadorias dos ditos judeus; 
- 2605420 reais de João Brandão, colector da capitação das 600 «casas" no Porto;

- 59280 reais de João Bispo, recebedor das taxas dos ferreiros e latoeiros;

- 1604110 reais de Afonso Gonçalves, encarregado de receber o dinheiro das 600 «casas» em Coimbra;

- 6439610 reais de João Mendes Cicioso, recebedor das 600 «casas» em Évora;

- 244252 reais de João Gonçalves Batavias, recebedor do Algarve;

- 3885000 reais de Antão de Figueiredo, antecessor de João Álvares, no cargo de recebedor;

- 92038 reais de Afonso Vasques, cobrador da taxa na porto de Marvão;

- 4578000 reais, pagos pelas comunas dos judeus «pollo perdam das recadações";

- 1130000 reais, entregues pelso judeus castelhanos, como parte do pagamento do dito perdão;

- 11700 reais de alguns judeus de 8 cruzados;

- 4080 reais de mestre Jacob (81).

As cartas de quitação acabadas de referir permitem-nos extrair algumas conclusões sobre a tributação que recaiu sobre os judeus castelhanos que entraram legalmente em Portugal. Assim, temos que:

- 8 cruzados foi a capitação paga por todos os judeus de maioridade, quer os designados das 600 «casas» que aqui permanéceriam, quer os que se encontravam de passagem para outros lugares, com excepção dos mesteirais do ferro, que pagavam metade;

- Sobre os bens móveis recairia uma taxa de valor desconhecido;

- Para libertar os insolventes, o soberano lançou um «perdão» general, pago pelas comunidades nacionais e pelos judeus castelhanos.

Podemos também, com uma certa cautela, tentar fazer uma estimativa sobre o número de indivíduos que entraram no reino, embora reconheçamos que ele ficará sempre aquém da realidade, atendendo ás discrepâncias apresenadas pela própria documentação e ao facto de ignorarmos completamente a quantidade de pessoas entradas pelos portos de Miranda e de Bragança 
e os imigrantes clandestinos que viriam a beneficiar da libertação dada por D. Manuel quando subiu ao trono. A outra ressalva respeita ao facto de desconhecermos se os totais apresentados indicam somente o quarto do tributo ou a sua globalidade por indivíduo.

Se partimos da hipótese de que as verbas referidas representariam o quarto da tributação individual, teriamos, pela carta do recebedor-mor da corte, um equivalente a 23.320 judeus aproximadamente. Cerca de 20.000 ter-seiam distribuido por Lisboa e Évora, os concelhos com maiores judiarias. Só a cidade alentejana deveria ter recebido um contingente que oscilaria entre os 8.256 e os 11.164 judeus, no seu máximo, além de cerca de 480 ferreiros e latoeiros (82). Dado o seu número elevado, os imigrantes não couberam nas casas do bairro judaico, devendo também distribuirem-se pelas casas dos cristãos (83). Mais tarde, após o édito de 1497 e da saída dos mouros do reino, muitos destes cristãos novos de origem castelhana iriam habitar a antiga mouraria.

D. João II tentaria afastá-los do Algarve, que só viria a receber uma parte mínima, cerca de 312 indivíduos. Procurava assin impedi-los de partir para terra mouros.

Conhecemos a existência de acampamentos fronteiriços, onde temporariamente se alojaram alguns destes judeus. Em Castelo de Vide, esteve erguido um, certamente para os que entrariam pelo porto de Marvão. segundo Velasco da Mota, oficial a quem cabia a vigilância, defesa e alçada deste arraiàl, em Setembro de 1492, encontravam-se nele entre 4.000 e 5.000 pessoas, guardadas de dia e de noite, para evitar os roubos e raptos feitos pelos castelhanos, durante as suas surtidas em território português (84). Em Vila Flor de Trás-os-Montes teria tido lugar outro desses acampamentos (85).

Os números que calculámos estão certamente aquém do número de judeus castelhanos, entrados em Portugal. Creemos, no entanto, que esse número nunca se aproximaria dos 100.000 individuos referidos pelos cronistas. No seu máximo andaria pela metade.

Embora a intenção do soberano fosse conceder residência a um número limitado de judeus, as 600 «casas», o facto é que muitos outros escolheram Portugal como local de permanência temporária. Um número indeterminado entrou clandestinamente. Sobre estes, por ñão lhes ter sido concedida autorização para aqui entrarem e sobre os que ficaram insolventes, a justiça real caiu dura: a servidão foi o seu castigo. Jacob tornou-se escravo da estrebaria real (86). Bernáldez calcularia na ordem do milhar o número de judeus castelhanos que se teriam tornado servos do rei (87). 
Para estes, D. João II publica a 19 de Outubro de 1492, uma lei tendente a atrai-los à conversão, concedendo-lhes amplos privilégios e a possibilidade de regressarem à sua terra de origem (88).

Aos que recussaem o baptismo e estivessem na situação de devedores da coroa ou de clandestinos, o soberano mandar-Ihes-ia tirar os filhos que entregaria a Álvaro de Caminha, em 1493. O seu destino seria S. Tomé, ilha atlântica que o soberano desejava povoar, além de nela sesénvolver a cultura da cana sacarina (89).

Apesar de toda a crueza de que se revestiu o acto, régio, D. João II não os deixou ao abandono, ficando o próprio capitão e donatário da ilha responsável por eles, segundo o próprio testemunho, que deixou exarado no seu testamento: «quamdo viim de Portuguall trouxe allvara del rrei dom Joham que Deus teem para a cada cimquo moços dar hũu escravo e hũua escrrava pera suas mamtemças ou os dar a quem os guovernase em quamto nom fosem pera per sy vyverem e porque niquem os podia milhor aguassalhados e curados teer que eu memcarreguey delles thomamdos em minha casa guovernados com os ditos sseus escrravos e com outros que dos del rrei pera isso thomey» (90). Apesar de caber ao so berano o vestir e a alimentação destés jovens judeus que ele baptizara e que se educavam em $S$. Tomé, a verdade é que a vida ñão era fácil para ninguém e muito menos para crianças. A fome, a doença e os animais selvagens viriam a dizimar muitas delas. o próprio Álvaro de Caminha no-lo afirmaria: «muyito çedo tyve a comy disso que avya no mato e mandey moços fora pellas amgrras pera sserem mamtheudos". Aos filhos dos judeus castelhanos que sobrevivessem, deixava os bens que possuia como donatário de S. Tomé Pedro Álvares, seu familiar, que ele instituia como sucessor no cargo de capitão e donatário da ilha, ficava com a incumbência de cuidar das crianças «e saber com sam limpos castiguados e emsignados e em sseus mamtimentos e em todo ho all que pera consservaçã de suas vidas e emsinos comprir» (91).

As informações da época ñão são abunantes em nomes dos que ficaram no reino. Se uns escolheram Portugal para segunda pátria, como Salomão, Mestre, rabi Habney (92), D. Samuel, físico (93), Benveniste Calahorra (94), Meir Sornaga (95), rabi Juda Corcoz (96), mestre Moisés de Saragoça, cirurgião (97), Moisés Hen da Corunha (98), os rabis Isaac Aboab que viria a falecer no Porto (99), Sem Tob (100) e Abraão Zacuto (101), etc, outros aqui entraram para passar a África ou à Europa e outros, os de menores posibilidades económicas, para retornarem baptizados à sua terra de origem e reocuparem suas casas e bens. $O$ apelo à conversão de $D$. João II surtira o seu afeito e tivera correspondência por parte dos Reis Católicos: «Sepades 
que por parte de algunos judios estantes en el reyno de Portugal, que por nuestro mandado salieron de nuestros reynos y señorios nos es fecha relaçion que ellos, alumbrados del Espiritu Santo conosciendo el herror en que estavan se querian bolber a estos nuestros a nuestros reynos para que se convertir a nuestra Santa Fe catholica e permanesce e morir en ella como catholicos christianos e por su petiçion nos fue soplicado e pedido por merçed que para venir a estos nuestros reygnos les diesemos nuestra carta de seguro para que libre e seguramente pudiesen venir ellos con sus hijos e mugeres e faziendas» (102). A conversão significava para muitos a possivilidade de retomar a liberdade perdida, a subsistência económica e a segurança físi$\mathrm{ca}$, ante os roubos e atrocidades cometidas, quer pelos mareantes, quer pelos mouros aos que passavam ao norte de África. Receber o baptismo em Portugal ou na fronteira castelhana era a possibilidade de retornar à terra de origem, aos seus bens vendidos ao desbarato, porque despreciados com a urgência da partida, e a esperança de amanhã poder noutras paragens e por moios mais seguros, voltar à fe dos seus antepassados.

A 15 de Janeiro de 1493, os Reis Católicos outorgavam carta de segurança a D. Çague Abuacar, físico «e a todos los judios e judias que con el se tornem christianos en el dicho reyno de Portogal o en el primer logar de christianos donde entraren en nuestros reynos e trayendo fe e testimonio dello para que puedan venir libremente a estos nuestro reynos e estar a bevir en ellos. Otrosy les damos liçençias en abrayco e en aravigo con tanto que no sean libros del Talmud ni Brivia ni otros libros de la lei musayca. E mandamos a qualesquier personas a quien ellos vendieron sus bienes rayzes despues que nos les mandamos salir destos nuestros reinos que ge los tornen a restituyan pagandoles lo que por ellos les dieron con lo que mas en ello ovieren gastado e mejorado" (103).

Juda Corcos, de Samora recebia carta de segurança e de perdão por ter passado mercadorias defesas para Portugal (104). João Soares e Ferrand Nuñes, vizinhos de Fuentidueña, obtiveram permissão para retomar os seus bens, uma vez que se baptizaram em Portugal (105). Cartas idênticas seriam outorgadas a Afonso García de Badajoz, Diego de Silvera, Francisco Nieto, fernando de Alcaraz, Henrique de la Torre, João dias e João de Toro, todos de Puente del Arzobispo, Rodrigo Arias Maldonado, de Cidade Rodrigo, etc. (106).

O mês de Dezembro de 1496 tornaria a trazer o desespero aos judeus. Desta vez seria o rei de Portugal que, obedecendo às exigências da política peningular, decidiria expulsá-los do reino, após ter tido logo após a subida ao trono a atitude magnânima de dar a liberdade aos judeus castelhanos que 
ainda se encontravam em cativeiro. O prazo limite para partirem seria o mês de Outubro de 1497. Só poderiam ficar os que decidissem receber o baptismo.

No entanto, D. Manuel ñão desejava a partida de uma minoria tão importante económica e culturalmente para o país. Enquanto os mouros partiriam, sem qualquer entrave, para Castela e Äfrica, os judeus veriam erguer-se obstáculos diversos, com a finalidade os dissuadir de partor. $\grave{A}$ limitação dos portos de embarque, seguir-se-ia o baptismo forçado das crianças, começando pelas de menos idade até atingir os adolescentes. A estes seguir-se-iam os adultos obrigados a converter-se, uma vez que muito poucos conseguiriam partir dentro do prazo estabelecido pelo soberano.

Baptizados, muitos destes judeus castelhanos preferiram permanecer em Portugal a retornar a Castela, definitivamente, embora a mobilidade fosse uma das suas principais características. Tal vez que um das razões fosse a promessa de $\mathrm{D}$. Manuel de não inquirir sobre a sua religião, durante os próximos vinte anos (107)

Rabi Moisés de Palência fixar-se-ia com a sua família em Tomar, onde viria a falecer, juntamente com a esposa antes do baptismo geral. Seu filho, casado com uma judia, receberia as águas do baptismo em Lisboa, aonde se dirigira para vender alguns bens para a partida e após the terem retirado o filho único, criança de meses. Se ignoramos o nome judaico desta família, conhecemos, no entanto, o nome cristão que aquele viria a tomar: Jorge Manuel. Mercador, home rico e conceituado, manifestaria uma arrogância perante os cristão e outros correligionários de origen castelhana, de apelido Jusarte. As duas famílias viriam a ser vítimas de actuação do Tribunal do Santo Ofício, em Tomar, e a Jorge Manuel não the valeria tão pouco o ter uma filha casada com um cristão velho, cavaleiro da casa real, e um filho, mestre antónio Manuel, cirurgião do mestre do convento de Cristo e inquisidor nas terras da ordem de Cristo. Jorge Manuel sairia no auto da fé de 1543, condenado por herege convicto e persistente. Os Jusarte, seus inimigos, sairiam reconciliados, embora condenados a cárcere e hábito perpétuos, com excepção do filho mais novo, nascido cirstão, Gaspar, que viria a ser queimado. O ódio e a rivalidade entre as duas famílias seria bem visível ao longo do processo de Jorge Manuel: este, orgulhoso da sua aristocracia e linhagem, da sua posição social, pois era mercador de grosso trato, enquanto os Jusarte eram simples plebeus, enriquecidos com o comércio das carnes e dos curtumes (108).

Tambén alguns familiares do rabi Abraão Seneor escolheriam Portugal para residir. A estes foi-lhes permitido mantener o apelido Coronel. Mestre 
Nicolau Coronel, físico de D. Manuel, receberia ainda o privilégio de ser feito fidalgo de solar. A sua nobilitação exigiria da parte do soberano, uma carta de limpeza de nascimento: «e the tiramos toda a macula que por seu naçimento ou por qualquer erro, outra cousa lhe posa seer posta» (109). Outro Membro desta família era o cirurgião metre Francisco Coronel, morador no Porto (110).

As genealogias referenciadas nos processos das diversas inquisiçãooes permitem-nos reconstituir a biografia de alguns judeus castelhanos que aqui permaneceram. As diversas comunidades transmontanas são disso uma pequeña amostraguem. Tomemos por exemplo a cidade de Bragança:

Francisco Aires era natural de Medina del Campo. Veio para Portugal adolescente. Foi baptizado na Lousã. Viveu em Lisboa antes de ser fixar definitivamente em Bragança. Aqui vivia dos redimentos e dedicava-se à arrematação das rendas. Era um indivíduo abastado e de prestígio social, pois era escudeiro do duque de Bragança. Com cerca de 62 anos de idade seria preso pela Inquisição e acusado de criptojudaísmo, vindo a beneficiar do perdão geral de 1548, depois de ter confessado as suas culpas (111). A sua terceira mulher, a portuguesa Branca Fernandes, de 25 anos de idade, presa pela mesma altura, não viria a ter a mesma sorte. a sua confisão não foi reconhecida como suficiente, pelo que viria a ser condenada por herege e queimada em Évora, a 23 de Novembro de 1551 (112). Seu marido já não conherecia o seu trágico fim, pois entretanto falecera.

Dinis Álvares de Carvajales era tido por rabi, dentro da comunidade cristã nova. Viria a ser relaxado, em Lisboa, cerca de 1544. Seu filho, Bento de Leão, receberia a reconciliação (113). Luis Álvares, preso na Inquisição de Évora, em 1544, era igualmente natural de Castela (114), o mesmo sucedendo com Gonzçalo (115) e Manuel de Aranda (†16).

Os Carriões eram naturais de Zamora. Luis do Mercado era um letrado na lei de Moisés que fora escrivão dos judeus, na comuna desta cidade. Alcolheu-se a Bragança, onde parte dos filhos ficariam a residir, enquanto outros regressariam à terra de origem. Seus netos, Luis do Mercado e Tomé do Mercado, este último residente em Castela, viriam a ser presos pela Inquisição de Valladolid, enquanto a mãe, a anciã Beatriz Gonçalves, a "carriona» o seria pela Inquisição de Évora (117).

Álvaro Gomes era originario de Ponferrada, na Galiza (118). Diogo de Ledesma, alfaiate, era natural de Leão e estava casado com Susana de Valladolid, natural de Carmona. Ambos seriam presos pela Inquisição, vindo a beneficiar do perdão geral de 1548 (119). Diogo Neto, tosador e mercador, era 
filho de Francisco neto e de Helena Álvares, naturais de Ledesma. Seu irmão António residia em Miranda Do Duoro (120). O sapateiro Sebastião Pires era galego e à sua terra de origem se alcoheria com a entrada da Inquisição em Portugal (121).

Exemplos dessa fixação foram os apelidos de origem toponímica que aqui permaneceram: os Sória, os Valladolid, os Ledesma, etc.

Enquanto na região transmontana, os cristãos novos de origem castelhana provinham das regiões vizinhas da Galiza, Leão e Castela, continuando a mantener relações com os seus familiares que aí permaneceram ou que a esses lugares retornaram posteriormente, em Évora, por exemplo a proveniência marcante seria Castela e Andaluzia. Apenas alguns exemplos:

Beatriz Álvares, a carvoeira, casada com João de Cáceres, borzegueiro, cristão velho, segundo a mulher, era natural de Mérida (122).

O judeu Samuel, de Talavera de la Reina, entraria em Porugal em 1492. Foi baptizado em Alcoutim, no Algarve, juntamente com sua mulher, natural de Escalona. Em cristãos, tomariam os nomes de Fernão Álvares e de Guiomar Rodrigues. Dois dos seus filhos emigrariam para Goa, como soldados, outro residia em Lisboa, enquanto uma filha se encontrava casada na Beira. Preso, com cerca de 75 anos, seria condenado a abjurar de leve (123). Naquela data, entraria tambén o castelhano António Caldeirão, tecelão de pano de linho (124).

Uma família cristã nova importante seria a dos Córdovas, relacionada com gente honrada e fidalga. Constança Fernandes «Cordona», natural de SeguraCórdova, definia-se como mulher rica, honrada e virtuosa. Era casada com o converso castelhano Álvaro Gonçalves Cordão. Era tia dos Córdovas, dos quais um deles era cónego no sé de Évora (125). Alguns dos seus irmãos seriam queimados pelas inquisições de Llerena e de Toledo.

Como conclusão, podemos dizer que foi constante a presença de judeus castelhanos, em Portugal, quer devido à imigração, provocada pelos diversos levantamentos antisemitas ao longo da Idade Média, e pela expulsão de 1492, quer devido à mobilidade natural deste povo, quer ainda às relações familiares e económicas que se estableceram entre os indivíduos de um e outro reino.

Algumas destas familias viriam a distingui-se pela projecção social, económica e cultural alcançada.

O êxodo, nos finais de quatrocentos, faria de Portugal e, nomedamente de Lisboa e da sua academia, e centro único da cultura judaica peninsular. 
Para aqui seriam trazidos os mais antigos códices, como o Hil-leli, que depois seria vendido em África, segundo Abraão Zacuto (126), enquanto outros livros hebraicos tomariam o caminho da Índia (127).

Com o baptismo geral de 1497, muitos dos judeus castelhanos optariam por aqui ficar; outros regressariam à sua pátria de origem. Permaneceria, no entanto, entre as comunidades cristã-novas naturais de Portugal e de Castela, as mesmas características ancestrais:

- Mobilidade constante, dentro e fora do reino, tendo a melhor fugir à Inquisição e a alcançar outras paragens, onde pudessem voltar ao judaísmo;

- permanência dos cruzamentos familiares entre os membros de aquém e além fronteira.

Como aspecto novo, encontramos agora o acesso fácil à universidades, onde se destacam Coimbra e Salamanca, aos cargos municipais, aos de administração central e aos eclesiásticos. Tudo isto os tornava prestigiados e poderosos pelas relações com a nobreza, a Igreja e a corte. $O$ "statu quo", odiado pelos cristãos iria permanecer na minoria, ja não judaica, mas cristã nova.

A importância da presença castelhana entre esta minoria seria marcada pela vivência dos ideais messiânicos que iriam fazer dos cristãos novos de origem castelhana as primeiras vítimas da Inquisição portuguesa. 


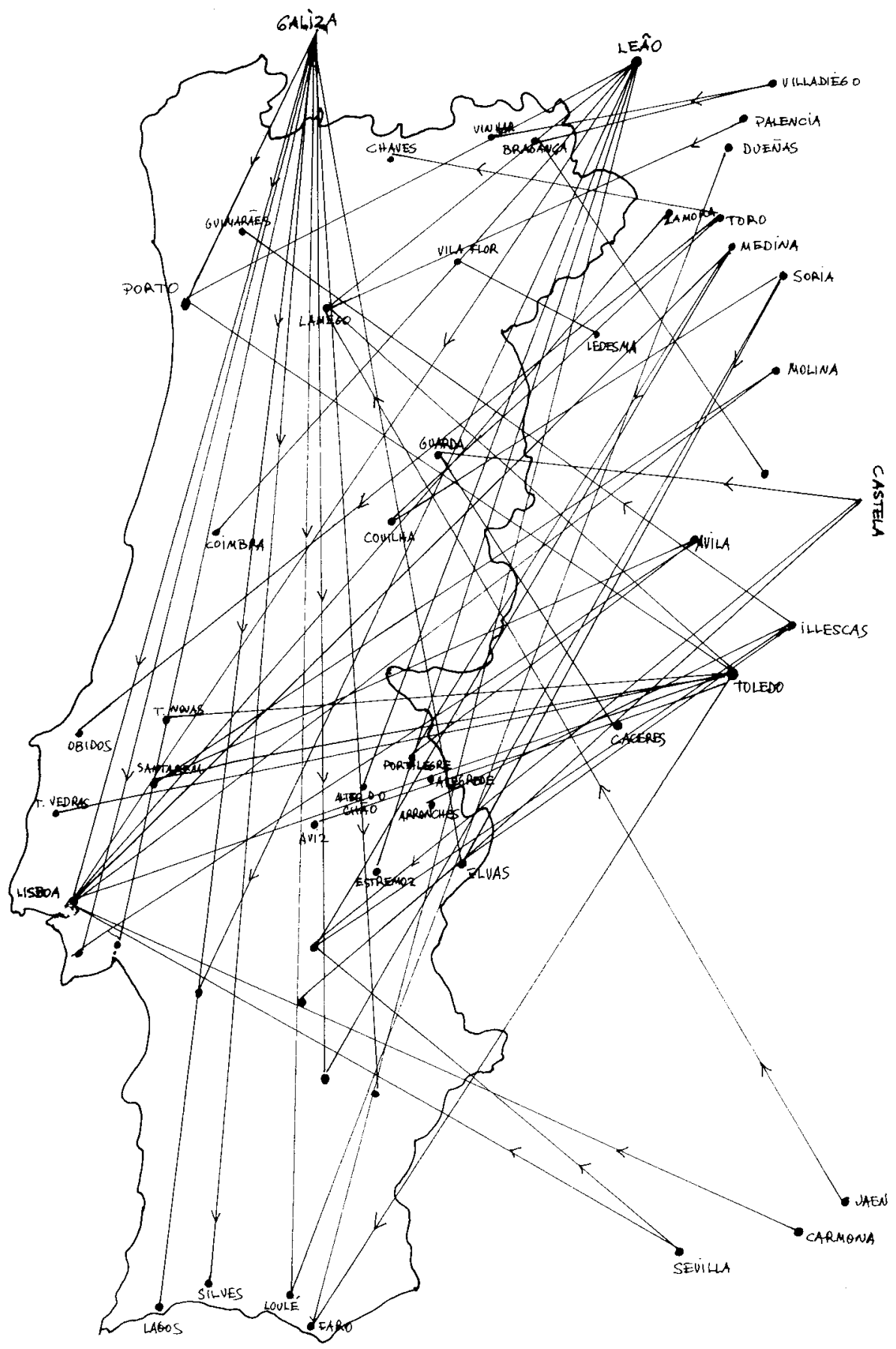

Mo 1.- Imjoracäo de judeus castelhanos, durante a

1. metade do séculoxv. 


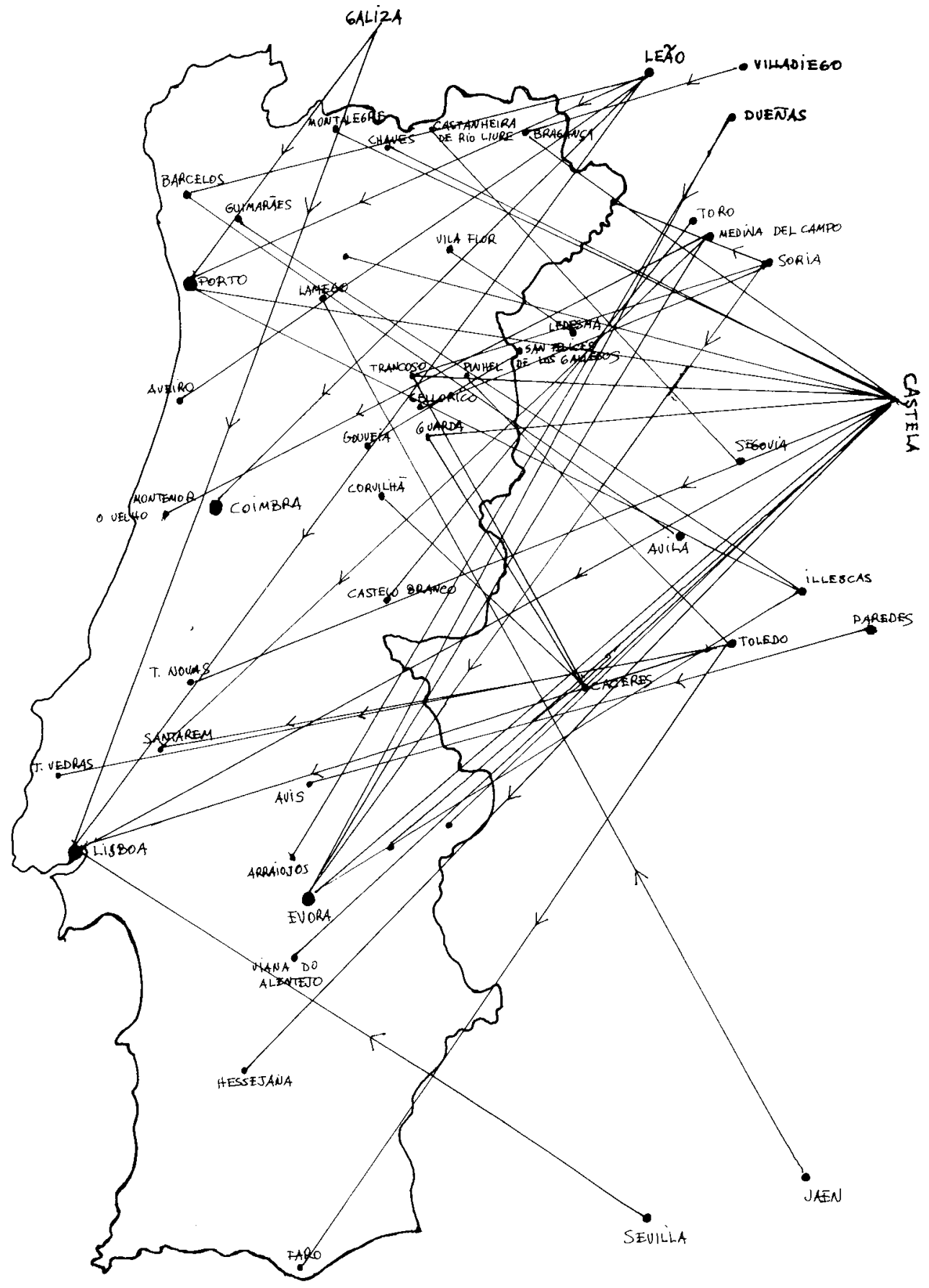

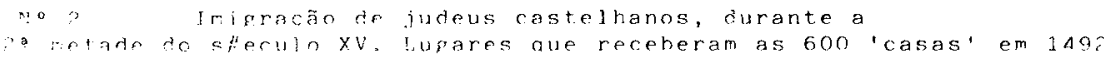




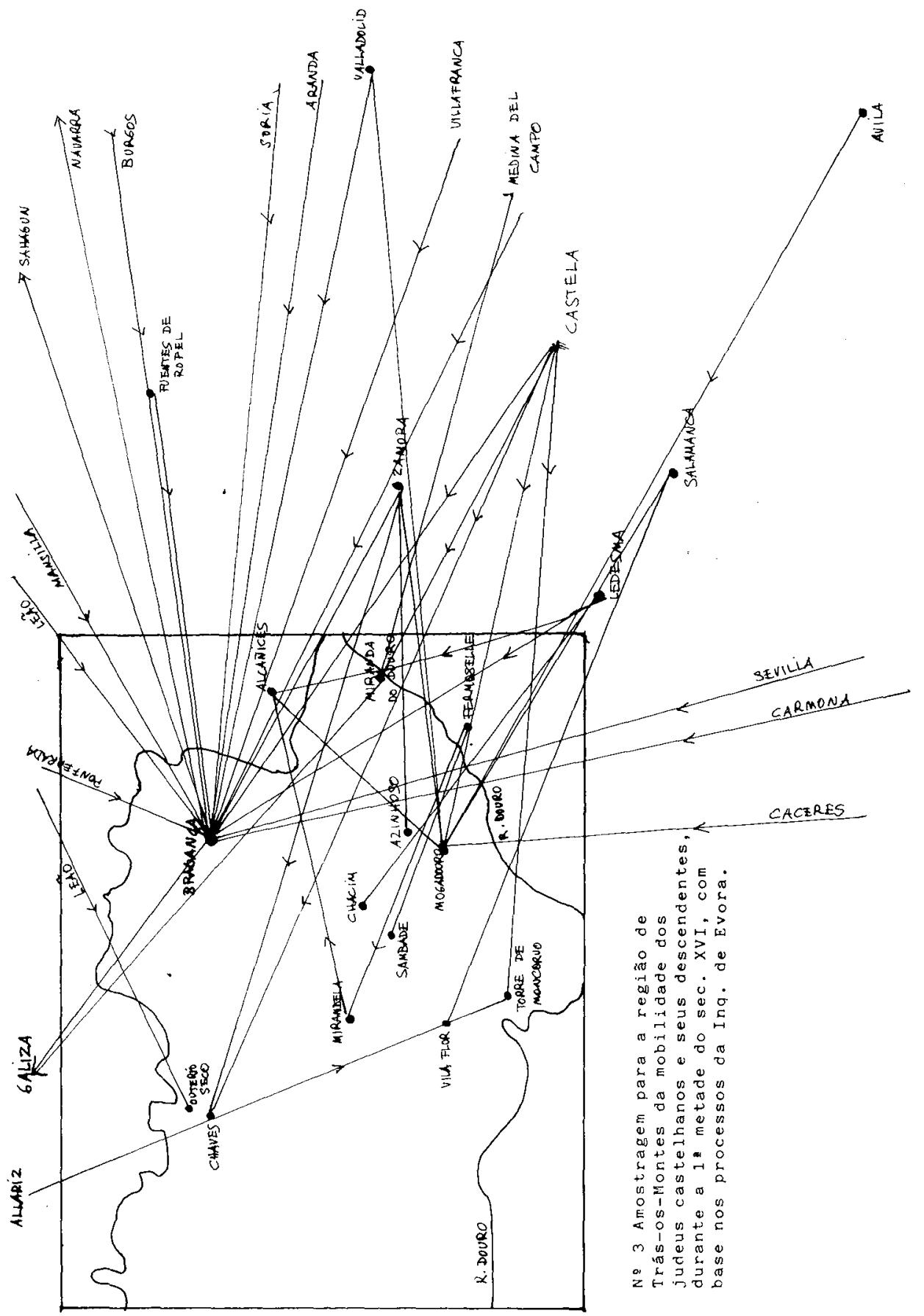





\section{NOTAS}

(1) Veja-se: AMADA LÓPEZ DE MENESES, «Una consecuencia de la peste negra en Cataluña: el pogrom de 1348", in Sefarad, Madrid 1959. vol. 19, pgs. 92-131 e 321-364, entre outros.

(2) J. AMADOR DE LOS RIOOS, Historia social, política y religiosa de los judíos de España y Portugal, eds. Aguilar, 2. ${ }^{2}$ ed., Madrid 1973, pgs. 456-550.

(3) MARÍA JOSÉ PIMENTA FERRO TAVARES, Os judeus em Portugal no século XV, Universidade Nova de Lisboa, Lisboa 1982, vol. I, cap. VII, pgs. 418-430.

(4) Ibidem, pgs. 400-404

(5) AMADOR DE LOS RIOS, ob. cit., pgs. 526-527.

(6) MARÍA JOSÉ FERRO TAVARES, ob. cit. pg. 421.

(7) Ordenaçōes Afonsinas, Coimbra 1792, liv. It, tit. 77, pgs. 457-460.

(8) Ibidem

(9) Ibidem, tit. 94 , pgs. 514-519.

(10) Sobre este asunto, veja-se: MARÍA JOSÉ FERRO TAVARES, ob. cit., pgs. 432-433.

(11) A. N. T. T., Reis, liv. 1, fis. 85-92; Monumenta Henricina, Coimbra 1964, vol. VI, pgs. 108-132; MARIA JOSÉ FERRO TAVARES, ob. cit., pg. 312.

(12) B. NETANYAHU, Don Isaac Abravanel, statesman and philosopher, 3. ${ }^{a}$ ed., Filadélfia 1972, pgs. 5-6 e 266-267, notas 12 a 14; Y. BAER, A history of the jews in christian Spain, Filadélfia 1966, vol. I, pg. 378 e vol. II, pg. 93.

(13) "Ya» aparece-nos na documentação sem qualquer abreviatura e exclusivamente aplicado aos Abravanéis. Poder-se-ia pensar numa forma abreviada de Jacob.

(14) A. N. T. T. Chancelaria de D. Afonso V, liv. 3, fis. 86v. -87 e Estremadura, liv. 8, fls. $299-$ 300 , respectivamente.

(15) Ibidem, Chancelaria de D. Afonso V, liv. 2, fl. 76v.

(16) Encyclopedia Judaica, Jerusalem 1971, vol. il, pg. 103.

(17) Henrique Fernandes Abravanel e Inês Fernandes, sua mulher, eram sobrinhos de Luna Abravanel, que em cristā se chamaria Leonor Fernandes (A. N. T. T., Chancelaria de D. Manuel, liv. 4, fl. 25; N. A. 318, fl. 23; Corpo Cronológico parte 1. ${ }^{\mathrm{a}}, \mathrm{m} .10, \mathrm{n} .{ }^{\circ}$ 165. Pela mesma altura, morava igualmente em Lisboa, Álvaro Fernandes Abravanel (Ibidem, Corpo Cronológico, parte 3. ${ }^{2}, \mathrm{~m} .4$, doc. 20 )

(18) Ibidem, Chancelaria de $D$. Afonso $V$, liv. 15, fls. $174 \mathrm{v}$. e $38 \mathrm{v}$., respectivamente.

(19) Ibidem, liv. 9, fl. 92v. e liv. 26, fls. 1-5; MARÍA JOSÉ P. FERRO TAVARES, ob. cit., vol. II, INIC 1984, pgs. 773-775.

(20) A. N. T. T., Chanceleria de D. Afonso V, liv. 32, fl. 38V.

(21) Ibidem, liv. 32 , fls. $77-77 \mathrm{v}$.

(22) Ibidem, liv. 4, fl. 14.

(23) Ibidem, liv. 15, fis. $38 \mathrm{v},-39$. 
(24) Ibidem, liv. 9, fl. 92v.

(25) Ibidem, liv. 33, fl. 182v.

(26) Ibidem, liv. 14, fls. 10v.-11; Estremadura, liv. 5, fl. 94v.

(27) A. TEIXEIRA DE ARAGÃO, Descripção geral e histórica das moedas cunhadas em nome dos reis, regentes e governadores de Portugal, 2. ${ }^{\text {a }}$ ed., Porto 1964, vol. I, pgs. 374-381.

(28) VIRGÍNIA RAU, "Alguns estudantes e eruditos portugueses em Itália no século XV", in Do Tempo e da História, IAC, Lisboa 1972, vol. V, pgs. 87-88.

(29) A. N. T. T., Chancelaria de D. Afonso V, liv. 3, fls. 86v. -87 ; Extras, fls. $69 \mathrm{v} .-70$ e 119v. -120.

(30) Ibidem, Chancelaria de D. João II, liv. 6, fls. 133v.-135.

(31) Ibidem, Corpo Cronológico, parte 1. ${ }^{a}$, m. 10, n. ${ }^{\circ} 165$.

(32) Ibidem

(33) Ibidem, Chancelaria de D. João II, liv. 21 , fls. 39v.-40.

(34) Ver nota 31.

(35) Ibidem, Chancelaria de $D$. Afonso $V$, liv. 1, fl. $16 \mathrm{~V}$

(36) Ibidem, liv. 6, fl. 95.

(37) A. BRAAMCAMP FREIRE, "As conspiraçãos no reinado de D. João \|», Archivo Historico Portuguez, vol. Il, docs. n. ${ }^{\circ} 4,6$ e 15.

(38) Ibidem, doc. n. ${ }^{\circ} 6, \mathrm{pg} .32$.

(39) GARCÍA DE RESENDE, Cancioneiro Geral, Coimbra, Imprensa da Universidade 1910, vol. I, pgs. 62-63. (Os sublinhados são da nossa responsabilidada e identificam Samuel e Isaac Abravanel).

(40) Ver mapa . $^{\circ} 1$.

(41) A. N. T. T., Chancelaria de D. Afonso V, liv. 27, fl. 155.

(42) Ibidem, liv. 34, fl. 64v.

(43) Ibidem, liv. 1, fl. 43.

(44) Ibidem, liv. 14, fl. 2.

(45) Ibidem, liv. 32, fl. 63.

(46) Ibidem, liv. 9, fl. 94; liv. 36, fl. 196v.

(47) Ibidem, liv. 8, fl. 109.

(48) Ibidem, liv. 9, fl. 110v.

(49) Ibidem, Chacelaria de D. João II, liv. 25, fl. 66.

(50) Ibidem, liv. 16, fl. 115v.

(51) Ibidem, liv. 1, fl. 48.

(52) Registro General del Sello, Valladolid 1950, vol. I. n. ${ }^{\circ} 886, \mathrm{pg} .109$; Records of the trials of Spanish Inquisition in Ciudad Real, ed. H. Beinart, Jerusalem 1985, vol. IV, pags. 50 , $53,61,63,68$, etc.

(53) Porto, Gabinete de História de Cidade, Vereações, liv. 5, fls. 9v.-10

(54) Porto, Gabinete de História de Cidade, Vereaçōes, liv. 5, fls. 99-100; MARÍA JOSÉ FERRO TAVARES, ob. cit., vol. I, pg. 479 , nota 366 .

(55) Ibidem

(56) Porto, Gabinete de História de Cidade, Vereaçôes, liv. 5, fl. 107v.

(57) Ibidem, fls. $111 \mathrm{v} .-111 \mathrm{v}$.

(58) RUI DE PINA, Chroniqua del rey dom Joham II, Coimbra 1950, pgs. 79-80; GARCÍA DE RESENDE, Crónica de dom João /l, Imprensa Nacional-Casa da Moeda, Lisboa 1973, pgs. 101-102.

(59) A. N. T. T., Chancelaria de D. João II, liv. 15, fls. 36v. e 42.

(60) Lx., A. H. C. M., Livro 2. ${ }^{\circ}$ de D. João II. fl. 69.

(61) Livro das Posturas Antigas, Câmara Municipal de Lisboa, Lisboa 1974, pgs. 172-173.

(62) Ibidem, pgs. 173-175; MARIA JOSÉ FERRO TAVARES, ob. cit., vol. I, pg. 481, nota 378.

(63) MARIA JOSÉ FERRO TAVARES, ob. cit., pg. 447.

(64) L. SUÁREZ FERNÁNDEZ, Documentos acerca de la expulsión de los judíos, Valladolid 1964, pgs. 402-403, 418, 500-502.

(65) Ibidem, pgs. $452-453$. 
(66) Ibidem, pgs. 464-465.

(67) Ibidem, pgs. 505-506.

(68) RUI DE PINA, ob. cit., pgs. 179-183.

(69) GARCÍA DE RESENDE, ob. cit., pgs. 238-240.

(70) DAMIÃO DE GÓIS, Crónica do felicissimo rei D. Manuel, Coimbra 1949, pg. 23.

(71) Cit. por J. LÚCIO DE AZEVEDO, História dos cristãos novos portugueses, 2. a ed., Clássica editora, Lisboa 1975, pg. 21.

(72) DAMIĀO DE GÓlS, ob. cit., pg. 23.

(73) MARÍA JOSÉ FERRO TAVARES, ob. cit, pg. 253.

(74) ANDRÉS BERNALDEZ, Historia de los Reyes Católicos D. Fernando y D. ${ }^{a}$ Isabel. Crónica inédita del siglo XV, Granada 1856, vol. I, pg. 255; ALONSO DE SANTA CRUZ, Crónica de los Reyes Católicos, ed. Juan Mata Carriazo, Sevilha 1951, vol, I, pg. 661.

(75) I. ABOAB, Nomologia, Amesterdam 1629, pg. 322.

(76) ALONSO DE SANTA CRUZ, ob. cit, pg. 61; A. BERNALDEZ, ob. cit. pg. 255.

(77) SUÁREZ FERNÁNDEZ, ob. cit., pgs. 500-502 e 452-453, 424-425, 418-419, 402-403.

(78) Ibidem, pg. 402.

(79) A. BRAAMCAMP FREIRE, "Cartas de quitação del Rei D. Manuel» in Archivo Historico Portuguez, Lisboa 1904, vol. II, pg. 79.

(80) Ibidem, vol. III, pg. 472.

(81) Ibidem, pg. 315.

(82) MARÍA JOSÉ FERRO TAVARES, ob. cit., pgs. 253-257.

(83) ÉVORA, A. D., Livro 3 de Originais, fl. 214.

(84) Ibidem, fl. 207.

(85) A. N. T. T., Chancelaria de D. Manuel, liv. 32, fl. 99.

(86) Ibidem, Corpo Cronológico, parte $1, m .2, n .{ }^{\circ} 9$.

(87) A. BERNÁLDEZ, ob. cit., pg. 258.

(88) ÉVORA, A.D., Livro 3 de Originais, fis. 205-206v.

(89) GARCIA DE RESENDE, ob. cit., pgs. 253-254; RUI DE PINA, ob. cit. pgs. 187-188; I. ABOAB, ob. cit., pgs. 322-323 e 331 . 504.

(90) J. da SILVA MARQUES, Descobrimientos Portugueses, IAC, Lisboa 1971, vol. III, pg.

(91) Ibidem, pg. 510.

(92) I. N. T. T., Chancelaria de D. Manuel, liv. 40, fl. 32v.

(93) Lx., A. H. C. M., Livro 3 de D. João II, doc. n. ${ }^{\circ} 52$.

(94) Ibidem, doc. n. ${ }^{\circ} 61$

(95) Ibidem, doc. n. ${ }^{\circ} 62$

(96) A. N. T. T., Chancelaria de D. Manuel, liv. 26, fls. $27 \mathrm{~V} .-28$ e $64 \mathrm{v}$.

(97) Ibidem, liv. 32, fl. 108v.

(98) SUÁREZ FERNÁNDEZ, ob. cit., pg. 509.

(99) I. ABOAB, ob. cit., pgs. 321-322.

(100) M. GASPAR REMIRO, Los cronistas hispano-judíos, Granada 1920, pg. 36.

(101) A. N. T. T., Corpo Cronológico, parte 1, m. 2, n. ${ }^{\circ} 18$

(102) SUÁREZ FERNÁNDEZ, ob. cit. pgs. 487-489 e 526-527.

(103) Ibidem, pgs. 504-505.

(104) Ibidem, pgs. 520-521.

(105) Ibidem, pg. 528.

(106) R. G. del Sello, vol. X, pgs. 524-525.

(107) MARIA JOSÉ FERRO TAVARES, ob. cit, pgs. 486-487.

(108) A. N. T. T., Ordem de Cristo, B-26-55.

(109) Ibidem, Chancelaria de D. Manuel, liv. 16, fl. 108 v.

(110) Ibidem, liv. 1, fl. 57v. 
(111) Ibidem, Inquisição de Évora, $\mathrm{n}^{\circ} 6117$. Todas estas anotaçôes pertencem a dois trabalhos que tenho em preparação, um deles em fase adiantada de redacção, um deles em fase adiantada de redacção: Os cristãos novos de Trás-os-Montes e Os cristãos novos em Portugal no século XVI.

(112) Ibidem, n. ${ }^{\circ} 1720$

(113) Ibidem, $n .{ }^{\circ} 2149,3738,1720,7726,6051,8612$; Inq. de Lisboa, $n .{ }^{\circ} 8612$. Os processos de ambos desapareceram.

(114) Ibidem, Inq. de Évora, $\mathrm{n}{ }^{\circ} 6051$

(115) Ibidem, n. ${ }^{\circ} 8612$

(116) Ibidem, Inq. de Lisboa, n. ${ }^{\circ} 2716$

(117) Ibidem, Inq. de Évora, n. ${ }^{\circ} 8612$ e 8447

(118) Ibidem, n. ${ }^{\circ} 8612$

(119) Ibidem, n. ${ }^{\circ} 6051$

(120) Ibidem, n. ${ }^{\circ} 2853$

(121) Ibidem, n. ${ }^{\circ} 8612$

(122) Ibidem, n. ${ }^{\circ} 4695$

(123) Ibidem, n. ${ }^{\circ} 6122$

(124) lbidem, n. ${ }^{\circ} 5992$

(125) Ibidem, n. ${ }^{\circ} 7951$

(126) J. RODRÍGUEZ FERNÁNDEZ, La juderia de la ciudad de León, Leão 1969, pgs. 34-35.

(127) MARIA JOSÉ FERRO TAVARES, ob. cit. pgs. 369-370; As Gavetas da Torre do Tombo, Lisboa 1970, vol. X, pág. 359. 


\title{
DOCUMENTACIÓN NOTARIAL E HISTORIA DE LA SANIDAD
}

\author{
MERCEDES GALLENT MARCO \\ Universidad de Valencia
}

Pretendemos en el presente trabajo incidir en algunos aspectos relativos a la Historia de la Sanidad en el País Valenciano a partir de una tipología de fuentes - archivo notariales - (1) distintas a las que hasta ahora habiamos utilizado. Tales fuentes, todavía poco explotadas por los historiadores, aportan un material de primer orden para todo aquél que intente aproximarse a la problemática económica, religiosa, social, a la vida material, a las actitudes mentales de una época determinada. Así lo constata André Corvisier en su obra Sources et méthodes en histoire sociale cuando anota: «Aucun document ne parait plus ponctuel et personnel qu'une minute notariale, puisqu'elle concerne la vie et les intérêts d'un individu, d'une famille, tout au plus d'un groupe d'associés, en fixant les clauses d'un contrat, les termes d'un testament ou d'une donation, etc. En effet on rencontre essentiellement dans les minutiers, des documents de caractère familial: contrats de mariage, donations, testaments, partages de biens, inventaires après decès qui marquent de grandes étapes dans la vie. En outre, relatifs à des intérêts matériels, les minutiers contiennent un nombre très important d'actes de caractère économique: ventes et achats, emprunts, constituions de rentes, baux, constitutions de sociétés, etc.» (2)

Esta primera incursión en los archivos notariales queremos, pues, plantearla desde una perspectiva, diríamos «metodológica», intentando elaborar unas pautas que puedan servirnos en un futuro como posible «modelo» a seguir cuando estudiemos documentación notarial referente a temas relacionados con la sanidad o sus representanes. 
El valor intrínseco que esta tipología de fuentes tiene para nosotros estriba en que nos permite entrever determinados aspectos, tanto científicos como cotidianos o sociales, de los profesionales de la sanidad valenciana. Dada la variedad de información que ofrecen orientaremos su estudio y análisis a partir de las perspectivas siguientes:

- Posibilidad de un mayor conocimiento de los profesionales de la sanidad valencianos, facilitado su posterior tratamiento prosopográfico.

- Posibilidad de conocer las fuentes de formación o consulta que solía utilizar el profesional sanitario.

El contenido del documento objeto de este trabajo (3) se refiere al inventario post mortem que se hizo de los bienes del cirujano valenciano Rafael de Mena y de la venta posterior (almoneda) de los mismos, los heredados por su esposa, Na Johana, y pos su hijo, Rafael de Mena, presbitero, beneficiado y «domer» de la Catedral de Valencia, actuando su madre como procuradora. Procuraremos comprobar en él los puntos citados anteriormente.

1. Trataremos, respecto al primer interrogante, de reconstruir paulatinamente la trayectoria de una serie de personajes, barberos y cirujanos en nuestro caso, por su interés para el estudio de la sanidad valenciana bajomedieval porque, como bien sabemos, tenemos información acerca de las actuaciones de ciertos profesionales socialmente reconocidos y encumbrados que encontramos detentando un número elevado de cargos: "protofisics», "protocirurgians», «desospitadors», examinadores del municipio, médicos de hospitales... (4), pero muy poco o nada sabemos de aquellos otros profesionales anónimos sobre los que, en definitiva, recáıa una responsabilidad y ejercían un quehacer diario no siempre reconocido.

La enumeración de todos los barberos y cirujanos que aparecen en nuestro documento así lo demuestra, de hecho, los 16 barberos y cirujanos en él citados: «mestre» Rafael de Mena; Petro Portogués, «barbitonsoris Valencie»; Lope de Navarro, «barber e cirurgià»; «mestre» Johan Eximeneç; «barber e cirurgiá»; «mestre» Arnau Guascó, «barber»; Johan Moles «barber»; Ferrando Caseres, "barber»; Anthoni Alguaro, "barber»; Berthomeu Sebastià, «barber»; Johan Draçan, alias De Leyda; Simó Soriguera, "barber»; Johan d'Aragón, «barber»; Sebastià Tort y Nicholau Florentí, son prácticamente desconocidos para nosotros y hemos podido constatar que sólo cuatro de ellos desempeñaron una serie de cargos importantes y de prestigio:

- Rafael de Mena, el "protagonista» y al parecer el de más renombre. Se encuentra en 1458 actuando como testigo en la petición que los mayora- 
les de la cofradía de barberos y cirujanos dirigieron al gobernador de Valencia para poder reunirse libremente, donde declara:

«En Rafael de Mena, barber e cirurgià de la ciutat de València, testimonis qui jura, etc. E dix que ell stat majoral del dit offici e ensemps ab sos companyons del dit offici e almoyna se son ajustats en lo monestir de la Mercè, contractant fets e negocis sens convocar-li may official algú per lo Senyor Rey, e axi u ha vist practicar de XV anys que té obrador...» (5)

Además es majoral de la «confratria e almoyna dels barbers» junto con Johan Masco, Goçalbo Sanç y Jacme Ros en 1460 (6). Así mismo, en 1468, con motivo de ciertas remodelaciones que se hace en las constituciones del colegio, aparece como diputado del mismo (7). Fue elegido "conseller» de oficio, representante de los «barbers» en los años 1461, 1464 y 1467 (8) y nombrado "examinador dels cirurgians" por el Consell de la ciudad durante los años 1460, 1466, 1470, 1472, 1480 (9).

- Johan Eximeneç, fue examinador de cirujanos en 1446 y «conseller» de oficio en 1448 (10).

- Simó Soriguera, es«conseller» de oficio en 1498 y 1506 (11).

- Anthoni Devot, se le nombró examinador de cirujanos en 1505 (12).

LLama la atención, en el tratamiento de estos personajes la confusión reflejada respecto a la titulación atribuida a estos profesionales, indicativa del desconocimiento general en esta sociedad sobre la gradación profesional, pues si bien encontramos correcta la distinción (por supuesto lenta y paulatina) entre "barber" y "cirurgià, o en su caso la utilización conjunta de ambos, nos llama la atención la utilización del término «mestre», que indica la adquisición del máximo grado académico en los estudios médicos (13).

2. Es útil, también, la información aportada por este documento para el reconocimiento de determinadas patologías, terapias y material quirúrgico, aunque no sea excesivamente explícito.

Reiteradamente se nos habla (en función de la utilización del instrumental) de «mal de lengua», 1; «mal de nas», 2; «mal de ses e del budell insà prop d'aquell», 3; «mal de cap», 4, 5, 9; «mal de cap e nafres», 6; «malalties o nafres de cap», 7, 10, 11, 12, 13; «malaltia de cap», 15; «mal de boqua», 22; «squinança»,56, indicios evidentemente vagos (cabria hablar de estomatitis, cefalalgias, amigdalitis, esquinancia, hemorroides...) pero referidos a dolencias susceptibles, como se constata, de un tratamiento quirúrgico: «levar squer- 
des de ossos per a levar malalties de cap», 16; «arrancar quexals», 20; cauterizar; "dar cauteris de fosch», 21; trepanar 8, 51.

Se enumera, por otra parte, de forma prolija el instrumental propiamente dicho, aunque tropezamos con la dificultad de su reconocimiento desde el punto de vista técnico (14), consecuencia, como cabe suponer, de la ignorancia de quien hace el inventario. A pesar de todo podemos hacer la siguiente relación indicativa:

- Instrumentos de hierro sin especificar; «instruments de ferre», «ferros», «erros de cirurgia», 1, 2, 3, 4, 10, 15, 16, 20, 25, 50, 51, 52, 54, 56, 57, 64.

- Instrumentos de hierro curvado: «Instruments de ferrer voltats" (¿separadores, forceps, cucharillas?), 6.

- «Ferros a manera de peus de grua», 26.

- «Caveguets de ferre» (a modo de «azadilla» de hierro, (¿lepra?), 5.

- «Lambroix de ferre», «ferros lambroxos» (hierros de rebajar, ¿gubia?), 7,55 .

- «Trepans» (trépanos), 8, 51.

- «Barrines de ferre» (taladro), «barrines ab ses virolles de ferrer» (taladros con sus abrazaderas de hierro), 9, 29, 30, 37.

- «Ferrer apellats gomietes» (doble hierro curvado utilizado por los herreros para engomar), 12.

- «Escarprets de ferre» (escalpelos), 11, 13.

- Varios tipos de tenazas: «mordaretes», «tenalletes de ferrer de barama neta», 17, 18, 57 .

- Pinzas: «guaffa per arrancar quexals», 19.

- Cauterios: «cauteris de ferre», en forma de dátil, de oliva: 21, 32, 33, $34,58,50,60,61,62,63$.

- Instrumentos de latón: «Instruments de leuto voltat», 22, 27.

- «Martellets de ferre a modo de clau d'arpa», 23.

- Tijeras: "Tisoretes de ferrer a odo de tisores de baxador», 24.

- «Levador de ferre tallant» (instrumento utilizado en cirugía para destapar una herida, ¿erina?), 26. 
- Especulos: «speculum», 56, 65.

- Abrebocas, utilizados para poder manipular en la cura de ciertas enfermedades: «baoales», 53; «badall de cura de squinança», 56; «instruments de ferre per a tenir la boca ubertaw, 31.

- «Ferros apellats enginchs de passadors», (probablemente agujas de diversos tipos, lancetas) 66.

- Diversos estuches con los instrumentos propios del barbero: «stoig de barber", "stoig de cinta ab sos arreus», 41, 71.

- Instrumentos para quitar esquirlas de los huesos: «bec de ferrer a manera de bec de grua», «bec de grua», 38, 54 .

- Instrumento para hacer pildoras: «magdalió de diafarmacium», 28 (15).

3. Incidiremos, por último en el tercer punto que se refiere, como dijimos, a la oportunidad que nos brinda esta tipología documental para poder entrever cuales eran las fuentes de estudio y/o consulta utilizadas normalmente por los médicos, cirujanos y barberos.

Conocemos bien los libros «de texto" obligatorios, e incluso los que se podían utilizar voluntariamente en los estudiso de medicina, fijados por los estatutos de cada estudio general (16), pero desconocemos cuáles eran los usados por los cirujanos y barberos.

Esto no significa que tales profesionales carecieran totalmente de una formación «institucional», pues, como indica Cardoner i Planas, "Al segle XIV a la Corona d'Aragó, pero, hi hagueren molts cirurgians formats "cientificament" a Montpeller o Itàlia, llocs en els quals els qui volien ésser-ho estudiaven la part teòrica, mentre que per a la pràctica es valie de l'ensenyament privat, posant-se durant cinc anys al servei —com a berbers- d'un cirurgià vell, mitjançant uns típics contractes d'aprenentatge» (17).

Este colectivo, al igual que el valenciano, demostró siempre una creciente preocupación -evidenciada en los diversos estatutos de su gremio, y en su interés por la institucionalización oficial de la enseñanza de la Cirugíapor adquirir una formación cientifica teórica y práctica.

Recordemos al respecto, lo estipulado en los estatutos de 1433, donde se regulan los estudios y aprendizaje de quien desee ejercer la cirugía; el establecimiento en 1462, por la ciudad y a instancias de aquellos, de una lectura de cirugia, puesto que era necesario "quel.s barbers e cirurgians fossen abtes e scients e experts en l'art e pratica de cirurgia» y estaban dispuestos 
a «aprendre e desijosos de saber en la dita art si havia quil.s instruits e legis de la dita art de cirurgia, e en la dita ciutat hi hagués de bons fisichs e doctors abtes e competents a legirn; el privilegio concedido por Juan II en 1478 para disecar cadáveres, que les permite profundizar en el conocimiento del cuerpo humano, pues es importante upoder veure, saber, tractar e provehir per los ropis vulls aquelles cosses ocultes e amagades dins los cossos mundanals» $y$, por último, los capítulos de 1486, en los que se plasma la voluntad de barberos y cirujanos por conformar su «status» social como y delimitar lo relativo a su formación y ejercicio profesional, se alude también en el punto cuarto, con cierta ambigüedad a las materias que debian conocer y de las que tenían que examinarse, ante los mayorales del colegio primero y luego, si eran aprobados, ante los examinadores del municipio:

«E si en lo dit examen... serà atribat abte e suficient axí en la dita pràtica et in moribus et vita sia per los quatre mayorals que en aquell any seràn, presentat als quatre examinadors reals en la forma contenguda en lo primer capitol per la dita insigne ciutat elects, los quals quatre examinadors lo hajen e sien tenguts interrogar de la theorica axí com en la dita art de cirurgia se pertany. E si per aquell lo qui al dit examen serà admés per tots concordantment et nemine discrepante serà atrobat abte e suficient in scientia moribus et vita...» (18)

La práctica, como sabemos, debía ejercerse con un cirujano experto y estaba sujeta a unas reglas (19), pero desconocemos las materias y los textos objeto de estudio. (In scientia moribus et vita...) aunque podamos imaginarlo a partir de los libros registrados en el inventario dado que su dueño era un cirujano bastante conocido (20) lo que nos obliga a suponer tuviera una buena formacion.

En el texto se citan las siguientes obras:

- «Un libre de cirurgia... apellat lo Embranc», 43, 68.

- «Altre libre de cirurgia compost per mestre Bru», 44, 69.

- «Altre libre... apellat Tederic de cirurgia, compost per frare Tedericus», $45,93$.

- «Altre libre de cirurgia apellat Albuaquasis compost per mestre Rasis», 46, 94.

- «Altre libre apellat Guido», 47.

- «Hun libre apellat Anathomia Mundi», 49, 92. 
El libro de cirugía citado como lo Embranc creemos que se refiere a la obra de Lanfranchi de Melas (+ 1306) titulada Chirurgia Magna. Lanfranco, discipulo de Guillermo de Saliceto, se formó en el estudio general de Bolonia, donde éste impartía la enseñanza. Forzado a exiliarse por razones políticas marchó a París (hacia 1296), donde llevó «la brillante cirugía italiana del siglo $X|I|$ ». Su obra más conocida, la Chrirurgia, es fruto «de una intensa actividad clínica y docente», erigiéndose como uno de los fundamentos de la cirugía francesa bajomedieval.

La gran difusión que tal obra tuvo nos la prueban las numerosas ediciones que de ella se han hecho, desde su traducción al francés en 1498 hasta la edición más reciente de Tabanelli en 1965. En la Corona de Aragón lo encontramos formando parte de los códices de la biblioteca del monasterio de Ripoll, junto con Tederico de Luca y Bru de Longoburgo, siendo traducido del latín al catalán en el siglo XIV por Corretger de Mallorca (21).

La «cirugia composta per mestre Bru» pensamos que se trata de una de las obras Chirurgia Magna o Chirurgia Parva del cirujano italiano Bruno de Longoburgo, formado también en Bolonia, en la escuela (tal vez privada) de Hugo Borgognoni de Lucca. Sus obras, compuestas hacia 1252, fueron impresas hacia 1498 en Venecia y traducidas al catalán en el siglo XIV (22).

El «Tederc de cirurgia» parece ser la obra llamada Chirurgia, compuesta por Teoderico de Lucca (1206-1298), dominico y obispo de Cervia, formado al igual que Bruno, en la escuela de Hugo Borgognoni y con «autorización eclesiástica para ejercer sin lucro personal la cirugía”. Dicho libro, Tederico, lo dedicó a Andrés Albalat, obispo de Valencia, con el que trabó amistad durante su estancia en Roma. También fue traducido al catalán en el siglo XIV por Guillem Corretger (23).

El manual citado como «libre de cirurgia apellat Albuquasis compost per mestre Rasis» (cuando se cita de nuevo sólo se refiere al «libre apellat Abducasis"), quizás indiquen dos libros de autores diferentes encuadernados juntos que crearon confusión y son citados como uno solo.

El primero acaso se refiere a la obra del cirujano cordobés del siglo $X$, Abul-Quasim Al-Zaharawi, titulada Katib-al-Tasrif, compendio del saber médico de su tiempo y cuyo libro XXX, dedicado a la cirugía gozó de gran prestigio hasta el siglo XVIII. Su uso y difusión fue importante, como atestiguan las diversas traducciones que de él se hicieron. Según Cardoner i Planas: «l'obra d'Abu-I-Qasim - que conté la millor cirurgia escrita per cap autor àrab- fou traduìda de l'arab al llatí en el segle XIl per Gerard de Cremona a Toledo; 
en la segona meitat del XIII del l'àrab a l'hebreu per Shem Tob Ibn Isaac a Marsella, i al començament del segle XIV fou traslldada de l'àrab al català pel jueu Jafuda Bonsenyor» (24).

La referencia a Rases quizás indique otro autor musulmán, el persa Rhazes (Abu Bakr Muhammad Ben Zakariyya al-Rhazi, 865-932), en palabras de Lain Entralgo «primera gran figura de la medicina árabe». Su obra más famosa fue la conocida como Kitab-al-Mansur, manual dividido en diez partes y en el que se trata de toda la teoría y la práctica de la medicina. Traducido también por Gerardo de Cremona al latín después de 1270, y en el siglo XIV al catalán, se convirtió, en especial el libro IX, en uno de los textos fundamentales para la enseñanza de la medicina (25).

El libro citado como "Guido", debe referirse sin duda a Guy de Chauliac ( +1368$)$, médico formado en Montpelier, donde se doctora (1325), y en Bolonia, cuya obra Chirurgia Magna, traducida en el siglo XV del latín al catalán por Bernat de Casaldovol y Jeroni Masnoves «es el tratado de cirugía más influyente desde la Baja Edad Media hasta el siglo XV|» (26).

Del último libro registrado sólo conocemos el título: «Anathomia Mundi», pero no aporta referencia o indicio alguno respecto a su autor; aventuramos, no obstante que se trata de la obra de Mondino de Luzzi (+ 1327), Anathomia compuesta en 1316.

Mondino, alumno y posteriormente profesor del estudio boloñés, ha sido considerado «como la máxima figura del saber anatómico medieval» siendo su obra «el texto básico para la enseñanza de la "medicina theórica" en muchas universidades hasta la publicación de la Fábrica de Vesalio, y en algunas hasta más tarde i lo que explica las sucesivas reimpresiones que de él se hicieron a partir de la aparición de la «editio princeps» en 1478 (27).

Estos datos confirman, pues, el evidente influjo de la medicina italiana en los profesionales valencianos (28) y un nivel «científico" bastante elevado, acorde con la opinión expuesta por Cardoner y Planas cuando, aludiendo a la formación de los cirujanos de la Corona de Aragón, dice «Per a documentarse... es feren traduccions vernacles dels llibres d'Abu-I-Quasim... així foren incorporats a la cultura quirurgica catalano-aragonesa, Roger de Salern, Bru de Longoburgo, Tederic de Lucca, Guillem de Saliceto i Lanfranc...», «A ells s'hi afegí —anota más adelante- peró el text acabat el 1363 a Avinyó pel francès Guy de Chauliac...» (29)

Es evidente, por consiguiente, la riqueza informativa de este tipo de documentación. Se impone, lógicamente, una búsqueda exhaustiva de docu- 
mentos similares para que, analizados y parangonados, podamos consolidar los datos aquí localizados, incorporar otros nuevos y, finalmente, configurar una visión más completa de los aspectos sanitarios de Valencia medieval y, muy especialmente, un conocimiento de lo más exacto posible de la formación y mentalidad de los profesionales.

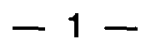

1485, enero, 13. Valencia

Inventario de los bienes de mestre Rafael de Mena.

A. P. P. V., Joan Cabanes

\section{Die iovis XIII ianuarii anno a Nativitate Domini M. ${ }^{\circ} \mathrm{CCCCLXXXV}$}

Consecutive vero dicta die iovis intitulata XIII ianuarii anno iamdicto a $\mathrm{Na}$ tivitate Domini $M .{ }^{\circ} \mathrm{CCCCLXXX}$ quinto, lo dit honorable En Johan Francesc en lo dit de procurador de la dita Na Johana, muller e hereva del dit mestre Raffahel de Mena, continuant lo inventari dels béns del dit mestre Rafael e de la herència dessus dita feu inventari dels bens següents atrobats dins dos caxonets cascú per si apel.lats caxonets de la ferramenta, ferros de cirurgia, los quals són los següents atrobats en los dits caxonets:

[1]. PRIMO: hun instrument de ferre per a curar malaltia de mal de lengua.

[2]. ITEM: altre instrument de ferre per a curar malaltia de mal de nas.

[3]. ITEM: altre instrument de ferre per a curar mal de ses e del budell insá prop de aquell.

[4]. ITEM: dos instruments de ferre a manera de ferrer per a curar mal de cap.

[5]. ITEM: set caveguets de ferre, instruments per a curar mal de cap.

[6]. ITEM: XII instruments de ferre voltats per a curar malalties de cap e nafres.

[7]. ITEM: hun lambroix de ferre per a curar malalties o nafres de cap.

[8]. ITEM: dos trepans de ferre per a obrar en mal de cap o nafres de cap.

[9]. ITEM: dos barrines de ferre per a obrar en mal de cap.

[10]. ITEM: dos instruments de ferre de dos peces cascú per a obrar en malalties o nafres de cap.

[11]. ITEM: dos scarpets de ferre per a curar malalties o nafres de cap.

[12]. ITEM: tres ferres apellats gomietes per a curar malalties o nafres de cap.

[13]. ITEM: dos starpres de ferre per a curar malalties o nafres de cap.//

[14]. ITEM: tres gomietes de ferre per a curar malalties de mal de cap.

[15]. ITEM: dos ferros per a curar malaltia de cap. 
[16]. ITEM: tres ferres a manera de peus de grua per a levar squerdes de ossos per a curar malalties de cap.

[17]. ITEM: dos mordacetes de ferre per a curar malalties en diverses parts.

[18]. ITEM: quatre tenalletes de ferre, totes de barma neta, per a obrar e curar en diverses malalties.

[19]. ITEM: una guaffa per arrancar quexals ab dos peus de ferre a modo de peus de porch.

[20]. ITEM: instruments de ferre per arrancar rahels de quexals.

[21]. ITEM: cauteriets de ferre per a dar cauteris de foch.

[22]. ITEM: hun instrument de leutó daurat voltat per a curar mal de boqua.

[23]. ITEM: hun martellet de ferre a modo de clau de arpa.

[24]. ITEM: unes tisoretes de ferre a modo de tisores de baxador.

[25]. ITEM: hun instrument de ferre per arrancar quexals.

[26]. ITEM: hun levador de ferre tallant.

[27]. ITEM: hun instrument de ferre tallant.

[28]. ITEM: hun magdalió de diafarmacium.

ITEM: l'altre caxonet de fusta foren atrobats los ferros següents:.

[29]. ITEM: tres barrines de ferre totes per a traure ferros de passadors dels cossos dels hòmens.

[30]. ITEM: dos altres barrines ab ses birolles totes de ferre per a traure passadors dels cossos dels hòmens.

[31]. ITEM: hun instrument de ferre per a fer tenir la boca uberta per a curar lo mal que es en la boca.

[32]. ITEM: XXIII cautiris instruments de ferre dells punials e dels coltellades per a obrar e curar diverses malalties.

[33]. ITEM: dos cautiris de ferres per a curar de grans mals.

[34]. ITEM: tres cautiris de ferre per a curar grans mals.

[35]. ITEM: tres cautiris redons per a curar de grans mals.

[36]. ITEM: quatre cautiris de ferre a manera de oliva./I

[37]. ITEM: una barrina tota de ferre ab nou altres peces de ferre per obrar en cures de diverses malalties.

[38]. ITEM: un bec de ferre a manera de boc de grua per a certa cura.

[39]. ITEM: hun instrument de ferre per a arrancar [...] o passados dels cossos dels hòmens.

[40]. ITEM: sis scalfados de leutó per a portar aygua calenta.

[41]. ITEM: hun stoig de barber per a portar en la cuita ab ses rahos e altres ferres dins guarnits alguns los caps de argent e al sol del stoig guarnit d'argent.

[42]. ITEM: una pedra verda per affilar rahos ab lo cap fornit e guarnit d'argent. 
Et hec sunt bona que ad presenti se nos inveni in domo et bonis dicti deffuncti et herentie precontente parte protestor tamen quod si aliqua bona invenro seu invenire potero. In bonis dicti deffuncti quod alia possum inventariare et in presenti inventario continuare eseti de novo aliud inventarium facere presenti inventario in aliquo non obsente et quo tempus michi nomine quo supra e dicti principali mee quo modo. Presentibus pro testibus Petro Portogues et Lope Navarro barbitonsores Valentie civibus testibus ad predicta vocatis et assumptis.

Continuatione. Dicta die iovis XIII ianuarii

Proinde vero die predictum intitulata tredecima mensis ianuarii anno iamdicto a Nativitate Domini $M .{ }^{\circ} C C C C L X X X V .{ }^{\circ}$, lo dit honorable En Johan Francesc el dit nom continuant lo dit inventari dels béns del dit mestre Rafahel de Mena e de la herència dessus dita feu inventari dels béns del dit mestre Rafahel de Mena o de la dita herència, los quals són los següents:

[43].- PRIMO: hun libre de cirurgia-scrit en paper liguat ab post e hun-guafet e dos scudets illuminats ab ses rubriques vermelles cabletrat de letres blaves e vermelles platonat ab platons, cubert de aluda, apellat to Emfranc.

[44]. ITEM: altre libre de cirurgia compost per mestre Bru, scrit tot en paper ab cubertes de paper engrutat e cabletrat e rubricat de vermelló./I

[45]. ITEM: altre libre en paper scrit apellat Tederic, de cirurgia, compost per frare Tedericus, rubricat de vermello ab cubertes de fust cubertes de aluda ab dos guafets e sos scudets.

[46]. ITEM: altre libre de cirurgia apellat Albuquasis compost per mestre Rasis tot en paper ab cubertes de fusta rubricat de vermelló.

[47]. ITEM: altre libre apellat Guido.

[48]. ITEM: hunes ores en perguami ab diversos officis ab cubertes de fusta e cubertes damunt la fusta de vellut, cerrat ab guaffet d'argent e son scudet d'argent.

[49]. ITEM: hun libre apellat Anathomia Mundi.//

Die iovis XIII ianuarii anno a Nativitate Domini M. ${ }^{\circ} \mathrm{CCCCLXXX}$ quinto

Deinde vero die iovis intitulata XIII ianuarii anno iamdicto a Nativitate Domini $M .{ }^{\circ} C C C C L X X X$ quinto. Lo dit mestre Johan Francesc el dit nom de procurador de la dita Na Joahana, muller e hereva del dit mestre Raffahel de Mena quondam continuant la dita almoneda feta primerament convocatió e aldana per lo corredor de la confratria dels barbers, anant per la ciutat dema- 
nant aquells que fossen per al depres dinar a la casa del dit mestre Raffahel hon se faria almoneda de la ferramenta necessária de cirurgia com axí sia cosa acostumada e útil per què de les coses e robes e ferros pertanyents a cirurgia se.n haria major a millor preu o preus que no faria si no.s feya la dita convocació lo deprés dinar en la dita casa del dit deffunt migancant Anthoní Aznar alias ferrer corredor de coll en publich encant presents molts e diversos barbers e cirurgians legitimes subastacions precedents feu vendes dels bés deius scrits per los preus en les persones infrasegüents:

[50]. PRIMO: huit ferros de cirurgia per a curar de diversos mals, lo hu dels quals ferros se nomena bec de grua, an Anthoni Devot, barber e cirurgià, per I s. X d.

[51]. ITEM: set ferros per a curar de cirurgia, lo hun dels quals se apella barrina e los altres trepans, a mestre Johan Eximeneç, barber e cirurgià, per VIIII d.

[52]. ITEM: tretze ferros per a curar mals de cap a mestre Arnau Guastó, barber e cirurgià, per I s. VI d.

[53]. ITEM: hun artifici de coure daurat apellat badalets per a curar a malaltia de boca, a mestre Pere Porthogues, barber e cirurgià, per I s. VII d.

[54]. ITEM: cinc ferros entre los quals hi havia hun bec de grua el altres ferres per a curar mals de cap e de boca, a mestre Lope Navarro, barber e cirurgià, per III s. Vld.

[55]. ITEM: nou ferros lambroxos e altres ferros per a cures de caps an Johan Moles, barber, per VIIII d.

[56]. ITEM: cinch ferros, lo hun dels quals ha nom speculum, e hun badall de cura de squinança, e hun trepan per a curar de diverses malalties al dit en Johan Molés, barber, per II s. III d.

[57]. ITEM: XII ferros de cirurgia entre los quals hi havia unes tenalles e altres ferres per a cura de mal de quexals, a mestre Arnau lo Guastón, barber e cirurgià, per II s./I

[58]. ITEM: cinch ferros, hun cautiri e les altres [...] pans per a cures de caps, a mestre Johan Eximeneç, barber e cirurgià, per VI s. III d.

[59]. ITEM: tres cautiris de ferro per a donar foch en nafres e altres malalties, a mestre Pere Porthogues, barber e cirurgià, per II $\mathrm{s}$.

[60]. ITEM: set peces de ferros apellats cautiris per a obrar diverses malalties, a mestre Arnau, barber, per II $s$.

[61]. ITEM: cinch ferros apellats cautiris a mestre Johan Eximeno, barber cirurgià, per $V \mathrm{~s}$.

[62]. ITEM: dos ferros cautiris per a curar malalties d'ossos an mestre Pere Portogues, barber e cirurgià, per VI d. 
[63]. ITEM: XIIII ferros apellats cautiris per a diversos cures al dit en Johan Molés, per I s. VI d.

[64]. ITEM: nou ferros per a curar diverses malalties, en temps ab lo caxonet de pi hon stavan los dits ferros e altres ferros an Johan Eximeno, barber e cirurgià, per II s. VI d.

[65]. ITEM: hun ferro apellat speculum, a mestre Ferrando Caseres, barber, per VI d.

[66]. ITEM: dos ferros apellats enginchs de passadors.

[67]. ITEM: hun scalfador de leutó per a portar aygua calenta.

[68]. ITEM: hun libre apellat el Enfranch en paper ab cuberta de fusta cubert de aluda ab guafets e escudets, a mestre Pere el Portogues, per XXXXIIII $\mathrm{s}$.

[69]. ITEM: hun altre libre apellat lo Bru en paper ab cubertes de paper engrutat an Antoni Alguaro, barber, per IIII s. VI d.

[70]. ITEM: hun caxonet hon staven los dits ferros al dit en Johan Moles, barber, per VIIII s.

[71]. ITEM: hun stoig de cinta ab sos arreus de rahos e altres arreus, alguns guarnits de argent e al sol guarnit de argent, an Berthomeu Sebastià, barber, per XV s.

Suma universal dels preus procehits de la dita almo // neda e vendes dessús dites dels dits béns, noranta sous e cinch diners, dels quals deduilts hun sou e [...] diners que pagua lo dit mestre Johan Francesc el dia [...] al corredor qui feu la aldana per València quant a les cases dels barbers convocant aquelles e notifficant-los que fossen a la almoneda fahedora lo deprés dinar a la casa hon lo dit mestre Rafahel en vida sua stava e habitava hon farien almoneda e vendes dels béns del dit mestre Rafael e senyaladament dels libres e ferres e instruments pertanyents a cirurgia. Item, dona e pagua lo dit mestre Johan al corredor qui subastà e feu les dites vendes dos sous, les quals despeses foren tres sous VI diners. Restaren nets en poder del dit mestre Johan Francesc noranta quatre sous e once diners

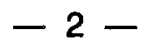

1485, enero, 18. Valencia

Procura de Rafael de Mena, "domer» y beneficiado de la Catedral de Valencia, en favor de su madre Na Johana, para que pueda subastar los bienes legados a éste por su padre.
A. P. P. V., Joan Cabanes

Rafahel de Mena presbiter domerius sedis Valentie et benefficiatus in dicta sede de benefficio annexo dicte domerie et in predicta sede in statuto sub 
invocatione Sancti Spiritui revocando sive infamia quoscumque procuratores meos per me actenus sive constitutos. Scienter et gratis, facio, constituo et ordino procuratricem meam certam specialem et ad subscripta generalem ut in rem vestram propiam vos honorabile domnam Johanam matrem meam, uxorem honorabilis magistri Rafahelis de Mena cirurgiti et barbitonsoris Valentie civis, absentem vel ut presentem videlicet ad petendum, habendum, exhigendum, recipiendum et recuperandum loco mee et pro me quasvis res, raubas $[. .$.$] mutua debita deposita comandas acciperunt quantitates et alia$ quamvis bona que michi debentum et debebuntur per quantum quam personas universitates et collegia tam cum cartis et scripturis publicus vel privatus quam sine apud. Et de hiis que habueritis, exhigeretis, receperitis et recuperavitis ac // dicta dona $\mathrm{Na}$ johana, muller e hereva de mestre Rafael de Mena, cirurgià e barber de la dita ciutat, segons de la dita procura ab carta regunda per lo notari deins crit migançant Johan Centelles, corredor públic de coll de la dita ciutat dels béns scrits a les persones e per los preus infrasegüents:

Suma universal dels preus procehits de la dita almo // neda e vendes dessús dites dels dits béns, noranta sous e cinch diners, dels quals deduits hun sou e [...] diners que pagua lo dit mestre Johan Francesc el dia [...] al corredor qui feu la aldana per València quant a les cases dels barbers convocant aquelles e notifficant-los que fossen a la almoneda fahedora lo deprés dinar a la casa hon lo dit mestre Rafahel envida sua stava e habitava hon farien almoneda e vendes dels béns del dit mestre Rafael e senyaladament dels libres e ferres e instruments pertanyents a cirurgia. Item, dona e pagua lo dit mestre Johan al corredor qui subastà e feu les dites vendes dos sous, les quals despeses foren tres sous VI diners. Restaren nets en poder del dit mestre Johan Francesc noranta quatre sous e once diners

\section{$-2-$}

1485, enero, 18. Valencia

Procura de Rafael de Mena, «domer» y beneficiado de la Catedral de Valencia, en favor de su madre Na Johana, para que pueda subastar los bienes legados a éste por su padre.

\section{A. P. P. V., Joan Cabanes}

Rafahel de Mena presbiter domerius sedis Valentie et benefficiatus in dicta sede de benefficio annexo dicte domerie et in predicta sede in statuto sub invocatione Sancti Spiritui revocando sive infamia quoscumque procuratores meos per me actenus sive constitutos. Scienter et gratis, facio, constituo et ordino procuratricem meam certam specialem et ad subscripta generalem ut 
in rem vestram propiam vos honorabile domnam Johanam matrem meam, uxorem honorabilis magistri Rafahelis de Mena cirurgiti et barbitonsoris Valentie civis, absentem vel ut presentem videlicet ad petendum, habendum, exhigendum, recipiendum et recuperandum loco mee et pro me quasvis res, raubas [...] mutua debita deposita comandas acciperunt quantitates et alia quamvis bona que michi debentum et debebuntur per quantum quam personas universitates et collegia tam cum cartis et scripturis publicus vel privatus quam sine apud. Et de hiis que habueritis, exhigeretis, receperitis et recuperavitis ac // dicta dona Na johana, muller e hereva de mestre Rafael de Mena, cirurgià e barber de la dita ciutat, segons de la dita procura ab carta regunda per lo notari deins crit migançant Johan Centelles, corredor públic de coll de la dita ciutat dels béns scrits a les persones e per los preus infrasegüents: [72]. PRIMO: una cadira de pi vellaja sotil antigua an Johan Molés, barber, per I s. VId.

[73]. ITEM: un baci de leutó sancer e bo al dit Moles, per VIII s. VIIId.

[74]. ITEM: altre baci de leutó sancer e bo al dit Molés, per VIII s. VIld.

[75]. ITEM: altre baci bo de leutó, emperò chich, al dit en Johan Moles, per $\mathrm{VI} d$.

[76]. ITEM: altre baci de leutó bo e sancer a ell mateix, per $\mathrm{VI} d$.

[77]. ITEM: altre baci de leutó bo e sancer am Johan Dracan, alias de Leyda, per VI s.

[78]. ITEM: hun scalfador de leutó bo e sancer an Simó Soriguera, barber, per XV s. VId.

[79]. ITEM: hum altre scalfador de leutó e bo e sancer al dit en Simó Soriguera, per XV s. VId.

[80]. ITEM: altre scalfador de leutó bo e sancer al dit en Johan Moles, per XV S. VId.

[81]. ITEM: altre scalfador de leutó bo e sancer al dit En Johan Molés, per $X V$ s. XVd.

[82]. ITEM: altre scalfador bo de leutó e sancer al dit En Johan Moles per obs de Sebastià Tort, barber, per XIIII s.

[83]. ITEM: altre scalfador de leutó, al costat hun poch trencat, an Johan Moles, per VII s. VIIIs.

[84]. ITEM: tres vergues de ferre per a tenir les calderetes al valor dels caps ab lo rajador al dit Moles, per III s.

[85]. ITEM: hun scalfador de caps de haram ab sos peus de ferre al dit En Moles, per XXIIII s. IId.

[86]. ITEM: hun ferre per a tenir los bacins al dit En Molés, per II $s$.

[87]. ITEM: un poal de coure b sa cadeneta de ferre per a poar aygua del pou al dit En Molés, per VI s. 
[88]. ITEM: un spill gran de porta ja trencat al dit En Molés, per II s.

[89]. ITEM: dos ferros de guins per a traure sagetes dels cossos dels hómens an Johan Francesc, per VI s.

[90]. ITEM: quatre altres ferros semblants als dessús dits, al dit En Johan Francesc, per IIII s.

[91]. ITEM: tres cadires sotils de pi de barber al dit En Moles, per [...].

[92]. ITEM: hun libre apellat Anathomia, scrit en paper ab cubertes de post an Johan d'Aragón, barber, per VII s.

[93]. ITEM: altre libre apellat Tederich, scrit en paper ab cubertes de fust, al dit En Molés, per VIs.

[94]. ITEM: altre libre apellat Abducasis, scrit en paper, al dit En Johan Franch, per $\mathrm{VI} d$.

[95]. ITEM: cinch tovalloles de lli trepades als caps al dit En Molés, per VIII s.

[96]. ITEM: una cortina de fil ab listes grogues per tenir en les barres a la porta, al dit Molés, per XII s.

[97]. ITEM: una cuberta de coxí sotil de lli ab hun trocet de drap sotil an $\mathrm{Ni}$ cholau Florenti, per I s.

[98]. ITEM: hun banc de pi sotil e ja vell ab tres banquets sotils per a tenir als peus dels que affayten, al dit En Moles, per I s.

Suma universal dels preus procehits de la dita almoneda dohents quaranta quatre sous sis diners, dels quals pagua al corredor de la dita almoneda III sous IIII. Item al lit on stava lo dit corredor ab la dita roba dos diners. De la resta pagua a Miquel Ortiz de València la dita herència XIIII lliures II sous VI diners. Restants dels dits preus per rahó de certa quantitat que li era dguda per lo dit mestre Rafahel e per ella dels quals lo dit Ortiz en lo dia de huy li.n ha fermat àpoca. 
NOTAS

(1) RODRIGO PERTEGAS, J. (1926) «Lo que hi ha en los protocols notarials de la epoca foral», Rev. de Cultura valenciana, p. 12-16. MATEU Y LLOPIS, F. (1956) «Notas sobre los archivos eclesiásticos y de protocolos del Reino de Valencia» Rev. de Árchivos, Bibliotecas y Museos, $L X I I, 3$, p. 669-737 (El catálogo completo del A. P. P. V. se está realizando en la actualidad). RODRIGUEZ TRONCOSO, R. (1986) Inventario de fondos notariales; Archivo del Reino de Valencia, Ed. Generalitat València-Conselleria de Cultura, col. Arxius Valencians 4, Valencia. DUALDE SERRANO. 147.

(2) CORVISIER, A. (1980) Sources et Méthodes en Histoire Sociale, Ed. SEDES, París, pág.

(3) A. P. P. V., Joan Cabanes (1485). Debo agradecer a mi compañero Vicente Pons Alós el haberme proporcionado desinteresadamente este documento.

(4) Cfr. GALLENT MARCO, M. (1980) La asistencia sanitaria en Valencia (1400-1512), 2 vols., tesis doctoral, inédita, vol. I, pág. 377-391; vol. II, p. 9-16, 38-66.

(5) GALLENT MARCO, M. (1980) Vol. II, p. 219-20; (1985) «El gremi de cirurgians de València: procés de constitució (1310-1499), Afers. fulls de recerca i pensament, 2, p. 249-269, cfr. p. 260.

(6) GALLENT MARCO, M. (1980), vol. II, p. 249-250; (1985) p. 260-61.

(7) GALLENT MARCO, M. (1985), p. 261-262.

(8) GALLENT MARCO, M. (1980), vol. II, p. 56-66.

(9) GALLENT MARCO, M. (1980), vol. II, p. 38-55.

(10) Cfr. notas 8 y 9.

(11) Cfr. nota 8.

(12) Cfr. nota 9.

(13) DULIEU, L. (1975) La Médecine a Montpellier, vol. l, Le Moyen Age, Ed. Les Press Universelles, Avignon, p. 40-49. CARDONER I PLANAS, A. (1973), História de la Medicina a la Corona d'Aragó (1162-1479), Ed. Scientia, Barcelona. Este autor refiriéndose a los estatutos del Estudio General de Perpiñán promulgados entre 1380-1390, y a los que califica como sla codificació més clara de l'ensenyament de la medicina a la Corona d'Aragón al tratar sobre los estudios de medicina anota: «Es podien aconseguir tres graus: batxiller, llicenciat i mestre... Si es volia tenir el títol de "Mestre" -equivalent al de "Doctor" dels juristes-es sotmetia al llicenciat a un nou examen..." p. 83.

(14) A fin de poder reconocer en lo posible algún instrumental hemos consultado ALCOVER, A.; MOLL, F. de B. (1927-1962), Diccionari català-valencià-balear, Ed. Palma de Mallorca y CORACHAN M. (dir) (1936) Diccionari de Medicina, Ed. Salvat, Barcelona. Así mismo es imprescindible la obra de GURTL, E. (1898), Geschichte der Chirurgie, Ed. Hirschwald, Berlín, a la que por causas ajenas a nuestra voluntad no hemos podido tener acceso. 
(15) Magdalio (magdaleon), pasta medicinal en forma de cilindro, ALCOVER-MOLL (19271962), vol. 7. p. 117. Consideramos que el texto indica a través de una expresión metonímica (contenido por el continente) el instrumento utilizado para hacer píldoras o "pindoler».

(16) CARDONER I PLANAS, A. (1973) Estatuts de Montpeller de 1309 y 1340, págs. 73 75; Perpinyà, p. 83.

(17) CARDONER I PLANAS, A. (1973) p. 101.

(18) GALLENT MARCO, M. (1985) p. 253-268.

(19) Cfr. nota 19.

(20) Cfr. notas $5,6,7,8$ y 9.

(21) LAIN ENTRALGO, F. (dir) (1972) Historia Universal de la Medicina, vol. III, Edad Media, Ed. Salvat, Barcelona, pág. 320-324; (1978) Historia de la Medicina, Ed. Salvat, Barcelona, p. 206. CARDONER I PLANAS. A. (1973), p. 30, 42.

(22) LAIN ENTRALGO, P. (dir) (1972), p. 317, 319-320. CARDONES I PLANAS, A. (1973), p. 42.

(23) LAIN ENTRALGO, F. (dir) (1972), p. 317-319; (1978) p. 205-206, 233-234, 236, CARDONES I PLANAS, A. (1973) p. 42. GARCÍA BALLESTER, L. (1969) «Aproximación a la Historia Social de la Medicina Española, VIII, Salamanca, págs. 45-78, pág. 53-62.

(24) LAIN ENTRALGO, P. (dir) (1972) p. 90-91; (1978), p. 159-160, 177, 190. CARDONES I PLANAS, A. (1973), p. 38, 164. VERNET, J. (1978), La cultura hispanoárabe en Oriente y Occidente, Ed. Ariel, Barcelona, p. 161-164.

(25) LAIN ENTRALGO, P. (dir) (1972) p. 92; (1978), p. 158-160, 169, 198, 235. CARDONES I PLANAS (1973), p. 38, 41.

(26) LAIN ENTRALGO, P. (dir) (1972), p. 305, 330-333; (1978), p. 209. CARDONER I PLANAS, A. (1973), p. 43.

(27) LAIN ENTRALGO, P. (dir) (1972), p. 300; (1978), p. 220.

(28) GARCIA BALLESTER, L. (1966-67), "Tres bibliotecas médicas en la Valencia del siglo XV», Asclepio, 18-19, p. 383-405; (1969) p. 73-75. BERGER, Ph. (1981), «La lecture a Valence de 1474-1560 (Evolution des comportements en fonction de milleur sociaux)", en Llibre et lecture en Espagne et en France sous l'Ancien Regine, Coloquio de la Casa de Velázquez, ed. A. D. P. F. París, p. 97-107.

(29) CARDONER I PLANAS, A. (1973), p. 168, 172. 


\title{
CERÁMICA AZUL Y DE REFLEJO DORADO EN ELCHE: CONJUNTO DE SAN JOSÉ
}

\author{
Grupo llicitano de Estudios Arqueológicos
}

El Grupo llicitano de Estudios Arqueológicos está compuesto por los siguientes miembros:
M. ${ }^{a}$ Carmen Albaladejo Pomares
Pascual Bolaños Argilés
Josefa Caballero Segarra
Fermín Crespo Rodríguez
Marga Durá i Guilló
Araceli Hoffman Javaloyes
Juan Antonio León Fabrellas
Marga Martínez García
Rafael Martínez García
Raquel Pastor Clement
Pedro Javier Ripoll Vivancos
Inmaculada Ruiz Pascual
José Antonio Sáez Zaragoza
Julián Salazar Vives
Juan Jesús Vallejo Padilla

\section{APARICIÓN DE LOS MATERIALES}

Los materiales que se analizan en este estudio aparecieron en una pequeña loma situada entre el Convento de San José y el cauce del río Vinalopó, no estando separada en la actualidad por más de una quincena de metros del primero. Presenta en sus lados Norte y Este sendos terraplenes, generando un fuerte desnivel que intentó ser contenido por un murete que la circundaba por tres de sus lados; mostrándose en el cuarto de ellos y más próximo al convento, un corte vertical producido, en este caso, por las obras de nivelación del terreno llevadas a cabo con motivo de la construcción del actual complejo cultural. 


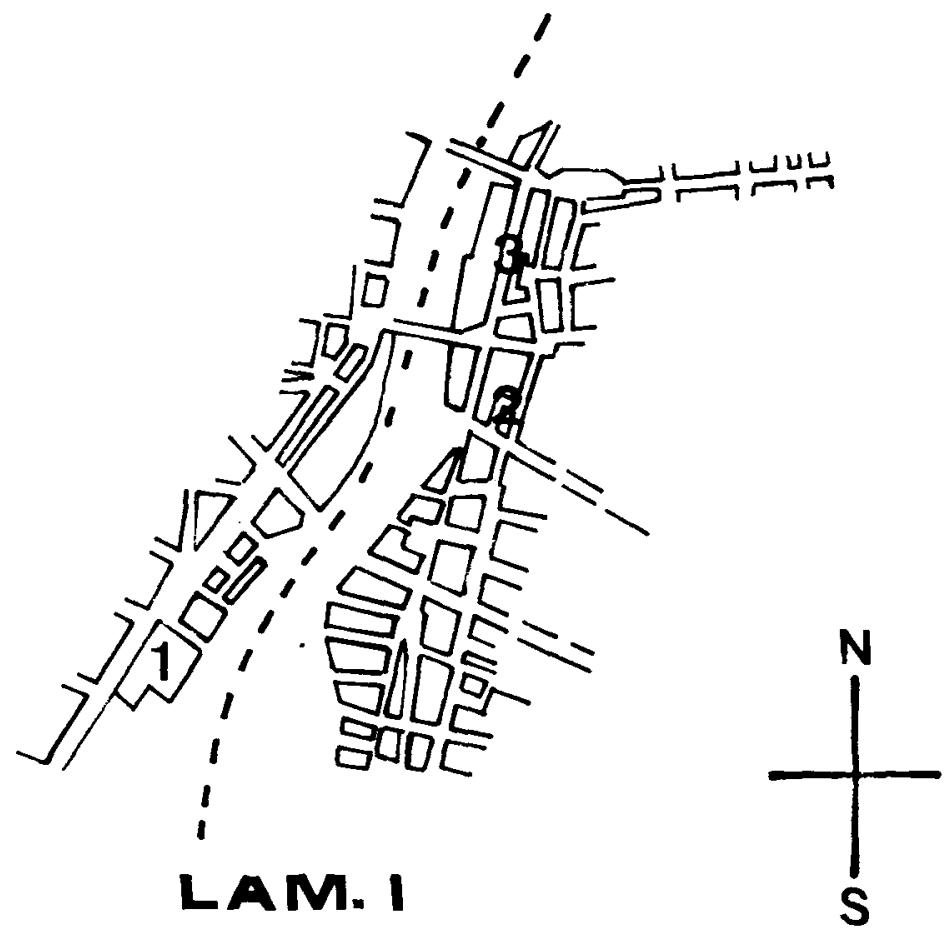

Lámina I. 1.-Convento de San José. 2.-Pobla de Sant Jordi. 3.-Huerto de Gil.

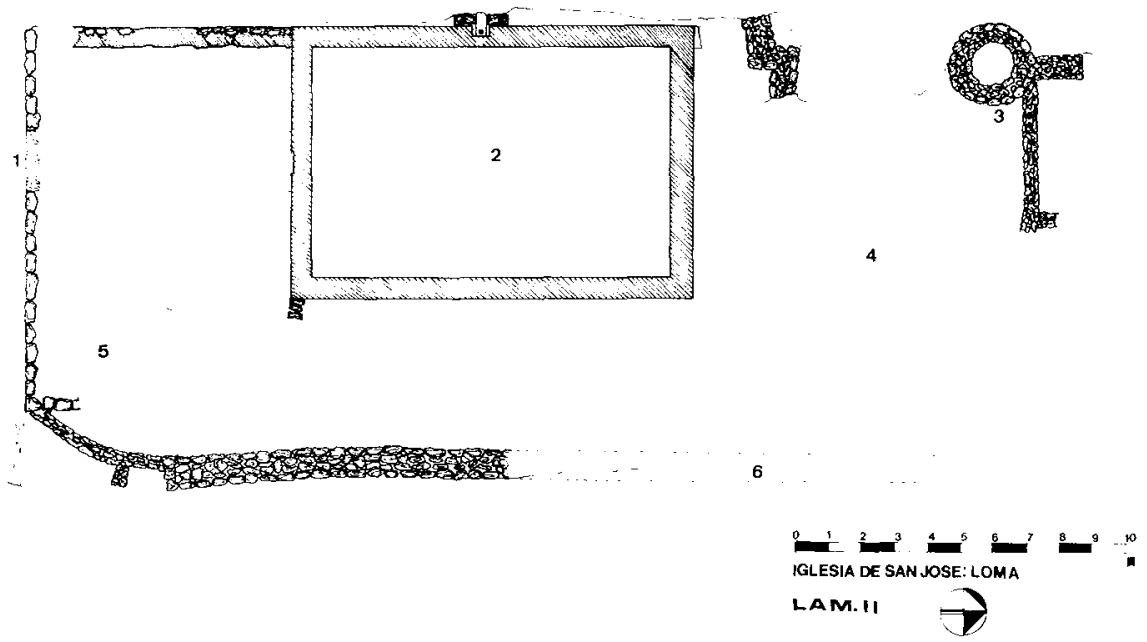

Lámina II. Planta de la loma. 1.-Construcción abovedada. 2.-Balsa. 3.-Pozo y restos de muretes. 4 y 5.-Zonas de concentración de humedad. 6.-Muro de contención desaparecido en parte. 
La loma en cuestión es de planta rectangular, su máxima longitud (dirección N-S) es de unos $35 \mathrm{~m}$. aproximadamente, en cuanto a su lado transversal (dirección E-W) tiene unos $15 \mathrm{~m}$., con una altura de cerca de 4,5 m. por su cara Este.

En la superficie encuadrada por dicha loma encontramos una balsa rectangular de $13,6 \mathrm{~m}$. de larga por $8,5 \mathrm{~m}$. de ancha, cuyo lado mayor está situado en el borde Oeste de la misma, efectuada en mortero de cal y cuyo alzado sólo se conserva hasta ras de suelo, y en la actualidad colmatada hasta éste.

También nos encontramos un recinto abovedado que, aprovechando el desnivel existente en la parte Sur, se adentra bajo la loma. Presenta una longitud de $8 \mathrm{~m}$. por 1,5 de anchura y $1,5 \mathrm{~m}$. de altura, estando construido en mampostería. En él tanto el suelo como la bóveda están recubiertos de ladrillos macizos, encontrándose en el lienzo frontal del recinto una pequeña hornacina de fondo plano.

Durante las obras de restauración y ampliación del Convento franciscano de San José para su utilización como complejo cultural, y más concretamente el 20 de enero de 1979, comienza a llamar la atención la aparición de restos de unas construcciones en la loma situada al Este de aquél.

Posteriormente, en septiembre de 1983 se hallan en una de dichas construcciones restos de ladrillos macizos, lo que llevó a algunos vecinos de la zona a comunicar a la prensa (1) el descubrimiento de un posible horno. El 10 de septiembre, este grupo amplió la noticia en el Diario Información, descartando la posibilidad de que se tratase de un horno al no encontrarse restos de ladrillos refractarios.

A pocos metros de la mencionada construcción, el día 12 del mismo mes, comenzaron a aparecer en el lado SW de la loma los restos de loza que aquí estamos tratando, a consecuencia de un pequeño desprendimiento de un lateral de la misma provocado por las lluvias.

\section{RESEÑA HISTÓRICA DEL CONVENTO DE SAN JOSÉ}

Según nos cuenta Pedro Ibarra i Ruiz, «el día 2 de febrero de 1561 y en el Capítulo congregado por los penitentes hijos descalzos del Serafín llagado San Francisco en el Convento del Pedroso, el glorioso Doctor y Padre San Pedro de Alcántara, eligió ocho religiosos para que vinieran a Elche a fundar un convento de su Orden» (2).

Fueron recibidos por el Justicia y Regimiento de la Villa y por el pueblo congregado para su recepción, siendo acompañados, tras la visita a Santa 
María, al lugar donde se edificaría el convento y que por aquel tiempo ocupaba una ermita dedicada a San José.

No queda en la actualidad ningún resto de aquel primitivo edificio fundado por el Marqués de Elche; «los sucesores del Marquesado fueron devotísimos patronos del Convento, cuyos frailes se dedicaron singularmente a la curación de enfermos y a la Enseñanza» (3).

«Fue este Convento Cabeza de la Provincial hasta el 4 de mayo de 1574, en cuya fecha se fundó el Convento de San Juan de Ribera, en Valencia, que por ser la capital adquirió este título» (4).

Dado que el convento se hallaba situado en la margen derecha de la rambla del Vinalopó y que ésta significaba una importante separación del resto de la población, que en las épocas de avenidas, heladas, etc, suponían el aislamiento de los frailes, puesto que la construcción del puente de Santa Teresa no comenzó hasta 1705, era deseo de la comunidad franciscana y también de la Villa, «establecer su morada en sitio más en contacto con la población» (5). Así, en 1613, se instó, con la autorización eclesiástica, el traslado de la comunidad. Sin embargo, esto no habría de tener lugar hasta que durante la trágica peste de 1647-48, el convento se vio afectado también por la epidemia. Por consejo de la Junta Local de Sanidad, el Ayuntamiento decidió desalojar las reducidas e infectas salas del Hospital Municipal «y trasladar a los apestados a las espaciosas y bien ventiladas habitaciones del Convento de S. José» (6), y así mismo, alojar a la comunidad en la Casa de los Malla, existente al fondo del callizo de la Alpujarra, lo que tuvo lugar el 23 de junio de 1648 (7).

Por parte del Ayuntamiento «se dio conocimiento del suceso al señor Duque, Marqués de Elche, Patrono de la institución, reseñándose la perentoria necesidad que les obligó al traslado, lo que estaban prontos a solucionar edificando el Ayuntamiento otro convento en el sitio que mejores condiciones reuniera a beneplácito de todos, pudiendo continuar desde luego, S.E. con el honor del Patronato, sin obligación de acudir para nada en la construcción de la nueva obras (8).

Pero el Duque ni aprobó el traslado ni quiso oír las razones expuestas por la corporación municipal, por lo que el asunto pasó a los Tribunales de Justicia. Al Ayuntamiento, no conveniéndole la disparidad de opiniones con aquél, hizo que los frailes volvieran a su convento, habiendo sido previamente restaurado y acomodado nuevamente a la vida monástica. En este sentido, la Sitiada de 18 de noviembre de 1650 , hace referencia a que tras la utili- 
zación del convento como hospital para el tratamiento de los contagiados, se ordena la quema de la ropa de éstos para purificar el lugar y que pueda ser ocupado de nuevo por los frailes (9).

«Del año 1650 es la escritura de Patronato del expresado convento de San José por los Duques, Marqueses de Elche» (10), que eran la base de financiación del mismo (11). El actual edificio es de 1678, siendo el anterior completamente derruido, habiendo con posterioridad una petición de la Orden Tercera para recabar fondos a fin de construir otra nave (12).

La comunidad, que en algún momento llegó a contar con 54 religiosos, se dedicaba a distintas artes y oficios, destacando la enseñanza superior.

Según el Cabildo de 20 de agosto de 1835 se procede al «cierre de los conventos y orden de salida de estos religiososm. No obstante, Ramos Folqués indica que la supresión de los conventos se decreta el 8 de marzo de 1836 y como consecuencia son expulsados los frailes, pidiendo el Ayuntamiento en 1837, la concesión del Convento de S. José como Casa Hospital de Beneficiencia (13), petición que se volvió a formular en 1841 ante las malas condiciones del hospital de la Corredora (14), siendo conseguida la cesión según Real Orden de 11 de junio de 1841, tomando el Ayuntamiento posesión inmediata del edificio.

\section{APROXIMACIÓN A LA ALFARERÍA EN ELCHE}

Dado que el objeto del presente estudio es dar a conocer un pequeño conjunto de materiales cerámicos encuadrados en los siglos XVII y XVIII, es de todo punto necesario el hacer siquiera un breve análisis de la industria alfarera en la ciudad de Elche, para lo cual habremos de remontarnos a 1438, fecha en que tenemos la primera referencia de la llegada a la villa de un "Mestre de fer teula e rajola" (15). A partir de dicha referencia podemos constatar documentalmente una industria alfarera que perdura durante los siglos $X V$ al $X \mid X$, con una clara interrupción en el XVIII.

No obstante, la escasez cuantitativa de las noticias y su parquedad para un espacio temporal tan amplio, así como el incipiente estado de las investigaciones en esta materia, dificultan por ahora elaborar un análisis de fondo sobre el tema. Sin embargo, sí podemos intentar esbozar aqui algunos rasgos genéricos sobre este tipo de industria, a pesar de no haber sido ésta una de las más características dentro de las producciones artesanales de la villa.

Hemos de tener presente, ante todo, la excelente situación que presenta la villa de Elche, al estar asentada en el cono de deyección del río Vinalopó, 
lo cual implica la presencia de arcillas, materia prima para esta industria, como bien se refleja en la petición de asentamiento de un maestro alfarero en $1462(16)$.

La ubicación de la industria cerámica dentro de la estructura urbana va a estar claramente determinada por su carácter polucionante, por ello los alfares se construirán algo alejados de la "vila murada», núcleo urbano principal, como el resto de industrias con análogo carácter (curtidores, jabonerías, tintorerias, hornos de vidrio (17), ...), concentrándose aguas abajo de la ciudad, dentro del anillo periurbano de la misma. Por la necesidad de agua para la fabricación, y por las impurezas que aquélla adquiere tras su uso, los talleres de ceramistas se van a situar cerca de las acequias, una vez concluido el trayecto urbano de las mismas. Este tipo de asentamiento de las industrias polucionantes era ya habitual en el esquema urbanístico musulmán (18). En Elche tenemos noticia de distintos asentamiento de esta industria, en el huerto de Gil (19), en la Plaça de Sant Jordi (20), en el Carrer de les Barques (21), es decir, en el barrio de la Pobla de Sant Jordi, asentamiento mudéjar hasta el XVI (22), y finalmente una última referencia de petición de asentamiento junto al desamortizado Convento de San José, en aquellos momentos Hospital de Caridad, próximo a la acequia de Marchena (23).

En cuanto a la importancia económica de esta industria en la ciudad, las referencias son escasas, aunque podemos, sin embargo, adivinar que se mantiene una evolución constante. Hubo de ser esta industria, cuando menos, atractiva ya que hay bastantes peticiones de asentamiento por parte de personas de dicho oficio y el Concejo las concede rápidamente, dando grandes facilidades a los peticionarios (24). Hay incluso alfareros que vienen temporalmente a trabajar a la ciudad y el Consejo paga su alojamiento (25). De estos dos hechos podríamos llegar a colegir que generalmente la demanda supera a la producción. Así mismo, podemos observar que desde el siglo XVII ya no se hace referencia a la construcción de hornos, lo que unido a la escasez de datos sobre el siglo XVIII podría indicar cierta decadencia de la industria alfarera, hasta el punto de que el Ayuntamiento llega a vender la canterería por mal estado en 1677 (26). Asi pues, ya no tendremos noticias de petición de establecimiento de un alfarero hasta 1853 (27), habiendo de señalar en este punto que durante el siglo XVIII no aparece ninguna referencia a la industria alfarera ni el Padrón de 1761, ni en los Libros de Padrones y Cabreves de 1787, como tampoco en las Matrículas de 1835-50 (28), aunque sí hay noticias de un cierto comercio, si bien no podemos precisar si la producción es de origen local o no.

Por último, también puede dar una idea de la relativamente escasa importancia dentro de la industria local el dato de que en 1684 los alfareros soliciten acogerse a los estatutos de otro gremio como es el de los carpinteros (29). 


\section{LOS MATERIALES}

Hemos de hacer constar que al no tratarse de un conjunto perteneciente todo él a una misma unidad estratigráfica $o$, por lo menos, no contamos con ese dato, y más bien, en base tanto a la forma de aparición de la cerámica como a la existencia de diversos fragmentos pertenecientes al $\mathrm{XIX}$, tenemos bastante certeza de lo contrario. De aquí que debamos ser extremadamente cautos al realizar cualquier datación.

Así pues, la sistematización del estudio de la cerámica, ha sido tratada desde un punto de vista meramente tipológico. En primer lugar, haremos referencia a la cerámica de reflejo dorado, para pasar después a la cerámica decorada en azul sobre barniz blanco, obviando el resto de fragmentos aparecidos a causa de su escasa representatividad cuantitativa.

\section{A. LOZA DORADA}

En España, muestras de cerámica dorada aparecen a partir del siglo XI en Medina Azahara, desde el siglo XII en Calatayud y Málaga, y en Granada desde el S. XIV, concretamente conocemos que Pere Boill, señor de Manises, es enviado como embajador de Jaime ll ante la corte granadina en 1308-9 y que su hijo, Ramón Boïll, en 1335 comercia entre Valencia y Granada (30).

Desde el momento en que se lleva la técnica del reflejo dorado a Mani-, ses, será característico el reflejo nacarado de esta cerámica, que vive sus momentos de máximo esplendor durante los siglos XIV al XVI, siendo en este último siglo cuando se introduce el uso del molde.

Con la expulsión de los moriscos en 1609 degenera la técnica por falta de mano de obra. A partir de entonces la cerámica, más que dorada, se hace claramente cobriza (31).

En el año 1617 aparecen unas Ordenanzas por las que sólo se permite cocer obra de reflejo dorado a los maestros en dicho arte. Sin embargo, esta prohibición es reiterada por el gremio de los «escudellers» un siglo más tarde, lo que prueba que no habia sido cumplida y que probablemente circularian unas piezas doradas similares a las de Manises, pero más vulgares (32).

En cuanto a los motivos decorativos más típicos, en el S. XV son características las hojas de cardo "a la manera de Damasco", en el centro del plato; en el S.XVI aparecen cordoncillos y tetones junto a solfas, a manera de nota musical, que se van repitiendo. En el XVII no existe un repertorio muy amplio y sí un manifiesto shorror vacui» que cubre todo el anverso de los platos e, 
incluso, en ocasiones, el reverso, aunque aquí la decoración ya no es tan abigarrada; es frecuente el motivo de hojas, representadas de perfil, con bordes en sierra y terminación central en espiral, ocupando prácticamente toda la superficie. También son características de este siglo unas hojas, más pequeñas que las anteriores y utilizadas como motivo secundario, con el interior rayado, y que salen de un mismo tallo o de varios que se unen formando una trenza; otros motivos florales, también frecuentemente utilizados, eran el de la flor de Lis, los ramilletes de pequeños claveles y las hojas filamentosas. Muy frecuente hasta mediados de siglo era el motivo del "pardalot", gran pájaro con el cuerpo cubierto con líneas que quieren imitar el plumaje; aparece dibujado sobre fondo de tallos y hojas redondeadas. Otra figura animal también bastante utilizada era la del león. Sin embargo, en este siglo, como ya hemos señalado, empiezan a darse las primeras muestras de la decadencia de este tipo de cerámica, manifestada en la menor calidad del reflejo utilizado, que comienza a ser rojizo, así como la falta de imaginación en los dibujos. A mediados de siglo comienzan también los ensayos de policromía unido a un cambio de fondos, en los que aparecen grandes hojas alternando con otros motivos florales y una especie de frutas triangulares $y$, a veces, salpicado de puntos dorados. Las formas más usuales de este siglo son el plato de $35 \mathrm{~cm}$. de diámetro y el de $19 \mathrm{~cm}$., conocidos estos últimos como catavinos, pues se cree que eran colocados bajo el grifo de los barriles o bien servían de soporte a las medidas y recogían el vino que rebosaba de ellas. Sus paredes son relativamente gruesas, marcadas en la parte externa por las acanaladuras del torno y, en el centro del anverso, por la marca provocada por el «atilfe», artilugio que servía para la colocación separada de las piezas apiladas en el horno y que dejaba como huella tres puntos formando triángulo. Son asi mismo piezas muy pesadas en relación a su tamaño (33).

En el siglo XVIII con reflejo dorado tan sólo se harán unas pocas piezas, fundamentalmente catavinos, y otros platos grandes destinados a tapar la boca de las tinajas, se trata además de un reflejo cobrizo de muy baja calidad, con la típica y conocida decoración del «pardalot» y, rara vez, algún ciervo. $\mathrm{Se}$ desarrolla, por el contrario, todo tipo de loza policromada (34).

Así pues, podemos afirmar que las piezas cerámicas aparecidas en el Convento de San José y signadas como 01 y 02 podrían considerarse catavinos y fecharse como Manises de finales del siglo XVII. Apoyaría también esta afirmación la existencia en los fondos del Museo Nacional de Cerámica González Martí de Valencia de una pieza signada con el número 1.678, expuesta en la vitrina VI, de las mismas características.

Dentro de este apartado, pero al magen de los dos catavinos ya reseñados, hemos de hacer obligada referencia al conjunto de fragmentos constitui- 
do por las piezas signadas con los números: $54,55,56,57,58,59,60,61$, 62,63 . Estos materiales pueden ser datados en el s. XVIII gracias al análisis comparativo tanto de decoración como de formas establecido entre ellos y los fondos del Museo Nacional de Cerámica «González Martí» de Valencia. No obstante debemos efectuar cierta matización puesto que los fragmentos signados con los números: $57,59,62$, podrian pertenecer con bastante certeza a fechas anteriores, al presentar motivos decorativos no plenamente característicos del citado siglo.

\section{B. LOZA DE REFLEJO METÁLICO DORADO: DESCRIPCIÓN DE MATERIALES}

N. ${ }^{\circ}$ Sig. 001. Catavino conservado casi en su totalidad. Presenta el motivo del "Pardalot" de alas desplegadas, ojo redondo y desproporcionado, cuerpo rayado y plumones en la cola, sobre fondo de puntos y volutas. Circundado por tres filetes al borde, siendo el exterior de mayor grosor. Todo ello aplicado sobre esmalte blanco.

Dim. 18,8 $\varnothing$ Máx; $5 \varnothing$ Mín; 5 H. cm.

N. ${ }^{\circ}$ Sig. 002. Catavino conservado casi en su totalidad. Presenta el motivo del «Pardalot», aunque en un deteriorado estado, sobre fondo de puntos. Circundado por tres filetes al borde, siendo el exterior de mayor grosor. Todo ello aplicado sobre esmalte blanco.

Dim.: 18,7 $\varnothing$ Máx; $6 \varnothing$ Mín; 5 H. cm.

N. ${ }^{\circ}$ Sig. 054. Fragmento indeterminado. Presenta al interior decoración vegetal y punteado separada por un filete, al exterior vegetal separada por una banda en volutas; tonalidad dorada sanguínea. Todo ello aplicado sobre esmalte blanco.

Dim. Máx: $13 \times 10,5 \mathrm{~cm}$.

N. ${ }^{\circ}$ Sig. 055. Fragmento borde, de sección aplanada. Presenta al interior decoración vegetal y filetes al borde, al exterior filetes; tonalidad amarillenta al interior y dorada sanguínea al exterior. Todo ello aplicado sobre esmalte blanco.

Dim.: $18,4 \varnothing$ Máx; $2,5 \mathrm{H}$. cm.

N. ${ }^{\circ}$ Sig. 056. Fragmento base plana. Presenta al interior decoración vegetal, sin decoración exterior; tonalidad dorada sanguínea. Todo ello aplicado sobre esmalte blanco.

Dim. Máx: $3,5 \times 5,5 \mathrm{~cm}$.

N. ${ }^{\circ}$ Sig. 057. Fragmento borde, de sección redondeada. Presenta al interior decoración vegetal y punteado circundado por un filete, al exterior filete al borde; tonalidad dorada ocre. Todo ello aplicado sobre esmalte blanco.

Dim.: 19,5 Ø Máx; 2,5 H. cm.

N. ${ }^{\circ}$ Sig. 058. Idem. Presenta al exterior decoración de filete al borde. Todo ello aplicado sobre esmalte blanco.

Dim.: Máx. $6 \times 2,4 ; 20 \varnothing$ Máx cm.

N. ${ }^{\circ}$ Sig. 059. Idem. Presenta al interior decoración vegetal y punteado, remarcado por una banda a cada lado, circundado por filete al borde, al exterior ondas entrecruzadas; tonalidad dorada sanguínea. Todo ello aplicado sobre esmalte blanco.

Dim.: 19,5 Ø Máx; 5,5 H. cm.

N. ${ }^{\circ}$ Sig. 060. Fragmento soporte u orejera. Presenta al interior decoración indeterminada; tonalidad marrón e indicios de azul. Todo ello aplicado sobre esmalte blanco.

Dim.: $5,5 \times 3,3 ; 1,5 \mathrm{H}$. cm. 

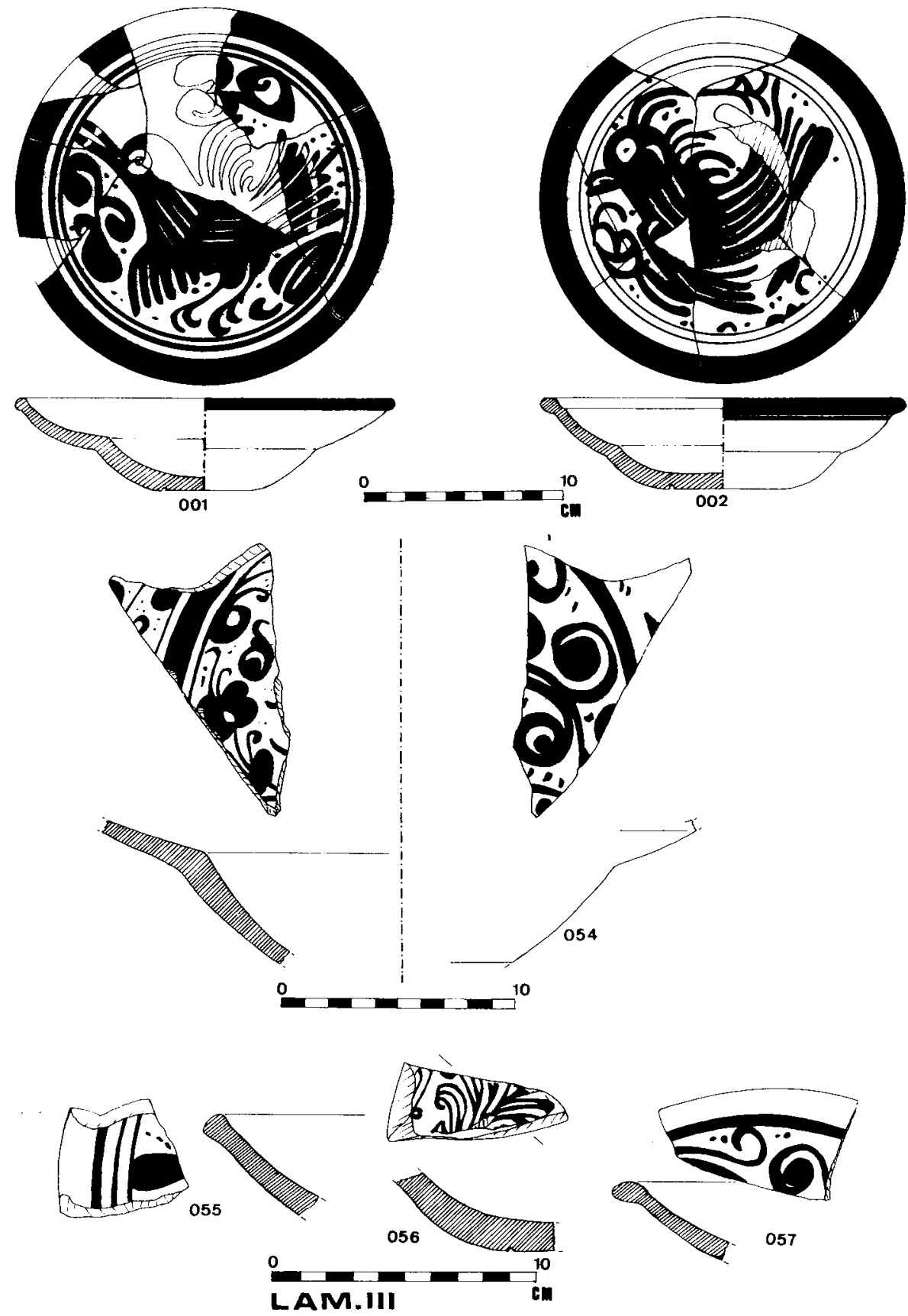

Lámina III. Loza dorada. 
N. ${ }^{\circ}$ Sig. 061 . Fragmento con borde y base, sección borde redondeada y base con anillo basal. Presenta al interior decoración vegetal y volutas, circundado por filetes al borde, al exterior vegetal y punteado, circundado por filete al borde y anillo basal; tonalidad marrón. Todo ello aplicado sobre esmalte blanco.

Dim.: $14,8 \varnothing$ Máx; $6,4 \varnothing$ Mín; $5 \mathrm{H}$. cm.

N. ${ }^{\circ}$ Sig. 062. Fragmento borde, de sección redondeada. Presenta al interior decoración en volutas, circundad por filete al borde, al exterior ondas entrecruzadas; tonalidad dorada sanguínea. Todo ello aplicado sobre esmalte blanco.

Dím. Máx.: $6,5 \times 5,4 ; 2,5 \mathrm{H}$. cm.

N. ${ }^{\circ}$ Sig. 063 . Fragmento base plana. Presenta al interior decoración indeterminada y punteado; tonalidad dorada sanguínea. Todo ello aplicado sobre esmalte blanco.

Dim. Máx.: $3,5 \times 3 ; 1 \mathrm{H} . \mathrm{cm}$.

\section{LOZA AZUL}

Pasamos ahora a examinar el conjunto con más representatividad dentro del presente estudio. Se trata de los platos decorados en azul, con tema vegetal simple (la palmeta) en el anverso y parte interior del borde -excepto el sig. 03 que tiene una $\mathrm{R}$ como tema central-, todo ello sobre vidriado blan$\mathrm{Co}$, existiendo, por otra parte, dos fragmentos de fuente que también incluimos en este apartado por presentar semejante decoración y pasta.

Dada la homogeneidad tipológica de este conjunto, utilizaremos, a la hora de describir cada una de las piezas, una división sistemática atendiendo a la superficie conservada en cada caso. De este modo distinguimos un grupo de piezas cuya superficie conservada es superior a un $60 \%$ como son las sig.: 03, 04, 05, 06, 07, 08, 09.

Del segundo grupo, es decir, el de aquellos cuya superficie conservada es inferior al $60 \%$, diferenciamos tres subgrupos. En primer lugar, aquellos fragmentos de plato que presentan borde y base, aunque sólo sea incipientemente, como los sig.: 11, 12 y 13 ; con las mismas características, pero perteneciente a una fuente, tenemos el sig. 10. El segundo subgrupo lo integran aquellos fragmentos de plato que sólo presentan borde, como son los sig.: $22,23,24,25,27,28,29,30,31,32,33,34,35,36,37,38,39,40,41,42$, $43,44,45$; de iguales características, pero perteneciente a un borde de fuente, tenemos el sig. 26. El último subgrupo lo componen aquellos fragmentos que presentan sólo base, como son los sig.: 14, 15, 16, 17, 18, 19.

Las circunstancias del hallazgo y las características de la cerámica, sumamente común, no nos permiten establecer una datación certera; no obstante, el parámetro temporal se sitúa entre mediados del XVII y finales del XVIII, en base a las características tipológicas de la cerámica, salvo sig.: 32,33 que quizás sean del XIX. Ello nos ha permitido plantearnos dos grandes hipótesis de trabajo como son, en primer lugar, la posibilidad de que dicho conjunto 
perteneciera en su totalidad o en parte a un alfar tradicional de las proximidades (Biar, Agost) o, por otro lado, que fuese de fabricación local. Para ello hemos utilizado el estudio bibliográfico, la encuesta directa y el trabajo de archivo.

No obstante hemos de acentuar las cautelas a la hora de intentar fijar la procedencia de los materiales puesto que podríamos estar tratando dos producciones distintas pero semejantes tipológicamente.

La posibilidad de que este conjunto cerámico pudiese pertenecer al alfar tradicional de Agost hemos podido descartarla tras haber mantenido varias conversaciones con dos de los ceramistas tradicionales más importantes de la localidad, como son Emili Boix, que en la actualidad realiza un tipo de cerámica artística a partir de métodos y técnicas tradicionales, y Pedro Mollá, cuya tradición familiar se remonta a diez generaciones de alfareros, trabajando siempre cerámica común. De estas conversaciones con dichos alfareros y de la contemplación «in situ» de las producciones y de los barros, podemos concluir que tradicionalmente en esta villa se ha producido un tipo de cerámica muy corriente, centrada, sobre todo, en botijos, orzas y lebrillos, siendo extraña la producción de vajilla. En segundo lugar, es de notar que no existen producciones vidriadas. Por último, el dato más importante es que, a pesar de la variedad de barros utilizados históricamente, la característica común a todos ellos es que tras su cocción el color de la pasta es un blanco muy puro y fino en textura, que en nada se asemeja a la que aquí estamos tratando.

En cuanto a que los materiales pertenezcan al alfar tradicional de Biar, hemos de decir, en primer lugar, que según afirmaciones del señor Maestre, único alfarero tradicional que queda en la población, la fabricación de loza fina es relativamente reciente, habiéndose producido tradicionalmente un tipo de cerámica común preferentemente cacharrería. Hay que reseñar en este punto que, a partir del primer tercio del siglo XIX comienza a haber una producción de cerámica vidriada, aunque de baja calidad, coincidiendo con el establecimiento en tales fechas de la familia de aquél, proviniente de Manises, que inició este tipo de producción. Así mismo, Madoz confirma en 1847 la existencia de loza fina en Biar. Por último, en cuanto a la pasta, es de destacar que ésta presenta un color rosáceo característico, que salvo escasas excepciones no está representado en el conjunto de materiales que estudiamos, pudiendo deberse éstas a la aleatoriedad de las mezclas de arcillas.

En definitiva, la hipótesis que parece tener mayores visos de certeza es la de la pertenencia de este conjunto de loza azul a la producción alfarera local, aunque la posibilidad de que el grupo cerámico perteneciente a la se- 
rie de loza azul fuese del alfar que se solicitó instalar en las inmediaciones del convento en 1853 y que desconocemos si se concedió, deberíamos descartarla en todo caso, puesto que las características del conjunto no corresponden a la de la cerámica que se produce en este área a mediados del siglo XIX.

\section{LOZA AZUL: DESCRIPCIÓN DE MATERIALES}

N. ${ }^{\circ}$ Sig. 003. Plato. Presenta al interior decoración vegetal al borde y representación de «R» en parte central del solero. Todo ello aplicado sobre esmalte blanco que deja entrever la pasta.

Dim.: $17 \varnothing$ Máx; $8 \varnothing \operatorname{Min} ; 3,2$ H. cm.

N. ${ }^{\circ}$ Sig. 004. Idem. Presenta al interior decoración vegetal al borde y palmeta central. Todo ello aplicado sobre esmalte blanco.

Dim.: $17 \varnothing$ Máx; 7,5 $\varnothing$ Mín; 4 H. cm.

N. ${ }^{\circ}$ Sig. 005 . Idem.

Dim.: 16,5 Ø Máx; $8 \varnothing$ Mín; 3,5 H. cm.

N. ${ }^{\circ}$ Sig. 006. Idem.

Dim.: 15,7 Ø Máx; 7,5 Ø Mín; 3,2 H. cm.

(La parte central del solero está completamente deteriorada).

N. ${ }^{\circ}$ Sig. 007 . Idem.

Dim: : 17,5 $\varnothing$ Máx; 8,5 $\varnothing$ Mín; 3,5 H.cm.

N. ${ }^{\circ}$ Sig. 008. Idem.

Dim.: 16,3 $\varnothing$ Máx; $8 \varnothing$ Mín; 3,5 H. cm.

N. ${ }^{\circ}$ Sig. 009. Idem.

Dim.: 16,5 $\varnothing$ Máx; $8 \varnothing$ Mín; 3,7 H. cm.

N. ${ }^{\circ}$ Sig. 010. Fragmento de fuente con base plana y borde de sección redondeada. Presenta al interior filete al borde y motivo central indeterminado, al exterior salpicaduras. Todo ello aplicado sobre esmalte blanco.

Dim.: 18,6 $\varnothing$ Máx; $8 \varnothing$ Mín; 3,5 H. cm.

N. ${ }^{\circ}$ Sig. 011 . Fragmento plato base plana y borde. Presenta al interior motivo simple al borde y palmeta central. Todo ello aplicado sobre esmalte blanco.

Dim.: $8 \varnothing \operatorname{Min} ; 3,5 \mathrm{H} . \mathrm{cm}$.

N. ${ }^{\circ}$ Sig. 012. Idem.

Dim.: $16 \varnothing$ Máx; 8,4 Ø Mín; 3,8 H. cm.

(Parte central indeterminada y esmalte deja entrever la pasta, adquiriendo una tonalidad rosácea)

N. ${ }^{\circ}$ Sig. 013. Fragmento plato base plana y borde. Presenta al interior motivo simple al brde. Todo ello aplicado sobre esmalte blanco.

Dim. Max.: $5 \times 5,5 ; 3,2 \mathrm{H}$. cm.

N. ${ }^{\circ}$ Sig. 014. Fragmento plato base plana. Presenta al interior posible palmeta central. Todo ello aplicado sobre esmalte blanco.

Dim. Máx.: $7 \times 6,5 ; 2,5 \mathrm{H}$. cm.

N. ${ }^{\circ}$ Sig. 015. Idem. Presenta restos de azul, sobre esmalte blanco.

Dim. Máx.: $8 \times 6 ; 2 \mathrm{H} . \mathrm{cm}$.

N. ${ }^{\circ}$ Sig. 016. Idem.

Dim. Máx.: $5 \times 4: 2 \mathrm{H} . \mathrm{cm}$.

(Sin ninguna decoración) 
N. ${ }^{\circ}$ Sig. 017. Idem.

Dim. Máx.: $4 \times 5,5 ; 3 \mathrm{H} . \mathrm{cm}$.

(Sin ninguna decoración)

N. ${ }^{\circ}$ Sig. 018. Fragmento plato base plana. Presenta al interior posible palmeta central. Todo ello aplicado sobre esmalte blanco.

Dim. Máx.: $7,5 \times 6,5 ; 2,6 \mathrm{H} . \mathrm{cm}$.

N. ${ }^{\circ}$ Sig. 019. Idem.

Dim. Máx.: $2,5 \times 2,4 ; 2 \mathrm{H} \mathrm{cm}$.

(Sin ninguna decoración)

N. ${ }^{\circ}$ Sig. 020. Fragmento plato base plana. Presenta al interior motivo vegetal cubriente. Todo ello aplicado sobre esmalte blanco.

Dim. Máx.: $8 \times 4,5 ; 2,5 \mathrm{H}$. cm.

N. ${ }^{\circ}$ Sig. 021. Fragmento borde de plato de sección redondeada. Presenta al interior motivo vegetal. Aplicado sobre esmalte blanco.

Dim. Máx.: 7,5×6; $3 \mathrm{H} ; 24 \varnothing$ Máx. cm.

N. ${ }^{\circ}$ Sig. 022. Fragmento borde de plato de sección ligeramente apuntada. Presenta al interior motivo simple. Aplicado sobre esmalte blanco.

Dim. Máx.: 4,5×4; 2 H; 15,5 凤 Máx. cm.

N. ${ }^{\circ}$ Sig. 023. Idem.

Dim. Máx.: $6 \times 4 ; 2 \mathrm{H} ; 15,5 \varnothing$ Máx. cm.

(Borde de sección redondeada)

N. ${ }^{\circ}$ Sig. 024. Idem.

Dim. Máx.: $7,5 \times 5 ; 2 \mathrm{H} ; 19 \varnothing$ Máx. cm.

N. ${ }^{\circ}$ Sig. 025 . Idem.

Dim. Máx.: $5 \times 2,5 ; 1 H ; 15,5 \varnothing$ Máx. cm.

(Borde de sección redondeada)

N. ${ }^{\circ}$ Sig. 026 . Idem.

Dim. Máx.: $3,8 \times 2 ; 1,2 H_{;} 16,4 \varnothing$ Máx. cm.

(Filete al interior del borde)

N. ${ }^{\circ}$ Sig. 027. Idem.

Dim. Máx.: 3,5×3; 1 H; $19,6 \varnothing$ Máx. cm.

N. ${ }^{\circ}$ Sig. 028. Idem.

Dim. Máx.: 3×2,3; 1,5 Ø Máx. cm.

N. ${ }^{\circ}$ Sig. 029. Idem.

N. ${ }^{\circ}$ Sig. 030. Idem.

Dim. Máx.: $2,3 \times 2,4 ; 1,5 \mathrm{H}$. cm.

(Borde de sección redondeada)

Dim. Máx.: $3 \times 2,9 ; 1,2 \mathrm{H} . \mathrm{cm}$.

(Borde de sección redondeada)

N. ${ }^{\circ}$ Sig. 031. Idem.

Dim. Máx:: $13,5 \times 4,5 ; 3,4$ H; $15,5 \varnothing$ Máx. cm.

(Borde de sección redondeada)

N. ${ }^{\circ}$ Sig. 032 . Fragmento borde de plato de sección redondeada. Presenta al interior filete al borde. Todo ello aplicado sobre esmalte blanco muy uniforme y compacto.

Dim. Máx: $4,5 \times 3,5 ; 2 \mathrm{H} ; 24,5 \varnothing$ Máx. cm.

N. ${ }^{\circ}$ Sig. 033. Idem.

Dim. Máx:: $8 \times 5,5 ; 2,7 \mathrm{H} ; 22,8 \varnothing$ Máx. cm.

N. ${ }^{\circ}$ Sig. 034. Fragmento borde de plato de sección redondeada. Presenta al interior motivo vegetal. Todo ello aplicado sobre esmalte blanco.

Dim. Máx: $7,5 \times 4 ; 2 \mathrm{H} ; 16 \varnothing$ Máx. cm.

N. ${ }^{\circ}$ Sig. 035. Idem.

Dim. Máx:: $12,5 \times 4 ; 2,5$ H; $16 \varnothing$ Máx. cm. 
N. ${ }^{\circ}$ Sig. 036. Fragmento borde de plato de sección apuntada. Presenta al interior motivo decorativo indeterminado en azul y ocre. Todo ello aplicado sobre esmalte blanco.

Dim. Máx.: 3,5×1,7; 1,2 H; $18 \varnothing$ Máx. cm.

N. ${ }^{\circ}$ Sig. 037. Fragmento borde de plato de sección apuntada. Presenta al interior motivo vegetal. Todo ello aplicado sobre esmalte blanco.

Dim. Máx.: 4,5×3; $2 \mathrm{H} ; 19 \varnothing$ Máx. cm.

N. ${ }^{\circ}$ Sig. 038 . Idem.

Dim. Máx.: 4 ×5,2; $2 \mathrm{H} ; 15 \varnothing$ Máx. cm.

N. ${ }^{\circ}$ Sig. 039. Idem

Dim. Máx.: $8,7 \times 3 ; 1,6 \mathrm{H} ; 16,4 \varnothing$ Máx. cm.

(Borde de sección redondeada y esmalte irregular)

N. ${ }^{\circ}$ Sig. 040. Idem

Dim. Máx.: $4 \times 3,7 ; 1,5 \mathrm{H} ; 18 \varnothing$ Máx. cm.

N. ${ }^{\circ}$ Sig. 041. Idem

Dim. Máx.: $4,1 \times 3,5 ; 1,7$ H. cm

N. ${ }^{\circ}$ Sig. 042. Idem.

Dim. Máx.: $6,5 \times 4,3 ; 2,5 \mathrm{H} ; 18 \varnothing$ Máx. cm.

N. ${ }^{\circ}$ Sig. 043. Idem.

N. ${ }^{\circ}$ Sig. 044. Idem.

Dim. Máx.: $6,4 \times 4,5 ; 2,5$ H; $18 \varnothing$ Máx. cm.

Dim. Máx.: 4,5×5,2; 3,5 H; 18,4 Ø Máx. cm.

(Borde de sección redondeada, presentando también una incipiente base)

N. ${ }^{\circ}$ Sig. 045. Idem.

Dim. Máx.: $3,6 \times 4,3 ; 2,3 \mathrm{H}$. cm.

(Borde de sección redondeada, presentando también restos irregulares en azul al exterior)

N. ${ }^{\circ}$ Sig. 046. Fragmento de borde de sección redondeada. No presenta decoración alguna y consta de esmalte blanco muy claro, dejando entrever la pasta.

Dim. Máx.: $3 \times 4 ; 14, \varnothing$ Máx. cm.

N. ${ }^{\circ}$ Sig. 047. Idem.

Dim. Máx: $3 \times 3 \mathrm{~cm}$.

N. ${ }^{\circ}$ Sig. 048. Fragmentos correspondientes a un único plato de base plana y sección de borde redondeada. Presenta al interior decoración vegetal con cierto recargamiento hacia el borde. Todo ello aplicado sobre esmalte blanco.

Dim.: $19 \varnothing$ Máx; 9,4 $\varnothing$ Mín; 4 H. cm.

(Está conservado en un 40\%)

N. ${ }^{\circ}$ Sig. 049. Fragmento indeterminado. Presenta al interior motivo en ondas que forman una banda, remarcada por dos líneas, y otra banda formada por semicírculos unidos. Todo ello aplicado sobre esmalte blanco.

Dim. Máx.: $13,5 \times 12 \mathrm{~cm}$.

N. ${ }^{\circ}$ Sig. 050. Fragmento indeterminado. No presenta decoración. Esmaltado en blanco.

Dim. Máx: $4,5 \times 2 \mathrm{~cm}$.

N. ${ }^{\circ}$ Sig. 051. Fragmento indeterminado. Presenta al interior restos de decoración. Esmaltado en blanco con carácter irregular.

Dim. Máx.: $3,5 \times 3 \mathrm{~cm}$.

N. ${ }^{\circ}$ Sig. 052. Fragmento indeterminado. No presenta decoración. Esmaltado en blanco.

Dim. Máx.: $4 \times 3,5 \mathrm{~cm}$.

N. ${ }^{\circ}$ Sig. 053. Fragmento indeterminado. Presenta al interior decoración indeterminada en azul y amarillo. Todo ello aplicado sobre esmalte blanco.

Dim. Máx.: 2,8 $82,5 \mathrm{~cm}$. 

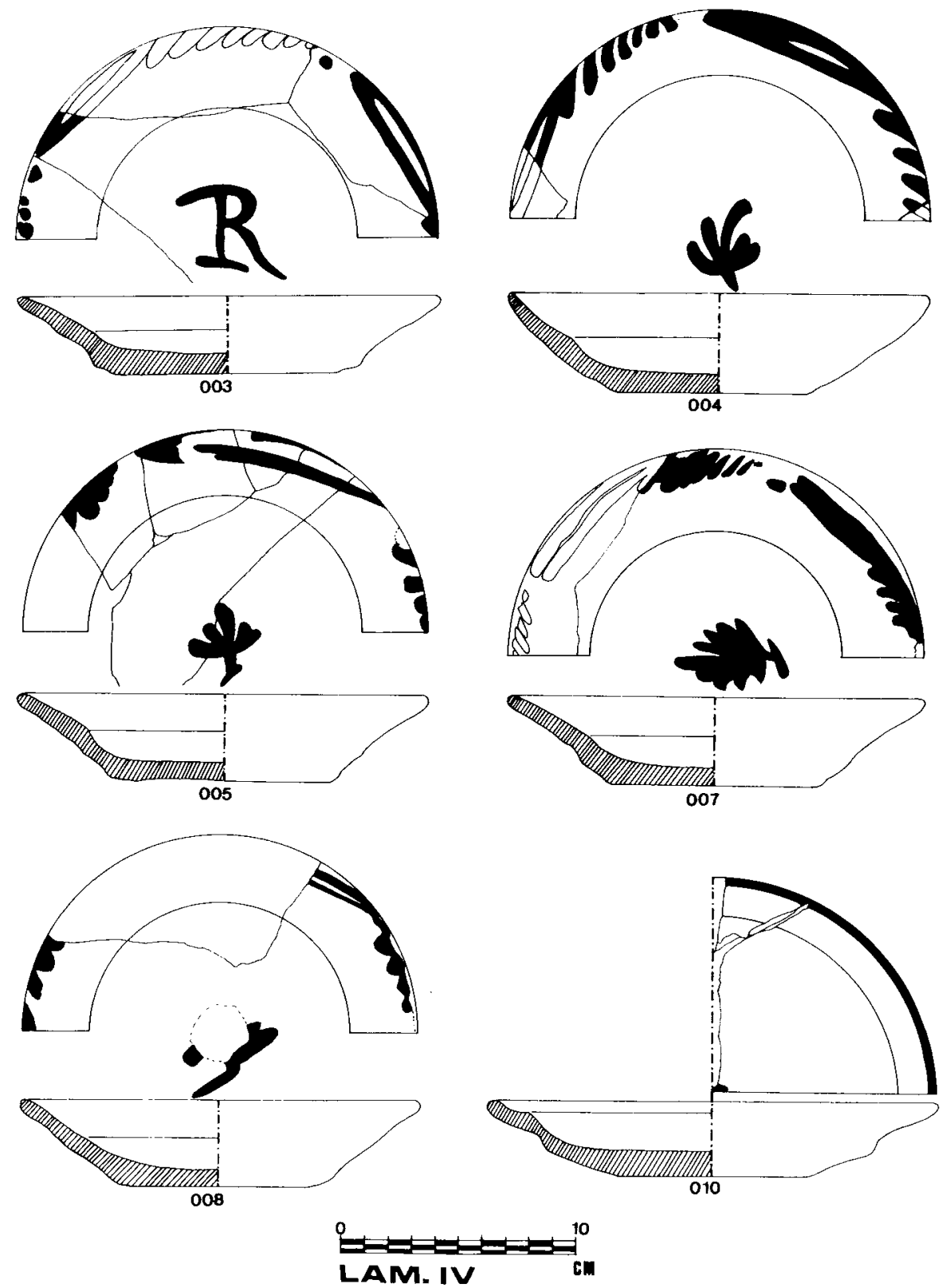

Lámina IV. Loza azul 

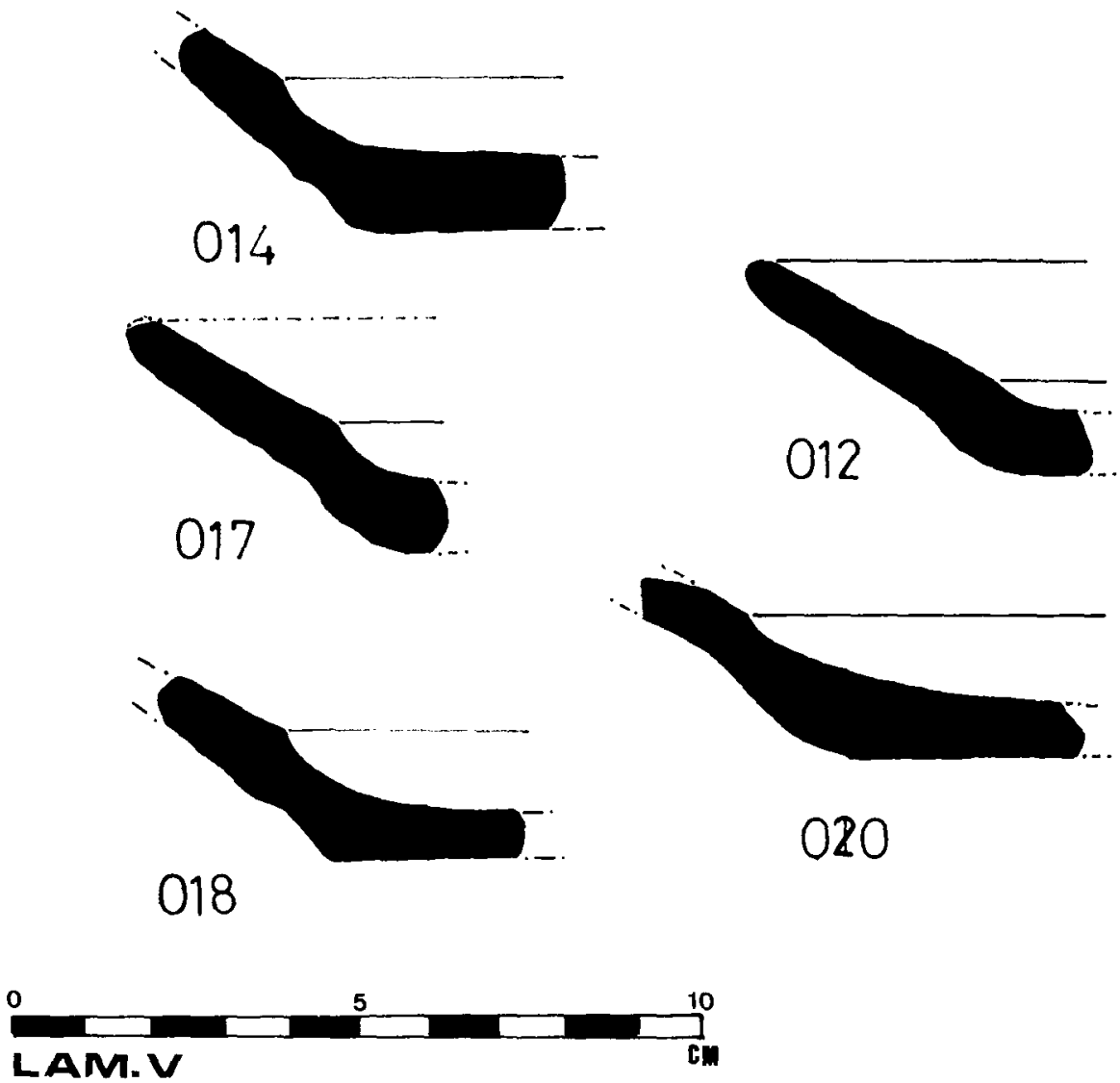

Lámina $\vee$. Secciones de bases de loza azul 


\section{NOTAS}

(1) Diario Información de 6 de Septiembre de 1983.

(2) IBARRA I RUIZ, P. «Convento de San José» Levante, n. ${ }^{\circ} 13$, año II, Elche, 10 de abril de 1926

(3) IBARRA I RUIZ, P. Op. cit.

(4) RAMOS FOLQUÉS, A. Historia de Elche t. II, Elche 1971, p. 491.

(5) IBARRA I RUIZ, P. Op. cit.

(6) IBARRA I RUIZ, P. Op. cit.

(7) IBARRA I RUIZ, P. Op. cit.

(8) IBARRA I RUIZ, P. Op. cit.

(9) Archivo Histórico Municipal de Elche, Libro de Sitiadas 14, 18 de noviembre de 1650.

(10) IBARRA I RUIZ, P. Op. cit.

(11) SERRANO I JAENN, J. «El temps dels senyors: la vila d'Elx entre dues cojuntures historiques (1262-1855): algunes notes». La rella n. ${ }^{\circ} 3$. Elx 1984, pp. 23-49.

(12) A. H. M. E., Libro de Cabildos 88,31 de mayo de 1758.

(13) RAMOS FOLQUÉS, A. Op. cit., p. 492.

(14) A. H. M. E., Libro de Cabildos 157, 4 de enero de 1841. «Suplicando (a su Majestad) digne conceder a esta villa el referido edificio y su iglesia con el objeto de trasladar dicho Hospital de Caridad y establecer en el mismo Casa de Beneficenciam.

(15) A. H. M. E., Cabildo de 12 de enero de 1438. «Mestre de fer teula e Rajola es vengut a la dita Vila dient q. si lo dit Consell li fa forn d'coure teula e Rajola franchament q. ell e muller e fills seus vendran per star en la dita e obrara del dit ofici. Per tal com la venguda del dit hom sia honorosa e profitosa a la dita vila. Hordena en tench per be que per lo obrer dels murs de la dita vila sia fet lo dit forn ab homens logats en aquell loch hon lo dit maestre designara e semylara aportant ans e primerament lo dit maestre llur muller e fills a la dita vila eço que lo dit obrer despendra en fer lo dit forn mostrant cautela li sia pres en compte lo qual dit obrer aja per llur salari per cascum dia dos sous".

RAMOS FOLQUES, A.: La industria, el comercio y la agricultura en Elche, Elche 1973, pág. 109.

IBARRA I RUIZ, P. Elche, materiales para su historia. Ensayos demostrativo de su antigüedad e importancia histórica. Cuenca 1926, pp. 145-148.

(16) A. H. M. E., Cabildo de 25 de abril de 1462. El Concejo ordena hacer un horno en la Plaça de Sant Jordi, trayendo un buen maestro moro que está en Elda y que quiere venir y dice que hay buena bierra «pera fer aci olles e canters llibrells e tases e llibrells e teules e Ralojes e altres coses d'obra d'terra".

(17) A. H. M. E., Cabildo de 20 de agosto de 1452. El Concejo ordena construir un horno de vidrio y casas para Nadal Torres, vidriero, en la Plaça de Sant Jordi. El pueblo de la villa 
se queja de que el horno quedaría lejos y que estaría mejor que se hiciera cerca de donde estaba el antiguo horno. El Concejo así lo ordena.

(18) DE EPALZA, M. «Un modelo operativo de urbanismo musulmán Sharq Al-Andalus, $n .^{\circ}$ 2, Anales de la Universidad de Alicante 1985, p. 137-149.

(19) RAMOS FOLQUÉS, A. La industria... p. 110

(20) Vide nota 16.

(21) GOZÁLVEZ PÉREZ, V: La ciudad de Elche, Universidad de Valencia 1976, p. 78.

(22) SERRANO । JAÉN, J. Op. cit., p. 30.

(23) A. H. M. E., Cabildo de 3 de noviembre de 1853. «Se dió cuenta de un memorial de Vicente Segui vecino de Alicante, solicitando autorización para establecer una fábrica de Alfarería en terreno que pertenece al Hospital de Caridad de esta Villa, inmediato al ex-convento de San José, en el pasaje donde se dirigen las aguas del pozo de dicho edificio cuyas vertientes se obliga a mantener limpias y corrientes, como asi mismo a pagar la cantidad que se convenga, siempre que se le autorice para extraer de la acequia de Marchena la poca agua que ha de invertir en la citada fábrica, por la retribución que corresponde. Enterado el Cabildo acordó se pase original esta solicitud a la Junta Directiva de las aguas de la expresada acequia para que manifieste cuanto se le ofrezca y parezca y verificado se oyga sobre ello a la Junta Municipal de Beneficiencia a fin de poder resolver con acierto este negocio».

(24) Vide notas 15, 16, 23.

A. H. M. E., Cabildo de 26 de septiembre de 1530. «Frances Sánchez vehi de la ciutat de Oriola besa les mans de vostre magnificiençies a les quals fa asaber com ell suplicant sía mestre e tinga ofici de canterer y de fer scudelles y plats y tota altra obra vidriada..."

Cabildo de 21 de diciembre de 1530.

Cabildo de 22 de abril de 1533. Avecindamiento de "Luis de Baxa, mestre de fer canters» por cinco años.

Cabildo de 13 de marzo de 1585. «ltem per quant los dits magnifiches Justicia y jurats an fet venir a la present vila un canterer pera que fasa canters, plats y escudelles peral servici de dita vila y lian promes de donar casa franca y mes cinquanta reais pera ajuda de fer forn e considerat ques molt util y profit pera tots los vehins de dita vila de que en aquella se fasen dites obres...”

Cabildo de 14 de junio de 1642. El Concejo compra una casa para Francisco Esteban para que venga a hacer cántaros a la villa.

(25) A. H. M. E., Cabildo de 30 de marzo de 1487 . Se ordena se paguen 15 sueldos a Antonio de Ortiz por razón de seis meses que estuvo en las casas de aquél un maestro de hacer ollas.

Cabildo de 15 de mayo de 1491. Treinta sueldos a Gaspar Vives que se los prestó a Pedro Colomines, maestro de hacer ollas, cuando aquél vino a la Villa a hacer ollas.

(26) A. H. M. E., Cabildo de 21 de diciembre de 1677. Carlos Ortiz vende a Juan Calvo por ciento cuarenta libras la cantarería, por hallarse ésta en mal estado, con la condición de que se utilice perpetuamente para dicha industria.

(27) Vide nota 23.

(28) RUIZ TORRES, P. Señores y propietarios. Cambios en el sur del País Valenciano (16501850), Valencia 1981.

(29) A. H. M. E., Cabildo de 21 de mayo de 1684.

(30) LLOBREGAT, E. e IVARS, J. F. Història de l'art al Pais Valencià, València 1986, vol. I. p. 275.

(31) SESEÑA, N. Barros y lozas de España, Madrid 1976.

(32) PINEDO, C. y VIZCAINO, E. La cerámica de Manises en la Historia. León 1979.

(33) PINEDO C. y. VIZCAINO, E. Op. cit. 469-478.

SOLER M. P. "Loza valenciana de los siglos XVII y XVIIl», Revista Faenza, n. ${ }^{\circ}$ 5-6, pp.

(34) PINEDO, C. y VIZCAINO E. Op.cit. 


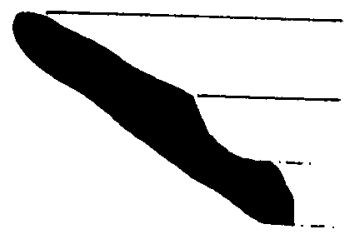

044

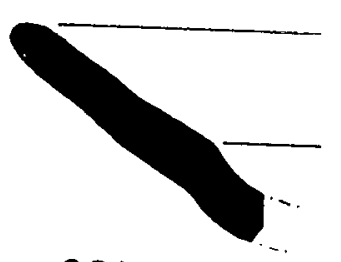

031
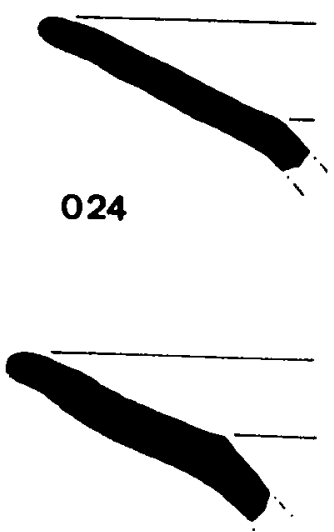

042

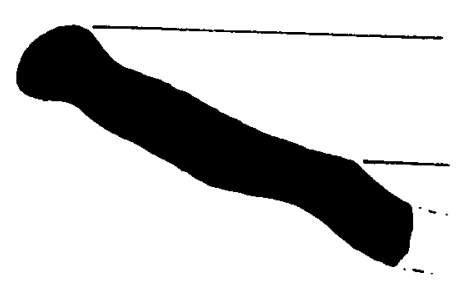

021

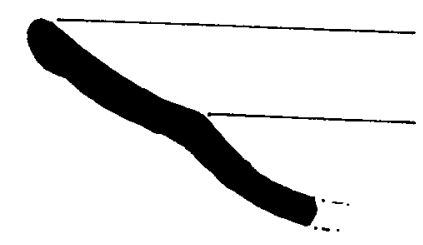

033

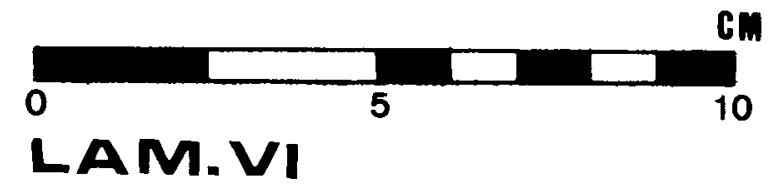

Lámina VI. Secciones de bordes de loza azul 


\section{FILIGRANAS DEL ARCHIVO MUNICIPAL DE CÓRDOBA (1450-1550)}

\section{RICARDO CÓRDOBA DE LA LLAVE - MANUEL CEREZO VILLEGAS Universidad de Córdoba}

La proliferación y variedad de las filigranas o marcas de agua es una de las características más llamativas de los diferentes tipos de papeles utilizados para la redacción de documentos en el curso de los siglos XV y XVI. Desde hace ya algún tiempo, diversos investigadores han destacado su importancia por lo que se refiere a la posibilidad de fechar a través de ellas documentos sin data, saber el momento en que se redactó una copia y conseguir, en líneas generales, un mejor conocimiento de la industria del papel en la época: lugares de origen, zonas de empleo, período de actividad de los molinos papeleros, relaciones comerciales que posibilitaron su difusión, etc. (1) Además de la información de carácter diplomático que las filigranas nos facilitan, ellas mismas tienen un valor intrínseco en absoluto desdeñable como testimonios gráficos de una época para la cual son tan escasos: martillos, tijeras, cuchillos, espadas, fuelles y un sinfín de útiles de trabajo han quedado registrados en ellas, asi como anclas, arcos, candelabros, guantes y muchos otros objetos cuyas formas tienen un evidente interés histórico para el medievalista.

Parece ser que el origen de las marcas de agua hay que buscarlo en la Italia del siglo XIII; esa innovación técnica, verdadera marca de fábrica impresa en la hoja en el momento de su fabricación, habría asegurado durante los sigios siguientes un puesto escogido al papel italiano en el mercado de los países de la Europa Occidental (2). El proceso de elaboración mediante el cual se obtienen las filigranas es muy sencillo y ha sido descrito por diversos autores, pero conviene recordario (3): la madera descortezada es reducida a fibras y cocida a presión en una caldera; luego, se combina con colas y se diluye para obtener la pasta de papel que, tras ser blanqueada y refinada, se mezcla en una tina donde finaliza la primera fase de su fabricación. 
De esa tina toma el operario la cantidad de pasta necesaria para hacer una hoja y la deposita en la forma o molde, un recipiente rectangular con fondo de tela metálica. El agua contenida en la pasta es eliminada por escurrido a través de dicha tela metálica, al mismo tiempo que las fibras exprimidas se entrecruzan longitudinal y transversalmente. Si esa tela metálica lleva un dibujo de alambre en relieve, que hace más delgado el papel por la zona que entra en contacto con la pasta, el mismo es luego visible al trasluz. Éste es el origen de la filigrana o marca de agua, a partir de una técnica que apenas ha cambiado desde su invención en el siglo XIII hasta nuestros días. Hay que destacar, como lo hace Sánchez Real, que ese método impide la existencia de dos formas (o alambres) de hacer filigranas idénticos - puesto que cada una, hecha manual e independientemente, daba marcas distintas-, de manera que dos filigranas iguales responden a la misma forma y han salido del mismo taller y bandeja con un intervalo de tiempo relativamente breve, por más que aparezcan en papeles muy alejdos entre sí geográficamente (4).

Si los italianos fueron los inventores de la marca de agua, es lógico suponer la trascendencia que sus modelos habrían tenido en la Europa bajomedieval. Jean Irigoin ha estudiado la introducción del papel italiano en España a partir del siglo XIII (5), y otros muchos autores han puesto el acento sobre el origen italiano de muchas de las filigranas $-y$, aparentemente por tanto, de los papeles en que se encuentran - halladas en documentos hispanos; según Josepa Cortes, la mayoría de las filigranas recogidas en el archivo de Sueca denotan ese origen (6); Bofarull y Sans defendía la procedencia italiana de todos los papeles con filigranas de animales (7); y Briquet, en su ya clásico y amplio estudio sobre filigranas procedentes fundamentalmente de archivos italianos y franceses, atribuye también un origen italiano a las figuras de anclas, anillos, carros, tijeras, flores con forma de tulipa y letras, todas las cuales resultan enormemente frecuentes en los documentos españoles (8).

¿Quiere esto decir que el papel empleado en Aragón y Castilla durante los siglos XV y XVI era importado, al menos en una buena parte, de Italia? Es muy posible que fuera así, pero también es evidente la existencia de industrias papeleras en Játiva y otros lugares peninsulares; $y$, por supuesto, no hay que perder de vista que artesanos locales, especialmente los levantinos, pudieron haber imitado esas marcas a partir de modelos italianos que ellos mismos habrian implantado y, en su caso, modificado para la realización de su propio papel. Por eso, y por la falta de estudios en profundidad, es tan difícil poder establecer con garantías el origen de cada filigrana y de su respectivo soporte. 
Al problema del origen se une el del significado de las marcas que, hoy por hoy, no está suficientemente clarificado. Es evidente que se trata de una marca de origen, tanto más en casos como el de las manos 123 y 124 de nuestra recopilación -muy parecidas entre sí y perfectamente diferenciadas del resto- y los jarrones 78 a 80 , procedentes todos ellos de documentos fechados en Bruselas en los primeros años del siglo XVI. Pero ¿qué significan la variedad de dibujos existentes? ¿Denotan su origen en una ciudad, en una región o en un taller concreto? Es difícil decirlo. Por nuestra parte, consideramos que, en efecto, esas filigranas tienen que ver con las marcas que durante la Baja Edad Media llevan los diferentes productos artesanales elaborados en cada lugar, a través de las cuales puede comprobarse la calidad de los mismos, su ciudad de procedencia y, en muchos casos, el taller o maestro ejecutor. Sin embargo, además de la variedad en las figuras, deseariamos llamar la atención sobre esas letras que aparecen en muchas de ellas y que autores como Briquet han considerado las iniciales del papelero que las hizo, letras que se repiten una y otra vez por todas partes: BF (figs. 50, 53, 195, 196), $F B(19,24,153,191), F M(40,155), \operatorname{BRP}(54,203)$ y otras similares aparecen en manos y figuras y nos hacen preguntarnos si no se podria pensar que, más que la misma forma de aquéllas, son esas letras o signos realizados junto a las mismas las que marcan el rasgo distintivo de cada tipo de papel. Quizá la repetición de unas mismas iniciales en dibujos distintos signifique el origen común de dos papeles con filigrana diferente, pero salidos del mismo taller.

Todo ello está aún por determinar con exactitud y, de momento, lo único realmente cierto es la coincidencia cronológica de las formas en un espacio de unos veinte años, pasado el cual desaparecen. Eso queda explicado por la idea de Sánchez Real antes citada (a dos filigranas idénticas corresponde una misma bandeja de fabricación) y también porque posiblemente las formas se gastaban, pasaban de moda, y eran sustituidas por otras (incluso en el mismo taller) en plazos de tiempo más o menos breves.

$Y$ asi resulta que las formas que aparecen en Córdoba y que hemos encontrado repetidas en otros lugares se insertan siempre en documentos de la misma época, cuando no exactamente del mismo año. Así, la mano230, de 1492, aparece en Palermo en 1487 y en Castellón (1491-93) y Mosqueruela (1493); el carro 32 (1449) aparece en papeles del archivo de Mosqueruela fechados en 1450, y el 35 (1460), en Villarreal (1465), Mosqueruela (1460) y Játiva (1453). Quizá el caso más notable de coincidencia (y repetición de un tipo de papel usado, por tanto, en todos esos lugares) sea el de la flor 
en forma de tulipa número 63 (1514), que se encuentra también en Castellón (1474), Villarreal (1491), Sueca (1493), Játiva (1494) y Zaragoza (1518), lo que evidencia la gran difusión de ese papel, tanto desde el punto de vista geográfico, como de su prolongación entre los años 1470 y 1520 . Otros casos similares pueden encontrarse en el anexo 3.

A través de ese cuadro y, simplemente, echando una ojeada a los diversos trabajos publicados sobre el tema, se llega fácilmente a la siguiente conclusión: que los mismos tipos de figuras aparecen en todas partes. Para su adecuado estudio, Sánchez Real propuso una división en tres categorías de formas: la familia, tema o motivo sobre el que versa la filigrana; el tipo, que vendría dado por las diferentes maneras de presentar el tema; y las variantes o variaciones producidas en cada uno de los tipos señalados (9). Las familias, como queda dicho, son comunes a todos los papeles de la época conservados en los archivos españoles y destacan entre ellas las manos, carros, montes, animales, letras, tijeras, anillos, cruces, flores y rostros humanos como las más corrientes, cada una de las cuales incluye en su interior un gran número de variantes.

Pero aunque en todos los archivos existen los mismos modelos, en Córdoba destaca de manera especial el motivo de la mano, que se repite con mayor cantidad de variantes que en cualquier otro fondo documental estudiado. Ello obedece, sin duda, al posible origen del papel empleado en Córdoba, importado de talleres que necesariamente usarían esa filigrana como tema principal (dado que en Córdoba no parece haber existido durante los años a que se refiere nuestro estudio, ningún centro de elaboración de papel $o$, si así fue, no nos ha quedado constancia alguna de ello, ni entre los documentos municipales ni entre las escrituras notariales). Pero también se explica por el marco cronológico que hemos asignado a nuestro estudio, puesto que es a partir de la primera mitad del siglo XVI cuando el predominio de la mano entre las familias de filigranas se hace más evidente y así, mientras que para el período 1450-1500 sólo 37 de las 88 figuras recogidas son manos (habría así un 42 por 100 de manos sobre un 58 por 100 de otros dibujos), para el de 1500-1550 el número de éstas asciende a 147 sobre 206 (es decir, el porcentaje se ha elevado hasta el 71 por 100 de manos y sólo el 29 por 100 de filigranas con otras figuras). Todo ello demuestra que las filigranas estuvieron sometidas en la época a una rápida evolución que sería importante poder determinar para tener un mejor conocimiento de las mismas. El ya citado es uno de sus principales rasgos, al menos tal y como se manifiestan en Córdoba, y otro podría ser la progresiva sustitución de los dibujos simples, de trazos sencillos e irregulares, que aparecen en los docu- 
mentos más antiguos (carros, montes, círculos, animales), por los más complicados y artísticos de los papeles más modernos (anillos, jarrones, escudos, pájaros), que llegarán en el siglo XVIII a hacer de las filigranas auténticas maravillas.

Para concluir esta pequeña introducción sobre las filigranas del Archivo Municipal de Córdoba queremos indicar que hemos examinado toda la documentación conservada en el mismo y datada entre los años 1450 y 1550; la mayoría de los documentos se encuentran en legajos sueltos, a los que hay que añadir los libros de Ordenanzas, los de Actas Capitulares y los de Sentencias de Términos, en general más monótonos, porque a lo largo de todas sus páginas suele aparecer el mismo tipo de dibujo. El motivo de escoger esas dos fechas como marco cronológico ha sido la práctica inexistencia de documentación anterior al siglo XV en este archivo, lo que nos ha obligado a llegar en nuestro estudio hasta la mitad del siglo XVI a fin de poder examinar en conjunto las filigranas cordobesas de la época pues, como destaca Sánchez Real, la importancia de una filigrana no está sólo en ella, sino en la relación que tenga con las otras que forman el fondo que se estudia (10). Por lo tanto, había que disponer de un número suficiente de estas figuras.

La técnica seguida para su recogida fue muy sencilla: sobre dos soportes laterales apoyamos un cristal opaco y bajo éste, enmedio de ambos soportes, un flexo de luz blanca que incidía directamente sobre la cara inferior del cristal y formaba así un foco de luz difusa muy apropiado para observar el trasluz del papel. Sobre éste, copiamos la figura a lápiz, sobre papel cebolla, y luego la trasladamos a tinta sobre papel vegetal. Ocasionalmente, usamos plásticos traslúcidos azules o verdes por si contribuían a definir los perfiles de la figura, pero en general llegamos a la conclusión de que eran poco útiles y resultaba mejor el copiado directo sobre el papel original. Las figuras están reproducidas a tamaño natural y agrupadas por orden alfabético. A cada una asignamos un número ordinal con el que señalamos el año de la fecha del documento del que fueron recogidas (anexo 1); la sección y serie del archivo en que se encuentran (anexo 2); y aquéllas que hemos encontrado repetidas en los papeles de otros archivos estudiados (anexo 3). Para éste último fin, hemos realizado un cuadro inspirado en el propuesto por Ariño Rico (11), a la izquierda del cual indicamos el tipo de figura encontrada en Córdoba, el número ordinal asignado y el año en que aparece; y a la derecha, la localidad y fecha en que aparece una figura equivalente, así como el autor del artículo que la recoge y el número que en él se le asigna. La principal conclusión que se obtiene del mismo es la ya señalada de coincidencia cronológica entre formas iguales. 
Completa el presente estudio una pequeña relación bibliográfica, útil para quien desee enfrentarse con el sugestivo tema de las filigranas y, por supuesto, la reproducción fiel de las conservadas en el Archivo Municipal de Córdoba, dibujos que son los auténticos protagonistas de este trabajo. 
(1) SÁNCHEZ REAL, J. «Las filigranas del papel», Ligarzas, 4 (1972), p. 264.

(2) IRIGOIN, J. «La datation par les filigranes du papier», Codicologica. Les materiaux du livre manuscrit, 5 (1980), p. 9.

(3) SÁNCHEZ REAL, J. Op. cit., pp. 261-262; GERARDY, M. Th., «Les techniques d'examen des filigranes", Les techniques de laboratoire dans l'etude des manuscrits, París, 1974, pp. 143-157; MADURELL MARIMON, J. M., El paper a les terres catalanes. Contribució a la seua historia, Barcelona 1972.

(4) SÁNCHEZ REAL, J. «Criterios a seguir en la recogida de filigranas», Ligarzas, 6 (1974), p. 362

(5) IRIGOIN, J., «L'introduction du papier italien en Espagne», Papiergeschichte, 10 (1960), pp. 29-32.

(6) CORTÉS, J., «Filigranes medieval de l'Arxiu Municipal de Sueca 1399-1500», Quaderns de Sueca, 5 (1984), p. 10.

(7) BOFARULL Y SANS, F., Los animales en las marcas del papel, Vilanova y Geltrú, 1910.

(8) BRIQUET, Ch., Les filigranes, Amsterdam, 1968, 4 vols.

(9) SÁNCHEZ REAL, J., «Criterios a seguir...», p. 365.

(10) SÁNCHEZ REAL, J., «Las filigranas del papel...", p. 263.

(11) ARIÑO RICO, L. «Filigranas de Mosqueruela», Ligarzas, 6 (1974), p. 122

\section{BIBLIOGRAFÍA}

ABELLÁN PÉREZ, J., "Las filigranas medievales del Archivo Municipal de Murcia 1399-1455», Miscelánea Medieval Murciana, 6 (1980), 135-146.

ARIÑO RICO, L., «Filigranas de Mosqueruela», Ligarzas, 6 (1974), 121-360.

BOFARULL Y SANS, F., «La heráldica en las filigranas de papel», Memorias de la Real Academia de Buenas Letras, VII, Barcelona, 1901. págs. 485-556.

BOFARULL Y SANS, F., Los animales en las marcas de papel, Vilanova y Geltrú, 1910.

BRIQUET, Ch., Les filigranes. Dictionaire historique des marques du papier de leur apparition vers 1282 jusq'en 1600. 3 vols. Leipzig, 1923, reimpresión New York, 1977.

CABANES, M. L., CARCEL, M. y YAGO, M. C., «El Archivo de la Colegiata de Játiva y sus filigranas», Ligarzas, 6 (1974).

CORTÉS, J., «Filigranes medievals de l'Arxiu Municipal de Sueca 1399-1500», Quaderns de Sueca, 5 (1984), 9-48.

DOÑATE SEBASTIÁ, J., «Filigranas del Archivo Municipal de Villarreal», Ligarzas, 5 (1973), 111-244. 
EINEDER, G., The ancient Paper Mills of the former Austro-Hungarian Empire and their Watermarks. 1962.

FISKAA, H. M. y NORDSTRAND, O. K., Paper and Watermarks in Norway and Denmark. 1978.

GAYOSO, G., «Antigua nomenclatura papelera española», Investigación y técnica del papel, 10 (1973).

GERARDY, M. Th., "Les techniques d'examen des filigranes", Les techniques de laboratoire dans l'etude des manuscrits, París, 1974, 143-157.

IRIGOIN, J., «La datation par les filigranes du papier», Codicologica. Les materiaux du livre manuscrit, 5 (1980), 9-36.

IRIGOIN, J., «La datation des papiers italiens des XIII' et XIV ${ }^{\circ}$ siècles», Papiergeschichte, 18 (1968), 49-52 y 76.

IRIGOIN, J., «L'introduction du papier italien en Espagne», Papiergeschichte, 10 (1960), 29-32.

IRIGOIN, J., «Les filigranes de Fabriano (noms de papetiers) dans les manuscrits grecs du debut du XIV ${ }^{\circ}$ siècle», Scriptorium, 12 (1958), 44-50 y 281-82.

LINDT, J., The Paper Mills of Berne and their Watermarks (1465-1859), Hilversum, 1964.

LÓPEZ, J. y Martín, M. J., «Filigranas del Archivo Municipal de Castellón de la Plana (Manual del Consells)», Ligarzas, 5 (1973), 7-110.

MADURELL MARIMÓN, J. M. El paper a les terres catalanes. Contribució a la seua história. Barcelona, 1972.

MOSIN, V., Anchor Watermarks. 1973.

MOSIN, V. y TRALJIC, S. M., Filigranes des XII/० et XIV० siècles. Zagreb, 1957. 2 vols.

RIDOLFI, R., Le filigrane di paleotipi. Firenze, 1957.

SÁNCHEZ REAL, J., Las filigranas de animales en los archivos de Tarragona. Tarragona, 1959.

SÁNCHEZ REAL, J., "Las filigranas del papel», Ligarzas, 4 (1972), 259-266.

SÁNCHEZ REAL, J., "Criterios a seguir en la recogida de filigranas», Ligarzas, 6 (1974), 361-371.

SÁNCHEZ REAL, J., El papel y sus filigranas en los incunables tarraconenses. Tarragona, 1980.

STEVENSON,A., "Watermarks are twins", Studies in Bibliography, 4 (1952), 57-91.

VALLS SUBIRA, O., El papel y sus filigranas en Cataluña, Amsterdam, 1970. 


\section{ANEXO II SIGNATURA DE LOS DOCUMENTOS}

El primer número indica la figura expresada; los dos siguientes, la Sección y la Serie del Archivo Municipal en que se encuentra el documento que la contiene.

\begin{tabular}{|c|c|c|c|}
\hline 1. $2-30$ & 24. $7-7$. & 47. $1-15$ & 70. 6-7. \\
\hline 2. $7-7$. & 25. $1-11$ & 48. $12-2$ & 71. 2-1. \\
\hline 3. $12-2$ & 26. LAC 1479. & 49. 6-1. & 72. $2-27$ \\
\hline 4. $2-30$ & 27. $1-2$ & 50. $2-12$ & 73. $7 \cdot 7$ \\
\hline 5. $12-1$ & 28. $5-67$. & 51. $2-1$ & 74. 1-11. \\
\hline 6. LAC 1479 (1). & 29. LAC 1493. & 52. 2.1. & 75. 16-1. \\
\hline 7. $2-30$ & 30. $6 \cdot 1$ & 53. $3-18$ & 76. $2-8$ \\
\hline 8. $2-14$ & 31. $2-2$ & 54. $6 \cdot 6$ & 77. $1-11$. \\
\hline 9. $2-1$. & 32. $2-20$. & 55. $2-2$ & 78. $1-1$ \\
\hline 10. $2-30$ & 33. $5-67$. & 56. $13-1$ & 79. $5-5$. \\
\hline 11. $1-6$. & 34. 6-7. & 57. $12-1$. & 80. $6-28$ \\
\hline 12. LAC 1496. & 35. $6-42$ & 58. LAC 1507. & 81. 2-1. \\
\hline 13. $6-1$ & 36. 2.8 & 59. $2-8$ & 82. $6-42$ \\
\hline 14. $7-7$. & 37. $18-2$ & 60. $2-20$ & 83. 6-1. \\
\hline 15. $2-30$ & 38. $6-42$. & 61. 1-2. & 84. 12-2. \\
\hline 16. 6-7. & 39. 1-6. & 62. $2-30$ & 85. 3-3. \\
\hline 17. $2-17$ & 40. LAC 1513. & 63. $2-30$ & 86. $1-10$ \\
\hline 18. 5-69. & 41. LAC 1514. & $64.6-42$ & 87. $12-3$ \\
\hline 19. $12-1$ & 42. $2 \cdot 2$ & $65.3-6$ & 88. $12-1$ \\
\hline 20. $6-20$ & 43. $2-1$ & $66.12-1$ & 89. 2-30. \\
\hline 21. $12-1$. & 44. $2-12$ & 67. 6-31. & 90. $2-1$ \\
\hline 22. 3-18. & 45. $2-1$ & $68.1-2$ & $91.12-2$ \\
\hline 23. $6-1$. & 46. 6-36. & 69. LAC 1479. & 92. $1-10$ \\
\hline
\end{tabular}




\begin{tabular}{|c|c|c|c|}
\hline 93. $1-2$ & 133. $6-1$ & 173. $12-3$ & 213. $1-5$ \\
\hline 94. 1-6. & 134. 6-7. & 174. $12-1$ & 214. 2-21. \\
\hline 95. $1-2$. & 135. $2-30$ & 175. $1-6$ & $215.1-4$ \\
\hline 96. $2-1$. & 136. 5-42. & 176. $1-11$. & 216. $12-7$. \\
\hline 97. 6-44. & 137. 1-6. & 177. $2-1$ & 217. 6-1. \\
\hline $98.1-2$ & 138. $2-6$ & 178. $6-21$ & 218. 5-67. \\
\hline 99. 5-21. & 139. $12-1$ & 179. $2-17$ & 219. $7-7$. \\
\hline 100. $6-1$ & 140. $12-2$ & 180. $5-40$ & 220. 6-1. \\
\hline 101. $12-1$. & $141.1-10$ & 181. 5-40. & 221. 7-7. \\
\hline 102. $2-20$ & 142. $1-6$ & 182. $5-40$. & 222. 1-11. \\
\hline 103. $1-2$ & 143. $6-1$ & 183. $1-6$ & 223. $7-7$ \\
\hline 104. $1-2$ & 144. $12-3$ & 184. $12-1$ & 224. $12-1$. \\
\hline 105. 1-2. & 145. 6-1. & 185. 6-21. & 225. 6-6. \\
\hline 106. $2-2$ & 146. $2-1$ & 186. $2-1$ & 226. 12-3. \\
\hline 107. $1-2$ & 147. $12-1$ & 187. $2 \cdot 12$ & 227. 1.15 \\
\hline 108. $1-4$ & 148. $1-6$ & 188. $6-29$ & 228. $3-7$ \\
\hline 109. 12-1. & 149. 6-13. & 189. $12-1$ & 229. $12-2$ \\
\hline 110. $2 \cdot 1$ & 150. $6-36$ & 190. 6-1. & 230. $12-2$ \\
\hline 111. $1 \cdot 17$ & 151. 5-50. & 191. $2-1$ & $231.6-1$ \\
\hline 112. 1-15. & 152. $12-1$ & 192. 12-3. & 232. 1-11. \\
\hline 113. $1-15$ & 153. $4-5$. & 193. LAC 1507. & 233. $1-7$. \\
\hline 114. 1-11. & 154. $2-30$ & 194. 3-18. & 234. $1-6$. \\
\hline 115. 1-2. & 155. 6-1. & 195. $5-67$. & 235. $2-1$ \\
\hline 116. 2-6. & 156. $6 \cdot 1$ & 196. $6-7$ & 236. LAC 1503. \\
\hline 117. $12-1$. & 157. $6-37$ & 197. 6-13. & 237. $12-7$. \\
\hline 118. 1-10. & 158. $12-1$ & 198. $2-30$ & $238.6-1$ \\
\hline 119. 3-6. & 159. $6-1$ & 199. 2-30. & 239. $2-30$ \\
\hline 120. 6-15. & 160. $12-4$ & 200. 3-6. & 240. 1-6. \\
\hline 121. $9-1$ & 161. $12-1$ & 201. 6-29. & 241. 1-11. \\
\hline 122. $6-7$ & 162. $6-1$ & 202. 6-7. & 242. $1-11$ \\
\hline 123. $1-4$ & 163. 2-13. & 203. 6-1. & 243. LAC 1498. \\
\hline 124. 1-7. & 164. $12-2$ & 204. 12-1. & 244. LAC 1498. \\
\hline 125. $6-2$ & $165.6-1$ & $205.2-4$ & 245. 6-1. \\
\hline 126. $2-4$ & 166. 1-11. & 206. 6-2. & 246. $7 \cdot 7$. \\
\hline 127. $1-11$. & 167. 1-6. & 207. 6-1. & 247. 7-7. \\
\hline 128. $1-11$ & 168. 3-18. & 208. $6-2$ & 248. $12-1$ \\
\hline 129. $1-11$. & 169. $1-8$ & $209.12-3$ & 249. 1-11. \\
\hline 130. $2-8$ & 170. 3-6. & 210. 6-1. & 250. $2-2$ \\
\hline 131. $2-30$ & 171. $2 \cdot 2$ & 211. 1-6. & 251. $2-1$ \\
\hline 132. $6-29$ & 172. $1-11$ & 212. 6-7. & 252. $1-12$ \\
\hline
\end{tabular}


253. 13-1.

254. 7-7.

255. 2-21.

256. 6-9.

257. 16-1.

258. 16-7.

259. 3-6.

260. 1-15.

261. 13-1.

262. $12-1$.

263. 4-2.
264. 6-7.

265. $1-2$.

266. 12-1.

267. $2-8$.

268. 1-11.

269. 12-1.

270. 6-29.

271. 1.11.

272. LAC 1496.

273. $2-8$.

274. $2-6$.
275. 2-1.

276. $1-10$.

277. $2-1$.

278. 12-2.

279. 1-11.

280. 1-7.

281. $1-7$.

282. 4-2.

283. 6-42.

284. $1-2$.

285. $1-2$.

286. $2-30$.

287. 12-3.

288. 1-2.

289. 5-32.

290. 5-12.

291. $12-1$.

292. 12-1.

293. $5-12$.

294. 1-2.

(1) Contenido en el Libro de Actas Capitulares del año mencionado. 


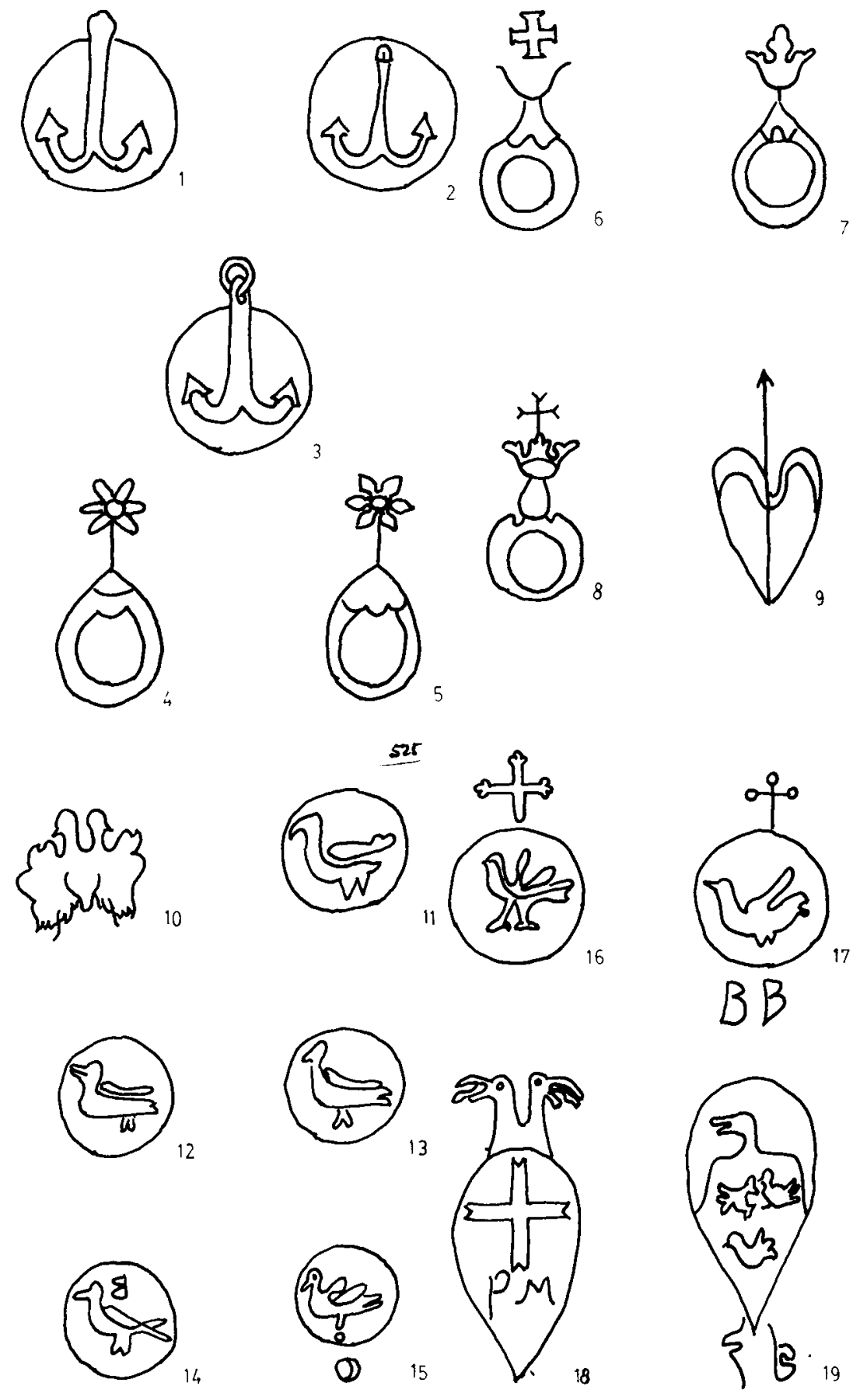

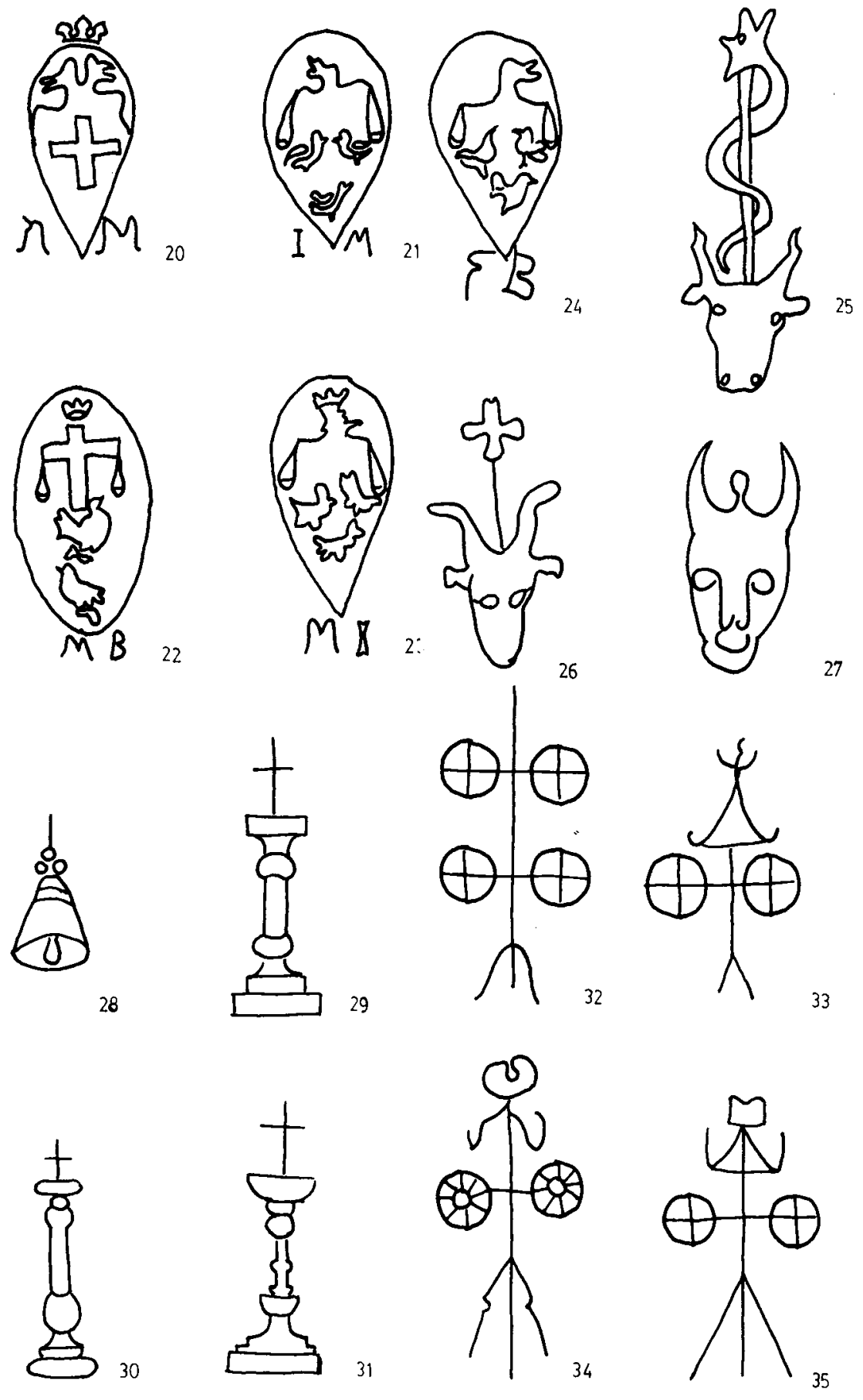

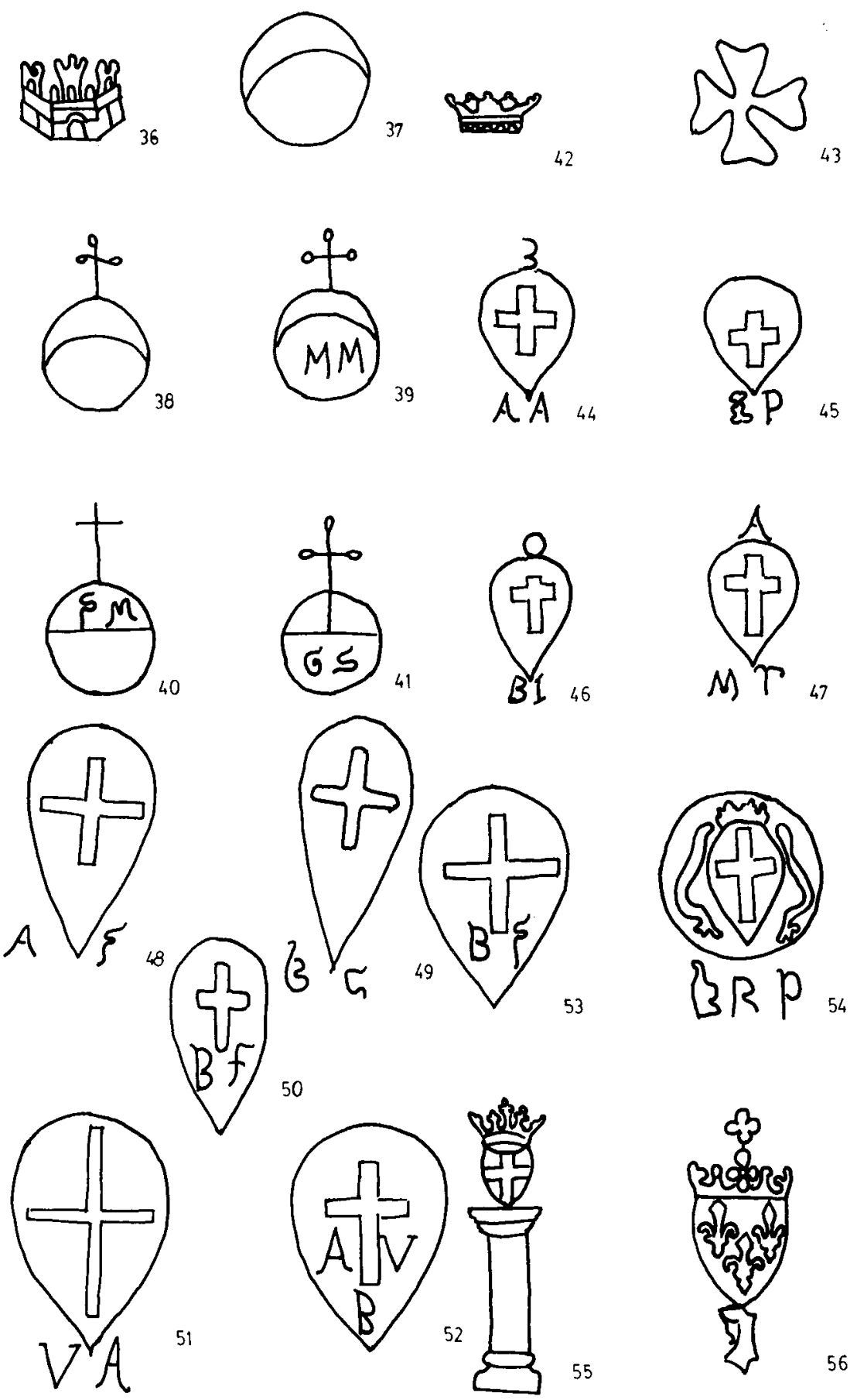
్ㅗ

57

ใิด

58
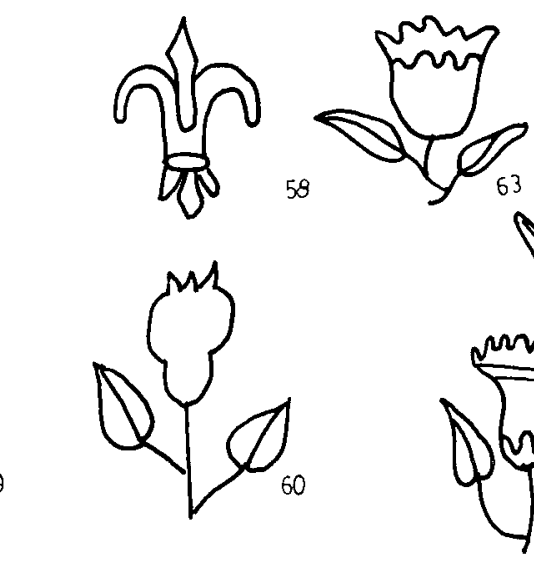

59
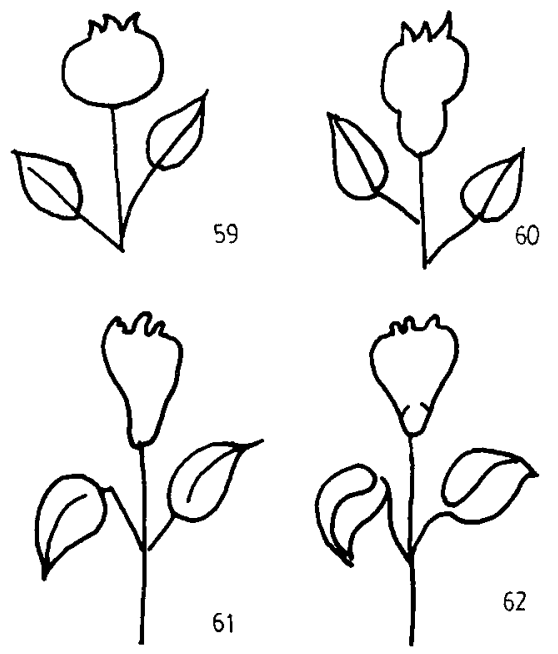

66
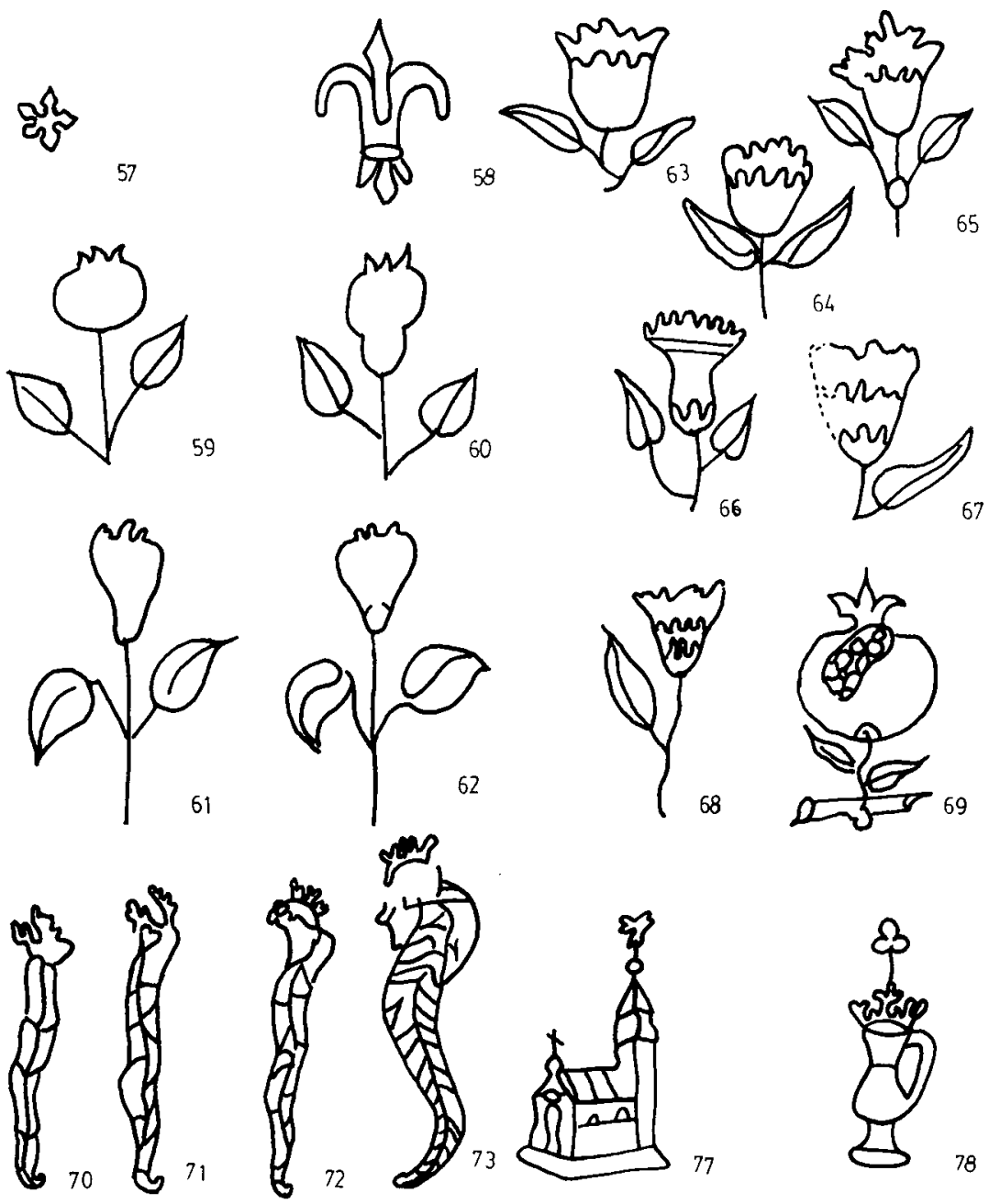

68
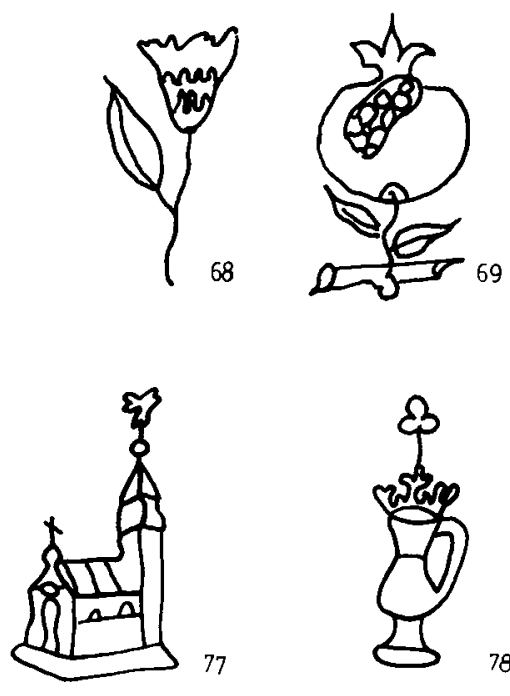

77

78
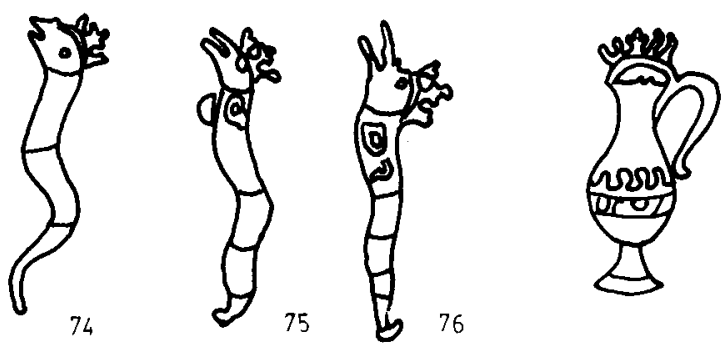

79

80

422 


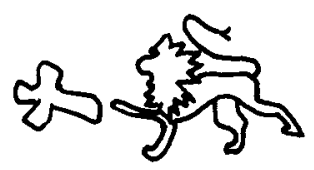

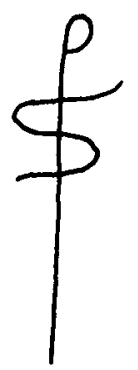

82

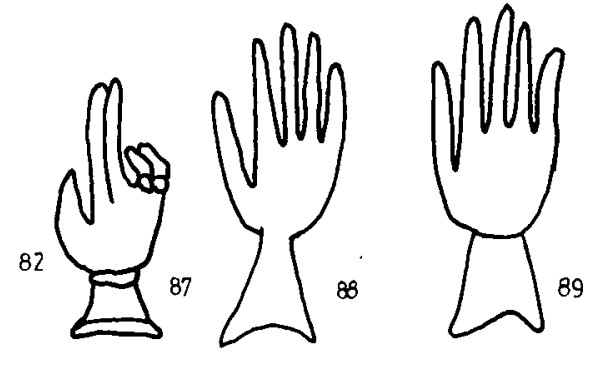

$\int_{83} P t_{04}$

4.

$\infty$

$D_{93}$

sos

sp

है is

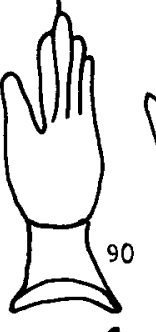

sos

क्ष

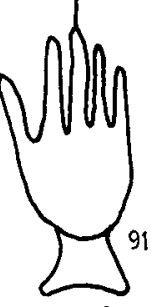

है?

Nih

94

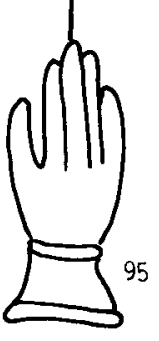

कs

Nih

96
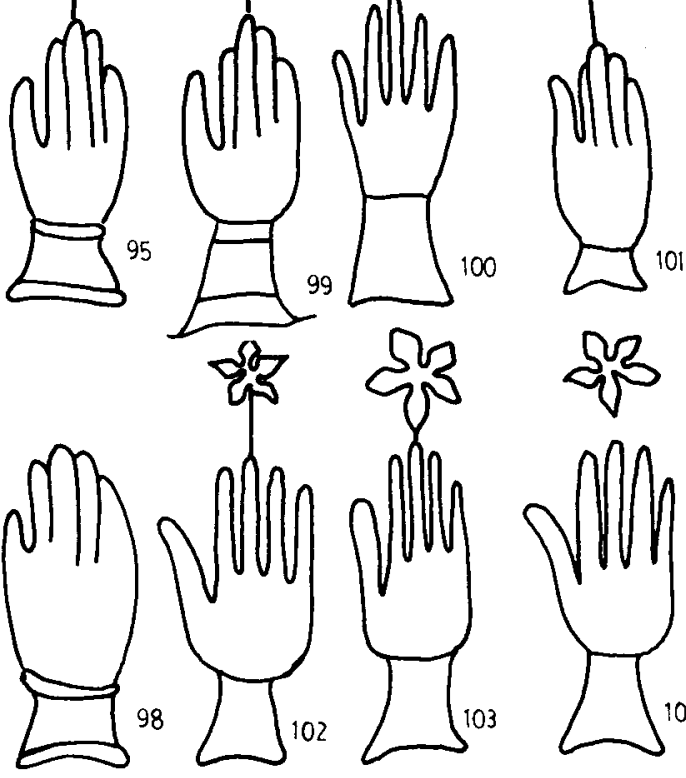

जु दूर

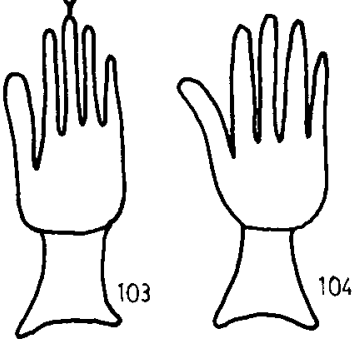



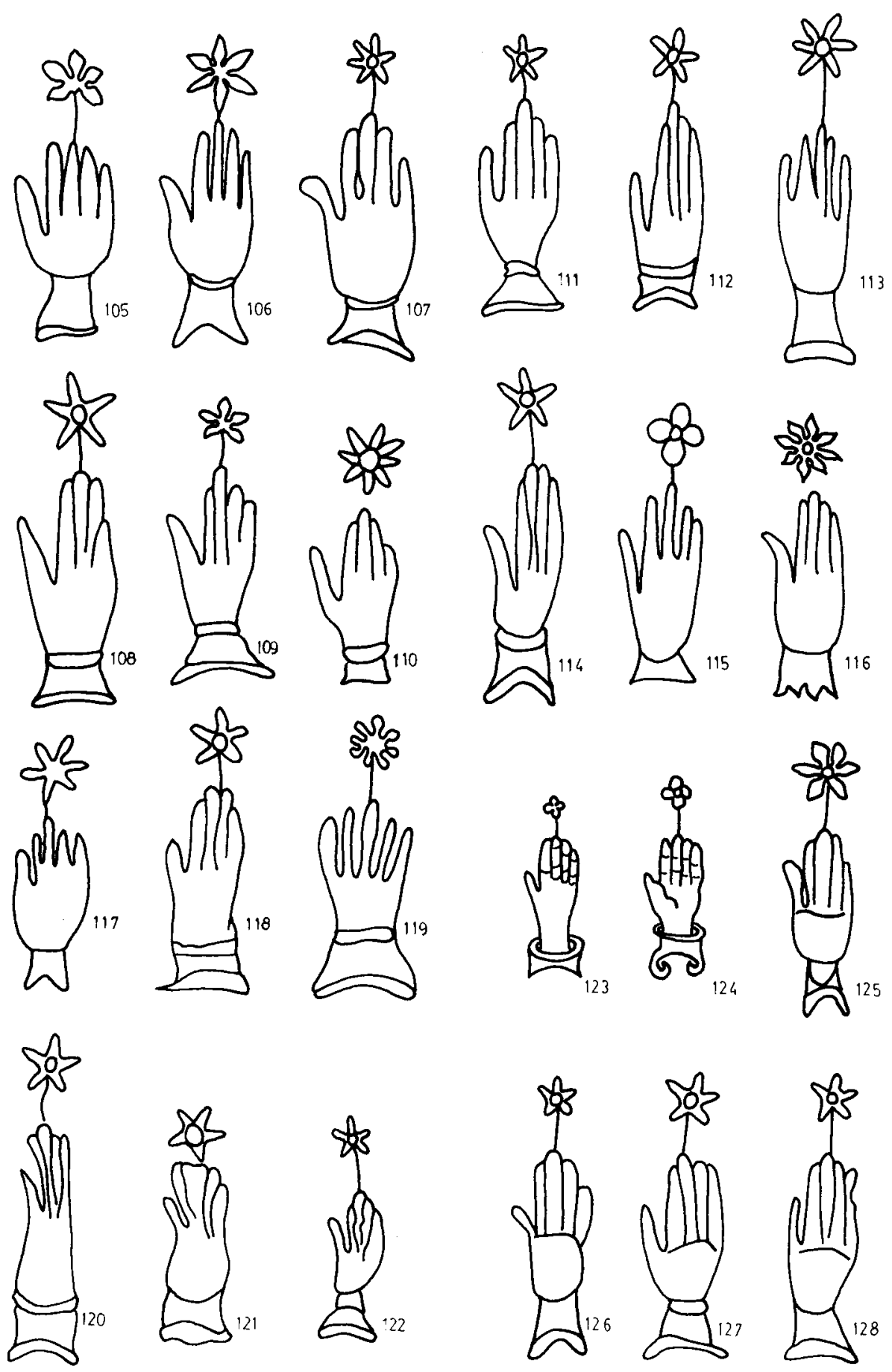

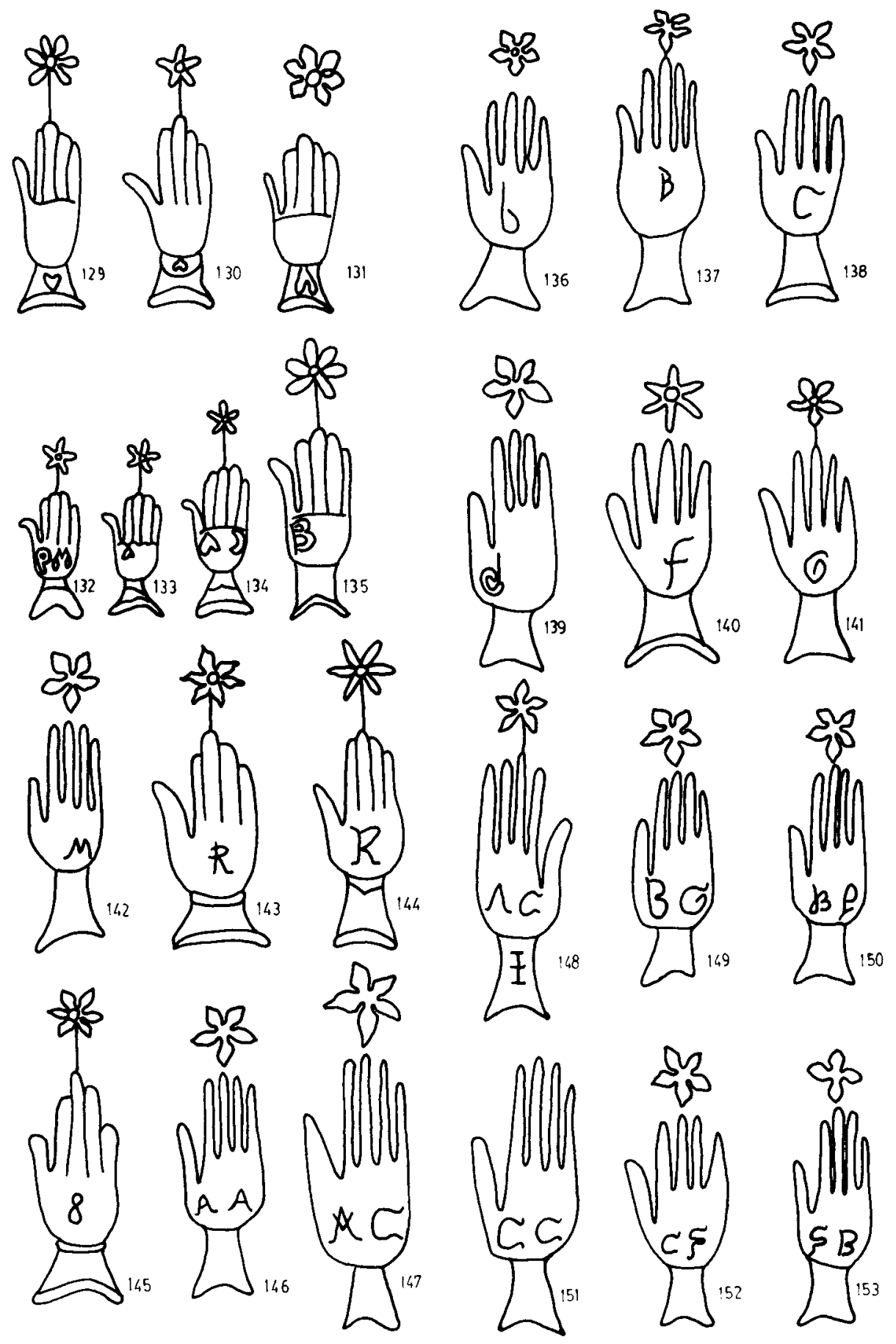

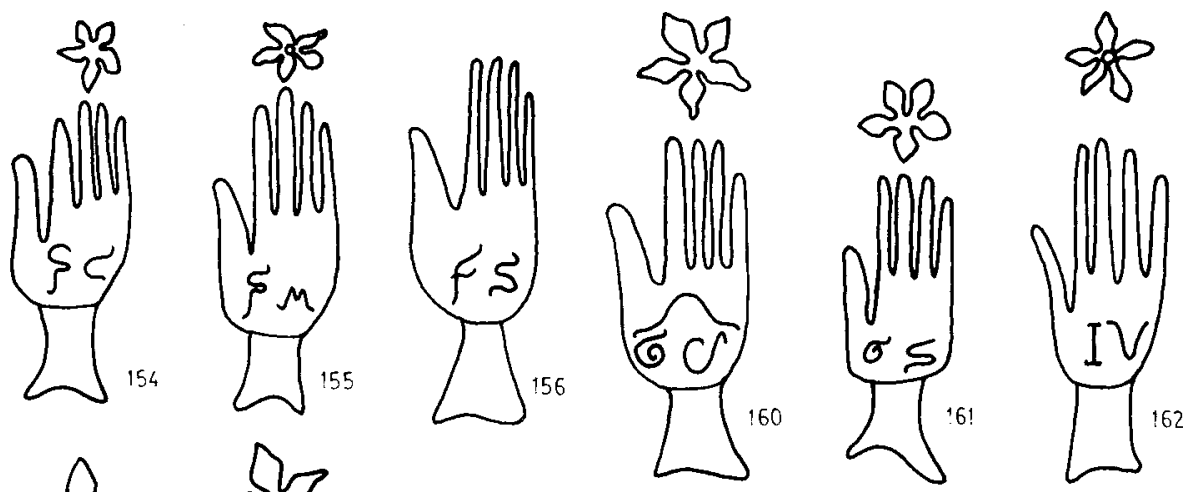

है दे
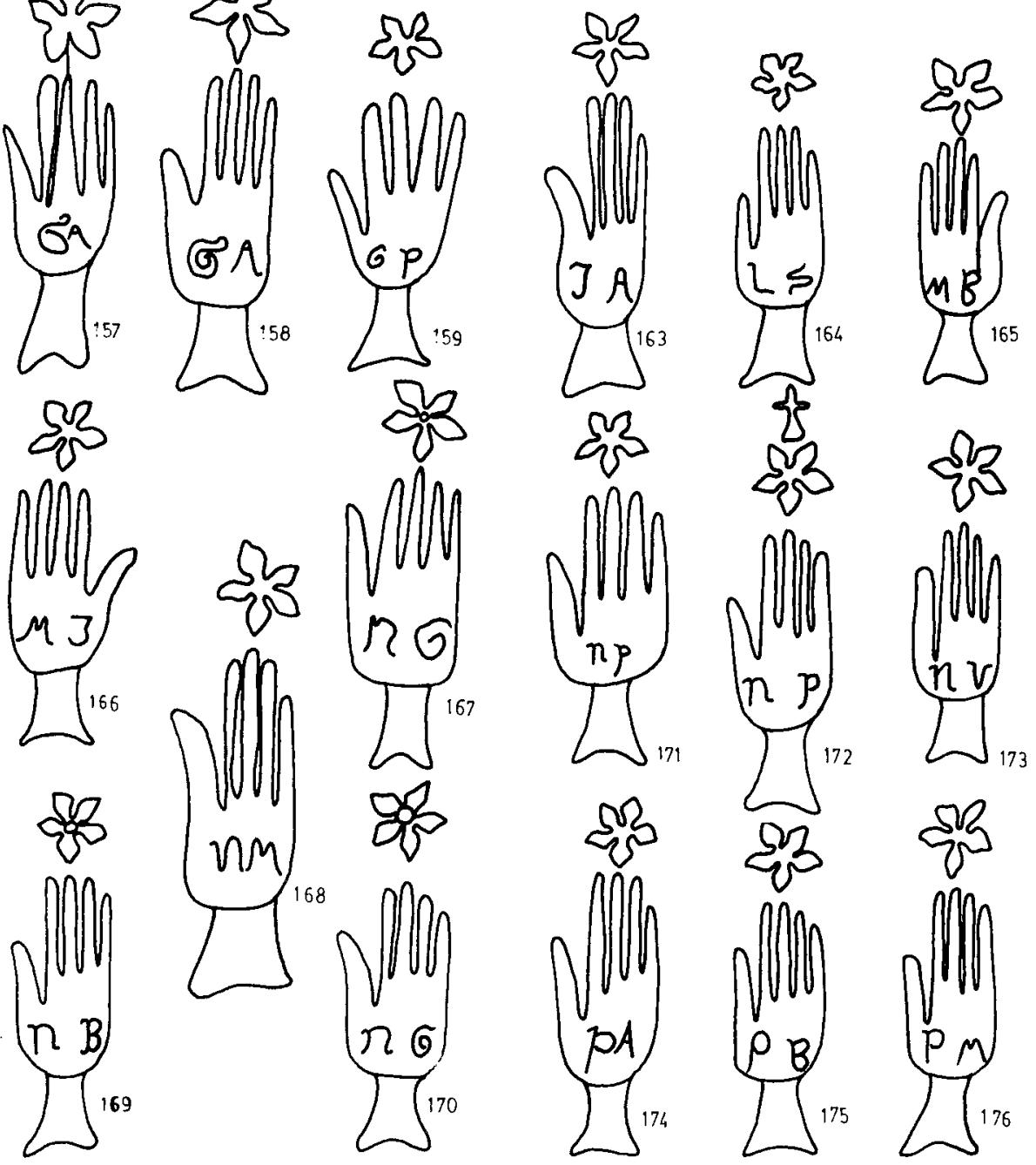


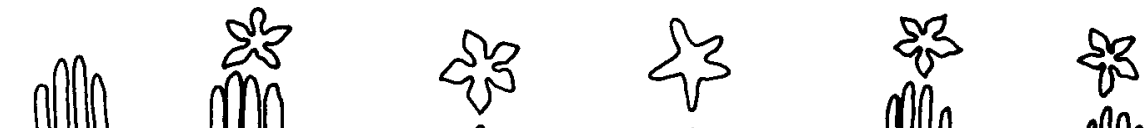
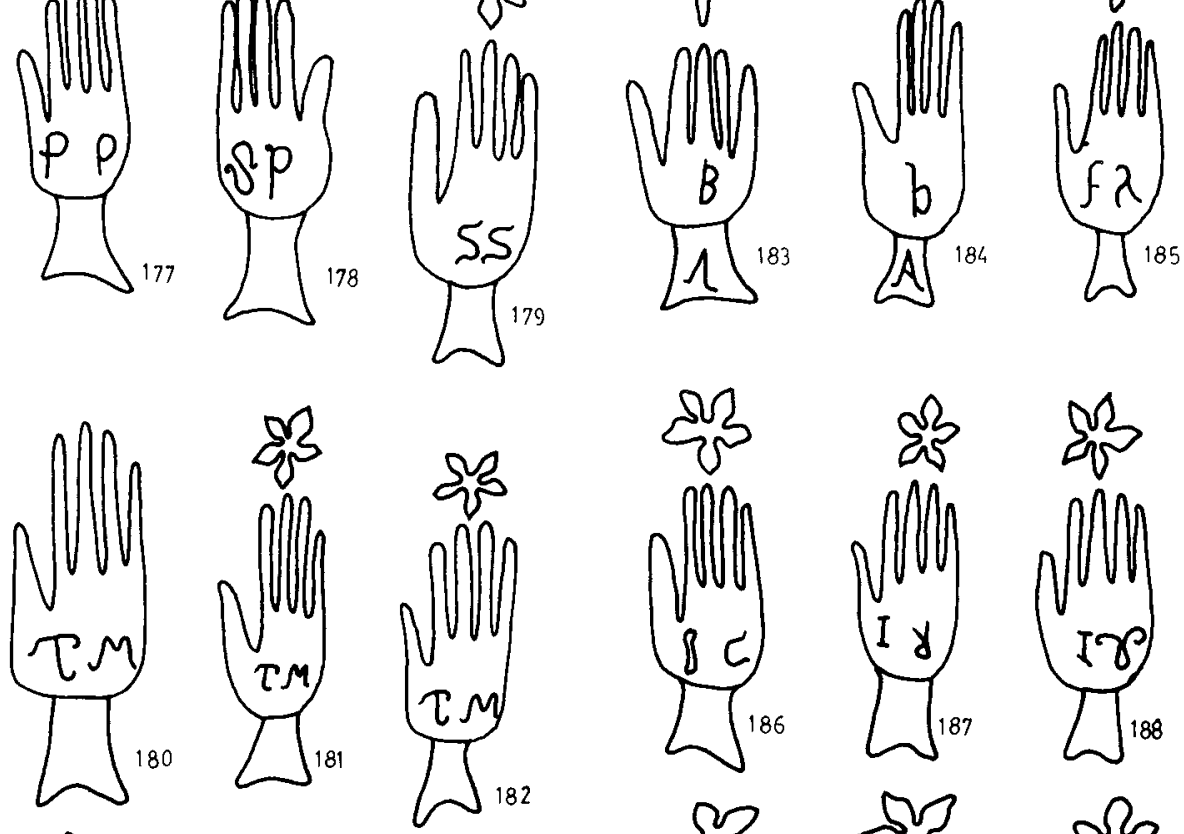

$\mathrm{C}^{3}$
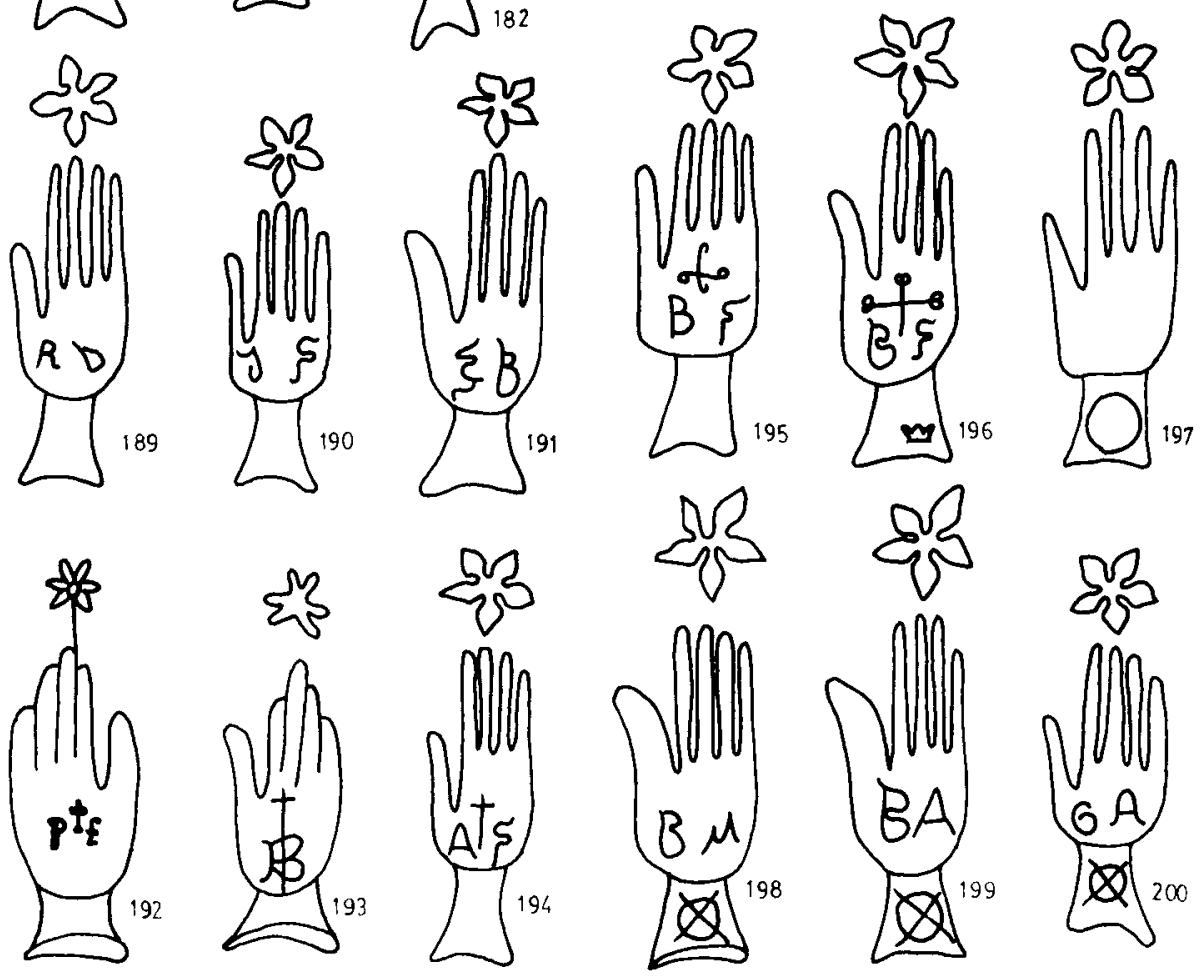


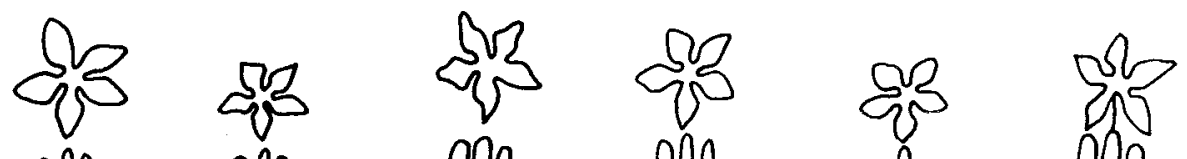
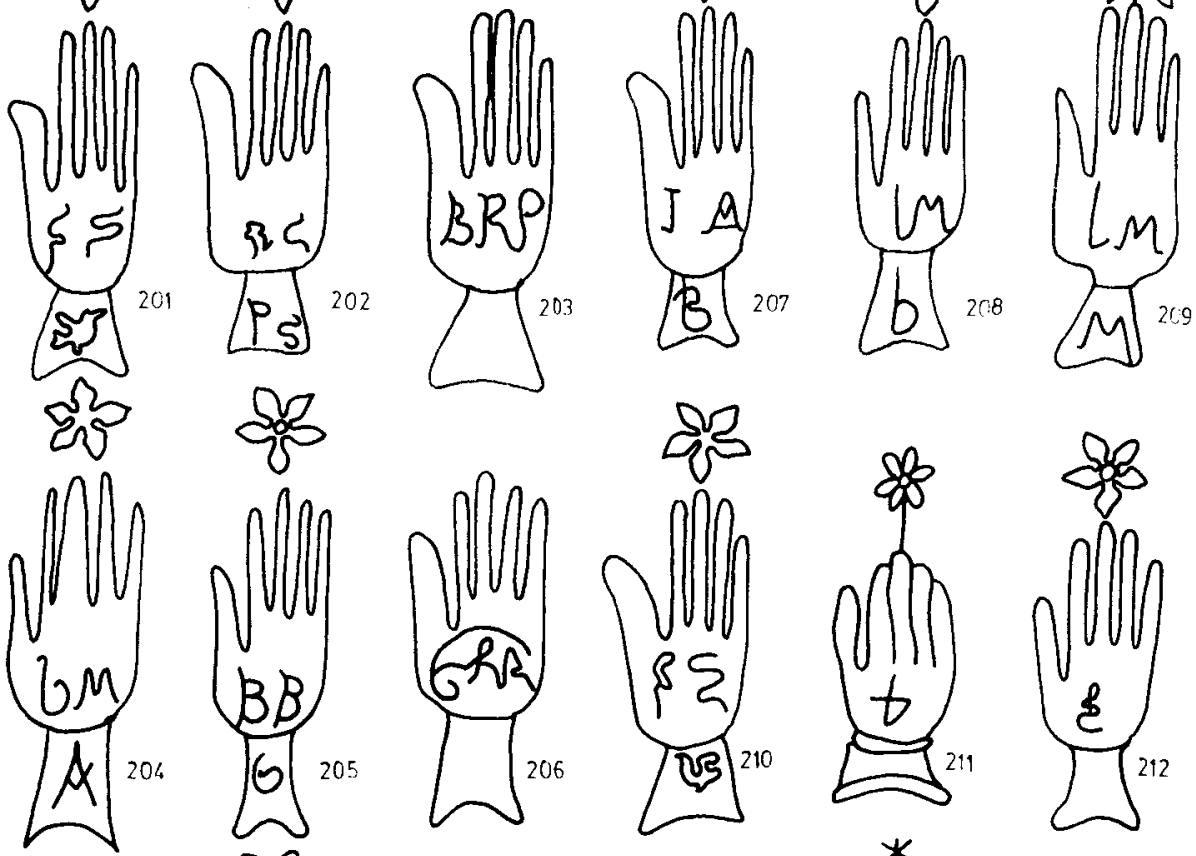

हु है
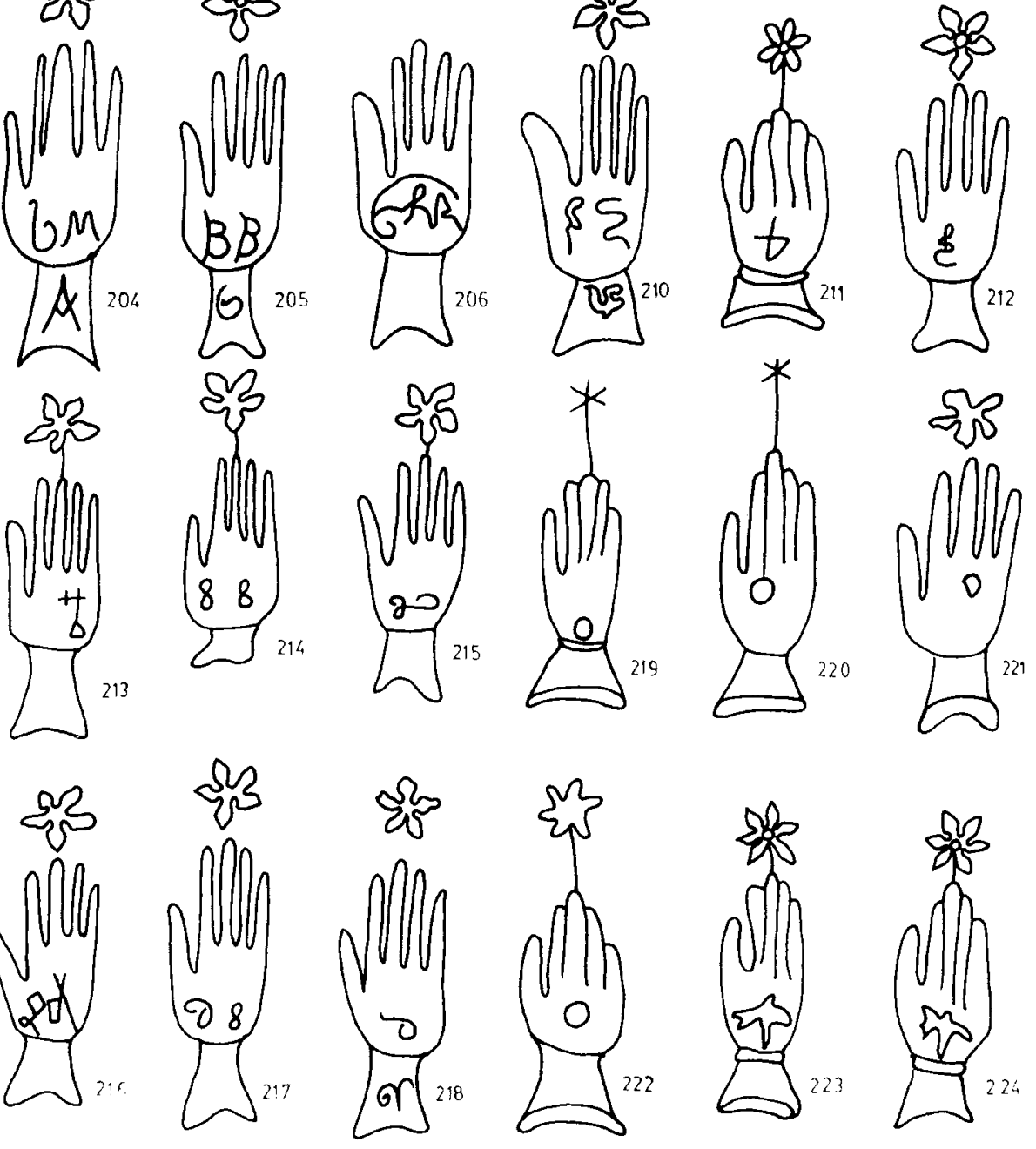

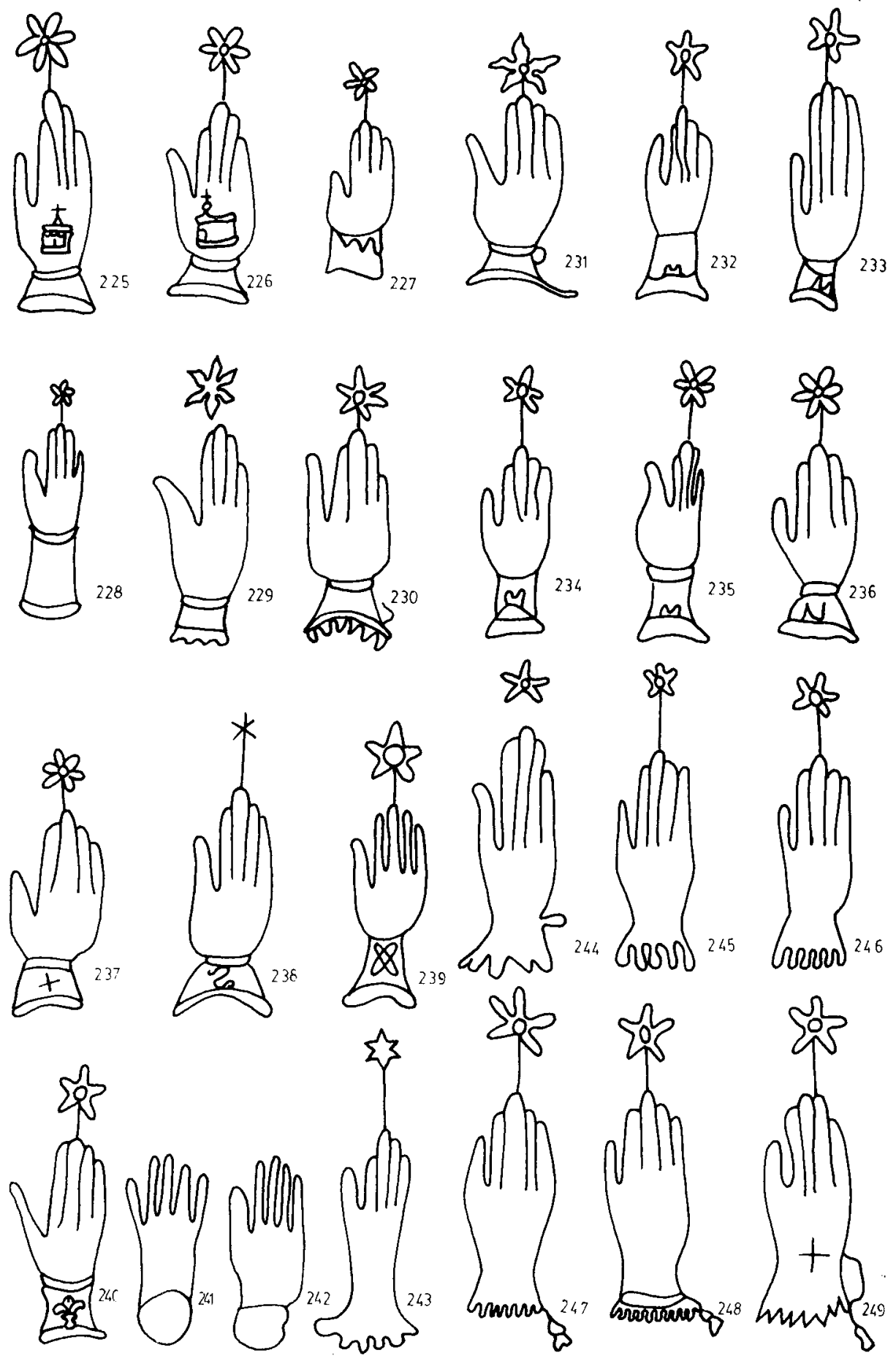

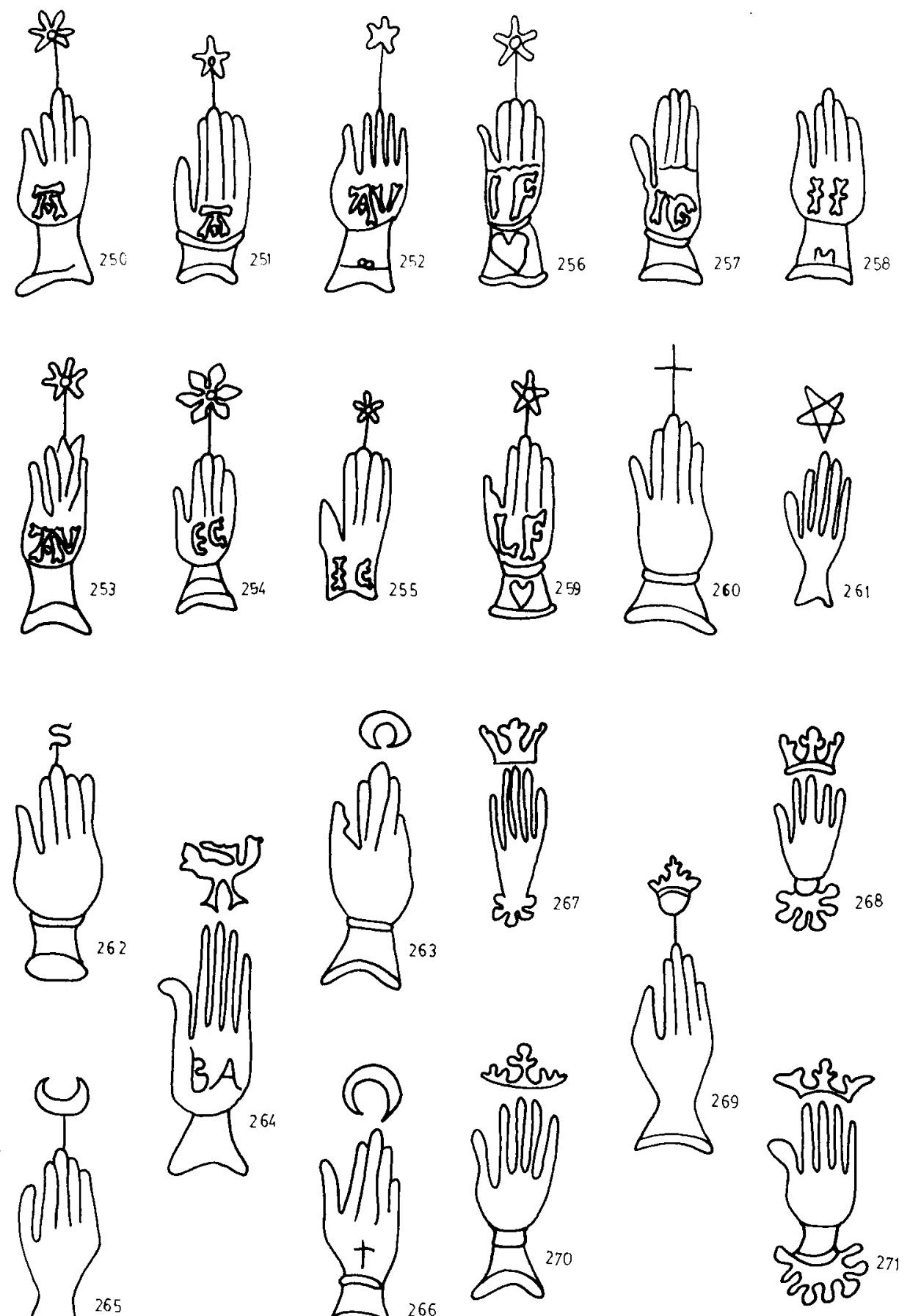

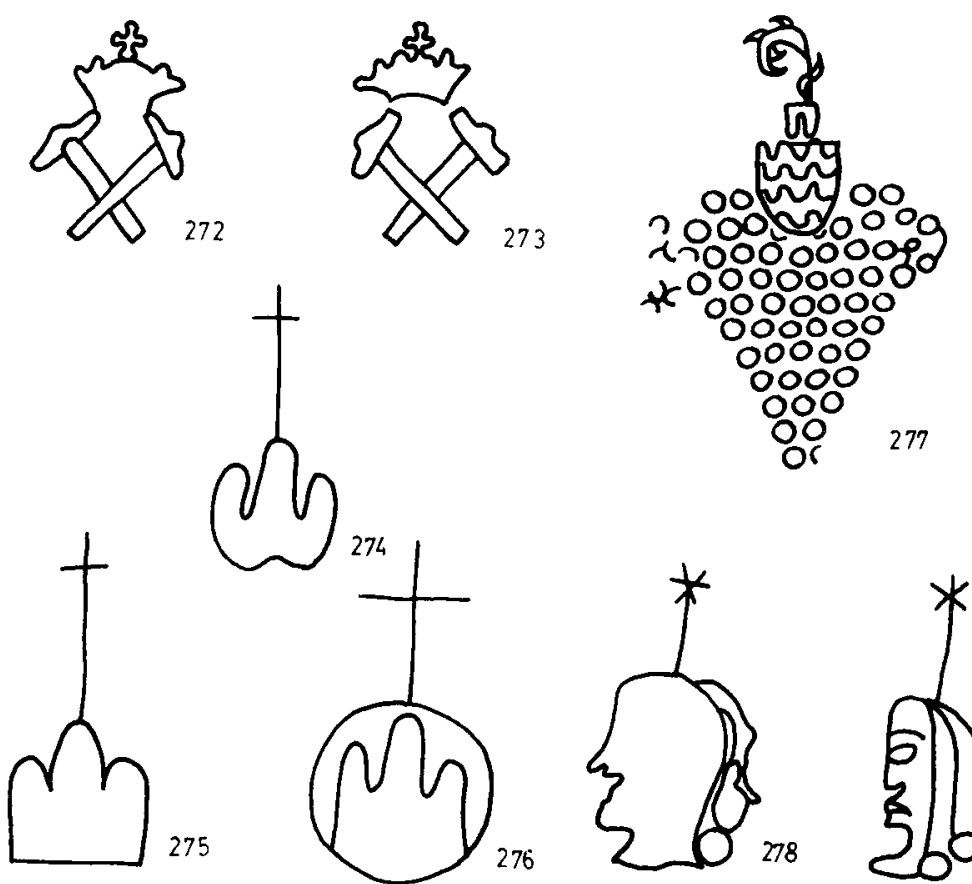

b

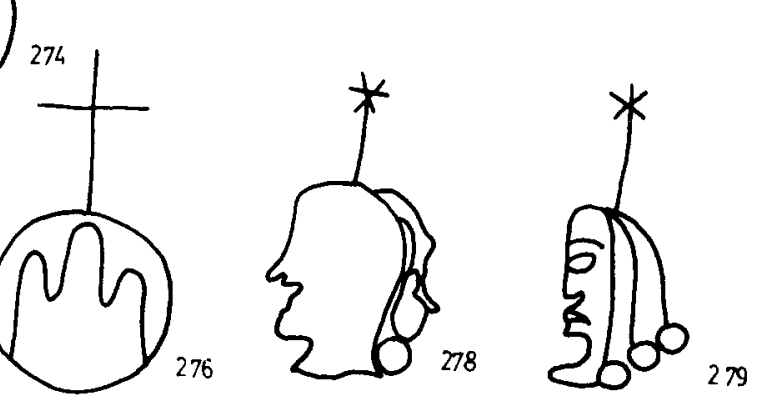

这直

281
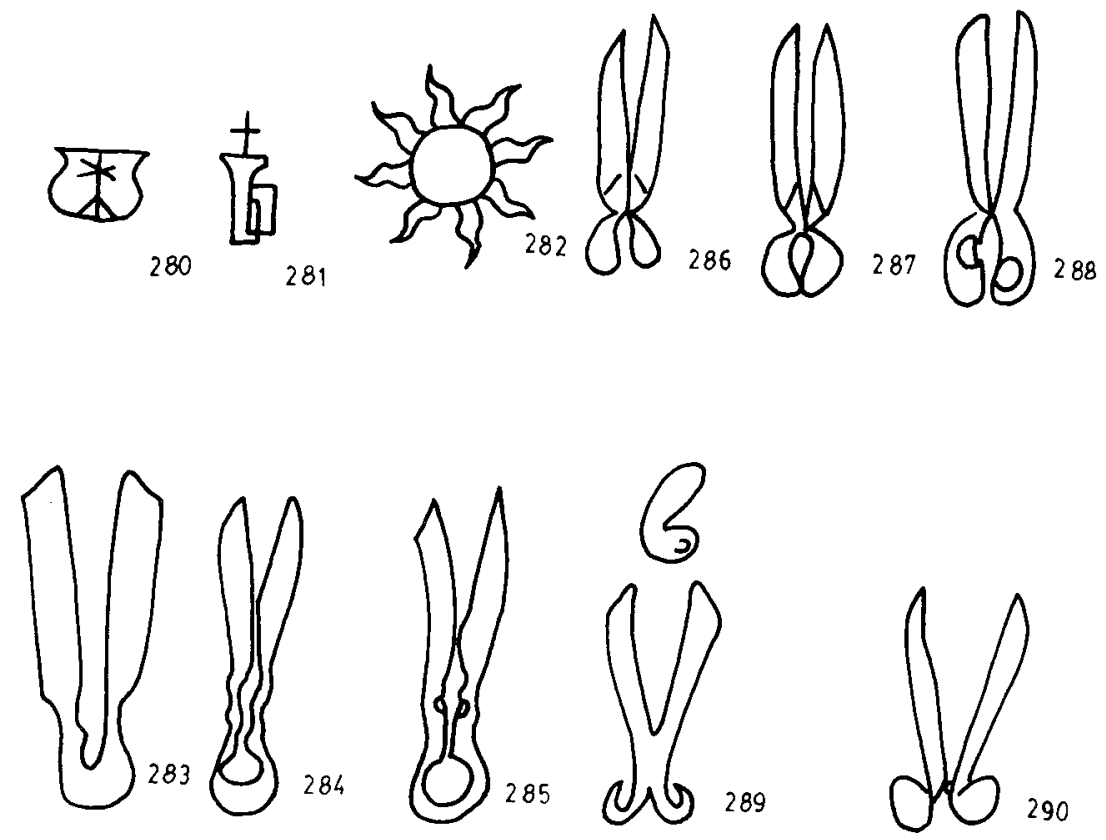

431 

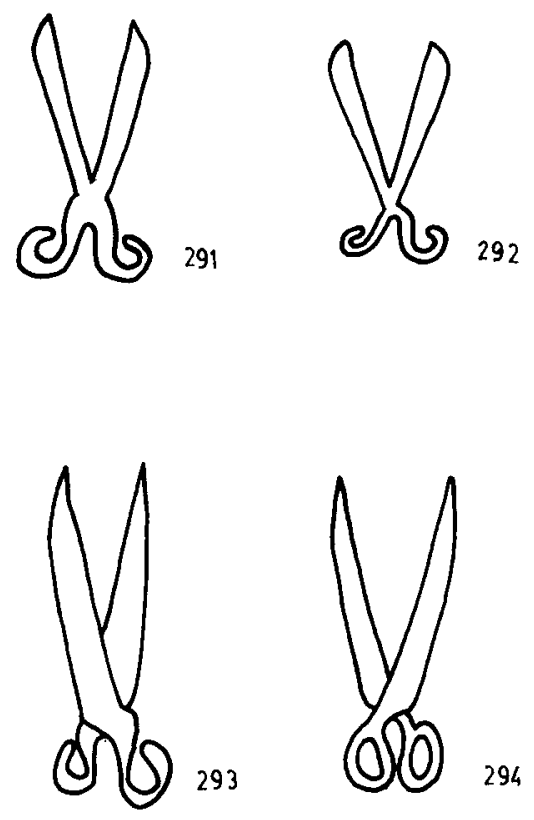

432 


\section{ANEXO III}

FIGURA CÓRDOBA

\begin{tabular}{|c|c|c|c|c|}
\hline TIPO & NÚMERO & FECHA & LOCALIDAD. FECHA & AUTOR. NÚMERO \\
\hline ANCLA & 1 & 1492 & $\begin{array}{l}\text { ITALIA. } 1490-92 \\
\text { SUECA. } 1492\end{array}$ & Briquet. 457 \\
\hline ANILLO & 5 & 1484 & $\begin{array}{l}\text { PIAMONTE. } 1483 \\
\text { CASTELLÓN. } 1480 \\
\text { MOSQUERUELA. } 1481\end{array}$ & $\begin{array}{l}\text { Briquet. } 692 \\
\text { López. } 6 \\
\text { Ariño. } 46\end{array}$ \\
\hline ÁGUILA & 19 & 1542 & MILÁN. 1541 & Briquet. 912 \\
\hline BUEY & 25 & 1512 & ALEMANIA. $1506-20$ & Briquet. 15445 \\
\hline BUEY & 26 & 1478 & TARRAGONA. 1437 & Sánchez Real. 5 \\
\hline CANDELABRO & 29 & 1492 & $\begin{array}{l}\text { LYON. } 1476 \\
\text { VILLARREAL. } 1464\end{array}$ & $\begin{array}{l}\text { Briquet. } 4364 \\
\text { Doñate. } 66\end{array}$ \\
\hline CARRO & 32 & 1449 & MOSQUERUELA. 1450 & Ariño. 120 \\
\hline CARRO & 33 & 1435 & LUCCA. 1434 & Briquet. 3544 \\
\hline CARRO & 35 & 1460 & $\begin{array}{l}\text { VILLARREAL. } 1465 \\
\text { JÁTIVA. } 1453 \\
\text { MOSQUERUELA. } 1460\end{array}$ & $\begin{array}{l}\text { Doñate. } 46 \\
\text { Cabanes. } 43 \\
\text { Ariño. } 94\end{array}$ \\
\hline CASTILLO & 36 & 1480 & $\begin{array}{l}\text { NÁPOLES. } 1469 \\
\text { VILLARREAL. 1466-67 } \\
\text { JÁTIVA. } 1498\end{array}$ & $\begin{array}{l}\text { Briquet. } 15913 \\
\text { Doñate. } 52 \\
\text { Cabanes. } 52\end{array}$ \\
\hline CRUZ & 53 & 1524 & FRANCIA. 1561 & Briquet. 5681 \\
\hline ESCUDO & 56 & - & HAMBURGO. 1494 & Briquet. 1660 \\
\hline FLOR & 63 & 1514 & $\begin{array}{l}\text { ZARAGOZA. } 1518 \\
\text { CASTELLÓN. } 1474 \\
\text { VILLARREAL. } 1491 \\
\text { JÁTIVA. } 1494 \\
\text { SUECA. } 1493\end{array}$ & $\begin{array}{l}\text { Briquet. } 6665 \\
\text { López. } 62 \\
\text { Doñate. } 92 \\
\text { Cabanes. } 69 \\
\text { Cortes. } 30\end{array}$ \\
\hline
\end{tabular}


FIGURA CÓRDOBA

\begin{tabular}{|c|c|c|c|c|}
\hline $\mathrm{TIPO}$ & NÚMERO & $\mathrm{FECHA}$ & LOCALIDAD. FECHA & AUTOR. NÚMERO \\
\hline FLOR & 66 & 1496 & ITALIA. 1435-63 & Briquet. 6640 \\
\hline FLOR & 68 & 1454 & MURCIA, 1454 & Abellán. 87 \\
\hline IGLESIA & 77 & 1486 & VILLARREAL. 1483 & Doñate. 105 \\
\hline LETRAS & 83 & 1516 & CARPENTRAS. 1523 & Briquet. 9070 \\
\hline LETRAS & 84 & 1492 & PALERMO. 1484 & Briquet. 9648 \\
\hline LOBO & 85 & 1464 & TARRAGONA. 1464 & Sánchez Real. 20 \\
\hline MANO & 124 & 1522 & NAMUR. 1530 & Briquet. 11428 \\
\hline MANO & 133 & 1554 & TOURS. 1548 & Briquet. 11245 \\
\hline MANO & 156 & 1514 & GÉNOVA. 1528 & Briquet. 10748 \\
\hline MANO & 195 & 1532 & GÉNOVA. 1549 & Briquet. 10736 \\
\hline MANO & 203 & 1540 & SIRACUSA. 1529 & Briquet. 10739 \\
\hline MANO & 226 & - & $\begin{array}{l}\text { PERPIÑÁN. } 1501 \\
\text { VILLARREAL. } 1496 \\
\text { MOSQUERUELA. } 1487\end{array}$ & $\begin{array}{l}\text { Briquet. } 11186 \\
\text { Doñate. } 130 \\
\text { Ariño. } 268\end{array}$ \\
\hline MANO & 230 & 1492 & $\begin{array}{l}\text { PALERMO. } 1487 \\
\text { CASTELLÓN. } 1487-92\end{array}$ & $\begin{array}{l}\text { Briquet. } 11135 \\
\text { López. } 97\end{array}$ \\
\hline MANO & 231 & 1490 & $\begin{array}{l}\text { PALERMO. } 1482 \\
\text { CASTELLÓN. } 1486-89\end{array}$ & $\begin{array}{l}\text { Briquet. } 11158 \\
\text { López. } 90\end{array}$ \\
\hline MANO & 240 & 1514 & BURGOS. 1515 & Briquet. 11187 \\
\hline MANO & 248 & 1492 & CASTELLÓN. $1487-89$ & López. 96 \\
\hline MANO & 249 & 1492 & $\begin{array}{l}\text { CASTELLÓN. 1491-93 } \\
\text { MOSQUERUELA. } 1493\end{array}$ & $\begin{array}{l}\text { López. } 98 \\
\text { Ariño. } 281\end{array}$ \\
\hline MANO & 251 & 1522 & BURGOS. 1523 & Briquet. 11189 \\
\hline MANO & 269 & 1484 & MOSQUERUELA. 1478 & Ariño. 226 \\
\hline MARTILLO & 272 & 1496 & FRANCIA. $1460-90$ & Briquet. 11638 \\
\hline MARTILLO & 273 & 1492 & FRANCIA. $1460-90$ & Briquet. 11639 \\
\hline MONTE & 274 & 1429 & MURCIA. 1429 & Abellán. 137 \\
\hline MONTE & 276 & 1450 & MURCIA. 1431 & Abellán. 141 \\
\hline RACIMO & 277 & 1514 & NANTES. $1507-40$ & Briquet. 13120 \\
\hline ROSTRO & 278 & 1492 & $\begin{array}{l}\text { CASTELLÓN. } 1489 \\
\text { JÁTIVA. } 1500\end{array}$ & $\begin{array}{l}\text { López. } 26 \\
\text { Cabanes. } 32\end{array}$ \\
\hline ROSTRO & 279 & 1518 & NIMES. 1533 & Briquet. 15695 \\
\hline TIJERAS & 283 & 1480 & GÉNOVA. 1452 & Briquet, 3762 \\
\hline TIJERAS & 286 & 1478 & VILLARREAL. 1485 & Doñate. 162 \\
\hline TIJERAS & 292 & 1490 & MOSQUERUELA. 1489 & Ariño. 329 \\
\hline
\end{tabular}




\title{
OTRO DISCURSO HISTÓRICO: LA NOVELA
}

\author{
JOSÉ M. ${ }^{\text {a }}$ BERNARDO PANIAGUA \\ Catedrático de Lengua y Literatura de I. B.
}

«El discurso histórico no sigue a lo real, sólo significa sin dejar de repetir: «ha ocurrido». Esa aseveración nunca puede dejar de ser otra cosa que el reverso significado de toda la narración históricam. (Roland Barthes) (1)

Reivindicar para la novela, discurso narrativo, la calificación de discurso histórico, lectura de la realidad con coordenadas historiográficas puede ser una osadía, en ningún caso una estultez, porque es un producto histórico, contextualizado socioculturalmente. Es una lectura de la realidad modelizada de forma especifica, por lo que constituye también un testimonio básico para la investigación histórica y, sobre todo, la novela contemporánea, constituye una explícita alternativa: discurso histórico débil frente a discurso histórico fuerte (historia cientifica).

Aclarar esta postura exige una triple operación: acercamiento al discurso narrativo e histórico como artefactos lingüísticos, narrativos e historizados o productos culturales; aproximación a los mismos, buscando una interrelación y mejor delimitación; confrontación de los supuestos teóricos provenientes de las operaciones anteriores con la producción de historiadores y novelistas contemporáneos.

\section{EL DISCURSO NARRATIVO}

Entendido el armazón narrativo como el invento del autor-novelista a través de un narrador que, responsable (indiciado en la afición) directo, construye el entramado necesario para relatar, contar una historia de forma dinámica por medio de unos personajes (actantes) que realizan una serie de acciones dentro de un espacio y de un tiempo con la finalidad de transmitir a los 
lectores la visión que dicho autor posee de una realidad (referente) bajo el pretexto, con el modelo, de la ficción.

Es, pues, la narración, el discurso narrativo (la trama, el relato) un producto del autor narrador y a él corresponde crear una lógica narrativa, una ordenación de acciones, un tratamiento del tiempo y del espacio. Constituye, en resumen, un producto mental, conceptualización o ideologización, de un autor que, valiéndose del narrador, manipula arbitrariamente (2), aunque haya de respetar la lógica especifica de ese discurso: la verosimilitud, lógica inherente al discurso imaginario y exigida por la forma de narrar, de contar la historia, puesto que este discurso no está determinado directamente por la dinámica o lógica causal de los hechos, de la realidad, sino por las convenciones discursivas que, al menos en su apariencia -estructura superficialson lingüísticas o narrativas, no históricas ni reales o experienciales (objetivas).

Hablar de normas lingüisticas en el discurso narrativo nos lleva a las consideraciones que en torno al texto ha realizado la llamada Lingüística Textual (3), una teorización surgida desde presupuestos propiamente lingüisticos, filosóficos, comunicacionales y semióticos. Teorización que, partiendo de un supuesto básico: el texto como unidad comunicativa fundamental, ha constituido un completo corpus y un modelo de explicación lingüística coherente $y$ tértil.

Una delimitación del propio término, de carácter más bien descriptivo, puede valernos para acortar el ámbito de nuestro acercamiento al texto con el fin de localizar el discurso narrativo en su dimensión textual correcta. Delimitación que Bernárdez elabora tras el análisis de las definiciones de autores diferentes, con planteamientos lingüísticos diversos, en estos términos: «Texto es la unidad lingüística comunicativa fundamental, producto de la actividad verbal humana, que posee siempre carácter social; está caracterizado por su cierre semántico y comunicativo, así como por su coherencia profunda y superficial, debida a la intención (comunicativa) del hablante de crear un texto íntegro, y a su estructuración mediante dos conjuntos de reglas: las propias del nivel textual y las del sistema de lengua" (4).

Evidencia esta definición básicamente la existencia de unos sujetos interlocutores, corresponsables de la eficacia en la producción textual, creación y recreación (producción de sentido) del mismo (5), la coherencia-cohesión (6) de su estructura y delimitación situacional a través de los elementos pragmáticos (7). Datos que pueden, para nuestro objetivo, leerse de este modo: un emisor transmite una visión de la realidad (establece una hipótesis de lectura) a un receptor, interno o externo; un autor pretende elaborar la lectura de una 
realidad y la presenta, como mensaje, para un lector ideal (8) y para cualquier otro posible lector capacitado de realizar una correcta decodificación, la producción de sentido a través del texto como pretexto (9) y para cumplir dicho objetivo necesita una competencia textual.

Dicha coherencia-cohesión ha de ser establecida a través de recursos fómicos, morfosintácticos y semánticos; así como, y sobre todo, pragmático, pues al decir de $\mathrm{C}$. Segre «más bien, se deben buscar en la situación pragmática todas las condiciones de coherencia de un discurso. Estas condiciones se realizarán explícitamente, bien en la formación de cada una de las frases, o bien, y sobre todo, en su encadenamiento (de aquí la importancia de las frases iniciales, o en los textos escritos, de los títulos): se puede decir que la sintaxis es capaz de introyectar, gramaticalizándola, gran parte de la pragmática» (10).

Los tipos de coherencia han sido descritos de formas diferentes por los autores. Lozano (11) habla de cohesión superficial, coherencia global, coherencia pragmática y coherencia interna o isotopía.

El discurso narrativo, por constituir un tipo de texto, aunque especial, ha de cumplir todos los requisitos de su producción, y en esto coincide, se relaciona, con cualquier otro texto: científico, diálogo, publicidad. No obstante, dicho texto posee los ingredientes suficientes que lo diferencian y delimitan respecto a cualquier otro, sea a partir de la coherencia pragmática como determinante (12) o, de forma más genérica, porque «el discurso literario es un acto lingüístico muy particular, sin una finalidad comunicativa inmediata (de hecho continúa siendo válido incluso para lectores alejados en el tiempo y en el espacio)... El mensaje literario comunica, en algunos casos puede renovar la visión del mundo, y siempre la profundiza. Su apariencia no finalista $y$, viceversa, la importancia de sus efectos, dependen de su muy particular modalidad de comunicación: el emisor (el escritor) desarrolla su obra sólo hasta que completa el mensaje; el receptor (lector) parte del mensaje para interpretarlo, sin preguntar al emisor...»(13).

En resumen, el texto narrativo, una modalidad del literario, constituye un modelo de tratamiento de la realidad diferente de cualquier otro texto, al menos en su estructura superficial ( $y$, por supuesto, tómese como se tome, la estructura profunda) aparece ante el lector como una construcción original: la trama, el relato, reflejan una coherencia-cohesión específica, una ordenación particular de los elementos. No podemos, ni sería demasiado útil ahora, repasar el proceso de configuración (definición y delimitación estructural) seguido por la narración, desde Platón a la moderna narratología, pero sí nece- 
sitamos, a fin de subrayar la especifidad de este tipo de discurso, trazar las líneas básicas que los formalistas, retóricos, estilistas o semióticos han resaltado para caracterizar este discurso, manifestación del significante que construye el artefacto narrativo (14).

Estos teóricos del discurso narrativo (15) inciden fundamentalmente en la consideración de este discurso como la configuración, estructuración coherente, de una ficción con la intencionalidad concreta de ofrecer la visión, el punto de vista, la focalización de una realidad (16) acorde con los supuestos ideológicos del narrador, del novelista. Esta configuración exige un supuesto básico, la verosimilitud, es decir: la construcción coherente, interrelación verosímil de los elementos que forman parte de dicho discurso. En principio, el referente, la realidad circundante y determinante, leida desde el bagaje cultural e ideológico del autor. Desde ahí, con la intención de emitir un mensaje (visión dialéctica, descriptiva o lúdica de esa realidad) se inicia todo el proceso creador, productor del texto narrativo, basado en una competencia semiótica, textual —dominio de los rasgos de coherencia-.

Dicho proceso o dinámica de la producción incluye la invención de un proyecto que pretende dinamizar esa visión de la realidad a través de un entramado accional en torno al cual giran los demás elementos, puesto que las acciones suponen actantes e implican un espacio donde situarse y un tiempo en el que transcurren. La ordenación lineal de dichas acciones constituiría la historia; la ordenación arbitraria, transgresora, constituiría la trama, el relato (17). Todo esto, desde la visión del narrador; el lector, en cambio, es quien desde su competencia lectora, productora de sentido (18) establece la organización del significante que se le presenta, descubriendo una morfosintaxis o fragmentación del texto; una semántica o tratamiento de la realidad y una pragmática o relación narrador-lector a través del lenguaje (19).

Insistimos, para finalizar este apartado, en la exigencia de resaltar la función determinante del narrador en la estructura del invento narrativo que se presenta ante el lector como texto. Es él, y no el autor, quien aparece como índice lingüístico, significante (voz verbal, modo, personaje o acotación) a partir del cual deducimos el tipo de visión que se nos intenta ofrecer (20), el punto de vista o la focalización: visión omnisciente, por encima de la narración; visión por debajo de la narración o visión a la misma altura que la narración.

Estas acotaciones han de entenderse como claves para comprender la hipótesis que pretendemos poner en evidencia, ya que si repasamos la historia de la narrativa observaremos cómo en función de las culturas, de las ideologías dominantes, predomina un tipo de acercamiento a la realidad narrada. 
Al fin y al cabo, un alejarniento de la realidad —la omnisciencia - no es más que el afán de crear el engaño, la ficción de la objetividad, base de la racionalidad y, en muchos casos, del dogmatismo; una difuminación de la voz del narrador, por el contrario, en el entramado de la propia narración es el cambio un intento de evidenciar el acercamiento débil y antidogmático a dicha realidad.

El narrador impone, en nombre del autor, su perspectiva de lectura configurando los personajes, las acciones, el espacio y el tiempo, instrumentos de esa visión desde fuera o del acercamiento a su misma altura. La coherencia del texto narrativo, por tanto, proviene de la correcta trabazón, de la lógica interna del propio relato, que llamaremos verosimilitud o apariencia de verdad, puesto que la fidelidad no ha de referirse a la realidad misma, que se considera radicalmente manipulable al ser básicamente el lenguaje, sino con las reglas lingüistico narrativas del relato.

Lo dicho hasta ahora en torno al discurso narrativo podría inducirnos, por su carácter sistemático y abstracto, al error de considerar la producción literaria y sus protagonistas como entes marginados de la realidad sociocultural en la que funcionan, como individualidades creadoras o intérpretes al margen de cualquier determinación, dentro de la idílica libertad del espíritu (21). Por el contrario, y tal como resalta N. Pizarro, creemos imprescindible hablar de la profunda historización del texto y de cada uno de los elementos que en él intervienen: autor, narrador, personajes, lenguaje, lector. Puesto que el lenguaje y los modelos narrativos, la tematización, tópicos sin duda, no son más que imposiciones del paradigma ideológico, de las matrices o ideologuemas de la culura como producción.

Esta dimensión histórica del texto narrativo, del texto en general, ha sido estudiada desde supuestos distintos, e incluso se ha llegado a dudar de la necesidad de la misma en base al afán excesivo de modelización como manifestación suprema de la sistematización, sobre todo desde el formalismo y estructuralismo, tendencias interesantes para el análisis, pero fragmentadoras por cuanto significan una aproximación descontextualizadora al texto, cuando en realidad «el hecho de hablar significa, como subraya N. Pizarro, más que el significado de los enunciados: significa la realización social reproducida por ellos» (22).

La historización del texto tiene una doble exigencia: la localización de los interlocutores del mismo y la contextualización del producto. Al menos así lo deducimos de este texto de C. Segre: «Al insertar el texto en un acto de comunicación, se evidencian automáticamente sus lazos de unión con la cultu- 
ra y se reivindica una perspectiva histórica. De hecho, el emisor extrae los códigos de que dispone para interpretar el texto. Detrás de la interpretación, existen grandes problemas originados por el encuentro entre dos culturas, y la posibilidad que uns cultura tiene de comprender ( $y$ asimilar) otra precedente. Los sistemas de significación están isntituidos dentro de una cultura y forman parte integrante de ella. Los procesos históricos, como señala Uspenski, son procesos comunicativos; coinciden con las respuestas del destinatario social a las nuevas informaciones ofrecidas por la cultura» (23).

Afirmación que se explicita más en este otro texto del mismo autor: «El ciclo análisis-sintesis-análisis-síntesis represneta en su simplicidad las fases principales de la vida comunicativa del texto. El emisor lleva a cabo un análisis de la realidad experimentada por él (y que comprende todos los elementos de continuidad histórica); lo sintetiza en el texto, recurriendo a los códigos de época de que dispone; el receptor analiza el texto, recurriendo a los mismos códigos de época, y lleva a cabo una síntesis interpretativa.

La historia parece, por tanto, revelarse bajo dos aspectos principales: como contenido histórico y como historicidad de los códigos. En un análisis más atento los dos aspectos resultan más homogéneos, dado que en el texto no importa tanto el dato o la evocación histórica como el "universo imaginario", por decirlo con Goldman, es decir, una historicidad interiorizada y estructurada como sistema. Este "universo imaginario" tiene estatuto de modelo y cosntituye un esquema para el funcionamiento de los códigos» (24).

Con estas afirmaciones estamos insistiendo en algo que las sistematizaciones, básicamente estructuralistas, han pretendido olvidar (25): el sujeto, emisor o receptor, como sujetos reales pertenecientes a una determinada sociedad, formación social y por lo mismo imposibles de ser comprendidos como indivíduos aislados, puesto que pertenecen, y por lo mismo reproducen los intereses de clase que determina cualquier actuación, incluida la producción ideológica y cultural, entiéndase ésta en los términos que se entienda. «El grado de competencia semiótica - subraya N. Pizarro- de los individuos sociales, las variaciones de esta competencia, serían analizadas en función de la pertenencia de los individuos a una clases social determinada, en consecuencia, la noción de clase podría estar relacionada a su vez con el concepto de competencia semiótica y el grado de competencia semiótica de una clase (su capacidad de producir productos significantes) podría estar relacionada de forma más o menos directa con la cantidad de materias primas disponibles...» (26). 


\section{EL DISCURSO HISTÓRICO}

Roland Barthes (27) ha realizado un interesante trabajo en torno al discurso histórico, analizándolo desde la perspectiva semiológica, superando los análisis meramente historiográficos, contenidísticos, al proyectar un modelo de análisis más completo y sistemático que introduce al texto histórico en el amplio ámbito de la teoría de la comunicación, donde deberán tenerse en cuenta todos los elementos que componen el proceso comunicativo.

Digamos, para empezar nuestro análisis del discurso histórico, con el propio Barthes que «A partir del momento en que interviene el lenguaje, el hecho sólo puede ser definido en forma tautológica: lo anotado proviene de lo notable, pero lo notable es - desde Herodoto, en quien la palabra ha perdido ya su aceptación mítica sólo aquello es digno de recordar, es decir, digno de ser anotado. Se llega asi a esa paradoja que regula toda la pertenencia del discurso histórico (con relación a otros tipos de discurso): el hecho nunca tiene sino una exigencia lingüística (como término de un discurso) y sin embargo todo ocurre como si esa existencia fuera sólo la 'copia' pura y simple de otra existencia situada en un campo estra-estructural, lo 'real'. Ese discurso es sin duda el único en que el referente es considerado exterior al discurso; sin embargo, nunca es posible encontrarlo fuera del discurso» (28).

Estas primeras acotaciones pueden deducirse de la afirmación introductoria de Barthes presenta en el trabajo ya citado, cuando dice «Esta lingüística (la del discurso) segunda debe investigar los universales del discurso (si existen), bajo la forma de unidades y de reglas generales y, al mismo tiempo, decidir, evidentemente, si el análisis estructural permite mantener la tipología tradicional de los discursos y si es legítimo contraponer aún el discurso poético al discurso novelesco, la ficción al relato. Precisamente sobre este último punto quisiéramos hacer algunas reflexiones: la narración de los hechos pasados, sometida por lo general en nuestra cultura, a partir de los griegos, a la sanción de la ciencia histórica, colocada bajo la imperiosa garantía de lo 'real', justificada por principios de exposición 'racional', ¿difiere realmente por algún rasgo especifico, por una indudable pertinencia, de la narración imaginaria tal como se la encuentra en la epopeya, la novela o el drama?. Y si ese riesgo - o esa pertinencia- existe, ¿en qué lugar del sistema discursivo, en qué nivel de la enunciación hay que situarla?..." (29).

De la respuesta a dicha interrogación, y centrando su atención en el análisis del discurso histórico que ahora nos preocupa. Como enunciación, dicho discurso histórico implica fijarse en el "shifter» de escucha, categoría «identificada, al nivel de la lengua, con el nombre de testimonial por Jakobson y se- 
gún la fórmula $\mathrm{C}^{\mathrm{e}} \mathrm{C}^{\mathrm{a}} / \mathrm{C}^{\mathrm{a} 2}$ : además del hecho $\left(\mathrm{C}^{e}\right)$, el discurso menciona a la vez el acto del informante $\left(C^{a}\right)$ y la parlabra del enunciante $\left(C^{a 2}\right)$ que se refiere a ese acto. Ese shifter designa, pues, toda mención de fuentes y testimonios, toda referencia a una 'forma de escuchar' del historiador que recoge una 'aufera' de su discurso y lo dice» (30); shifter, por lo demás, que «no es pertinente al discurso histórico; se lo encuentra con frecuencia en la conversación y en ciertos artificios de exposición de la novela (anécdotas contadas según ciertos informantes ficticios de los que se hace mención)» (31).

Por otra parte, los que podriamos denominar shifters de organización: «todos los signos declarados por medio de los cuales el enunciante, en este caso el historiador, organiza su propio discurso, lo retoma, to modifica a to largo de su camino, en una palabra, le asigna referencias explícitas» (32). La problemática que conllevan estos shifters de organización «nace de la coexistenciao mejor dicho, del roce de dos tiempos: el tiempo de la enunciación y el tiempo de la materia enunciada" (33). Coexistencia que dará lugar a hechos del discurso imprtantes, referidos al proceso mismo de la enunciación:

-Aceleración de la historia.

-Profundización del tiempo histórico en torno a determinados personajes.

-Destrucción del espacio crónico de la historia.

Conjunto de fenómenos discursivos que «apuntarían a 'descronologizar' el 'hilo histórico' y a restituir, aunque no fuera por reminiscencia o nostalgia, un tiempo complejo, peramétrico, no lineal, cuyo espacio profundo recordara el tiempo mítico de las viejas cosmogonías ligado por esencia, también a él a la palabra del poeta o del adivino...» (34).

Además de los citados signos explícitos de enunciación en la narración histórica, y citando de nuevo a Jakobson, Barthes añade que deben observarse los signos referidos a los protagonistas de dicha enunciación: el destinatario y enunciante. En el discurso histórico, los primeros «están generalmente ausentes y sólo se encuentran cuando la historia se presenta como lección» (35), por más que el sujeto de lectura está implicado en todo el discurso, y por supuesto, en el histórico.

"Los signos del enunciante o destinador, dice, son evidentemente, mucho más frecuentes; hay que agrupar alli todos los fragmentos del discurso en que el historiador, sujeto vacío de la enunciación se va llenando de predicados diversos destinados a fundarlo como una persona, provista de plenitud psicológica o más aún de una capacidad» (36); afirmación propia de una lógica estructural no compartida por los planteamientos dialéctos. 
Constata, por otra parte, el predominio de tipos de enunciante característicos en este discurso: el pretendidamente ausente con «carencia sistemática de todo signo que remita al emisor del lenguaje históricon, intentando poner de manifiesto «una historia que se cuenta ella sola» y un discurso histórico llamado "objetivo», donde «el enunciante anula su personalidad pasional pero la sustituye por otra persona, la persona objetiva; el sujeto subsiste plenamente pero como sujeto objetivo» (37).

En segundo lugar, constata «el caso particular en que el enunciante del discurso es al mismo tiempo participante del proceso enunciado; en que el protagonista del enunciado es también el protagonista de la enunciación; en que el historiador, actor en el momento del hecho, se transforma en narradorn (38).

«El enunciado histórico - dice Barthes analizando lo referente al enunciado- debe permitir cortes destinados a determinar unidades de contenido que más tarde podrán ser clasificadas. Esas unidades de contenido representan aquello de que habla la historia; como significados, no son ni el referente puro ni el discurso completo: su conjunto está constituido por el referente segmentado, nombrado, ya inteligible, pero no sometido a una síntaxis" (39).

La constatación y profundación de estas unidades exigen para este autor un trabajo previo encaminado a dilucidar tanto en el enunciado histórico como en el frástico los "exigentes» y los "ocurrentes»: seres, entidades y sus predicados que, en un primer examen «pueden constituir listas relativamente cerradas, es decir, colecciones cuyas unidades terminan por repetirse a través de combinaciones evidentemente variables y pueden permitir ciertas reglas de sustitución y transformación y deben ser posible estructurarlas, tarea más o menos fácil según los historiadores” (40).

Conlleva también, este apartado, el análisis del estatuto especifico del proceso histórico que, a diferencia de otros procesos caracterizables como aseverativos, negativos, interrogativos, etc., "es uniformemente aseverativo, verificativo; el hecho histórico está ligado lingüísticamente a un privilegio de ser: se cuenta lo que ha sido, no lo que no ha sido o lo que ha sido dudoso. En una palabra: el discurso histórico no conoce la negación (o la conoce rara vez y en forma marginal)» (41).

Finalmente, la aproximación al enunciado histórico presupone abordar «las clases de unidades del contenido y su sucesión»: la de los segmentos del discurso que remiten a un significado implícito; la de los fragmentos del discurso de naturaleza razonadora, silogística o, más precisamente, entimé- 
mica, puesto que se trata casi siempre de silogismos imperfectos, aproximativos y la de las unidades que «a partir del Propp se llaman 'funciones del relato', o puntos cardinales desde donde la anécdota puede tomar un curso diferente; esas funciones están agrupadas, sintagmáticamente, en series cerradas, lógicamente saturadas o secuencias» (42).

En resumen, y tras las citadas acotaciones, «puede sugerirse que el discurso histórico oscila entre dos polos según la densidad respectiva de los índices y sus funciones. Cuando en un historiador las unidades indiciales predominan, la historia se ve arrastrada hacia una forma metafórica y se aproxima a lo lírico y lo simbólico... Cuando, en cambio, dominan las unidades funcionales, la historia adopta una forma metonímica, se emparienta con la epopeya» y «existe, en realidad una tercera historia: aquella que por la estructura del discurso intenta producir la estructura de las elecciones vividas por los protagonistas del proceso relatado; en ella dominan los razonamientos; es una historia reflexiva, que se puede llamar también historia estratégica» (43).

Por último, fija su atención en el significado, existente irremisiblemente en el discurso histórico, analizándolo a través de la fragmentación en niveles, al menos dos: el inmanente a la materia enunciada que «retiene los sentidos que el historiador da voluntariamente a los hechos que relata", como pueden ser lecciones morales o políticas obtenidas a partir de ciertos episodios y el que trasciende todo el discurso histórico y se transmite por la temática del historiador. De ahí se deduce que «el discurso histórico de nuestra civilización es esencialmente elaboración ideológica». Con esto se pone en crisis la misma noción de hecho histórico, desde el momento en que interviene el lenguaje y cuando se defiende que el hecho sólo puede ser definido dentro de su existencia lingüística. Esto constituiría un segundo nivel.

Lo anteriormente dicho plantea una última acotación en torno al discurso histórico: ¿qué lugar ocupa lo real en la estructura discursiva? Cuestión despejada en los siguientes términos: «El discurso histórico supone, por así decir, una doble operación harto complicada. En un primer tiempo, el referente está separado del discurso, se vuelve exterior a él, debe fundarlo, regularlo: es el tiempo de la res gestae, y el discurso se presenta simplemente como historia rerum gestarum; pero en un segundo tiempo el significado mismo es desplazado, confundido con el referente; el referente entra en relación directa con el significante, y el discurso, encargado solamente de expresar lo real, considera posible eliminar el significado, término fundamental de las estructuras imaginarias. De esta manera, como todo discurso con pretensión "rea- 
lista", el discurso de la historia cree posible sólo un esquema semántico con dos términos: el referente y el significante; la confusión (ilusoria) del referente y del significado define, como se sabe, los discursos sui-referenciales, tal como el discurso performativo; puede decirse que el discurso histórico es un discurso perfomativo engañoso en el cual el verificativo no es más que el significante del acto del habla como acto de autoridad. En otras palabras, en la historia "objetiva" lo real es siempre sólo un significado no formulado que se refugia tras la apariencia omnipotente del referente. Tal situación define lo que podría llamarse el efecto de realidad" (40).

Resumiendo, pues, el pensamiento del citado autor y completándolo con aportaciones de la ya citada Lingüística Textual, podremos delimitar el texto, discurso histórico, como el complejo significante estructurado según las reglas de competencia textual, semiótica, cuya finalidad es transmitir la visión (historiográfica, ideologizada) que un historiador, a través de un mecanismo lingüístico-retórico, posee de la realidad histórica. Mecanismo de transmisión que implica crear la ficción de la objetividad científica.

Explicitar lo dicho es, simplemente, localizar la historia, el discurso histórico, dentro de la tipología textual, constatando no sólo las implicaciones pragmáticas, sino también los recursos empleados para consolidar la coherencia y cohesión textuales. En resumidas cuentas, estamos diciendo que un texto histórico no puede ser analizado solamente desde la perspectiva de su transmisión de verdad (confrontación referente-texto) que es un semiótica y, podriamos decir, retórica, puesto que como tal texto es básicamente una construcción ideológica de la realidad, hecha a través de mecanismos textuales y determinada, en cualquier caso, por la postura historiográfica del historiador que realiza tal discurso.

Con lo cual estamos exigiendo para el texto histórico una dinámica metodológica, un modelo de análisis similar al del texto narrativo, debiendo aplicar idéntica aproximación textual, literaria (retórica) e histórica, para constatar, en primer lugar, que el discurso histórico desde la Lingüistica Textual ha de ser considerado un tipo de texto, con sus particularidades y concomitancias respecto al resto de texto. Lo que de común tiene con todos los demás se centrará en la constatación de la coherencia-cohesión, pragmática, semántica o morfosintáctica; teniendo en cuenta que dicha coherencia viene determinada por la pragmática, la intencionalidad del emisor empeñado en desarrollar una lógica discursiva histórica y a partir de ahí se elige el aspecto o voz desde donde se presenta a los lectores dicho discurso histórico - crónica, narración, discurso moral, análisis crítico y dialéctico-y, sobre todo, se reali- 
za la elección de la terminología en conexión con el corpus científico, moral, visión del mundo, etc.; la tematización (términos individuales y campos semánticos) y, por supuesto, la propia sintaxis y tono del discurso, en conexión con la entonación y con el modo verbal, ennunciativa, interrogativa, conativa, etc.

El análisis retórico, literario si queremos, es el que hemos realizado siguiendo a Roland Barthes. De sus carencias, más bien respecto a la contextualización y a la determinación social del producto discursivo debidas a la lógica y modelo estructuralista, ha hablado N. Pizarro en estos términos: «Lo esencial es, pues, que la noción de equivalencia gramatical identifica el sentido de la frase con una relación conceptual (una proposición) despreciando asi el efecto significante de la frase como fenómeno del lenguaje ( $y$ no de ideas) que se produce en la realidad práctica. Esta identificación conlleva una concepción racionalista del lenguaje, que va siempre aparejada por una concepción expresiva e instrumental del mismo: el punto de partida del acto de hablar es, en esta concepción, doble. Por una parte, la existencia en la conciencia del sujeto, de una relación conceptual. Por otra, la existencia de una voluntad de significar (un querer decir lo que se piensa). En esto consiste el racionalismo... Deberíamos añadir, una vez más, que el racionalismo y el instrumentalismo lingüístico presuponen un sujeto del habla libre de toda determinación, social o psicológica. El sujeto libre de decir lo que piensa en la forma que elige no existe más que en la ideología. O en los libros de lingüística (iy de ciencias sociales!) (45).

Esto, sin duda, significa una superación del indispensable análisis estructural y semiótico, donde cientificidad se identifica con racionalismo y esto con sistematización (46), abstracción (47) absoluta al margen de las determinaciones sociales: el hecho de hablar, no obstante, ya dijimos, significa más que el significado de los enunciados: significa la relación social reproducida por ellos (48). Es necesario, pues, profundizar para comprender correctamente el discurso histórico en el proceso de historización o culturización que sigue el desarrollo de dicho texto, desde la elección del proyecto hasta la utilización del lenguaje como instrumento de expresión (49).

Para realizar esta operación pueden seguirse modelos diferentes. Nos parece eficaz el que propone $\mathrm{C}$. Segre (50) siguiendo a la semiótica de la cultura soviética, pero, no sería menos eficaz el planteamiento dialéctico que, partiendo de Marx y las explicaciones que en torno a la producción y reproducción ideológica han realizado sus seguidores, expone N. Pizarro aplicándolo a las ciencias sociales y a la propia historia. Brevemente, este autor, tras 
diseñar su tipología discursiva y estudiar las aproximaciones lingüísticas, retóricas, y semióticas al discurso, asi como tratar de profundizar en la propia estructura del discurso literario o sociológico, diseña su paradigma y los supuestos básicos.

«Los discursos, dice, están modelados a partir de unas prácticas sociales reales» (51), de tal modo que «la ideología es, por lo tanto, en esta perspectiva, la estructura generadora del proceso de producción de los discursos cuyo efecto social específico es la determinación del lugar de los agentes en los procesos sociales y, por lo tanto, en las relaciones sociales de producción» (52). Estos serían los puntos claves en que centra su modelo que resume en un conjunto de propuestas finales donde especifica el largo proceso de creación de discursos desde «los mecanismos, estructuras y procesos que hacen posible que las operaciones efectuadas por el cerebro sobre sus propios estados internos coincidan ampliamente con los procesos sociales objetivos» hasta la elaboración, a través del lenguaje, de los citados discursos, concluyendo del modo siguiente "situados en una larga tradición interpretativa, los intelectuales olvidan con frecuencia que toda producción comprendida como babal, es una relación social. El hecho de hablar significa más que el significado de los enunciados: significa la relación social reproducida por ellos» (53).

\section{POSTMODERNIDAD, HISTORIA, RELATO}

Sentadas las identidades y diferencias entre el texto narrativo y el texto histórico, discursos quizás menos distantes de lo que normalmente se ha pretendido en base a la prejuiciada opinión de acotar el primero como discurso propio de la libérrima voluntad creadora del sujeto, dejando para el segundo la prerrogativa de discurso objetivo que reproduce la realidad o intenta interpretarla, pretendemos al menos sugerir la proximidad existente entre ambos constatando el acercamiento, más que superficial, en la producción actual de historiadores y novelistas por caminos sólo aparentemente paralelos, pero quizás, sería una propuesta de hipótesis, evidentemente cercanos, puesto que, a nuestro parecer, son la reproducción, en línea con la historización de ambos discursos anteriormente delineada, de un paradigma ideológico determinante que, con mayor o menor precisión, llamaremos postmodernidad.

Este paradigma se encuentra a veces desprestigiado por identificársele con unos comportamientos superficiales de carácter eminentemente lúdico. No obstante, y a pesar de no existir -coherente con su lógica de la debilidad (54) - un corpus doctrinal, el paradigma postmoderno posee una historia (55), unos supuestos (56) documentados y divulgados entre otros por el 
filósofo italiano Vattimo, puesto en entredicho por Habermas (57) y, sobre todo, reproducido en discursos específicos: arte, novela, historia, política, etc. (58).

En estos problemas pensaba, sin duda, J. Sádaba, al decir: «No quisiera ser tan ingenuo como para intentar dar una idea completa, una descripción suficiente de la postmodernidad. En primer lugar, porque no suele estar al alcance de uno familiarizarse con la crítica literaria, la socioeconomia, la historia del arte y de la arquitectura, los movimientos vanguardistas, etc. A esta razón subjetiva se añade que es probablemente un pecado de incomprensión intentar definir la postmodernidad. $Y$ es que si alguien está perplejo, si siente que aquello que fue su vida pasada no le sirve, si quiere, en consecuencia, vivir sin prefigurar grandes orientaciones, sería absurdo pedirle una rotunda y delimitada explicación» (59).

Tras estas precauciones, arriesga una somera caracterización:

- Identificación de razón y poder. O, por lo que es lo mismo, en todo lugar se sigue reproduciendo el poder. Al Poder se le opone semejante poder y a la Razón la misma razón aunque poderes y razones actúen «a la contra». Combatir, en fin, el Poder es reproducirlo y en consecuencia, reproducir la Razón misma. Es la llamada paradoja de la revolución.

- El rol grandioso que jugaron la historia o la economía se desplaza, ahora, en favor de categorías supuestamente menos estables y más elementales como es, Vg. la líbido.

- La Historia aparece como un mito más y no como la superación de un estadio mítico. Su logos sería tan mítico como cualquiera de las fábulas que dice suplantar. La Historia, más bien, sería el cuento que nos contamos los hombres blancos para seguir en pie.

- Si la Historia no da más de sí - «el final de la Historia» es una frase con fortuna de la postmodernidad - habría que utilizar otras categorías, otro vocabulario. No es extraño, por tanto, que se hable de esquizofrenia, descodificación, desterritorialización (60).

Características que, explicitadas, significan básicamente que «la Modernidad queda desvalorizada en cuanto que ésta habría sido el gran mito de la razón», es decir, se rechaza el monoteísmo de la razón y se opta por su politeísmo, con lo cual «tendríamos que admitir, en nietzscheanos de nuestro tiempo, que lo único que hay es relato o narración más o menos fabuloso, pero sin fundamentos de origen. Sólo nos cabe describir con la conciencia 
de que de ahí no pasamos; en nada nos sustentamos, no hay Dios pequeño o grande que sea la garantía de nuestro pensamiento y de nuestra acción. Como también diría el Wittgenstein más tardío, el logos, en su voracidad, no ha sido capaz de tomarse por lo que es: uno más en esta historia. Sólo quedaría, por así decirlo, una "lógica de la ocasión", pragmática, sin universalidad que huela a trascendentalismo... Dicho de otra manera: nadariamos en una total fragmentación, en "juegos del lenguaje" o formas de vida con relativa independencia, autojustificadas, sin fundamento ni reposo, dependientes solamente de su propio éxito. No hay, en fin, ni mirada hacia atrás que sustente ni mirada hacia adelante que anime... Efectivamente, el postmodernismo siente lo que Nietzsche pronosticó: el vacío, la soledad de un mundo no sólo sin dioses sino sin hombres fuertes, capaces de hacer de ellos mismos un destino» (61).

Sádaba añade una última acotación de la modernidad al incidir, glosando a Rorty, en su afán de «considerar la esencia del hombre como la de descubridor de esencias en el mundo», para establecer una nueva característica, fundamental, de la postmodernidad, al proponer «una especie de vuelta a la hermenéutica, un arte interpretativo frente a la anquilosada razón. Por hermenéutica no atiende ciertamente un método académico cerrado, una escuela con más o menos adeptos sino el reconocimiento de la diversidad de las razones, de la relatividad de los distintos y encontrados puntos de vista» (62).

Si quisiéramos resumir los planteamientos subrayados deberíamos centrarnos en la consideración del pensamiento débil como supuesto básico de la postmodernidad (63), definido por l. Tono Martínez en estos términos: «Esta metáfora de la debilidad, esta incursión en mi patología particular es interesante porque nos permite alojar el pensamiento postmoderno en su justo lugar: el purgatorio a expensas de lo moderno (el infierno) y lo conservador (el cielo). Parte de las iras que suscita el relato post en ambas instancias de lo divino vienen de esta situación intocable: "está y no está, critica y se evade". Es inaprensible, intocable y su escapismo acentúa su dificultad, su papel mediador y antidefinitorio. Como todo pensamiento reversible es antitotalitario y esto provoca ásperas llagas. En otros países hablan de pensamiento débil y nosotros casi añadiríamos un matiz y hablaríamos de pensamiento enfermo o, a lo sumo, por sus pretensiones, humilde» (64).

En cuanto a nuestra hipótesis de la contigüidad entre el discurso histórico y narrativo, la postmodernidad conlleva, así lo ha estudiado principalmente Lyotard (65), una deslegitimación del discurso «fuerte», dogmático, racio- 
nalista y hasta científico, porque las bases en que se apoyaba han sufrido un profundo descrédito, el metadiscurso del metasujeto, sistematizado y abstracto, ha cedido en favor sin aspiraciones de dogma ni afán de objetividad epistemológica. El relato adquiere sus dimensiones reales y los lectores pueden encontrar los indicios necesarios para no sucumbir al engaño de considerar la ficción como verdad, el discurso como dogma.

Por otra parte, como subraya Jameson, «la desaparición de un sentido de la historia, la forma en que todo nuestro sistema social contemporáneo ha empezado poco a poco a perder su capacidad de retener su propio pasado, ha empezado a vivir en un presente perpetuo y en un perpetuo cambio que arrastra tradiciones de la clase que todas las anteriores formaciones sociales han tenido que preservar de un modo u otro" (66).

Todo lo afirmado desde un punto de vista teórico impone un análisis de algunos ejemplos de la producción histórica y de la narrativa más reciente empleando algunas de las claves citadas a fin de confirmar los supuestos que el paradigma ideológico de la postmodernidad impone en su lectura de la realidad, contemporánea o remota que, desde esta perspectiva, no es tan diferente.

Un supuesto básico de lectura, que ya hemos anotado es la concepción del tiempo, determinante en la elaboración del discurso histórico y narrativo: «Hay dos lecturas, dice J. Ibáñez, del tiempo, Cronos (sólo hay pasado y futuro, el presente es un corte vacio), e lôn (sólo hay presente, que contiene el pasado y el futuro). La postmodernidad va - quizás demasiado- en dirección a lôn: de ahí el énfasis en el "aquí y ahora", de ahí el "carpe diem". Pero tiene en cuenta, por primera vez quizás desde los epicúreos, el presente: el presente que es una intersección no vacía (pues estoy yo con mis recuerdos y mis proyectos) del pasado y el futuro» (67).

Desde ahí, lógicamente, se puede afirmar que la postmodernidad es la época en que empezamos a habitar el mundo real. La sobrevaloración del presente. Esto aparece con bastante claridad en la reciente producción de ciertos historiadores que en sus obras rompen las barreras del tiempo y la ficción del pasado es eliminada: «Iglesia y Estado, Fe y Razón: el juego dialéctico entre estos cuatro elementos - dice Cipolla - se desgrana a lo largo de una historia inmemorial, tanto más enrevesada, por la complejidad de las fuerzas en liza, cuanto que los dos binomios rara vez supieron coincidir. El estado no es necesariamente el adalid de la razón, la Iglesia no es taxativamente sinónimo de Fe y religiosidad no exluye el anticlericalismo" (68). Es decir, el historiador renuncia, en la construcción de su discurso, relato al fin y 
al cabo, a reconstruir o imitar la realidad en su desarrollo cronológico para imponer el presente como tiempo dominante del relato y de la historia, que sucede únicamente en su propio presente, desde el cual estructura la realidad que efectivamente sucedió en el pasado y el lector así lo entiende por los indicios suficientes que el narrador introduce en el texto para que reconozca que se le está contando algo, reivindicación de la historia contada, originaria (69). No existe en este caso el tiempo, sino el narrador que cuenta en su tiempo: el presente.

Si pasamos a la narrativa esto es más evidente y en versiones diversas. Desde los alegatos teóricos que reafirman la tesis de la superación de la categoría tiempo con sus digresiones pasado y futuro como punto clave de la narración novelesca: El Tirano de Taormina ("para mí todos los tiempos son el Tiempo... que, como muy bien sabes, en mi cuerpo ha quedado varado») (70), hasta la transgresión radical del mismo, por medio de la ironía donde el pasado se convierte en el pretexto de un juego presente: El rapto del Santo Grial (71); e incluso se llega a prescindir de él, puesto que en la historia, según el narrador, no se trata de contar unos hechos del pasado, sino justificar unos objetivos, la intencionalidad pragmática, del emisor: en las Cruzadas no interesan los sucesos, sino el significado que quiera darles el narrador; el hecho, por lo mismo, pasa por encima de su proceso cronológico a un plano totalmente secundario, reivindicando en cambio su lectura desde la ficción - debilidad- de la vivencia frente a la observación, con lo cual el tiempo del narrador y no de lo narrado es lo que predomina: Mansura («Las libertades que me he tomado con el original eximen de toda responsabilidad a Joinville, pero casi todos los sucesos que aquí se cuentan también los cuenta él.

Resulta muy arriesgado suponer que tal o cual rareza no pudo suceder en el siglo XIII, pero tal otra sí. Quien, llevado por su curiosidad, lea la crónica de Joinville, comprobará cuántas veces lo increíble es más verdadero que lo posible.

Para nosotros, atrofiados por la información, es casi imposible concebir la aventura como algo más que una forma primitiva de expolio, o la sobredosis de disfraz que precisa toda empresa codiciosa. Pero si la aventura sólo fuera negocio y latrocinto, no perviviría. La imaginación es la hermana eterna de la memoria mortal. Es el recuerdo de lo que nunca sucedió, porque nada sucede como es debido. Ojalä este relato renueve la vida de un cruzado que peregrinó a Tierra Santa movido por la codicia, sin duda, pero también por la imaginación») (72).

En algún caso se trasciende el tiempo y lo que fuera pasado se convierte en el punto de partida para una fábula «nacionalista»: Cercamón (73) con in- 
gredientes narrativos de absoluta actualidad. Si nos fijamos en otras novelas podemos observar la manipulación del tiempo histórico, por medio del relato, de tal modo que un fragmento mínimo de la historia adquiere la amplísima dimensión que el narrador le concede: Memorias de Adriano, La muerte de Virgilio (74). Otro problema relacionado con el tiempo, más reciente en este caso, se refiere al tratamiento que Juan Benet en Herrumbrosas Lanzas (75) da a la guerra civil, donde el objeto, el tiempo, quedan de lado, para dar lado a la parodia del absurdo de esa guerra y cualquier otra.

Conectamos, pues, en todos los ejemplos, con el tiempo del narrador sobre el de la historia y del propio relato, el tiempo psicológico por encima del cronológico. Sólo existe el tiempo pensado, el tiempo del autor que se cuenta a sí mismo la historia inventada o recreada y provoca al lector para que realice una operación similar, reduciendo el proceso temporal a su propio tiempo de lectura: «Bueno, mira, la cuestión cronológica no es mi fuerte... Esto le ocurre a todo el mundo, aunque después ponga en marcha la estropeada razón que le ordena los hechos... La realidad es que pensamos y recordamos muy anárquicamente... de repente, un perfume, un murmullo, una palabra, una madalenita, otra palabra, otro murmullo, otro perfume... El orden temporal debe ser cosa vuestra... A mí no me importan las fechas, los antes y después..." (76).

En segundo lugar es imprescindible estudiar, en ambos discursos, las dimensiones del narrador. Discurso histórico y discurso narrativo pretenden radicalmente lo mismo: poner en crisis el modelo racionalista de cualquier texto histórico y cualquier artefacto novelesco, reivindicando frente a la verdad, la verosimilitud; el objeto no existe para el narrador más que como objeto leído: «La actitud postmoderna frente a la historia no renuncia a los métodos analítjcos de las décadas anteriores, pero sí desconfía de las visiones totalizadoras. Cuanto más general, más falso es el discurso y, por lo tanto, más se aleja de esa pretensión de sinceridad que caracteriza a la modernidad. La gran historia se disuelve en muchas historias microscópicas. El objetivo no es ya tanto la verdad como la verosimilitud, la adecuación a las reglas del juego. La historia hoy se afirma como relato y por este camino se acerca al único mundo que no discrimina la ficción frente a la realidad: el arte» (77).

En palabras de otro autor, el papel del narrador es poner en evidencia que lo que hacen la historia y la narración es contar y evidenciar esto es una forma de desmitificar sobre todo el discurso histórico, puesto que lo que se cuenta es un invento del narrador, en ningún caso un producto objetivo; es decir, se deslegitima cualquier discurso, lenguaje al fin y al cabo, como vehiculo de verdad que era el afán de la modernidad, tratando de ocultar un discurso manipulado, cuando en realidad «todos los ideales son ilusorios, todos 
los relatos mienten, cada objetivo es un espejismo. Los que corren en post de ideales en vez de pasar al otro lado se estrellan contra el espejo» (78).

La desconfianza, por tanto de la ideología postmoderna frente a toda apariencia de racionalidad y sobre todo de dogma e incluso objetividad lleva a historiadores y novelistas a replantear la configuración del punto de vista o focalización de sus discursos. Se desconfía de las visiones totalizadoras y se minusvalora todo afán de imponer visión alguna del mundo, optando por la propuesta de un discurso débil que permita al lector, reivindicando radicalmente, elaborar su propia lectura.

Esta operación se realiza en ambos discursos de forma similar, si bien en el histórico aún no abunden ejemplos, puesto que tiene demasiado peso el fantasma de la necesaria cientificidad. No obstante, podemos encontrar modelos suficientes y válidos para constatar un camino apenas iniciado. El narrador en tercera persona, pretexto de objetividad, que era el modelo generalizado, es transgredido por algunos autores (79) que intentan prescindir de dicho modelo por una doble vía: la introducción, primero, de acotaciones que patentizan la dimensión subjetiva de su discurso o el cambio de perspectiva historiográfica que implica la introducción de nuevos protagonistas y diversos en el discurso histórico: "Antes era válido acusar a quienes historiaban el pasado, de consignar únicamente las "gestas de los reyes". Hoy día ya no lo es, pues cada vez se investiga más sobre lo que ellos callaron, expurgaron o simplemente ignoraron. ¿Quién construyó Tebas de las siete puertas? pregunta el lector obrero de Brecht. Las fuentes nada nos dicen de aquellos albañiles anónimos, pero la pregunta conserva toda su carga» (80).

En segundo lugar el reconocimiento de voz propia a los diversos protagonistsa de la historia que desean contarnos, no como testimonio de veracidad, sino como plurivocidad discursiva: ¿Quién rompió las rejas de Monte Lupo?, Montaillou, aldea occitana. Por supuesto, este objetivo no siempre se realiza a través del discurso directo, pero, en el estilo indirecto, tal como está configurado, se ve incluida la afirmación anterior.

Un tercer ejemplo indicador de la ruptura con el metanarrador o metasujeto del historiador que aparecía como vehículo de transmisión de la verdad, la realidad, dotado de la omnipresencia y omnipotencia de la selección, de la organización y, por descontado, de la interpretación, podría observarse en la formulación teórica del modelo historiográfico llamado paradigma indiciario y su correlato práctico El queso y los gusanos, donde se concede el protagonismo a la intuición del narrador, detective, frente a la racionalidad o determinación ideológica del historiador científico. 
En cualquier caso, los historiadores contemporáneos pretenden por todos los medios, incluso siguiendo esquemas determinados por la racionalidad historiográfica del modelo que defienden (positivista, Annales, marxista, Nueva Historia), resaltar esta circunstancia, la determinación ideológica de su trabajo, con el fin de alertar al lector respecto de su intencionalidad, lo que constituye, sin duda, una forma de deslegitimación del discurso, al observar con claridad que no presentan la verdad, el referente, sino su visión del mismo.

En la novela esto es más evidente e incluso más acorde con el oficio de narrador en otros tiempos. Básicamente se rompe con el narrador omnisciente que, distanciado del relato, va dirigiendo cada uno de los elementos estructurales del mismo a larga distancia, y se impondrá el narrador en primera persona, aunque se hable de un referente medieval: «Si os ha llegado alguna noticia de los sucesos de estas tierras, me creeréis sin tener que jurároslo, que no me ha faltado ocasión de arrepentirme de haber aceptado llevar a cabo una tarea tan arriesgada. Si el galardón de esta empresa no fuera mi propia libertad y la correspondencia de vida al excelente trato... Debo vencer, pues, la tentación de añadir interpretaciones y comentarios que ahora se me ocurren... Pero, así y todo, temo que los sentimientos que aún permanecen muy vivos en mi corazón enturbien mi razón y nublen mi pecho...» (83).

Este narrador normalmente apoya la credibilidad en su propia experiencia: «He nacido para morir y siendo mi muerte una cosa cierta, tanto que ni Dios puede impedirla sin menoscabo de la justicia, pues si todos los nacidos han de morir, la gracia a uno de ellos concedida sería agravio de todos los restantes, no debo, ni quiero, emplear mis talentos de manera mala. Es por ello que cuanto aquí se diga será verdad y cosa o acontecer que yo mismo he vivido" (84).

Pero la mayor radicalidad del nuevo modelo narrativo proviene de la introducción de la plurivocidad, es decir el enfoque de la realidad tratada desde distintos ángulos de visión, ángulos normalmente simbólicos puesto que un personaje en la novela no es el paradigma de la individualidad, sino el representante del colectivo (85), de tal forma, que no funciona en el relato como vehículo de su propia opinión, sino de la de su grupo o clase.

Insistiendo más en el nuevo narrador como producto de la postmodernidad, defensora del antidogmatismo, reivindicadora de la liberación personal ante el agobio del sistema empeñado en condenar al anonimato a todo personaje, como manifiesto de libertad no sólo de expresión sino también de desinhibición, debemos resaltar el predominio del relato autobiográfico, a veces descarnado, pero siempre ficticio, como modelo narrativos. (86). 
Entremos ahora en el orden del relato o secuenciación y organización de las acciones. Lógicamente este apartado es continuación del anterior y, sin duda, un capítulo básico para dilucidar la hipótesis tanto de que la novela es una forma de discurso histórico como de que el discurso histórico posee una estructura discursiva cercana al relato literario, en cuanto a discurso organizado por el narrador, sustituto del autor-emisor.

Básicamente conviene poner en claro que ambos discursos constituyen la disquisición en torno a la visión de la realidad dependiente de la intencionalidad del autor: en la historia, apoyada por los testimonios elegidos por el propio sujeto emisor; en la novela, basada únicamente en el armazón ficticio o imaginario. Lo que unifica ambos discursos es, sin duda, la determinación pragmática, intencionalidad del proceso de coherencia y de la puesta en evidencia a través de la cohesión del enunciado.

Es necesario, no obstante, recalcar la diferencia, no radical, de ambos discursos en este aspecto: la coherencia, sobre todo semántica, pero también sintáctica, viene definida por el modelo historiográfico, la ideología histórica del emisor narrador en el discurso histórico. La de la narración por los supuestos narratológicos. Esto es, el historiador construirá su discurso apoyándose en la terminología epistemológica propia y elaborará la tematización y los campos semánticos plasmando la visión del mundo que su ideología le impone. La sintaxis, por su parte, responderá a la determinación conceptual: descriptiva, positivista o dialéctica. La estructura discursiva tendrá, en fin, como secuencias básicas, la enunciación de una hipótesis, el desarrollo de la misma y la conclusión pertinente. En consecuencia con sus paradigmas ideológicos se primarán unas situaciones, unos acontecimientos, unos personajes.

El novelista, a su vez, hallará en la visión del mundo, en la ideología, la base de la tematización, tópica por supuesto, de las acciones a resaltar o de los acteantes a responsabilizar, pero el esquema de estructuración aunque básicamente, digamos en la estructura profunda, sea el mismo que el del discurso histórico, dadas las exigencias del modelo de la ficción, la secuenciación habrá de seguir el esquema narratológico: éxito a conseguir, fechoría a cometer, etc., respetando únicamente la verosimilitud.

Quizás, y para finalizar con este análisis, la mayor apariencia de diversidad entre ambos discursos sea el tratamiento del referente, no del referente elegido pues no cabe duda que en esto puede darse una coincidencia, ya que la postmodernidad, la historia social, la Nueva Historia y la narrativa contemporánea están empeñadas en reivindicar el antihéroe, la cotidianeidad, 
la marginación y las situaciones débiles y un tanto insignificantes. Sino que se pretende subrayar aquí cómo la Historia intenta contar, interpretar la realidad y, con todos los reparos que podamos poner, busca desvelar los entresijos (modelo causa-efecto) de la realidad.

En cambio, el narrador se siente, por su modelo de ficción imaginario, libre de ese compromiso y el referente, es más bien un pretexto de creación, hasta el punto de que aún siendo reproducida la matriz ideológica en todo momento, siempre se presentará el discurso narrativo como tratamiento del objeto leído, nunca objetivo. No obstante, difícilmente podrán separarse ambos discursos de la operación que se les atribuye desde el paradigma postmoderno, ser traductores de la realidad, aunque en el caso del narrativo sea básicamente irónica.

Resalta, y ya lo recordamos en otra ocasión (87), el afán de reconstruir el medievo. Así lo justifica F. Solano comentando reconstruir la obra de Félix de Azúa, Mansura: «La crónica - la actual, la periodística- es hoy género comodín, aplicable a todo, hasta el punto de contaminar la novela, sin proponérselo, de una verosimilitud que la empobrece. De ahí, tal vez, la eclosión de crónicas medievales bretonas, islandesas, celtas. Ese interés por la arqueología literaria contrapesa, al menos, la triste mitología de nuestro tiempo... Azúa se sirve de unos ideales caducos, de una anacrónica moral, de una época fenecida, no para hacer novela histórica. Su intención es didáctica» (88). Del medievo se sirven los autores para ensayar modelos de interpretación (U. Eco), para recrear su ficción (Racionero), para evadirse lúdicamente de la realidad contemporánea (R. Ruiz), para fabular sobre el pasado de un pueblo (M. Onaindía) y hasta para reivindicar problemas actuales ( $P$. Díaz Mas).

Queda, pues, como proyecto de trabajo, como hipótesis a discutir, el que desde la postmodernidad como modelo epistemológico, cualquiera de sus productos, lo postmoderno, están determinados por la debilidad como ingrediente discursivo, debilidad que podría resumirse en la huida de la racionalidad, del dogmatismo o del distanciamiento objetivista para albergarse en la propuesta, a veces provocación de las diversas focalizaciones, puntos de vista, evidenciados en la cohesión de los propios discursos que propalan los supuestos del acercamiento a la realidad, presente o pasada, porque el tiempo es ya una categoría periclitada. La historia, como la novela, serán dos discursos igualmente deslegitimados para las visiones fuertes, válidos en cambio, para la aproximación, en parte diversa en parte similar, al referente, donde la determinación del paradigma ideológico, la intencionalidad del autor y el componente pragmático del relato son datos ineludibles, tal como lo expre- 
san los interlocutores de El Tirano de Taormina: "Todo lo que he dicho corresponde al ámbito mítico-cultural de Creta... y no sé cómo ligarlo con Taormina.

No me vengas con remilgos, Arnaldo. Me ha gustado demasiado tu idea como para que ahora la eches por la borda... No tengas escrúpulos, no los tuvieron ni Homero ni Ovidio, por ejemplo. Las historias más seductoras que jamás haya leído son las Metamorfosis del Nasón: pura y encantadora mentira tras mentira...» (89).

¿Significa acaso todo este planteamiento una transgresión del discurso histórico, entendido como manipulación del objeto histórico por parte del propio historiador, del narrador distanciado de la historia que narra (omnisciente) desvelando ese mecanismo como pseudocientífico o simplemente un idealismo que intenta crear la ficción, postmoderna por supuesto, de la libertad a través de la reivindicación del sujeto narrador en primera persona, o la plurivocidad que implican las prerrogativas de crear un nuevo tiempo, un espacio diferente y unas acciones a su propia medida? Los postmodernos dirán que es la consagración del pensamiento débil frente al absoluto, dogmático y trascendental; nosotros... albergamos nuestras dudas y no descartamos la posibilidad de que constituyan un nuevo artificio de racionalidad, sólo en apariencia carente de sistematicidad. 


\section{NOTAS}

(1) BARTHES, R. (1972), «El discurso de la Historiam, en VV. AA., Estructuralismo y Literatura, Ed. Sudamericana, Buenos Aires, p. 49.

(2) Será necesario delimitar posteriormente esta arbitrariedad, insistiendo en la determinación sociocultural del proceso de producción del texto narrativo.

(3) BERNARDEZ, E. (1982), Introducción a la lingüística del texto, Ed. Espasa-Calpe, Madrid. PETÜFI, J. S.; GARCÍA BERRIO, A. (1978), Lingüistica del texto y crítica literaria, Ed. Comunicación, Madrid, pp. 19-53.

(4) BERNARDEZ, E. (1982), p. 85.

(5) LOTMAN, Y. M. (1978), Estructura del texto artístico, Ed. Istmo, Madrid.

(6) BERNARDEZ, E. (1982), pp. 90-101. SEGRE, C. (1985), Principios de análisis del texto literario, Ed. Crítica, Barcelona, p. 46 ss. LOZANO, J. et al. (1982), Análisis del discurso, Ed. Cátedra, Madrid, p. 19-33.

(7) AKMAJIAN, A. et al. (1984), Lingüistica: introducción al lenguaje y a la comunicación, Ed. Alianza, Madrid, p. 313-325.

(8) ECO, U. (1981), Lector in fabula, Ed. Lumen, Barcelona.

(9) LOZANO, J. et al. (1982), p. 252.

(10) SEGRE, C. (1985), p. 219.

(11) LOZANO, J. et al. (1982), pp. 22-32.

(12) SEGRE, C. (1985), p. 292.

(13) Cfr. nota 12.

(14) PIZARRO, N. (1979), Metodología sociológica y teoría lingüística, Ed. Comunicación, Madrid, pp. 45-93.

(15) PROPP, V. (1971), Morfología del cuento, Ed. Fundamentos, Madrid. BARTHES, R. (1966), «Introduction à l'analyse structurale des récits», Comunications, 8, pp. 1-27. BREMOND, C. (1976), «El mensaje narrativo» en Comunicaciones, 4, pp. 71-105. GREIMAS, A. J. (1971), Semántica estructural, Ed. Gredos, Madrid.

(16) SEGRE, C. (1985), p. 134-140.

(17) MARCHESE, A.; FORRADELLAS, J. (1986), Diccionario de retórica, crítica y terminologia literaria, Ed. Ariel, Madrid, pp. 199-200.

(18) LOZANO, J. et al. (1982), p. 252.

(19) ROMERA DEL CASTILLO, J. (1980), El comentario semiótico de textos, Ed. S. G. E. L., Madrid.

(20) Cfr. nota 16.

(21) PIZARRO, N. (1979), pp. 131-195.

(22) PIZARRO, N. (1979), p. 237.

(23) SEGRE, C. (1985), p. 142; (1981), Semiotica, historia y cultura, Ed. Ariel, Madrid. 
(24) SEGRE, C. (1985), p. 143.

(25) Cfr, nota 21.

(26) PIZARRO, N. (1979), p. 223.

(27) BARTHES, R. (1972).

(28) BARTHES, R. (1972), p. 48.

(29) BARTHES, R. (1972), p. 37

(30) BARTHES, R. (1972), p. 38.

(31) Cfr. nota 30.

(32) BARTHES, R. (1972), p. 39

(33) Cfr. nota 32.

(34) BARTHES, R. (1972), p. 40.

(35) BARTHES, R. (1972), p. 41.

(36) Cfr. nota 35.

(37) BARTHES, R. (1972), pp. 41-42.

(38) BARTHES, R. (1972), p. 42.

(39) BARTHES, R. (1972), p. 43

(40) Cfr. nota 39.

(41) BARTHES, R. (1972), p. 45.

(42) BARTHES, R. (1972), p. 46.

(43) BARTHES, R. (1972), pp. 46-47.

(44) BARTHES, R. (1972), p. 48-49.

(45) PIZARRO, N. (1979), pp. 139-40.

(46) PIZARRO, N. (1979), p. 68.

(47) PIZARRO, N. (1979), p. 229.

(48) PIZARRO, N. (1979), p. 237.

(49) PIZARRO, N. (1979), p. 144.

(50) Cfr. nota 23. LOTMAN, Y. M. (1979), Semiótica de la cultura, Ed. Cátedra, Madrid.

(51) PIZARRO, N. (1979), p. 219.

(52) PIZARRO, N. (1979), p. 221.

(53) PIZARRO, N. (1979), pp. 234-237.

(54) VATTIMO, G.; ROVATTI, P. A. (1984), Il pensiero debole, Ed. Feltrinelli, Milán.

(55) TONO MARTÍNEZ, J. (1986), La polémica de la postmodernidad, Ed. Libertarias, Madrid, FOSTER, $H$. et al. (1985), La postmodernidad, Ed. Kairos, Barcelona. CARRAVETTA, P.; SPEDICATO, P. (1984), Postmoderno e letteratura, Ed. Bompiani, Milán. WV. AA. (1984), Cuadernos del Norte, 26.

(56) VATTINO, G. (1986), El fin de la modernidad, Ed. Gedisa; Barcelona. (1986 a), Introducción a Heidegger, Ed. Gedisa; (1986 b), Las aventuras de la diferencia, Ed. Península, Barcelona. IBÁN̄EZ, J. (1986), «Tiempo de postmodernidad» en TONO MARTÍNEZ, J. pp. 27-67.

(57) HABERNAS, J. (1985, «La modernidad, un proyecto incompleto", en FOSTER, H., pp. $19-37$

(58) Cfr. nota 55.

(59) SADABA, J. (1986), «La postmodernidad existe» en TONO MARTÍNEZ, J., p. 165.

(60) SADABA, J. (1986), p. 167.

(61) SADABA, J. (1986), p. 169.

(62) SADABA, J. (1986), p. 171.

(63) VATTINO, G.; ROVATTI, P. A. (1984), pp. 9-10.

(64) TONO MARTÍNEZ, J. (1986), «Los dos poderes».

(65) LYOTARD, J. F. (1986), La condición postmoderna, 2. ed. Ed. Cátedra, Madrid, pp. $43-89$

(66) JAMESON, F. (1985), «Postmodernismo y sociedad de consumo» en FOSTER, H., p. 185.

(67) IBAÑEZ, J. (1986), p. 59. 
(68) CIPOLLA, C. M. (1984), ¿Quién rompió las rejas de Monte Lupo?, Ed. Muchnik, Barcelona, p. 13.

(69) RUIZ, R. (1980), El tirano de Taormina, Ed. Hiperión, Madrid, p. 20.

(70) RUIZ, R. (1980), p. 17.

(71) DIAZ MAS, P. (1984), El rapto del Santo Grial, Ed. Anagrama, Barcelona.

(72) AZÚA, F. (1984), Mansura, Ed. Anagrama, Madrid.

(73) RACIONERO, LL. (1982), Cercamon, Ed. 62, Barcelona.

(74) YOURCENAR, M. (1983), Memories d'Adrià, Ed. Laia, Barcelona

(75) BENET, J. (1983), Herrumbrosas lanzas, Ed. Alfaguara, Madrid.

(76) RUIZ, R. (1980), p. 27.

(77) RAMIREZ, J. A. (1986), "Catecismo breve de la postmodernidad", en TONO MARTí. NEZ, J., p. 21.

(78) IBÁÑEZ, J. (1986), p. 30.

(79) CIPOLLA, C. M. (1984). GINZBURG, C. (1981), El queso y los gusanos, Ed. Muchnik, Barcelona. Le Roy Ladurie, E. (1981), Montaillou, aldea occitana de 1294 a 1324, Ed. Taurus, Barcelona. SCHMITT, J. Cl. (1984), La herejia del Santo Lebrel, Ed. Muchnik, Barcelona.

(80) GINBURG, C. (1981), p. 13.

(81) Cfr. nota 79.

(82) GINZBURG, C. (1981); (1979), "Spie. Radici di un paradigma indiziario», en GARGA$\mathrm{NI}, \mathrm{A}$. (dir), Crisi della ragione, Ed. Einaudi, Turín.

(83) ONAINDÍA, M. (1985), La tau y el caldero, Ed. Grijalbo, Barcelona, p. 7.

(84) AZÚA, F. (1984), p. 9.

(85) CEBRIÁN, J. L. (1986), La Rusa, Ed. Alfaguara, Madrid. GARClA MORALES, A. (1985), El silencio de las sirenas, Ed. Anagrama, Madrid.

(86) GOYTISOLO, J. (1985), Coto vedado, Ed. Seix Barral, Barcelona; (1986), Los reinos de taifa, Ed. Seix Barral. GOYTISOLO, L. (1985), Investigaciones y conjeturas de Claudio Mendoza, Ed. Anagrama, Barcelona. GUELBENZU, J. M. (1984), El esperado, Ed. Alianza, Madrid.

(87) BERNARDO PANIAGUA, J. M. (1984), «Leyendo el medievo: El nombre de la rosa», Anales de la Universidad de Alicante, 3, pp. 195-236.

(88) SOLANO, F. (1984), "Una crónica medieval» (Recensión de Mansura), Libros, 33-34, pp. $9-10$.

(89) RUIZ, L. (1980), pp. 16-17. 




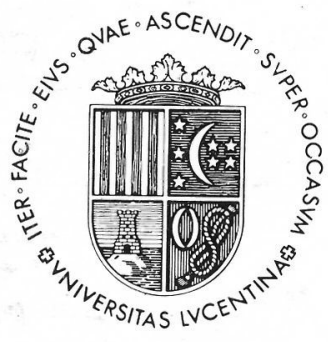

